,

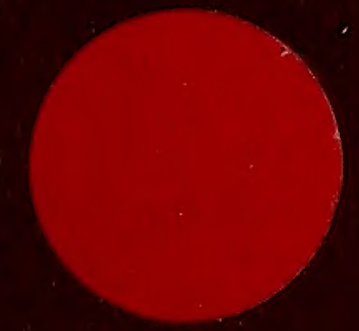




\section{5 \\ ( \\ स ह $=2$

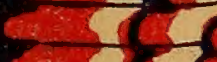 \\ $-72$ \\ $\therefore \quad-15$

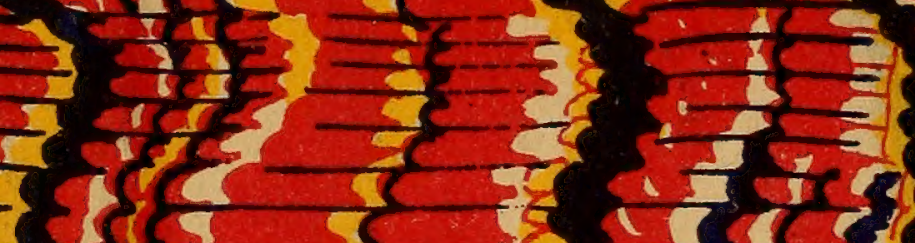

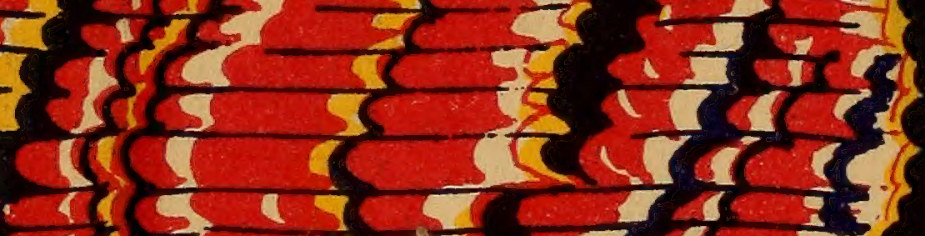

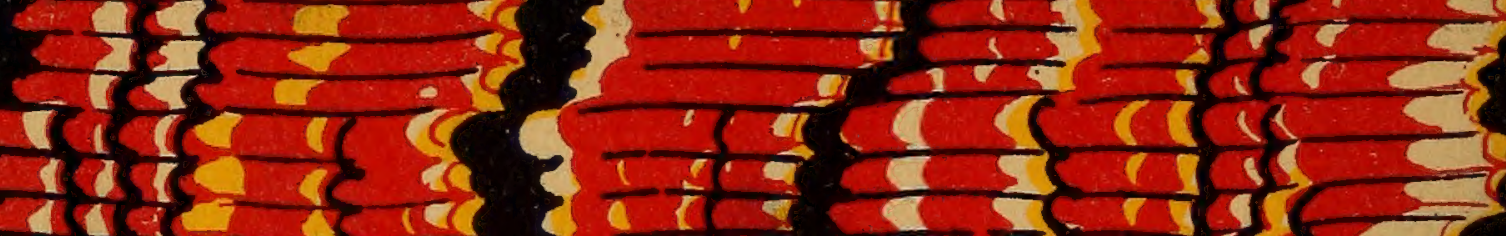

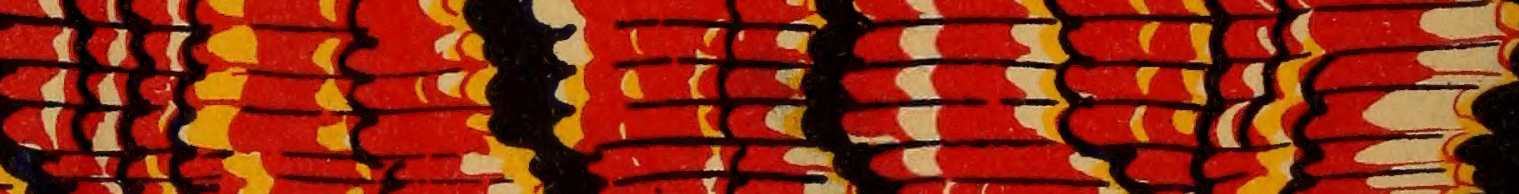

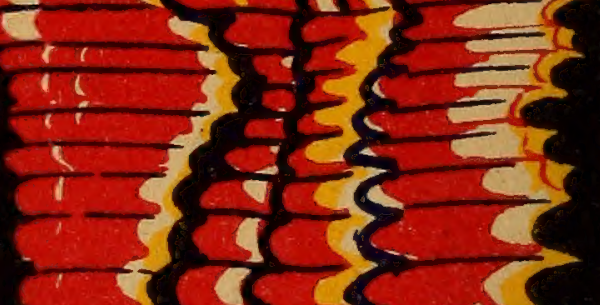

$5<\frac{3}{5}<1 \frac{1}{3}$

4
4

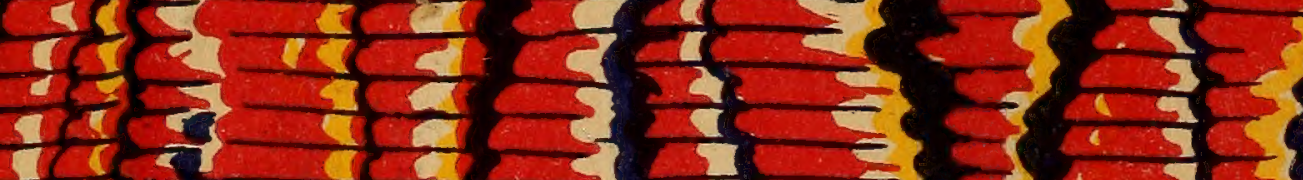

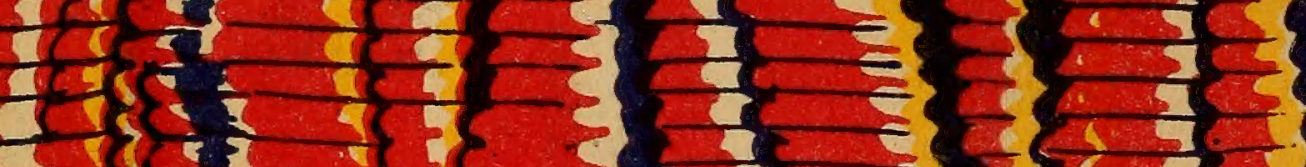

$\operatorname{lis}_{10}$ तो की

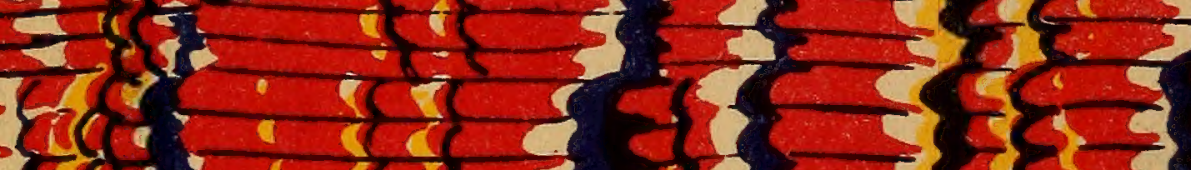

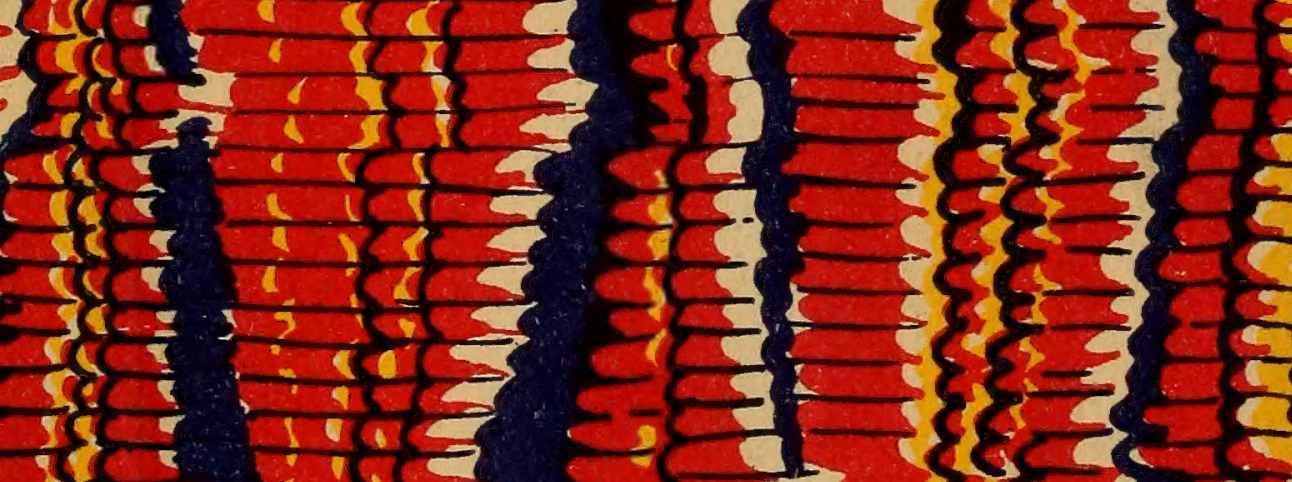

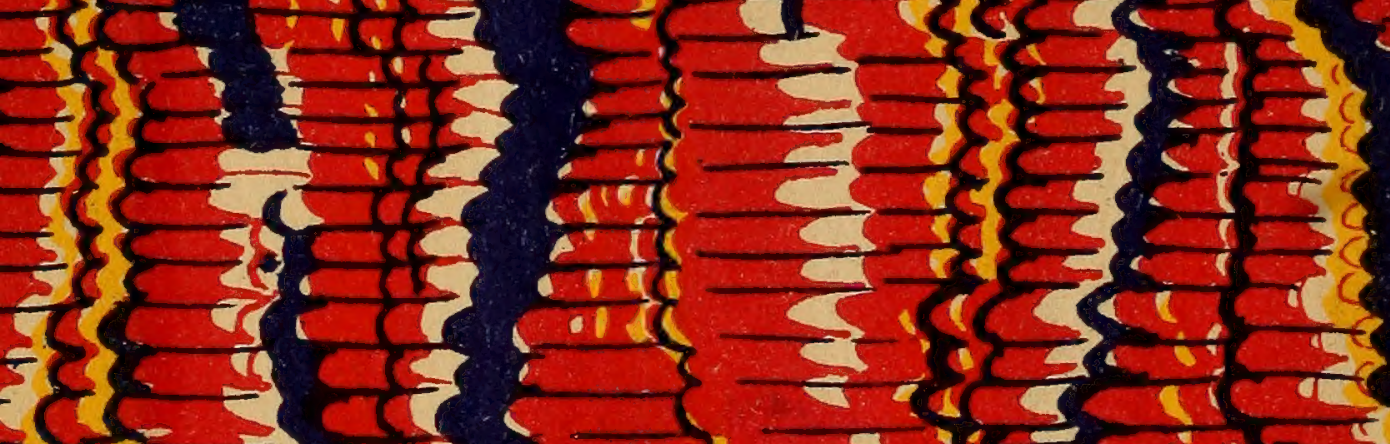

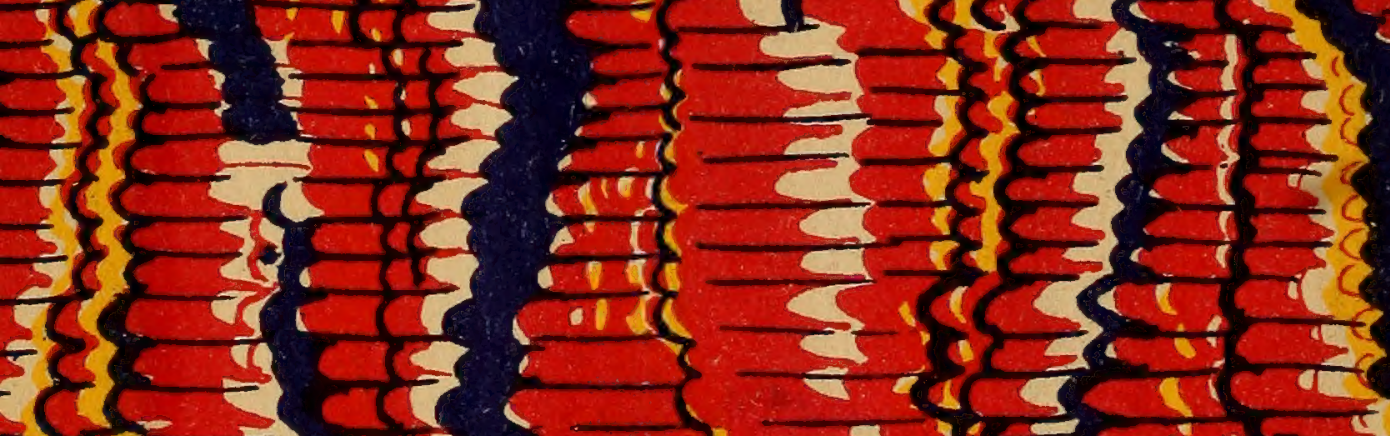

$5<<\leqslant$$$
\div-5 ; 1520
$$

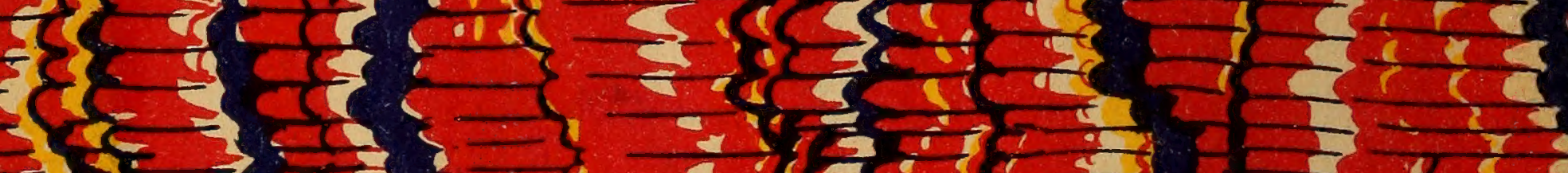

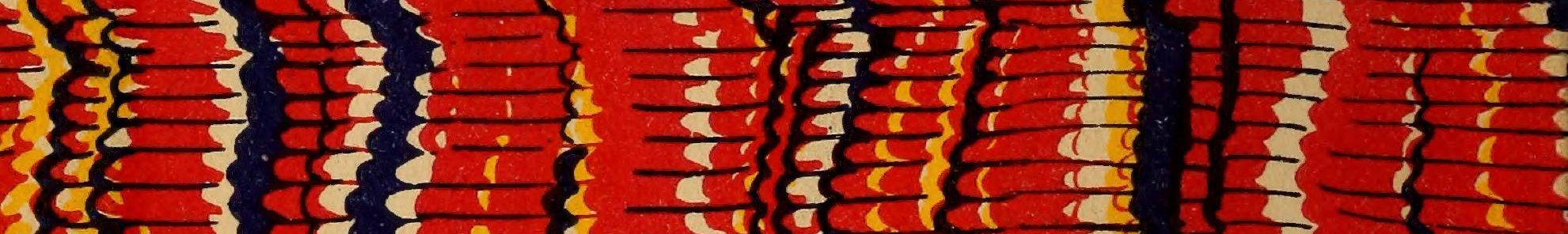

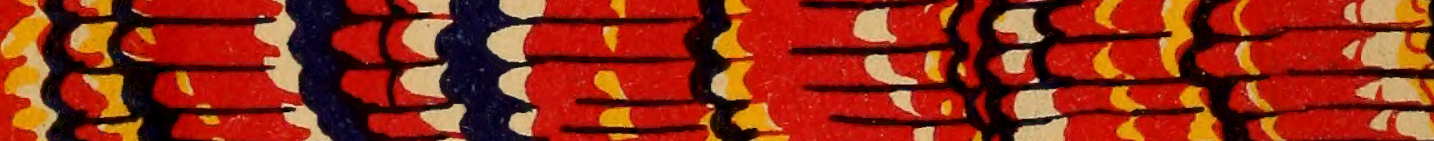
ह 1 ? I)

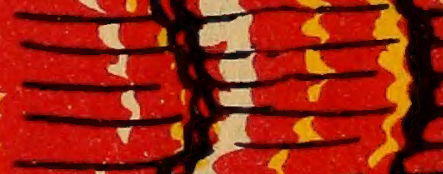

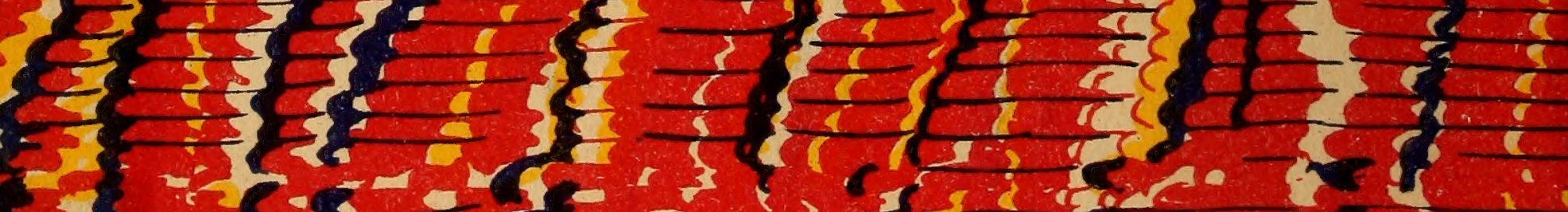

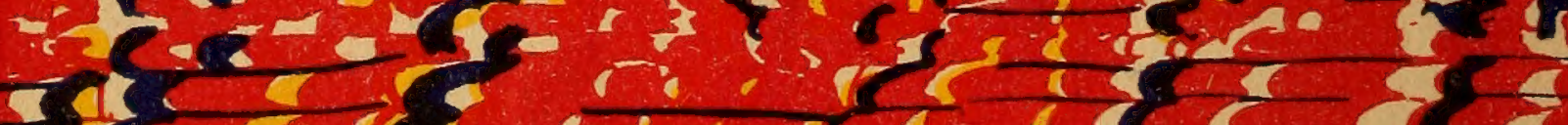

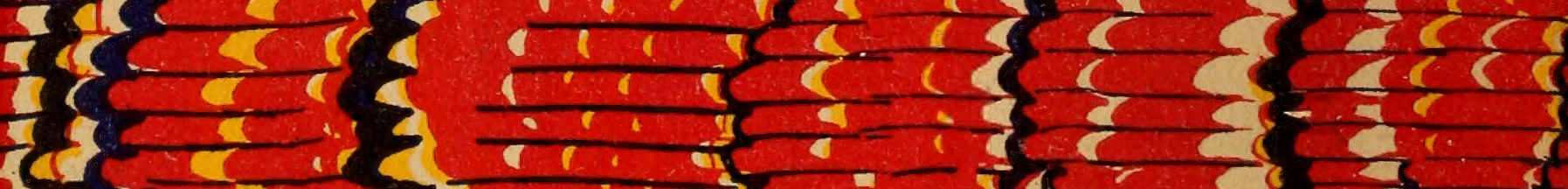

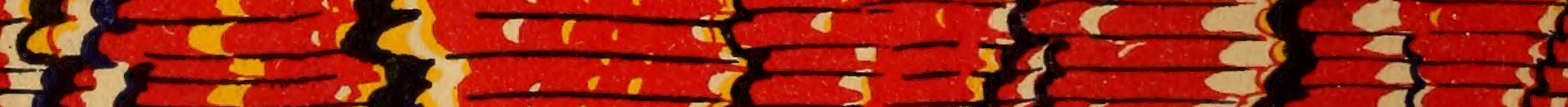

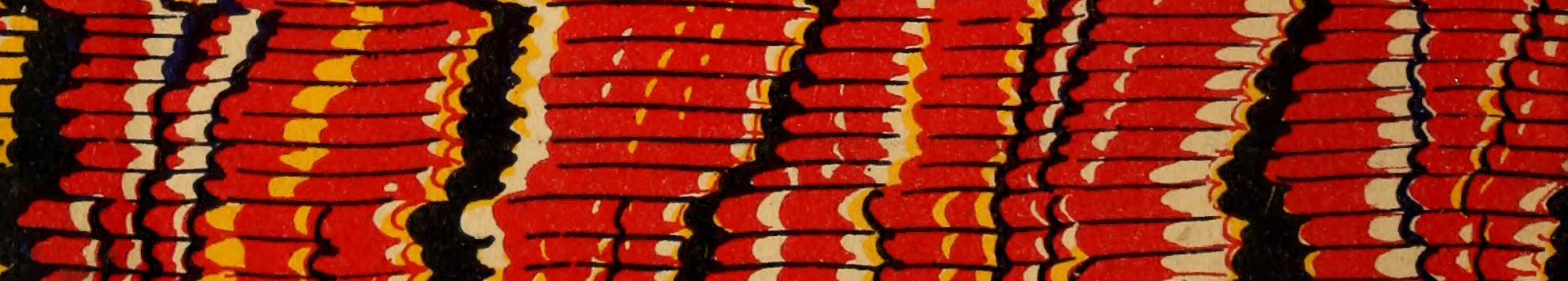




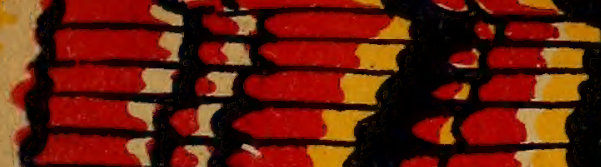

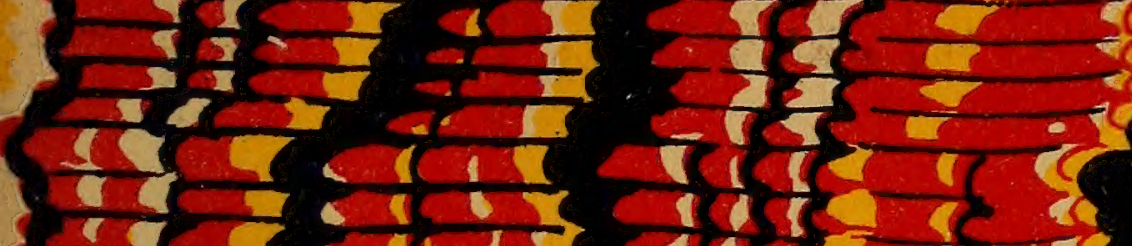

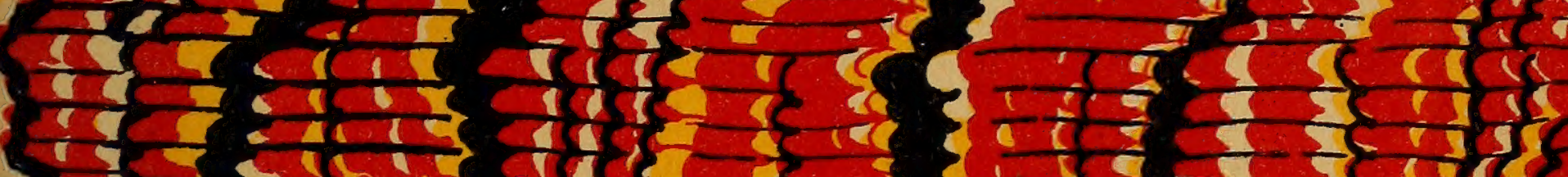

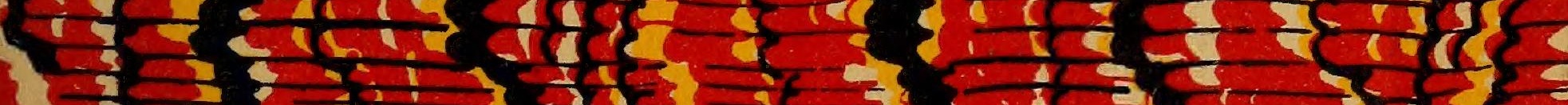

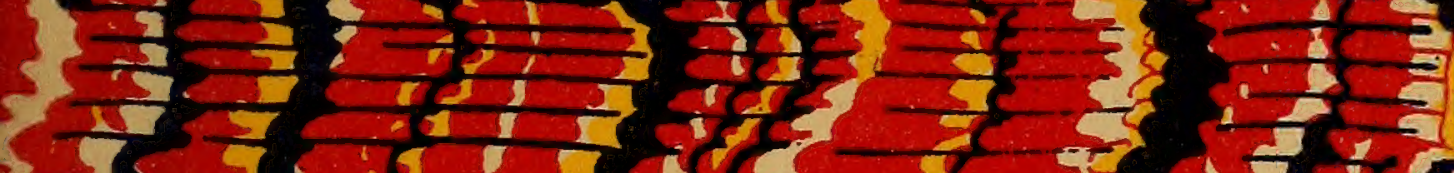

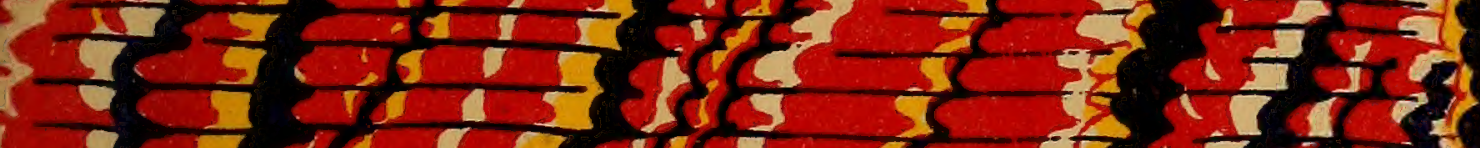

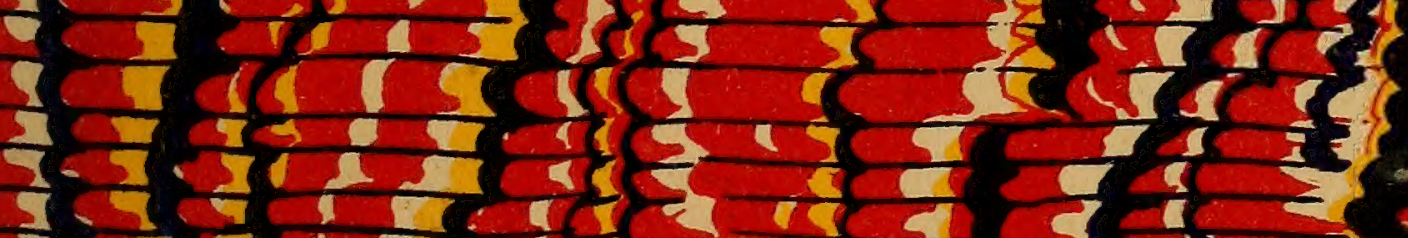

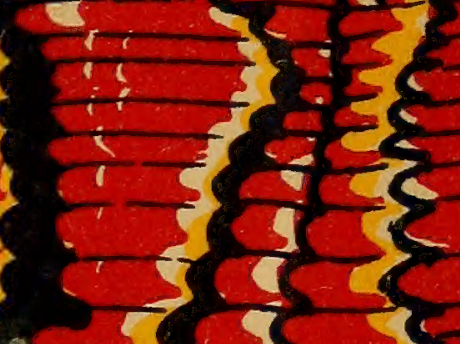

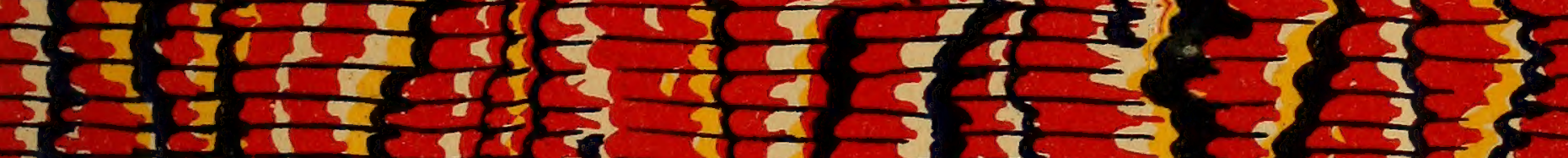

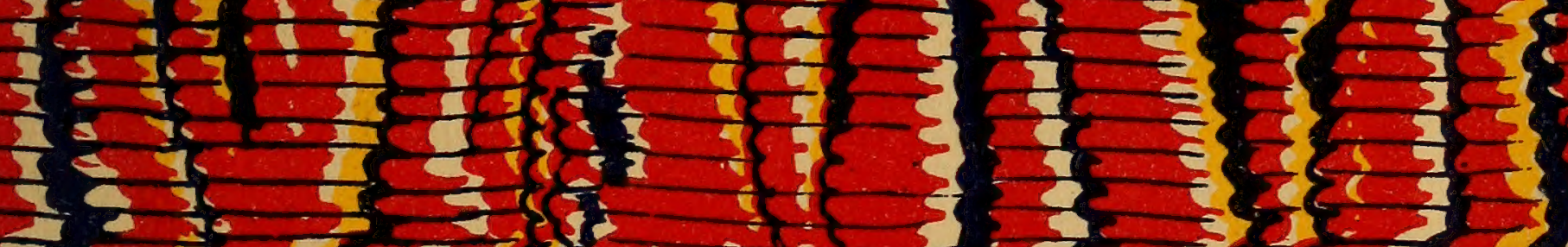

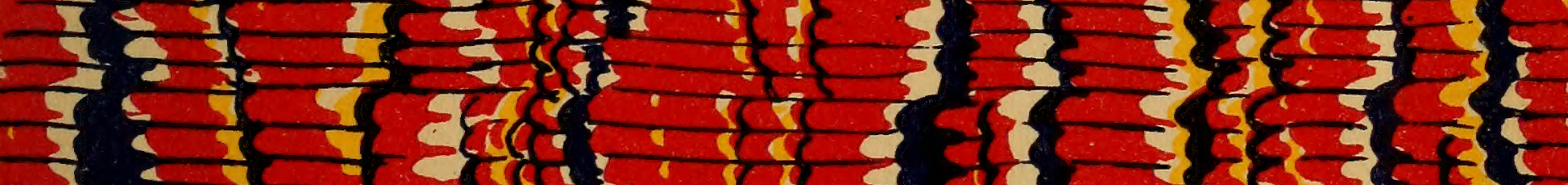

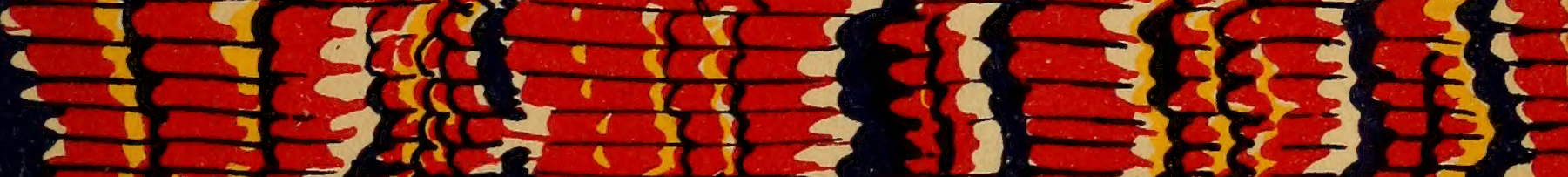

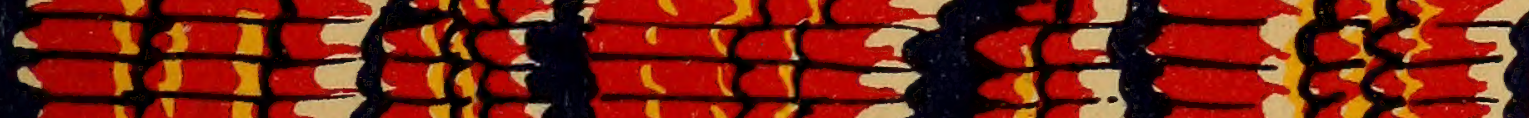

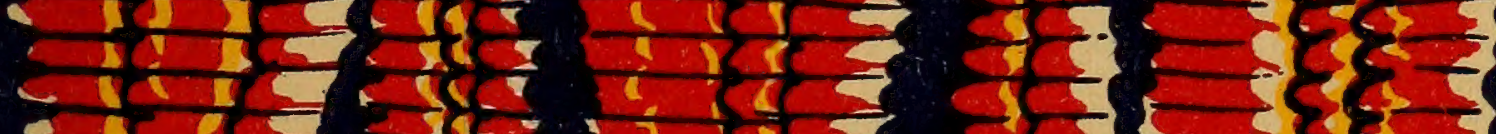

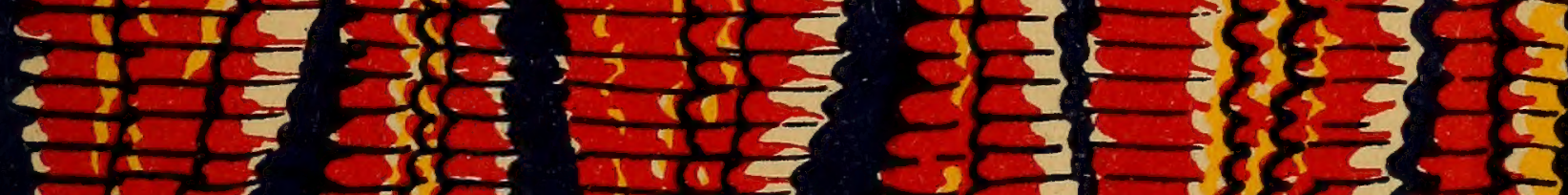

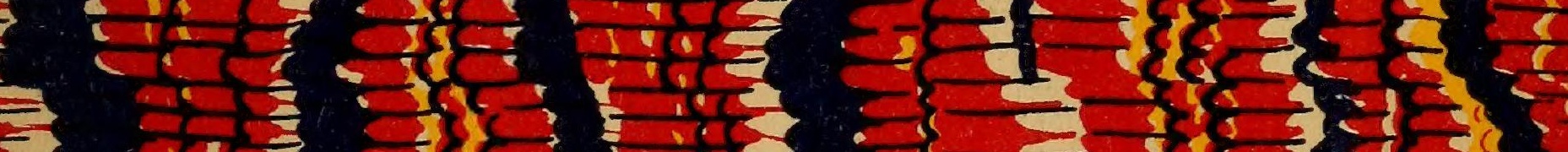

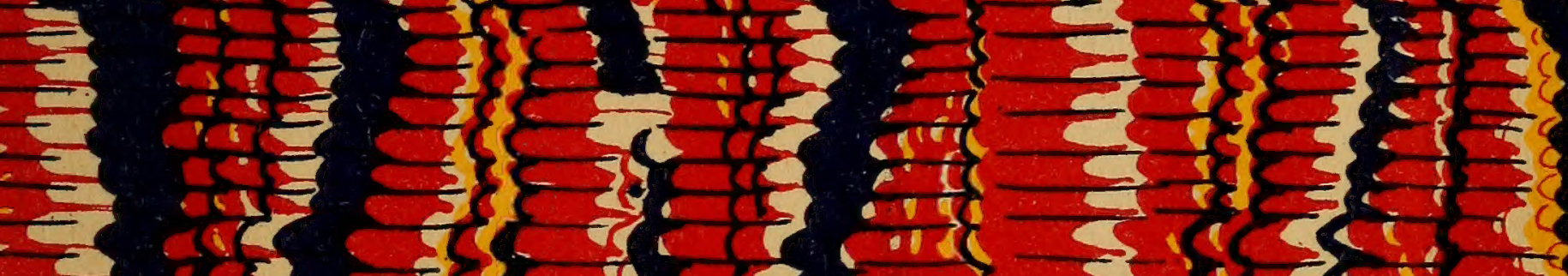

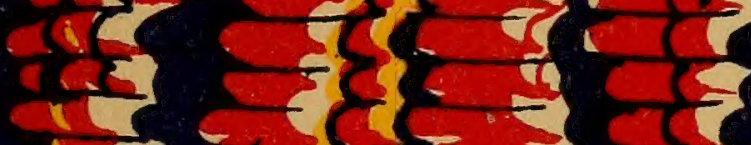

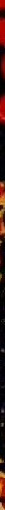

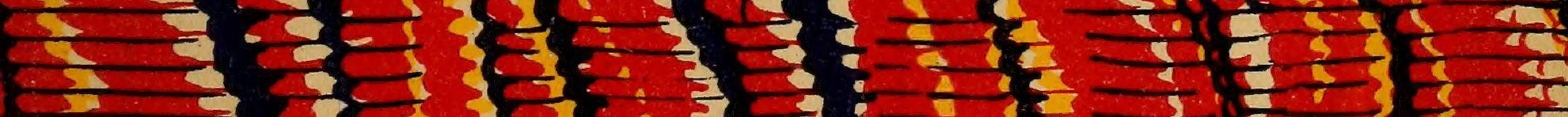

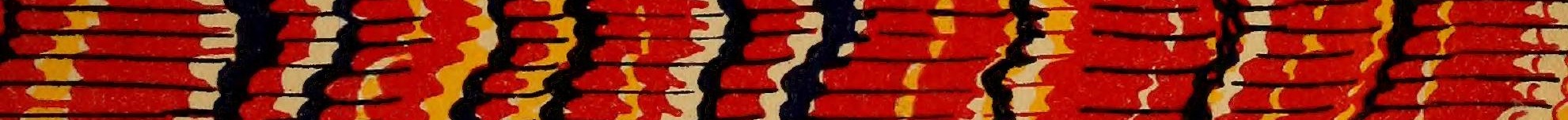

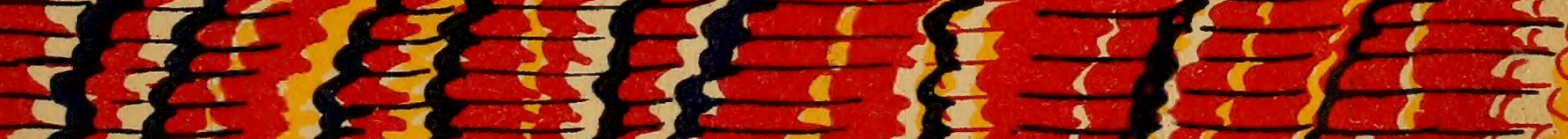

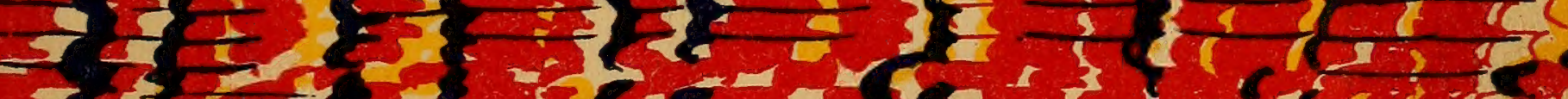

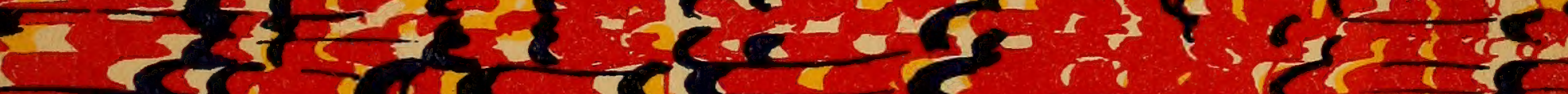

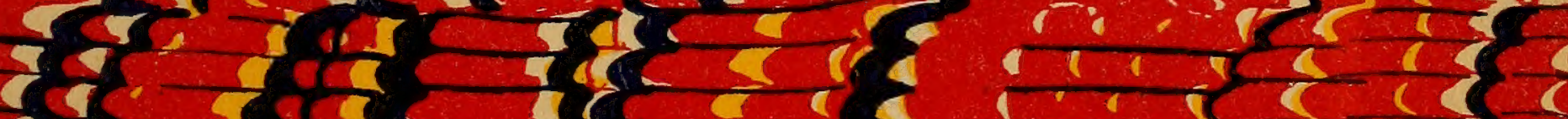

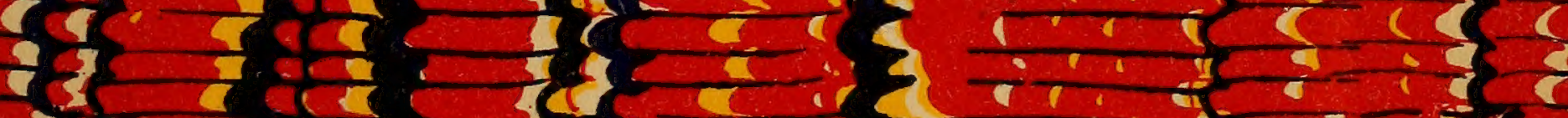

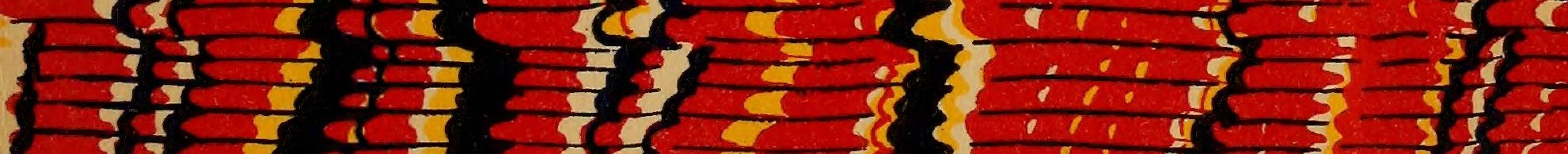
$\frac{1}{2} \leq 2 \leq$

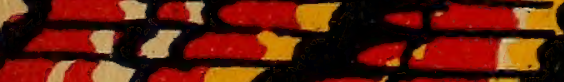

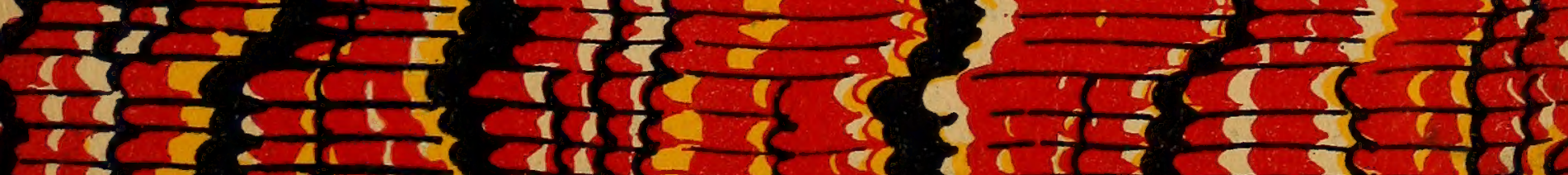

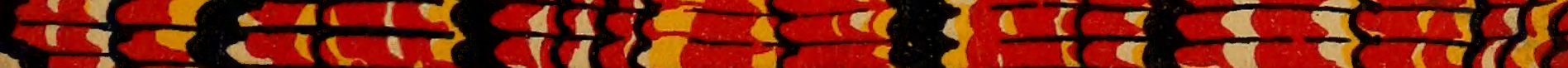


1. Notes, chiefly botanical, of a visit to the Island of Coll. Proc. Nat. Hist. Soc. Glasgow, Feb., 1880, pp. 226-230.

2. On some of the rarer plants found in the neighbourhood of Greenock. Proc. Nat. Hist. Soc. Glasgow, March, 1881, pp. 77-83.

3. No. XIII.--Some notes on a fossiliferous shale, a little below the Cloch Lighthouse. Trans. Geol. Soc. Glasgow, May, 1884, pp. 402-405, figs. $1,2$.

4. XXVIII. Notes on the land and fresh-water mollusca of Greenock and surrounding district. Trans. Nat. Hist. Soc. Glasgow, April, 1886, pp. 279-285.

5. XVI. Notes on a few crustacea and mollusca new to the fauna of the Forth, with Exhibition of specimens. Proc. Roy. Physical Soc. Bdinburgh, 1888-89, Vol. $X$, pp. 154-156.

6. The ancient lakes of Edinburgh. Proc. Roy. Physical Soc., Edinburgh, Vol. X, Pt. i, 1889, pp. 126-154.

7. Notes on some fresh-water, brackish-water, and marine entomostraca new to the fauna of orkney. Trans. Nat. Hist. Soc. Glasgow, August, 1890 , pp. 91-100.

8. Some notes on the Scotch species of the Molluscan genus Vertigo. Scottish Naturalist, Apr., 1891, pp. 2-7, figs. 1-4.

9. On the land and fresh-water Mollusca of Bute. Trans. Nat. History Soc. Glasgow, Apr., 1891, pp. 170-181, 1 map.

10. Notes on some Scottish Echinodermata. Ann. Scottish Nat. Hist., Jan., 1892, pp. 49-51, pl. 2.

11. On new and rare crustacea from the east coast of Scotzand. Ann. Scottish Nat. Hist., July, 1892, pp. 149-156, pls. 6, 7 . 
12. Notes on Rhincalanus gi.gas Brady and Ectinosoma atlanticum Brady and Robertson. Trans. Nat. Hist. Soc. Glasgow, Oct. 1892, pp. 264-265.

13. Notes on Cecrops latreillii Leach and Laemargus muricatus Kroyer. Trans. Nat. Hist. Soc. Glasgow, Oct. 1892, p. 266.

14. Notes on Copepoda from the Firth of Forth: Longipedia coronata Claus; and a preliminary description of an apparently new genus and species. Ann. Scottish Nat. Hist., Apr. 1893, pp. 89-94, pl. 2.

15. The land and fresh-water crustacea of the district around Edinburgh. Part II. The Ostracoda and Copepoda. Proc. Roy. Physical Soc., Mdinburgh, 1892-93, vol. xii, July, 1893, pp. 45-76.

16. On some Intomostraca from Castlemilk, near Rutherglen. Trans. Nat. Hist. Soc. Glasgow, Nov. 1893, pp. 1-4.

17. XXIII. On some fresh-water Entomostraca from the Island of Mull, Argyllshire, collected by the late Mr. George Brook. Proc. Royal Physical Soc. Edinburgh, Vol. XII, pp. 321-329.

18. Xxx. The land and fresh-water Crustacea of the District around Edinburgh. Part II.I.--The Cladocera. Proc. Roy. Physical Soc. Idinburgh, Vol. XII, pp. 362-377.

19. On new and rare species of Copepoda from Scotland. Ann. Scottish Nat. Hist., Jan. 1895, pp. 28-35. pl. 2.

20. Notes on freshwater Entomostraca, with special reference to Loch Leven. Ann. Scottish Nat. Hist., July, 1895, pp. 163-173.

21. Notes on some rare freshwater and marine Copepoda from Scotland. Ann. Scottish Nat. Hist., Oct. 1895, pp. 233-239. 
22. XIII. Report on a collection of marine dredgings and other natural history materials made on the west coast of Scotland by the late George Brook, F.I.S. Proc. Roy. Physical Soc. Tdinburgh, Vol. XIII, 1896, pp. 166-193, pl. 5.

23. On some new and rare Copepoda from the Clyde. Ann. Scottish Nat. Hist., O ct. 1896, pp. 224-230, pl. 4.

24. The Upper Elf Loch, Braids. [\#dinburgh] Trans. \#dinburgh Field Naturalists' \& Microscopical Society' Session, 1897-98, pp. 369-384, 1 photo.

25. Notes on the micro-fauna of Ailsa Craig, Firth of Clyde. Trans. Nat. Hist. Soc. Glasgow, Vol. V (New Series), Pt. II, 1897-98, pp. 153-158.

26. Some notes on the fresh-water Intomostraca of Aberdeenshire. Ann. Scottish Nat. Hist., Oct. 1899, pp. 216-221.

27. Notes on some Crustacea from Fairlie and Hunterson, Firth of Clyde. Trans. Nat. Hist. Soc. Glasgow, Vo1. V. (N.S.), Pt. III, 1898-99, pp. 346-355.

28. On Copepods living in the nostrils of fishes. Ann." Scottish Nat. Hist., July, 1900, pp. 153-155.

29. The land and fresh-water Mollusca. Brit. Assoc. Handbook on the Nat. Hist. Glasgow and the West of Scotland (1901), pp. 183-188.

30. Land, fresh-water, and marine Crustacea. Brit. Assoc. Handbook on the Nat. Hist. Glasgow and the West of Scotland (1901), pp. 328-358.

31. The marine and fresh-water fishes. Brit. Assce. Handbook on the Natural History of Glasgow and the West of Scotland (1901), pp. 173-180. 
32. Notes on fresh and brackish-water Intomostraca found in Aberdeenshire. Ann. Scottish Nat. Hist., Jan. 1902, pp. 21-29.

33. Some observations on the distribution of the smaller Crustacea. Trans. Edinburgh Field Naturalists' and Microscopical Society, ' Session 19021903, pp. 1-14.

34. Notes on some Copepoda from the Faroe Channel. Linn. Soc. Journ., Zool., Vol. 29, pp. I-11, pls. 1-3.

35. A report on the free-swiming Crustacea found in the First of Clyde, 1901 to 1902. Proc. Roy. Soc. Idinburgh, Session 1904-1905, Vol. 25, Pt. 9, pp. 79?-805. 



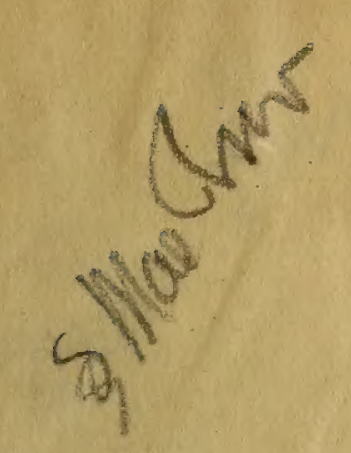

\section{CRUSTACEA}

AND

MISCELLANEOUS PAPERS.

T. SCOTT

$1881=1905$

$1880-1905$ 
ATOARerser

dith

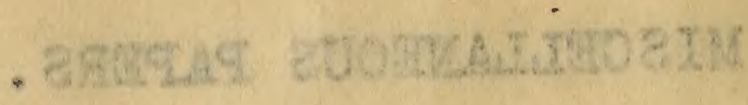

$.42002 \cdot 1$

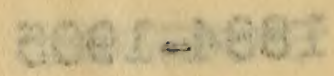

$$
\begin{aligned}
& x^{2}+x^{2}+4-2 x+2
\end{aligned}
$$






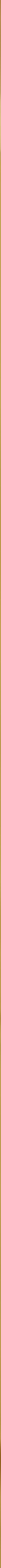



[From the Proceedings of the Natural History Society of Glasgow24th February, 1880.]

\title{
NOTES, CHIEFLY BOTANICAL, OF A VISIT TO THE ISLAND OF COLL.
}

\author{
By Mr. THOMAS SCOTT.
}


I.-Notes, chiefly Botanical, of a Visit to the Island of Coll.

By Mr. Thomas Scotr.

Not long before the Greenock Fair Holidays last year; as I was casting about for a place where I could conveniently spend a day or two, and perhaps have an opportunity of adding some specimens to my herbarium, a Greenock friend, who has a good deal of business intercourse with the Island of Coll, offered to procure for me a free passage there and back. Knowing that it lies rather out of the usual line of migration of botanists, while at the same time it formed a sort of Ultima Thule to myself, I gladly accepted the offer, and thus it was that I came to spend my holidays in Coll. I trust you will accord me your forbearance while I note a few particulars of my observations, chiefly as to its flora.

The Island of Coll, which lies a few miles to the north-west of Mull, is about 14 miles long, by about an average breadth of $2 \frac{1}{2}$ miles, and is comparatively low-lying, its highest elevation not reaching 300 feet. Though forming one of the Inner Hebrides, it is, from its position, exposed to the full fury of the Atlantic 
gales, and, as a consequence, few trees have been able to obtain a foothold, and even these few owe their scraggy existence to their being sheltered by walls or other artificial protection. The phanerogamic flora of the island consists nearly altogether of dwarfed shrubs and herbaceous plants, such as-Vaccinium VitisIdaea, Arctostaphylos Uva-ursi, Juniperus nana, Ranunculi, orchids, grasses, etc. The hills, or knolls rather, also present a bare and rugged, uninviting appearance, so you will thus understand that to the inexperienced botanist, the island presents a very unpromising look when first sighted; but, as the sequel will show, appearances here, as elsewhere, are sometimes deceptive.

The rocks of which almost the whole of the island is composed are gneiss, nearly, if not all, metamorphic conditions of hornblende, \&c., belonging, I believe, to the Upper Laurentian system. In section they present generally a series of light and dark bands, rather coarse-grained, which are so constantly varying in thickness and structure that no two specimens are exactly alike. Sometimes beds or veins of a different and, occasionally, more homogeneous structure occur, as serpentine, felspar, hornblende, and quartz. At Acha Mill there is an extensive ridge of almost pure quartz, which has such a tempting look that it was quarried, and an endeavour made to prepare it for monumental purposes, but, as might have been anticipated from its structure, the attempt failed, and so the ridge is still left to adorn the landscape. I noticed the veins of hornblende on the west coast, not very far from the school-house. The sea had not long left off the work of hewing down its rocky barrier, the wind was pleasantly refreshing as it came from the Atlantic, and the air was flooded with sunlight when I first saw them, and as they glittered in the noon-day sun one could easily imagine each crystal a gem, and the spot a veritable El Dorado! The rocky knolls, with which the north end of the island is covered, have that peculiar rounded and polished appearance said to be due to the abrading action of moving ice.

Somewhat extensive accumulations of blown sand occur, principally along the west coast, and in the hollows which have been scooped out by the wind great quantities of land and marine shells are found indiscriminately mixed up. The land shells consist mainly of Helix nemoralis and Bulimus acutus, and the marine shells, of Patella and Littorina. As the shells become decomposed, the calcareous matter gets mixed up with the sand, and being of a

VOL. IV. 
binding nature, forms a coarse-grained calcareous sandstone-of which considerable quantities are carted to a lime-kiln, near Aranagour, and burned as lime for building and agricultural purposes.

As the surface of the island is broken up by numerous small lochs and peat-mosses, and by many small streams, and as there are numerous sheltered bays and inlets, it is evident that there is a great variety of soil and situation favourable to many different plants. So that the more one extends his researches the more is he surprised at the comparative richness and variety of the flora.

I will now proceed to enumerate a few of the more interesting species.

Thalictrum minus is plentiful along the sandy shore of the west coast. Nymphaea alba grows in a small loch not far from the overseer's new house, near Aranagour. Papaver (sp.?) I noticed in a corn-field near the Free Church. Arabis hirsuta was found in a meadow, not far from the school-house. Geranium sanguineum, in most beautiful profusion, was found growing on the banks of a stream, not very far from Major Stewart's house, and I felt fain to linger beside this lovely spot. Geranium sanguineum is one of our finest wild flowers, and is also one of those that are never so beautiful as when growing in the wild freedom of their native habitat. Long-leaved Sundew was very plentiful beside a small loch about a mile-and-a-half from Aranagour. I did not get it in flower, but from the lengthened petioles I have marked it Drosera anglica. Veronica anagallis was found completely filling the bed of a stream flowing west, not very far from the school-house, and I never saw finer plants; they were just beginning to flower, and at that time would be fully two feet in height. Ajuga pyramidalis I found in a few places, and it seemed to favour rocky situations. This plant seems to be very restricted in its distribution as far as the British Islands are concerned, being confined to the North of Scotland and West of Ireland. The number of counties set down for it in the London Catalogue is 9, while some of our commonest plants reach as high as 103 .

The next I have to notice is one of the interesting insectiverous plants, Utricularia (sp.?), which was frequent in ditches having an outlet into the small loch already mentioned as situated behind the overseer's new house. The plants were very attenuated, and 
whether this was owing to the great number of confervae which were attached to them I cannot say, but, one circumstance I noticed was, that a specimen brought home in a bottle continued to grow for a time, but latterly vanished, while some of the confervae, which could not be disengaged from the plant when collected, continued to grow with increasing vigour till the whole space was filled. When the water was examined about this time, a number of animalcules were seen disporting themselves, and appeared as if feeding on the algae; whether that was the ease or not, the quantity of confervae began to show signs of diminution, and continued to do so till scarcely a fragment remained; but the animalcules increased in numbers and now have usurped the place formerly held by the two vegetable organisms. May we call this a practical example of evolution? I have not been able to make out the species, the plants not being in very good condition-could they have been specimens of Utricularia minor? Besides the above-named station, I also noticed some plants of the same genus in a pool by the side of the road between Aranagour and Acha, but they seemed to be different from the last-mentioned, having the utricles on separate branches, while the latter had them on the leaves. They seem therefore to partake more of the character of Utricularia intermedia, but, meanwhile, not having sufficient knowledge of the genus to enable me to determine their species without the aid of the flowers, I leave them without particularizing the species till I know more about them. Anagallis tenella was common by ditch sides, \&c. Alisma ranunculoides was also of frequent occurrence. Another plant, somewhat rare in Scotland, which I found in the small loch behind the overseer's new house, was Cladium mariscus. Hooker says of this plant:- "found in Sutherland, Wigtown, Berwick, only, in Scotland," but its number (35), in the London Catalogue, would indicate a wider range in the other divisions of the British Islands. Its long-pointed, rigid, and saw-edged leaves, form a very good distinctive character. Koeleria cristata was common in many places.

The next plant to which I wish to draw your attention I was rather surprised to find on the island, though that might be accounted for because of my imperfect knowledge. I refer to Sclerochloa loliacea. Hooker speaks of its distribution "from Fife southwards, and in Ireland," thus indicating that, so far as Great Britain is concerned, it is decidedly an east country plant. 
Besides, it is not mentioned in "Clydesdale Flora," and it is also absent from the list of "Casuals" in the "Fauna and Flora of the West of Scotland." I found it plentiful on the walls of the old castle of the MacLeans of Coll. We have thus an extreme westerly station for an east country plant-a point which those having some knowledge of the causes of the distribution of plants may be able to explain.

I will conclude my notes by referring to a few ferns, many of the commoner species of which were observed on the island. Some fine plants of Asplenium marinum were found on rocks a little to the south of Major Stewart's house, and this fern is likely to occur on other parts of the coast. Osmunda regalis-the Royal fern-was frequent on the side of the loch, behind the overseer's house, and also on a small island in a loch about midway between Aranagour and Acha. I heard also of its occurrence in other parts of Coll. Botrychium lunaria I found on some grassy banks a little west of the school-house. One very rare plant said tc be found in Coll -but of whose existence there I did not learn till I came home, which caused me not a little regret-was Eriocaulon septangulare. There are only two counties given for it in the "London Catalogue," and in "Withering's British Flora." Coll and Skye are given as stations. However, it is perhaps best that something worth looking for is left, in case I should be able to renew my visit.

I have now gone over a few of the more interesting plants found during a two day's ramble over the Island of Coll, and there is no doubt, I think, that the list could be largely increased by a more extended search. I may add, that Major Stewart, the proprietor of the greater part of the island, and his overseer, were most obliging, both as to affording the fullest liberty to ramble over the island, or in giving what information they possessed regarding its history, \&c. The old castle I have spoken of might alone form an interesting subject for a paper, but perhaps what I have said may induce some member with more leisure and ability to visit Coll, and to place before the Society a more thorough record of its natural history and antiquities than I have been able to do. 

.

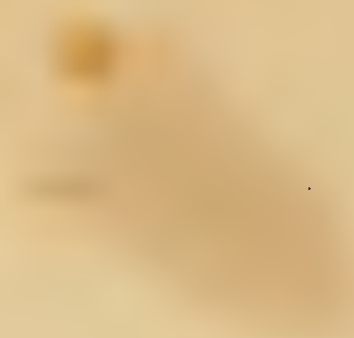

.

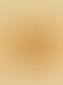

$-$ 


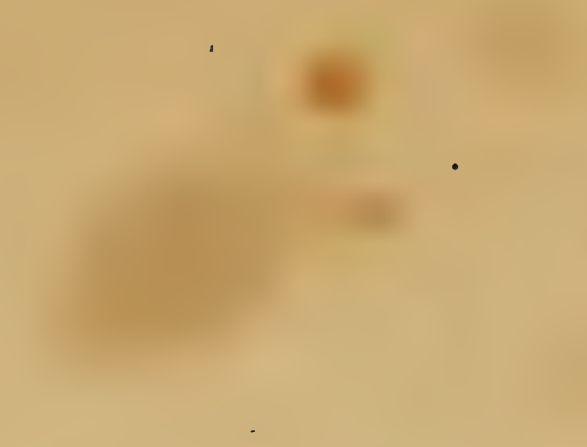

,

an

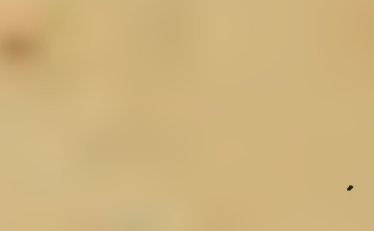

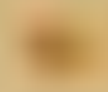

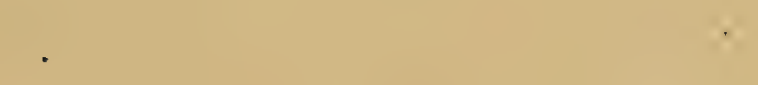



ave

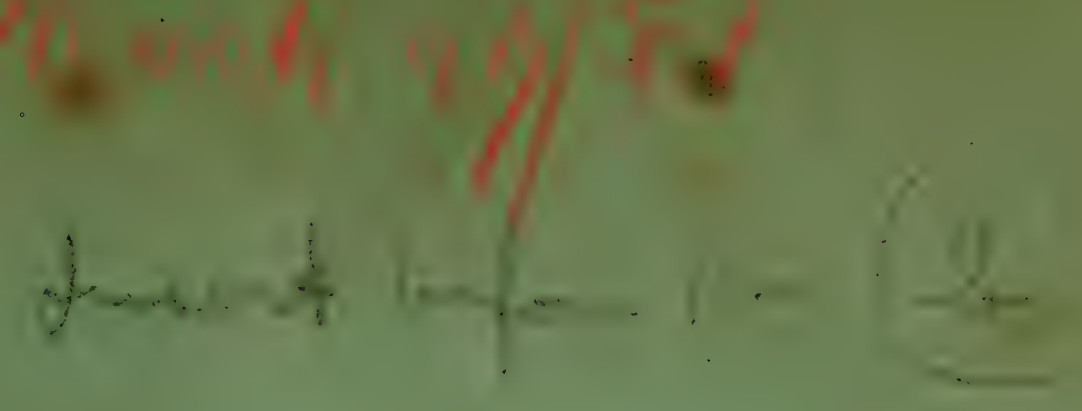


.

.

$+$

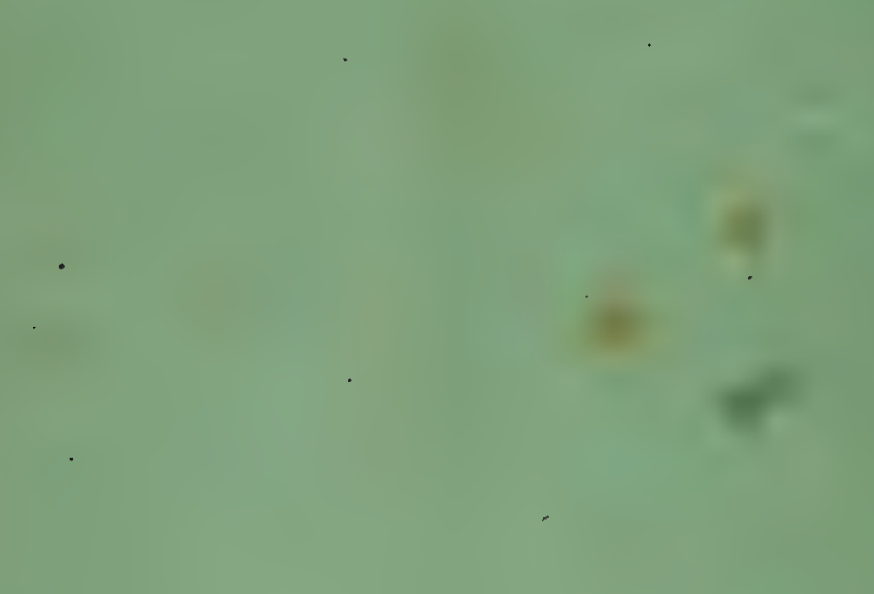

.

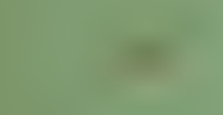

4

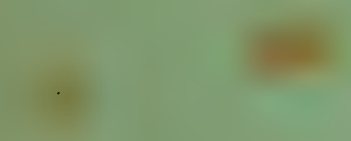

$=$

e e 
[From the Proceedings of the Natural History Society of GlasgowMarch Q9th, 1881.]

I.-On some of the rarer Plants found in the Neighbourhood of Greenock. By Mr. Thomas Scott.

It will be as well, at the outset, to indicate the extent of the district I intend to refer to in the following notes, and that is the ground included in a radius of about six miles, which will take in such localities as the Cloch, Shielhill Glen, and Kilmalcolm.

I do not mean to take up your time by referring to any of those plants, which, so far as Clydesdale, at least, is concerned, may be termed cosmopolitan, my intention being simply to place before you a record of those plants which may be said to be rare or uncommon, 
and which are known to the writer to occur; or to have occurred, in the included district. Such a record may serve to indicate that though there is "no new thing under the sun" there may be enough to reward the diligent and careful working up of a district which has been thought to have been well explored. It may also sometimes prove useful as an indication of the geographical extension of certain species, and may serve as a basis of comparison for future investigation, just as some such records have been of use to myself.

The surface rocks of a great portion of the country round Greenock are trap of various kinds, but there are many places, and especially nearly all along the shore of the Firth, where sandstone crops out, and it is interesting to observe, that while the vegetation of those places where the igneous rock prevails, is, with regard to phanerogams, generally meagre both in genera and species, the vegetation where the sandstone occurs is rich, the number and variety, as well as the luxuriance, of the flowers, forming a marked contrast to the monotonous and desolate appearance of the flora of the former; consequently nearly all the rarer plants of the district are found where sandstone comes to the surface.

The order Ranunculaceae is, with the exception of only 3 or 4 species, represented by the most common forms. Ranunculus lingua is said to have been found at Gourock, though I have not seen it there or anywhere in the neighbourhood. $R$. auricomus is found at the old Castle of Duchal, Kilmalcolm, and $R$. sceleratus is plentiful a little east of Langbank. Aconitum Napellus, one of the "doubtful natives" which we noticed some years ago, still grows where we first found it-at the "Roman Bridge" near Inverkip. Trollius europaeus is common, as at Kilmalcolm and Shielhill Glen. Papaver Argemone is occasionally found in the corn-fields and on the railway embankments about Kilmalcolm, but the most notable of the Papaveraceae found in the district is the Common Celandine-Chelidonium Majus. About 18 years ago this plant was noticed at Duchal Castle, and the summer before last when visiting that locality along with some members of my botanical class we observed a most beautiful specimen, an evidence that this species had not become extinct, a fact which is the more striking when we take into consideration that the place is very much frequented in summer-time by picnic parties and others.

Draba muralis was found for a number of years upon some old walls about Greenock, but these walls have now been taken down or 
repaired and the plants destroyed. Lepidium Smithii, which is said to be rare, I have found in several places; it was very plentiful on an old road at Kilmalcolm and is still found near Fort Matilda and at several other places by the shore. Iberis amara is occasionally found about the shore near Fort Matilda. One of the rarest plants of the West of Scotland, and belonging to the order Caryophyllaceae, should be mentioned; I refer to Cerastium arvense, which was noticed about 6 years ago by Mr. Charles Pennell of Greenock (a member of the Society), and which grows by the shore a short distance west from Fort Matilda in a field locally known as the Battery Field. Silene inflata, S. noctiflora, Lychnis vespertina, and Githago segetum have also been found in the neighbourhood of Greenock within the last few years. Touch-me-not, Impatiens noli-me-tangere, is found by the shore about quarter of a mile west from the Cloch Light-house, growing at one place especially in great profusion; I first noticed it about 4 years ago.

A few plants belonging to the Leguminosae may be noted. Melilotus officinalis, the Yellow Melilote, was found last year in the Battery Field by Mr. Struthers of the Watt Museum. Trifolium arvense, well named the "Hare's-foot Trefoil," is found in the suburbs of Greenock; and the pretty little Ornithopus perpusillus, which I have observed for a number of summers on a dry bank by the side of the road on the north side of the Glasgow and South-Western Railway, and about $1 \frac{1}{2}$ miles west from Kilmalcolm. These are the most noteworthy plants belonging to this order found in our district, but there are other two species which, though not found, strictly speaking, within the specified limits, might be noticed before passing on. These are, first, Vicia lathyroides, which I happened to find on Dumbarton Rock, in June, 1878 , and at a subsequent date. This plant cannot be confounded with $V$. angustifolia, Roth, especially when examined in fruit as well as in flower, its smooth pods and granulated seeds forming a very distinctive characteristic. I am not aware of any station having been found for it so near Glasgow. The second is also a Vetch-V. sylvatica, which I noticed in Auchinreoch Glen, near Dumbarton, in 1878, when I was very much struck with its beauty. Among the Rosaceae, Rosa arvensis is found at Gourock, and by the shore near Leven House below Ashton. The Crab Apple, Pyrus Malus, is found a little off the Larkfield road and about midway between Gourock and Ravenscraig, where it forms part 
of an old hedge between two fields. Saxifraga aizoides, S. hypnoides, and Chrysosplenium alternifolium are found in Shielhill Glen, the last mentioned plant being also found in various other localities. Hippuris vulgaris is still found where previously recorded, in a small shallow loch on the hilly moors near Ravenscraig. Peplis Portula we find at Loch Thom and other places in the neighbourhood of Greenock. Dipsacus sytvestris I have found occasionally in the Battery Field near Gourock Toll. 'The only species of the Umbelliferae I will mention is Peucedanum Ostruthium, which we find near the Roman Bridge, near the Whinhill reservoir, and about Kilmalcolm.

Of the Compositaceae very few that may be called rare are found in our district. Senecio viscosus and S. sylvaticus both occur in the neighbourhood of Greenock. Great-Leopard's-bane, Doronicum pardatianches, has been observed for a number of years in a wood near Dunrod Farm. Anthemis arvensis has been occasionally found in a field at the east end of Gourock. The very rare and pretty little Ivy-leaved Bellflower, Campanula hederacea, need scarcely be alluded to here, it being already so well known to Glasgow botanists, were it not to notice the somewhat interesting fact that the only two stations as yet recorded for it in Clydesclale, the Cloch and Dunoon, are as nearly as may be opposite to each other, as if the idea of near neighbourhood was a factor in the arrangement of the stations. Vaccinium Oxycoccos occurs in a marshy hollow a little west of the station mentioned for Ornithopus perpusillus. Echium vulgare and Anchusa sempervirens are the only rare Borages found near Greenock, the first in the western suburbs, the other at the Roman Bridge. Myosotis palustris, which we find occasionally, is said to be a common species, and there is no reason for doubting the assertion so far as certain localities are concerned; but in regard to the district under consideration, an experience extending over several years tends to shew that it is rather scarce. No doubt the experienced botanist finds little diffculty in making out this species; but still, having on several occasions seen $M$. reprens mistaken for $M$. palustris, I am inclined to think that its reported commonness may be due, partly at least, to want of familiarity with its characteristics, and consequently a. more restrictive term than "common" would be a more appropriate one. One of its characteristics which I have always found very constant and very distinct is, that the calyx segments are shorter than 
the tube of the corolla; and therefore not bent outwards by the rotate divisions of the corolla, as is the case with $M$. repens. In August, 1878, I got Solanum nigrum on some rubbish heaps in the neighbourhood of Greenock.

Of plants belonging to the order Scrophulariaceae, a few may be mentioned Bartsia viscosa is common in a field behind Ashton. Linaria Cymbalaria I have found at various times on old walls about Greenock. Verbascum Thapsus is found in a plantation at Wemyss Bay. A plant belonging to this order, and which is truly a stranger to these parts, has made its appearance in our district of late,--V. blattaria. Last year some very luxuriant specimens were noticed in a field between Fort-Matilda and Gourock; and the other day I saw in the same field some rootstocks which gave promise of producing specimens well worth a place in our herbaria. This species is said to be native in the south-west of England, but after standing such a winter as we are just now emerging from-1880-81 - I think it is qualified to take its place as a sub-arctic species. Mimulus luteus, another plant belonging to the order, is found in a ditch about four miles out on the Inverkip road; and although the ditch is cleared out every season, the Mimulus always comes up the following spring as plentifully as ever, which shews it agrees well with its location. The Gipsy-wort, Lycopus europaeus, the only rare species of the Labiatae occurring in our district, is found below the Cloch Lighthouse. Scutellaria galericulata, which is common on the shore below Gourock, is, I notice in Hooker's Flora entered as "rare in Scotland." Primula veris I have found both at Parklea near Port-Glasgow, and at Inverkip. Lysimachia vulgaris was found some years ago near Inverkip by Mr. Peter Mackellar, Greenock. Parietaria officinalis I once found growing on the Roman Bridge. Whether I had injured the plant when securing a part of it for a specimen I cannot say, but I have not seen it there since; this species grows plentifully on the old wall at the Abbey Walk, St. Andrews.

Of the Orchidaceae few that may be called uncommon are found in our district. Habenaria viridis and H. albida are got on the hills behind Greenock, and one or two other places; I have got very fine specimens of $H$. albida on the Tower hill, Gourock; Neottia nidusavis, which used to be met with in a wood below the Cloch Lighthouse, has not been seen for a number of years. The curious little Listera cordata, as well as its more robust companion, L. ovata, are 
frequent in some parts of our district, such as Shielhill Glen and Target Glen.

I shall now mention a few Carices which are to be met with in the circumscribed area under review. Carex dioica is found on the hills behind Greenock, Shielhill Glen, and other places ; C. teretiuscula is got in a wet meadow by the side of the Inverkip road near Ravenscraig; C. aquatilis, var. Watsoni of Syme, is found in Shielhill Glen; C. pendula is also found in the same glen; C. riparia grows in a meadow near Dunrod Castle. A reference to a few Grasses will conclude the list of flowering plant. Setaria vividis I found on some rubbish in the neighbourhood of Greenock, being no doubt an outcast. Avena fatua was got in a corn-field near the Whinhill; $A$. pubescens is found in Shielhill Glen near the middle of the glen. Lepturus filiformis, var. incurvatus, grows in a meadow by the shore between Fort Matilda and Gourock. I found this plant some years ago, and though not yet included in Hennedy's Clydesdale Flora, there can be no doubt about its being indigenous. This grass presents us with a good example of the law of compensation; the spikelets which are lateral have only one glume, the part of the rachis opposite the spikelet taking the place of the second glume, but the terminal spikelet, which cannot get protection from the rachis, has two glumes.

I will now notice one or two of the higher Cryptogams, which will conclude the present list. Cryptogramma crispa I found near Kilmalcolm, where it was discovered many years ago, but I am afraid it is now almost if not altogether extinct. Aspidium angulare is got at Gourock and the Cloch. Asplenium viride grows in Shielhill Glen and by the side of the Routen Burn near Loch Thom. We get the Adder's tongue, Ophioglossum vulgatum, near the Roman Bridge. The Moonwort, Botrichium Lunaria, is found on the hills behind Greenock, at Gourock, and other places in the district. The Royal Fern, Osmunda regalis, which used to be found near Gourock is now extinct-exterminated I should say. It is much to be wished that something could be done to put a stop to the extermination of plants for mere pecuniary gain. The only other Cryptogam I will mention is the Great Water-horsetail, Equisetum Telmateia, got in Shielhill Glen, where it grows most luxuriantly; one plant I got measured fully six feet in length.

It will be observed from what has been said that a good many interesting plants are found about Greenock and neighbourhood, 
and doubtless others will yet be added to the list, for it cannot be questioned, I think, that a constant redistribution is going on locally and generally, so that in a number of years rare plants may become commoner and common ones scarcer. The watching of such redistribution is one of the pleasures of the botanist and I should say not the least one.

I may mention that the nomenclature which I have followed is that of Hooker's Students' Flora.

[NotE-Dec., 1881.-Of the two following plants the first was overlooked in the preparation of my paper and the second was found after the paper had been read before the Society.

Claytonia alsinoides, which seems to have become naturalized in many places, is found in a small wood between Ashton and the Cloch, where it has by some means been introduced. It has retained its hold here for many years, and judging by its luxuriance it appears to find the conditions very suitable. Very probably this species will, ere long, have to be included amongst British plants, C. perfoliata having been already admitted.

A specimen of a new introduction, Salvia verbenaca, has been shown me by Dr. J. K. Robertson, of Greenock, who found it this summer, 1881, in a field near where the Clyde Floating Baths were moored. I have since gathered other specimens at the same place. This plant has hitherto only been found on the East Coast at Salisbury Crags, and in Fifeshire from Burntisland eastwards.] 






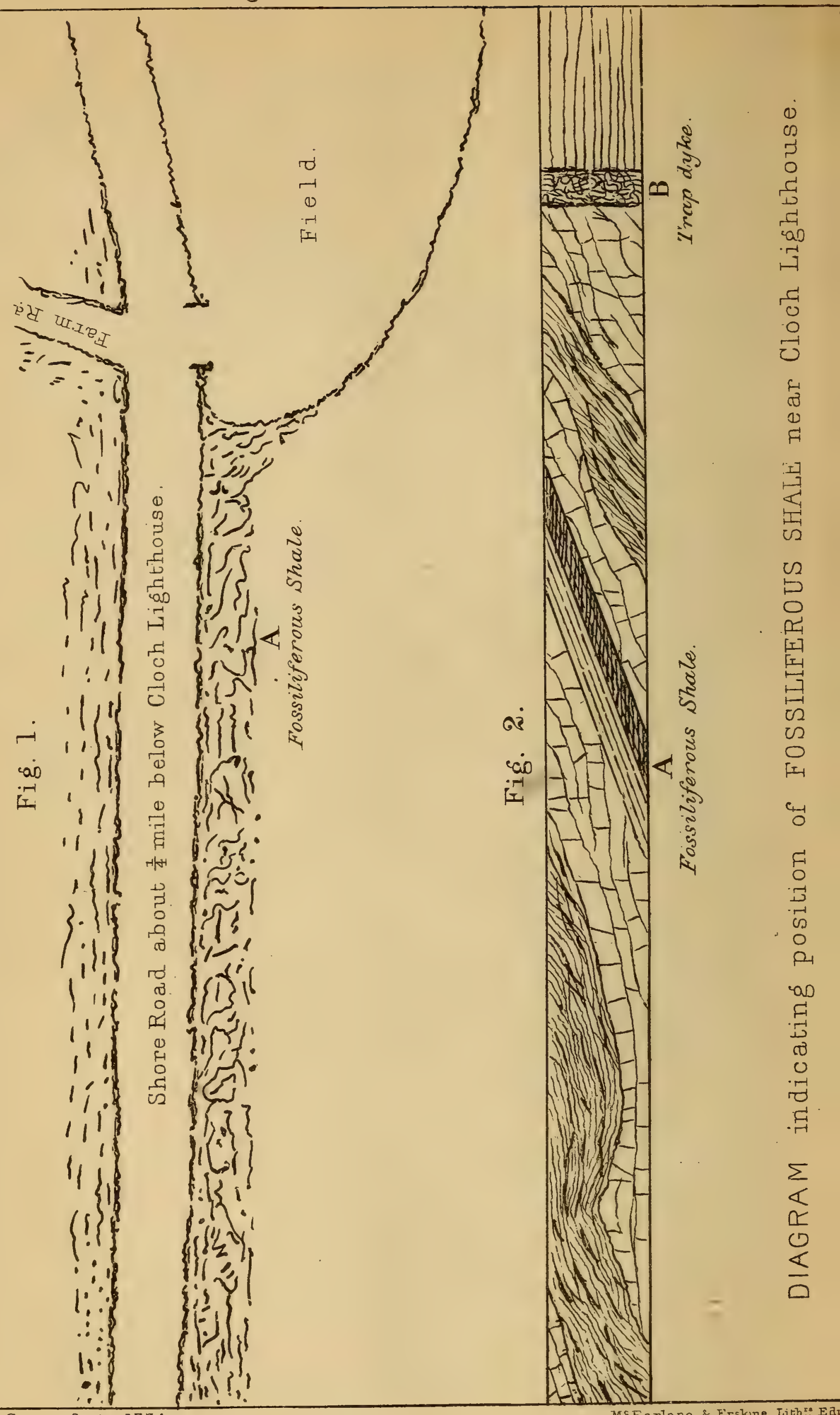


[From the Transactions of the Geological Society of Glasyow-

8th May, 1884.]

No. XLiI._Some Notes on a Fossiliferous Shale, a little below the Cloch Lighthouse. By Thomas Scott, Cor. Mem. With a Section. [Plate XVII.]

[Read 8th May, 1884.]

ONE day in October of last year while walking round by the Cloch, I happened to take a look at the rock sections seen near the shore in that neighbourhood. Being aware that the sandstone rocks exposed for a considerable distance along our coast line-that is south-westwards, from Greenock and Gourock-belong to the calciferous sandstone series, and being also aware that organic remains have been found in this series of rocks in different parts of Scotland, the thought often occurred to me that vegetable or animal remains might be found in the similar strata here. I was thus often tempted, while botanizing by the shore, to take a look at the rocks in passing, and on the day mentioned I examined some alternating beds of sandstone and shale exposed near the shore, ahout a quarter of a mile below the lighthouse.

Some of the sandstones contained carbonaceous matter, which was quite structureless, but on carefully examining one of the beds of shale I found part of it crowded with vegetable remains, consisting for the most part of ferns and calamites-one species of 
fern, the Sphenopteris affinis, being in great abundance in some parts, and Calamites cannceformis equally plentiful in other parts; while very sparingly appeared the fern, Pecopteris dentata. On the top of the fossiliferous part of the shale I found a piece of tree stem, but not sufficiently preserved to allow of it being identified. I wish here to say that I am much indebted to Mr. John Young, F.G.S., to whom I submitted specimens, for his kindness in examining and identifying the species named. As the changes that have taken place in the structure of the tree stem are rather interesting, I shall take the liberty of quoting what Mr. Young says :- "No. 1 is a portion of a squeezed stem of what I think has been some coniferous plant. It has been very much bituminized so as to have lost all trace of its original woody structure, and has been subsequently altered by heat, so that it now gives very little flame. I noticed it contains some minute crystals of iron pyrites, and some fissures are filled with green carbonate of copper (malachite), which is elsewhere found in the Gourock beds."

Now, before proceeding further, I will try to point out as near as possible where the fossil-bearing shale occurs, and the section herewith [Plate XVII.] will help me in doing so. The road for some distance past the Cloch Lighthouse closely skirts the shore, but proceeding we come to a place where the road bends a little inland, while the shore bends for a short distance rapidly outwards, so that a gradually widening field is situated between the shore and the road, as indicated by the section. Where the shore and the road thus part company we find the shale above referred to. The bed is fully three feet thick, with sandstone above and below, and dips to the north-east with an inclination of about 20 degrees, only half (the lower half) being fossiliferous. It is very friable, so that it is almost impossible to lift a large piece of it, and even when we do get a moderate-sized bit, we find that in drying it is very apt to break up into small fragments. I have already said that the structure of the piece of tree stem found in this shale has been very much altered; the alteration of the vegetable structure and also the friable condition of the shale itself having been probably caused by the action of the trap-dyke which is found about 30 or 40 yards to the south [Plate XVII., sec. 2]. The upper part of the shale is, so far as I can make out, entirely destitute of fossils. Wishing to know if the traces of 
copper, which were associated with the fossil tree, were derived from the enclosing shale, I got a friend to analyze a piece of it. He found "iron and alumina in great abundance, also silica-the iron appeared to be mostly in the ferrous state, mixed with a little ferric"-but there was no trace of copper, so that the copper we find associated with the fossil tree must be derived from some other source than the surrounding shale.

It would appear from the fossil contents of this shale, and from its thin laminated structure, that while it was being deposited the country round about, if not the whole of mid-Scotland, was a comparatively level marshy plain, through which possibly some slowmoving stream wended its course; that this plain was luxuriant with ferns, but which, although very abundant, did not present a great diversity of species. One species at anyrate predominated, and had a distribution over central Scotland from its east to its west coast line. That the river, or rivers, now and again overflowed and covered great tracts of the adjacent land and buried the luxuriant vegetation under a layer of mud. Ferns would again cover the land and be again buried, but after these alternations had gone on a while, there came a time when the soil seemed not so suitable for the growth of ferns, and calamites took their place, became equally abundant, and were equally subject to be now and again buried under the diluvium spread over the district by inundation. By and by trees flourished and helped to diversify the landscape. But another change ensued, the conditions became such that they could not support vegetable life, and consequently we find the upper part of the shale to be quite barren of organic remains. I have now touched on one or two points which the distribution of the fossil remains in this shale seem to indicate.

I wish now to say a few words on what appear to me to be some interesting features in connection with the relative position of the rocks, on each side of the trap-dyke [shown on the section, Fig. 2]. It will be observed that on the upper or north side the strata, consisting of alternating sandstone and shale, dip considerably, as I have already stated, to the N.E., while on the south side of the dyke the strata, consisting of conglomerates and fine grained dark-red sandstones, are almost horizontal, having but a slight dip westwards, while there can be no doubt that the rocks on the north side of the dyke belong to the lower carboniferous group. I. am inclined to think that those on the south side are the lower 
red Calciferous sandstones, from their close resemblance to those about Wemyss Bay. If such be the case, we have here evidences of a very extensive displacement having taken place - the dark-red sandstones and conglomerates have undergone little change, but the calciferous sandstones and shales on the north side of the dyke have been extensively faulted down, in all likelihood during the time of volcanic activity, of which this trapdyke and others in the neighbourhood are the mementoes.

Time will not permit me to say more at present, but if what I have said leads to more interest being taken in the rocks along our coast line my purpose shall have been served. I may, however, explain that since I set myself to write these few notes a great many things have had to be attended to which curtailed my little leisure, with the result that I have been able to touch only on a few of the more salient points connected with the geology of this part of Clydesdale. 



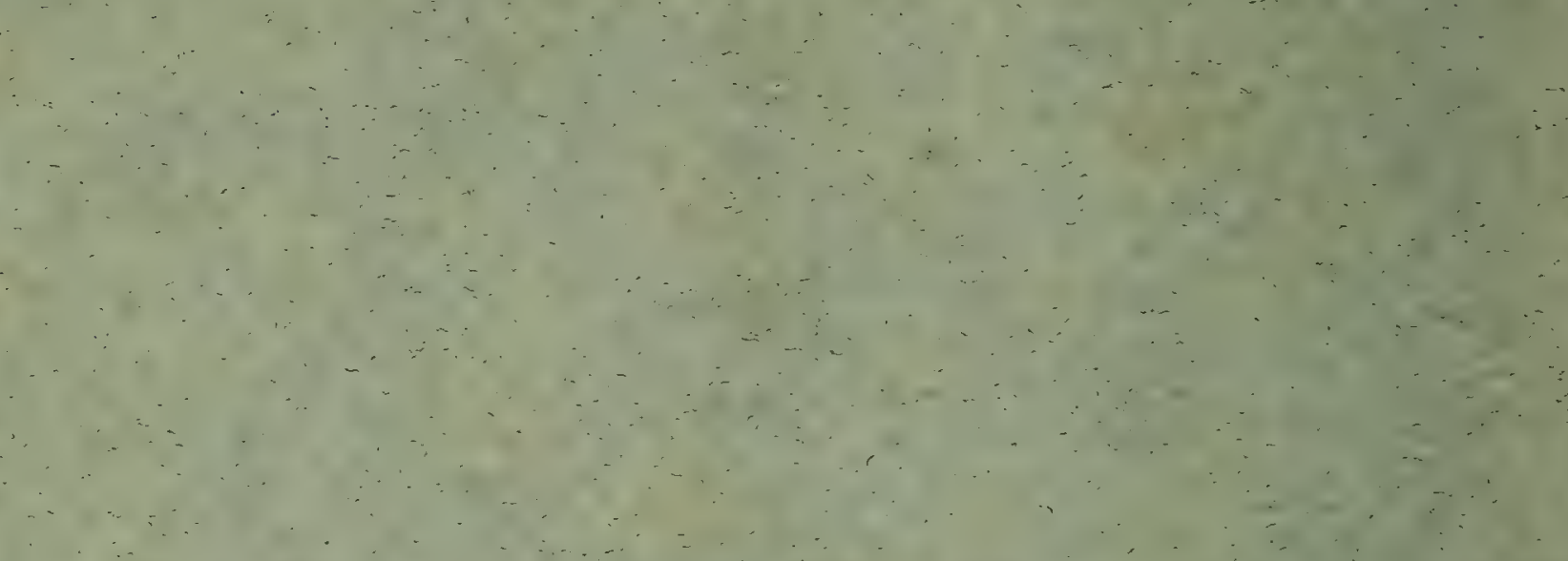


[From the Transactions of the Natural History Society of

Glasgow.]

\section{XXVIII.}

NOTES ON THE LAND AND FRESH-WATER MOLLUSCA OF GREENOCK AND SURROUNDING DISTRICT.

\section{BY THOMAS SCOTT.}

[Read 29th December, 1885.]

Nine years ago, when the British Association held its meetings in Glasgow (in 1876), a number of very useful lists of species belonging to various groups, both of animals and plants, were prepared; and these form 110 inconsiderable part of the Fauna and Flora of the West of Scotland, a book which is very useful to all students of Natural History for reference. Among these lists is one of the Land and Freshwater Mollusca, which includes all the species known to its compiler as occurring in the West of Scotland at that time.

I Through the zeal and energy of various workers, our knowledge of the Natural History of the West of Scotland has been considerably increased during these nine years; and one of the branches which have to some extent been successfully worked up is that of the Land and Fresh-water Mollusca. Not only have new stations been found for the species already known to occur, but several species and varieties have been added to the list of those previously recorded; and no doubt, as the study of this branch becomes more widely and thoroughly carried out, other additions will yet be made. Accordingly, with the progress made in other branches of Natural History, it will possibly be found that ere long the second edition of the Fauna and Flora, referred to in the preface to the first, will be much needed; and it is to be hoped that this will by-and-by be an accomplished fact. Not only will a 
second edition be useful-as the first has been and still is-for ascertaining the number of species and their local habitats; but it will also be of great value for showing how much our knowledge, especially of the local and general distribution of species belonging to the different groups, has been increased within a definite period.

Having devoted part of my leisure, during the past year or two, to the working out of the distribution of the Land and Fresh-water Mollusca about Greenock, as well as in a few places beyond but within easy access of that town, perhaps the result of these researches, embodied in the following Notes and List, may form a contribution-though possibly not a very important one-to the second edition of the Fauna and Flora referred to.

Those who are studying this group of the Mollusca will doubtless have noticed a growing tendency among conchologists to be more and more discriminating. Differences in banding and coloration, as well as in form, which used to be only incidentally referred to in the description of the species, are being more and more separated and raised to varietal or subvarietal rank; and considering the exceeding variableness of many species, it becomes to some extent interesting to note the number and distribution of the different varieties. This critical study of the variations in different species may, if judiciously carried out, be of considerable importance in increasing our knowledge of the relationship of species; but whether the variation in the colour and number of bands of the shells of such species as Helix nemoralis and $H$. hortensis deserves all the attention it is receiving, I will not venture to say. I think, however, that these variations may be regarded as at least worthy of some study by those who have time to devote to it. The local distribution of some of these colour-varieties is rather interesting. By the side of the branch line connecting the quarries in Shielhill Glen with the Wemyss Bay Railway, I 
find a variety of Helix nemoratis with the shell slightly smaller than usual, semitransparent, and of a greenish-yellow colour; but after the animal has been killed the shell becomes opaque and of a more decided yellow colour. This variety-the only one I have noticed at that place-I do not find anywhere else in the district. At the "Moat-hill," Cupar-Fife, I got an almost black variety of the same species. At that place most of the shells are of a blackish colour; but nowhere else in the neighbourhood did I find them so dark, though I have got them of a somewhat similar colour on the Castlerock, Edinburgh. Again, at a place near Kenmore, Perthshire, I gathered some specimens of the same species, of a yellow ground-colour, with dark brown bands; but in adult specimens these bands became broken up and diffused over the ground-colour just before reaching the lip, thus producing a rather pleasing effect. This peculiar band-dispersion was not observed in specimens gathered from any other place in that locality. Accordingly, when variations, though only in colour, are met with, and appear to be strictly local, as in these examples, the reason for such restriction forms a subject of enquiry at once interesting and important.

It will be seen from the List, which has been prepared for me by my son Andrew, that the aquatic species are but poorly represented in our district. With perhaps one or two exceptions, all those recorded are comparatively common, the reason being that there are few places suitable for the propagation of aquatic molluscs. One of the exceptions I have mentioned is Pisidium nitidum. I find this species-along with other two interesting things, viz.: Candona euplectella (an ostracode) and Utricularia minor (a bladderwort)-in some pools by the side of the road leading from Port-Glasgow to Kilmalcolm. These pools occur in a natural hollow through which the road passes, and are probably all that remain of what was once a considerable 
though shallow loch. If that be the case, then this Fisidium and its neighbours in these pools may be the descendants of ancestors dating back to a "remote and venerable antiquity," and not comparatively recent introductions, as some species undoubtedly are. A year or two ago I introduced Sphorium corneum, Bythinia tentaculata, and Limncea stagnalis, into a dam near Greenock; but by the following year they all appeared to have died out, as no trace could be seen of any of them. Though aquatic species be so few about Greenock and the neighbouring districts, there are a good many terrestrial molluses; and my son and I have been able to add not only new stations for some of the rarer species recorded in the list of 1876 , but also a few species and varieties not included therein. The species and varieties added are Amalia marginata, Limax flavus, Zonites alliarius var. viridula, Helix aspersa var. scalariforme, $H$. arbustorum vars. alpestris and flavescens, $H$. rufescens var. alba, $H$. caperata var. major, $H$. rotundata vars. pyramidalis and alba, Pupa umbilicata vars. edentula and albina, Vertigo pygmcea var. pallida, V. substriata, and Clausilia rugosa monst. decollatum (?). This form of Clausilia rugosa was found on a wall by the side of the Inverkip road about four miles from Greenock. My son and I picked up a good number of living: specimens; but these were not all exactly alike, some having lost more and some less of the apical end of the shell. We could not arrive at any conclusion as to the reason why the shells were thus broken; but whatever may have been the cause the animals appeared to be uninjured, as they were as lively as any of those possessing whole shells. We also got a specimen which either had had its shell broken and the broken part attached again-but in an awkward position, being nearly at right anglesor else the end was in process of being broken off. In all the damaged specimens found, we did not see one that had the broken end soldered up, as is 
observed in truly decollated shells, such as Bulimus decollatus. Possibly, however, we may have come on them too soon for that to have taken place; or perhaps the closing up of the broken end would be an after consideration, especially if. it were found that there was some danger of an attack being made on the animal from behind; or perhaps it was a "new departure"-an experiment as to the economising of space in order to lighten as much as possible the burden that had to be carried, so that the "struggle for existence" might be engaged in with a greater likelihood of success;-but the working out of these abstruse questions I leave to those with more subtile intellects.

Among the rarer species, for which new stations are recorded, is Acme lineata, which my son found near the Cloch in 1881. In the following year he found another specimen about the same place, but it was partially crushed. Of the species and varieties mentioned in the annexed List, the only form which I do not possess or have not seen is Zonites purus var. margaritacea, for which, in the 1876 list, the Cloch is given as a habitat.

I have to acknowledge my obligation to the late Dr. Gwyn Jeffreys for his kindness in identifying: a few of the rarer and more critical species mentioned in this List.

The arrangement of the Conchological Society's List of British Land and Fresh-water Mollusca (1883) has been generally followed.

\section{List of Land and Fresh-water Mollusca of Greenock and surrounding District.}

C ON CHIFERA.

$S P H A R I I D A E$.

Pisidium fontinale (Drap.), var. Pulchella, Jenyns.-Mossclave pond, near Greenock.

PUSILLUM (Gmel.).-Mossclave pond, and other places.

NITIDUM, Jenyns.-Pools, side of Kilmalcolm road, near Port-Glasgow. 
284 TRANSACTIONS, NATURAL HISTORY SOCIETY OF GLASGOW.

UNIONIDAE.

Unio MARgARITIFer (L.).-River Gryfe at Denniston, Kilmalcolm.-Thomson-Denniston.

\section{GASTEROPODA. \\ A quatic. \\ LIMN EID E.}

Planorbis spirorbis, Mull.-In pools, Garvel Park, Greenock; Kilmalcolm road. Near Inverkip. -Binnie.

Physa fontinalis (L.).-Cemetery pond, Greenock (probably introduced).

LIMNAA PEREGRA (Mull.).-Various places about Greenock.

var. ovAtA, Drap.-Filter dam, Greenock.

PALUSTRis (Mull.).-Pools, side of Kilmalcolm road, near Port-Glasgow.

TRUNCATULA (Mull.).-Various places about Greenock.

Anoylus Fluviatilis, Mull.-Various places about Greenock.

$$
\text { Terrestrial. }
$$

ARIONIDË.

ARION ATER (L.).-Common.

HoRTENsIs, Fer.-Frequent; Shielhill Glen, Kilmalcolm, \&c.

\section{LIMACIDAE.}

Amalia marginata (Mull.). - Frequent in gardens about

Lmax maximus, L.-Frequent. Greenock.

FLAVUS, L.-Rare about Greenock.

AGRESTIS, L.-Too common.

LEVIs, Mull.-Frequent; Shielhill Glen, and other places.

ARBoRUn, B.-Ch.-Cloch, and other places.

\section{HELICID EE.}

Succinea PUTRIs (L.).-Cloch, and other places.

Vitrina Pellucida, Mull.-Frequent about Greenock.

ZONITES CELLARIUS (Mull.).-Common.

ALLIARIUS (Miller).-Cloch, and other places.

var. VIRIDULA, Jeff.-Cloch (1885).

NITIDULUS (Drap.).-Common.

PURUS (Alder).—Shielhill Glen.

var. MARGARITACEA, Jeff.-Cloch.-Binnie.

RADIATULUS (Alder).-Cloch and Shielhill Glen.

Excavatus (Bean).-Cloch and Shielhill Glen.

CRYstaluinus (Mull.).-Frequent about Greenock.

FULvus (Mull.).-Various places.

Helix lamellata, Jeff.-Cloch (1881).-Andreve Scott.

ACULEATA, Mull.-Cloch, frequent. 
ASPERSA, Mull.-Common about Greenock.

monst. sCALARIFORME, Tayl.-Old wall, Crawford Street, Greenock (1885).

NEMORALIS, L.-Common. Variously banded and marked. HoRTENsis, Mull. - "Scott's Glen," Greenock. - Thomas Fisher, Greenock.

ARBustorum, L.-Frequent about Greenock.

var. ALPESTRIS, Ziegl.-Shielhill Glen.

var. FLA VESCENs, Moq. -Shielhill Glen.

RUFEscens, Penn.-Locally common about Greenock.

var. ALBA, Moq.-Side of wall, Madeira Street, Greenock

HISPIDA, L.-Frequent about Greenock.

SERICEA, Mull.-Towerhill, Gourock, and Wemyss Bay.

FuscA, Mont.-Shielhill Glen and Wemyss Bay.

CAPERAta, Mont.-Wemyss Bay.

var. MAJoR, Jeff.-Wemyss Bay.

RotUNDATA, Mull.-Common.

var. PYRAMIDALIS, Jeff.-Shielhill Glen (1884).

var. ALBA; Moq.-Cloch and Shielhill Glen.

PUPA RINGens, Jeff.-Rottenburn and Shielhill Glens.

var. PALLIDA, Jeff.-Rottenburn Glen and Cloch.

UMBLlCATA, Drap.-Common.

var. EDEnTulA, Moq.-Whielhill Glen.

var. ALbINA, Moq.-Shielhill Glen.

Vertigo PYGMæA (Drap.).-_Shielhill and Rottenburn Glens.

var. PALLIDA, Jeff.-Rottenburn Glen.

SUBSTRIATA (Jeff.).--Rottenburn Glen.

EDENTULA (Drap.).-Shielhill Glen.

BALEA PERVERsA (L.).-Wemyss Bay.

Clausilia Rugosa (Drap.).-Shielhill Glen, Cloch, \&c., frequent. monst. DECOLLATUM?-On a wall on the Inverkip road, about four miles from Greenock (1885).

Cochlicopa lubrica (Mull.).-Common.

var. ?-Cloch (1885).

Carychium mintmum, Mull.-Common.

ACME LineatA (Drap.).-Cloch (1881).-Andrew Scott. 



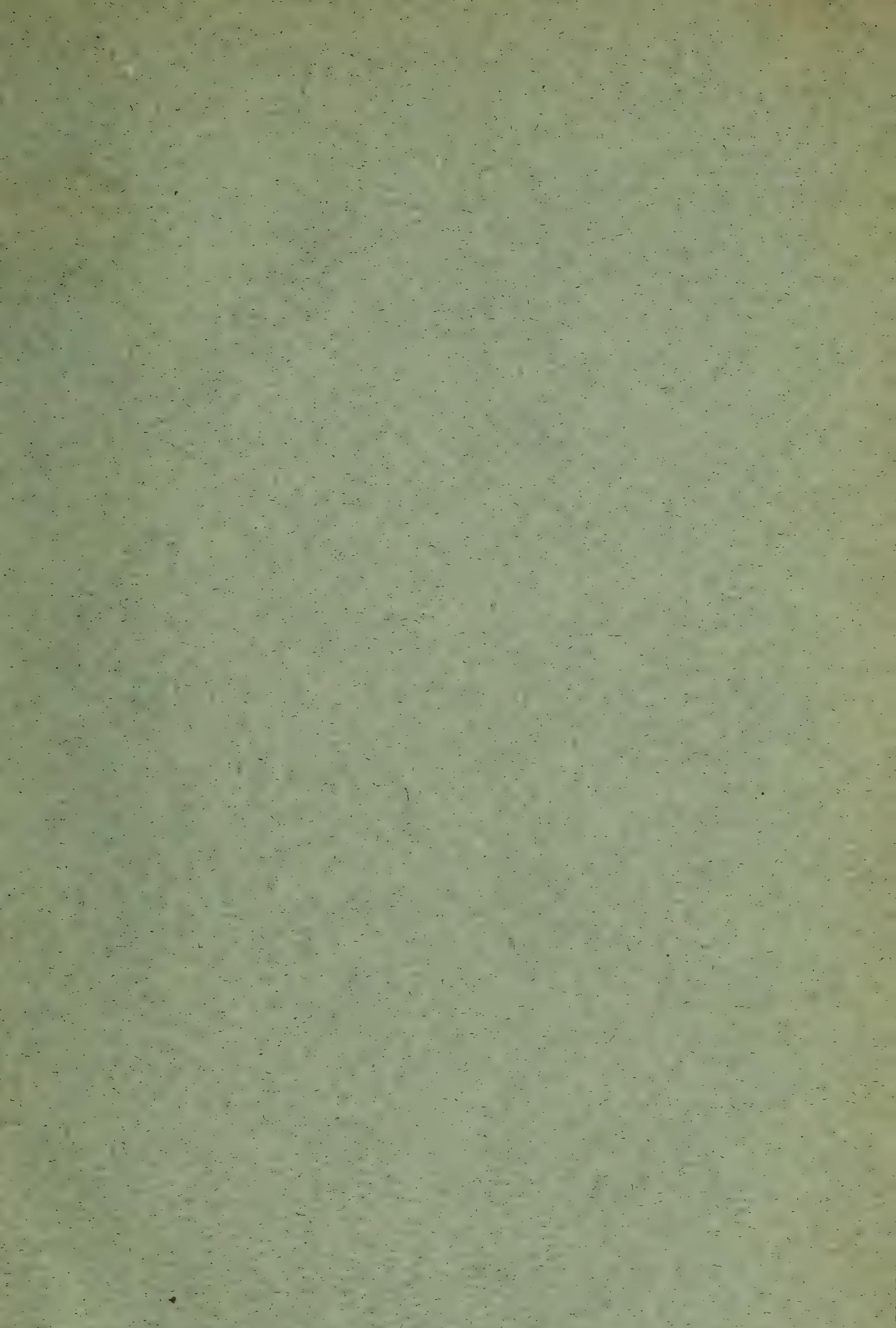



[From the Proceedings of the Royal Physical Society, Edinburgh, 1888-89, Vol. X.] 


XVI. Notes on a few Crustacea and Mollusca new to the Fauna of the Forth, with Exhibition of Specimens. By Thomas ScotT, F.L.S.

I.

(Read 20th February 1889.)

The Scientific Committee of the Scottish Fishery Board have kindly agreed to allow me to exhibit the following specimens to the Society :-

\section{SCHIZAPODA.}

P'revious to the summer of 1887, four species of Schizapods were known to occur in the Firth of Forth, viz.: Boreophausia raschii, M. Sars; Nyctiphanes norvegica, M. Sar's; Macropsis slabberi, Van Ben.; and Mysis flexuosa, Müller. $H$. Goodsir described one or two forms, but the descriptions and figures are not precise enough to enable those forms to 
be ascribed to any known species. Through the investigations carried on by the Fishery Board thirteen additional species of Schizapods have been added to the Forth fauna. Nine of these are recorded in the Board's Report published last year. The species which I now exhibit have been observed since that Report was published. They are as follows :-

\section{Mysidopsis didelphys, Normản.}

Mysis didelphys, Norman, Dredging Report, Trans. Tyne Nat. F. Club, vol. v., p. 270, pl. xii., figs. 9-12.

Mysidopsis didelphys, G. O. Sars, Mon. over de ved Nor. Kyster forekommende Mysider, part ii., p. 20, pl. vii. (1872).

This appears to be a rare species in the Forth. I observed it among some tow-net material collected near Fidra during November last.

\section{Erythrops goësii, G. O. Sars,-new to Britain.}

Mysis erythrophthatma, Goës, Crust. Decap. mar. Svec., p. 18.

Erythrops goësii, G. O. Sars, Mon. over de ved Nor. Kyster forekommende Mysider, part i., p. 24, pl. i. (1870).

I find this species frequent all over the Forth from Iuchkeith to the May Island, as well as outside the May. How it happens to have escaped observation hitherto may not be easily explained. Another species, E. pyymcec, G. O. Sars, which I first observed in East Loch Tarbert, Loch Fyne, was also new to Britain. A third species, E. serratus, G. O. Sars, was discovered by Dr A. M. Norman among the Shetland Islands. They are all small, but easily recognised, when living, by their bright red eyes. The eyes turn whitish after being kept in spirit awhile.

\section{Leptomysis gracilis, G. O. Sars.}

Mysidopsis hispidla, Norman, Report Brit. Assoc. for the Advancement of Science, 1868 , p. 267.

Leptomysis gracilis, G. O. Sars, Mon. over de ved Nor. Kyster forekommende

Mysider, part iii., p. 31, pls. xix., xx (1879).

Several specimens of this species have been observed among tow-net material collected to the east of Inchkeith. Previous Scotch records for it are the Moray Firth and the Shetland Islands. 


\section{Heteromysis formosa, Smith.}

Described by Professor Smith for the United States. I noticed this species in some tow-net material collected to the east of Inchkeith during October last year. Dr A. M. Norman informs me that he procured two specimens of this species at Guernsey in 1856, and that he knows of no other 3ritish habitat for it than the two now recorded. This species comes very near Heteromysis (Chiromysis) microps, G. O. Sars.

\section{COPEPODA.}

\section{Cymbasoma rigidum, J. C. Thompson.}

I observed two specimens of this among tow-net material collected to the east of Inchkeith. Both of them, $\mathrm{Mr}$ Thompson tells me, were females. Unfortunately he found it necessary to dissect them, so that I have only the dissected parts to exhibit. Mr Thompson has the following records of its distribution, viz.: the Canary Islands, the Mediterranean, Jersey (Channel Islands), Lamlash Bay, Arran, Clyde, and Loch Linnhe. It does not appear to have been previously noticed on the east coast of Scotland.

\section{II.}

(Read 20th March 1889.)

\section{MollusCA.}

Stilifer turtoni, Broderip.-Two living specimens found by Miss Janet Carphin (grand-daughter of the late Principal Cunningham) on an Echinus brought by one of the Newhaven fishing boats from near the Isle of May on March last (1888).

Clio borealis, Brug = Clione papitionacea, Pallas.-The specimen now exhibited was captured by me near Inchkeith in January last. 




\section{THE}

\section{ANCIENT LAKES OF EDINBURGH.}

BY

J A M E B B N I E,

Geological Survey of Scotland;

AND

THOMAS SCOTT, F.L.S.,

Naturalist to the Fishery Board of Scotland.

for

Reprinted from the "Proceedings" of the Royal Physical Society, Vol. X., Part i., 1889. 




XV. The Ancient Lakes of Edinburgh. By James Bennie, Geological Survey of Scotland, and Thomas ScotT, F.L.S., Naturalist to the Fishery Board of Scotland.

(Read 17th April 1889.)

The country round Edinburgh is markedly picturesque from the combination of crag and hollow in the more rocky parts, and of softly contoured hillocks with wide open spaces between them, where boulder clay, the peculiar drift of glacial periods, prevails. The crags and hillocks have often captivated the attention of the painter and the geologist, and their forms have been portrayed and their structure described in pictures or essays which have made them famous as illustrations of scenic beauty or geological phenomena. The crags, consisting chiefly of trap-rocks, have been taken as types of volcanic action in open eruptions or injections of lava among sedimentary strata, and the hillocks, composed chiefly of boulder clay, as typical of ice action by ice-sheets or glaciers. The hollows which contain lake marls, silts, or peats, have not been so much studied, partly because such deposits do not obtrude on general observers, and partly because the knowledge to understand them is rarer and more special. But in certain moods these lake marls, silts, or peats have also an attraction not only 
for what they are in themselves, and the circumstances and conditions they represent-istill waters and green pasturesbut also for the contrast they afford to the fire-raised rocks or the ice-laid hillocks they lie among. The crags remind us of volcanic eruptions with lava streams and clouds of ashes, earthquakes and rock-rendings, or injections of molten matter; and the hillocks remind us of ice in all its varied forms and actions-ice-sheets, glaciers, and icebergs,-disrupting rocks by ice wedges, and grinding them to powder by its pressures exerted by the weight by thousands of feet of thickness, and its carrying powers when in motion, by which it transports rocky débris hundreds of miles and deposits it in these hillocks. Visions such as these, suggested by the environments of the lakes, contrast finely with those derived from the life-remains found in these lake marls, silts, or peats, glimpses of quiet lakes in which the liveliest life is that of the pond snail (Limnea), or of the water fleas (Ostracoda), - the one creeping slowly along the surface of the water at its proverbial pace, the other darting through it in little leaps, or nibbling the green confervæ on the leaves or stems of pond weeds; or the still quieter life of the lake peat period represented by the seeds found in them, which tell only of vegetable growth which the eye cannot detect, and we only know by a comparison of now and then.

From these remarks an idea may be had of the object of this paper: It is intended to give brief notices of the localities and positions from which the lake marls, silts, or peats were obtained, and then either separate lists or a general list of the Mollusca and. Ostracoda found in each. The notices will necessarily be brief, and confined mainly to the acquirement of the silts or marls, without any lengthened or detailed statement of the circumstances under which each was deposited. But in one case-that of the marl from the Meadows-we have a description of the lake deposits, and of the manner of their deposition, so far exceeding any we can of our own knowledge give, that a summary of it may be given, referring those who wish for further details to "Edinburgh and its Neighbourhood," by Hugh Miller, pages 6-10 and 134-147. Mr Miller tells us that in 1842 the Meadows- 
the site of the old Borough Loch-were laid open by a series of deep drains, the sections of which exhibited in the "lower and earlier deposits a fine silt separated into laminæ as thin as pasteboard," crowded with impressions of the common water flag and reed, then above the silt "a bed of grey marl composed mainly of lacustrine shells with an occasional land shell." Over this marl occurred in some parts three feet of peat-moss, having still preserved in it the "glossy elytra of beetles in their prismatic tints of azure and green." The silt is considered to be a rain wash of clay and soil from the ground surrounding the old lake. The marl is referred to as the "dead exuvix of generation after generation of freshwater Mollusca for many ages, which at length filled up the depths of the lakes till there was no place for the living; then water mosses sprang up in the marly shallows, and gradually contracted its area, until what had been open water became unsightly morass, and the old Borough Loch was transformed into the Meadows." Mr Miller records two species of Cyclas, three species of Limnea, but makes no mention of Ostracoda, probably because in 1842 their significance as indicative of lacustrine conditions was not recognised.

The lake marls we have examined are ten in number, and were gathered within the last twenty years from the various exposures which occurred during that time; not, it should be mentioned, with the view of being described and their organisms enumerated. as in this paper, but partly as employment for leisure hours, and partly at the instance of $\mathrm{Mr}$ David Robertson, who was engaged in the study of the recent freshwater Ostracoda, and who made some use of the material collected. It was only within the last few months that the idea of making this use of the surplus material occurred to us as preliminary to a more exhaustive study of the freshwater Crustacea of the Edinburgh district which one of us (T. Scott) intends to make. Six of the marls or silts were obtained from within or immediately around Edinburgh; three-those of Corstorphine, Hailes, and Reuhall - about four miles west of it; and one-that of Kethymyreabout six miles to the north across the Forth, and is included because it conforms, in the conditions and circumstances of 
its deposits, to the most typical lakes within the immediate range of our inquiry. The times represented by these lake silts or marls extend from the end of last century, as in the cases of the North Loch and the Borough Loch, back to the interglacial lakes of Hailes and Redhall. By the end of last century is simply meant that about that time the North Loch and the Borough Loch became extinct as lakes. As to the time when they first became lakes, Hugh Miller's later suggestion in 1854 - by which he amended his first suggestion in 1842 by extending their period from the time of the Noachian flood about 4000 years ago to the times of the later upheavals of the land, which in the case of the higher lying lakes might be four times 4000 years ago-must be taken as the nearest approach to the actual date we can at present make. The interglacial lakes of Hailes and Redhall must be considerably earlier in date than any of the others, which must all be reckoned postglacial; but to put it in figures is beyond our present intentions.

\section{The North LoCh.}

The material from this lake was given to us in 1871 by the late $\mathrm{Mr} \mathrm{J}$. Wallace Young, who obtained it from his uncle, Mr Bell, for many years chief engineer of the North British Railway. It was taken from the excavations for the new arrival platforms made at that time for the trains coming from the west. We cannot give any details of the thickness or extent of the deposit of which it was a part, but as it is said that the North Loch stretched from the Castle eastward to beyond the North Bridge, it was probably extensive, and most likely represented several diverse conditions determined by the depth and exposure of the water. The material from which the shells and Ostracoda were obtained was not marl as in most instances, but a brown earthy mud, which did not separate into dust or grains, but remained in small solid pellets even after boiling a considerable time. It is therefore evidently from the latest deposit ere the loch was drained dry, and the life remains are probably not more than 100 years old. When the railway was made

VOL. $X$. 
in 1843 , all the deposits laid down by the waters of the loch would be thoroughly exposed; but we have not seen any notices of the exposures at that time.

\section{Bristo Port Lake.}

In a cutting for a sewer at Bristo Place in 1872, a deposit of black mud was exposed, portions of which were secured and washed. A few seeds were found in it, and a good number of oblong bodies somewhat boat-like in shape, yellowishbrown in colour, with two black spots or dots near the middle. These bodies have been determined by Dr Woodward and Professor G. S. Brady to be the epiphia or winter eggs of Daphnia, and being such, they prove that a small lake or water pool existed in the grounds just outside of Bristo Port. At that time Edinburgh was a walled city, probably about the time of Flodden, say in the fifteenth century. No Mollusea or Ostracoda were found with them, but they of themselves are sufficient to prove lake-like conditions.

\section{Lake, North Side of Blackford Hill.}

The material from this place was sent as a curiosity to Professor A. Geikie in 1872 by a builder who had made some drains in the hollow on the north side of Blackford Hill. No particulars were given of the circumstances of the deposit, but it is evident, from the character of the material itself, a perfectly pure marl, that it had been deposited from the waters of a small lake formed by, and probably drained by, the Pow Burn, which flows through the hollow. It was probably of long standing, as the marl was quite free from any clay or earth, or vegetable matter, in the shape of peat, or stems or roots of water plants; the only vegetable remains in it being seeds of Chara, which are very numerous, and in good preservation.

\section{JORDANVALE LAKE。}

The Suburban Railway cut through a series of recent deposits in the hollow between the ridge on which Morning- 
side Asylum stands and that in which the Plewlands Cemetery is situated. The Jordan Burn flows through the hollow, and doubtless now drains off the surplus water that once stagnated in it and formed a lake. The section cut through was (1.) vegetable soil, 2 feet; (2.) peat, 3 feet; (3.) marl, irregular in thickness, but generally 2 to 3 feet. In places, however, it went down 15 or 16 feet, but in these places it extended only 2 or 3 feet in breadth, showing that the marl occupied deep holes or "plums" in the bottom of the lake. The marl was free from peaty matter, but was crowded with stems of water plants, very thin and ribbonlike, of a yellowish-green hue. In washing they could be easily floated off, and the animal remains secured without any difficulty. The marl and peat extended along the railway cutting several hundred yards from near the rock section at Myreside to within a short distance of Morningside Station, and its breadth was of course only shown by that of the railway, but it probably extended from side to side of the hollow, which might be 100 yards.

The Borough Loch, now The Meadows, Ėdinburgh.

The material examined was obtained in 1871 during operations then in progress to level the West Meadows and raise them several feet higher. The soil was lifted and drains made, and rubbish from building operations in the town laid down to the thickness of 3 or 4 feet in some places, and in others 6 or 7 feet, and then the soil was spread over the surface, and the grounds restored to grass again. The depth of the marl was, I think, about 3 feet, and was topped by peat as described by Hugh Miller in the article already referred to. The marl washed with difficulty, and there were comparatively few Ostracoda in it, which we suppose due to their cast-off coverings having, through decay, lost the animal matter interwoven in their substance. The mineral constituents were resolved into white mud, which is the principal component of these old lake marls. The lake from which the Meadows' marls were shed was well known as the Borough Loch. 


\section{Holyrood LaKe.}

In the years 1887 and 1888 a new sewer was made through the hollow that lies between Salisbury Crags and the slope of St John's Hill, and several beds of gravel, clay marl, and peat were cut into, which marked the site of an old lake. For distinction sake it may be called the Holyrood Lake, as, from the configuration of the ground, the lake deposits must extend under the palace. These lake deposits have been referred to by three of our local geologists:first by Mr Andrew Taylor in describing the strata cut into in making a gas tank, Trans. Geol. Soc. of Edinburgh, vol. v., p. 44; secondly by $\mathrm{Mr}$ John Henderson, also in same Transactions, vol. v., p. 407; and thirdly by Messrs J. A. Johnston and J. Lindsay in Trans. Edinburgh Naturalist Field Club, vol. ii., p. 135, who give a plan and section from measurements and bores furnished by Mr J. Massie of the Burgh Engineer's Office. One of the bores may be quoted entire, as it gives the strata passed through from the surface to the rock-head-(1.) Forced material, $3 \mathrm{ft} .2$ in. ; (2.) yellow clay, 2 ft. 4 in.; (3.) peat, 3 ft.; (4.) marl, 9 ft.; (5.) mud (white and brown), 2 ft. 6 in.; (6.) clay (blue and red), $1 \mathrm{ft}$. 9 in.; (7.) rough gravel, 4 ft. 6 in.; (8.) clay and small stones, 5 ft. 6 in.; (9.) blue clay, 7 ft. 7 in.; (10.) Blaes;-in all, 39 ft. 3 in., 26 feet of which we may consider as deposited by the ancient lake, proving that the lake period was a long one from first to last. Those who wish further details may consult with advantage the three papers to which we have referred, especially that of Johnston and Lindsay, which is the most minute in its descriptions. For ourselves we shall notice roughly the section as it appeared to us while gathering the samples of marl and clay. Lowest was a bed of sand and gravel, the gravel being well rounded and the sand free from clay or earth; then a bed of white clay without shells, or only a few; then a marl crowded with shells, very cohesive and felted with regetable débris; then uppermost a bed of peat, brown and compact, in which twigs and portions of wood were frequent. The shells, as usual in these 
old lake marls, separated with difficulty from the white mud; and the Ostracoda were loth to "rise again" from the charnel dust in which they had been buried. The white clay was more amenable to the persuasions of washing and boiling, and the Ostracoda came forth in great numbers from the charnel dust. There was very little vegetable matter in this clay, merely thin ribbon-like stems of water plants, of which only the epidermis remained. There were a few seeds of the larger plants, and those of Chara were in thousands.

The Holyrood Lake must have been of very ancient date, probably existing a long time before the building of the Abbey or even the Palace-that time in sooth when the "doe made its den" in the woods which we know once occupied the site of Holyrood.

\section{Corstorphine LaKe.}

On the farm of Broomhouse, at the distance of several hundred yards from Corstorphine Station on the line of the short cut railway from the Forth Bridge, it was found necessary to make a culvert for an underground water-course, and a cutting 7 feet in depth was made for that purpose. The soil cut into was not boulder clay or gravel as in other cuttings in the neighbourhood, but lake silt and peat. The silt was crowded with freshwater shells and Ostracoda, and the peat was composed chiefly of the stems of water plants, being essentially a water peat. The cutting was not seen by us, and we cannot give details of the section. From answers to inquiries, however, we learnt from the workmen that the peat was not lying above the silt, but interstratified with it. The 7 feet did not exhaust the silt with shells, which was evidently several feet more, as the culvert had to be founded upon concrete. The ground through which the underground water-course ran is still slightly lower than the surrounding fields, and there can be no doubt that a small lake existed here for a considerable time ere say 10 feet of silt and shells could be formed, nearly every grain of which seems to have been once organic. The plain in which this old lake occurs, extending from Edinburgh to near Gogar, is said in the 
Geological Map of the district (Edinburgh, Sheet 2) to be an old alluvial plain, and from traditions we learn that the eastern part of it from Edinburgh to Corstorphine was formerly a marsh difficult to cross, especially at night, and that a beacon light used to be affixed to the gable end of Corstorphine Church to guide benighted wayfarers safely across it. This little lake, of which the silt and the shells are now the only memorials, was doubtless one of many which once studded this plain in parts with water pools, each not many acres in extent, in which the little life which luxuriates in plashy places dwelt for many generations through a lengthened period ere a bed of organic silt 8 or 10 feet in thickness could be elaborated, every grain of which silt was without doubt once alive.

\section{Kethymyre Lake.}

In making a private railway from Binnend Oil Works to Kinghorn in 1887, an old lake marl was cut through in a low flat hollow named Kethymyre at the foot of Rodanbraes, about two miles N.E. of Burntisland. The section exhibited was as follows:-(1.) Pèat, $1 \mathrm{ft}$; ; (2.) marl, $1 \mathrm{ft}$.; (3.) greenish clay with shells, $3 \mathrm{ft}$; (4.) clay without shells, $1 \mathrm{ft}$; (5.) boulder clay. The peat was rusty brown and very loose in texture, and an oak tree trunk about $1 \frac{1}{2}$ feet in diameter stretched across it. At one place an irregular bed of sand 3 to 4 feet in thickness, and striped with bands of light and dark red sand, seemed at one place to be upon the marl and at another upon the boulder clay. I note this as giving a rather ancient date for the lake of Kethymyre, but still the name shows that it was extant during the human period. The height of this flat space is about 150 feet above the sea, and its situation not far from the shore of the 100 -foot beach period. These peat and marl beds are still (1889) accessible just west of the bridge which carries the road to Kinghorn over the railway.

Ancient Lake at Hailes Quarry。

In the summer of 1886 a tirring in the N.E. of Hailes Quarry exposed deposits which could only have been made 
by the waters of an ancient lake, as the sections which I will detail will prove. Upon the rock head lay 3 or 4 feet of boulder clay; above this were several feet of sandy clay in which were two layers of peat, one about two inches, the other about a foot in thickness. What lay upon the sandy clay was uncertain, as the ground had been much disturbed by alterations caused by the operations of the quarrymen, and sometimes quarry débris rested on it, and sometimes what seemed to be natural soil, and at one place a patch of boulder clay which, seemingly in its natural position, would indicate an interglacial position for the old lake silts and peat. But that this sandy clay with its layers of peat belonged to some of the later stages of the glacial period is certain, as in the middle of it were two trap boulders standing side by side, each about 6 feet in height, and 2 or 3 feet in diameter, and only 4 or 5 inches apart. They seemed as if they had been originally only one, and had been split in two in situ. Round these boulders the sandy clay had been deposited, and the gap between was filled with vegetable matter which had grown in the lake, and been drifted into the gap or slit. Now it was in the laminated clay at the bottom of these old lake deposits that the shells and Ostracoda were fcund, and within 2 feet or so of the base of these boulders under which the laminated clay extended.

From the washings of the peat many seeds were obtained, 25 species of which have been determined by $\mathrm{Mr}$ C. Reid; and also many insect remains, chiefly beetles, nine species of which have been determined by Mr C. O. Waterhouse of the British Museum. There was no marl in this old glacial lake of Hailes, and the shells and Ostracoda occurred in silt.

There are other evidences which may be stated here that seem to prove that the peats and silt found in the northeast corner of Hailes Quarry were deposited in an interglacial lake, or perhaps more correctly in the lake-like expansions of a water-course or river. In 1886 a tirring in the southwest corner of Hailes Quarry, directly beneath the farmhouse of Kingsknowe, showed in section, first, upon the rock head 
1 foot or so of boulder clay, then 18 inches of fine laminated silt, then about 10 feet of sand and gravel with large waterworn boulders of trap rock. Upon this gravel lay 20 to 30 feet of boulder clay, with the farmhouse of Kingsknowe crowning it. At the west end of this section the sand and gravel abutted abruptly against the boulder clay, which then extended from the rock head up to the farm buildings as a steep cliff more than 30 feet in height. The eastern side of this bed of sand and gravel was not seen, as it was covered by a mass of run débris which had slipped down from above. Beyond this slipped stuff, the sand and gravel was again seen resting on the rock with a much larger proportion of waterworn blocks. It was clear from this fact that the gravel was the débris of a river which once occupied the hollow it now fills, and that the quarry had cut it obliquely, exposing its western end, while the eastern was hid by the débris. In 1886 this gravel was free from vegetable remains, but in 1984 occurred several small lumps of peat that had evidently been torn from a peat bed, and carried away and deposited in the gravel forming by the torrential action of the river. These stray pieces of peat, when washed, were found to be merely masses of granular vegetable cébris, quite identical with peaty matter washed from sand got in 1887 in situ in the southeast corner of Hailes Quarry, which consisted only of vegetable débris and spores of Isoetes, which latter were innumerable. Above this peaty sand were 6 or 7 feet of boulder clay, brown and rusty from being near the surface, and in it were some trap boulders 2 feet in diameter. Between these gravel and peat beds on the south side of the quarry, and the peat beds in the sandy clay in the north-east corner, there is the great gap of the quarry, and all physical connection is now wanting between them, but there can be little reasonable doubt that both are parts of the same series of deposits which took place at the same time under similar circumstances, and, taken together, they suggest a river, rapid and torrential in parts, and in others, slow, and with lake-like expansions, in the quieter water of which the shells and Ostracoda lived, and the plants grew, whose remains we now find buried in its peats and silts. 


\section{Ancient Lake at New Redhall Quarry.}

In 1874 , when this quarry was first opened, a lake peatbed was disclosed beneath the boulder clay, and resting partly on sand lying upon the rock and partly on a lower boulder clay. A description and sketch of the section as then exposed is given by $\mathrm{Mr}$ J. Henderson in the Trans. of the Geol. Soc. of Edinburgh, vol. ii., p. 391. An attempt was made to get the plant remains found in the peat-bed named, but it was unsuccessful. At various tirrings since 1874, the same lake peat-bed was exposed, and, though further attempts were made to get the plants and other things named, nothing effective was done till 1887, when $\mathrm{Mr}$ Clement Reid, of the Geological Survey of England, succeeded in naming about 46 species of plants, whose names and characters will be found in his paper on the "Early History of the British Flora," published in the Annals of Botany for August 1888. At the same time, through the kindness of Mr Reid, the beetles found along with the seeds were submitted to $\mathrm{Mr}$ C. O. Waterhouse of the British Museum, who was able to name about 30 species. The samples of peat from the tirring of 1887 were got from the coup, the bed in situ having been rendered inaccessible by a landslip. In 1889, during another tirring, access was got to the peat-bed in situ, and many samples taken from different parts of the bed were subjected to improved methods of research, with results far exceeding those obtained previously. The seeds and beetles obtained, greatly surpassed in number those got before, and the record will be considerably extended. One interesting addition was a number of Ostracod shells, which come as an agreeable surprise, for it has been generally held by experienced students that these shells, which consist, partly at least, of limy matter, would be dissolved by the carbonic acid of the decaying peat, and nothing left to tell of their existence in the lakes in which the peat was formed.

The section in which the lake peat occurred in 1889 consisted of - (1.) sandy stony clay, presumably rotten boulder clay, resting on the rock; (2.) brown compressed vegetable matter 4 inches in thickness, with only a few seeds of the 
bogbean and many spores of Isoetes. This compressed peaty layer was distinctly laminated, and seemed to consist wholly of stems of reeds. It lay partly on several large trapboulders, and partly in the hollow spaces between them, showing that it had been deposited on an uneven bed out of which the boulders protruded. (3.) The next layer was a mud or silt, three or four inches in thickness at the north end of the section, but increasing to as many feet at the south end-only rootlets were found in several samples of it. (4.) A bed of peat about three feet in thickness in the middle of the section where it was best exposed and most typical. The peat consisted chiefly of vegetable mud or earth felted with mosses or reed stems or simple vegetable fibres, probably the compressed rootlets of plants. From being felted with these it would not dissolve or separate, and had to be crushed mechanically by the hand in water, which made the washing and separating of the seeds and other things from the matrix rather laborious, but the labour was well repaid by the extraordinary number of seeds, insect remains, chiefly beetles; and cases of caddis worms of two or three forms, one of which was in hundreds or rather thousands. Full lists of all, we hope, may form the subject of a future paper, when the identification of the whole is completed. The uppermost six inches of this bed was even more felted with mosses and reed stems, some parts consisting wholly of them cemented by a little reddish-brown mud. A small quantity of the finest portion of this mud was examined in 1887 for Diatoms by Mr R. Kidston and Dr J. Rae, R.N., who found in it about 40 species, a list of which-as determined by them-is given at page 154 . Throughout the whole of this peat-bed stones were frequent, mostly sandstones and trap, but a few were of silurian grit or greywacke. (5.) Above this peat-bed stood, in section, 10 or 12 feet of stony clay, but being nearly covered by vegetation its character was not visible at a glance, though there could be little doubt it was boulder clay. Near the southern end of the peat-bed is an assemblage of waterworn boulders with gravel, resting on the rock, and it is likely that, as at Hailes, a river with quiet lake ex- 
pansions existed here also during some part of the glacial period.

In conclusion we wish it to be distinctly understood, that from the furtive manner in which the material from these old lake deposits was collected, the number of Mollusca and Ostracoda given in our lists cannot be taken as exhaustive for all or any of the deposits, but tentative merely, and that new exposures of these or any other lake deposits in or around Edinburgh would likely yield more species than we have here recorded. In the division of labour connected with this paper, it should be stated that the material was collected by Mr J. Bennie, and the naming of the species and the identification of their characters was done entirely by Mr Scott.

\section{The "NoR' Loch."}

We were able to procure from the old bed of this loch only a small quantity of material for examination, and in it organic remains, both animal and vegetable, were fairly abundant. Among the organic remains were several species of Ostracoda,-two of which, viz., Cypris prasina, Fischer, and Candona candida (Müller), were moderately common,- and some imperfectly preserved molluscan shells.

The following are the species of Ostracoda and Mollusca from this deposit identified by us.

It may be stated that the site of the loch is about $2 \frac{1}{4}$ miles from the sea, and about 150 feet above sea-level.

\section{MOLLUSCA.}

Pisidium pusillum (Gmelin). One valve.

Limnoea peregra (Müller). A few imperfect specimens.

OSTRACODA.

Cypria ophthalmica (Jurine). Rather scarce.

Cypris prasina, Fischer. Common.

Erpetocypris reptans (Baird). Rather scarce.

Candona candida (Müller), ơ $q$. Both forms common.

lactea, Baird. Frequent.

Limnicythere inopinata (Baird). Frequent. 
Lacustrine Deposit, North Side of Blackford Hill.

This deposit does not require any special description beyond that already given. The organic remains observed in the material examined are such as are usually found in small lochs or ponds. The remains of comparatively few Molluses were observed. The following comprise all the species of Molluscs and Ostracods we identified in the material examined :-

\section{MOLLUSCA.}

Pisidium fontinale (Draparnaud). Frequẹnt.

" pusillum (Gmelin). Very conmon.

Sphoerium corneum (Linné). Scarce.

Planorbis glaber, Jeffreys (P. parvus, Say). Rare.

Limncea peregra (Müller). Scarce.

OSTRACODA.

Cypria ophthalmica (Jurine). Not common.

" serena (Koch). Common.

Cypridopsis vidua (Müller). Frequent.

Potamocypris fulva, Brady. Common.

Candona candida (Müller). Not.common.

" lactea, Baird. Frequent.

" pubescens (Koch). Rare.

" fabceformis (Fischer). Frequent.

Ilyocypris gibba (Ramdohr). Scarce.

Limnicythere inopinata (Baird). Common.

\section{Lacustrine Deposit at Jordanvale.}

The site of this loch is about 4 miles from the sea and about 300 feet above sea-level. Molluscan shells, especially Limnoce peregra, were fairly abundant in this deposit, as were also those of the more comnion Ostracoda. The following species have been identified:-

\section{MOLLUSCA.}

Sphcerium corneum (Linné). Rather scarce.

Pisidium nitidum, Jenyns. Scarce.

" pusillum (Gmelin). Common 
Planorbis glaber, Jeffreys. Frequent.

" nautileus (Linné). Scarce.

Limnoca peregra (Müller). Very common.

Physa fontinalis (Linné). Rare.

\section{OSTRACODA.}

Cypria serena (Koch). Rare.

Cypris incongruens, Ramdohr. Rare.

Erpetocypris reptans (Baird): Common.

Cypridopsis vidua (Müller). Scarce.

Potamocypris fulva, Brady. Frequent.

Candona candida (Müller). Common.

"faboeformis (Fischer). Rare.

Limnicythere inopinata (Baird). Frequent.

\section{The Meadows.}

Hugh Miller has so fully described this interesting locality, that little more can be said about it than is stated in "Edinburgh and its Neighbourhood." Molluscan shells have. been observed in great abundance in the deposit, and Hugh Miller refers to at least 9 species as having been found while the meadows were being drained. One species of Planorbis, described by him as having "a delicate dorsal keel," which was probably $P$. complanatus, - a species still common in Lochend and Duddingston Lochs, - we have not seen, and we have only been able to identify one species of Limnaca; neither have we been able to recognise Planorbis glaber, mentioned by R. Etheridge, jun., as having been found in this deposit. ${ }^{1}$ Ostracod remains were not very abundant, but among those observed is Darwinula stevensoni, which has only recently been found as a post-tertiary fossil at Whittlesea, England.

The following are the only Scotch localities where Darwinula has been observed living: Loch Fell, Wigtownshire; Lochs Aber and Ruter, and White and Borean Lochs, Kirkcudbrightshire; Broom Loch, Dumfriesshire; and Loch Mack, near Oban. Darwinula seems to have been of frequent

1 Trans. Geol. Soc. of Edinburgh, vol. ii., p. 223. 
occurrence in the Borough Loch. The following are the Mollusca and Ostracoda observed in the material examined by us from this locality:-

\section{MOLLUSCA.}

Pisidium nitidum; Jenyns. Frequent. " pusillum (Gmelin). Frequent.

Planorbis nautileus (Linné). Scarce.

Valvata cristata, Müller. Common. , piscinalis (Müller). Common.

Limnoec peregra (Müller). Very common.

Several variations in form occurred in the last two species, and especially in the Limnoca.

\section{OSTRACODA.}

Cypria serena (Koch), Frequent.

Erpetocypris reptans (Baird). Rare.

Candonx candida (Müller). Frequent.

lactec, Baird. Rare.

Darvinula stevensoni, Brady and Robertson. Frequent.

\section{Holyrood Lake.}

Though Molluscan remains were fairly abundant in this old lake deposit, only five species have been identified by us, and these are common freshwater species. Ostracoda on the other hand were numerous, both in individuals and species. No fewer than twelve species belonging to nine genera have been observed, and one species, viz., Limnicythere sancti-patricii, is now recorded for the first time as fossil in Scotland. The following are the species of Mollusca and Ostracoda observed by us.

NoTE.-In a paper read at a meeting of the Edinburgh Field Naturalists and Microscopical Society, in February 1888, by Messrs J. A. Johnston and J. Lindsay, on "An Ancient Lake Deposit in Queen's Park" (here called Holyrood Lake), two species of Mollusca, not found by us-viz., $V x l$ vatce cristate and Planorbis nitidus, - are recorded as having been observed in the material forming this deposit. ${ }^{1}$

${ }^{1}$ See Trans. Edin. Field Natur. and Micro. Soc., vol. ii., p. 138 (Part 2). 


\section{MOLLUSCA.}

Limnoca peregra (Müller). Frequent, but many of them fragmentary.

Planorbis glaber, Jeffreys. Scarce.

Valvata piscinalis (Müller).

Pisidium pusillum (Gmelin). Frequent often perfect. " fontinale.

\section{Ostracoda.}

Cypria lcevis (O. F. Müller). Rather scarce.

$"$ serena (Koch). Rather scarce.

Cypris incongruens, Ramdohr. Rare.

Erpetocypris reptans (Baird). Frequent.

Cypridopsis villosa (Jurine). Common.

Potamocypris fulva, Brady. Frequent.

Candona candida (Müller). Very common.

" lactea, Baird. Rather rare.

"pubescens (Koch), Rare.

Ilyocypris gibba (Ramdohr). Common.

Limnicythere sancti-patricii, Brady and Robertson. Frequent.

Cytheridea lacustris (G. O. Sars). Common.

\section{Corstorphine Lake near Station.}

This deposit is about 200 feet above sea-level, and 4 miles from the sea; in it Molluscan remains were abundant and in good preservation. Ostracod shells were also numerous. The following are the species of Mollusca and Ostracoda identified by us :-

\section{MOLLUSCA.}

Pisidium fontinale (Draparnaud). Frequent. " nïtidum, Jenyns. Frequent.

Planorbis glaber, Jeffreys. Rather common.

" nautilens (Linné). Rare.

Limncea peregra (Linné). Very common.

" truncatula (Müller). Not common. 
OSTRACODA.

Cypria loevis (O. F. Müller). Frequent.

Cypris incongruens, Ramdohr. Rather rare.

Erpetocypris reptans (Baird). Not very common.

Ilyocypris gibba (Ramdohr). Frequent.

Candona candida (Müller). Common.

" pubescens (Koch). Rather rare.

Cypridopsis aculeata (Lilljeborg). Rather common.

" vidua (Müller). Frequent.

$" \quad$ villosa (Jurine). Frequent.

Limnicythere inopinata (Baird). Frequent.

\section{KeTHYMYRE.}

This deposit occurs between Burntisland and Kinghorn, and is about 150 feet above sea-level, and about threequarters of a mile from the sea. There were few Molluscan remains in the material from this deposit, but the shells of Ostracoda-mostly valves-were fairly abundant. The following are the species observed:-

\section{MOLLUSCA.}

Pisidium nitidum, Jenyns. A few specimens.

Valvata piscinalis (Müller). Several specimens-some of them eroded as if they had been acted on by an acid.

Planorbis albus (Müller). Two imperfect specimens.

Limnoca peregra (Linné). A few specimens.

\section{OSTRACODA.}

Cypria serena (Koch). Frequent.

Erpetocypris reptans (Baird). Rare; valves only.

Ilyocypris gibba (Ramdohr). Rare; valves only.

Potamocypris fulva, Brady. Frequent; many perfect.

Candona candida (Miiller). Frequent; mostly valves.

? pubescens (Koch). Rare; a single valve.

Limnicythere inopinata (Baird). A few specimens;

some perfect. 


\section{HAILES QUARRY.}

The Mollusca and Ostracoda from this place were found in silt and not in marl, and were tolerably well preserved. In some parts of the bed a solid peaty mud has recently been found (1889), in which occur innumerable chitinous scales which are provisionally referred to Daphnia, also many small brown dises which are supposed to be the statoblasts or winter eggs of freshwater polyzoa. In the solid peaty mud of Hailes, as well as in that of Redhall, many round black shining bodies occurred, probably the cases of water mites-Acaridoe.

\section{MOLLUSCA.}

Pisidium fontinale (Draparnaud). A few whole valves and some fragments.

Planoibis glaber, Jeffreys. Several specimens.

Limncea peregra (Müller). Rather scarce, and imperfect. Vertigo pygmoea (Draparnaud). Imperfect. This has very likely been washed into the deposit from the vicinity, as it is not unusual to find this and other Vertigos beside freshwater lochs.

\section{OSTRACODA.}

Candona candida (Müller). Not common; valves only. Ilyocypris gibba (Ramdohr). Frequent; valves mostly. Cytheridea torosa (Jones), var. teres. Not common.

\section{ReDHaLl QUaRry.}

The Ostracoda were found in the solid peat mud from the upper layer of peat by the improved methods of washing recently adopted, and the number of each species is comparatively small at present, but it is expected that the continuation of these researches will yield an increased number of species as well as individuals. This record of their occurrence in peat at Redhall it is also hoped will induce research for Ostracoda in other lake peats, as, however

VOL. X. 
unlikely it may appear that the shells of Ostracods can resist decomposition, yet here we have proof that they have done so. A considerable number of the freshwater foraminifer, Deflugia, sp., also occurred along with the Ostracoda.

\section{MOLLUSCA.}

Pisidium pusillum (?), Gmelin. One immature specimen.

OSTRACODA.

Cypria ophthalmica (Jurine). This species was of frequent occurrence, but few were well preserved, and some had the appearance of being coated with a ferruginous dust.

" serena (Koch). One or two specimens.

Cypris incongruens; Ramdohr. One specimen.

Erpetocypris olivacea (?), Brady and Norman. One specimen.

Candona rostrata, Brady and Norman. One specimen. This is the first record of the occurrence of this species as a post-tertiary fossil, but one of the Authors has since found it in a somewhat similar deposit in Ross-shire, in moderate abundance.

Candona candida (Müller). One or two specimens.

Limnicythere inopinata (Baird). One specimen.

\section{MOLLUSCA}

Found in the various Lacustrine Deposits.

The following is a full list of the Molluscan remains observed in the various lacustrine deposits referred to in the preceding notes :-

Sphoerium corneum (Linné).

Pisidium fontinale (Draparnaud).

" pusillum (Gmelin).

"nitidum, Jenyns.

Valvata piscinalis (Müller).

" cristata, Müller. 
Planorbis nautileus (Linné).

albus, Müller.

" glaber, Jeffreys.

Physa fontinalis (Linné).

Limnoea peregra (Müller).

" truncatula? (Müller).

Vertigo pygmoea (Draparnaud).

The following is a full list of the OsTRACoD remains observed in the various lacustrine deposits referred to in the preceding notes. As considerable changes have quite recently been made in the nomenclature of the Ostracoda, and especially of the fresh and brackish water species, we have considered it advisable to add a synonomy sufficiently full to enable those not conversant with this group to more easily recognise the various forms referred to.

\section{OSTRACODA}

Found in the various Lacustrine Deposits.

Family Cy PRIDID E.

Cypria ophthalmica (Jurine).

Cypria, Zenker.

Monoculus ophthalmicus, Jurine, Hist. des Monocles, p. 178, pl. xix., figs. 16, 17.

Cypris compressa, Baird, Trans. Berw. Nat. Club, vol. 1, p. 100, pl. iii., fig. 16 .

" compressa, Brady, Mon. rec. Brit. Ostrac., 372, pl. xxiv., figs. 1-5 ; pl. xxxvi., fig. 6 .

Cypria ophthalmica, Brady and Norman, Mon. M. and Fw. Ostrac. of the N. Atlantic and N.-W. Europe, p. 69, pl. xi., figs. 5-9 (1889).

Cypria lævis (O. F. Müller).

Cypris lcevis, Müller, Entom., p. 52, pl. iii., figs. 7-9.

" minuta, Baird, Brit. Entom., p. 155, p. xviii., figs. 7, 8.

" ovum, Brady, Mon. rec. Brit. Ostrac., p. 373, pl. xxiv., figs. 31-34, 43-45; and pl. xxxvi., fig. 8.

Cypria laevis, Brady and Norman, Mon. M. and Fw. Ostrac. of the N. Atlantic and N.-W. Europe, p. 69 (1889). 


\section{Cypria serena (Koch).}

Cypris serena, Koch, Deutschlands Crustaceen, H. xxi., 22.

, lavis, Brady, Mon. rec. Brit. Ostrac., p. 374, pl. xxiv., figs. 6-8.

Cypria serena, Brady and Norman, Mon. MI. and Fw. Ostrac. of the N. Atlantic and N.-W. Europe, p. 70 (1889).

Cypris, Müller.

\section{Cypris incongruens, Ramdohr.}

Cypris incongruens, Ramdohr, Ueber die Gattung Cypris; der naturforsch. Freunde zu Berlin Magazin, 2 Jahrg 1808, p. 86.

" aurantia, Baird, Brit. Entom., p. 159, tab. xiv., fig. 13.

" incongruens, Brady, Mon. rec. Brit. Ostrac., p. 362, pl. xxiii., figs. 16-22 (1868).

" incongruens, Brady and Norman, Mon. M. and Fw. Ostrac. of the N. Atlantic and N.-W. Europe, p. 73, pl. xii., figs. 8,9 (1889).

\section{Cypris prasina, Fischer.}

Cypris strigata, Baird, Brit. Entom., p. 157 (1850), (non Müller).

" prasina, Fischer, Beitrag zur Kenntniss der Ostracoden, p. 644, pl. xix., figs. 9-13 (1855).

" salina, Brady, Mon. rec. Brit. Ostrac., p. 368, pl. xxvi., figs. 8-13 (1868).

" prasina, Brady and Norman, Mon. M. and Fw. Ostrac. of the N. Atlantic and N.-W. Europe, p. 78 (1889).

Erpetocypris, Brady and Norman.

\section{Erpetocypris reptans (Baird).}

Candona reptans, Baird, Brit. Entom., p. 167 (1850).

similis, Baird, loc. cit., p. 162, pl. xix., figs. 2, 2a (pullus). Cypris reptans, Brady, Mon. rec. Brit. Ostrac., p. 370, pl. xxv., figs. 10-14; pl. xxxvi., fig. 4 (1868).

Erpetocypris reptans, Brady and Norman, Mon. M. and $\mathrm{Fw}$. Ostrac. of the N. Atlantic and N.-W. Europe, p. 84, pl. xiii., fig. 27 (1889).

Erpetocypris olivacea (?), Brady and Norman.

Erpetocypris olivacea, Brady and Norman, Mon. M. and Fw. Ostrac. of the N. Atlantic and N.-W. Europe, p. 89, pl. i., figs. 3,4 (1889). 
Cypridopsis vidua (Müller).

Cypris vidua, Müller, Entom., p. 55.

Cypridopsis,

Cypridopsis vidua, Brady, Mon. rec. Brit. Ostrac., p. 375, pl. xxiv., figs. 27-36, 46 (1868).

" obesa, Brady and Robertson, Ann. Nat. Hist., ser. iv., vol. iii., p. 364, pl. xviii., figs. 5-7 (1869).

vidua, Brady and Norman, Mon. M. and Fw. Ostrac. of the N. Atlantic and N.-W. Europe, p. 84, pl. xiii., fig: 27 (1889).

Cypridopsis aculeata (Lilljeborg).

Cypris aculeata, Lilljeborg, De Crust. ex-ord. trib., p. 117.

Cypridopsis aculeata, Brady, Mon. rec. Brit. Ostrac., p. 376, pl. xxiv., figs. 16-20 ; pl. xxxvi., fig. 10 (1868).

" aculeata, Brady and Norman, Mon. M. and Fw.

Ostrac. of the N. Atlantic and N.-W. Europe, p. 90 (1889).

Cypridopsis villosa (Jurine).

Monoculus villosa, Jurine, Hist. des Monocles, p. 178.

Cypris westwoodii, Baird, Brit. Entom., p. 156.

? Cypris elongata, Baird, loc. cit., p. 156.

Cypridopsis villosa, Brady, Mon. rec. Brit. Ostrac., p. 377, pl. xxiv., figs. 11-15 ; pl. xxxvi., fig. 9 (1868).

" villosa, Brady and Norman, Mon. M. and Fw. Ostrac. of the N. Atlantic and N.-W. Europe, p. 90 (1889).

Potamocypris fulva, Brady.

Bairdia fulva, Brady, Mon. rec. Brit. Ostrac., p. 474, pl. xxviii., Potamocypris, Brady. fig. 21 (1868).

Potamocypris fulva, Brady, Nat. Hist. Trans. Northum. and Durham, p. 366, pl. xiv., fig. 4 (1870).

" fulva, Brady and Norman, Mon. M. and Fw. Ostrac. of the N. Atlantic and N.-W. Europe, p. 93, pl. xxii., figs. 13-17 (1889).

Candona candida (Müller).

Cypris candida, Müller, Entom., p. 62, tab. vi., figs. 7-9.

Candona, Baird.

Candona lucens, Baird, Brit. Entom., p. 160, tab. xix., fig. 1.

" candida, Brady, Mon. rec. Brit. Ostrac., p. 383, pl. xxv., figs. $1-9$; pl. xxxvi., fig. 13 ; and pl. xxxvii., fig. 1 (1868). 
Candona candida, Brady and Norman, Mon. M. and Fw. Ostrac. of the N. Atlantic and N.-W. Europe, p. 98, pl. x., figs. 1, 2, and 14-23 (1889).

\section{Candona lactea, Baird.}

Candona lactea, Baird, Proc. Zool. Soc. Lond., p. 255, pl. xviii., figs. 25-27.

, $\quad$ detecta, Müller, Entom., p. 49, tab. iii., figs. 1-3.

$" \quad " \quad$ Brady (var.), Mon. rec. Brit. Ostrac., p. 384, pl. xxiv., figs. $35-38$; pl. xxxvii., fig. 2 (1868).

" laictea, Brady and Norman, Mon. M. and Fw. Ostrac. of the N. Atlantic and N.-W. Europe, p. 100 (1889).

\section{Candona pubescens (Koch).}

Cypris pubescens, Koch, Deutschlands Crustaceen, H. 11, p. 5 (1837).

", setigera, Jones, Mon. Tert. Entom., p. 12, pl. i., figs. $6 a-6 d$.

Candona compressa, Brady, Mon. rec. Brit. Ostrac., p. 382, pl. xxvi., figs. 22-27 (1868).

" albicans, Brady, loc. cit., p. 381, pl. xxv., figs. 20-25 ; pl. xxxvi., fig. 12 (1868). (Junior:)

$\because \quad$ pubescens, Brady and Norman, Mon. M. and Fw. Ostrac. of the N. Atlantic and N.-W. Europe, p. 101, pl. xii., figs. 32-37 (1889).

Candona rostrata, Brady and Norman.

Candona rostrata, Brady and Norman, Mon. M. and Fw. Ostrac. of the N. Atlantic and N.-W. Europe, p. 101, pl. ix., figs. $11,12,12 a$ and $b$; pl. xii., figs. 22-31 (1889).

Cypris compressa, Fischer, Ueber das genus Cypris, p. 144, pl. ii., figs. 7-12 ; pl. iii., figs. 1-5 (1851).

\section{Candona fabæformis (Fischer).}

Cypris fabaformis, Fischer, Ueber das genus Cypris, p. 146, pl. iii., figs. $6-16$ ๆ $0^{*}$ (1851).

Candona diaphana, Brady and Robertson, Ann. and Mag. Nat. Hist., ser. iv., vol. iv., p. 18, pl. v., figs. 1-3 $q$ (1870). "fabaformis, Brady and Norman, Mon. M. and Fw. Ostrac. of the N. Atlantic and N.-W. Europe, p. 103, pl. ix., figs. 1-4 of ô (1889). 
Ilyocypris gibba (Ramdohr).

Ilyocypris, Brady and Norman.

Cypris gibba, Ramdohr, Mag. und Gesellsch. naturforsch. Freunde zu Berlin, ii., p. 91.

" " Brady, Mon. rec. Brit. Ostrac., p. 369, pl. xxiv., figs. 47-54; pl. xxxvi., fig. 2 (1868).

Ilyocypris gibba, Brady and Norman, Mon. M. and Fw. Ostrac.

of the N. Atlantic and N.-W. Europe, p. 107, pl. xxii., figs. 1-5 (1889).

\section{Family DARWINULID瓜.}

Darwinula stevensoni, $B$. and $R$.

Polycheles stevensoni, B. and R., Ann. and Mag. Nat. Hist., ser. iv., vol. vi., p. 25, pl. vii., figs. $1-7$; pl. x., figs. 4-14 (1870).

Argilleccia aurea, B. and R., Ann. and Mag. Nat. Hist., ser. iv., vol. vi., p. 16, pl. viii., figs. 4, 5 (1870).

Darwinella stevensoni, B. and R., ibid., ser. iv., rol. ix., p. 50 (1872).

Darwinula stevensoni, Brady and Norman, Mon. M. and Fw. Ostrac. of the N. Atlantic and N.-W. Europe, p. 123, pl. x., figs. 7-13; pl. xiii., figs. 1-9 ; pl. xxiii., fig. 5 (1889).

Family CYTHERID蚱。

Limnicythere inopinata (Baird).

Cythere inopinata, Baird, Brit. Entom., p. 172, pl. xx., figs. 1, Limnicythere, $1 a$-1e.

Limnicythere inopinata, Brady, Mon. rec. Brit. Ostrac., p. 419, pl. xxix., figs. 15-18 (1868).

" inopinata, Brady and Norman, Mon. M. and Fw. Ostrac. of the N. Atlantic and N.-W. Europe, p. 170 (1889).

" inopinata, Brady and Norman, loc. cit., pl. xvii., figs. $18,19$.

Limnicythere sancti-patricii, Brady and Robertson.

Limnicythere sancti-patricii, B. and R., Ann. and Mag. Nat. Hist., ser. iv., vol. iii., p. 17, pl. xviii., figs. 8-11; pl. xxi., fig. 4 (1869).

" sancti-patricii, Brady and Norman, Mon. M. and Fw. Ostrac. of the N. Atlantic and N.-W. Europe, p. 171, pl. xvii., figs. 1, 2 (1889). 
Cytheridea, Bosquet.

\section{Cytheridea lacustris (G. O. Sars).}

Cythere lacustris, G. O. Sars, Zool. Reise i Sommeren, 1863, p. 30. Cytheridea lacustris, Brady, Mon. rec. Brit. Ostrac., p. 427, pl. xxvi., figs. 18-21 ; pl. xl., fig. 2 (1868).

, lacustris, Brady and Norman, Mon. M. and Fw. Ostrac. of the N. Atlantic and N.-W. Europe, p. 176 (1889).

Cytheridea torosa (Jones), var. teres.

Candona torosa, Jones, Ann. and Mag. Nat. Hist. (ii.), vol. vi., p. 27, pl. iii., fig. 6 .

Cytheridea torosa, Brady, Mon. rec. Brit. Ostrac., p. 425, pl. xxviii., figs. $7-12$; pl. xxxix., fig. 6.

" torosa, Brady and Norman, Mon. M. and Fw. Ostrac. of the N. Atlantic and N.-W. Europe, p. 175 (1889).

\section{TABLE I.}

\section{Showing Distribution of Mollusca Mentioned} IN THE PRECEDING Notes.

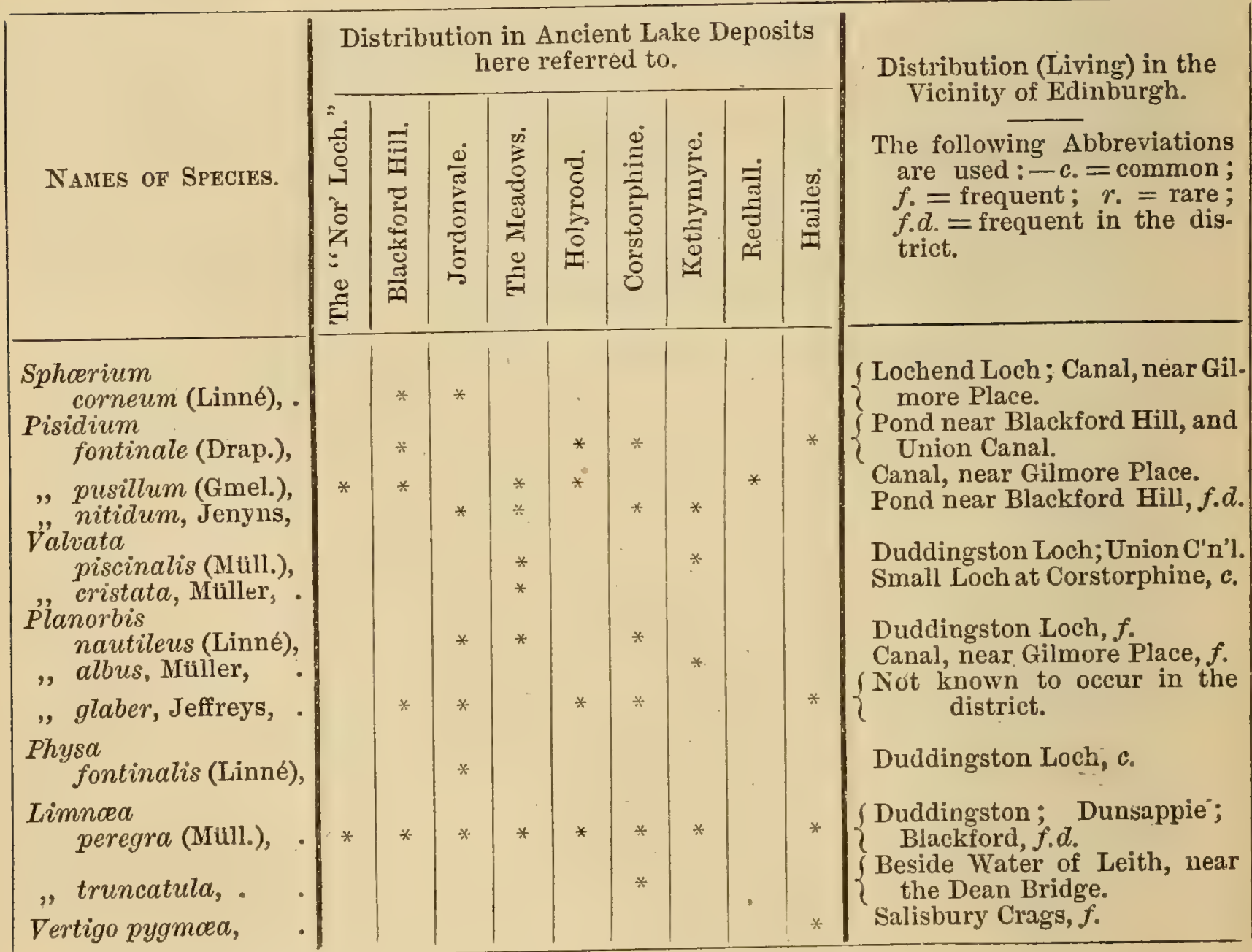


TABLE II.

\section{Showing Distribution of the Ostracoda mentioned in the PRECEDING Notes.}

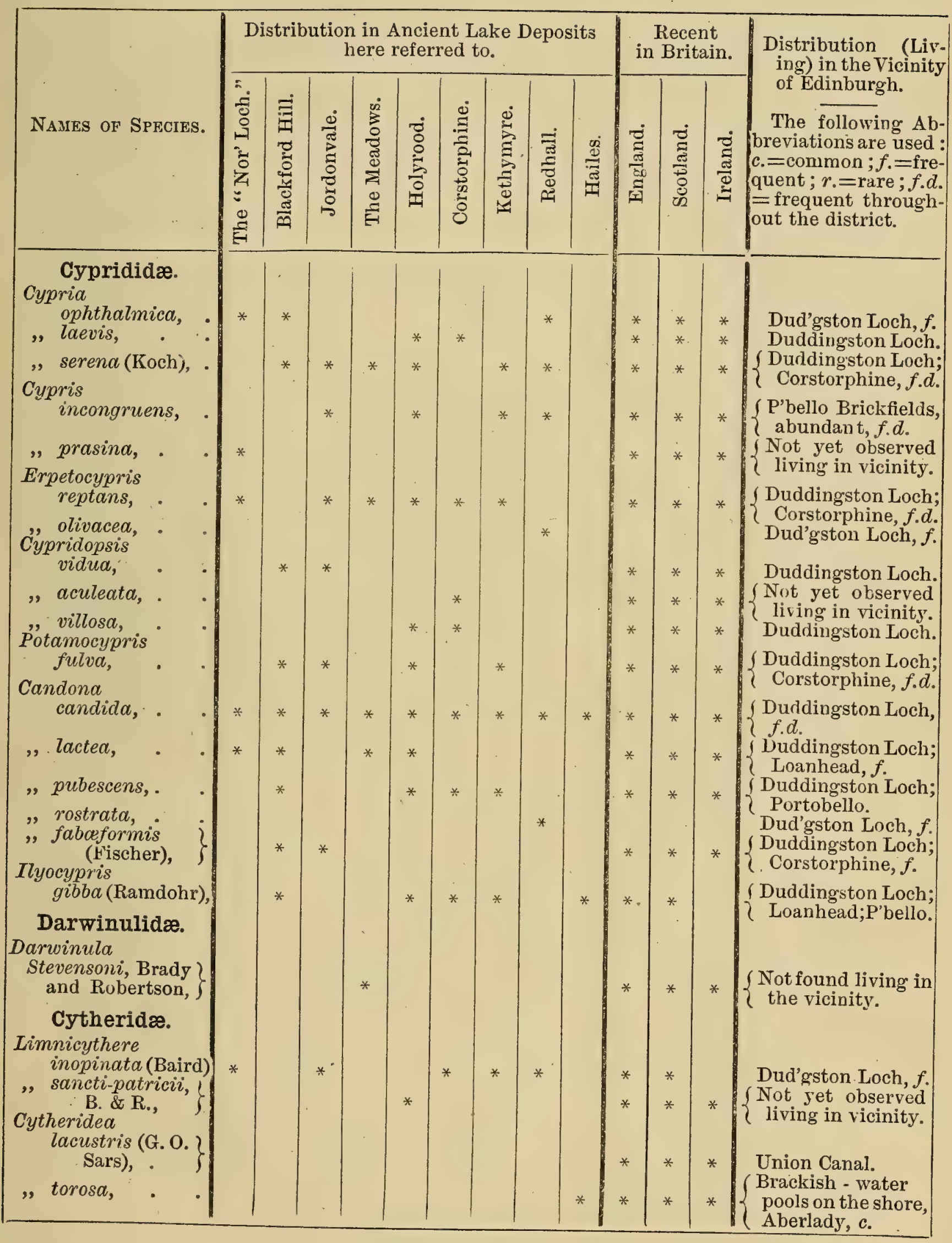




\section{Diatoms from Interglacial Peat-Bed in Boulder Clay,} Redhall Quarry, Near Edinburgh.

Amphore ovalis, Ktz.

Ceratoneis arcus, Ktz.

,, $\quad$,, var. majus.

Cymbella lanceolata, Ehr.

, $\quad$ cistula, Hemper.

,, gastroides, Ktz.

", $\quad$, var. minor.

Stauroneis phonicenteron, Nitz.

, acuta, W. Sm.

,. gracitis, W. Sm.

,, anceps, Ehr.

Navicula major, Ktz.

,, nobitis, Ktz.

,, viridis, Ktz.

,, gibba, Ktz.

, limosa, Ktz.

, oratis, Sm.

, anglica, Ralfs.

, $\quad$ radiosa, $\mathrm{Ktz}$.

, cuspidata, Ktz.

, rhynchocephala, Ktz.
Navicula, sp.

Pleurosigma attenuatum, W. Sm.

Gomphonema insigne, Grev., forma major.

Epithemia gibba, Ehr.

$$
\text { ,, ", var. ventricosa. }
$$

Asterionella formosa, Hassal.

Synedra pulchella, Ktz.

,, danica, Ktz.

Tabellaria fenestrata, Lyngb.

Cymatopleura solea, Sm.

, elliptica, Breb.

Surirella elegans, Ehr.

,, spiralis, Ktz.

,, biseriata, Breb.

Campylodiscus costatus, W. Sm.

Nitzschia angustata, Grun.

Hantzia amphioxis, var. intermedia, Grun.

Cyclotella comte, $\mathrm{Ktz}$.

Note. - I have no doubt that further investigations would increase the list of diatoms from this bed.-R. K. 


Aniraw-den

(d)

1890 

[From the Transactions of the Natural History Society of Glasgow.]

NOTES ON SOME FRESH-WATER, BRACKISHWATER, AND MARINE ENTOMOSTRACA NEW TO THE FAUNA OF ORKNEY:

Printed, Augnest, 1890. 

$\mathrm{X}$.

NOTES ON SOME FRESH-WATER, BRACKISHWATER, AND MARINE ENTOMOSTRACA NEW TO THE FAUNA OF ORKNEY.

BY THOMAS SCOTT, F.L.S., NATURALIST TO THE FISHERY BOARD FOR SCOTLAND.

[Read 29th October, 1889.]

DURING July of the present year (1889), I was engaged carrying out some investigations among the Orkney Islands, on behalf of the Scientific Committee of the Fishery Board for Scotland, and took the opportunity while there to collect, by hand-net and dredge, a quantity of fresh-water and marine organisms, including a number of Entomostraca. I now propose, in the following notes, to refer to a few species of Ostracoda obtained in this way which do not appear to have been previously recorded from these islands.

1. Fresh-water and Brackish-water Species.

I was able on only one occasion to make a passing examination of the Fresh- and Brackish-water Entomostracan fauna, viz., on the Saturday evening previous to our departure for the Firth of Forth. We had anchored near Stromness, and about 5.30 p.m. I went ashore, taking with me one of our smaller tow-nets, my intention being to visit the famous "Standing Stones of Stenness" said to be distant from Stromness about six miles, and to take a look at the flora of the district and try a dip with the tow-net in any suitable ditch or other fresh-water 
locality observed on the way, while at the same time keeping in view that it was desirable to be on board our steamer again about ten o'clock.

Leaving Stromness by the Kirkwall road, I ere long reached the side of Loch Stenness. The scenery along the shores of this loch is rather tame and uninviting to those familiar with our Highland landscapes; but its interesting associations with the dim past more than compensate for its tameness, for here the old Vikings, in all their rude strength and fearless courage, dominated the land.

Crossing the bridge that spans the outlet of Loch Stenness, I proceeded eastward along the highway leading to Kirkwall as far as the road that strikes off northward across the so-called "Bridge of Brogar" which divides Loch Stenness into two parts, the lower part being recognised as Loch Stenness proper while the upper part is known as Loch Harray. The water in the vicinity of the "Bridge" is rather brackish, but is fresh or nearly so at the upper end of Loch Harray.

A few of the stones, and these considerably the tallest, are met with before the "Bridge" is reached, but the famous circle is situated a good distance beyond its further or north end. Of the stones comprising the circle, 16, large and small, are still standing, while many are lying prone. The circle is of great extent, being about 400 yards in diameter, and the mound and fosse (or trench) surrounding it are still well-defined, especially the latter. The stones bear ample evidence of hoary age, and well they may, for we see them looming up through the mists of uncertainty that form the borderland of authentic history as even then the memorials of an unknown past. We stand beside the old grey lichencovered stones, and try to peer into the impenetrable gloom and catch perchance a glimpse, though only of the shadowy outline, of the men who, either by some ingenious though doubtless rude contrivance or by mere physical strength, set these ponderous 
slabs on end. We think of the numberless generations that have existed and passed away since that far-off time, while like lone sentinels these monuments have stood through sunshine and storm telling of the insignificance of human life, and the old question imperceptibly forces itself upon the mind"What is man that Thou art mindful of him, or the son of man that Thou shouldest visit him?" As we turn away, a gleam of encouragement strikes athwart these gloomy reveries with the thought that the good as well as the "evil that men do lives after them," even though their personality be lost in oblivion.

Whether this and similar circles were formed for religious purposes, or for commemorating some great battle, or in honour of some great hero, is only matter of conjecture and seems likely to remain so; but the stones themselves will continue to be viewed by the ignorant with superstitious awe, while, to the intelligent and devout mind, thoughts full of interest and instruction will be suggested. Numerous other stones, mostly solitary, are scattered over this part of the mainland, all of which appear to be of equally ancient date; and possibly many of these single stones may be monumental in their significance.

At the south end of the "Bridge of Brogar," and on both sides of it, were some shallow weedy pools, and a ditch by the side of the road leading down to it that had the appearance of being suitable habitats for Entomostraca. These were the only places I had time to try my tow-net in. On examining the material collected in these places, I found that besides other things there were at least ten species of Ostracoda, which are as follows: Cypria ophthalmica (Jurine) (=Cypris compressa,
Baird).

" lcevis (C. F. Müller) (= Cypris ovum, Jurine)

$" \quad \operatorname{serena}($ Koch) $(=$ Cypris loevis, Brady).

Cypris prasina, Fischer (=Cypris salina, Brady). 
Potamocypris fulva, Brady.

C'andona candida (Müller).

" pubescens (Koch) (= Candona compressa, Brady, and C. albicans, Brady).

Kingsleii, B. and R.

Iyocypris gibba (Ramdohr) (=Cypris gibba, Ramdohr).

Cytheridea torosa (Jones).

Of the above the following are additions to the Fauna of the Orkney Islands:

Cypris prasina, Fischer.

Cypris prasina, Fischer, Beitrag zur Kenntniss der Ostrac., p. 644, pl. xix., figs. 9-12 (1853).

" salina, Brady, Mon. Rec. Brit. Ostrac., p. 368, pl. xxvi., figs. 8.13 (1868).

, prasina, Brady and Norman, Mon. M. and Fw. Ostrac. of the N. Atlantic and N.W. Europe, p. 78 (1889).

Habitat.-In pools in the vicinity of the north end of the "Bridge of Brogar"; frequent.

Hitherto this species does not seem to have been observed in Scotland further north than the Island of Lewis. Clyde localities are-Hunterston (Ayrshire), and Cumbrae (Robertson); Langbank (Scott). Also within highwater mark, Aberlady Bay, Firth of Forth $(S \cot t)$.

\section{Candona pubescens (Koch).}

Cypris pubescens, Koch, Deutschlands Crustaceen, etc., H. 11, p. 5 (1837).

Candona compressc, Brady, op. cit., p. 382, pl. xxvi., figs. 22-27. , albicans, Brady, op. cit., p. 381, pl. xxv., figs 20.25 (junior).

,, pubescens, Brady and Norman, op. cit., p. 101, pl. xii., figs. 32-37.

Habitat.-Ditch by the side of the road leading: down to the "Bridge of Brogar"; frequent.

Though this species has been found in many places in the Lowlands of Scotland, this is the first record of its occurrence so far north. It is found in many Clydesdale localities and in the Forth district. 
Candona Kingsleii, Brady and Robertson.

Candona Kingsleii, B. and R., Ann. and Mag. Nat. Hist., Ser. iv., vol. vi., p. 17, pl. ix., figs. 9-12 (1870). , $\quad$, Brady and Norman; op. cit., p. 102, pl. ix., figs. 19-22; pl. xiii., fig. 19.

Habitat.-With the last; rather rare.

The most northerly limit of distribution hitherto observed for this species in Scotland seems to be the Island of Lewis. In Clydesdale and the Forth district it has been observed in a number of localities.

\section{Cytheridea torosa (Jones).}

Candona torosa, Jones, Ann. and Mag. Nat. Hist., Ser. ii., vol. vi., p. 27 , pl. iii., fig. 6 .

Cytheridea ,, Brady and Norman, op. cit., p. 175.

Habitat.-In the pools with Cypris prasina; common.

Though the Clyde district seems to have been hitherto looked upon as the northern limit of this species in Scotland, I have observed it, in the vicinity of Montrose Basin, as well as in Orkney. It has been found near Kilwinning in great abundance by Mr. Robertson. It has beeń obtained by me at Langbank, and near Port-Bannatyne, Bute, as well as in the Firth of Forth district.

Although these are the only additions, as regards the fresh-water and brackish-water species of Ostracoda, that I am able to record at present, it is highly probable that if the inland waters of these islands were more thoroughly examined, an additional number of new records would be obtained.

It may be worth while to mention here that the mollusc Neretina fluviatilis, recorded long ago as occurring in Loch Stenness, is still quite common there, but none of the specimens obtained by me wer'e so large as those I' have from England.

\section{Marine Species.}

There were comparatively few opportunities for dredging during the time we were at the Orkneys (and few of the Ostracoda can be got without the use of 
the dredge), still the following records, if few, tend to show that although a good deal has already been done towards working out the marine fauna of these islands, yet a judicious use of the dredge will still yield results sufficient to reward the painstaking investigator. The species observed by me that do not seem to have been previously recorded for these islands are as follows:

\section{Pontocypris acupunctata, Brady.}

Pontocypris acupunctata, Brady, Mon. Rec. Brit. Ostrac., p. 386, pl. xxiv., figs. 53-56 (1868).

Brady and Norman, op. cit., p. 109.

Habitat.-Near the mouth of Holm Sound; rare.

The only other Scottish localities recorded for this species are the Minch; St. Magnus Bay, Shetland; and Firth of Forth.

\section{Cythere robertsoni. Brady.}

Cythere robertsoni, Brady, Ann. and Mag. Nat. Hist., Ser. iv., vol. ii., p. 33, pl. iv., figs. 5, 8:10 (1868).

Brady and Norman, op. cit., p. 139, pl. xiv., figs. $32,33$.

Habitat.-Near the mouth of Holm Sound, south of Deerness, in 12 fathoms; not common.

This is a distinct though small species. With regard to its distribution, Drs. Brady and Norman say: "We have no record of this pretty and wellmarked species from any part of the Scottish coast north of Loch Fyne." *

\section{Cythere navicula, Norman.}

Cythere navicula, Norman, Last Report Dredging among the Shetland Isles, Brit. Assoc. Report, p. 292 (1868).

Brady and Norman, op. cit., p. 143, pl. xvi., figs. $15,16$.

Habitat.-With the last.

The only other Scottish localities where this species has been observed are the Firth of Forth; the Minch; Papa, and St. Magnus Bay, Shetland.

* Mon. M. and Fw. Ostrac. of the N. Atlantic and N.W. Europe, p. 140 (1889). 
Cythere cluthæ, Brady, Crosskey, and Robertson.

Cythere cluthce, B. C. and R., Mon. Post-tert. Entom., p. 1533, pl. xiii., figs. 16,17 (1874).

Brady and Norman, op. cit., p. 145, pl. xiv. figs. 25-27; pl. xvii., figs. $35,36$.

Habitat.-Stromness Bay, three to four fathoms, bottom mud; rare.

The only other Scotch locality where this species has been observed alive is Loch Fyne, where I dredged it in 1886.

Loxoconcho fragilis, G. O. Sars.

Loxoconcho fragilis, Brady and Robertson, Ann. and Mag. Nat. Hist., Ser. iv., vol. vi., p. 24, pl. x., fig. 3 (1870).

, " , Brady and Norman, op. cit., p. 187, pl. xvii., figs. $32-34$.

Habitat.-With the last; rare.

The only Scottish localities where this species has been observed hitherto are the Clyde at Greenock (where I have also dredged it); the Firth of Forth; and Montrose Basin.

\section{Xestoleberis aurantia, Baird.}

Cythere aurantia, Baird, Mag. Zool. and Bot., vol. ii., p. 143, tab. v., fig. 26 (1835).

Xestoleberis ,, Brady, Mon. Rec. Brit. Ostrac., p. 437, pl. xxvii., figs. 34-37; pl. xxix., fig. 6 (1868). Brady and Norman, op. cit., p. 188.

Habitat.-South of Deerness, near the entrance to Holm Sound.

This species has been recorded from Shetland, but otherwise the most northerly localities where it seems to have been observed are the Moray Firth and Loch Carron.

\section{Cytherura producta, Brady.}

Cytherura producta, Brady, Mon. Rec. Brit. Ostrac., p. 443, pl. xxxii., figs. 60, 61 (1868).

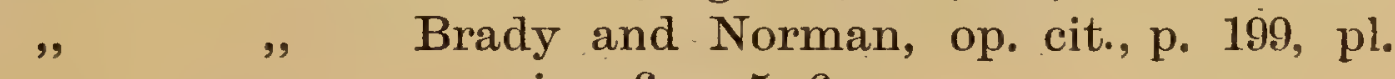
xix., figs. 5,6 .

Habitat.-With the last; rather rare. 
The only other Scottish localities for which this species has been recorded are the Clyde; the Minch; the Firth of Forth; and Shetland.

Cytheropteron depressum, Brady and Norman.

Cytheropteron subcircinatum, Brady, Mon. Rec. Brit. Ostrac., p. 447, pl. xxxiv., figs. 39-42 (1868). (Non Cy. subcircinatum, G. O. Sars.)

, depressum, Brady and Norman, op. cit., p. 218, pl. 20, figs. $22,23$.

Habitat.-Near the entrance to Holm Sound.

The only other Scottish localities I know for this species are the Firth of Forth and the Moray Firth.

Bythocythere turgida, G. O. Sars.

Bythocythere turgida, G. O. Sars, Oversight af Norges Marine Ostracoder, p. 84.

Brady and Norman, op. cit., p. 221.

Habitat.-Near the entrance to Holm Sound.

Other Scottish localities where this species has been observed are the Firth of Clyde; Firth of Forth $(S c o t t)$; and Shetland. It does not seem to be so generally distributed as some of the others.

Bythocythere simplex (Norman).

Cythere simplex, Norman, Nat. Hist. Trans. Northumb. and Durh., vol. 1, p. 17, pl. v., figs. 1-4.

Bythocythere , Brady and Norman, op. cit., p. 224, pl. xxiii., fig. 9.

Habitat.-With the last; rather rare.

This seems to be more widely distributed than B. turgida. It has been observed in the following Scottish localities: the Clyde (in several places); the Minch; Firth of Forth $(S \cot t)$; Aberdeenshire coast; and Shetland.

Paradoxostoma hibernicum, Brady.

Paradoxostoma hibernicum, Brady, Mon. Rec. Brit. Ostrac., p. 460, pl. xxxv., figs, 35,36 ; and pl. xl., fig. 7 (1868).

, , , Brady and Norman, op. cit., p. 232, pl. xxi., figs. 15-17. 
Habitat.-Outside of Holm Sound; not common.

This species has been recorded from the Clyde and from Loch Carron. I have also lately observed it in the Firth of Forth.

\section{Paradoxostoma arcuatum, Brady.}

Paradoxostoma arcuatum; Brady, op. cit., p. 461, pl. xxxv., figs. $37,38$.

Brady and Norman, op. cit., p. 234,

Habitat.-With the last. pl. xxi, figs. 5,6 .

This does not seem to be a common species, the only Scottish localities for which it has been recorded are the Firth of Forth; the Moray Firth; and St. Magnus Bay, Shetland.

\section{Asterope mariæ (Baird).}

Cypridina marice, Baird, Proc. Zool. Soc. Lond., 'part xviii., p. 257, pl. xvii, figs. 5-7 (1850).

Cylindroleberis,, Brady, op. cit., p. 465, pl. xxxiii., figs. 18-22; pl. xli., fig 1.

Asterope , Robertson, Fauna and Flora of the West of Scotland, p. 39 (1876).

Habitat.-Vera Sound; not common.

This species has been observed at Shetland; Skye; the Clyde; and the Moray Firth.

\section{Asterope teres (Norman).}

Cypridina teres, Norman, Anñ. and Mag. Nat. Hist., vol. viii, pl. xiv., fig. 10 (1861).

Cylindrolebcris teres, Brady, op. cit., p. 465, pl. xxxiii,, figs. 6-9;

Asterope pl. xli., fig. 2.

, Robertson, Fauna and Flora of the West of Scotland, p. 39 (1876).

Habitat.-In the same locality as the last.

This species is not so common as the preceding. The only other Scottish records I can find for it are the Clyde (one or two places) and Oban.

Polycope compressa, Brady and Robertson.

Polycope compressa, B. and R., Ann. and Mag. Nat. Hist., p. 372, pl. xxi (1869). 
100 TRANSACTIONS, NATUURAL HISTORY SOCIETY OF GLASGOW.

Habitat.-Near the entrance to Holm Sound; rather rare.

The only other Scottish localities I know of where this species has been observed are the Firth of Forth and the Moray Firth.

In preparing these notes I have consulted the Monograph of the Recent British Ostracoda (1868), by Dr. G. S. Brady, and the Monograph of the Marine and Fresh-water Ostracoda of the North Atlantic and North-western Europe (1889) by Drs. Brady and Norman. I am also much indebted to my kind friend Dr. G. S. Brady, who has on this and many other occasions assisted me by looking over my collections and identifying obscure and difficult species. 


SOME NOTES ON THE SCOTCH SPECIES OF THE MOLLUSCAN GENUS VERTIGO.

\section{BY THOMAS SCOTT, F.L.S.}

Naturalist to the Fishery Board for Scotland.

Reprinted from The Scottish Naturalist, April, I89I.

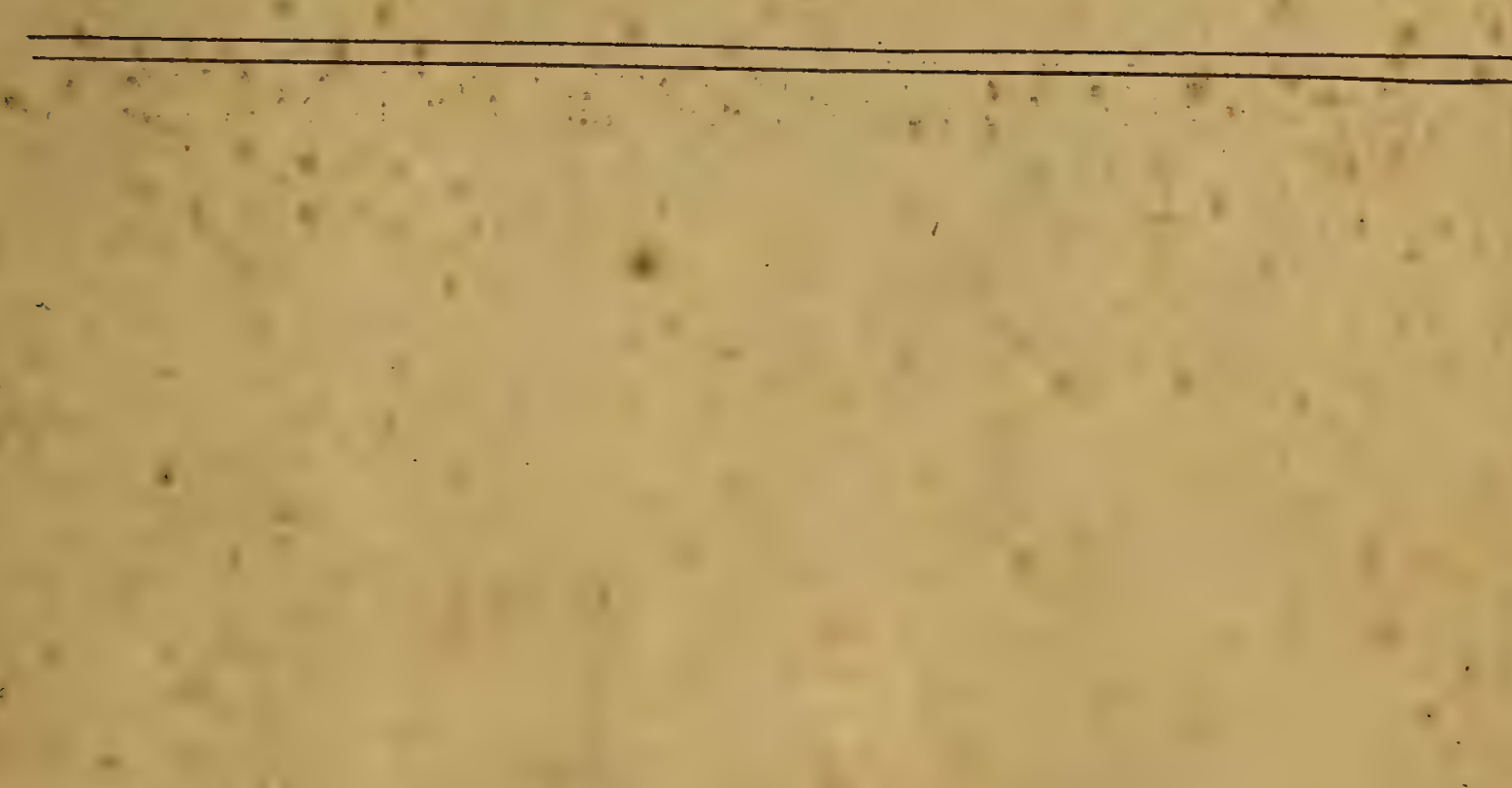




[Scot. Nat..I\&gI, Pl.I.

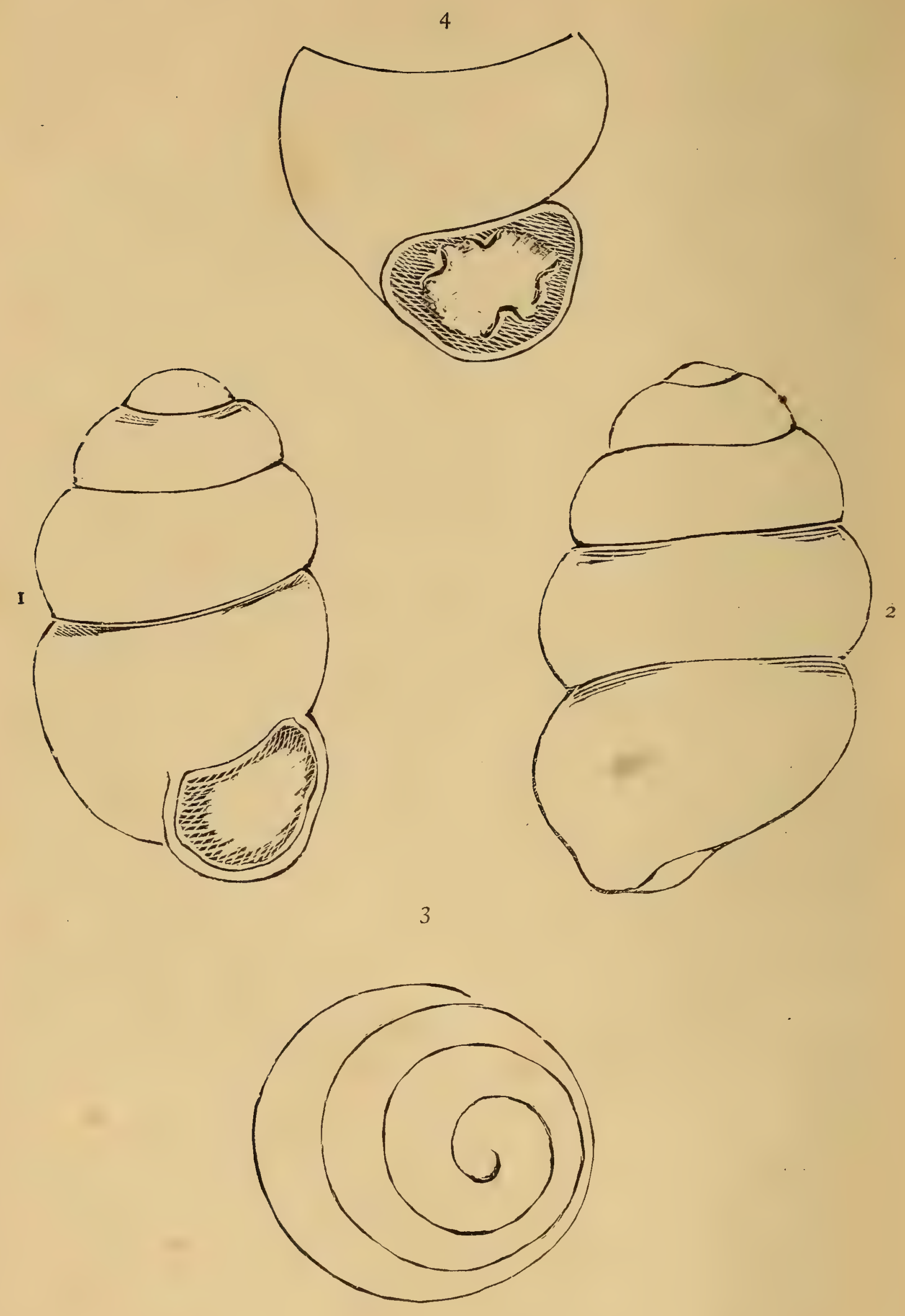

Figures I, 2, 3, show different positions of Vertigo concinna. Figure 4 shows the mouth of Vertigo pygmcea for comparison. (All magnified.) 


\title{
SOME NOTES ON THE SCOTCH SPECIES OF THE MOLLUSCAN GENUS VERTIGO.
}

\author{
By Thomas Scott, F.L.S.
}

PLATE $\mathrm{I}$.

$\mathrm{N}$ the following Notes, though reference is made to the 1 distribution of the recent (or living) species of Vertigo observed in Scotland, my chief purpose is to bring together the various records I have been able to collect bearing on their fossil distribution. The nomenclature and arrangement of Jeffrey's "British Conchology" are adhered to. The Rev. Canon A. M. Norman, F.R.S., \&c., is publishing in the "Annals and Magazines of Natural History" a "Revision of British Mollusca" which will be of great value to students of systematic conchology. In this revision he includes the species of Pupa and Vertigo under the one generic name, $P u p a$, Draparnaud, and retains Vertigo as a sub-genus in which the two sinistral species, $V$. pusilla Müll., and $V$. angustior Jeff. are included.

The following papers will be found useful as bearing on the recent distribution of the species.

1836. "Excursions illustrative of the Geology and Natural History of the Environs of Edinburgh," by William Rhind, M.R.C.S.E. \&c.

1843. "The Molluscous Animals of Scotland," by Professor Macgillivray.

I870. "A Catalogue of the Mollusca of the Counties of Aberdeen, Banff, and Moray," by Robert Dawson, A.M. (published by the Aberdeen Natural History Society).

1873-74. "List of Land and Fresh-water Mollusca of Scotland," by Dr. F. Buchanan White (pub. in the "Scottish Naturalist").

1876. "Land and Fresh-water Mollusca," by F. G. Binnie (In "Fauna and Flora of the West of Scotland"). 
1885. "Notes on the Land and Fresh-water Mollusca about Greenock and surrounding District," by Thos. Scott. ("Tran. Nat. Hist. Soc. of Glasgow").

I886. "Preliminary Notes on the Land and Fresh-water Mollusca about Tarbert, Loch Fyne," by Thos. Scott ("Journal of Conchology").

1889. "The Land and Fresh-water Shells of the Neighbourhood of North Berwick, Haddingtonshire," by Rev. John M'Murtrie, M.A. ("Journal of Conchology").

I89r. "Census of Scottish Land and Fresh-water Mollusca," by Wm. Denison Roebuck, F.L.S. ("Proc. Roy. Phys. Soc., Edin.").

The species of the genus Vertigo referred to in the following. Notes are-

Vertigo antivertigo (Drap.).

This Vertigo as a recent (or living) species is, where the conditions are favourable, of comparatively frequent occurrence. It is recorded in Roebuck's "Census" from six different counties, including Sutherlandshire-to these I am able to add another, viz., Fifeshire. Some time ago Mr. J. W. Paterson of Edinburgh, submitted for my inspection a number of shells obtained by him near Largo during last autumn, and among them I observed this species. The fossil distribution of Vertigo antivertigo in Scotland seems to be very limited, as yet I only know of its occurrence in the Elie post-tertiary deposits described in the Proceedings of the Royal Physical Society, Edinburgh, vol. x., p. 334, and since in what appears to be an older deposit than that described in the Proceedings referred to. This deposit-which also occurs at Eliewas exposed while some drainage operations were being carried out. This Vertigo was comparatively common in both deposits.

Vertigo PyGMea (Drap.).

This is a common species in many places; at least I have found it so both in the east and west of Scotland. Last autumn I collected a good number of specimens among the ruins of an old boundary wall near Elie, and J. W. Paterson showed me specimens collected by him near Largo. I have also obtained it on Inchkeith. Fife is not included in the "Census" of distribution for this species. 
Its fossil distribution is limited, though not so much so as the last; it was obtained at Elie with the other; it was also obtained in a post-tertiary deposit at Kirkland of Leven, and in what appears to be an interglacial peat-bed at Hailes, near Edinburgh.*

\section{Vertigo substriata (Jeff.).}

This, though apparently not a common species, is widely distributed. In Roebuck's "Census" Loch Fad, Bute; Kinkell Braes, near St. Andrews; and Brora, Sutherlandshire, are mentioned as localities. In my collection are specimens from Routen-burn Glen near Greenock, certified by the late Dr. J. G. Jeffreys. It was obtained by T. Edwards of Banff, and one specimen was found by Dr. Macgillivray in the Den of Rubislaw, Aberdeenshire.

As a fossil I do not know of its occurrence anywhere else than at Elie, where it was obtained in the two separate deposits, one apparently older than the other, referred to above.

\section{Vertigo pusilla (Müll.).}

This seems to be a rare shell in Scotland; only two localities are mentioned in the "Census"-Banks of the Clouden near Maxwelltown, Kirkcudbright ; and Largs, Ayrshire. My friend, Mr. James Steel of Glasgow, has also obtained it in the vicinity of the Clyde near Lanark. I saw one of the specimens he obtained, and he also exhibited them at a meeting of the Natural History Society of Glasgow during the last summer session of the Society. So far as I know this species has not been recorded as a fossil in Scotland.

\section{Vertigo ANGUStior (Jeff.).}

This interesting and rare shell has been added to the Scotch List of Land Mollusca, by Mr. W. Baillie, Brora, Sutherlandshire. Fts solitary occurrence in this northern county might naturally raise some doubt as to its being really indigenous. What I have now to record, however, will tend to dispel such a doubt, if any existed. Duringsome drainage operations at Elie last year, a deposit of earthy peat was cut into. A quantity of the material was sent to me by $\mathrm{Mr}$.

* "The Ancient Lakes of Edinburgh" (Proceed. Roy. Phys. Soc. Edin., vol. x., p. I26). 
James Bennie of the Geological Survey; in the material there were land and fresh-water shells in considerable abundance, and among other rarities this Vertigo was of frequent occurrence. I obtained no fewer than six species of Vertigo in the material sent to me from the deposit referred to, viz., Vertigo antivertigo, $V$. pygmea, $V$. substriata, $V$. angustior, $V$. edentula, and $V$. minutissima. The presence in such numbers of Vertigo angustior, as a fossil at Elie, points to its more frequent occurrence in Scotland when this deposit was being formed than it appears to be now, and also proves its claim to be an indigenous species.

\section{Vertigo edentula (Drap.).}

As a recent shell, this species, though widely distributed, is not very plentiful. As a fossil it occurred in the same deposit with the last. It is also recorded by Mr. David Robertson, F.L.S., from the Arctic shell clays at Garvel Park, near Greenock.*

\section{Vertigo minutissima (Hartm.j.}

This pretty shell is still very local and rare in Scotland. It is not the smallest of our Vertigos, though the name might lead one to suppose it was. There are seven specimens of this shell in my collection collected among the debris at Salisbury Crags, and none of them can be considered very small comparatively. In Rhind's List of Land Shells found near Edinburgh, and published in 1836 , the following are recorded-Pupa pygmaea, King's Park, Pupa edentula, Roslin, King's Park, and Pupa cylindrica, Salisbury Crags. This last seems to be Vertigo minutissima (Hartm.), not Helix Cylindracea ( $\mathrm{Da}$ Costa), which, according to Jeffreys, appears to be Pupa umbilicata, Drap. (Dr. Norman in his Revision of the British Mollusca restores I)a Costa's name, Pupa cylindracea), and what makes it more likely that this Vertigo is referred to is, that Dr. Rhind records Pupa mu corum (= P. umbilicata?), Pupa marginata and Pupa bidentata, all from the King's Park, but he only records Pupa cylinarica from Salisbury Crags which is the only known habitat for Vertigo minutissima. If my conjecture is right, this rare species has been known as a resident among the debris of Salisbury Crags for a much longer time than is usually supposed.

* "The Post-tertiary Beds of Garvel Park, Greenock" (Trans._Geol. Soc. of Glasgow, vol. vii., p. 36). 
This species, as already stated, was one of the fossil Vertigos obtained in the material from the Elie post-tertiary deposit, and so far as I know this is the first record of its occurrence as a fossil in Scotland. In the "Census" it is stated that "Dr. Buchanan White speaks of its having been found at Balmerino in Fifeshire, a locality which it is desirable should be reinvestigated." If this implies a doubt as to the genuineness of the "find," the following will show that Dr. William Turton had no doubt about it. In his "Manual of the Land and Fresh-water Shells of the British Islands," p. 201, (1840), he says - "It (Vertigo minutissima) was sent to Dr. Fleming by Mr. Chalmers, Surgeon, Kirkcaldy, who found it in the parish of Balmenna (Balmerino), Fifeshire." Captain Thomas Brown also refers to it under the name Vertigo cylindrica, Ferussac, and says, "Found near the village of Balmenna, Fifeshire, by my friend, Mr. Chalmers, Surgeon, Kirkcaldy."* Though there can be no doubt that Dr. Chalmers did obtain this Vertigo as stated, it would be interesting to have the district "reinvestigated," as perhaps other "rarities" might be secured besides this species.

\section{VERTIGO CONCINNA, provisional name.}

In the post-tertiary marl at Kirkland, Leven, described in the Proceedings of the Royal Physical Society, Edinburgh, vol. x., p. 334, a Vertigo closely resembling $V$. pygmaa occurred as a. moderately common shell. The surface is smooth and polished, the form is somewhat oval, rather tumid, whorls convex, more rounded on the lower side, apex of spire blunt, whorls $4 \frac{1}{2}$, suture distinct, mouth small, rounded, scarcely if at all flexuous as in $V$. pygmea, destitute of teeth-not even a trace of a tooth being observed in the most perfect of the shells. Length, about $2 \mathrm{~mm}$.; breadth, fully I $\mathrm{mm}$. In the "Preliminary Notes on a Post-tertiary Fresh-water Deposit at Kirkland, Leven, and at Elie, Fifeshire," in the Proceedings of the Royal Physical Society already referred to, I have proposed Vertigo concinna as a provisional name for this shell.

* See also Dr. Fleming's description in "British Animals" (I828). 

(if)

1891 

From the Transactions of the Natural History Society of Glasgow.]

\section{ON THE LAND AND FRESH-WATER MOLLUSCA OF BUTE。}

Printed, April, 1891. 



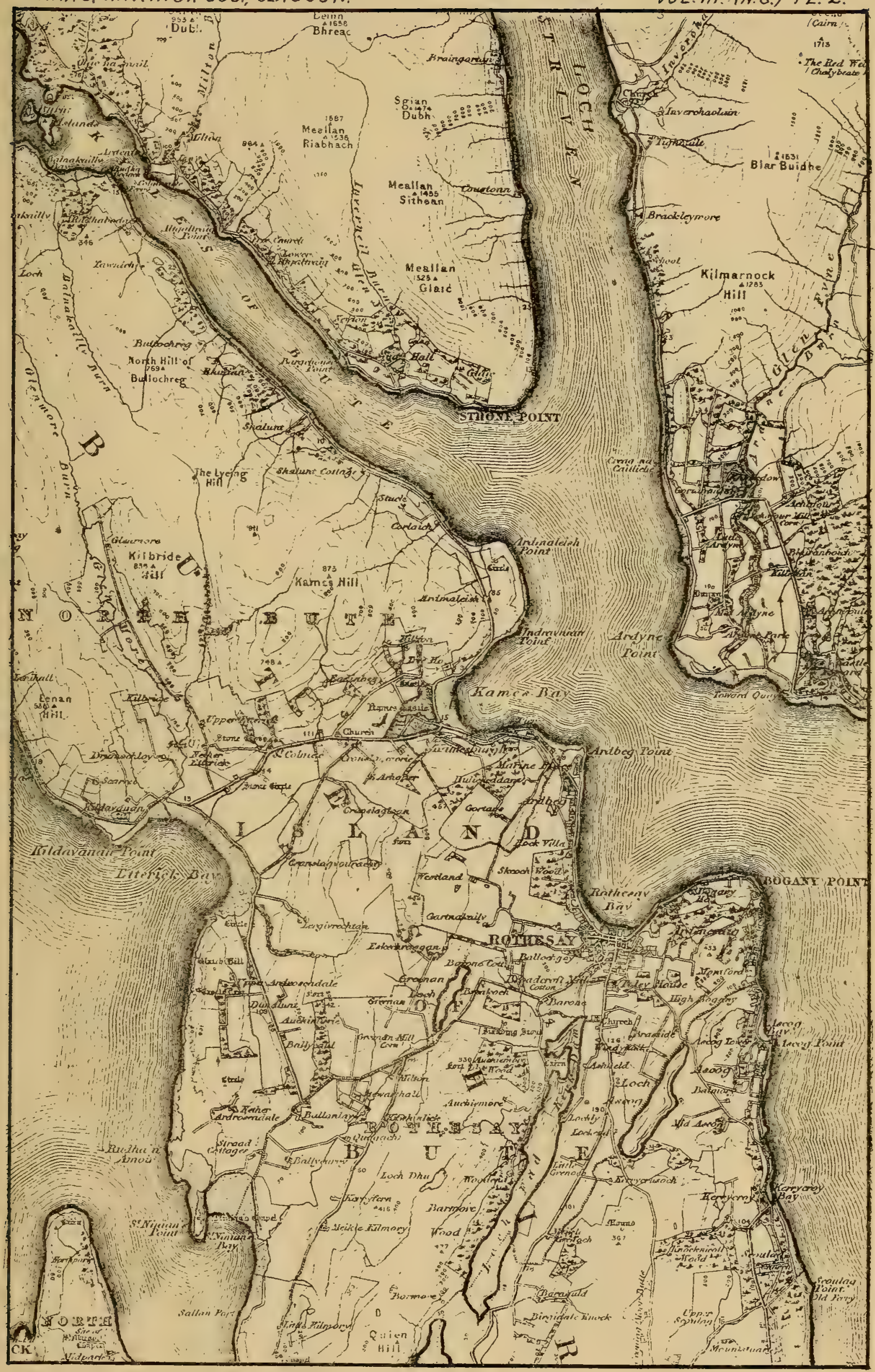

ISLAND OF BUTE. (CENTRALPORTION) SCALE 3/4 IN. TO MILE. 

TRANSACTIONS, NATURAL HISTORY SOCIETY OF GLASGOW. 170

XVIII.

ON THE LAND AND FRESH-WATER

MOLLUSCA OF BUTE.

BY THOMAS SCOTT, F.L.S., NATURALIST TO THE FISHERY BOARD FOR SCOTLAND.

With Map [Plate II.].

[Read 25th March, 1890.]

Is 1869, Mr. William Haddin published in the Proceedings of this Society his paper "On the distribution of the Helicidæe in Bute and in the vicinity of Largs." Since then little further appears to have been done towards working up the molluscan fauna of that interesting island. The references to Bute in the List of the Land and Fresh-water Mollusca in The Frana and Flora of the West of Scotland (1876), p. 40, are made chiefly on the authority of Haddin's records, so that for over twenty years these records have contained the fullest account we possess, and afforded our principal source of information, regarding the Bute Mollusca.

A perusal of Mr. Haddin's paper shows that considerable care was taken in its preparation so that it might be as exhaustive as his opportunities for observation would allow, and it must be acknowledged that his efforts were fairly successful. Unfortunately, however, no attempt appears to have been made by him to work up either the fresh-water species or the Limacidæ; and that is to be regretted, as the fresh-water conditions of the island seem to be very favourable to the existence of aquatic molluses.

My object, therefore, in preparing these notes is to try to fill up in some measure the gap left by Mr. Haddin, as well as to revise his list of the 
Helicidæ in as far as it relates to the species observed in Bute, and thus bring together all the information we at present possess concerning the number of species known to occur in the island, and also what we know as to their distribution.

By way of explaining how I am in a position to attempt this work, it may be stated that in October, 1886, the Fishery Board for Scotland requested me to proceed to Rothesay to carry out some investigations at the Royal Aquarium; and I was stationed there till the end of June in the following year, that is, between eight and nine months. During these months a good deal of my leisure time was devoted to the examination of the land and freshwater invertebrate fauna of the island.

My modus operandi was somewhat as follows. During the shorter days the locality in the vicinity of the Aquarium was examined, and here a few interesting "finds" were secured, including the rare Limax (Amalia) gagates. One or two visits were also made to Loch Ascog and Loch Fad, but comparatively little was done throughout the winter. As soon, however, as the longer days of spring and early summer arrived, I frequently visited, in the early morning and also in the evening, localities more distant than those I had been able to reach during the winter months. Two or three times every week, when the weather was favourable, I was in the habit of leaving Rothesay between 3 and 4 a.m., or sometimes earlier, and proceeding to some place previously fixed on, where I would spend a short time collecting material and taking notes, after which I returned so as to reach the Aquarium before 9 a.m. In this way I have visited Loch Ascog, Loch Fad, Greenan Loch, Ettrick Bay, St. Ninian's Bay, Kames Bay, and other places. A good deal of time was thus also devoted to the examination of the shores as well as the landward part of the island, and that without interfering in any way with the Board's work. These early morning. 
rambles were never lacking in interest, and I now look back on these hours, "snatched from sleep" that they might be given to the study of natural history, as the pleasantest and happiest I spent in Bute.

It was my intention to have explored the whole island, but the shortness of my stay prevented this being done. All that I was able in some measure to overtake was the examination of the central and perhaps the more interesting portion of it, which may be roughly defined as bounded by Kames Bay and Ettrick Bay on the north, and Kerrykroy and St. Ninian's Bay on the south. It will be observed that within this area are included the principal lochs of the island, and judging from its physical conditions in other respects, it might reasonably be expected to yield as great a variety of forms of molluscan life as either of the parts to the north or the south of it.

In referring to the distribution of the Mollusca within this area, it may be well first of all to note some of the species observed in the vicinity of the

\section{Royal Aquarium.}

As already remarked, the lateness of the season when I came to Rothesay caused me at first to confine my researches to the neighbourhood of the Aquarium, but the advent of longer daylight did not prevent me from still taking an occasional look around its vicinity. Among the species observed here were Limax (Amalia) gagates, L. (Amalia) marginatus, Helix aspersa var. depressa, H. arbustorum type and var. marmorata, besides a number of more common forms.

During the spring and early summer months, on the glass sides of the fresh-water tank in which a number of large pike were kept there might frequently be seen considerable numbers of Planorbis nautileus creeping about, as well as small individuals of Limncea; while in another tank, in which were a number of perch and roach, not a molluse was to 
be seen, although all the fresh-water tanks were supplied from the same source, viz., Loch Ascog. It would thus appear that the pike were inclined to look after larger "game" than tiny molluses. It may be asked: How did the Planorbis and Limncea get into the tanks? The reason is simple enough; the water from Loch Fad was not filtered, and consequently numbers of Mollusca as well as Entomostraca were occasionally brought down along with the water into the tanks.

\section{Loch Fad.}

This loch is artificially divided into two parts by an embankment formed across it opposite the farm of Lochly. A road is carried along the top of the embankment, which is very convenient for persons wishing to cross to the other side. The part next to Rothesay is called the "Kirk Dam," and the other is known as Loch Fad proper. The extreme length of the loch, including both parts, is about $2 \frac{1}{2}$ miles; while the breadth, which is somewhat variable; is barely a quarter of a mile at the embankment.

Loch Fad occupies part of a natural hollow or valley stretching in a north-easterly and southwesterly direction. The south-east side of the loch is formed of carboniferous rocks-sandstone, shale, and trap;-the north-west side is of grey schistose rocks, passing in some places into blue slate. Along the south-east side, from the embankment southwestward, I found a considerable number of Helicidæ -20 species at least-including 4 species of Vertigo. As a matter of fact, I found here a greater variety of Mollusca than in any of the other places examined. I did not find the nórth-west shore so productive, but one reason for this might be that that side was not examined so thoroughly as the other. I f feel assured, however, that the chief reason was the absence of molluscan species, due perhaps to unsuitability of habitat. The finding of so many 
species by the shores of Loch Fad is the more interesting, seeing that Haddin, as he states in his paper, failed to observe any Helicidæ at all along these shores. After referring to the distribution of several of the Helicidæ, he says : "It will be observed from the preceding remarks that $I$ have not been able to record a single species from the banks of Loch Fad, while on the shores of Loch Ascog and Loch Greenan are found Zonites nitidus," etc. He then goes on to say: "The reason of this I would not venture to affirm, but it is a fact worthy of note that the banks of the former are formed of shale, while those of the latter are of sand." I am quite at a loss to understand how it happened that Haddin failed to observe any Helicidæe on the shores or banks of Loch Fad, though his misapprehending their geological conditions might be more easily explained. The only plausible reason I can offer is that he had examined the shores of Loch Fad at a time when the weather was hot and dry, and when, as might be expected, few if any molluscs would be seen, whereas the very different results obtained by me were owing to the examination having been made in the morning while the air was cool and moist. As has been stated, a good number of species were observed, but they were nearly all of the commoner kinds-Vertigo substriata, $V$. antivertigo, and $V$. edentula being the only ones that could be considered uncommon or rare. As regards Loch Fad itself, although I got a boat and dredged a part of the loch, only the common aquatic forms were observed, as will be seen by referring to the list at the end of this paper.

Before leaving Loch Fad, it may be stated that in a little patch of marshy ground on the south-east side, and about a quarter of a mile south-west from the embankment, an Ostracode was observed which had been known previously only as a Post-tertiary fossil under the name of Cypris browniana, Jones. The examination of living specimens from this 
place showed that it belonged to a genus not previously described. The species is figured and described by Brady and Norman in their recently published Monograph.

Loch Fad can easily be reached by the Barone Road, or by the inland road to Kilchattan Bay. The near end of the Kirk Dam is about threequarters of a mile from Rothesay, and the embankment fully $1 \frac{1}{2}$ mile by either road.

\section{Loch Ascog.}

This loch is much smaller than Loch Fad, from which it is about half a mile distant at its southwest end. It is about a mile long, and scarcely a quarter of a mile broad at the widest part. The shore of the upper or south-west end is of fine sand, and well known to local botanists as the habitat of a few interesting aquatic phanerogams, such as Lobelia Dortmanna. A large portion of the shoreline on both sides towards the north-east end is trap-rock, or stones and rough gravel. I did not observe many molluscs about or in $t l_{i} ;$ loch; and the only forms worthy of special notice are Planorbis nautileus (type and var. albus), Zonites excavatus, and Vertigo antivertigo.

This loch can easily be reached by the inland road to Kilchattan Bay, or by the road passing Folly House and Braeside.

\section{Loch Greenan,}

or Greenan Loch, as it is called by the people in the district, is quite a small sheet of water, being only about half a mile in length and scarcely two hundred yards wide. It is situated about one mile north-west of the Kirk Dam, and is easily reached by the Barone and St. Ninians Bay Road.

During summer the lower or south-west end is overgrown with vegetation. There are white and yellow water-lilies (Nymphcea alba and Nuphar luteum) growing in abundance, on the stems and 
leaves of which may be found the curious polyzoon Cristatella mucedo, and the equally interesting and pretty entomostracan Sida crystallina. Here Hydra vulgaris also luxuriates, and many other strangelooking organisms. This end is so shallow, and dries up so much, that in some places it may be crossed on foot. There is so much decaying vegetation that the water, as it becomes warmed with the summer's sun, is found to be literally teeming with minute forms of life, and no doubt forms a "happy huntingground" for the micro-zoologist who may happen to find his way to the spot.

I found comparatively few terrestrial molluses about this loch; and although aquatic forms were numerous enough, those observed belonged to common species, with the exception of Planorbis glaber, Jeffreys ( $P$. parvus, Say), which occurred at the lower end of the loch, and was not unfrequent.

\section{Kames Bay District.}

The promontory on the opposite side of the bay from Port Bannatyne is known as Undranian Point, and there are here what appear to be the ruins of a limekiln. Under the loose stones which lie scattered about were observed Helix pulchella, $H$. pygmcea, Zonites radiatula, and several common species. By the side of a wall a short distance north from the Hydropathic Establishment, and at the side of an old inland road which joins the road to Ettrick Bay, a short distance to the west of the head of Kames Bay, were found Helix aspersa var. conoidea and $H$. hispida var. alba; while, by the side of a small rivulet above Skeoch Wood, Zonites nitidus was of somewhat frequent occurrence.

\section{Ettrick Bay District.}

The species observed here were chiefly common ones, the only forms calling for special notice being Helix caperata, H. pulchella, and a very small variety of Clausilia rugosa. Haddin records finding one 
specimen of Helix rufescens at Ettrick Bay, but I did not observe this molluse here or elsewhere within the area examined.

When at Ettrick Bay I had a hunt round for the Horned Poppy (Glaucium luteum) which used to grow by the side of a little burn that runs into the bay, but failed to find it. I hope that it has not become extinct.

\section{St. Ninians District.}

Helix ericetorum, which Haddin recorded as having been observed here, still exists, but apparently is not very common. With this exception, all the molluscs observed about St. Ninians Bay were common species.

\section{Ascog and Kerrykroy District.}

The only place where I observed Planorbis spirorbis was in a pond above Ascog Bay; and in the wood by the shore, near the entrance to the old coal-mine, I got the curious little Helix aculeata, as well as Vertigo edentula. Some of the commoner molluses, such as Pupa umbilicata, were plentiful in this district. Haddin records finding Pupa ringens in Mountstuart Wood; but I did not observe this species in any of the localities examined, and have included it in the list on his authority.

I have now made a general though hasty reference to the more or less noteworthy molluses found within the area described. A full list follows of all the species known to occur in Bute, including those recorded by Haddin but which I failed to observe. A map is appended of the portion of Bute specially referred to in this paper. 
TRANSACTIONS, NATURAL HISTORY SOCIETY OF GLASGOW. 178

\section{List of SPECIES, INCLUdiNg ALSO SOME VARIETIES, OF Mollusca observed in the Island of Bute.}

The arrangement and nomenclature of Jeffreys'British Conchology are followed.

\section{Conchifera.}

S P H R I I D

Plaldium, C. Pfolffer.

Pisidium fontinale (Drapernaud).-Loch Fad; frequent.

, pusillum (Gmelin).-Loch Fad, Loch Ascog, and other places.

," nitidum, Jenyns.--Loch Fad; frequent.

Gasteropoda.

LI M N E I D 瓜.

Planorbio, Guettard.

Physa, Lamarck. IImnara, Bruguiere.

Anoylus, Geoffroy.

\section{Arion,} Eerussac. Limax, linné.

Planorbis nautileus (Linné).-Loch Ascog, Grènan Loch.

, : " var. alba, mihi.-Loch Ascog ; rare.

, albus, Müller.-Loch Fad, Greenan Loch.

", glaber, Jeffreys ( $P$. parvus Say).-Greenan Loch.

, spirorbis, Müller.-Small loch or pond near Ascog.

, contortus (Linné).-Loch Fad, Greenan Loch.

Physa fontinalis (Linné).--Side of Loch Fad.

Limncea peregra (Müller).-Common in ditches and lochs.

, palustris (Müller).-Marshy ground at the west end of Greenan Loch.

,. truncatula (Müller).-Frequent in ditches and lochs.

Ancylus fluviatilis, Müller.-Loch Fad, Loch Ascog.

\section{M A C I D E.}

Arion ater (Linné).-Common.

Limax gagates, Drapernaud.-Frequent in a garden near the Aquarium.

, marginatus, Müller.-Not very common in the vicinity of the Aquarium.

, agrestis, Linné.-Common.

, arborum, Bouchard-Chantereaux.-Frequent; vicinity of the Aquarium, near Loch Fad, and on beech trees west of Rothesay.

," maximus, Linné.-Vicinity of the Aquarium, among herbage on the shore at Ettrick Bay, and other places.

, lavis, Müller.-Frequent in damp situations under stones ; shore of Loch Fad, and other places. 
Succinea, Drapernaud.

\section{Vitrina,} Drapernaud.

\section{Zonites,} De Montfort.

\section{H E L I C I D $\approx$.}

Succinea putris (Linné).-Loch Fad. (St. Ninians Bay.*)

Vitrina pellucida, Müller.-Shores of Loch Fad.

Zonites cellarius (Müller).-Common; shores of Loch Fad, and other places.

, alliarius (Müller).-Common; shores of Loch Fad, and other places.

, alliarius var. viridula, Jeffreys.-Shore of Loch Fad; not common.

, nitidulus (Drapernaud).-Frequent; shores of Loch Fad, and other places. (Woodend.*)

, radiatulus (Alder).-Shores of Loch Fad. (Chapelton.*

, purus (Alder).-Shores of Loch Fad; not very common.

", nitidus (Müller).-Whores of Loch Fad. (Loch Ascog," Greenan Loch.*)

", excavatus (Bean).-Shores of Loch Fad and Loch Ascog. (Near Chapelton, ${ }^{*}$ above Ardbeg Point.*)

,, crystallinus (Müller).-Common; shores of Loch Fad, and other places.

, fulvus (Müller).-Frequent; shores of Loch Fad, and other places.

Eeliz,

Linne:

Helix lamellata, Jeffreys.-(Woodend, ${ }^{*}$ Mountstuart.*) I did not observe this species.

" aculeata, Müller.-(Woodend, ${ }^{*}$ Mountstuart.*) Wood by the side of the shore road near Ascog.

, aspersa, Müller.-Common; shores of Loch Fad, and other places.

" aspersa var. conoidea, Picard.-By the side of an old wall at Port Bannatyne.

" aspersa var. depressa, Scott. -- In the vicinity of the Aquarium.

", nemoralis, Linné, including several colour-varieties.Common; shores of Loch Fad, and other places.

" arbustorum, Linné.-Common in the vicinity of the' Aquarium. (Woods behind Kamesburgh.*)

" arbustorum var. marmorata, Taylor.-In the vicinity of the Aquarium.

", rufescens, Pennant.-(Ettrick Bay, one specimen.*)

" ? concinna, Jeffreys. - In the vicinity of the Aquarium. Specimens were sent to Mr. Taylor, Leeds, and while he agreed with me as to their identity with $H$. concinna, Jeffreys, he stated that he did not consider the species a very satisfactory one. It certainly comes very near $H$. hispida, and considerable famili-

On Haddin's authority. See his paper in Proc. Nat. Hist. Soc., Glasg., 1869. 
arity with this form is required to be able to distinguish it from some varieties of $H$. hispida. With some doubt, therefore, as to its being distinct from the latter species, it is included in my list.

Helix hispida, Linné.-Frequent; shores of Loch Fad, Port Bannatyne, and other places.

, hispida var. albida, Jeffreys.-By the side of a wall near the Hydropathic Establishment, Port Bannatyne.

,fusca, Montague.-Shores of Loch Fad. (Mountstuart,* Ardbeg.*)

, caperata, Montague.-By the shore at Ettrick and St.

Ninians Bays. (Banks of Greenan Loch.*)

,. ericetorum, Müller.-St. Ninians Bay, ${ }^{*}$ where I also - observed it.

, rotundata, Müller.-Common everywhere; Loch Fad, etc.

" pygmoe, Drapernaud.-Near Ardmalish Point, Kames

Bay ; rare.

, pulchella, Müller.-Near Ardmalish Point, Ettrick Bay.

(St. Ninians Bay.*)

Pupa, Lamarck.

Vertigo, Muiller.

Balia, Prideaux.

\section{Olausilia,} Drapernaud.

Pupa ringens, Jeffreys. - (Mountstuart Woods.*) I did not observe this species.

" umbilicata, Drapernaud:-Common ; shores of Loch Fad, etc.

Vertigo antivertigo (Drapernaud).--By the shores of Loch Fad; frequent. Loch Ascog; not common. (Greenan Loch.*)

" pygmoea (Drapernaud).-By the shores of Loch Fad; frequent. (Loch Ascog.*)

" substriata, Jeffreys.-By the shores of Loch Fad; rather scarce.

" edentula (Drapernaud).-By the shores of Loch Fad, in a wood at Ascog. (Side of Greenan Loch, ${ }^{*}$ Skeoch Wood.*)

Balia perversa (Linné).-On trees near the side of Loch Fad, on trees near the old church west of Rothesay, St. Ninians Bay, ${ }^{*}$ and other places.

Clausilia rugosa, Drapernaud.-Common; in the vicinity of the Aquarium, and other places.

rugosa, small var.-By the side of an old wall at Ettrick Bay.

Cochlicopa, Cochlicopa lubrica (Müller).-Frequent; shores of Loch Fad, Ferussac. and generally throughout the district.

\section{CA R Y CHIIDE.}

Oargohium, Carychium minimum (Müller).-Commonly met with throughMüller. out the district, in moist places; shores of Loch Fad, eto. 
A perusal of the foregoing List will, I think, show that there is every likelihood of further research being rewarded by the discovery of other additions to the Mollusca of the island. Thus several aquatic species - such as Sphorium corneum, S. lacustre, Valvata piscinalis, $V$. cristata, Planorbis nitida, etc. - may yet be found to occur in one or other of the lochs or ditches. The Swan Mussel (Anodonta cygnoea) may also yet be discovered in some of the lochs, as the conditions seem to be as favourable for its existence-say, in Greenan Loch-as they are in Lochend Loch, Edinburgh, where it is moderately common.

It may be noted here in passing, that Planorbis complanatus, which Haddin, when he read his paper on the Bute Helicidæ in 1869, recorded from Lochend Loch as being an addition to the Scottish Fauna, was previously known for more than thirty years to be a common species in that Loch. The second edition of Excursions illustrative of the Geology and Natural History of the Environs of Edinburgh, by William Rhind, M.R.C.S., etc., published in Edinburgh and London in 18:36, contains a list of the local Land and Fresh-water Mollusca, which includes the species referred to, with the remark "Common; Lochend." It was thus recognised as a Scottish species long prior to Haddin's record.

Though, as has been pointed out, several aquatic molluses may yet be added to the fauna of Bute few additions to the terrestrial species now recorded are likely to be met with in the island. The following, however, may yet be observed: Arion hortensis, Limax flavus, Succinea elegans, Helix rupestris, Pupa marginata, Bulimus obscurus, and Acme lineata.

Sixty-one species and varieties are recorded in the preceding list, and these, with one or two exceptions, have all been certified by Mr. John W. Taylor F.L.S., Leeds. 
$=$ 


NOTES ON SOME SCOTTISH ECHINODERMATA 


\section{The Annals}

OF

\section{Scottish Natural History}

A QUARTERLY MAGAZINE

WITH WHICH IS INCORPORATED

\section{"The Scottish 嗮aturalist"}

EDITED BY

J. A. HARVIE-BROWN, F.R.S.E., F.Z.S. Member of the British Ornithologists' Union

JAMES W. H. TRAIL, M.A., M.D, F.L.S.

Professor of Botany in the University of Aberdeen and

WILLIAM EAGLE CLARKE, F.L.S., MEM. BRIT. ORN. UNION Natural History Department, Museum of Science and Art, Edinburgh 


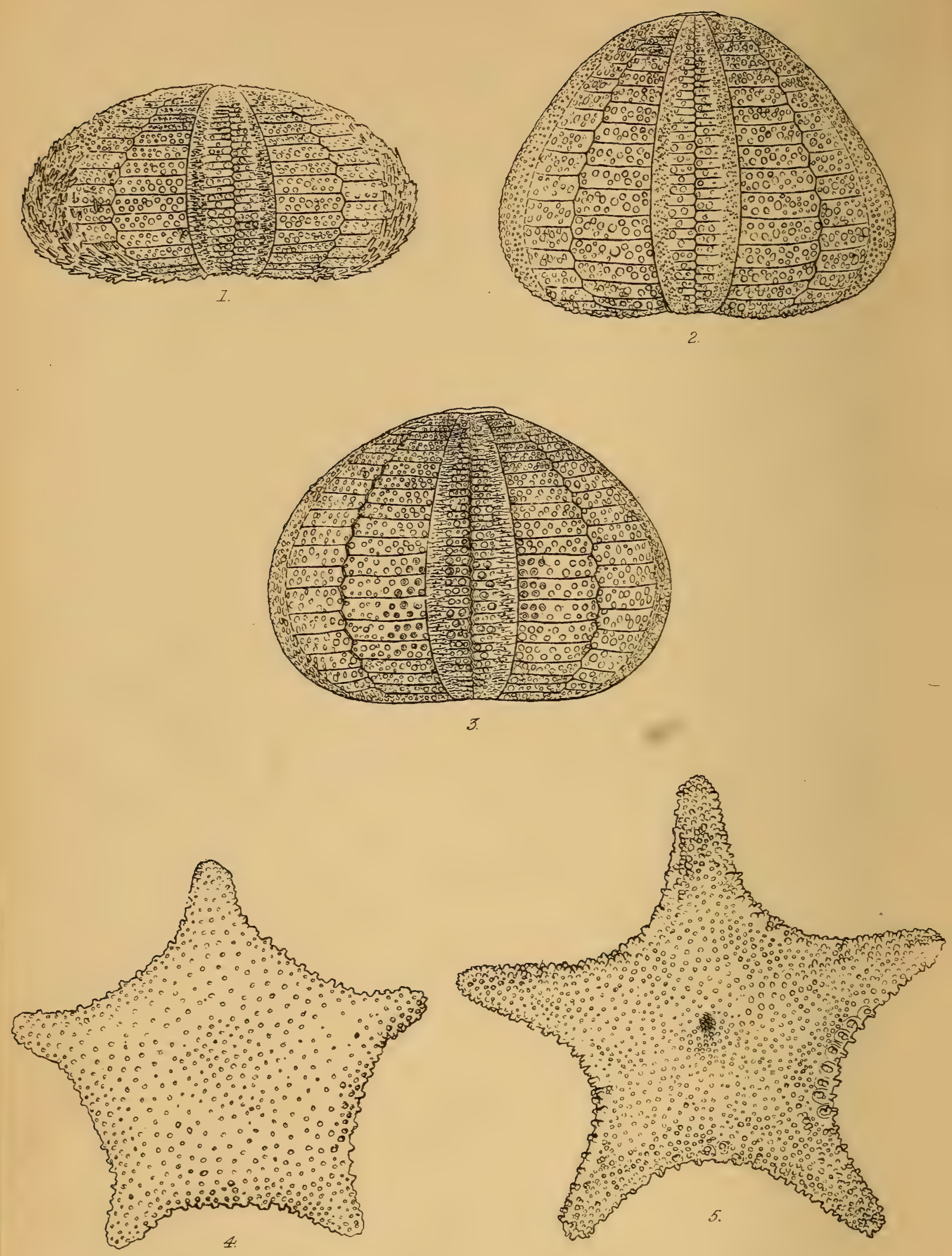


\title{
NOTES ON SOME SCOTTISH ECHINODERMATA.
}

\author{
By Thomas ScotT, F.L.S., \\ Naturalist to the Fishery Board for Scotland.
}

\section{Plate II.}

\section{On a Depressed Form of Echinus esculentus, Linn.}

A MORE than usually depressed form of Echinus esculentus was obtained in the Firth of Forth in June last (I89I), which it may be of interest to notice. There is, as is well known to students of the Echinodermata, considerable variation in in the form of this species, but the variety now under consideration is the most depressed of the numerous specimens I have observed among the captures made during several years' trawling on the east coast of Scotland. In form it approaches very closely to Strongylocentrotus drobachiensis, Müller,-a species which we have obtained on one or two occasions in the vicinity of Inchkeith, a little east of the south end of the the island, ${ }^{1}$ - but is to be distinguished at once by the possession of three pairs of pores in the row instead of four or five pairs as in Strongylocentrotus. This variety is represented $\frac{2}{5}$ the natural size on Plate II. Fig. I, and measures 4.65 inches in diameter, and 2.3 inches in height. Fig. 2 represents another variety of the same species with somewhat flattened sides, which was obtained off Musselburgh at from five to six fathoms. Fig. 3 gives us a specimen of the usual form, both natural size. These latter figures show by comparison more clearly the unusual form of the variety under consideration: they, also, are represented $\frac{2}{5}$ of their natural size.

\section{On Goniaster phrygianus (Parelius) = Goniaster equestris, Agassiz.}

During the last few years I have obtained two specimens of a Goniaster from the Firth of Forth which closely resemble each other in form, but which differ considerably from specimens of Goniaster phrygianus taken in the Moray

1 Strongylocentrotus drobachiensis is common in the Cromarty Firth, and we almost invariably obtain a number of specimens of this species every time we trawl between Cromarty and Invergordon. 
Firth, where, in the deep water ( 30 to 50 fathoms) the species is moderately common, being of frequent occurrence among the refuse of the trawl net. Plate II. Fig. 4 represents one of the Firth of Forth specimens, while Fig. 5 is one of the Moray Firth specimens; respectively $\frac{1}{4}$ and $\frac{1}{6}$ their natural size. In the Forth specimen, as shown by the figure, the space between the arms is shallow, and the arms are very short. In the Moray Firth specimen, on the other hand, the space between the arms is deeply concave, and the arms comparatively long. I have examined a considerable number of the Moray Firth specimens and find that, though the length of the arms and the concavity of the space between them varies to some extent, none of those examined possessed the short arms, or the shallow, and nearly straight, interspaces that distinguished the two specimens from the Firth of Forth.

One of the Forth specimens was obtained a few miles east of May Island by a trawler, and is the one represented by Fig. 4. The other was obtained by myself from deep water some distance west of the May Island, and is now in the Museum of Science and Art, Edinburgh.

\section{On Brissopsis lypifera (L. Agassiz).}

I have on several occasions during the last three years obtained specimens of Brissopsis lyrifer $\mathrm{in}$ the vicinity of May Island, Firth of Forth. Though by no means a rare species on some parts of the Scotch coasts it does not appear to have been known to occur in the Forth estuary or its vicinity previous to my discovery of it in I888. It was first obtained about two miles north-westward of the May, and since then further specimens have been captured both in the locality referred to and also at Trawling Station ix., a few miles southeastward of that Island. The following records of this species from the latter localityare from the "Eighth and Ninth Annual Reports of the Fishery Board for Scotland ":-6th June I 889 , three specimens; I 7 th August I 889, one specimen; I 3 th May I 890 , one specimen; 5 th August I 890 , one specimen. A few others have been obtained this year (I 89I). In Mr. W. E. Hoyle's "Revised List of the British Echinoidea" in the "Proceedings of the Royal Physical Society of Edinburgh" for I 889-90, "Aberdeenshire and the Moray Firth" and 
"Off Montrose 42 fms.," are the only localities for this species on the east coast of Scotland.

This species does not appear to be common on our east coast, but on the west it is sometimes obtained in great abundance. In the early part of I887 I was on board a trawler working over 20 fathoms water off Craigmore, near Rothesay, when the trawl net on being hauled up was found to contain a large quantity of fine mud, amongst which there were a great number of Brissopsis. I counted more than sixty whole specimens, besides which there were many others more or less damaged. This large capture of Brissopsis has been however far exceeded by one recorded by Mr. W. Anderson Smith in the Fishery Board's "Ninth Annual Report" (I 89I), part iii. p. 298. I cannot do better than quote Mr. Anderson Smith's description of his interesting capture. He says, - "Besides the ordinary echinoderms we had a most remarkable haul of what we formerly considered a rare form of heart urchin, Brissopsis lyrifera, completely choking our net, which hung like a huge bag of potatoes and could not be lifted. We calculated the quantity of these urchins as representing not less than three tons weight."

That it should occur in such enormous numbers on the west coast and only one or a very few at a time on the east coast, where the physical conditions appear to be equally favourable for its existence, is rather singular, and is not easily explained. Beam-trawling has been more vigorously prosecuted on the east coast than on the west and may have something to do with the difference alluded to, but the true explanation will have, I think, to be sought for elsewhere. 



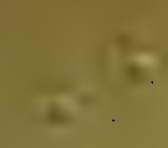



ON NEW AND RARE CRUSTACEA FROM THE EAST COAST OF SCOTLAND. 


\section{The Annals}

\section{OF \\ Scottish Natural History}

A QUARTERLY MAGAZINE WITH WHICH IS INCORPORATED

\section{"Tbe Scottigh 师aturalist"}

$$
\text { EDITED BY }
$$

J. A. HARVIE-BROWN, F.R.S.E., F.Z.S.

Member of the British Ornithologists' Union

JAMES W. H. TRAIL, M.A., M.D., F.L.S.

Professor of Botany in the University of Aberdeen and

WILLIAM EAGLE CLARKE, F.L.S., MEM. BRIT. ORN. UNION Natural History Department, Museum of Science and Art, Edinburgh 
[Reprinted from "The Annals of Scottish Natural History," July 1892.]

\section{ON NEW AND RARE CRUSTACEA FROM} THE EAST COAST OF SCOTLAND.

By Thomas Scott, F.L.S., and Andrew Scott.

Plates VI. and VII.

Lichomolgus aberdonensis, n. sp. (Plate VI. Figs. I-I 2).

LENGTH, exclusive of tail setæ, $1.46 \mathrm{~mm}$. (about $\frac{1}{18}$ of an inch). The cephalo-thorax is composed of five segments, the first of which is longer than the combined length of the other four, rounded in front, and not produced into a rostrum ; the fifth segment is rather longer than, and little more than half the breadth of, the preceding segment. Abdomen in both sexes composed of five segments, the first segment nearly twice the breadth of the next one, and as long as the second and third together. In the male the lateral distal angles of this segment are furnished with two small unequal spines (Fig. I 2). The fourth segment of the abdomen in both sexes is shorter than either of the other segments. The whole length of the abdomen (exclusive of the caudal stylets) is scarcely half the length of the cephalo-thorax. Caudal stylets about half as long again as the last abdominal segment and furnished with six setæ, the fourth seta (counting from the outside) is considerably longer than the entire length of the abdomen and caudal stylets combined. Anterior antennæ seven-jointed, alike in both sexes, and 
provided with numerous setæ; the proportional length of the joints are nearly as shown by the annexed formula :-

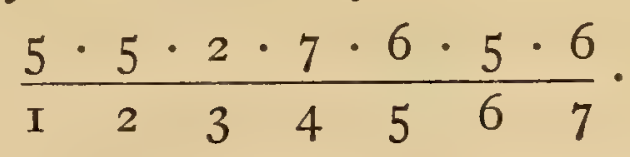

Posterior antennæ four-jointed; the first and second joints are elongate, the third and fourth very short (Fig. 3). Mandible short and moderately stout, armed at the extremity with two processes and two spiniform setæ; one of the processes is conical and tooth-like, and serrate on the inner edge, the other is somewhat cylindrical, and rounded at the end-the margin that is opposed to the tooth-like process, and also the end, being hispid (Fig. 4). Maxillæ stout, broad, and bearing a number of terminal spiniform setæ. Anterior footjaws stout, with a proportionally large marginal setiferous lobe, and several terminal spines (Fig. 5). Posterior foot-jaws two-jointed, those of the male armed with a strong, uncinate, and sinuous terminal claw, which is considerably longer than the stout broad joint from the end of which it springs, and with which it forms a powerful grasping organ. At the base of the claw, on the inside, there is a stout, short, and blunt spine. The inner edge of the last joint of the foot-jaw is furnished with a double (? or treble) row of elongate bluntpointed teeth. Two long stout plumose setæ spring from the inner margin, and near the distal end of the first joint. The terminal claw probably passes down between these two setæ, and forms with them an interlocking apparatus (Fig. 7). The posterior foot-jaws in the female, are also moderately stout, but the terminal claw is feeble; the last joint is not so broad, and its inner margin bears two setiferous spines instead of the double row of teeth possessed by that of the male. The first, second, third, and fourth pairs of swimming-feet are nearly alike; both branches are short (the outer being rather shorter than the inner) and three-jointed. The outer branch is armed exteriorly with a number of dagger-like spines, as shown in the figures (Figs. 8 and 9). The inner distal angle of the first basal joint of all the four pairs bears a spiniform seta. The inner distal angle of the second basal joint of the first pair bears also an elongate dagger-like spine, while a moderately long and stout seta springs from the outer margin of the same joint. The fifth pair of feet are 
broad and foliaceous-more so in the female than the male, as shown in the figures (Figs. IO and II).

Habitat.-Aberdeen Bay. Several specimens were obtained in bottom-townet material collected in I89I; but only a few of them were mature.

Lichomolgus aberdonensis resembles in general form and structure the species described in the "Tenth Annual Report of the Fishery Board for Scotland" under the name of Lichomolgus littoralis, but differs from it in several important points, as in the proportional length of the joints of the anterior and posterior antennæ, in the form of the posterior foot-jaw and fifth pair of feet, and in the proportional length of the segments of the abdomen.

Lichomolgus arenicolus, Brady (Plate VII. Figs. I-IO).

I 872. Boeckia arenicola, Brady, "Nat. Hist. Trans. of Northumberland and Durham," vol. iv. p. 430.

I 880. Lichomolgus arenicolus, Brady, "Mon. Brit. Copep." vol. iii. Plate LXXXVII. Figs. I-7.

Female.-Lergth, exclusive of tail setæ, $2 \cdot 3 \mathrm{~mm}$. Anterior antennæ not more than half the length of the first body segment, and composed of six joints, which are all more or less setiferous; the proportional length of the joints are nearly as in the formula :-

$$
\frac{\text { I I } \cdot \text { I } 8 \cdot 6 \cdot \text { I }_{4} \cdot \text { I } 2_{2} \cdot \text { I }_{7}}{\text { I } 2 \cdot 3 \cdot 4 \cdot 5 \cdot 6}
$$

Posterior antennæ stout, four-jointed; the first two joints short, the third about twice the length of the second, and the last about two-thirds the length of the preceding one. The last joint is armed with three stout terminal clawed spines, which are elongate, and distinctly articulated and swollen near the middle-the distal half being strongly curved and claw-like. There is a fourth terminal articulated spine, but it is more slender and less curved than the other three (Fig. 3). Mandibular stylets two, the upper one provided with a row of marginal teeth, the first two of which are large, while the others gradually decrease in size towards the distal end. The lower stylet bears a number of fine hairs on its upper margin (Fig. 4). The maxillæ consist of a broad laminar plate rounded at the end, and 
furnished with a moderately long terminal spine; there is also a small marginal bifid process on the one side, while a small seta springs from the margin on the other side (Fig. 5). The last joint of the anterior foot-jaw terminates in four moderately large subequal sub-marginal spines, and a small lateral spine springs from near the proximal end of the joint (Fig. 6). Posterior foot-jaw rudimentary, moderately broad and stout, and having a very small subterminal tooth-like process (Fig. 7). The first, second, third, and fourth pairs of swimming-feet nearly alike; both branches short (the inner rather longer than the outer one), and three-jointed (Figs. 8 and 9). The armature of the inner branches differs to some extent, especially in the following manner: the last joint of the inner branches of the first pair is provided with one submarginal short and stout dagger-shaped spine, and round the distal end with five moderately long setæ, as shown in Fig. 8. In the second pair the last joint bears one terminal and two submarginal dagger-shaped spines, which are rather longer than that of the first pair, and three submarginal setæ. In the third pair the last joint bears two terminal and two submarginal spines, and two marginal setæ. In the fourth pair the last joint is armed with the same number of spines as in the third pair, but with only one marginal seta, as shown in Fig. 9. Fifth pair elongate, foliaceous, furnished with one short seta on the external margin and near the distal end; immediately anterior to the seta is a number of small marginal teeth. The somewhat truncate extremity of the foot bears three setæ, the middle one of which is very small, while the other two are moderately long and stout, and nearly of equal length (Fig. Io). Abdomen four-jointed, the first segment about twice the length of the next, and somewhat dilated; the other three segments are subequal, the last being rather longer than either of the other two. Caudal stylets rather longer than the last abdominal segment, and about three times as long as broad; each stylet is furnished with several terminal plumose setæ, and with one seta near the middle of the exterior margin.

Habitat.-Off St. Monans, Firth of Forth. One specimen only (a female) of this interesting species was obtained, and is recorded (but not described or figured) in 
the "Tenth Annual Report of the Fishery Board for Scotland" (I 892).

Lichomolgus arenicolus appears to be a rare species. Some important details of structure not noticed in "British Copepoda" are here described and figured, as are also several others, to illustrate the description of the species, viz.: the posterior antennæ with its remarkably articulated and clawed terminal spines, the rudimentary female posterior foot-jaw, and the fourth pair of swimming-feet, which, like the other three pairs, has both branches three-jointed, and which in this respect forms, with Lichomolgus aberdonensis, Lichomolgus littoralis, and Lichomologus sabella, ${ }^{1}$ a distinct group - the other species of Lichomolgus being distinguished from these three by having the inner branches of the fourth pair of swimming-feet one- or two-jointed. The one- or two-jointed inner branches of the fourth pair of feet constitute one of the characters of the genus Lichomolgus, while a second character is that of the mandible, which has the form of "a slender stylet, dilated at the base, but excessively slender and filiform beyond the middle." In Lichomolgus arenicolus there are two mandibular stylets, and in Lichomolgus aberdonensis and littoralis the mandible, which is moderately stout and broad, has no stylets, but is armed at the extremity with one or two tooth-like processes and a few setæ. In consequence of this divergence from some of the generic characters of Lichomolgus, it may become necessary to institute one, or possibly two, sub-genera for the reception of these aberrant forms, or otherwise to alter the generic definition of Lichomolgus so as to include them.

Should it be found desirable, for the reasons stated, to remove Lichomolgus littoralis and aberdonensis into a different genus or sub-genus, we would suggest-Platycheiron as an appropriate generic name,-being descriptive of the remarkably broad ultimate joint of the male posterior foot-jaws of the two species referred to.

1 A species described by I. C. Thompson in " Proc. Liverpool Biol. Soc.," vol. ii. p. 68. He also records L. albens, Thorell, from Liverpool Bay, but we have not as yet seen any description of this species. Another species (apparently new), having the inner branches of the first four pairs of swimming-feet three-jointed, has just been obtained by us, and will be described and figured later. 


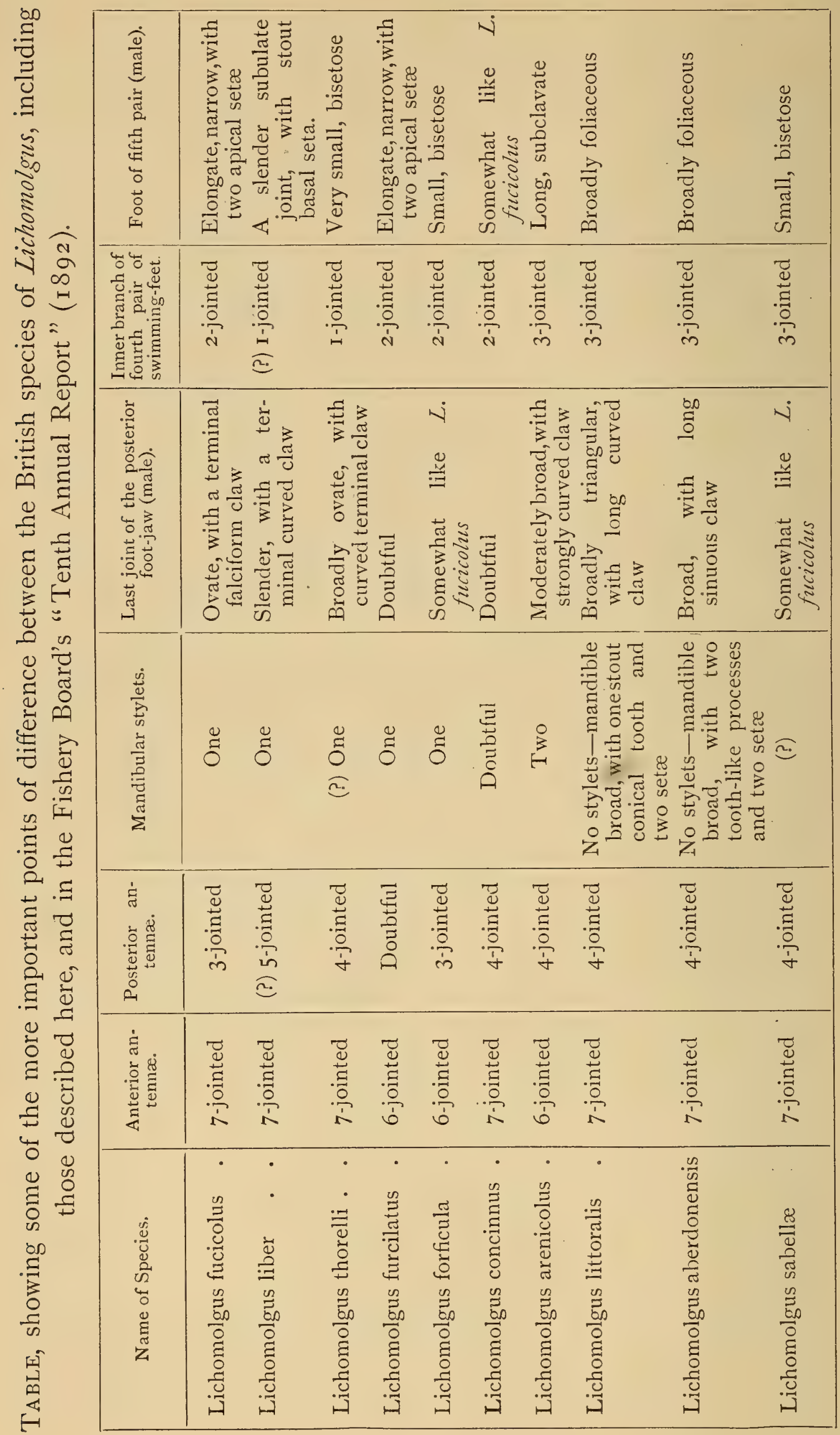


Thysanoessa borealis (G. O. Sars).

I 882. Thysanoessa borealis, "Oversigt over Norges Crustaceer," Bd. I. pp. $52,53$.

This Schizopod has been obtained in various parts of the Firth of Forth, but never in quantity-one, or at most only a few specimens being taken at a time. Thysanoessa has the first pair of legs long, but not so long or so slender as those of Nematocelis, which it somewhat resembles. It is further distinguished from Nematocelis by the penultimate joint of the first pair of legs being provided throughout its length with stout ciliated setæ, the last joint-which is very small -being also furnished with a number of hairs. On the other hand, the first pair of legs in Nematocelis have both the penultimate and antipenultimate joints (which are long and slender) naked, but there is a bunch of spiniform setæ at the apex of the legs. The first legs are very easily broken, so that in handling specimens, or in collecting them, great care is required to keep the legs intact. We are indebted to the Rev. A. M. Norman for the name of the Thysanoessa here recorded.

Among a few specimens of Forth Schizopoda forwarded to Dr. Norman for identification, and which included the Thysanoessa referred to above, he observed what he considers to be a specimen of Nematocelis megalops (G. O. Sars); but the specimen he examined, and one or two others that seem to belong to the same species, having lost their first legs, and thus wanting the character which chiefly distinguishes them, it is perhaps better for the present to leave the claim of Nematocelis megalops for a place in the Forth fauna in abeyance till more satisfactory specimens turn up. Dr. Norman informs us that Nematocelis. megalops was sent to him from Banff by Thomas Edward twenty or thirty years ago; from Aberdeen by Mr. Sim in I872; and that it has quite recently been obtained at Redcar.

The eyes of Thysanoessa and Nematocelis have a marked constriction near the middle, which divides the eye into what appears to be a lower and upper eye, and thus imparts to them a peculiar and rather striking appearance, and which 
serves to distinguish them at a glance from either Boreophausia or Nyctiphanes.

\section{Explanation of Plate VI.}

Lichomolgus aberdonensis, n. sp.

Fig. I. Adult female

2. Anterior antenna

"3. Posterior antenna. $. \quad \times 125$

"4. Mandible; $a$, maxilla . . . . $\times$ I 25

"5. Anterior foot-jaw . . . . $\times 190$

"6. Posterior foot-jaw (female) . . . $\times$ I 90

"7. Posterior foot-jaw (male) . . . $\times 190$

" 8. Foot of first pair . . . . $\times 125$

"9. Foot of fourth pair . . . . $\times 85$

"I I. Foot of fifth pair (female) . . . $\times$ I 25

"I I. Foot of fifth pair (male). . . . $\times$ I 25

"I 2. Abdomen of male . . . . . $\times 40$

\section{Explanation of Plate VII.}

Lichomolgus arenicolus, Brady.

Fig. I. Adult Female . . . . . $\times 40$

, 2. Anterior antenna. . . . $\times$ I 25

". 3. Posterior antenna . . . . . $\times 190$

"4. Mandible . . . . . $\times 250$

"5. Maxilla . . . . . $\times 280$

"6. Anterior foot-jaw . . . . . $\times 280$

" 7. Posterior foot-jaw . . . . $\times 280$

"8. Foot of first pair . . . . . $\times$ I 25

"9. Foot of fourth pair . . . $\times 85$

" Iо. Foot of fifth pair . . . . . $\times$ I 90 


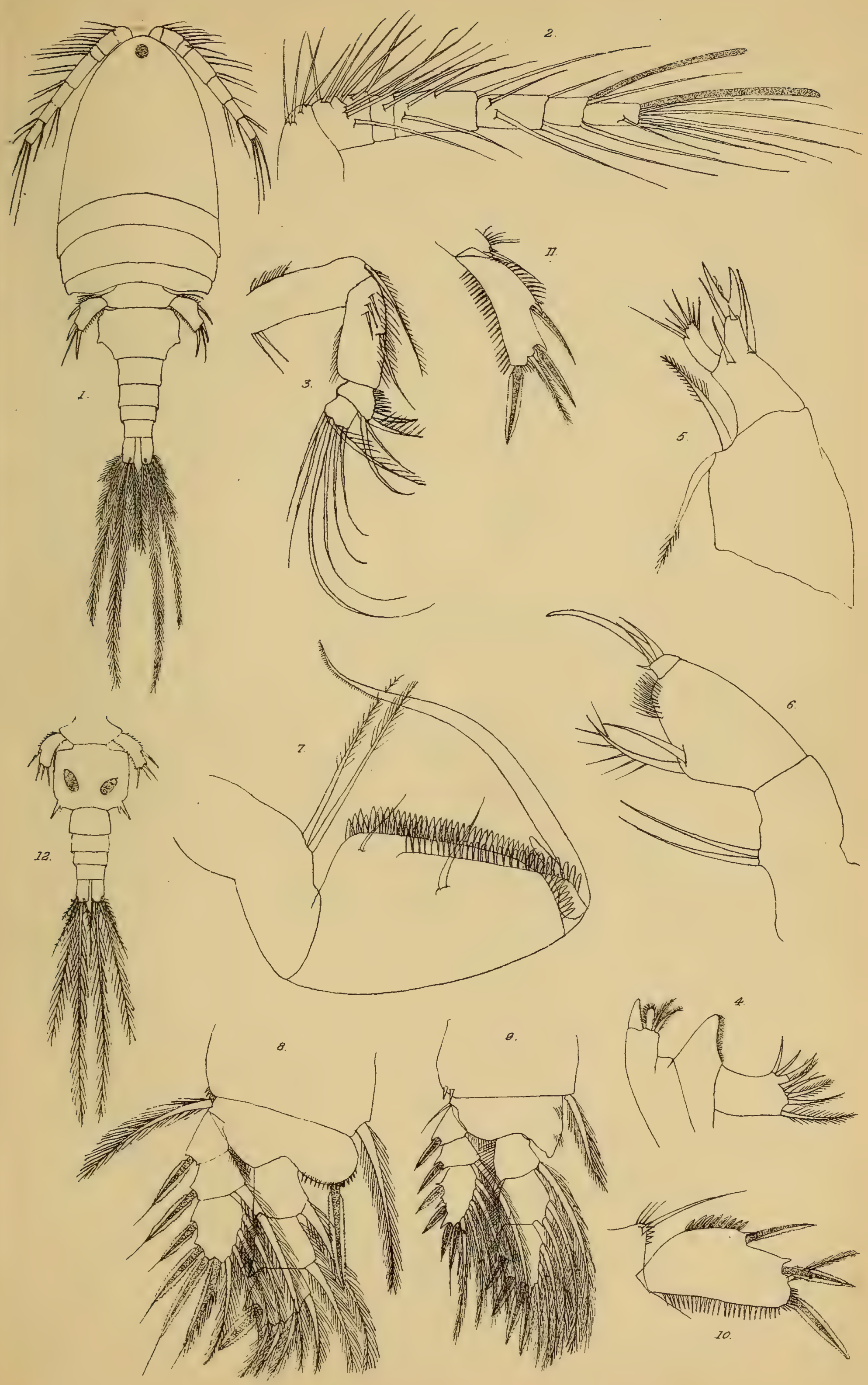




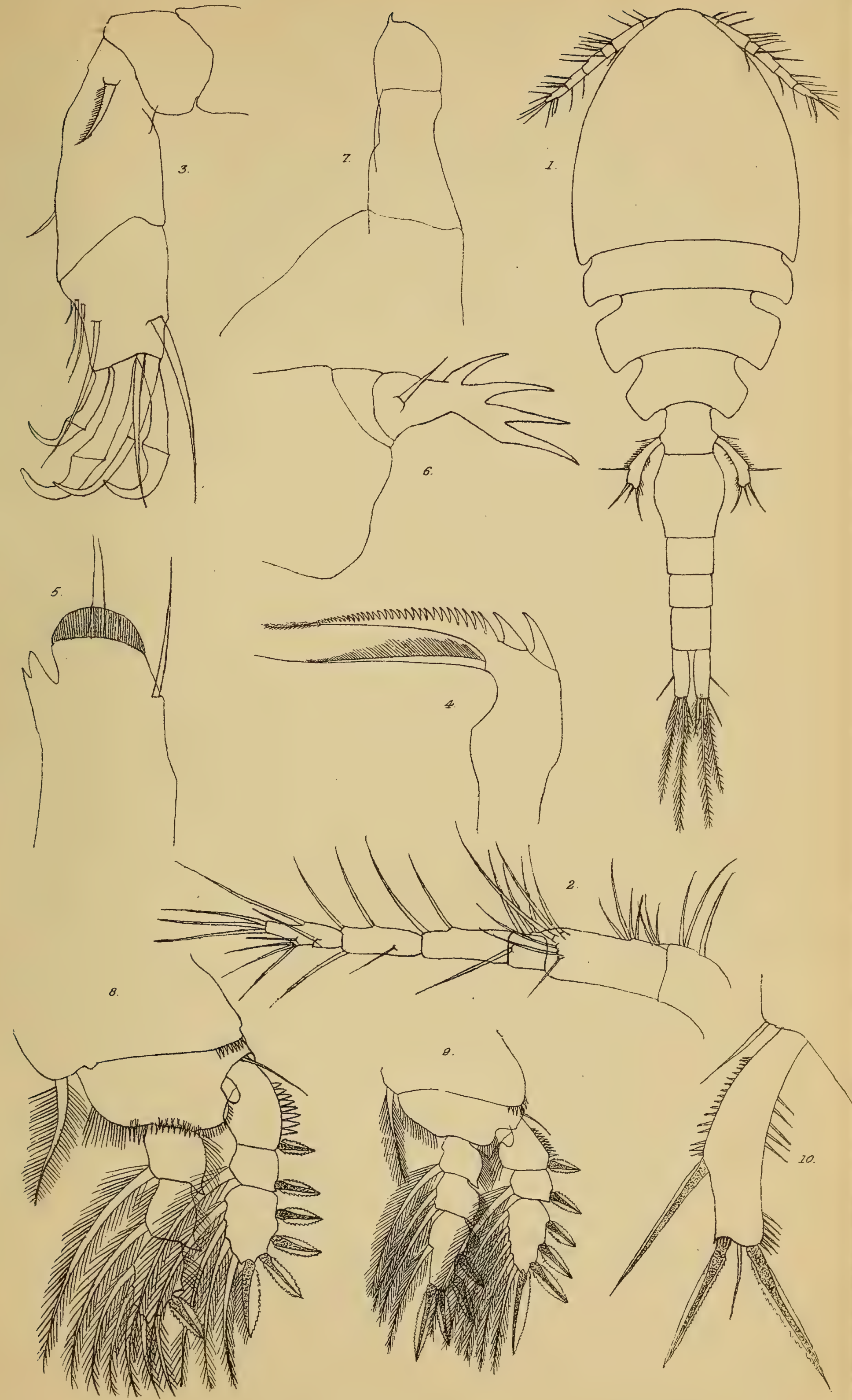





[From the Transactions of the Natural History Society of Glasgow.]

NOTES ON RHINCALANUS GIGAS, BRADY, AND ECTINOSOMA ATLANTICUM, BRADY AND ROBERTSON.

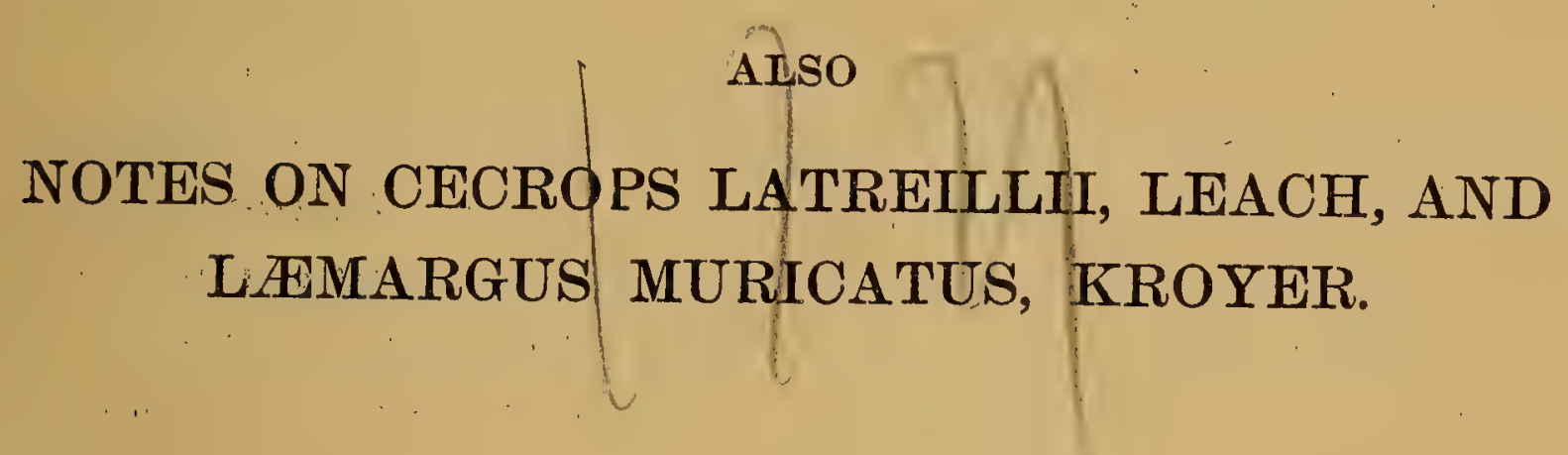


XXXI.

NOTES ON RHINCALANUS GIGAS, BRADY, $A N D$ ECTINOSOMA ATLANTICUM, BRADY AND ROBERTSON.

BY THOMAS SCOTT, F.L.S., NATURALIST TO THE FISHERY BOARD FOR SCOTLAND.

[Read 25th November, 1890.]

Rhincalanus gigas was first observed by my son (Andrew Scott) when looking over some tow-net material collected at Orkney in 1889 . He drew my attention to two specimens, but I laid them aside with the intention of examining them at my leisure, and they were forgotten for a considerable time. During the early part of the present year, I was examining some tow-nettings collected about 22 miles south-east of Montrose in the beginning of February, when another example was obtained. I thereafter submitted specimens to Professor G. S. Brady, F.R.S., who identified them as Rhincalanus gigas, Brady. He stated at the same time that he had some doubt as to Rh. gigas being really distinct from Rh. cornutus, Dana. Rhincalanus has been recorded from various places, but has not, so far as I know, been previously observed in British waters. It is fully described in the Report on the Challenger Copepoda.

Ectinosoma atlanticum was first described, under the generic name of Microstella, from specimens collected by Mr. E. C. Davidson in the open sea to the West of Ireland (see Mon. Brit. Copep.). It is an exceedingly small species. I have not yet had time to measure the dimensions of any of the specimens, but Dr. Brady gives $\frac{1}{60}$ of an inch as 
the size of those described by him. It is a wellmarked species, and is easily distinguishable from any other British Ectinosoma by the comparatively elongated joints of the anterior antennæ and by the long setæ of the fifth feet. It has been obtained at several places in the open sea to the west and south-west of Ireland, and in Kinsale Harbour; while Giesbrecht and Mobius have taken it, and also Rhincalanus gigas, in the neighbourhood of Kiel. There is no previous record of its occurrence on the East of Scotland. It was frequent in midwaternet material collected eastward of Inchkeith, Firth of Forth, but less frequent in the surface-net gatherings. 


\section{XXXII.}

NOTES ON CECROPS LATREILLII, LEACH, AND

\section{LAMARGUS MURICATUS, KROYER.}

\section{BY ANDREW SCOTT.}

\section{[Read 25th November, 1890.]}

THE two species of fish-parasites under notice were found on a specimen of the Short Sunfish (Orthagoriscus molce), about 4 feet in length, which was captured near Inchkolm, in the Firth of Forth, on 10th October last.

Cecrops latreillii, which was found adhering to the gills of the fish, seems to be of frequent occurrence on O. molce. It is mentioned by Baird, in his History of the British Entomostraca, as having been found in a number of localities, and he states that "in all instances they were taken from the Sunfish and adhering to the gills." White, in his Popular History of British Crustacea, says that "it is found on the gills of the Sunfish occasionally caught on the coasts of England and Ireland." Edward of Banff also recorded it from the Moray Firth, where it was taken on the gills of the Oblong Sunfish (Orthagoricus oblongus) as well as on those of $O$. molce.

Lomargus muricatus was found in two hollows which it had eaten inwards through the skin of the fish. One of the hollows was in front and the other behind the anal fin. The species appears to be gregarious in its habit, as a number of specimens were occupying each hollow. They adhered to the flesh of the fish by means of the strong hooks of the foot-jaws, so that it was somewhat difficult to detach them without injuring them. This species is mentioned by Baird and White. Edward also records it from the Moray Firth, but it does not appear to be so common as Cecrops latreillii.

Loemargus differs from Cecrops in the feet being foliaceous and branchial, and the upper segments of the thorax are also small but distinct. 
$=$ 

NOTES ON COPEPODA FROM THE FIRTH OF FORTH : LONGIPEDIA CORONATA, CLAUS; AND A PRELIMINARY DESCRIPTION OF AN APPARENTLY NEW GENUS AND SPECIES 


\title{
The Annals
}

\section{OF \\ Scottish Natural History}

\author{
A QUARTERLY MAGAZINE
}

WITH WHICH IS INCORPORATED

\section{"The Scottigh 㸱aturalist"}

EDITED BY

J. A. HARVIE-BROWN, F.R.S.E., F.Z.S. Member of the British Ornithologists' Union

JAMES W. H. TRAIL, M.A., M.D., F.L.S.

Professor of Botany in the University of Aberdeen and

WILLIAM EAGLE CLARKE, F.L.S., MEM. BRIT, ORN. UNION Natural History Department, Museum of Science and Art, Edinburgh

EDINBURGH : DAVID DOUGLAS, CASTLE STREET 


\title{
NOTES ON COPEPODA FROM THE FIRTH OF
} FORTH : LONGIPEDIA CORONATA, CLAUS; AND A PRELIMINARY DESCRIPTION OF AN APPARENTLY NEW GENUS AND SPECIES.

\author{
By Thomas Scott, F.L.S., \\ Naturalist to the Fishery Board for Scotland,
} and ANDrew Scott.

\section{Plate II. ${ }^{1}$}

Longipedia coronata, Claus, is one of the most beautiful as well as one of the most common of the Copepoda in the British Seas, and has long been familiar to us.

It belongs to the Harpacticide, a family not only very extensive, but which also includes many interesting and curious species. As regards distribution, Longipedia coronata is to be obtained in a great variety of places, and at very various depths; it usually lives on or near the bottom, and is thus much more frequently obtained in materials collected by means of the dredge than in tow-net gatherings. Its favourite habitat seems to be among the zoophytes and weeds of the littoral and coralline zones.

Though many hundreds of specimens have passed through our hands, especially during the last few years, so that its appearance has become familiar to us, we have nevertheless had our suspicions occasionally aroused as to whether there were not really two species mixed up together under the name Longipedia coronata as understood by British Carcinologists. On several occasions during the past few years a partial investigation has been made by us for the purpose of ascertaining whether there were really two species or not; but from want of time, or from some other cause, no satisfactory solution was arrived at. On referring to some of the literature dealing with the Copepoda, it was ascertained that a certain amount of dissatisfaction had been expressed by various authors with the diagnosis of Longipedia coronata as given in "Die freilebenden Copepoden" and in the "British

\footnotetext{
1 . This plate will be issued with the July number.
} 
Copepoda." Geisbrecht ${ }^{1}$ in I 882 pointed out some of the doubtful characters in the description of this species in both the works named, but he apparently failed to realise the important significance of the characters he had called in question. In a capital work by Dr. Eugene Canu lately published, entitled "Les Copepodes du Boulonnais," that author again calls in question the accuracy of the description of Longipedia coronata in these same two monographs, but ascribes the error, in the one case to a young male having been described for an adult, and in the other case to a misunderstanding as to the sexes. The following are Dr. Canu's remarks: "Formes jeunes très fréquentes et peut-être plus nombreuses dans une même pêche que les adultes; ce que pourrait expliquer les méprises faites par Claus (jeune $\delta$ décrit pour l'adulte) et Brady (confusion entre les deux sexes o immatures) et relevées par Geisbrecht." ${ }^{2}$ Dr. Canu has thus evidently missed the true explanation of the difference between the so called "male" and "female" forms; at least so far as regards the description of Longipedia in "British Copepoda."

A short time ago one of the writers of the present remarks (Andrew Scott), while examining a quantity of material dredged in Largo Bay, Firth of Forth, in I89 I, observed as usual both forms of Longipedia coronata-i.e. "males" and "females"; he also observed that some of the "males" carried one ovisac! and one or two of the "females" two ovisacs! This discovery naturally led to further inquiry being made, with the result that two distinct species of Copepoda were found to have been mixed up under the one name, the so-called "male" being the true "female" of the Longipedia, while the so-called "female" was found to be the female of a new and distinct species, for which we have had to provisionally institute a new genus. Both males and females of this new species have now been obtained. A preliminary description of the true Longipedia coronata and of the new species is given below. Full descriptions (with drawings) are being prepared for the Annual Report of the Fishery Board for Scotland, to be published during the summer.

1 "Die freilebenden Copepoden der Kieler Föhrde."

2 "Les Copepodes du Boulonnais" (1892), p. I46. 


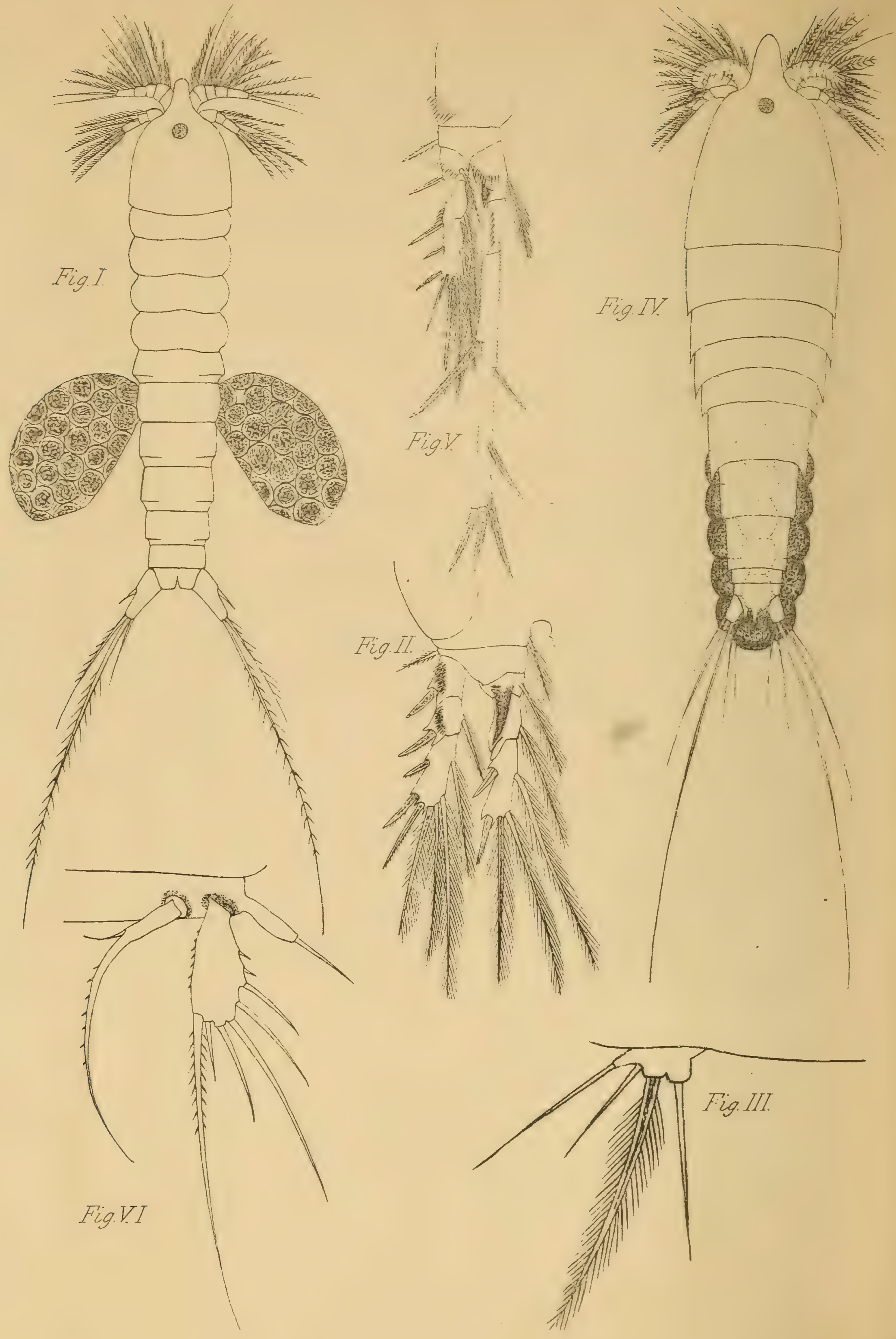

Figs I. III CANuelita PERPLEXA sp.n. Figs MV-VI LONGIPEdia CORONATA, Claus. 


\section{LongIPEDIA, Claus.}

Longipedia coronata, Claus, Plate II., Figs. 4-6.

I863. Longipedia coronata, Claus, "Die freilebenden Copepoden," p. I I o, t. xiv.

I 880. Longipedia coronata, Brady (in part), "Mon. Brit. Copep.," vol ii. p. 6, Plates XXXIV and XXXV.

Female.-Secondary branch of posterior antennæ nearly as long as the primary branch, six-jointed, all the joints rather longer than broad. Inner branches of second pair of swimming-feet in both sexes conspicuously elongate, being much longer than the outer branches, or fully two and a half times longer. Fifth pair of feet foliaceous: those of the female consist of a moderately long inner segment, obovate in outline, bearing three setæ of moderate length and two very small ones on the outer distal margin, and one long and two short terminal setæ; a long stout and curved seta with a minute hair, arising from its inner aspect and near the proximal end, springs from the inner part of the basal joint; this spine-like seta is distinctly articulated to the basal joint. The rounded posterior dorsal margin of the last abdominal segment bears three spiniform processes, the central one large and easily observed, the lateral ones smaller. The postero-lateral angles of the cephalo-thoracic and abdominal segments acutely angular. Caudal stylets short, slightly divaricate. Length, $1.5 \mathrm{~mm}$. ( $\frac{1}{17}$ th of an inch). One ovisac.

One of the most prominent characters of this species, and one by which it is readily distinguished, is the very long inner branches of the second pair of swimming-feet.

Longipedia coronata is common all over the Forth, and especially so off Musselburgh.

CANUElla, ${ }^{1}$ gen. nov., provisional name.

LONGIPEDIA, Brady (in part).

Anterior antennæ less robust and less plumose than those of Longipedia coronata, five-jointed, first and second

1 So named by us in compliment to Dr. Eugène Canu, author of "Les Copepodes du Boulonnais." 
joints large. Posterior antennæ somewhat similar to those of Longipedia, but the secondary branch is shorter, the width of the joints being greater than the length. Mouth organs similar to those of Longipedia. Both branches of each of the first four pairs of swimming-feet of about equal length, and, with the exception of the second pair, somewhat like those of Longipedia; the first joint of the inner branches of the second pair very short, and armed with a stout conical spine about equal in length to the second joint (Fig. 2). Fifth, in both sexes rudimentary, consisting of a small basal joint, bearing in the female four setæ, one of which is rather longer than the others, and densely plumose (Fig. 3). The first and fourth segments of the abdomen without spinous armature. Caudal stylets about equal in length to the two last abdominal segments, and considerably divergent. The animal is more slender than Longipedia coronata, and the postero-lateral angles of the cephalo-thoracic and abdominal segments are rounded (Fig. I). Ovisacs two, large.

One of the most conspicuous differences between Canuella and Longipedia is in the structure of the second pair of swimming feet. In Longipedia the inner branches of the second pair are greatly elongated in both sexes, and form one of the distinctive characters of the genus, the name of which has also reference to this character. In Canuella, on the other hand, both branches are of about equal length in both male and female, and the fifth feet are rudimentary. Therefore, notwithstanding the number of important points in which the two forms agree, the differences described clearly separate the one from the other ; and, moreover, while Longipedia has only one, Camuella has two ovisacs.

Canuella perplexa, sp. n. (provisional name) Plate II. Figs. I-3.

I880. Longipedia coronata, Brady (fem.), "Brit. Copep." vol. ii. p. 6, Plate XXXIV. Figs. 3, 9 ; Plate XXXV. Figs. I, 3, 9 .

The characters of the genus are applicable to the species, and therefore need not be repeated, this species being the only one known. Length, $\mathrm{I} \cdot 4 \mathrm{~mm}$. ( $\frac{1}{18}$ th of an inch).

Additional Notes.-(a) Males and females of a small (?) 
variety of Longipedia were observed after the above Notes had been prepared. This variety agrees in size and with the detailed figures and description of Longipedia coronata in Dr. Geisbrecht's work on the free-living Copepoda of Kiel Föhrde, but differs from the description and figures of the "male" in "British Copepoda," and from Longipedia coronata, partially described and figured in the present Notes, in the following particulars, viz:

(Ist) In the armature of the first pair of swimming-feet being more slender; (2nd) in the outer branches of the second pair being proportionally longer. The two first joints of the outer branch are about equal in length to the two first joints of the inner one, and the large spiniform seta on the outer edge of the long third joint of the inner branch has a position nearly intermediate between the two smaller setæ on the inner edge; and ( $3 \mathrm{rd}$ ) the middle lamellæ of the fifth pair of feet in the female are much narrower and more elongate. These differences, so far as we can make out, appear to be constant. For the purpose of provisionally distinguishing this variety, we propose to call it variety minor. Length of variety, $.85 \mathrm{~mm}$. ( $\frac{1}{29}$ th of an inch). On the other hand, the form partially described here as Longipedia coronata (type) agrees practically in size and in structure with the so-called "male" of Longipedia described in "British Copepoda" and in "Die freilebenden Copepoden," while that described here as Canuella perplexa agrees in structure with the so-called "female" of Longipedia in "British Copepoda." We have not seen Boeck's description, and are unable to say which of the forms now referred to agrees with that described by him.

(b) In I 867 M. Hesse recorded ${ }^{1}$ a new Copepod (Sunaristes paguri) living as a commensal in the same shell with Pagurus (a kind of hermit-crab), and which in some respects agrees with the form described by us here as Camuella perplexa, but differs from it in the following important points. The first abdominal segment in the female is "aussi long que les quatre autres; il est séparé du thorax par un espace assez écarté et arrondi qui facilite les mouvements du corps," and each of the two ovisacs "forment un ovale très-allongé et

1 “Ann. Sc. Nat. (Zool.)," 5th series, vol. vii. p. 205, Plate IV. Figs. I I25 ; also op. cit. p. 2 I I. 
sont presque pointus des deux bouts. Ils sont attachés, par leur extrémité supérieure et par un pédicule, au bord inférieur du dernier anneau thoracique, et leur longueur égale celle de l'abdomen." There also appear to be important differences in the structure of the mouth appendages and swimming-feet in both sexes. Sunaristes is also much longer than our species, being " 5 millimètres de long" (? including tail setæ). The habitat is quite different, for the Sunaristes "sont les compagnons intimes des Pagures, et c'est avec la plus grande peine qu'on peut les en séparer, non qu'ils soient fixés sur eux comme le sont leurs parasites, mais par leur adresse à se cacher dans l'intérieur, ou en dessous des coquilles que ceuxci habitent."

In I 884 Dr. Wilh. Müller described ${ }^{1}$ a large Copepod (Longipedina paguri) that he had discovered living with Pagurus bernihardus. This is considered by Dr. Canu to be the same as the Sunaristes of M. Hesse; it also resembles, even more .closely than Sunaristes, the form now described by us.

After a careful study of the descriptions and figures of Sunaristes and Longipedina we find that, if both authors are correct, the difference in their descriptions and figures are scarcely reconcilable, and appear to refer to different species; and further, the difference both in respect of structure and habitat between both of these and the species described by us is apparently so considerable that we prefer for the present to consider the Forth species as distinct from both. Canuella perplexa is, so far as we know, a free-living Copepod, and is not associated in any way whatever, as commensal or parasite, with any other animal.

\section{Explanation of Plate.}

Canuella perplexa, gen. et sp. n.

Fig. I. Adult female

2. Foot of second pair

"3. Foot of fifth pair

$\times 46: 6$ $\times 126 \cdot 5$ $\times 760$

Longipedia coronata, Claus.

Fig. 4. Adult female

$"$ 5. Foot of second pair

"6. Foot of fifth pair, female

$\times$ I 90

1 "Archiv für Naturgesch." Jahrgang 50, Erste Band, p. I9, Plate III. 





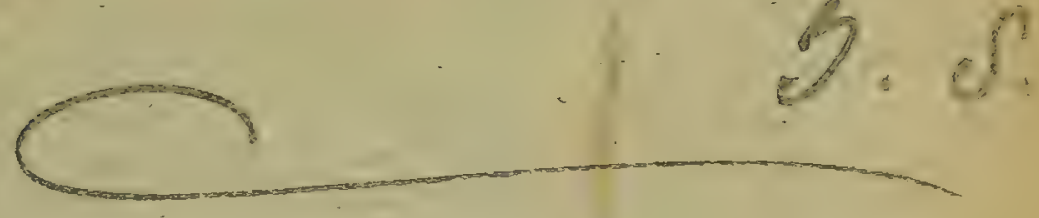

\section{THE LAND AND FRESH-WATER CRUSTACEA}

OF THE

\section{DISTRICT AROUND EDINBURGH.}

PART II.-THE OSTRACODA AND COPEPODA.

BY

THOMAS SCOTT, F.L.S.

[Reprinted from the Proceedings of the Royal Physical Society, Edinburgh, 1892-93, vol, xii., July 12, 1893.] 

VI. The Land and Fresh-Water Crustacea of the District around Edinburgh. Part II.-The Ostracoda and Copepoda. By Thomas Scotт, Esq., F.L.S., Cor. Mem. Glas. Geol. Soc. and Nat. Hist. Soc. of Glasgow.

(Read 19th April 1893.)

In a previous communication I gave a short account of the land and fresh-water Amphipoda and Isopoda of the Edinburgh district; in this paper I propose to notice two of the groups of the Entomostraca, viz., the Ostracoda and Copepoda. I intended to have given an account of these groups during the previous session of the Royal Physical Society, but want of time compelled me, reluctantly, to delay doing so till a more convenient season. One of the chief difficulties in dealing with the larger or "higher " Crustacea is to find the specimens, but the chief difficulty with the micro-forms- 
which, as a rule, are plentiful enough-is rather the determination of the species. To critically examine thousands of these minute organisms is a task requiring not only patience, but a considerable amount of time, because it is often absolutely necessary to dissect the specimens in order to determine, not only specific, but, also, generic differences. To simply crush the animal under a cover-glass, and take the risk of finding one or more of the appendages in a favourable position, is, to say the least of it, a clumsy and unsatisfactory method. No doubt, to dissect, for example, a Copepod, perhaps the thirtieth to the fiftieth of an inch in length, limb from limb, in consecutive order, so as to ascertain the exact relative position of each member, and thus be enabled to make a correct comparison of the one with the other, requires some practice and dexterity, yet only in this way can a reliable knowledge of the structure and relationship of the parts be acquired. But, though the difficulty of such a procedure be apparently great, it is quite surmountable-my son, Mr Andrew Scott, to whom I am much indebted for help of this kind in preparing material for the present paper, is often able to prepare a complete series of appendages from a single Copepod, viz., anterior and posterior antennæ, mandibles, maxillæ, anterior and posterior foot-jaws, and the five pairs of thoracic feet, and this has often permitted a satisfactory discrimination to be made, which would otherwise have been well-nigh impossible.

Next session I hope to be able to prepare an account of the Cladocera of the district, when I shall, probably, notice any species belonging to the other groups which may have previously escaped observation.

\section{THE OSTRACODA.}

I propose, in the first place, to deal with the Ostracoda of the area.

It will be understood that the district limits are the same as described in my previous paper, and in Mr Evans's memoir on the Mammalia in the Proceedings of the Royal Physical Society, published in 1892.

At a meeting of the Royal Physical Society, held on the 22nd of January 1890, I had the privilege of exhibiting a 
small collection of Ostracoda, and of drawing attention to a few of the more interesting species that had been obtained within the Edinburgh district; the aim of the present communication is to put on record all the species-common as well as rare-that are known to occur within the prescribed area. But, before proceeding to give an enumeration of the species, it may be desirable to offer a few remarks upon the distribution of the Ostracoda.

Speaking generally, the Ostracoda are to be found almost everywhere where there are pools of water. Some of them are more commonly found in water of questionable purity, such as may be seen stagnant in ditches and marshy ground, and possessing an odour of a rather disagreeable kind; but, while that is the case, I do not remember having ever observed Ostracoda in water that was largely mixed with sewage,- - the impurity of the water in which such species are found is usually the result of the decay of vegetable matter in the bottom or round the sides of the pool, or loch. It may be also stated, as a rule, that all the species are more or less confined to still water, as that of ponds, lochs, canals, etc., and are rarely obtained in running water. There are some curious and interesting problems, relating to the laws of distribution of species, presented by the Ostracoda-in one locality a single species may be found in the greatest abundance to the exclusion of almost every other form, while in another locality, where the conditions appear to be equally favourable, that species may be very scarce or entirely absent. To bring out this more clearly, I may relate my experience of a single species, viz., Cypris incongruens. In Garvel Park, Greenock, previous to the construction of the James Watt Dock, there were some pools of water, and during May 1880, the weather being dry and warm, one of these pools dried up. There had been a good deal of conferva in the pool, and this, when the water disappeared, formed a substance, almost like felt, covering the bottom. On removing some of this felt-like material, Cypris incongruens was observed in myriads, and, so far as I remember, was the only Ostracod present. During the autumn of 1888 I happened to be several times in the neighbourhood of 
Portobello, and visited the brickfield at the west end of the town; in one or two of the pools in the disused part of the brickfield, the same species was in great abundance, to the exclusion of almost every other form. During September 1890, I made an examination of some shallow pools of water on May Island, when Cypris incongruens was observed to be moderately common, and this was the only fresh-water Ostracod I found on the island. I have now to notice a still more curious fact relating to the distribution of this species. In September 1887, my son, Mr Andrew Scott, who was, at that time, assistant chemist in the laboratory of the Baker Street Sugar Refinery, Greenock, belonging to Messrs Alexander Scott \& Sons,-wrote me as follows:"I was up at one of the tanks on the roof of the sugar-house, and observed that the bottom was quite yellow. On closer examination the yellow substance turned out to be Ostracoda-chiefly Cypris incongruens; there is also a Candona, I think" (this was Candona candida). "The tank was being cleaned out, so I took some of the mud, etc., for preservation. Now the curious thing is, how did the Ostracods get into the tank, seeing that any water that gathers is rain water, and the tank is cleaned out once a year?"

Being desirous for further information about this matter, I wrote to the manager of the sugar-house, Mr Alexander S. MacLean (whom I have the privilege of counting as one of my friends), drawing his attention to the subject, and asking if he knew of any means by which the Ostracods could have been introduced; and on 21st January 1888, he sent me the following interesting note:- "Now as to the Ostracods, the tanks referred to consist of a set of three, measuring 40 feet by 16 feet by 4 feet 6 inches deep, they are formed of castiron plates, and stand about 100 feet above the ground. One is covered with yellow pine boards, the other two are uncovered. They were wont to be supplied with water from Loch Thom, but the supply was shut off at the meter inlet four years ago when the tanks ceased to be used. Rain water collects in the two uncovered tanks, and that is the only water that has entered them since the Loch Thom water was shut off. I know, therefore, of no way by which these little animals could get in except by adhering to the claws of 
birds. And that this is probably the true means, appears from the fact that, the char-house being idle, birds have all freedom to alight undisturbed in and about the tanks. I have frequently seen starlings, wagtails, and house-sparrows, and sometimes a robin redbreast, sitting on the sides of the tanks." Such is Mr MacLean's account of this interesting example of the apparently erratic distribution of these Ostracods.

In case it may be thought that the Ostracods were descended from those that may have been introduced before the supply of the Loch Thom water was shut off, I should, perhaps, add this further explanation. The only water that could get into the tanks, during the lengthened period they were not in use, was, as stated by my correspondent, supplied from the clouds, and, though that supply is sometimes considerable, it was seldom allowed to collect in any quantity. The uncovered tanks were separated from each other by a partition formed of iron plates; one of the tanks had an outlet pipe flush with the bottom, so that when necessary all the water from that tank could be run off; the second tank communicated with the first by a round hole through the iron partition, at about three or four inches from the bottom. In the one tank, therefore, all the water drained off as it fell, while, in the other, not more than a depth of three or four inches could collect, unless the hole in the iron partition was closed, which was rarely done. Being continually exposed to the sun and air, both tanks were consequently dry during a considerable part of the summer, unless the season were unusually wet. Mud, consisting of dust, blown by the wind, and of carbonaceous matter from the chimneys, collected in the bottoms of the tanks, but it was never allowed to accumulate, though the tanks were not in use; as a matter of fact, the tanks had been cleaned out, at least, twice since the time when the Loch Thom water was shut off, and before Ostracods were discovered. When the tanks were cleaned, the rust was carefully chipped or scraped off the cast-iron sides, which were then coated with tar, and the bottoms were swept with a brush; it is, therefore, hardly possible that the Ostracods observed could have been descendants from any that may have been introduced with the Loch Thom VOL. XII. 
water; and, moreover, I do not remember having ever obtained Cypris incongruens in Loch Thom.

It has, also, to be kept in mind that Ostracoda die very soon if exposed to the air, though they can survive a few days when enclosed in damp mud or vegetable matter. The eggs of Entomostraca possess much greater vitality than the adult animals, and may, after a considerable lapse of time, be revived, as has been demonstrated by Professor G. O. Sars, who has raised Entomostraca from dried Australian mud; but the case I have described is different, in that the tank was cleaned out with a brush, so that, practically, no mud was left to form a protection, for either adults or eggs, from the scorching rays of the summer's sun, yet nevertheless, here was a species of Ostracod in such immense numbers as to impart a yellow colour to the bottom of the tank.

Cypris incongruens, though thus abundant and occurring in such out-of-the-ray places, is yet by no means so ubiquitous as such examples would seem to imply. It is no uncommon experience to seek for it in vain where all the conditions favourable to its existence appear to be present. But this Ostracod is not only seemingly capricious in its selection of a habitat, it is also capable of living under very varied conditions, both as regards the temperature and the purity of the water. Mr David Robertson, the veteran Scottish naturalist, obtained it, many y ears ago, in a mill coolingpond at Paisley. "Where the water issued into the pond, the temperature was $90^{\circ}$ Fahr., and the surface water $80^{\circ}$ Fahr.; the Ostracods were found in the mud farthest from the heat." On the other hand, my son obtained the same species at Greenock, in a ditch where there was very little water, and what there was of it, covered with a coating of ice. It may also be found in brackish, as well as in clean, water, and in water so impure, from decomposing vegetable matter, as to be offensive both to sight and to smell.

It will not be understood, though I have thus tried to illustrate the vagrant distribution of a particular species, that such a distribution is exceptional, or confined to that species. It may be observed, more or less, in many other species belonging to the group. It is this kind of distribution that makes the study of these minute organisms 
more interesting, because rare forms turn up in such unlikely and exceptional localities, that the expectation is kept always, more or less, active and on the alert.

The Ostracoda, which may thus form a suitable subject for a leisure-time study, are not only of interest to the naturalist, but are also of value from a merely utilitarian point of view, seeing that fish are not indifferent to them as an article of food; hence, it is the experience of the student that limited localities frequented by the trout and the stickleback are not, commonly, the best hunting-grounds for Ostracoda. Another point worth noticing is the dissimilarity of species between the east and the west sides of Scotland. Though a considerable amount of attention has been devoted to the Ostracoda for many years, the difference in this respect remains fairly constant. No doubt, the difference has varied during the course of these years,-species that appeared to be confined to one side have been discovered on the other; but, while there was this tendency to equalisation, the research which led to it also brought to light other forms, and these, being, for the present, at least, apparently confined to the east or the west sides, cause the difference still to remain. The species that are at present apparently confined to the east or the west of Scotland are few in number, and may be best shown in tabulated form, thus:

\section{TABLE $I$.}

Species found on the east side of Scotland, but not hitherto on the west side.

Cypris puberc, O. F. Müller.

Erpetocypris violacec, Brady and Norman.
Species found on the west side of Scotland; but not hitherto on the east side.

Scuttia browniana ${ }^{1}$ (T. R. Jones).

Erpetocypris robertsoni, Brady and Norman.

Cypridopsis newtoni, Brady and Robertson.

Cypridopsis variegata, Brady and Norman.

Darwinula stevensoni, ${ }^{1}$ Brady and Robertson.

1 Scottia browniana has been obtained common in a post-Tertiary deposit at Elie in Fifeshire (see Proc. Roy. Phys. Soc. Edin., vol. x., p. 334), and Darwinula stevensoni from a somerwhat similar deposit at the Meadows, Edinburgh (see Proc. Roy. Phys. Soc. Edin., vol. x., p. 141). 
The following table, by showing what species are found in Scotland, but not in England, and vice versâx, may also be of interest.

\section{TABLE II.}

Species found in Scotland, but not hitherto known to occur in England.

Scottia browniana ${ }^{1}$ (T. R. Jones).

Erpetocypris robertsoni, Brady and Norman.

Cyprois flava (Zaddach).

Candona euplectella, Robertson.
Species found in England, but not hitherto known to occur in Scotland.

Cypria joanna (Baird).

Cypris elliptica, Baird.

Cypriscambrica, Brady and Robertson. Cypris ornata, O. F. Muiller.

Cypris clavata, Baird.

Cypris trigonella, Brady.

Erpetocypris serrata, Norman.

Metacypris cordata, Brady and Robertson.

Limnicythere monstrifica (Norman).

Table III. shows the species found both in England and Scotland, but not in Ireland, and those peculiar to Ireland only.

\section{TABLE III.}

Species found in both England and Scotland, but not hitherto in Ireland.

Cyclocypris globosa (G. O. Sars).

Cypris obliqua, Brady.

Erpetocypris strigata (O. F. Müller).

Erpetocypris tumefacta. Brady and Robertson.

Erpetocypris olivacea, Brady and Norman.

Cypridopsis newtoni, Brady and Robertson.

Candona rostrata, Brady and Norman. Candona acuminata (Fischer).

Ilyocypris gibba (Ramdohr).

Lymnicythere inopinata (Baird).
Species hitherto only found in Ireland.

Cypris bispinosa, Lucas.

Candona elongatc, Brady and Norman.

Though only two species are peculiar to the fresh-water Ostracod fauna of Ireland, they are both of special interest.

1 Scottia browniona is found as a post-Tertiary fossil in several places in the south of England. 
The first, Cypris bispinosa, is one of the finest of the British species, and the only other two places where it has been observed are the island of Guernsey and Egypt; while the second, Candona elongata, has been obtained nowhere else,-its Irish habitat being Lough Neagh.

\section{LOCAL LISTS OF SPECIES.}

The following lists of species are intended to exhibit how the Ostracoda vary in number and kinds in different localities in the district, and, also, to show that, while some forms are more or less common to all the localities, others are restricted to one or to only a few places. The lists may also be of use to collectors, by indicating where the rarer species may be obtained, and where the richest gatherings have been made. A few of the species mentioned in this paper are more frequently obtained in brackish than in purely fresh water, but they are included because of their close relationship with true fresh-water species. The true fresh-water and the true marine species merge together in these brackish-water forms, and any boundary line that may be drawn between the two is at best more or less arbitrary.

As Duddingston Loch is in our immediate vicinity, and has, so far, yielded a greater number of species than any other locality within the district, it may be better first to give a list of the Ostracoda that have been obtained in this loch.

Ostracoda obtained in DUdDingsTon Loch, near Edinburgh.

Cypria ophthalmica (Jurine).

Cypria loevis (O. F. Müller).

Cypria serena (Koch).

Cypris fuscata (Jurine).

Cypris pubera, O. F. Müller.

Cypris virens (Jurine).

Cypris reticulata, Zaddach.

Erpetocypris reptans (Baird).

Erpetocypris strigata (O. F. Müller). Erpetocypris tumefacta (Brady and

Robertson).

Erpetocypris olivacea, Brady and
Cypridopsis vidua (O. F. Müller).

Cypridopsis villosa (Jurine).

Potamocypris fulva, Brady.

Cyprois flava (Zaddach).

Candona candida (O. F. Müller).

Candona lactea, Baird.

Candona pubescens (Koch).

Candona rostrata, Brady and Norman.

Candona fabceformis (Fischer).

Ilyocypris gibba (Ramdohr).

Limnicythere inopinata (Baird).

Norman. 
Ostracoda obtained in pools at LUFFNess LiNks, near Aberlady. These pools have been long known to the botanist if not to the zoologist, and there can be no doubt that they harbour a micro-fauna fully as interesting as their flora. The following species were collected in September 1889 :-

Cypria ophthatmica (Jurine).

Cypria loevis (O. F. Müller).

Cypris fuscata (Jurine).

Cypris virens (Jurine).

Erpetocypris reptans (Baird).

Erpetocypris tumefacta (Brady and

Robertson).

Cypridopsis villosa (Jurine).
Notodromas monacha (O. F. Müller).

Candona candida (O. F. Müller).

Candona pubescens (Koch).

Candona kingsteii, Brady and Robertson.

Candonce faboformis (Fischer).

Ilyocypris gibba (Ramdohr).

Threipmuir Reservoir, two to three miles south of Balerno, is formed in one of the valleys of the Pentlands; the surrounding scenery has a rather bleak and barren appearance, especially towards the Pentlands. The reservoir is of considerable extent, and to make a careful examination of it would require the use of a boat, so that a tow-net and dredge could be used. If that were done it is quite possible that some interesting Entomostraca might be captured. I have only been able to make an examination of the sides of the reservoir with a hand-net, and the following were the Ostracoda obtained :-

Cypria ophthalmica (Jurine).

Cypria serena (Koch).

Cpyris fuscata (Jurine).

Erpetocypris tumefacta (Brady and

Robertson).

Cypridopsis vidua (O. F. Müller).
Candona candida (O. F. Müller).

Candona kingsleii, Brady and Robertson.

Candona acuminata (Fischer).

Candona sp.

It sometimes happens that the ditches by which the surface water drains off into a loch or pond harbours a richer micro-fauna than the loch or pond to which they are tributaries. This was my experience at HARELAW DAM, which was visited about the same time as Threipmuir. The dam itself yielded very little in the way of Ostracoda, but in a ditch that for a considerable distance runs parallel 
with the dam, I found the following species of Ostracoda, and one or two rare things belonging to another group:-

Cypria ophthatmica (Jurine).

Cypria serena (Koch).

Erpetocypris reptans (Baird).

Erpetocypris tumefacto (Brady and

Robertson).

Cypridopsis vidua (O. F. Müller).
Cypridopsis villosa (Jurine).

Candona candida (O. F. Müller).

Candona kingsleii, Brady and Robert.

son.

Candona acuminata (Fischer).

Ilyocypris gibba (Ramdohr).

In company with an old friend-Mr Thomas Strutherswho is thoroughly familiar with the district around Edinburgh, I examined some pools near GoREBRIDGE in December 1889, and obtained the following species:-

Cypria ophthalmica (Jurine).

Erpetocypris tumefacta (Brady and

Robertson).

Potamocypris fulva, Brady.
Candona candida (O. F. Müller).

Candona pubescens (Koch).

Candona kingsleii, Brady and Robertson.

At Seafield, near Dunbar, there is an old disused brickfield in which are several pools of water. The brickfield is close to the sea-shore, so that during high tides the sea flows into the pools and causes the water to become brackish. The little shrimp-like Crustaceans, Mysis vulgaris and Palcemonetes varians, frequent some of the pools. Being desirous to learn about the Ostracod fauna of these pools, I got my friend Mr Jamieson, Assistant Naturalist to the Fishery Board, to collect some material and send it to me. I also, in company with him, made a personal examination of the pools. The following species of Ostracoda were obtained:-

Cypris prasina, Fischer.

Erpetocypris tumefacta (Brady and

Robertson).

Cypridopsis aculeata, Lilljeborg.

Potamocypris fulva, Brady.
Candona candida (O. F. Müller).

Candona pubescens (Koch).

Ilyocypris gibba (Ramdohr).

Cytheridea torosa (Jones).

The brackish-water pools at the mouth of the CockLEMILL Burn, near Largo, Fifeshire, were examined, and yielded the following species :-

Cypria ophthalmica (Jurine).

Cypris (?) virens (Jurine).

Potamocypris fulva, Brady.
Candona lactea, Baird.

Cytheridea torosa (Jones).

Along with the species enumerated from these two brackishwater localities, there were several others more nearly allied 
to the marine than the fresh-water forms, which, though not entered in the regular lists, may be mentioned to show how the so-called marine and fresh-water species sometimes mingle together. The following are the species referred to:Cythere lutea, Muiller, Cythere pellucida, Baird, Cythere villosa (G. O. Sars), Cythere culbomacilca, Baird, and Cytherurc gibba, Müller. These were not dead shell, but were living in the pools along with the others. There were also some Foraminifera, as Miliolince fusca, Lituola canariensis, etc., associated with these Ostracoda.

RAITH LAKE, near Kirkcaldy, is an artificial Iake, formed during last century. It is situated within the pleasuregrounds of the Raith estate, the property of Mr MunroFerguson, M.P., and is private. Permission to visit the loch may be obtained by applying to Mr Prentiss, the factor on the estate. This little lake harbours an abundant Crustacean fauna, especially Ostracoda and Cladocera. The loch is said to be 25 feet deep in some places, and to cover not less than 21 acres. The following are the species of Ostracoda obtained in Raith Lake in August 1890 :-

Cypria ophthatmica (Jurine).

Cypria serena (Koch).

Erpetocypris reptans (Baird).

Cypridopsis vidua (O. F. Miiller).

Cypridopsis villosa (Jurine).

Potamocypris fulva, Brady.

Notodromas monacha (O. F. Mïller).
Candona candida (O. F. Mïller).

Caindona lactea, Baird.

Candona rostrata, Brady and Norman. Candona fabaformis (Fischer).

Ilyocypris gibba (Ramdohr).

Limnicythere inopinata (Baird).

Lindores Loch, near Newburgh, Fifeshire. Whether this little loch, which is situated in a district profoundly interesting to the student of old-world history, be to the zoologist or botanist a " happy hunting-ground" or not, it is certainly well known to, and much frequented, during the proper season, by the fraternity of the "roaring game." Often on the icebound surface of this loch the fate-not of kingdoms certainly but what is nearly of equal importance to those engaged in the contest-of the "clubs" of Fifeshire and of Perthshire, and sometimes of other shires as well, is decided for the year. It is easy for the onlooker to see by the gestures and ejaculations of the combatants that momentous issues are at stake. It is no. wonder, then, that the humble seeker after Ostracods 
and Copepods should desire to find out if there was anything of special interest to him in or about this famous loch. The following species rewarded my examination of it in July 1886. I have not been there since.

Cypria exculpta (S. Fischer).

Cypria ophthalmica (Jurine).

Cypria lavis (O. F. Müller).

Erpetocypris reptans (Baird).
Cypridopsis vidua (O. F. Müller).

Candona lactea, Baird.

Candona rostrata, Brady and Robertson.

Limnicythere inopinata (Baird).

The next list is that of the Ostracoda obtained in LocH Leven, Kinross-shire, in June 1890. (For a description of this loch see the Ninth Annual Report of the Fishery Board for Scotland, 1891.)

Cypric exculpta (Fischer). Cypria ophthalmica (Jurine).

Cypria serena (Koch).

Erpetocypris reptans (Baird).

Erpetocypris strigata (O. F. Müiller).

Erpetocypris tumefacta (Brady and

Robertson).

Cypridopsis vidua (O. F. Miuller).

Cypridopsis villosa (Jurine).

Potamocypris fulva, Brady.
Candona candida (O. F. Mïller).

Candona lactea, Baird.

Candonakingsleii, Brady and Robertson. Candona pubescens (Koch).

Ilyocypris gibba (Ramdohr).

Cytheridea lacustris (G. O. Sars).

Limnicythere sancti-patrici, Brady and Robertson.

Limnicythere inopinata (Baird).

On the 18th of September 1890, I visited LochGELLY Loch, Fifeshire, but, from want of time, was able to examine only a small part of it. The gathering then made was, however, rich in micro-crustacea, and showed that a thorough examination would, doubtless, have yielded satisfactory results. Nineteen species of Ostracoda were obtained at this time, as follows :-

Cypria exculpta (S. Fischer). Cypria ophthalmica (Jurine). Cypria lcevis (O. F. Miiller). Cypris pubera, O. F. Müller. Cypris obliqua, Brady.

Erpetocypris reptans (Baird). Cypridopsis viduce (O. F. Müller). Cypridopsis villosa (Jurine). Potamocypris fulva, Brady. Notodromas monacha (O. F. Müller).
Candona candida (O. F. Muiller).

Candona lactea, Baird.

Candona pubescens (Koch).

Candonakingsteii, Brady and Robertson.

Candona fabceformis (Fischer).

Candona hyalina, Brady and Robertson. Candona ambigua, Scott.

Ilyocypris gibba (Ramdohr).

Limnicythere inopinata (Baird).

KILCONQUHAR LOCH, in the vicinity of Elie, Fifeshire, is a fine sheet of water. The sides are overgrown with vegetation, and appear to be a good hunting-ground for Entomostraca; 
but no visitors are allowed near it, except on the north side, near the village of Kilconquhar. I visited the loch during September 1890, and obtained a fairly satisfactory gathering. The following Ostracoda were got:-

Cypria ophthalmica (Jurine).

Cypria loevis (O. F. Müiller).

Cypris pubera, O. F. Müller.

Cypris virens (Jurine).

Erpetocypris reptans (Baird).

Erpetocypris tumefacta (Brady and

Robertson).

Cypridopsis viduce (O. F. Müller).
Cypridopsis villosa (Jurine).

Potamocypris fulva, Brady.

Candona candida (O. F. Müller).

Candona lactea, Baird.

Candonakingsteii, Brady and Robertson. Candona faboformis (Fischer).

Ilyocypris gibba (Ramdohr).

Limnicythere inopinata (Baird).

KINGHORN LocH, which is reached from Burntisland by the road that passes the "Oil Works," is close by the roadside and readily accessible. On the west side the ground is marshy, and harbours a few interesting species. Large and fine specimens of Cypris pubera were obtained at the time when I, along with my good friend Mr Benrie, visited the loch in September 1889. The following were the species gathered at that time :-

Cypria ophthalmica (Jurine). Cypria loevis (O. F. Müller). Cypris pubera, O. F. Müller. Erpetocypris reptans (Baird). Erpetocypris olivacec, Brady and Norman,
Potamocypris fulva, Brady. Candona candida (O. F. Müller).

Candona lactea, Baird.

Candona pubescens (Koch).

nyocypris gibba (Ramdohr).

The Black Loch, near Loch Glow, among the Cleish Hills, in the west of Fifeshire, was visited on the 14th September 1889, and yielded a few rare species. There are four little lochs here, in hollows among the hills, and they all appear to form suitable haunts for Entomostraca and other microscopic life. The following species were obtained in the Black Loch:-

Cypria ophthalmica (Jurine).

Cypria loevis (O. F. Müller).

Cyclocypris globosa (G. O. Sars).

Erpetocypris strigata (O. F. Müller).

Erpetocypris tumefacta, Brady and

Robertson.

Erpetocypris olivacea, Brady and

Norman.

Erpetocypris sp.
Cypridopsis vidua (O. F. Müller).

Cypridopsis villosa (Jurine).

Potamocypris fulva, Brady.

Candona candida (O. F. Müller).

Candona rostrata, Brady and Norman. Candonakingsleii, Brady and Robertson.

Ilyocypris gibba (Ramdohr).

Limnicythere inopinate (Baird). 


\section{Classified List of Ostracoda obTained in the District AROUND EDINBURGH.}

The following classified list includes all the genera and species known to occur in the district, and they are all represented in my collection. In order to make the list useful to those who may not possess the more recent literature on the Ostracoda, I have added a few synonyms; and for further information would refer the reader to the "Monograph of the Marine and Fresh-Water Ostracoda of the North Atlantic and of North-Western Europe," Section I., "Podocopa," by Professor G. S. Brady and the Rev. Canon Norman.

Family CYPRIDID 死.

This family includes all but a few of the fresh-water species.

\section{Genus Cypria, Zenker (1854).}

Cypria exculpta (S. Fischer, 1854).

1868. Cypris striolata, Brady, Mon. Brit. Ostrac., p. 372, pl. xxiv., figs. 6-10.

1880. Cypris granulata, Robertson, Fresh and Brackish Water Ostrac. of Clydesdale, p. 18 (young).

1889. Cypria exculpta, Brady and Norman, Mon. Ostrac. N, Atlantic and N.-W. Europe, p. 68, pl. xi., figs. 1-4.

Habitat.-Loch Leven, Kinross-shire; Lindores Loch, Lochgelly Loch, Lurg Loch, and Loch Dow, Fifeshire. Frequent.

Cypria ophthalmica (Jurine, 1820).

1835. Cypris compressa, Baird, Trans. Berw. Nat. Club, vol. i., p. 100, pl. iii., fig. 16.

1868. Cypris compressa, Brady, op. cit., p. 372, pl. xxiv., figs. 1-5; pl. xxxvi., fig. 6.

1875. Cypris compressa, Brady; Crosskey, and Robertson, Post-Tert. Entom., p. 127, pl. i., figs. 5, 6.

1889. Cypria ophthalmica, Brady and Norman, op. cit., p. 691, pl. xi., figs. 5-9.

Habitat.-Common throughout the district. 
Cypria lcevis (O. F. Müller, 1785).

1820. Monoculus ovum, Jurine, Hist. de Monocles, p. 179, pl. xix., figs. 18, 19.

1835. Cypris minuta, Baird, Brit. Entom., p. 155, pl. xviii., figs. 7,8 .

1868. Cypris ovum, Brady, op. cit., p. 373, pl. xxiv., figs. 33,34 , 43-45; pl. xxxiv., fig. 8.

1875. Cypris ovum, Brady, Crosskey, and Robertson, op. cit., p. 123, pl. i., figs. 5, 6.

1889. Cypric loevis, Brady and Norman, op. cit., p. 69.

Habitat.-Frequent throughout the district.

Cypria serena (Koch, 1838).

1868. Cypris lcevis, Brady, op. cit., p. 374, pl. xxiv., figs. 6-8.

1875. Cypris loevis, Brady, Crosskey, and Robertson, op. cit., p. 126, pl. i., figs. 25-28.

1889. Cypria serena, Brady and Norman, op. cit., p. 70.

Habitat.-Generally distributed throughout the district.

Genus Cyclocypris, Brady and Norman (1889).

Cyclocypris globosa (G. O. Sars, 1863).

1868. Cypris cinerea, Brady, op. cit., p. 374, pl. xxiv., figs. 39-42 ; pl. xxxvi., fig. 7.

1875. Cypris cinerea, Brady, Crosskey, and Robertson, op. cit., p. 126, pl. ii., figs. 6,7 .

1889. Cyclocypris globosa, Brady and Norman, op. cit., p. 71, pl. xiv., figs. 1, 2; pl. xi., figs. 10-18.

Habitat.-Loch Leven; Loch Fitty, Fifeshire; Black Loch and Loch Dow.

\section{Genus Cypris, Müller (1785).}

Cypris fuscata, Jurine (1820).

1868. Cypris fusca, Brady, op. cit., p. 362, pl. xxiii., figs. 10-15.

1889. Cypris fuscata, Brady and Norman, op. cit., p. 73, pl. xii., figs. 3,4 .

Habitat.-Duddingston Loch, ponds at the Braid Hills, Edinburgh; ponds near Dunbar; and Loch Fitty, Fifeshire. 
Cypris incongruens, Ramdohr (1808).

1868. Cypris incongruens, Brady, op. cit., p. 362, pl. xxiii., figs. 16-22.

1889. Cypris incongmeens, Brady and Norman, op. cit., p. 73, pl. xii., figs. 8,9 .

Habitat.-Brickfields at Portobello; side of the Union Canal at Slateford; May Island.

\section{Cypris pubera, O. F. Müller (1785).}

1868. Cypris punctillata, Brady, op. cit., p. 365, pl. xxvi., figs. $1 \cdot 7$; pl. xxxvi., fig. 11.

1889. Cypris pubera, Brady and Norman, op. cit., p. 74.

Habitat.-Duddingston Loch, Edinburgh; Kilconquhar Loch, Kinghorn Loch, Lochgelly Loch, Fifeshire.

Cyprïs virens (Jurine, 1820).

1868. Cypris virens, Brady, op. cit., p. 364, pl. xxiii., figs. 23-32; pl. xxxvi, fig. 1.

1889. Cypris virens, Brady and Norman, op. cit., p. 74.

Habitat.-Frequent throughout the district-Duddingston Loch, pools at Luffness Links (large and fine specimens), pools at Slateford, Kilconquhar Loch.

Cypris reticulata, Zaddach (1844).

1868. Cypris tessellatc, Brady (in part), op. cit., p. 336, pl. xxiii., figs. 39-45.

1880. Cypris tessellata, Robertson, Fresh and Brackish Water Ostrac. of Clydesdale, p. 15.

1889. Cypris reticulata, Brady and Norman, op. cit., p. 76, pl. viii., figs. 1,$2 ; \mathrm{pl}$. xi., figs. 5.7.

Habitat.-Camilla Loch, Fifeshire (August 20, 1890); Duddingston Loch (April 8, 1893).

Cypris obliqua, Brady (1868).

1889. Cypris obtiqua, Brady and Norman, op. cit., p. 77, pl. xii., fig. 10.

Habitat.-Lurg Loch (near Loch Glow), Kinross-shire; Lochgelly Loch, Fifeshire. The colour of the shell of this species from these two localities was a fine, light, chocolatebrown; the colour of the shells of the same species from a 
tarn near Cragengower Farm, Cumbrae, was bright green (Robertson).

Cypris prosin $\alpha$, Fischer (1855).

1850. Cypris strigata, Baird, Brit. Entom., p. 157 (not C. strigata, Müiller).

1868. Cypris salina, Brady, op. cit., p. 368, pl. xxvi., figs. 8-13.

1889. Cypris prasina, Brady and Norman, op. cit., p. 78 .

Habitat.-Pools in an old brickfield at Seafield, near Dunbar, August 1890.

Genus Erpetocypris, Brady and Norman (1889).

Erpetocypris reptans (Baird, 1835).

1850. Candona similis, Baird, Brit. Entom., p. 162, pl. xix., figs. $2-2 \alpha$ (young).

1868. Cypris reptans, Brady, op. cit., p. 370, pl. xxv., figs. 10-14; pl. $x \times x v i$, fig. 4.

1889. Erpetocypris reptans, Brady and Norman, op. cit., p. 84, pl. xiii, fig. 27.

Habitat.-More or less common throughout the district.

Erpetocypris strigata (O. F. Müller, 1785).

1889. Erpetocypris strigata, Brady and Norman, op. cit., p. 85, pl. viii.; figs. $14,15$.

Habitat.-Duddingston Loch, common; Loch Leven, rare; Black Loch (near Loch Glow), 14th September 1889.

Erpetocypris tumefacta (Brady and Robertson).

1870. Cypris tumefacta, Brady and Robertson, Ann. and Mag. Nat. Hist., ser. iv., vol. vi., p. 13, pl. iv., figs. 4-6.

1889. Erpetocypris tumefacta, Brady and Norman, op. cit., p. 87, pl. viii., figs. $5-7$; pl. xiii., fig. 18.

Habitat.-Duddingston Loch, and several other places within the district.

Erpetocypris olivacee, Brady and Norman.

1889. Erpetocypris olivacca, Brady and Norman, op. cit., p. 89, pl. i, figs. $3,4$.

Habitat.-Duddingston Loch, not very common; Kinghorn Loch, rare; Black Loch (near Loch Glow), scarce. 


\section{Genus Cypridopsis, Brady.}

Cypridopsis vidua (O. F. Müller, 1785).

1868. Cypridopsis viduc, Brady, op. cit., p. 375, pl. xxiv., 27-36, 46.

1889. Cypridopsis viduc, Brady and Norman, op. cit., p. 89.

Habitat.-Generally distributed throughout the district.

Cypridopsis aculeata (Lilljeborg, 1853).

1868. Cypridopsis aculeata, Brady, op. cit., p. 376, pl. xxiv., figs. 16-20 ; pl. xxxvi., fig. 10.

1889. Cypridopsis aculeata, Brady and Norman, op. cit., p. 90.

Habitat.-Pools in an old brickfield at Seafield, near Dunbar.

Cypridopsis villosa (Jurine, 1820).

1868. Cyy ridopsis villosa, Brady, op. cit., p. 377, p1. xxiv., figs. 11-15; pl. xxxvi, fig. 9 .

Habitat.-Generally distributed throughout the district, but not so common as Cypridopsis vidua.

\section{Genus Potamocypris, Brady (1870).}

Potamocypris fulva, Brady.

1889. Potamocypris fulva, Brady and Norman, op. cit., p. 93, pl. xxii., figs. 13-17.

Habitat.-Generally distributed throughout the district; and moderately common in some localities, as in marshy ground at Gorebridge, and at Raith Lake, Kirkcaldy.

Genus Notodromas, Lilljeborg (1853).

Notodromas monacha (O. F. Müller), 1785.

1889. Notodromas monacha, Brady and Norman, op. cit., p. 96.

Habitat.-Luffness Links, near Aberlady; Lochgelly Loch and Camilla Loch, Fifeshire. Frequent in all the three localities. 


\section{Genus Cyprois, Zenker (1854).}

\section{Cyprois flava (Zaddach).}

1838. (?) Cypris gibbosa, Baird, Mag. Zool, and Bot., vol. ii., p. 137, pl. $\nabla .$, fig. 15.

1844. Cypris flava, Zaddach, Syn. Crust. Prus. Prodr., p. 33.

1850. Cypris gibbosa, Baird, Brit. Entom., p. 156, pl. xix., fig. 8.

1854. Cyprois dispar, Zenker, Mon. der Ostrac. (Archiv für Naturgesch.), p. 18.

1889. Cyprois flava, Brady and Norman, op. cit., p. 97, pl. viii., figs. 18,19 ; pl. xii., figs. 13-21, 38 .

Habitat.-Duddingston Loch, upper end, common (1889). Mr David Robertson has obtained this species in Burnside Loch, near Rutherglen. It is thought that the Cypris gibbosa of Dr Baird is, probably, this species, and, if so, his name ought to have precedence of the other. Dr Baird's figure of Cypris gibbosa is, certainly, very different from the specimens of Cyprois flava obtained in Duddingston Loch. He also describes the shell as "much elevated on the upper margin, the centre exhibiting a large gibbosity or hump," and also as being "of a light green colour"-characters which do not very closely agree with the Duddingston specimens.

\section{Genus Candona, Baird (1845).}

Candonci candida (O. F. Müller, 1785).

1889. Candona candida, Brady and Norman, op. cit., p. 98, pl. $x_{0}$, figs. 1, 2, 14-23.

Habitat.-Generally distributed, and common throughout the district.

Candona lactea, Baird.

1868. Candona Zactea, Brady, Mon. rec. Brit. Ostrac., p. 382, pl. xxiv., figs. 55-58.

1868. Candona detecta, idem, ibidem (var.), p. 384, pl. xxiv., figs. 35-38; pl. xxxvii., fig. 2.

1889. Candona lactec, Brady and Norman, op. cit., p. 100.

Habitat.-Generally distributed, but not so common as the last. The young of Candona candida, which is a very variable species, are sometimes apt to be mistaken for 
Candona lactea; careful discrimination is, therefore, necessary. Candona lactea is somewhat cylindrical in shape, moderately robust, and with the ends evenly rounded.

\section{Candona pubescens (Koch).}

1837. Cypris pubescens, Koch, Deutschlands Crustaceen, H. 11, p. 5.

1838. (?) Cypris compressa, idem, ibidem, H. 21, p. 17.

1868. Candona compressa, Brady, Mon. rec. Brit. Ostrac., p. 382, pl. xxvi., figs. 22-27.

1868. Candona albicans idem, ibidem, p. 381, p], xxv., figs. 20-25 ; pl. xxxvi., fig. 12.

1889. Candona pubescens, Brady and Norman, op. cit., p. 101, pl. xii., figs. 32-37.

Habitat.-Duddingston Loch, Loch Leven, Luffness Links, Kinghorn Loch, brackish-water pools in an old brickfield near Dunbar.

\section{Candona rostrata, Brady and Norman.}

1889. Candona rostrata, Brady and Norman, op. cit., p. 101, pl. ix., figs. $11,12,12 c$ and $b$; pl. xii., figs. 22-31.

Habitat.-Duddingston Loch, Raith Lake, Lurg Loch, Lindores Loch. Not very common.

\section{Candona kingsleii, Brady and Robertson.}

1870. Candona kingsleii, Brady and Robertson, Ann. and Mag. Nat. Hist., ser. iv., vol. vi., p. 17, pl. ix., figs. 9-12.

1889. Candona kingsleir, Brady and Norman, p. 102, pl. ix., figs. 19-22 ; pl. xiii., fig. 19.

Habitat.-Generally distributed. Frequent in Duddingston Loch.

Candona fabceformis (Fischer, 1851).

1870. Candona diaphana, Brady and Robertson, Ann. and Mag. Nat. Hist., ser. iv., vol. vi., p. 18, pl. v., figs. 1-3.

1889. Candona faboeformis, Brady and Norman, op. cit., p. 103, pl. ix., figs. 1-4.

Habitat.-Duddingston Loch, frequent; pond on north side of Corstorphine Hill, common; Luffness Links; Loch Fitty; etc. 
Candona acuminata (Fischer, 1851).

1889. Candona acuminata, Brady and Norman, op. cit., p. 104, pl. ix., figs. 9,10 ; pl. x., figs. 5, 6 .

Habitat. - Ditch beside Harelaw Dam; Threipmuir Reservoir, Balerno; Loch Fitty, Fifeshire. Not common.

Candona euplectella, Robertson.

1880. Candona euplectella, Robertson, Fresh and Brackish Water Ostracoda of Clydesdale, etc., p. 23.

1889. Candona euplectella, Brady and Norman, op. cit., p. 105, pl. ix., figs. $7,8,8 a$.

Habitat.- Loch Dow, near Loch Glow, Kinross-shire, 14th September 1889. Rather rare.

Candona hyalina, Brady and Robertson.

1870. Candona hyalina, Brady and Robertson, Ann. and Mag. Nat. Hist., ser. iv., vol. vi., p. 18, pl. ix., figs. 5.8 ; pl. $\nabla_{\text {., }}$ figs. 4-11.

1889. Candona hyalina, Brady and Norman, op. cit., p. 247 (woodcuts of $\pi$ ).

Habitat.-Threipmuir Reservoir, near Balerno (ठ); Loch Fitty, Fifeshire; Loch Dow, near Loch Glow, Kinross-shire ( + ).

Candona ambigua, Scott.

1891. Candona ambigua, Scott, Invert. Fauna of Inland Waters of Scot. (Ninth Annual Report of the Fishery Board for Scotland), p. 277, pl. iv., figs. 7 a-c.

Habitat.-Lochgelly Loch and Loch Fitty, Eifeshire. Not common.

Genus Ilyocypris, Brady and Norman (1889).

Ilyocypris gibba (Ramdohr, 1808).

1868. Cypris gibba, Brady, op. cit., p. 369, pl. xxiv., figs. 47-54; pl. xxxvi., fig. 2.

1889. Ilyocypris gibba, Brady and Norman, op. cit., p. 107, pl. xxii., figs. 1-5.

Habitat.-Duddingston Loch, 1888; vicinity of Gorebridge, 1889; Kinghorn Loch, 1889; Kilconquhar Loch, 1890 ; Loch Leven, 1890 ; Lochgelly Loch, 1890. 
Family CYTHERID

Genus Limnicythere, Brady (1867).

Limnicythere inopinata (Baird, 1850).

1868. Limnicythere inopinata, Brady, op. cit., p. 419, pl. xxix., figs. 15-18.

1889. Limnicythere inopinata, Brady and Norman, op. cit., p. 170, pl. xvii., figs. 18, 19 (var. compressa).

Habitat.-Duddingston Loch, 1889; Loch Leven, 1890; Lindores Loch, 1886; Kilconquhar Loch, 1890; Raith Lake, 1890; Lochgelly Loch, 1890 ; etc.

Limnicythere sancti-patrici, Brady and Robertson, 1869.

1889. Limnicythere sancti-patrici, Brady and Norman, op. cit., p. 171, pl. xvii., figs. 1, 2.

Habitat.-Loch Leven, Kinross-shire, 1890. (Obtained in a post-Tertiary deposit at Holyrood-see Proc. Roy. Phys. Soc., vol. x., p. 143, 1889.)

Genus Cytheridea, Bosquet, 1850.

Cytheridea lacustris (G. O. Sars, 1862).

1889. Cytheridea lacustris, Brady and Norman, op. cit., p. 176.

Habitat. - Loch Leven, frequent, 1890; canal near Morningside, Edinburgh (David Robertson).

Cytheridea torosa (Jones, 1850).

1868. Cytheridea torosa, Brady, op. cit., p. 425, pl. xxviii., figs. 7-12; pl. xxxix., fig. 5.

1889. Cytheridea torosa, Brady and Norman, op. cit., p. 175.

Habitat.-Brackish-water pools at the mouth of the Cocklemill Burn, near Largo, July 1890 ; brackish-water pools in an old brickfield at Seafield, near Dunbar, August 1890.

The preceding list of Ostracoda contains thirty-six species belonging to twelve genera; and it is not improbable that, owing to the erratic distribution of the group, the list may be still further increased when the district has been more thoroughly examined. 


\section{THE COPEPODA.}

I shall now proceed to give a short account of the Copepoda of the district.

This group is equally interesting with the preceding one, but rather more difficult to deal with; they want the hard shell-like covering of the Ostracoda, which allows of those organisms being conveniently mounted and preserved as cabinet specimens. The only manner in which the Copepoda can be preserved is by mounting them in balsam, or some other suitable medium, or by keeping them in methylated spirits; yet, notwithstanding this difficulty, they form a very profitable leisure-time study.

The distribution of the Copepoda is, perhaps, not so capricious as that of the Ostracoda, yet here, as in the other group, we meet with examples of special interest. I shall mention one or two of these. In $1892 \mathrm{I}$ had an opportunity of making an examination of Loch Morar, ${ }^{1}$ in Inverness-shire, and obtained a number of rare Entomostraca; but, though the Copepoda were numerously represented, not a single specimen of Canthocamptus minutus was observed, and this is one of the most common of the fresh-water Harpacticida. I do not, of course, mean to say that this species was entirely absent, but only, that, though a careful examination of the material collected was made (partly to ascertain if this Canthocamptus was present), no specimens were obtained. In the Journal of Microscopical Science for 1868, Professor G. S. Brady described a small species of Copepod, specimens of which had been sent to him by Mr Atthey. They had been found by Mr Atthey "living amongst films of gelatinous algæ " on "the damp roof of the pit-workings of the low main, West Cramlington Colliery, near Newcastle," and the species was named Attheyella cryptorum, after its discoverer. The locality described appeared to be the only known habitat of the species till last year, when it was obtained in Loch Morar, in material collected by dragging a small tow-net

1 An account of this loch will be found in the Annual Report of the Fishery Board for Scotland for 1893. 
through the plants and algæ in the shallow water at the head of the loch. It has been obtained, more recently, in material, collected by hand-net, from a ditch in the neighbourhood of Harelaw Dam, Balerno, near Edinburgh, and also in Duddingston Loch.

Equally interesting is the distribution of Diaptomus serricornis, Lilljeborg. This species was not known to be a member of the British fauna till it was discovered in townet gatherings from Loch Mullach, Corrie, Sutherlandshire, collected by $\mathrm{Mr}$ W. S. Caine. ${ }^{1}$ After its discovery in this loch, it was ascertained that Mr David Robertson had taken the same species in a pond, near Lerwick, in 1867, but it had remained since that time unnoticed in print. At present the only known British habitats for Diaptomus serricornis are the two places here mentioned. It occurs "in fresh-water lakes at Lumbowski in Russian Lapland," and this, so far, is the only European district where it has been obtained, unless Diaptomus wierzejskii, Richard, be held as being merely a local variety of Diaptomus serricornis (and really the difference between these two forms seems to be so very small that they can hardly be considered as specifically distinct). Diaptomus wierzejskii has been recorded from Spain (neighbourhoods of Madrid and Valladolid) and from Saxony. If, therefore, we are to consider these two forms as belonging to the one species, its known distribution is thus of considerable extent, and may indicate that, though it is only recorded from a few localities, it will yet be found of more frequent occurrence than is apparent at present.

The following lists of Copepoda from a few of the principal places within the district, will help to show how this group is locally distributed, and how different species are associated together. These local lists are not to be considered exhaustive, but simply as an effort to bring together the species that have been obtained in the various localities, and thus far satisfactorily determined. The first list will be that of the species obtained in the loch at Duddingston-a loch that has

${ }^{1}$ See Scottish Naturalist for October 1891, p. 172; also A Revision of the British Species of Fresh-Water Cyclopidæ and Calanidæ, by Professor Brady, p. 36 (1891). 
from time immemorial been the resort of both the zoologist and botanist. The names of not a few who have been eminent in one or other of these departments could be given who have been interested in the fauna and flora of Duddingston Loch.

Copepoda obtained in DUdDINGSTON Loch :

Diaptomus gracilis, G. O. Sars.

Cyclops signatus, Koch.

Cyclops bicuspidatris, Claus.

Cyclops thomasi, Forbes.

Cyclops viridis (Jurine).

Cyclops serrulatus, Fischer.
Cyclops phaleratus, Koch.

Cyclops fimbriatus, Fischer.

Canthocamptus minutus (Miiller).

Canthocanptus northumbricus, Brady. Attheyella spinosa, Brady.

Attheyella cryptorum, Brady.

Loch Leven, Kinross-shire.-In 1890 I found Cyclops very abundant in this loch, but only a few species were obtained, as shown by the following list. The other fresh-water groups were also very sparingly represented.

Diaptomus gracitis, G. O. Sars. Cyclops signatus, Koch.

Cyclops strenuus, Fischer.

Cyclops vicinus, ${ }^{1}$ Uljanin.
Cyclops serrulatus, Fischer.

Cyclops fimbriatus, Fischer.

Canthocamptus minutus (Müller).

Attheyella spinosa, Brady.

RAITH LAKE, KIRKCALDY.-This loch, though comparatively of small size, yielded several interesting species. It is well worth a visit, not only on account of its abundant microfauna, but also because of its beautiful and picturesque surroundings.

The Copepoda obtained in this little loch were as follows:-

Diaptomus gracilis, G. O. Sars.

Cyclops signatus, Koch.

Cyclops viridis (Jurine).

Cyclops serrulatus, Fischer.
Cyclops affinis, G. O. Sars.

Cyclops phaleratus, Koch.

Cyclops fimbriatus, Fischer.

Canthocamptus minutus, Müller.

Locharlly Loch.-The following species of Copepoda were obtained in Lochgelly Loch :-

Diaptomus gracilis, G. O. Sars.

Cyclops signatus, Koch.

Cyclops phaleratus, Koch.

Cyclops serrulatus, Fischer.

Cyclops thomasi, Forbes.
Cyclops viridis (Jurine).

Cyclops finbriatus, Fischer.

Canthocimptus minutus (Mïller).

Attheyella spinosa, Brady.

1 See Prof. Brady's Revision of the British Cyclopidæ and Calanidæ, p. 12 (1891). 
Classified List of the Copepoda obtained in the District around Edinburgh.

Family CALA I D $\mathbb{E}$.

Genus Diaptomus, Westwood (1836).

Diaptomus castor (Jurine).

1785. Cyclops coeruleus, Müller, Entomostraca, p. 102, pl. xv., figs. 1-9.

1820. Monoculus castor, Jurine, Hist. des Monoc., p. 50, pls. iv.-vi.

1850. Diaptomus castor, Baird, Brit. Entom., p. 219, pl. xxvi.

1891. Diaptomus castor, Brady, Revision of the Brit. Sp. of F.-W. Cyclop. and Calanidæ, p. 27, pl. xi., figs. 1-6.

Habitat.-Braid Ponds, near Edinburgh, August 1888. ${ }^{1}$

Diaptomus gracilis, G. O. Sars.

1863. Diaptomus gracilis, G. O. Sars, Videnskabsselsk. Forhandl., 1862, p. 9.

1863. Diaptomus westwoodii, Lubbock, Trans. Linn. Soc., vol. xxiv., p. 203, pl. xxxi., figs. 1.6.

1888. Diaptomus graciloides, Lilljeborg, Bull. Soc. Zool. de France, xiii., p. 156.

1889. Diaptomus graciloides, De Guerne and Richard, Revision des Calanides d'eau douce, p. 36, pl. i., figs. 26, 27.

1889. Diaptomus gracilis, idem, ibidem, p. 14, pl. ii., figs. 12, 16, 20.

1891. Diaptomus gracilis, Brady, op. cit., p. 29, pl. xi., figs. 7-9; pl. xii., figs. 1-8.

Habitat.-Generally distributed throughout the district.

Genus Eurytemora, Giesbrecht (1881).

Eurytemora clausii (Hoek).

1876. Temora clausii, Hoeck, Tijdsch. d. Nederl. Dierkund., Vereenig iii., p. 23, pls. iv. and v.

1878. Temora velox, Brady, Mon. Brit. Copep., vol. i., p. 56, pl. vi., figs. 1-5.

1889. Eurytemora lacinulata, De Guerne and Richard, op. cit., p. 82, figs. 44,45 .

1891. Enrytemora clausii, Brady, Revision of the Brit. Sp. of F.-W. Cyclop. and Calan., p. 40, pl, xiii., figs. 1-5.

Habitat.-Brackish-water pools in an old brickfield at Seafield, near Dunbar, August 1890; in brackish-water

1 Ann. Scot. Nat. Hist, p. 202 (1892). 
pools at Seafield, near Leith, 1892; brackish-water pools by the shore at Aberlady, 5th September 1889.

Eurytemora affinis (S. A. Poppe).

1881. Temora affinis, Poppe, Abhandl. des Naturw. ver Bremen, vi., p. 55, pl. iii., figs. 1-14.

1889. Eurytemora affinis, De Guerne and Richard, op. cit., p. 84, figs. 46,47 .

1891. Eurytemora affinis, Brady, Revision Brit. F.-W. Cyclop. and Calanid., p. 42 , pl. xiii., figs. 6-9.

Habitat.-Forth, about Culross and Alloa. Common.

Family CYCL O P I $Æ$.

Genus Cyclops, Müller (1785).

Cyclops signatus, Koch.

1841. Cyclops signatus, Koch, Deutschlands Crustaceen, etc., H. 21, tab. viii. (antenna with serrated ridge).

1857. Cyclops tenuicornis, Claus, Weigmann's Archiv., p. 21, pl. iii, figs. 1-11 (antenna with simple ridge).

1891. Cyclops signatus, Brady, op. cit., p. 6, pl, ii., fig. 5.

Habitat.-Duddingston Loch (ridge simple); Cocklemill Burn, near Largo (ridge simple and serrated); Raith Lake (ridge simple); Loch Leven (ridge simple); Lochgelly Loch (ridge simple); Kinghorn Loch (ridge simple); pools at Luffness Links (ridge simple).

Cyclops strenuus, Fischer.

1851. Cyclops strenuus, Fischer, Bull. Soc. imp. Moscon., p. 419, pl. ix., figs. 12-21.

1891. Cyclops strenuus, Brady, op. cit., p. 8, pl. ii., figs. 1-4.

Habitat.-Loch Leven, Kinross-shire, common; Loch Fitty, Fifeshire; Cocklemill Burn, near Largo.

Cyclops vicinus, Uljanin.

1875. Cyclops vicinus, Uljanin, Crustacea of Turkestan, p. 30, pl. x., figs. $1-7$; pl. xii., figs. $7-9$.

1878. Cyclops pulchellus, Brady, Mon. Brit. Copep., p. 107, pl. xvii., figs. 1-3.

1891. Cyclops vicinus, Brady, Revision Brit. F.-W. Cyclop. and Calanid., p. 12, pl. i., figs. 6-9.

Habitat.-Loch Leven, Kinross; Cocklemill Burn, near Largo ; Kinghorn Loch, Fifeshire. 
Land and Fresh-Water Crustacea around Edinburgh. 73

\section{Cyclops bicuspidatus, Claus.}

1857. Cyclops bicuspidatus, Claus, Weigmann's Archiv., p. 209, pl. xi., figs. $6,7$.

1891. Cyclops bicuspidatus, Brady, op. cit., p. 13, pl. v., figs. 1-5.

\section{Habitat.-Duddingston Loch.}

\section{Cyclops thomasi, Forbes.}

1882. Cyclops thomasi, Forbes, American Naturalist, vol. xvi., p. 640 , pl. ix., figs. 10, 11, 16.

1891. Cyclops thomasi, Brady, op. cit., p. 15, pl. vi., figs. 1-4.

Habitat. - Duddingston Loch, Lochgelly Loch, Camilla Loch.

\section{Cyclops viridis (Jurine).}

1820. Monoculus quadricornis viridis, Jurine, Hist. des Monoc, p. 46, pl. iii., fig. 1.

1857. Cyclops brevicornis, Claus, Weigmann's Archiv., pl. iii., figs. 12-17.

1857. Cyclops gigas, ibid., p. 207, pl. xi., figs. 1-5.

1891. Cyclops viridis, Brady, op. cit., p. 17, pl. v., figs. 6-10.

Habitat.-Generally distributed throughout the district. Duddingston Loch; Loch Leven, Kinross-shire; etc.

\section{Cyclops serrulatus, Fischer.}

1838. Cyclops serrulatus, Fischer, Bull. Soc. imp. Moscou., p. 423 pl. x., figs. 22, 23, 26-31.

1891. Cyclops serrulatus, Brady, op. cit., p. 18, pl. vii., fig. 1.

Habitat.-Generally distributed throughout the district. Colour of ovisacs very variable-blue, reddish, green.

\section{Cyclops affinis, G. O. Sars.}

1863. Cyclops affinis, G. O. Sars, Videnskabsselsk. Forhandl., 1862, p. 47.

1891. Cyclops affinis, Brady, op. cit., p. 21, pl. viii., figs. 1-6.

Habitat.-Raith Lake, Kirkcaldy; Black Loch, near Loch Glow, Kinross-shire. 
Cyclops ewarti, G. S. Brady.

1888. Cyclops ewarti, Brady, Sixth Annual Report of the Fishery Board for Scotland, p. 232, pl. viii. figs. 1-6.

1891. Cyclops ewarti, Brady, Revision Brit. F.-W. Cyclop. and Calanidæ, p. 22, pl. vii., figs. 4-7.

Habitat.-Forth estuary, west of Queensferry, near the mouth of the Ironmill Burn. (Loch Morar, a fresh-water loch in Inverness-shire.)

Cyclops phaleratus, Koch.

1841. Cyclops phaleratus, Koch, Deutschlands Crustaceen, etc., H. 21, tab. ix.

1891. Cyclops phaleratus, Brady, op. cit., p. 25, pl. ix., fig. 2.

Habitat.-Duddingston Loch; Raith Lake, Kirkcaldy; Black Loch, near Loch Glow, Kinross-shire.

Cyclops fimbriatus, Fischer.

1785. Cyclops crassicornis, Müller, Entomostraca, p. 113, pl, xviii., figs. 15-17.

1853. Cyclops fimbriatus, Fischor, Bull. Soc. imp. Moscou., p. 94, pl. iii., figs. 19-28, 30.

1878. Cyclops crassicornis, Brady, Mon. Brit. Copep., vol. i., p. 118, pl. xxiii., figs. 1-6.

1891. Cyclops fimbriatus, Brady, Revision Brit. F.-W. Cyclop. and Calanidæ, p. 25, pl. ix., fig. 1.

Habitat.-Generally distributed throughout the district. Duddingston Loch; in a small spring among the rocks on the side of Arthur's Seat above the "Targets"; Raith Lake, Kirkcaldy; Loch Fitty; ditch in the vicinity of Harelaw Dam, Balerno, near Edinburgh, etc.

Cyclops cequoreus, Fischer.

1860. Cyclops cequoreus, Fischer, op. cit., p. 654, pl. xx., figs. 26-29.

1878. Cyclops oequoreus, Brady, Mon. Brit. Copep., vol. i., p. 119, pl. xix., figs. 8-10; pl. xxi., figs. 10-17.

1891. Cyclops cequoreus, Brady, Revis. Brit. F.-W. Cyclop. and Calanidæ, p. 26, pl. x., fig. 1.

Habitat. - Brackish-water pools at high-water mark, Cramond Island, Firth of Forth. 


\section{Family HARPACTICIDA.}

Genus Canthocamptus, Westwood (1836).

Canthocamptus minutus (Müller).

1776. Cyclops minutus, Müller, Zool. Dan. Prod., Entom., p. 101, pl. xvii., figs.

1785. Cyclops minutus, idem, Entom., p. 101, pl. xvii., figs. 1-7.

1850. Canthocamptus minutus, Baird, Brit. Entom., p. 204, pl. xxv., figs. $4-8$; pl. xxx., fig. 3.

1880. Canthocamptus minutus, G. S. Brady, Brit. Copep., vol. ii., p. 48, pl. xliv., figs. 1-17.

Habitat.-Generally distributed throughout the district. Duddingston Loch, frequent; Black Loch and Lurg Loch, near Loch Glow, Kinross-shire; Camilla Loch, Raith Lake, and Lochgeliy Loch, Fifeshire; Loch Leven, Kinross-shire. Ovisac large, pale blue.

Canthocamptus northumbricus, Brady.

1880. Canthocamptus northumbricus, Brady, op. cit., vol. ii., p. 57, pl. xlv., figs. 1-14.

Habitat.-Duddingston Loch. This is distinguished from Canthocamptus minutus by the inner branches of the second, third, and fourth pairs of swimming feet being two-jointed. It is also smaller. The second and third joints of the inner branches of the first swimming feet are proportionally shorter. Ovisac smaller, proportionally; colour whitish, with a tinge of red.

Canthocamptus palustris, Brady.

1880. Canthocamptus palustris, Brady, Mon. Brit. Entom., vol. ii., p. 53, pl. xxxix., figs. 13.23.

Habitat.-Pools on May Island, August 1890.

Genus Attheyella, Brady (1880).

Attheyella spinosa, Brady.

1880. Attheyella spinosa, Brady, op. cit., vol. ii., p. 58, pl. xliii., figs. 15-18; pl. xlvi., figs. 13-18.

Habitat.-Duddingston Loch; Kilconquhar Loch; Black Loch, near Dunbar; Lochgelly Loch; Loch Leven, Kinross, 
frequent. In this species both branches of the first pair of swimming feet are three-jointed, and of nearly equal length.

Attheyella cryptorum, Brady.

1868. Canthocamptus cryptorum, Brady, Jour. Microscop. Soc., vol. ix., pl. vi., figs. 1-10.

1880. Attheyella cryptorum, Brady, Mon. Brit. Entom., vol. ii., p. 60, pl. lii, figs. 1-18.

Habitat.-Duddingston Loch; in a ditch in the vicinity of Harelaw Dam, Balerno, near Edinburgh. Apparently rare. 




On some Entomostraca from Castlemilk, near Rutherglen. By Тномаs Sсотт, F.L.S., Naturalist to the Fishery Board for Scotland.

[Read 28th November, 1893.]

THE little loch from which the Entomostraca now to be recorded were obtained is situated on the hillside above the Ancient and Royal Burgh of Rutherglen, on the estate of Castlemilk, and immediately below the mansion-house of that name. It is fed by a small stream which rises on the Cathkin Hills. The loch is apparently artificial, but judging from its appearance and surroundings, it seems to have been in existence for a considerable period. Whatever may have been its origin or the date of its formation, the loch evidently contains a fairly rich Entomostracan fauna. The material collected by Mr. James Steel, and which he kindly banded over to me for examination, was contained in a small bottle; but although the quantity was small, it has vielded no fewer than eighteen species representing fifteen genera, and comprising five species of Ostracoda, six of Copepoda, and seven of Cladocera. The following is a list of the species obtained :-

\section{The Ostracoda.}

The Ostracoda, whose outside covering so closely resembles in miniature the shell of the bivalve molluscan shell-fish, are found not only in the sea but more or less frequently in nearly all fresh waters, with the exception, perhaps, of streams and rivers that flow with a rapid current. Their favourite habitats are shallow weedy lakes, ponds, ditches, and such like localities. Some species occur almost everywhere, wherever such localities exist, while others appear to be somewhat erratic in their distribution, and are sometimes obtained in places that differ much in regard to the quality of the water. The particular grouping of species in each locality is, therefore, in itself a fairly interesting study. 
The five species of Ostracoda obtained in the material from the loch at Castlemilk are-

Cypria ophthalmica (Jurine).

C. loevis (O. F. Müller).

Erpetocypris reptans (Baird).

Candona acuminata (Fischer).

Limnocythere inopinata (Baird).

With the exception of $C a n d o n a$ acuminata, these are all moderately common and generally distributed species. Candona acuminata, which is comparatively rare, was added to the British fauna only a few years ago, and is fully described and figured in Brady and Norman's excellent Monograph of the Marine and Fresh-Water Ostracoda of the North Atlantic and of North-Western Europe. The occurrence of this Candona is interesting because of the apparent absence of more common and widely distributed species, e.g. Candona candida, de.

\title{
The Copepoda.
}

The species of Copepoda obtained in the material are the following :-

\author{
Eurytemora clausii (Hoek). \\ Cyclops thomasi, Forbes. \\ C. signatus, Koch. \\ C. serrulatus, Fischer. \\ C. fimbriatus, Fischer. \\ Canthocamptus minutus (Müller).
}

Eurytemora clausii is of frequent occurrence in the material, and is a very interesting find. It has been recorded from various localities in England, and from the following places in Scotland:(1) in the Forth, above Queensferry; (2) at the mouth of the Peffer Burn, near Aberlady; (3) in an old brick-field frequently overflowed by the sea, near Dunbar; (4) in pools at the mouth of the River Alness, Ross-shire-all on the East Coast; and (5) on the West Coast, at Cumbrae, Firth of Clyde. At all these places the water is more or less brackish, and I know of only one other record of its occurrence in Britain in a purely fresh-water locality, viz., at Higham Park, Essex, where it was obtained by Mr. D. T. Scourfield, London. Though the occurrence of Eurytemora clausii in fresh water is rare in Britain, it seems to be otherwise on the 
Continent of Europe. Nordquist obtained it in fresh water in Finland, Dr. Poppe records it from North-West Germany, and De Guerne and Richard from Abbeville. The position of the little loch at Castlemilk is so far from the influence of anything like marine conditions that there can be no doubt as to the water there being perfectly fresh. The fact that this species can live under such varied conditions is of some importance in its bearing on the theory of evolution, and also suggests the question as to whether Eurytemora clausii was originally a purely marine or a purely fresh-water species.

Cyclops thomasi occurred sparingly in the material. There is some doubt as to its being specifically distinct from $C$, bicuspidatus, Claus. In Britain it is one of the rarer species of Cyclops.

The Cyclops signatus recorded here is the form with smooth anterior antennæ, and known as $C$. tenuicornis, Claus. This form is now regarded as the penultimate stage of $C$. signatus, Koch. Cyclops thomasi and C. signatis have both eighteen-jointed anterior antennæ.

Cyclops serrulatus, which has twelve-jointed anterior antennæ, is a very common and widely distributed species, not only in Britain, but also on the Continent of Europe and in North America.

Cyclops fimbriatus, the anterior antennæ of which are only eight-jointed, is a small but pretty and distinct species. It has a fairly wide distribution, and is recorded by various European and A merican authors.

Canthocamptus minutus is a comparatively small species, but is not the smallest of the fresh-water Copepoda. It usually frequents the vegetation at the sides and bottom of the water. Spiritspecimens of this and other fresh-water Harpacticidre have the abdomen usually bent at right angles (or nearly so) to the body, and in this they differ from the Cyclopidæ.

\section{The Cladocera.}

The British Cladocera are nearly all confined to fresh water. The only marine forms hitherto observed belong to three species, and include the well-known Evadne nordmanni, which may sometimes be obtained in great numbers with the surface tow-net, and. 
Podon polyphemoides and $P$. intermedius, which are also sometimes captured in the tow-net with the Evadne.

Some beautiful as well as grotesque forms are to be found among the Cladocera. What, for example, can be more beautiful than the delicate structure of Leptodora seen through its perfectly transparent covering, or than Sida crystallina, as it moves gracefully through the water? or what can be more curious than the Bythotrephes with its enormously long postabdominal spine, or Leptorhynchus with its long strongly-curved beak, or Holopedium with its huge dorsal sack-like appendage? And how amusing it is to watch the ungainly movements of Ilyocryptus as it struggles to surmount the difficulties in its way-but the pleasures of the study of Natural History are endless.

The species of Cladocera observed in the Castlemilk material are, as previously stated, seven in number, the names of which are-

Bosmina longirostris (Müller).

Ilyocryptus sordidus (Lievin).

Acroperus harpce, Baird.

Alona quadrangularis (Müller).

Pleuroxus uncinatus, Baird.

Leydigia quadrangularis (Leydig).

Chydorus sphoricus (Müller).

Ilyocryptus has been obtained in several localities in Scotland. I have records of its occurrence in Loch Morar, Inverness-shire; in a little loch in the Island of Mull; in Loch Leven, Kinrossshire; and in Lochend Loch, Edinburgh.

Leydigia appears to be the rarest in Scotland of the seven species from Castlemilk. The only other Scotch record I have for this species is Lochgelly Loch, Fifeshire.

Pleuroxus uncinatus is also a somewhat scarce species, though it is sometimes moderately common where it does occur.

Bosmina longirostris, Acroperus harpoe, Alona quadrangularis, and Chydorus sphcericus, are all more or less common throughout Scotland.

While the material from Castlemilk Loch, as collected by $\mathrm{Mr}$. Steel, has yielded so large a number of species, it is almost certain that if there had' been time to have made a more thorough examination of the loch the number of species would have been considerably increased. 




\title{
ON SOME \\ FRESH-WATER ENTOMOSTRACA
}

FROM THE

\author{
ISLAND OF MULL, ARGYLLSHIRE, \\ COLLECTED BY THE LATE MR GEORGE BROOK.
}

BY

THOMAS SCOTT, F.L.S.;

Naturalist to the Fishery Board for Scotland. 

XXIII. On some Fresh-Water Entomostraca from the Island of Mull, Aryyllshire, collected by the late Mr George Brook. By Thomas Sсотт, F.L.S., Naturalist to the Fishery Board for Scotland.

(Read 17th January 1894.)

During the year 1890 the late Mr George Brook visited a number of small fresh-water lochs in the island of Mull, when several gatherings of invertebrates-chiefly Entomostraca-were collected and preserved. I happened to meet Mr Brook on one or two occasions afterwards, when he spoke of the collections he had made, and offered to hand them over to me for examination if I would arrange to send for them. Having at the time a good deal of other work on hand, I delayed doing so till there was some prospect of my being able to examine and describe them. Owing to the lamented death of Mr Brook last year, I had given up all thought of the collections, but a few months ago $\mathrm{Mr}$ Binnie - Mr Brook's assistant-informed me that they were still intact, and that I could have them; and this explains how I have been able to prepare the following report.

The collections having been carefully worked up, the report I now propose to lay before the Royal Physical Society contains a record of the results obtained. I have the more confidence in submitting this communication, 
because Mr Brook was, for several years, a respected Fellow of this Society, taking much interest in its welfare, and, also, because the collections are fairly interesting in themselves, and add considerably to our knowledge of the distribution of the fresh-water Entomostraca of Scotland.

The collections, contained in twelve bottles, representing an equal number of separate gatherings, were from the following lochs:- "Swiss Loch," "Loch Uisg," "Sheep Loch," "American Loch," "Loch Airdeglais," "Middle Loch," and "Loch Squabain." The names of the three lochs - the "Swiss Loch," "Sheep Loch," and "American Loch,"-are probably the local names for some small tarns in the neighbourhood of Loch Uisg, for the names do not occur on the one-inch Ordnance Survey map of the island of Mull, but I think there can be no doubt of their being situated in the vicinity of Loch Uisg, from the circumstance that all four were visited on the same day, viz., the 26th February 1890; Loch Uisg is, on the other hand, a well known, although comparatively small, fresh-water loch between the head of Loch Buy and Loch Spelve-two of the sea-lochs of Mull. The positions of the various lochs are more particularly referred to in the sequel. With these preliminary remarks I now proceed to notice each of the lochs separately, and in the order in which they are enumerated.

\section{THE "SwISS Loch."}

As already pointed out, I have not been able to ascertain the position of this loch, but it very probably occurs somewhere in the vicinity of Loch Uisg. It was visited on the 26 th of February 1890, and the only material collected there was a shore gathering, containing very few organisms. The only Entomostraca obtained were the following two species of Copepoda:-

Diaptomus gracilis, G. O. Sars; few.

Cyclops serrulatus, Fischer; few.

Both of these are generally distributed throughout the British Islands. 


\section{LOCH UISG.}

Loch Uisg is a little over one and a half miles in length, by about a quarter of a mile in breadth. It is situated almost midway between the south-west end of Loch Spelve and the head of Loch Buy, in a narrow valley that extends between these two sea-lochs. The material from Loch Uisg consisted of a tow-net gathering from a depth of four fathoms, collected on the 26th February 1890. The only Entomostraca obtained in this gathering were a few specimens of

Diaptomus gracilis, G. O. Sars.

\section{3. "SheEP Loch."}

The "Sheep Loch" is probably a small loch or tarn in the neighbourhood of Loch Uisg. (On the hills towards the west end of Loch Uisg, and about half a mile to the south of it, there is a small lochan called "Lochan nan Caorach," or (?) the Loch of the Sheep.) The material from the "Sheep Loch" was collected on the same date as the other two, and consisted of a shore gathering. Entomostraca, though comparatively scarce, were more numerous and better represented than in the two previously described; they comprised the following species :-

Diaptomus gracilis, G. O. Sars.

Cyclops serrulatus, Fischer.

Bosmina longirostris (Müller).

\section{The "American Loch."}

This loch is also probably situated in the vicinity of Loch Uisg. The material from it was collected on the same date as that from Loch Uisg, and consisted of a shore gathering. Three species of fresh-water Entomostraca were obtained, and are as follow:-

Diaptomus gracilis, G. O. Sars.

Cyclops strenuus, Fischer.

Bosmina longirostris (Müller).

A specimen of Scutellidium viride, a littoral marine species, was obtained in this material, but it had probably been accidentally introduced. 


\section{LoCH Airdeglats.}

The Lussa Water, in an upland valley near its source, north-west of Creach Bheinn, forms a number of expansions or "lochs" that extend northward for nearly two miles in a more or less continuous and slightly curved line. The southmost and largest of these expansions is called Loch Airdeglais or Ardglash, the northmost is called Loch Squabain or Scuban, and between these are two other and smaller lochans. Loch Airdeglais was visited on the 19th of March 1890, when two collections were made,-one a shore gathering, the other a surface tow-netting. In the former the following species were obtained:-

Diaptomus gracilis, G. O. Sars.

Cyclops servulatus, Fischer.

Bosmina longirostris (Müller).

Eurycercus lamelląus (Müller).

In the surface tow-netting only three species were obtained, but individuals were more plentiful than in the shore gathering. The species were as follow:-

Diaptomes gracilis, G. O. Sars.

Bosmina longirostris (Müller).

Daphnella brachyura (Liẻvin).

\section{The "MiddLe Loch."}

Though I have been unable to find any loch called the "Middle Loch" on the Ordnance Survey map of the island of Mull, there is every probability that the name is applied to one of the two small sheets of water or expansions of the Lussa River, situated between the loch last described, viz., Loch Airdeglais and Loch Squabain, for the reason that all three lakes were visited on the same day, viz, on 19 th March, while at a later date-vir, 4th July-the "Middle Loch" and Loch Squabain were again visited on the same day. The material from the Middle Loch consisted of three collections-(1) a shore gathering, got on the 19th of March; (2) a surface and an under-surface tow-net gathering, collected on the 4th of July 1890. In the shore gathering made in March the following species were obtained :- 
Diaptomus gracilis, G. O. Sars.

Cyclops viridis (Jurine).

Cyclops serrulatus, Fischer.

Bosmina longirostris (Müller).

Alona quadrangularis (Müller).

Acroperus harpce, Baird.

The surface tow-net gathering of 4th of July contained a large number of Entomostraca, especially of Cladocera. The following are the species then obtained:-

Diaptomus gracilis, G. O. Sars.

Cyclops viridis (Jurine).

Cyclops serrulatus, Fischer.

Sida crystallina (Müller).

Daphnella brachyura (Liévin).

Ceriodaphnia reticulata (Jurine).

Bosmina longirostris (Miuller).

Eurycercus lamellatus (Müller).

Chydorus globosus, Baird.

Polyphemus pediculus (Linné).

Bythotrephes longimanus, Leydig.

In the under-surface tow-net gathering, collected on the same date as the last, the following species were obtained:-

Diaptomus gracilis, G. O. Sars.

Daphnella brachyura (Liévin).

Bosmina longirostris (Müller).

Acroperus harpoc, Baird.

Polyphemus pediculus (Linné).

Bythotrephes longimanus, Leydig.

\section{Loch Squabain (or Scuban).}

Loch Squabain, as already described, is the northernmost of the group of small lochs near the source of the river Lussa, and was visited on the 19th of March, and again on the 4 th of July 1890 . On the former date a shore gathering was collected, and on the latter visit a surface and an undersurface gathering were got. Six species were obtained in the shore gathering, the names of which are as follow :- 
Diaptomus gracilis, G. O. Sars.

Cyclops viridis (Jurine).

Cyclops serrulatus, Fischer.

Bosmina longirostris (Müiler).

Acroperus harpoe, Baird.

Alona quadrangularis (Müller).

The surface tow-net gathering collected on 4th July was rich in Cladocera. The following species were obtained :-

Diaptomus gracilis, G. O. Sars.

Cyclops signatus (type), Koch.

Cyclops viridis (Jurine).

Sida crystallina (Müller).

Daphnella brachyura (Liévin).

Bosmina longirostris (Miuller).

Eurycercus lamellatus (Müller).

Acroperus harpec, Baird.

Camptocercus macrourus (Müller).

Alonopsis elongata, G. O. Sars.

Alona quadrangularis (Müller).

Peracantha truncata (Müller).

Chydorus globosus, Baird.

Polyphemus pediculus (Linné).

Bythotrephes longimanus, Leydig.

The under-surface tow-net gathering was from a depth of one fathom, and was collected on the same date as the surface gathering. Twelve species were obtained in this gathering, the names of which are as follow:-

Cypris reticulata.

Diaptomus gracilis, G. O. Sars.

Cyclops viridis (Jurine).

Cyclops serrulatus, Fischer.

Sida crystallina (Müller).

Daphnella brachyura (Liévin).

Bosmina longirostris (Müller).

Ilyocryptus sordidus (Liévin).

Alonopsis elongata, G. O. Sars.

Eurycercus lamellatus (Muller).

Chydorus globosus, Baird.

Polyphemus pediculus (Linné). 


\section{TABle I.}

A classified List of the Species recorded in the preceding Notes, with their distribution in the various Lochs described. In the Table, - signifies absent, $\mathrm{r}_{\mathrm{.}}=$ rare, $\mathrm{f}_{\mathrm{o}}=$ few, fr. $=$ frequent, c. = common.

\begin{tabular}{l|l} 
CLASSIFIED LIST \\
OF \\
SpECIES.
\end{tabular}

Remarks on the Distribution of SOME of the RaRer SPECIES RECORDED IN THESE Notes.

\section{OSTRACODA.}

Cypris reticulata, Zaddach.

This was the only Ostracod observed in the material from the Mull lochs; its distribution in Scotland is limited to 
comparatively few places, and these are chiefly in the south and west. The present record is an extension of the distribution of Cypris reticulata northward on the west side of Scotland; on the east side we have a record of its occurrence at Loch Achnacloich, near Invergordon, Ross-shire.

\section{COPEPODA.}

The Copepoda recorded in this report, with, perhaps, one exception, belong to species that are more or less generally distributed throughout Scotland. Cyclops strenus is much less common than the others, and its occurrence in the Mull lochs is of interest, as being an extension of its distribution on the West Coast.

\section{CLADOCERA.}

Sida crystallina (Müller).

This is a large and apparently a local species in Scotland. I have records of it from only two other places, viz., Greenan Loch, near Rothesay, Island of Bute, and Raith Lake, near Kirkcaldy, Fifeshire, in both of which it is moderately common.

Daphnella brachyura (Liévin).

This species is considerably smaller, and is perhaps more generally distributed than the last, and, like it, seems to prefer the shelter of aquatic plants rather than the open. water.

Ceriodaphnia reticulata (Jurine).

The distribution of Ceriodaphnic reticulata appears to be local, but the species may be a common one where it does occur. It was very common in Loch Strathbeg, Aberdeenshire, in September 1890.

\section{Camptocercus macrourus (Müller).}

This also appears to be one of the less common species of Scottish Cladocera. I have met with it in material from only two other localities in Scotland, viz., Castle Loch, Lochuaben; and Loch Morar, Inverness-shire. 
Chydorus globosus, Baird.

There are very few Scottish records for this fine-species, and they are all from the west side; the localities to which these records refer are Paisley Canal (Robertson and $\mathrm{T}$. Scott); The Hebrides (Rev. A. M. Norman); Lismore Island, Argyllshire (T. Scott).

Bythotrephes longimanus, Leydig.

This curious Crustacean, with its enormously long postabdominal spine, would seem to be widely, if not generally, distributed in Scotland. I have obtained it in Loch Leven, Kinross-shire, and in Loch Ness and Loch Morar, Invernessshire. Its occurrence in the Mull lochs is a further extension of its distribution on the West Coast. 

$=$ 



\section{THE \\ LAND AND FRESH-WATER CRUSTACEA \\ OF THE}

\section{DISTRICT AROUND EDINBURGH.}

Part III.-The Cladocera.

BI

THOMAS SCOTT, F.L.S. 

XXX. The Land and Fresh-Water Crustacen of the District around Edinburgh. Part III.-The Cladocera. By Thomas Scott, F.L.S.

(Read 18th April 1894.)

In my two previous communications on the land and freshwater Crustacea of the district around Edinburgh, I gave an account of the Amphipoda and Isopoda, and of the Ostracoda and Copepoda, that had been observed within the prescribed area. In the present paper I propose to deal with the Cladocera. Unfortunately, I have not been able to devote so much time to the study of this curious and troublesome, but very interesting, group of the Crustacea as it was my desire to do. It may therefore be necessary, later on, to prepare a supplementary paper, for the purpose of recording species belonging to the various groups that may yet be discovered in the district as the result of more extensive and careful investigation. It is scarcely possible that the lists I have prepared can be exhaustive, seeing that, comparatively, only a small portion of the district has been examined.

Two orders of the Crustacea-the PhyLlopoda and the BrANCHIURA-are not yet, so far as I know, represented in the district around Edinburgh. I, at one time, thought that Artemia salina (the Brine Shrimp) - one of the Phyllopodsmight be obtained within the district, where "salt-pans," past or present, existed; but after inquiring in various directions, no trace of this strange organism has been discovered. Apus cancriformis-another member of the Phyllopoda-is also absent from our district. Both Apus and Artemia are included in the British fauna. Though Apus is not now known to occur anywhere within the area around Edinburgh, or even in Scotland, the interesting discoveries of $\mathrm{Mr}$ James Bennie, of the Geological Survey, have shown that in ages long ago Apus ${ }^{1}$ was a common Crustacean in what is now the neighbourhood of Edinburgh. Since there is, therefore, no doubt that Apus was common in our district sometime

1 See Mr Bennie's paper in the Annals of Scottish Natural History, No, 9 (1894), p. 46. 
within the post-Tertiary period, why is it at present found only in the south and west of England, and is scarce even in these localities? If the Apus remains found by Mr Bennie belong to Apus glacialis, and there is reason to believe that they do, the reason why Apus was common in the post-Tertiary lake at Corstorphine, but is not known to occur anywhere in Scotland now, is not difficult to explain. Apus glacialis is a dweller in regions where an arctic or subarctic climate prevails, so, when the rigorous climate of our country, during the early portion of the postTertiary period, became gradually more and more temperate, Apus glacialis died out, just as Pecten islandicus, once so common in our seas, and the shells of which are so plentiful in some of the laminated clays of the west of Scotland, disappeared, and is only now found living in high latitudes. Mr Bennie discovered the remains of boreal plants in the same deposit with those Apus, and this strengthens still more the supposition that the fragments from the Corstorphine lake-deposit are those of the northern Apus. Apus cancriformis, on the other hand, has apparently a more southern distribution, which may account for it, also, not being found in Scotland. Though it is thus almost certain that no Phyllopods now exist in our district, I should not be surprised if Argulus foliaceus-the British representative of the Branchiura - may yet be found to be a member of the district fauna. Argulus is a parasite on various fresh-water fishes, as the trout, pike, carp, stickleback, etc. It is very depressed. and round, and only about the one-fifth of an inch across, and as it sticks close on the skin of the fish, it may be easily overlooked. Argulus can swim freely when it chooses to do so, and may then be caught by tow-net, but usually it is obtained adhering to fish.

The Cladocera obtained in the district around Edinburgh number twenty-nine species, and belong to twenty-two genera. In the following list the arrangement and nomenclature of C. L. Herrick's "Final Report on the Crustacea of Minnesota" is more or less adhered to. Dr Baird's classical work on the British Entomostraca, and the "Monograph of the British Entomostraca belonging to the families Bosminidæ, 
Macrothricidæ, and Lynceidæ," by the Rev. A. M. Norman and Dr G. S. Brady, have also been largely consulted. Various other papers on the Cladocera, both by British and Continental authors, have been made use of in determining the different species recorded in the list.

\section{Order CLADOCERA. \\ Suborder Calyptomera. \\ Family SIDID \\ Genus Sida, Straus.}

Sida crystallina (O. F. Müller).

1776. Daphne crystallina, O. F. Müller, Żool. Dan. Prod., No. 2405. 1850. Sida crystallina, Baird, Brit. Entom., p. 107, pl. xii., figs. 3, 4 ; pl. xiii., fig. $1 a-h$.

This large and fine species has only been obtained in one locality within the prescribed area, viz., in Raith Lake, Kirkcaldy, Fifeshire. I have records of the species for the following Scottish localities beyond our district:-Greenan Loch, Bute; Middle Loch (near the source of the river Lussa), Mull; Loch Awe, district of Assynt, Sutherlandshire; and Loch Tay, Perthshire.

\section{Genus Daphnella, Baird.}

Daphnella brachynera (Liévin).

1848. Sida brachyura, Liévin, Branch. d. Danziger Geg.

1850. Daphnella wingii, Baird, op. cit., p. 109, pl. xiv., figs. 1.4.

Daphnella is much smaller than the last. It has been obtained in two localities within the district, viz., Loch Leven, Kinross-shire; and Raith Lake, Kirkcaldy. Also in the following Scottish localities beyond the limits of the district, viz., Miảdle Loch, Loch Scuban, Loch Ardglass, and Loch Uisg, all in the island of Mull. Greenock (M. F. Dunlop). 
Land and Fresh-Water C'rustaced around Edinburgh. 365

\section{Family D A P H N I D E.}

\section{Genus Ceriodaphnia, Dana.}

Ceriodaphnia reticulata (Jurine).

1820. Monoculus reticulatus, Jurine, Hist. Nat. Monoc., p. 139 , pl. xiv., figs. 3,4 .

1850. Daphnia reticulata, Bairl, op. cit., p. 97, pl. vii., fig. 5 ; pl. xii., fig. 1 ( $\delta$ ), and fig. 2 (var.).

Raith Lake, Kirkcaldy, is the only locality within the district where this species has been obtained. I have records of its occurrence in the following localities beyond the area: -Loch Strathbeg, Aberdeenshire; Loch Eye, Ross-shire (East); and Middle Loch, Mull.

\section{Genus Scapholeberis, Schödler.}

Scapholeberis mucronata (O. F. Müller).

1776. Daphne mucronata, O. F. Müller, Zool. Dan. Prod., No. 2404.

1850. Daphnia mucronata, Baird, op. cit., p. 99, pl. x., figs. $2,3$.

The only Scottish locality I know of for this species is Raith Lake, Kirkcaldy, where it was moderately common when I visited the loch in August 1890.

\section{Genus Simocephalus, Schödler.}

Simocephalus vetulus (O. F. Müller).

1776. Daphne vetula, Müller, Zool. Dan. Prod., No. 2399.

1850. Daphnia vetula, Baird, op. cit., p. 95, pl. $x_{\bullet}$, figs. $1,1 a$.

This is evidently a more common species than the last. It has been obtained in Duddingston Loch, near Edinburgh; in Kilconquhar Loch, Raith Lake, and Lochgelly Loch, Fifeshire ; and beyond the district, in Loch Strathbeg, Aberdeenshire.

\section{Genus Daphnia, O. F. Müller.}

Daphnia pulex (Linné).

1758. Monoculus pulex, Linné, Sjst. Nat., 10th ed., vol. i., p. 635, No. 41.

1850. Daphnia pulex, Baird, op. cit., p. 89, pl. vi., figs. 1-3.

Daphnia pulex has been obtained in Duddingston Loch, 
near Edinburgh; Raith Lake, Kirkcaldy; Loch Leven, Kinross; and in the following other Scottish lochs:-Loch Strathbeg, Aberdeenshire; Loch Achnacloich; Ross-shire (East); Loch Mullach Corrie, in Assynt, Sutherlandshire; and in Loch Harray, Orkney.

\section{Daphnia longispina, O. F. Müller.}

1785. Daphnia longispina, O. F. Müller, Entomostraca, p. 88, t. xii., figs. 8-10.

1850. Daphnia pulex, var. longispina, Baird, op. cit., p. 89, pl. vii., figs. 3,4 .

This appears to be less common than Daphnia pulex. The only locality within the district where it was obtained was Loch Leven, Kinross-shire. It has also been observed in Loch Strathbeg, Aberdeenshire; and Loch Ness, Inverness-shire.

\section{Family B OS MINID E.}

Genus Bosmina, Baird.

Bosmina longirostris (O. F. Müller).

1776. Lynceus longirostris, O. F. Müller, Zool. Dan. Prod., No. 2394. 1867. Bosmina longirostris, Norman and Brady, Nat. Hist. Trans. of Northumb. and Durham, vol. i., p. 357, pl, xxii., fig. 4.

Loch Leven is the only locality within the district where I have observed this Bosmina. But I have records of it from several other Scottish localities-Loch Ness, Inverness-shire; Loch Balnagowan, island of Lismore, Argyleshire; Loch Ardglass, Loch Scuban, Middle Loch, Mull; Loch Ascog, Bute; a small loch near Rutherglen, Lanarkshire; Loch Tay, Perthshire.

\section{Family LY N O D A P H I D E, Sars (1861).}

Genus Ilyocryptus, G. O. Sars.

Ilyocryptus sordidus (Liévin).

1858. Acanthocercus sordidus, Liévin.

1861. Ilyocryptus sordidus, G. O. Sars, Om de i Omegnen af Christi. forekom. Clad., p. 11.

This species is usually more or less coated with mud, from its habitat being among mud at the roots of aquatic plants, 
and is thus very liable to be overlooked. Ilyocryptus sordidus has been obtained in three localities within the district around Edinburgh, viz., Lochend Loch, where it was common; Loch Leven; and in a ditch by the side of Harelaw Dam,- the first and last localities are in the vicinity of Edinburgh. I have also records of its occurrence in Loch Morar, Inverness-shire; Loch Tay, Perthshire; and in a small loch near Rutherglen, Lanarkshire. Greenock (M. F. Dunlop).

\section{Family LYNCEID Æ.}

Genus Eurycercus, Baird.

Eurycercus lamellatus (O. F. Müller).

1776. Lynceus lamellatus, O. F. Müller, Znol. Dan. Prod., No. 3396. 1850. Eurycercus lamellatus, Baird, op. cit., p. 124, pl. xv., fig. 1.

Eurycercus is comparatively a common species. I have obtained it in Duddingston Loch, Raith Lake, Lochgelly Loch, and Loch Leven. The following are some of the localities beyond the prescribed area where I have obtained it:-Goldenhoof Dam, near Howietoun, Stirlingshire; Loch Strathbeg, Aberdeenshire; Loch Morar, Inverness-shire; Loch Scuban and Loch Ardglass, island of Mull, Argyleshire; Loch Tay, Perthshire; and the Paisley Canal, Renfrewshire.

\section{Genus Acroperus, Baird.}

Acroperus harpoe, Baird.

1835. Iynceus harpoe, Baird, Trans. Berw. Nat. Club, vol. i., p. 100, pl. ii., fig. 17.

1841. Lynceus leucocephalus, Koch, Deutsch. Crust. (Myriap. u Arach.), p. $36, \mathrm{pl} . \mathrm{x}$.

1850. Acroperus harpo, Baird, Brit. Entom., p. 129, pl. xvi., fig. 5.

Baird's name for this species has clear priority over that of Koch. Acroperus harpoce is a moderately common species. It has been obtained in Duddingston Loch; in Raith Lake, Camilla Loch and Lochgelly Loch, Fifeshire; and in Loch Leven, Kinross-shire. Also in the following among other localities beyond the district:-Goldenhoof Dam, near Howietoun, Stirlingshire; Loch Tay, Perthshire; Loch Scuban, Mull; and a small loch near Rutherglen, Lanarkshire. 
Genus Alonopsis, G. O. Sars.

Alonopsis elongata, G. O. Sars.

1862. Alonopsis elongata, G. O. Sars, Om. de i Omeg, af Christi. forekom. Clad., Andet Bidrag., p. 41.

1867. Lynceus elongatus, Norman and Brady, Mon. of the Brit. Entom., p. 376, pl. xviii., fig. 1; pl. xxi., fig. 2.

1884. Alonopsis elongata, Herrick, Crust. of Minnesota, p. 85.

The only locality within the district for which I have a record of this species is Loch Leven, but I think it will yet be obtained in other fresh-water localities around Edinburgh, because it is by no means a rare Cladoceran. I have Alonopsis from several places beyond the prescribed area-as Loch Tay, Perthshire; Loch Mullach Corrie, Sutherlandshire; Loch Scuban, island of Mull, etc.

\section{Genus Leydigia, Kurz.}

Leydigia quadrangularis (Leydig).

1860. Lynceus quadrangularis, Leydig, Naturges. der Daphn., p. 221, pl. viii., fig. 59.

? Leydigia quadrangularis, Kurz, Dodekas Neuer Cladoceren.

1891. Leydigia quadrangularis, T. Scutt, Ninth Ann. Report, p. iii., p. 292, pl. ii., figs. $5 a, b$.

I recorded this species in the Ninth Annual Report of the Fishery Board for Scotland (1891), as having been obtained in Lochgelly Loch, Fifeshire, and it has occurred nowhere else within the district. Last year Mr James Steel, Glasgow, presented me with some material he had collected in a small loch near Rutherglen, Lanarkshire; there were several interesting things in this material, and one of them was Leydigia quadrangularis. I do not know of any other Scottish record for this species.

\section{Genus Graptoleberis, G. O. Sars.}

Graptoleberis testudinarius (Fischer).

1851. Lynceus testudinariues, Fischer, Mem. des Sav. étrangers, St Petersbourg, vol. vi., p. 191, pl. ix., figs. 3-6.

1862. Graptoleberis testudinarius, G. O. Sars, op. cit., p. 41.

I obtained this curious little species in Lochend Loch, 
Edinburgh, and this is the only locality within the district where Graptoleberis has been observed. I have it also from Loch Tay, Perthshire; from Loch Mullach Corrie, Sutherlandshire; and from Loch Morar, Inverness-shire.

\section{Genus Alona, Baird.}

Alona guttata, G. O. Sars.

1862. Alona guttata, G. O. Sars, op. cit., p. 38.

1867. Lynceus guttatus, Norman and Brady, Mon. Brit. Entom., p. 380 , pl. xviii., fig. 6 ; pl. xxi., fig. 10.

1884. Alona guttata, Herrick, Crustacea of Minnesota, p. 94.

I have only one record for this species in the district, viz., for Camilla Loch, Fifeshire. It is almost certain to occur in other localities, as it has a fairly wide distribution, but being small it is easily overlooked. I have records of its occurrence in Loch Tay, Loch Mullach Corrie, and Loch Morar.

\section{Alona tenuicaudis, G. O. Sars.}

1862. Alona tenuicaudis, G. O. Sars, op. cit., p. 37.

1867. Lynceus tenuicaudis, Norman and Brady, op. cit., p. 376, pl. xix., fig. 3.

1884. Alono tenuicaudis, Herrick, op. cit., p. 95, pl. i., fig. 2.

I have this from the same locality as the last, viz., Camilla Loch, and I know of no other Scottish record for Alona tenuicaudis. It is distinguished from other Lynceidce by the slender form and armature of the post-abdomen.

Alona costata, G. O. Sars.

1862. Alona costata, G. O. Sars, op. cit., p. 38.

1867. Lynceus costatus, Norman and Brady, op. cit., p. 379, pl. xviii., fig. 2 ; pl. $x \mathbf{x i}$, , fig. 7.

1884. Alona costata, Herrick, op. cit., p. 94.

Alona costata has been obtained in two localities within the district, viz., Lochgelly Loch, and in a ditch by the side of Harelaw Dam. The only other record I have for this species is for Loch Morar, Inverness-shire. 
Alona quadrangularis (Müller).

1776. Lynceus quadrangularis, O. F. Müller, Zool. Dan. Prod., p. 199, No. 2393.

1850. Alona quadrangularis, Baird, Brit. Entom., p. 131, pl. xvi., fig. 4.

This moderately common species was obtained in Raith Lake, Camilla Loch, and Lochgelly Loch, Fifeshire; and in Loch Leven, Kinross-shire. I have it also from Loch Tay, Loch Mullach Corrie, Loch Morar, small lochs in the island of Mull, etc.

Genus Alonella, G. O. Sars.

Alonella exigua (Lilljeborg).

1853. Lynceus exignus, Lilljeborg, De Crust. in Seania occur., p. 79, pl. vii., figs. 9, 10.

? 1862. Alonella excisa, G. O. Sars, op. cit., p. 52.

1884. Alonslla exigua, Herrick, op. cit., p. 105.

Loch Leven, frequent along the north and south shores. I have no record of this species for any other locality within the prescribed area. Alonella exigua was obtained in Loch Morar, Inverness-shire; and Loch Hempriggs, Caithnessshire.

\section{Alonella nana (Baird).}

1843. Acroperus nanus, Baird, Ann. and Mag. Nat. Hist., vol. ii., p. 92 , pl. iii., fig. 8 .

1862. Alonella pygmoea, G. O. Sars, op. cit., p. 52.

1884. Alonella pygmoea, Herrick, op. cit., p. 105, pl. H., fig. 7.

Alonella nana has been obtained in two localities within the district around Edinburgh, viz., Raith Lake, Kirkcaldy; and Loch Leven. I have Alonella nana also from Loch Morar. This is a very small species, being only about $\cdot 25$ $\mathrm{mm}$. ( $\frac{1}{10} \overline{0}$ of an inch); it is therefore easily overlooked. Seen under a moderately high power of the microscope, the sculpture of the skull of this species is very pretty; it has a distinct and more or less regular fluted appearance, the striæ are obliquely transverse, extending downwards from the front in more or less regular curved lines. 
Genus Peracantha, Baird.

Peracantha truncata (O. F. Müller).

1781. Lynceus truncatus, O. F. Müller, Entomostraca, p. 75, pl. ii., 4-6. 1850. Peracantha truncata, Baird, Brit. Entom., p. 136, pl. xvi., fig. 1.

Lochgelly Loch, Fifeshire, is the only locality within the prescribed area where this species was obtained. I have records of it from two localities beyond our district, viz., Loch Morar, Inverness-shire; and Loch Scuban, in the island of Mull. Peracantha truncata was frequent in the material from the Mull loch.

Genus Pleuroxus, Baird.

Pleuroxus loevis, G. O. Sars.

1861. Pleuroxus leevis, G. O. Sars, Om. de i Omeg. af Christi. forekom. Clad., p. 22.

1862. Pleuroxus hastatus, idem, ibid., Andet Bedrag., p. 52.

1867. Lynceus lavis, Norman and Brady, Mon. Brit. Entom. belong. ing to the Bosmin. Macrothric. and Lynce., p. 38, pl. xviii., fig. 5 ; pl. xxi., fig. 14 .

Pleuroxus laevis was obtained only in Camilla Loch, Fifeshire, where it occurred sparingly.

Pleuroxus trigonellus (O. F. Müller).

1776. Lynceus trigonellus, O. F. Müller, Zool. Dan. Prod., No. 2395. 1850. Pleuroxus triyonellus, Baird, Brit. Entom., p. 134, pl. xvii., fig. $3($ \% $)$.

, Pleuroxus hamatus, idem, ibid., p. 136, pl. xvii., fig. 5( o).

This species appears to be more common than the last. It has been obtained in two localities within our area, viz., Raith Lake, Kirkcaldy; and Loch Leven, Kinross. Other localities where I have records of its occurrence are Loch Strathbeg, Aberdeenshire; and Loch Tay, Perthshire.

Pleuroxus uncinatus, Baird.

1850. Pleuroxus uncinatus, Baird, op. cit., p. 135, pl. xvii., fig. 4. 1884. Pleuroxus uncinatus, Herrick, Crustacea of Minnesota, p. 114.

This was obtained in the same two localities as the last 
species-Raith Lake, and Loch Leven. It was also obtained in a small loch near Rutherglen, Lanarkshire.

\section{Genus Chydorus, Baird.}

Chydorus sphoericus (O. F. Müller).

1776. Lynceus sphoricus, O. F. Müller, Zool. Dan. Prod., No. 2392.

1850. Chydorüs sphoericus, Baird, op. cit., p. 126, pl. xvi., fig. 8.

This is one of the commonest species among the Cladocera. I have it from Duddingston Loch; Raith Lake, Kirkcaldy; Camilla Loch, and Lochgelly Loch; Loch Leven; Clubbiedean Reservoir, near Edinburgh, etc. And the following among other Scottish localities, Loch Tay, Perthshire; Loch Achnacloich, East Ross-shire; Loch Mullach Corrie, Sutherlandshire; Loch Morar, Inverness-shire; lochs on the island of Lismore, Argyleshire; small loch near Rutherglen, Lanarkshire; Black Loch, Dunbar, Haddingtonshire, etc., etc.

\section{Genus Mionospilis, G. O. Sars.}

Monospilis tenuirostris (Fischer).

1854. Iynceus tenuirostris, Fischer, Bull. de Soc. Imp. des Nat. de Moscou, p. 427, pl. M., figrs. 7-10.

1861. Monospilis dispar, G. O. Sars, Om. de i Omeg. af Christi. forekom. Clad., p. 23.

1867. Monospilis tenuirostris, Norman and Brady, op. cit., p. 52, pl. xix., fig 2 ; pl. xx., fig. 9.

This is a remarkable Cladoceran; instead of casting its shell during the process of ecdysis, each new shell is formed inside of, and is coalesced with, the older one, and being somewhat larger it projects beyond the margin of the older shell. When the animal has undergone several ecdyses, the outer portion of the shell bears a number of concentric lines very like the growth-lines seen in various Lamellibranch Molluscan shells.

This curious species was frequent in one or two places on the south shore of Loch Leven, Kinross. I have no record of Monospilis for any other locality in Scotland. 


\section{Suborder Gymnomera.}

Family POLYPHEMID \&.

Genus Polyphemus, O. F. Müller.

\section{Polyphemus pediculus (Linné).}

1746. Monoculus pediculus, Linné, Faun. Suec., No. 2048.

1776. Polyphemus pediculus, O. F. Müller, Zool. Dan. Prod., No. 2417.

1850. Polyphemus pediculus, Baird, Brit. Entom., p. 111, pl. xvii., fig. 1.

Polyphemus was obtained in Raith Lake and in Loch Leven. This species seems to have a preference for moderately large sheets of water. It was frequent in Loch Ness, Loch Oich, and Loch Lochy in 1890; abundant in Loch Morar in 1892; frequent in Loch Tay in 1893; and in Middle Loch, island of Mull.

\section{Genus Bythotrephes, Leydig.}

Bythotrephes longimanus, Leydig.

Bythotrephis longimanus possesses an enormously long post-abdominal spine; it has otherwise somewhat the aspect of a Polyphemus. The only locality within the area where it has been obtained is Loch Leven, Kinross-shire. I found it common in Loch Ness and Loch Oich; frequent in Loch Morar; and rather scarce in Loch Tay. I have also notes of its occurrence in Loch Scuban and Middle Loch, island of Mull.

\section{Family LEP T O D OR ID E.}

Genus Leptodora, Lilljeborg.

Leptodora hyalina, Lilljeborg.

This beautiful species was obtained in Loch Leven, but nowhere else within the district. It was moderately common in some of the tow-net gatherings from that loch. I also found it frequent in Loch Morar tow-net gatherings, and 
also in those made in Loch Tay. The Rev. A. M. Norman obtained it in Lochmaben Loch, Dumfriesshire. When alive, its presence in the water can only be detected by the black pigment-spot that constitutes the creature's eye. Leptodor $a$ is a large Cladoceran; some of my specimens from Loch Leven measure at least three-eighths of an inch in length, but with the exception of the black eye-spot it is perfectly transparent; hence, though by no means rare in Britain, it had been overlooked even by such a careful observer as Dr Baird, and was only discovered when the Rev. A. M. Norman examined Lochmaben Loch, a locality that had previously been examined by Dr Baird.

With Leptodora hyalina I complete my list of the fresh-water Cladocera observed within the district around Edinburgh; and this also finishes, for the present, my enumeration of the land and fresh-water Crustacea of the area.

In my first paper I recorded one Amphipod and nine Isopods, and in the second paper thirty-five Ostracods and twenty-one Copepods, for the district; in the present paper I have recorded twenty-nine species of Cladocera, making the total number of species of land and fresh-water Crustacea recorded for the district around Edinburgh ninety-five. This number is likely to be considerably augmented when the district comes to be more thoroughly investigated.

It may be of interest to those not familiar with the Entomostraca, if, before leaving this part of my subject, I should indicate one marked and characteristic difference in the manner in which the reproduction of the species is accomplished in each of the three large groups of the Entomostraca dealt with in the preceding lists, viz., the Ostracoda, the Copepoda, and the Cladocera.

The Ostracoda may be described as the "oviparous group." In this group the eggs are usually deposited on floating or submerged leaves of aquatic plants, pieces of wood, etc., or on stones at the bottom, and are left there to hatch out, without apparently any further parental care.

The Copepoda and Cladocera, on the other hand, may be described as the "ovoviviparous groups," but with this difference between them. In the Copepoda the eggs are usually 
deposited in either one or two-but never more than twolittle external sacs-the ovisacs-which are attached to the genital segment of the abdomen, and are in communication with the oviducts, so that the eggs, as they are successively matured within the body of the animal, pass into them. The ovisacs, especially when there are two of them, one on each side of the abdomen, as in Cyclops, enhance the graceful appearance and beauty of the little creatures, as they are usually more or less, and, occasionally, even brilliantly coloured. In the Cladocera the eggs are carried in an ovigerous chamber situated within the posterior portion of the sort of bivalve test with which many species are furnished, as for example in Daphnia, or within a dorsal sac formed by an outgrowth of the dorsal surface, as in Polyphemus or Bythotrephes. But whether the eggs are carried in ovisacs, as among the Copepoda, or in an ovigerous chamber, as among the Cladocera, they remain in these receptacles till the young are hatched. These two groups thus differ very markedly from the Ostracoda. The so-called winter eggs of the Cladocera are enclosed in a portion of the parental test, or in a special covering formed by the parent Cladoceran, and then becoming detached within this specialised covering or ephippium, they fall to the bottom and remain there till the season favourable for their development arrives. Of course there are exceptions, and, if the marine species belonging to the three groups were included, very peculiar exceptions, to the characteristic differences I have tried briefly to indicate; but as I am only dealing at present with the fresh- and brackish-water species, the exceptions are fewer.

One serious trouble experienced by the student of the fresh-water Crustacea, and especially of the Copepoda, is the large number that are to be met with in all stages of development; and as the penultimate, or antepenultimate, stage of one species frequently closely resembles the mature stage of another and different species, the greatest vigilance is necessary to avoid mistaking the young stage of one species for the adult stage of another; the surest course to adopt is to discard all specimens except those where the 
females are bearing ovisacs, as the possession of these is usually an indication of maturity.

I now propose, by way of conclusion to the present paper, to append a list of Scottish species of Cladocera that have not yet been observed in the district around Edinburgh, together with a note of a few of the localities where each has been obtained; such a list will be useful for comparison, and will indicate the blanks that have yet to be filled up, ere we have a complete list for the district.

\section{A Tist of Scottish Species of Cladocera not yet obserted in the District around Edinburgh.}

Holopedium gibberum, Zaddach. This has been obtained in Loch Ness and in Loch Morar, Inverness-shire. (In Beith's Dam, and in a reservoir behind the Cut, at Greenock-M. F. Dunlop, Greenock.)

Daphnia Jardinii, Baird. Frequent in Loch Ness, Invernessshire; and in Loch Tay, Perthshire.

Bosmina longispina, Leydig. Loch Skene, Dumfriesshire (G. S. Brady); Stornoway, Lewis (A. M. Norman); Loch Balnagowan, Lismore Island, Argyleshire.

Bosmina coregoni, Baird. Lochmaben Castle Loch, Dumfriesshire. This curious species forms a considerable part of the food of the vendace (Coregonus albula) - a rare British fresh-water fish found in Lochmaben Loch.

Macrothrix laticornis (Jurine). This was obtained in Loch Morar (1892); also in North Shaws Loch, Selkirkshire (G. S. Brady, 1867).

Macrothrix rosea (Jurine). Lochmaben Loch, Dumfriesshire (Sir W. Jardine, Bart., and Mr W. Yarrell).

Drepanothrix dentata, Euren. (D. hamata, Sars). Lochend Loch, Kirkcudbrightshire; and Loch Skene and Lochmaben Loch, Dumfriesshire (G. S. Brady).

Acantholeberis curvirostris (O. F. Müller). Found in a tarn in the island of Cumbrae, by Mr David Robertson.

Camptocercus macrurus (O. F. Müller). This was obtained in Loch Morar, Inverness-shire; Loch Tay, Perthshire; and Loch Scuban, island of Mull, Argyleshire; near 
Stornoway, island of Lewis (Rev. A. M. Norman); Alemoor and North Shaws Lochs, Selkirkshire; and Lochmaben Loch, Dumfriesshire (Dr G. S. Brady); Paisley Canal (Mr David Robertson).

Leptorhynchus falcatus (G. O. Sars). Loch Morar, Invernessshire. Dr G. S. Brady obtained it in Lochend Loch, Kirkcudbrightshire; and Lochmaben Castle Loch, Dumfriesshire.

Chydorus globosus, Baird. Paisley Canal (D. Robertson);

Loch Balnagowan, island of Lismore, Argyleshire; Loch Scuban, island of Mull.

Anchistropus emarginatus, G. O. Sars. In the Paisley Canal, Renfrewshire (Mr David Robertson). Herrick states that it is just possible this may be the male form of Chydorus globosus ("Crust. of Minnesota," p. 118).

It will be observed from the preceding supplementary list, that twelve species, recorded from various parts of Scotland, have not yet been obtained in the district around Edinburgh. But it is almost certain that, at least, some of them will be discovered within our area, when it comes to be more thoroughly examined. 


[Reprinted from "The Annals of Scottish Natural History," January 1895.]

\section{ON NEW AND RARE SPECIES OF COPE- PODA FROM SCOTLAND}

By Thomas ScotT, F.L.S., and ANDREW SCOTT 


\section{The Annals}

\section{OF \\ Scottish Natural History}

A QUARTERLY MAGAZINE: WITH WHICH IS INCORPORATED "The Scottigh 隹aturaligt"

$$
\text { EDITED BY }
$$

J. A. HARVIE-BROWN, F.R.S.E., F.Z.S: Member of the British Ornithologists' Union.

JAMES W. H. TRAIL, M.A.; M.D., F.R.S., F.L.S. Professor of Botany in the University of Aberdeen and

WILLIAM EAGLE CLARKE, F.L.S., MEM. BRIT. ORN. UNION Natural History Department, Museum of Science and Art, Edinburgh

EDINBURGH : DAVID DOUGLAS, CASTLE STREET 



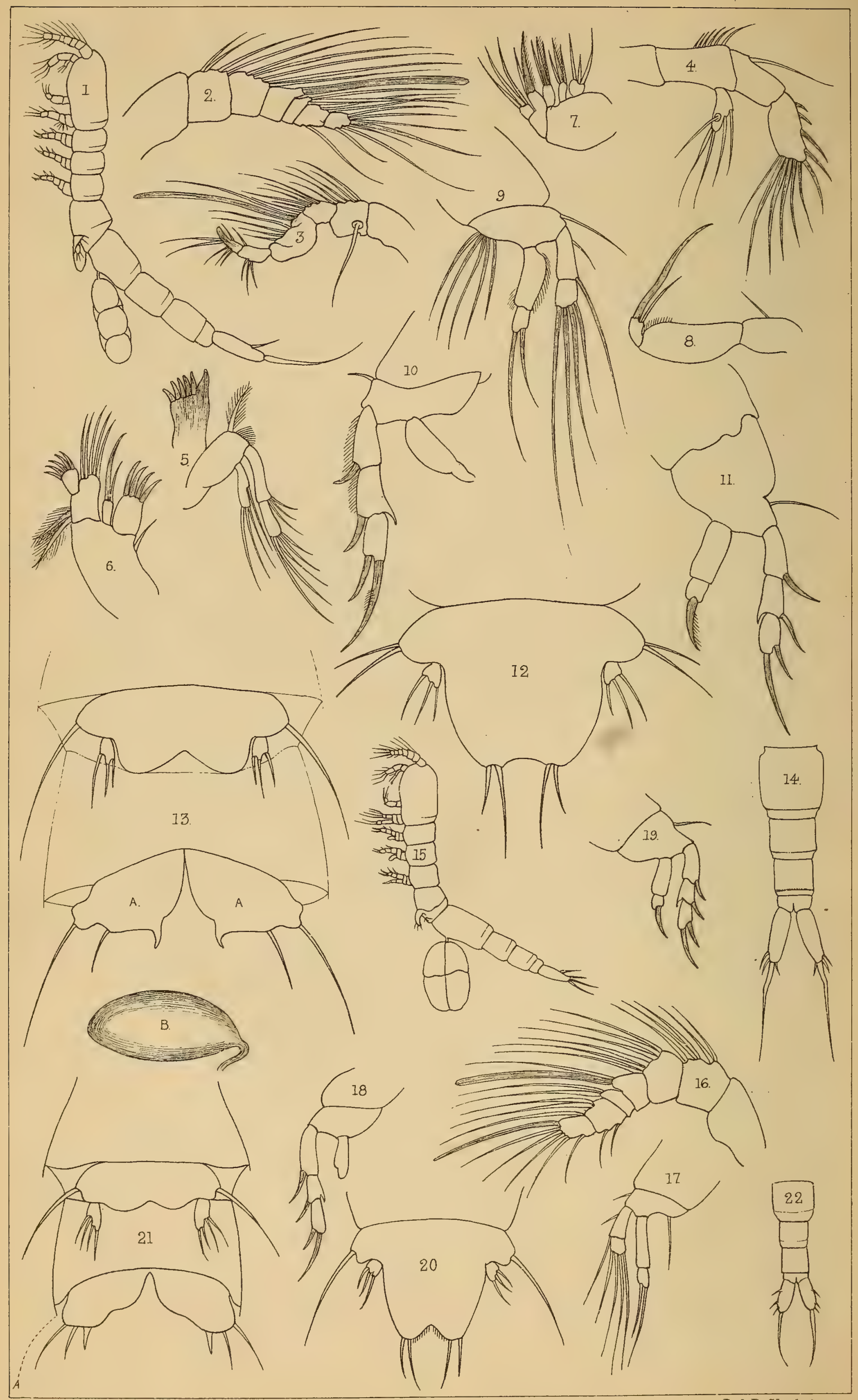


[Reprinted from "The Annals of Scottish Natural History," January I 895.]

\title{
ON NEW AND RARE SPECIES OF COPEPODA
} FROM SCOTLAND.

\author{
By Thomas ScotT, F.L.S.,
} Naturalist to the Fishery Board for Scotland, and ANDREW SCOTT, Fisheries Assistant, University College, Liverpool.

\section{Plate II.}

IN the following Notes we propose, first, to describe two new species of Copepoda, belonging apparently to the genus Leptopsyllus, - - a somewhat curious genus recently instituted; and, second, to give additional records indicating an extension of distribution for several species already described.

Descriptions of two New Species of Leptopsyllus.

Preliminary Remarks.-The genus Leptopsyllus was instituted for a somewhat abnormal and very slender form of Copepod captured in the Forth, a few miles west of Queensferry, 
on the 25 th of January I 894 : there were several specimens of this form. On the 2 oth of August following, three species (two of which are described here), apparently belonging to the same genus, were obtained in the Forth, near Musselburgh -they were taken in pools on the shore, near low-water mark; but these three species, though similar in habit and in general structure to the one obtained west of Queensferry, and for which the genus Leptopsyllus was instituted, differ from it in the following points:- Ist, the mandible-palp is two-branched instead of one-branched-the distal branch being two-jointed, while the proximal branch, which is smaller, is one-jointed; 2nd, the second and third pairs of swimming feet are two-branched-the inner branches, which are one or two-jointed, being more or less rudimentary. But notwithstanding these and one or two other minor differences, the Musselburgh species are, in our opinion, undoubtedly congeneric with that from west of Queensferry, and we therefore prefer to amend the generic definition as published in part iii. of the "Twelfth Annual Report of the Fishery Board for Scotland," rather than establish a separate subgenus for them. The definition of the genus Leptopsyllus as amended will therefore be as follows ${ }^{1}$ :-

Leptopsyllus (amended), T. Scott, "Twelfth Annual Report of the Fishery Board for Scotland," part iii. p. 253 ( I 894).-Body elongate, cylindrical, somewhat similar in form to Cylindropsyllus, Brady. Anterior antennæ (in the female, seven or) eight-jointed, short. (In the male the anterior antennæ are modified and hinged for grasping.) Posterior antennæ three-jointed; secondary branch small, one-jointed. Mandibles well developed, the broad biting part armed with several strong teeth; palp comparatively large, consisting of a single two-jointed branch (or of two branches-the distal branch being two-jointed, while the proximal branch, which is smaller, is one-jointed). Other mouth appendages as in Cletodes, except that the posterior foct-jaws are three-jointed. Both branches of the first pair of swimming feet short, twojointed. In the second and third pairs the inner branches (are one or two-jointed and more or less rudimentary, or)

\footnotetext{
1 The Amendments are within ( ).
} 
are obsolete or entirely absent, but the outer branches are three-jointed. Inner branches of the fourth pair (usually) two-jointed and the outer branches three-jointed. Fifth pair foliaceous, small, two-branched (basal joints sometimes coalescent and forming a broad lamelliform plate; the fifth pair in the male are smaller than those of the female. One ovisac, containing a few large ova).

Leptopsyllus Robertsoni, Sp. nov. (Plate II. Figs. I-I 4).

Description.-Female.-Length $.63 \mathrm{~mm}$. ( $\frac{1}{40}$ of an inch). Body elongate and very slender. Anterior antennæ moderately stout, shorter than the first cephalothoracic segment, seven-jointed : the fifth joint is shorter than any of the others, as shown by the formula:-

Proportional length of joints

Number of the joints

\begin{tabular}{lcccccc}
22 & I 3 & IO & 7 & 5 & 8 & 9 \\
\hline $\mathrm{I}$ & 2 & 3 & 4 & 5 & 6 & 7
\end{tabular}

Posterior antennæ nearly as in Leptopsyllus typicus, T. Scott. Mouth organs also nearly as in that species, except that the mandible-palp is two-branched; the distal branch, which is slender and elongate, has the end joint equal to about twothirds the length of the first joint; the proximal one-jointed branch is nearly as long as the first joint of the distal branch. The first pair of swimming feet are similar to those of Leptopsyllus typicus, but the inner branches are rather longer than the outer, and there is a fascicle of moderately long setæ on the inner margin of the second basal joint (Fig. 9). In the second and third pairs the outer branches are somewhat similar to those of Leptopsyllus typicus; the inner branches, which are rudimentary, are two-jointed, the endjoint being very small (Fig. IO). The fourth pair are similar to those of Leptopsyllus typicus. The basal joints of the fifth pair are coalescent, forming a broad lamelliform plate, the end of which is broadly truncate and slightly concave, the obtuse angles being each furnished with two small setæ, and on each side near the base of the joints the outer margin is produced into a broadly rounded lobe terminating in two setæ; the length of the basal joints is equal to about two- 
thirds of their entire width across the broadest part; the secondary branches are very small, obscurely triangular in outline, and furnished each with three small setæ on the outer edge (Fig. I 2). The caudal stylets are in the form of elongateovate lamellæ; in length they are equal to both the last two abdominal segments together, and their breadth is about equal to two-thirds of their length; they are also each furnished with four terminal setæ, the principal seta being about twice the length of the stylets, but the others are very small. Ovisac small, containing a number of moderately large ova.

Male.-The male is similar to the female, except in the following particulars:- The anterior antennæ are each sixjointed; the last four joints are modified and hinged, and form powerful grasping organs. The basal joints of the fifth pair of thoracic feet are coalescent, as in the female, but are much shorter, being only about half the length; the sixth pair of appendages are foliaceous, broadly subtriangular in outline, and not coalescent (Fig. I 3).

Habitat.-In pools near low water on the shore of the Firth of Forth, at Musselburgh; rather rare.

Remarks.-This species is at once distinguished from any others of the same genus by the large, lamelliform caudal stylets, and by the form of the fifth pair of thoracic feet, as also by the structure of the anterior antennæ. We have much pleasure in giving to this species the name of our kind friend Mr. David Robertson of Millport, the veteran Scottish Naturalist, who was one of the first to introduce us to that most interesting study-the study of the Microcrustacea.

\section{LePTOPSYllus MinOR, sp. nov. (Plate II. Figs. I 5-22).}

Description.-Female.-Length, $\cdot 46 \mathrm{~mm}$. ( $\frac{1}{54}$ of an inch). Body elongate, very slender. Anterior antennæ short, moderately stout, seven-jointed, somewhat similar in structure to those of Leptopsyllus robertsoni. The proportional lengths of the joints are shown by the formula--

Proportional length of joints

Number of the joints

\begin{tabular}{ccccccc}
20 & I 4 & I I & 7 & 5 & 9 & 10 \\
\hline I & 2 & 3 & 4 & 5 & 6 & 7
\end{tabular}


Posterior antennæ and mouth organs similar to those of Leptopsyllus robertsoni. The first pair of swimming feet are also similar in structure to those of that species, but smaller, and the outer branches are considerably shorter in proportion to the inner branches (Fig. I 7). Inner branches of the second and third pairs one-jointed and very rudimentary (Fig. I 8 ). Fourth pair similar in structure to those of Leptopsyllus robertsoni, but considerably smaller. The fifth pair are also similar in structure to those of that species, but the coalescent basal joints are proportionally longer, being in length equal to about three-fourths of their entire width at the broadest part. They also differ in form, being subconical in outline and with the apex distinctly bifid. Each of the two apical angles bears two short setæ, and the lateral basal lobes are each furnished with a moderately long hair. The secondary joints are very small (Fig. 20). The length of the caudal stylets is scarcely equal to the combined lengths of the last two abdominal segments, while their breadth is nearly equal to half the length. They are each furnished with a few setæ, the principal terminal seta being about twice the length of the stylets; while one of the others, which are very small, springs from near the middle of the outer margin (Fig. 22). The ovisac contains a few very large ova.

Male. - The male is very similar to the female, but the anterior antennæ are modified for grasping, and resemble those of the male of Leptopsyllus robertsoni. The fifth pair of thoracic feet, which are very small, also resemble those of that species; but the coalesced basal joints are shorter, and scarcely extend beyond the base of the secondary joints, while the secondary joints are proportionally larger. In the sixth pair of appendages the inner margins are sinuated and slope considerably outwards, the outer margins are short and nearly straight, and the broadly rounded apex is furnished with two small setæ on the outer aspect and a small but stout spine interiorly (Fig. 2 I).

Habitat.-On the shore at Musselburgh, in the same pools with Leptopsyllus robertsoni.

Remarks. - This species is much smaller than the one last described, and is readily distinguished from it by the form of the caudal stylets, which are comparatively shorter 
and broader, and by the difference in the structure of the first and fifth thoracic feet. The ovisac of this species appears to contain fewer but larger ova than that of Leptopsyllus robertsoni.

RECORds INDICATING AN EXtension OF Distribution.

CyClops EQUOREus, Fischer, "Abhandl. der Akad. der Wissenschaft,” Bd. viii. p. 654, Taf. XX., Figs. 26-29 (I 860). -This, which is one of those curious species that form a link between the truly freshwater and the truly marine Copepoda, was obtained in brackish pools near the head of West Loch Tarbert, Argyleshire, on both the north and south sides of the loch. Though widely distributed, the Scottish localities where Cyclops equorcus has been recorded from are, so far as known to us, few in number. It has been "taken by the Rev. A. M. Norman in the West of Scotland"; in pools above high-water mark at Cramond Island, Firth of Forth; in the mussel beds at the mouth of the river Eden, Fifeshire; and Loch Stennis, Orkney.

Tachidius littoralis, Poppe. [Tachidius CRAssiCornis, T. Scott, "Tenth Annual Report of the Fishery Board for Scotland," part iii. p. 250, Plate VIII. Figs. I4-27 (I 892).]

Tachidius littoralis was recorded from the Firth of Forth, the first time for Scotland, in I 892. Though as yet known from only a few localities in the British Islands, we believe that it will yet be found distributed all round our shores wherever there is a suitable habitat, i.e. brackish water with a muddy and weedy bottom. It was obtained in pools of this description during the month of July last year around the head and north side of West Loch Tarbert.

Delavalia Palustris, Brady, " Nat. Hist. Trans. Northumb. and Durham," iii. p. I 34, Pl. V. Figs. I o-I 5 (I 868).This species was taken in pools between tide-marks near the head of West Loch Tarbert. Its distribution in Scotland appears as yet to be very limited. The Firth of Forth is

1 "A Monograph of the Free and Semiparasitic Copepoda of the British Islands," ii. p. I 20 ; no locality is given. 
the only other Scottish locality known to us where Delavalia palustris has been obtained.

Canthocamptus Palustris, Brady, "Mon. Brit. Copep.," ii. p. 53, Plate XXXIX. Figs. I 3-23 (I 880). - This wellmarked species has, like the last, a very limited known distribution in Scotland; but we believe that, in this case also, it will be found to be more or less frequent when carefully sought for in suitable situations. It has during the last few years been obtained in one or two places in the Firth of Forth, and we have now to record its occurrence in brackish-water pools at the head and on the north side of West Loch Tarbert, Argyleshire.

Cletodes tenuiremis, $T$. Scott, "Eleventh Annual Report of the Fishery Board for Scotland," part iii. p. 204, Plate III. Figs. 2 I-28 (I 893).-This interesting and easily distinguished species of Cletodes has not been observed beyond the Forth area till last summer, when it was obtained at West Loch Tarbert in brackish-water pools along with Canthocamptus palustris.

Platychelipus littoralis, Brady, "Mon. Brit. Copep.," ii. p. IO3, Plate LXXIX. Figs. I 5-I9 (I880); T. Scott, op. cit., p. 205, Plate V. Figs. I I-I 3 (I 893). - The known distribution in Scotland of this curious species is, like that of most of the others recorded here, hitherto very limited, and so far as we know the present record of its occurrence in West Loch Tarbert is the only record for the West Coast. It was obtained in hand-net gatherings from brackish-water pools along with Canthocamptus palustris and Cletodes tenuiremis.

All the species recorded in the preceding notes have hitherto been obtained only where there was an admixture in greater or less proportions of sea and fresh water. These brackish-water forms frequently exhibit a curious combination of characters interesting to the biologist, but often very troublesome to the systematist. We believe that there is still a rich harvest to be reaped by the study of these peculiar intermediate conditions of habitat and life. It may well be said-

"The earth is full of Thy riches;

So is this great and wide sea." 


\section{EXPLANATION OF PLATE II.}

\section{LEPTOPSYlLUS ROBERTSONI, $s p$. nov.}

Fig. I. Female, lateral view $\times 80$ dia.

2. Anterior antenna,

$$
\text { female . } \quad \times 330,
$$

, 3. Anterior antenna,

$$
\text { male : } \times 500,
$$

, 4. Posterior antenna $\times 380$,"

, 5. Mandible $\times 380$,

"6. Maxilla . . $\times 380$,

,, 7. Anterior foot-jaw $\times 380$,

, 8. Posterior foot-jaw $\times 380$,

\section{Fig. 9. Foot of first pair of} swimming feet $\times 380$ dia.

, Io. Foot of second pair $\times 380$,"

, II. Foot of fourth pair $\times 380$,"

I2. Fifth pair of feet, female $\times 380$,

, I3. Fifth pair and sixth pair, male . $\times 3^{80}$,

,I4. Abdomen and caudal stylets $\times 80$,

\section{LEPTOPSYLLUS MINOR, $s p, n o v$.}

Fig. I 5. Female, lateral view $\times 80$ dia.

, I6. Anterior atnenna $\times 500$,

, I7. Foot of first pair of swimming feet $\times 380$,

,, I8. Foot of second pair . , ×380,
Fig. 19. Foot of fourth pair $\times 380$ dia. , 20. Fifth pair of feet, female $\times 380$, , 21. Fifth pair and sixth pair, male . $\times 380$,

22. Abdomen and caudal stylets $\times 80$, 


[Reprinted from "The Annals of Scottish Natural History," July 1895.]

NOTES ON FRESHWATER ENTOMOSTRACA, WITH SPECIAL REFERENCE TO LOCH LEVEN

By THOMAS SCOTT, F.L.S. 


\section{The Annals}

OF

\section{Scottish Natural History}

- A QUARTERLY MAGAZINE

WITH WIICH IS INCORPORATED

"The Scottigh Jaturalist"

\section{EDITED BY}

J. A. HARVIE-BROWN, F.R.S.E., F.Z.S.

Member of the British Ornithologists' Union

JAMES W. H. TRAIL, M.A., M.D., F.R.S., F.L.S.

Professor of Botany in the University of Aberdeen

$$
\text { and }
$$

WILLIAM EAGLE CLARIKE, F.L.S., MEM. BRIT. ORN. UNION

Natural History Department, Museum of Science and Art, Edinburgh

EDINBURGH : DAVID DOUGLAS, CASTLE STREET 
[Reprinted from "The Annals of Scottish Natural History," July r 895.]

\section{NOTES ON FRESHWATER ENTOMOSTRACA, WITH SPECIAL REFERENCE TO LOCH LEVEN.}

By Thomas Scott, F.L.S., Naturalist to the Fishery Board for Scotland.

SoME time ago I had my attention directed to an interesting correspondence of a semi-private nature, relating to the presence of Copepoda in the River Leven-the effluent of Loch Leven, Kinross-shire.

Along the banks of this river there are various public works, such as powerloom factories, paper-mills, etc. At one of these paper-mills, belonging to Mr. Tullis, Auchmuty, minute red spots were observed from time to time in the paper that was being made. It was shortly after the New Year when these spots were first noticed, and they continued to be observed for several weeks. For a time no satisfactory reason could be given for the occurrence of the red spots, but eventually when the strainers were examined numerous little objects that at first were supposed to be fish spawn were found collected upon them. These were afterwards examined under the microscope, and were then seen to be small freshwater crustaceans, chiefly Copepods, that had evidently been carried down from the loch. On this discovery being made, the origin of the red spots was easily explained; and moreover, when the spots themselves were examined under the microscope, each spot was seen to be a crushed Copepod, the test of the animal being in some instances quite distinct.

When a lot of the little objects from the strainers was transferred to a bottle of water, some of them were still alive and commenced swimming about, but the majority were dead. Globules of oily matter were visible, with the aid of the microscope, inside the bodies of almost all the dead specimens.

When Mr. Tullis perceived, from the large numbers of crustacea on the strainers, that an extensive exodus of these little creatures from Loch Leven was in progress, he wrote to some friends, who like himself are interested in natural 
history, and gave them a detailed account of the observations that had been made. I had the privilege of reading $\mathrm{Mr}$. Tullis's narrative, and later on he himself favoured me with some additional notes, and from these I obtained the information embodied in the preceding remarks.

The phenomenon observed by Mr. Tullis and described in the communication to his friends suggests one or two questions relating to the micro-crustacea, that, for several reasons, appear to be of some importance, and which I propose to notice in the remarks which follow.

One of these questions, and perhaps the foremost in importance, is the place that the micro-crustacea-or entomostraca, as they are usually called-hold in the fishes' "bill of fare"; or, in other words, their value as fish-food. That the entomostraca hold an important place in this respect seems to be undoubted; for not only do they occur in vast numbers, but when healthy and vigorous they are rich in a kind of oily matter that is more or less diffused through their tissues, and it is owing to the presence of this oily matter in their bodies, as much as to their numbers, that, as fish-food, they are so nutritious and valuable.

The entomostraca when collected together en masse soon die, and the oily matter in their bodies is set free and collects in the form of globules within the carapace, or it escapes and rises to the surface of the water and forms a perceptible scum. When strong and vigorous, this oily matter exudes from their bodies even during life, and hence it is-as sailors know well enough-that during summer, when the sea is teeming with small crustacea and other minute animals, a film of oil may frequently be seen spread over considerable areas of the surface of the water, so that during stormy weather the waves do not rise so high nor break so readily as during the winter months, when minute crustacea and other organisms are usually less abundant and vigorous.

But though the entomostraca are unquestionably of great importance as fish-food, and specimens of various kinds are frequently obtained in the stomachs of fishes, it cannot be gainsaid that, as regards trout and other freshwater species, the larvæ of insects_- "freshwater shrimps" (Gammarus), 
small shell-fish, and others of the comparatively larger invertebrates - form a considerable portion of the food of most of the more or less full-grown specimens; and I have no doubt, from personal observation and otherwise, that the superiority of the Loch Leven trout is due very much to the abundance of these organisms in the loch; rather than directly to the entomostraca. Wherein then does the importance of the entomostraca appear? In trying to answer this question, it may not be out of place to quote a statement by Professor MacIntosh of St. Andrews, who is perhaps one of the greatest authorities on fish and fisheries in Britain. In a paper on the pelagic fauna of St. Andrews Bay he thus refers to one of the entomostracan groups: "As has been often pointed out, no group is more important than the Copepoda in connection with the nourishment of fishes, especially in their post-larval stages : and they are ubiquitous in distribution; their varying sizes, from the minute larval nauplii to the larger adults, such as Calanus, as well as their highly nutritious nature, render them perhaps the most valuable fish-food in the ocean" ("Eighth Annual Report of the Fishery Board for Scotland," part iii. p. 27 I, I 890). Objection may be taken to the above statement because it refers only to the marine crustacea; but though that is so, the general bearing of the statement is equally true of the freshwater Copepoda. But further, when we take into account the fact that the Cladocera-another important group of the entomostraca, which, as regards variety, and sometimes also as regards numbers, is only sparingly represented among sea organisms-are found in myriads, even frequently out-numbering the Copepoda, in most freshwater lochs, and the larval and post-larval stages of which may well rank in importance with those of the Copepoda as a suitable food-supply for the young of the different freshwater fishes, we begin to realise somewhat the value of these minute crustaceans.

But the importance of the entomostraca does not end here. While, as has been shown, their value as a direct source of fish-food is great, their importance becomes more apparent when it is remembered that they are also the prey of many of those larger organisms that constitute such a 
considerable portion of the food of half-grown and adult trout and other fishes. Many of the insect-larvæ and other of the larger invertebrates feed voraciously on the smaller crustacea, and where these are abundant their devourers are also usually more or less common.

When I examined Loch Leven in June I 890, entomostraca were plentiful all over the loch, and it is only necessary to give the following extract from my Report which details the results of the investigation to show that the larvæ of insects were also at the same time in considerable abundance. In referring to these larvæ, the Report goes on to say: "Some idea may be formed of the myriads of these organisms present in the loch, when it is stated that a conspicuous ridge composed of the cast-off skins of insect-larvæ, which had been washed ashore during the preceding stormy weather, extended along the margin of the loch for a considerable distance" ("Ninth Annual Report of the Fishery Board for Scotland," part iii. p. 273, I 89 I).

The freshwater entomostraca, and especially the Cladocera, include many curious and beautiful forms; and who knows but that the trout may be able in some measure to appreciate the beautiful as well as the useful, and if so they will find in Loch Leven much to please the eye as well as tickle the palate. The following remarks by the Rev. A. M. Norman, bearing, though somewhat indirectly, on this point, may be of interest. Speaking of one of the most beautiful of the freshwater Cladocera, and a species by the way which is frequent in Loch Leven, and referring to the liability of even careful observers sometimes to overlook rare things, he says: "Dr. Baird many years ago published a very interesting paper on the food of the Vendace. No author at that time was more competent to undertake the task, and two of the entomostraca in the stomachs were new to science, one of which, Bosmina coregoni, has not been met with elsewhere in our Islands than in Lochmaben; yet when I repeated these investigations three years ago I found that while the Vendace fed on those species recorded by Dr. Baird, a large portion, perhaps in bulk the largest portion, of its food was Leptodora hyalina-an entomostracan unknown to Dr. Baird, and which for its extraordinary tenuity, delicacy, and transparency, and its 
totally different form from that usual among Cladocera, was no doubt passed over by my old friend as something he could not make out, though it is much larger than the species he satisfactorily determined. A more dainty dish to set before a fish cannot well be imagined than Leptodora hyalinaan animal so transparent that, notwithstanding its size, it can scarcely be detected in a glass of water unless held up against the light" " Fourth Annual Report of the Fishery Board for Scotland," p. I 55 , I 886 ).

Since there can be no doubt, then, that the presence of an abundant entomostracan fauna is an important desideratum in lochs that have become, or that it is desirable should become, good trout lochs, any cause that tends to produce a serious diminution of the numbers of such organisms is worthy of earnest consideration; because if the diminution becomes extensive and prolonged it is almost certain to react prejudicially on the finny inhabitants of the loch where such diminution has occurred. Hence Mr. Tullis in his letter, after referring to the large numbers of entomostraca discovered on the strainers of his mill, goes on to say: "I wonder how this destruction of these 'water-fleas' is to affect the fish in the loch. The cause which has killed them will no doubt kill other insects, and if so the trout will this season not get so much to feed on in the water, and will have to come more to the surface to look for their food, and in this way we may at last see some improvement in the fly-fishing. It will therefore be interesting to watch how this season goes."

I do not know if any examination of the loch has since been made to ascertain whether such a destruction of entomostraca and other invertebrates had taken place as would produce a serious diminution of their numbers; but whether or not such an examination has been made, it is hardly likely that the destruction would be so great as that. Entomostraca exist in myriads in Loch Leven, and they are very prolific; and as the cause, whatever it may have been, that resulted in so many of them being carried down by the river was probably only temporary, the loss of a few millions in this way would make scarcely any appreciable difference in the vast multitudes inhabiting the loch. To show how 
prolific some of these creatures are, the following statements are submitted:-A few months ago, when examining some gatherings of freshwater entomostraca, I selected at random ten specimens of Daphnia pulex and counted the number of ova and embryos in each : in some of the specimens the ova were in the earlier stages of development, in others the embryos were well formed. The first specimen examined contained 27 ova; in the second there were 30 ; in the third, 32 ; in the fourth, 20 ; in the fifth, 23 ; in the sixth, 32 ; in the seventh, I 8 ; in the eighth, I 8 ; in the ninth, I6; and in the tenth, 20-in all 236 ova and embryos, or an average of 23.6 for each Daphnia. Many years ago the late Dr. Baird, the eminent English naturalist, made a number of experiments with Daphnia pulex, and the following brief statement of some of the results he obtained throws much light on the fecundity of the species. ${ }^{1} \quad$ I give the results of the experiments in his own words:- "29th November, I isolated a $D$. pulex with an ephippium; 30 th, ephippium is thrown off ; 4 th December, Daphnia has eggs ; 8th, young ones are born ; 9th, the mother, having been removed from the young immediately after their birth, was found to have eggs again; I6th, young ones born; 20th, has eggs again;

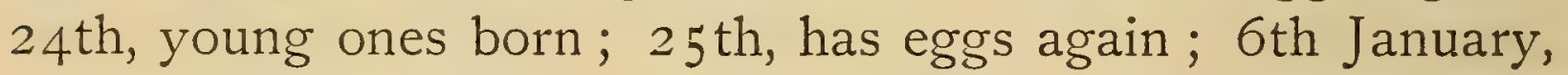
young born-mother has eggs in ovary again; I 4 th, young born - mother has eggs again; 22nd, young born; Ist February, has eggs again ; 8th, young born.

"On the 8th December, isolated one of the young born from the subject of last series of observations on 3oth November. On the 2 Ist December she was found to have eggs ; 2 sth, young born ; 29th, has eggs again ; 9th January, young born-mother has eggs again; 24th, young born;

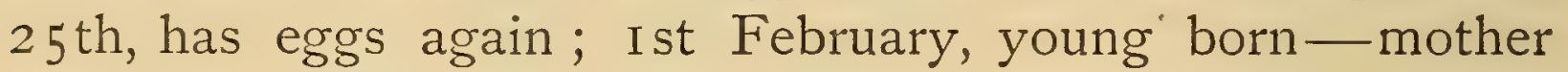
has eggs again; 9th, young born; 27 th, has eggs again; Sth March, young born" ("Natural History of the British Entomostraca," p. 80, I850). Dr. Baird also states that he isolated two specimens born on I 8 th January, and that both

1 Although Dr. Baird's experiments are made use of here to prove the fertility of Daphnia, the purpose he had in view was rather to show that though the Daphniæ are not hermaphrodite, as had been supposed, one union with the male " is sufficient not only to fecundate the mother for her life, but all her female descendants for several successive generations." 
gave birth to young on 8th February (op. cit., p. 8I). Now if in the first series of observations we exclude the ephippial egg thrown off on 30th November, and reckon from 4th December when the normal eggs were first observed, we find that this Daphnia had seven broods of young in 67 days; or, reckoning from 8th December, when the first brood of young ones were born, and not counting that brood, then there were six broods in 62 days, or an average of about Io days between each brood. It must be remembered also that these experiments were carried on during mid-winter, when the productiveness of the little creatures, even though artificial heat may have been used, would naturally be less than during the genial weather of the summer and autumn months.

If the ten specimens first referred to be now considered, and taking for granted that they would have proved to be as prolific as those described by Dr. Baird, and also allowing on an average twenty young to each brood for each of them, they would in the seven broods have given birth to I 400 young Daphnia; and, moreover, when we take into consideration that the young at certain seasons consist only of females, and that the young females, according to Jurine, begin to produce eggs in about Io days after birth, and in winter, as Dr. Baird has shown, they produce young in 20 or 2 I days after birth, it is not difficult to imagine in how short a time a loch will become replenished with a numerous fauna. As a matter of fact, if the ten specimens already referred to and their offspring were as fertile as the examples cited, and taking for granted that all or most of their young ones were females, which at certain seasons of the year is not unusual among some of the entomostraca, as shown by Dr. Baird, our ten specimens of Daphnia pulex would in the course of a little over two months have become the progenitors of several millions of descendants.

The following table shows the actual increase in numbers of Daphnia in 80 days, beginning. with the first brood of the I O Daphniæ referred to, and allowing 20 young ones to each brood, and presuming that these young will themselves reproduce 20 days after birth - all the young being females :- 


\begin{tabular}{|c|c|c|c|c|c|c|c|c|c|c|c|c|c|c|c|c|c|}
\hline \multirow{2}{*}{$\begin{array}{c}\text { No. } \\
\text { of } \\
\text { days }\end{array}$} & \multirow{2}{*}{$\begin{array}{l}\text { No. of } \\
\text { broods } \\
\text { of first } \\
\text { ro } \\
\text { speci- } \\
\text { mens. }\end{array}$} & \multicolumn{7}{|c|}{ Young of the } & \multicolumn{5}{|c|}{ Young of the young of the } & \multicolumn{3}{|c|}{$\begin{array}{l}\text { Young of young of } \\
\text { young of the }\end{array}$} & \multirow{2}{*}{\begin{tabular}{|c|}
$\begin{array}{c}\text { Young of } \\
\text { young of } \\
\text { young of } \\
\text { young of }\end{array}$ \\
$\begin{array}{c}\text { Ist } \\
\text { brood. }\end{array}$
\end{tabular}} \\
\hline & & $\begin{array}{c}\text { Ist } \\
\text { brood. }\end{array}$ & brood. & brood. & $\begin{array}{l}4^{\text {th }} \\
\text { brood. }\end{array}$ & $\begin{array}{c}\text { sth } \\
\text { brood. }\end{array}$ & $\begin{array}{c}\text { 6th } \\
\text { brood. }\end{array}$ & 7th & $\begin{array}{c}\text { Ist } \\
\text { brood. }\end{array}$ & $\begin{array}{l}\text { and } \\
\text { brood. }\end{array}$ & $\begin{array}{c}3^{\text {rd }} \\
\text { brood. }\end{array}$ & 4th & $\begin{array}{c}5^{\text {th }} \\
\text { brood. }\end{array}$ & $\begin{array}{c}\text { Ist } \\
\text { brood. }\end{array}$ & and & $\mid \begin{array}{c}3 \text { rd } \\
\text { brood. }\end{array}$ & \\
\hline $\begin{array}{c}0 \\
10 \\
20 \\
30 \\
40 \\
50 \\
60 \\
70 \\
80\end{array}$ & $\begin{aligned} \text { Ist } & =a \\
\text { 2nd } & =b \\
3^{\text {rd }} & =c \\
4 \text { th } & =d \\
5 \text { th } & =e \\
6 \text { th } & =f \\
7 \text { th } & =g \\
8 \text { th } & =h \\
9 \text { th } & =i\end{aligned}$ & $\begin{array}{l}\text { Ist } a^{1} \\
\text { 2nd } a^{1} \\
3 \text { rd } a^{1} \\
4 \text { th } a^{1} \\
5 \text { th } a^{1} \\
6 \text { th } a^{1} \\
7 \text { th } a^{1}\end{array}$ & $\begin{array}{l}\text { Ist } b 1 \\
\text { 2nd } b 1 \\
3 \text { rd } b 1 \\
4 \text { th } b 1 \\
5 \text { th } b 1 \\
6 \text { th } b 1\end{array}$ & $\begin{array}{l}\text { Ist } c^{1} \\
\text { 2nd } c^{1} \\
3 \text { rd } c^{1} \\
4 \text { th } c^{1} \\
5 \text { th } c^{1}\end{array}$ & $\begin{array}{c}\text { Ist } d 1 \\
\text { 2nd } d 1 \\
3 \text { rd } d 1 \\
\text { 4th } d^{1}\end{array}$ & $\begin{array}{c}\cdots \\
\text { Ist } e^{1} \\
\text { 2nd } e^{1} \\
\text { 3rd } e^{1}\end{array}$ & $\begin{array}{c}\cdots \\
\ddot{y} \\
\text { ist } f^{1} \\
\text { 2nd } f^{1}\end{array}$ & $\begin{array}{c}\ddot{ } \\
\ddot{*} \\
\ddot{I s t} g^{1}\end{array}$ & $\begin{array}{l}\text { Ist } a^{2} \\
\text { 2nd } a^{2} \\
\text { 3rd } a^{2} \\
\text { 4th } a^{2} \\
\text { 5th } a^{2}\end{array}$ & $\begin{array}{c}\text { Ist } b^{2} \\
\text { 2nd } b^{2} \\
3 \text { rd } b^{2} \\
4 \text { th } b^{2}\end{array}$ & $\begin{array}{l}\text { Ist } c^{2} \\
\text { 2nd } c^{2} \\
\text { 3rd } c^{2}\end{array}$ & $\begin{array}{c}\ddot{1} d d^{2} \\
\text { 2nd } d^{2}\end{array}$ & $\begin{array}{c}\because \\
\text { Ist } e^{2}\end{array}$ & $\begin{array}{r}\text { Ist } a^{3} \\
\text { 2nd } a^{3} \\
\text { 3rd } a^{3}\end{array}$ & $\begin{array}{r}\text { ist } b^{3} \\
\text { 2nd } b^{3}\end{array}$ & Ist $c^{3}$ & Ist $a^{4}$ \\
\hline
\end{tabular}

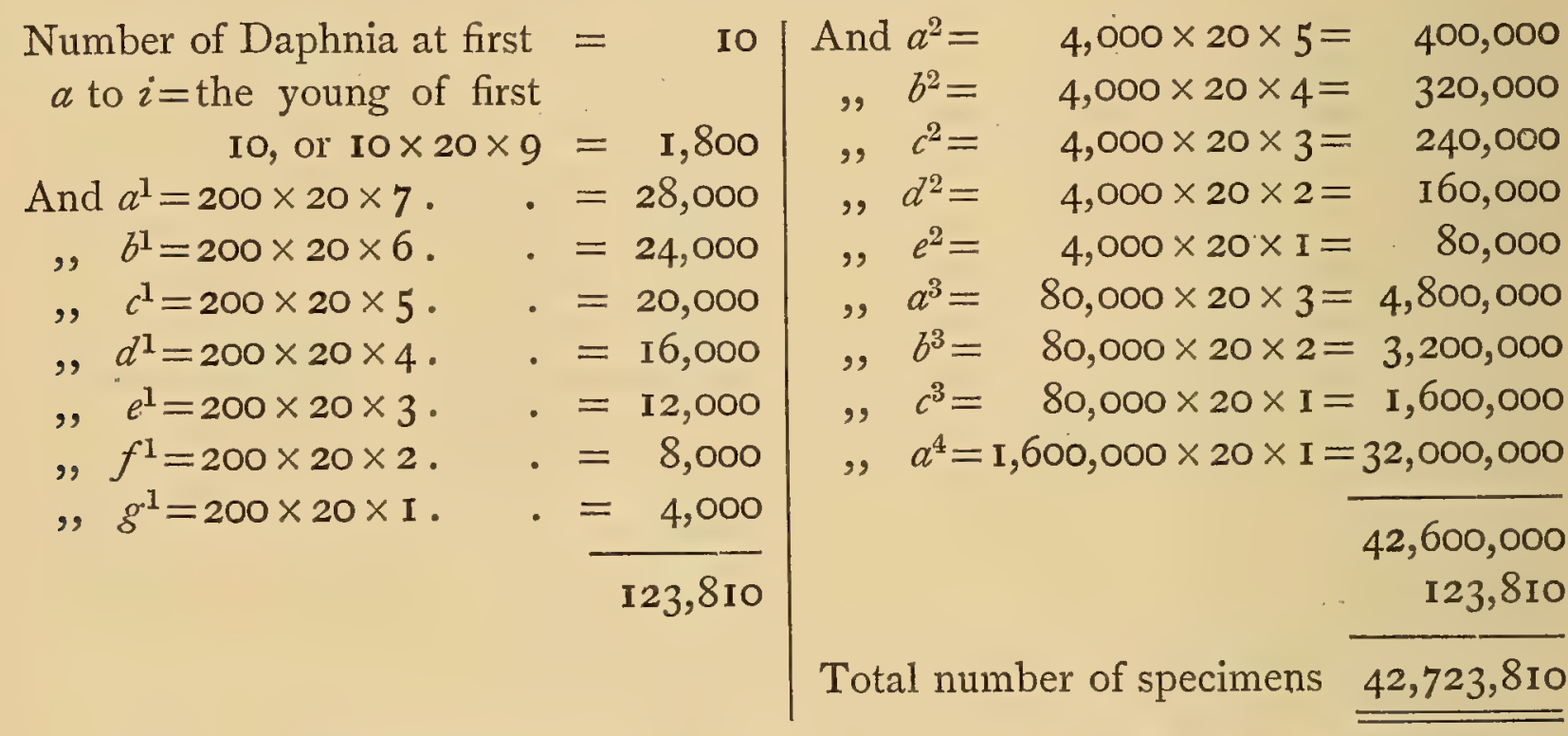

The above is a slightly extended and modified copy of a table prepared by my son, Mr. Andrew Scott.

Though in the preceding remarks Daphnia pulex only has been considered, there are many others of the entomostraca equally prolific. But though the fecundity of micro-crustacea were considerably less than that shown, it would still be sufficient to fill up in a short time even an extensive blank that some destructive but temporary cause may have produced.

"Full nature swarms with life; one wondrous mass."

COWPER.

The natural habitat of the freshwater entomostraca is the still water of lakes, ponds, ditches, and those parts of streams or rivers where the current is slow and cumbered with waterplants: entomostraca may be found in all such places. Running water is not their natural resort, and when they happen to be in such a situation they are usually there against their will. Nevertheless an exodus of Copepoda such as that observed by Mr. Tullis is not unknown to those who 
have made a study of the little creatures. The cause that leads to such an exodus - it can scarcely be called destruction - taking place may not always be obvious, but in the majority of cases it is probably brought about by a sudden change of temperature, when the weather from being mild and warm becomes cold and ungenial, or when there happens to be a prolonged and intense cold such as has been experienced during the past winter. Under such conditions, free-swimming entomostraca-and it is only such that seem to be much affected-appear to become temporarily enfeebled; and those of them which happen to be in the neighbourhood of that part of the loch where the river takes its rise are thus less able to contend against the currents, which gradually increase in force the nearer the overflow or excess of water of the loch approaches the opening of the river, and so, being overpowered, are carried away with the stream. This is the more likely to take place in a loch where the water is comparatively shallow, as it will in that case be more readily influenced by atmospheric changes.

I have records of several instances where entomostraca have been observed in unlooked-for places. At Rothesay, in the spring of I 887 , these little "beasts" occurred in considerable numbers in the water supplied to the town for domestic purposes. They were collected by fixing a piece of thick flannel cloth on the water-tap; and after allowing the water to run through the cloth for an hour or two, it was taken off and washed in water in a glass tumbler-myriads of the creatures could then be seen swimming about in the water. In the spring of I 888 a friend sent me a number of entomostraca from Campbelltown that had been collected in the same way. Last year I happened to be at Barra during the month of May, and the weather for part of the time was cold and unpleasant. One day my attention was directed to the presence of numerous "beasts" in the water that was supplied for domestic use from a reservoir behind the village of Castlebay. These "beasts" proved to be Diaptomus serricornis and one or two Cyclops. "Beasts" that had been obtained in the water supplied to Edinburgh have likewise on one or two occasions been brought to me, and they also turned out to be 'water-fleas,'-Cyclops viridis, if I remember right. It 
may be of interest to mention that on several occasions I have thoroughly examined the Edinburgh water in the same way as was done at Rothesay in I 887 , and have rarely been rewarded with even a single specimen of "beasts" of any kind: the water supplied for domestic purposes to Edinburgh appears to be so carefully and efficiently filtered that organisms of any kind rarely find their way to the water-tap.

The following reference to an example of an opposite kind to those given above may be of interest. In June I 889 an examination was made of Loch Coulter: it is from this loch that the water-supply for the famous Howietoun fishhatcheries and nurseries is obtained. The weather was mild and warm at the time the loch was examined, and the water was teeming with entomostraca. Being desirous to find out if any of the little creatures were being carried down by the stream which flows out of the loch and supplies the hatcheries and nurseries, a tow-net was fixed in the bed of the stream a short distance up from where the water is led off into the nurseries, and so arranged that most of the water in the stream had to pass through it. The net was placed in position at 7.I 5 P.M. on the I 3 th, and removed at 8.I 5 A.M. next day. Although the water had thus been allowed to flow continuously through the tow-net for thirteen hours, only a few Cyclops, Gammarus, Ostracods, and the larvæ of insects were captured. With the exception of the few Cyclops, which were the only organisms that were likely to have been brought down from the loch, all the specimens captured appeared to be stragglers from places in the vicinity of the position where the net had been fixed. (See "Eighth Annual Report of the Fishery Board for Scotland," p. 338, I 890.)

I may mention that $\mathrm{Mr}$. Tullis very kindly sent me two bottles containing water-fleas from the River Leven: one was a sample of those first obtained by him from the strainers in the early part of the year; the other contained several living specimens recently collected. Though the specimens in the first bottle were somewhat decomposed owing to the length of time since they had been gathered, I yet had no difficulty in identifying most of the species. The following are the names of them:-Diaptomus gracilis, G. O. Sars, Cyclops strenuus, Fischer, Cyclops vicinis, Uljanin, and Cyclops 
serrulatus, Fischer ; they are all free-swimming species, which, as I have already pointed out, are more liable to be affected by changes of temperature than those that lodge among the aquatic plants or in the mud at the bottom and sides of the loch.

I may also mention, in concluding these remarks, that a short time ago, when examining a small gathering of entomostraca collected in Loch Leven in June 1890 , but somehow overlooked till now, two rare species of Copepoda were obtained. One of these, called Canthocamptus Schmeilii, and which is frequent in the gathering, was described by Mrazek in I893, and is new to Britain; the other is Canthocamptus minutus, Claus, and is also an addition to the British fauna. My friend D. J. Scourfield of Leytonstone, Essex, tells me in a letter recently received from him that he obtained Canthocamptus minutus, Claus, last year in two different localities, viz. one at Wanstead Park, and another in the Isle of Wight; and though no record of its occurrence has yet been published, to him belongs the credit of its discovery in the British Islands. The fact of its occurrence in such widely distant localities as Loch Leven and the Isle of Wight is an indication, I think, that its distribution in our islands may be really more general than at present it seems to be. Descriptions and drawings of the two species are being prepared for publication. 

6

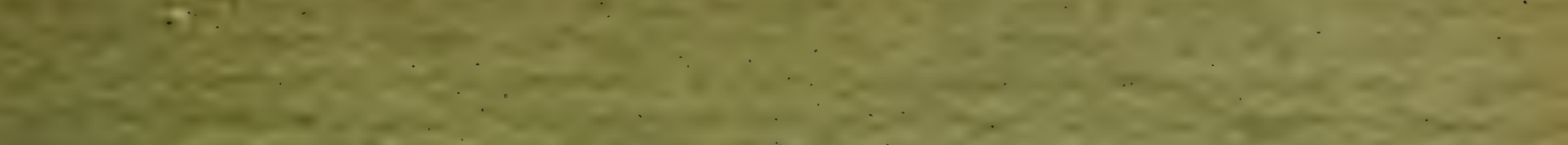

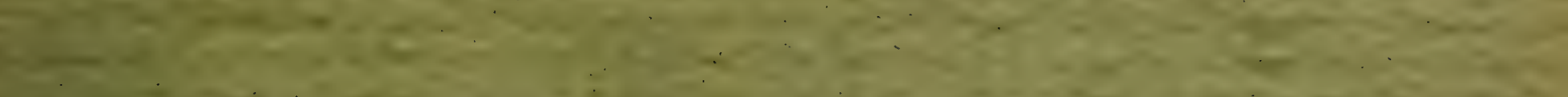

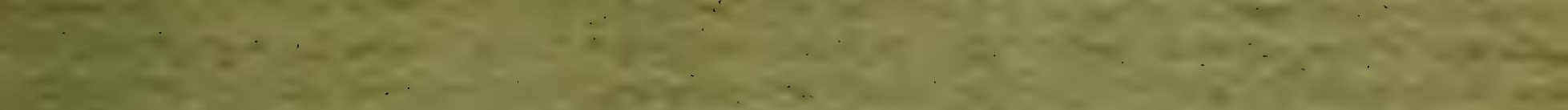

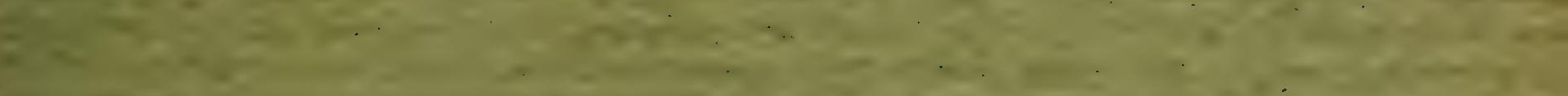

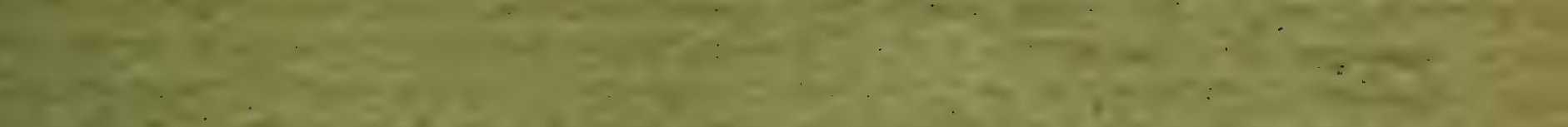

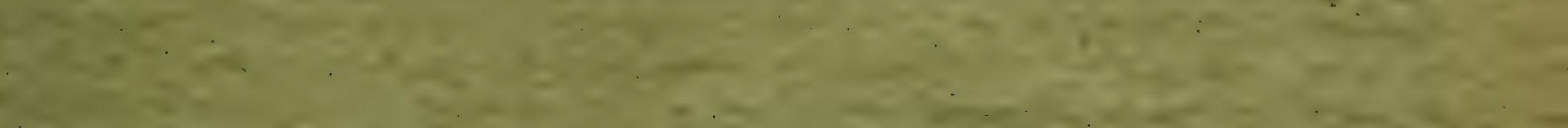

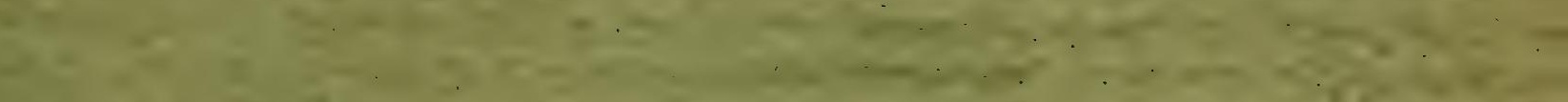

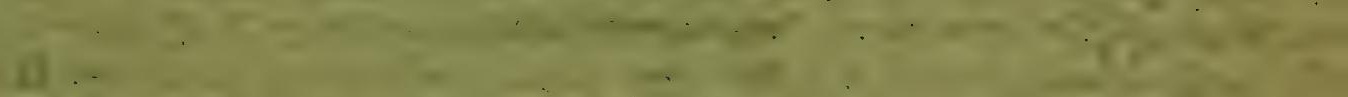
a.

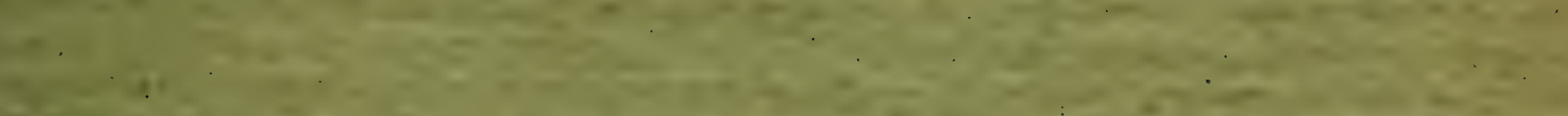

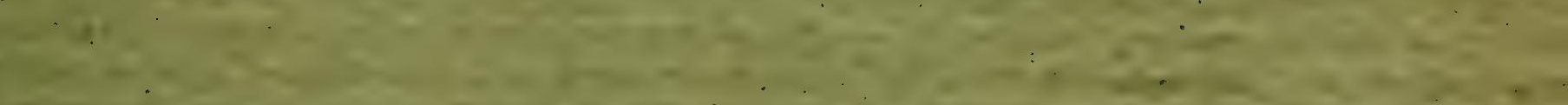

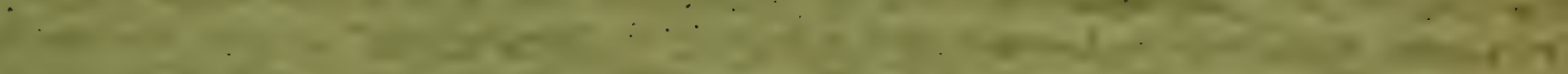

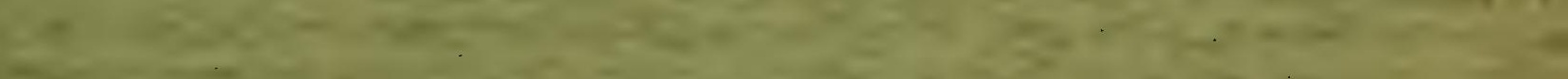

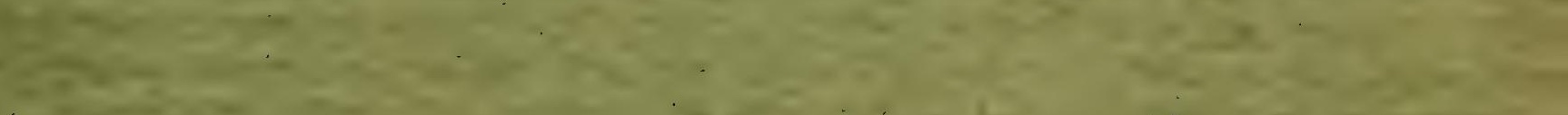

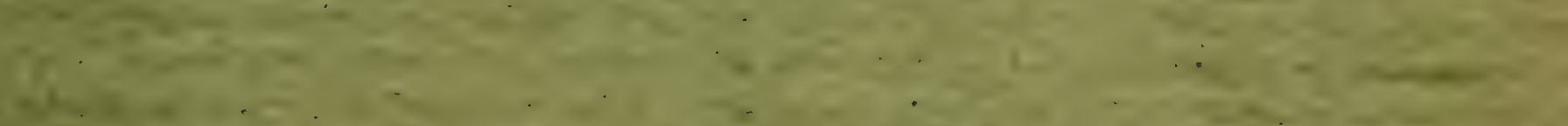

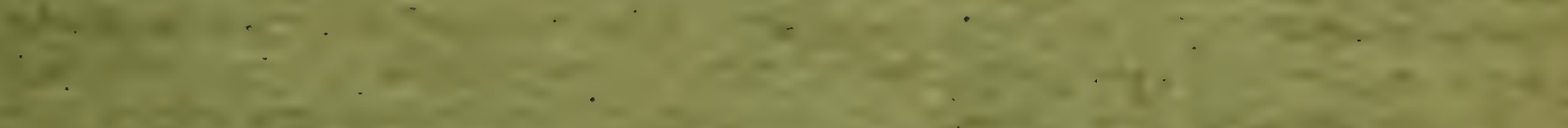

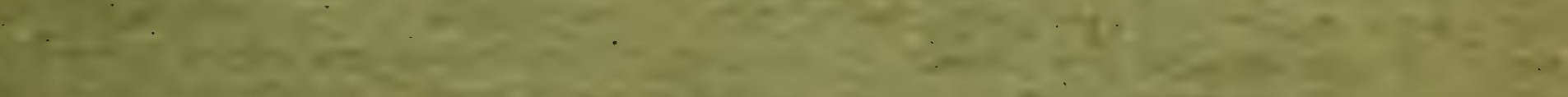

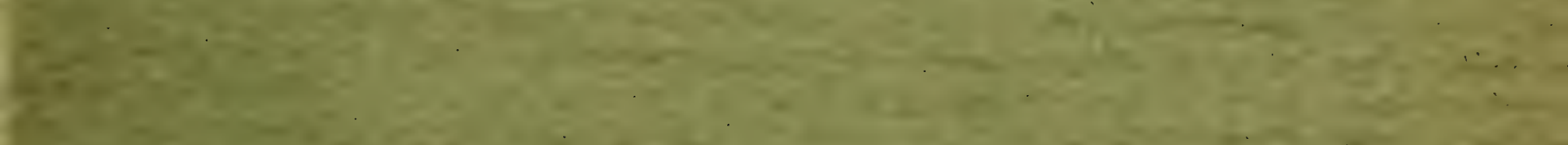

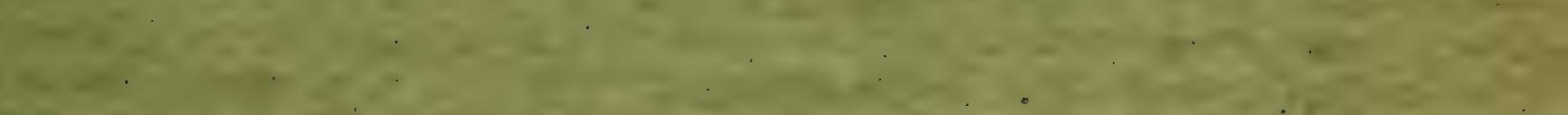

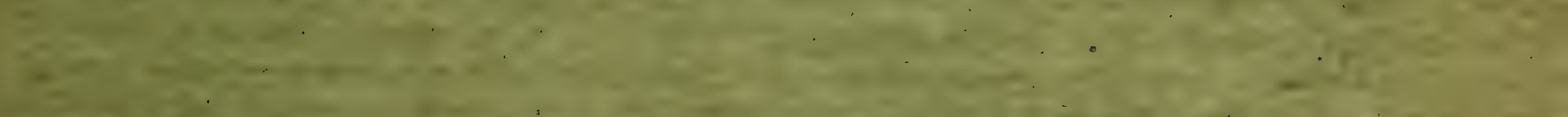
(1) 
[Reprinted from "The Annals of Scottish Natural History," October 1895.]

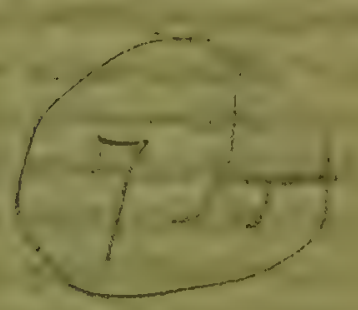

NOTES ON SOME RARE FRESHWATER AND MARINE COPEPODA FROM SCOTLAND

By THOMAS SCOTT, F.L.S., and ANDREW SCOTT 


\section{The Annals}

\section{OF \\ Scottish Natural History}

A QUARTERLY MAGAZINE WITH WHICH IS INCORPORATED

"The Scottigh Jaturalist"

$$
\text { EDITED BY }
$$

I. A. HARVIE-BROIVN, F.R.S.E., F.Z.S. Member of the British Ornithologists' Union

TAMES W. H. TRAIL, M.A., M.D., F.R.S., F.L.S.

Professor of Botany in the University of Aberdeen

$$
\text { and }
$$

WILLIAM EAGLE CLARKE, F.L.S., MEM. BRIT. ORN. UNION Natural History Department, Museum of Science and Art, Edinburgh

EDINBURGH : DAVID DOUGLAS, CASTLE STREET 



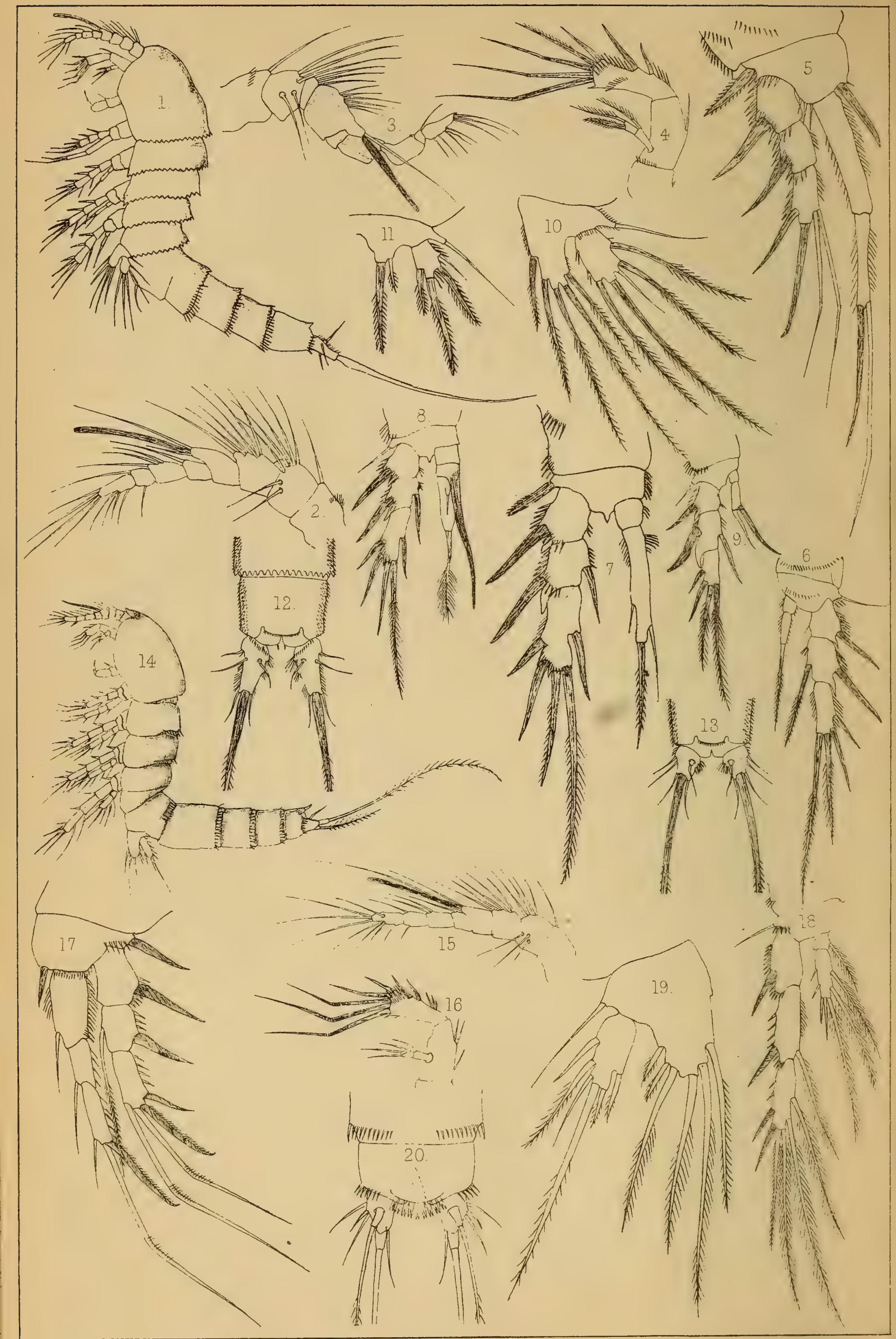


[Reprinted from "The Annals of Scottish Natural History," October I 895.]

NOTES ON SOME RARE FRESHWATER AND MARINE COPEPODA FROM SCOTLAND.

\author{
By Thomas Scott, F.L.S., \\ Naturalist to the Fishery Board for Scotland, \\ and ANDREW SCOTT, \\ Fisheries Assistant, University College, Liverpool.
}

\title{
Plate IV.
}

ONE of the Authors of the following Notes, in a paper recently published in the "Annals of Scottish Natural History," refers very briefly to the recent discovery of two freshwater Copepods in Loch Leven, Kinross-shire, that have not previously been recorded as members of the British fauna. Though both species have been described in continental works, we do not know of any description of them in English, and have therefore prepared, and now submit, the following descriptions, with illustrative drawings, based upon specimens obtained in Loch Leven. We also take this opportunity to record some observations on the habits 
of two marine Copepods that have been added to the British fauna within the last year or two.

We first describe the species from Loch Leven.

Canthocamptus schmeilit, Mrazek, Plate IV. Figs. I-I 3.

I893. Canthocamptus schmeilii, Mrazek, "Beitrag zur Kenntniss der Harpacticidenfauna des Süsswassers" ("Zoologische Jahrbücher," Siebenter Band), p. I 6, 'Taf. VII. Figs. I 07 -I I 7 .

Description.-Female.-Length $.8 \mathrm{~mm}$. ( $\frac{1}{31}$ of an inch). The cephalothoracic segments serrated on the posterior margins both dorsally and laterally; the abdominal segments with the posterior edges serrated only on the dorsal aspect, while laterally they are fringed with setæ; the whole integument of the thorax and abdomen covered with minute hairs. The antennules (anterior antennæ) somewhat shorter than the first cephalothoracic segment, and eightjointed: the fifth and seventh joints are shorter than any of the others, the seventh only about half the length of the end joint. The proportional lengths of all the joints are shown by the annexed formula :-

\begin{tabular}{lcccccccc} 
Proportional lengths of the Joints & I 3 & I 3 & I 4 & I 2 & 8 & I I & 6 & I 2 \\
\cline { 2 - 8 } Number of the Joints & I & 2 & 3 & 4 & 5 & 6 & 7 & 8
\end{tabular} .

The secondary branches of the antennæ (posterior antennæ) are two-jointed: the first joint bears one seta, but the end joint is furnished with two terminal setæ-one slender, and one stout and spiniform (Fig. 4). The mandible-palp consists of a single very small joint and bears two terminal hairs. The inner branches of the first pair of swimming feet are considerably longer than the outer branches, they are two-jointed, the first joint reaches to about the end of the outer branches, the second is equal to about threefourths of the length of the first joint, and is also more slender and provided with two apical setæ-one very long, the other about half the length; the marginal spines of the outer branches are moderately stout and elongate; a moderately stout spine springs from the interior distal angle of the second basal joint, and extends to about the middle of the first joint of the inner branches (Fig. 5). The inner branches of the second, third, and fourth pairs are also twojointed and much shorter than the outer branches, and the first joint of all the inner branches of these three pairs is considerably shorter than the second joint; in the fourth pair the inner branches are furnished with' only one seta, which is terminal and spiniform (Fig. 6). The secondary joint and the inner produced part of the basal joint of the fifth pair are subquadrangular in outline: the secondary joint does not extend much beyond the end of the basal 
joint, and is provided with five setæ, four at the apex and one on the outer margin, - the middle seta is short, but the others are elongate and plumose; the inner produced part of the basal joint is also furnished with five setæ, all of which are plumose and arranged as shown by the drawing (Fig. Io). Caudal stylets narrow, subconical, and equal to about three-fourths the length of the last abdominal segment: they each bear a long spiniform terminal seta and several very small hairs (Fig. I 2).

Male. - Fig. 3 in the plate is a drawing of one of the male antennules, which are strongly hinged, as shown. In the male the second pair of swimming feet have the inner branches slender and two-jointed: the second is of considerable length, and reaches to nearly the end of the outer branches (Fig. 7). The inner branches of the third pair are three-jointed, the first two joints are short, but the second joint has the inner angle produced into a long spiniform appendage that extends considerably beyond the end of the third joint (Fig. 8). In the fourth pair the inner branches are two-jointed, and scarcely longer than the first joint of the outer branches: the two terminal setæ are bent inwards at an obtuse angle, which seems to be the normal position of them; the second joint in the outer branches is not only armed with a stout, elongate, and somewhat curved spine, but has also the exterior distal angle produced into a strong, conical, and slightly bent tooth-like process (Fig. 9). The male fifth pair are much smaller than those of the female: the basal joint is only slightly produced interiorly, and bears two setæ, one moderately long and stout and one very short; the secondary joint is furnished with three moderately stout setæ (Fig. I I). The caudal stylets are considerably shorter than those of the female, and the terminal setæ are more elongate (Fig. I3).

Habitat.-Amongst mud by the shore at the west end of Loch Leven, Kinross-shire; collected, June I 890.

REMARKS. - Canthocamptus schmeilii was described and figured by Dr. Mrazek in the "Zoologische Jahrbücher" in May I893, from specimens obtained by him in two different localities in the neighbourhood of Pribram, in Bohemia, in I89I-92. The species is quite distinct and easily recognised. The peculiar angularity of the specimens is so characteristic that they can be identified with certainty with an ordinary hand-lens. The species differs from its nearest allies by the elongate form of the two-jointed inner branches of the first pair of swimming feet. The female also differs further in the form of the fifth pair of feet and of the caudal stylets, and the male in the structure of the inner branches of the second, third, and fourth pairs of feet. Dr. Mrazek in his description appears to have inadvertently taken the fourth pair of the male for the second, and he also represents the inner produced part of the basal joint of the male fifth pair as furnished with three setæe instead of two, but 
otherwise his description and figures agree very well with the Loch Leven specimens. There can be no doubt that our drawings of the second, third, and fourth swimming feet in the male are correct, and represent them in their proper sequence." The difference in the number of hairs in the fifth pair of the male may be due to local variation.

Loch Leven, so far as we know, is as yet the only British locality where Canthocamptus schmeilii has been obtained; and though collected in 1890 , the gathering in which the specimens occur was somehow overlooked until the present year.

\section{Canthocamptus minutus, Claus, Plate IV. Figs. I 4-20.}

I863. Canthocamptus minutus, Claus, "Freileb. Copep.," p. I i2, Taf. XII. Figs. I-3, Taf. XIII. Fig. I.

I893. Canthocamptus minutus, Schmeil, "Deutschlands freileb. Sussw. Copep.," p. 3I, Taf. II. Figs. I-I4.

Description.-Female.-Length $.6 \mathrm{~mm}$. ( $\frac{1}{42}$ of an inch). Body slender, rostrum small. Antennules moderately stout, shorter than the first cephalothoracic segment, eight-jointed; the fifth joint being shorter than any of the others. The proportional lengths of the various joints are as follow :-

Proportional lengths of the Joints

Number of the Joints

\begin{tabular}{cccccccc} 
I0 & 10 & 9 & 8 & 5 & 9 & 8 & 10 \\
\hline I & 2 & 3 & 4 & 5 & 6 & 7 & 8
\end{tabular}

The secondary branches of the antennæ are small and two-jointed, the end joint is shorter than the other, the first joint bears one and the end joint three setæ (Fig. I6), the mandible-palp is very small and one-jointed. The inner branches of the first, second, and third pairs of swimming feet are three-jointed. The inner branches of the first pair are rather longer than the outer branches, the first and third joints are nearly equal in length and rather longer than the middle joint, the three joints are each furnished with a small seta near the distal end of the inner margin, and the end joint is also armed with two setæ-one long and slender and one short and spiniform; a moderately long plumose hair springs from the middle of the inner margin of the second joint of the outer branches, and the exterior marginal spines of the outer branches are stout and elongate (Fig. I7). In the second and third pairs the inner branches are considerably shorter than the outer branches. In the fourth pair the inner branches are two-jointed, and only extend to a little beyond the end of the first joint of the outer branches (Fig. 18). The fifth pair has the inner produced portion of the basal joint broadly but irregularly rounded and provided with six setæ: the setæ are divided into two groups of three setæ each, and with a comparatively wide space between each group; those of the 
inner group are all elongate and plumose, the middle one being rather longer than the other two; the outer group consists of one elongate and two very short setæ. The secondary joint is narrow, subcylindrical, and extends somewhat beyond the end of the basal joint; it also bears six setæ-three on the distal half of the outer margin, one small seta on the inner margin, and two apical setæ, one of which is long and stout and one very short (Fig. I9). The caudal stylets are short, and the anal operculum carries a fringe of short bifid spines on the posterior margin (Fig. 20).

Habitat.-Loch Leven, Kinross-shire, along with Canthocamptus schmeilii, but not nearly so common.

Remarks. - This is a more typical Canthocamptus than the one previously described, and may be distinguished from other species of the same group by the structure of the first pair of swimming feet, as also by the bifid spines on the anal operculum, which appear to be peculiar to this species.

Loch Leven is, so far, the only Scotch locality where Canthocamptus minutus has been obtained; but since its discovery in Loch Leven we have obtained information of its occurrence in several localities in England. Mr. D. J. Scourfield obtained it last year at Wanstead Park and in the Isle of Wight, and this year in Wales; while one of the authors of the present memoir (Mr. A. Scott) has recently discovered it in a marshy drain near Leasowe Lighthouse, Cheshire.

The genus Canthocamptus, as described by several authors, seems to us to be too inclusive, and to contain forms so diverse in structure that a revision of the genus will ere long become necessary in order to facilitate the study of the various divergent species of which it is composed. We need only refer to the following among other diversities of structure to show how heterogeneous are the forms at present included in this genus. Thus, for example, in some species the secondary branches of the antennæ (posterior antennæ) are one-jointed, and in others two-jointed. In some species again the inner branches of the first pair of swimming feet are composed of two equal or nearly equal joints, while in others they are three-jointed: these inner branches are in various species either equal in length to, or considerably longer than, the outer branches. Moreover, in some species the inner branches of all the first four pairs of swimming feet are two-jointed or three-jointed, while in some the inner branches of the first pair or the first two or three pairs are three-jointed, and of the other pairs two-jointed. In I 880 Dr. Brady established the genus Attheyella for one or two aberrant forms of the Canthocamptince; but objection is taken by Continental authors to this genus, who regard it as synonymous with Canthocamptus. But Canthocamptus as it at present stands is not, as we have indicated, a very satisfactory genus. 
The following are the notes on two species of Marine Copepods :-

\section{Dermatomyzon gibberum, $T$. and $A$. Scott.}

I894. Dermatomyzon gibberum, T. and A. Scott, "Ann. and Mag. Nat. Hist." (vi.), vol. xii. p. I44, Plate IX. Figs. I o-I 4.

This species was described from a single specimen obtained in a tow-net gathering collected in the vicinity of the Bass Rock, Firth of Forth. Its structure seemed to indicate parasitic habits, but there was nothing at the time of its discovery to show what animal formed its host. In the early part of this year one of the authors, while superintending some line-fishing experiments in the Firth of Forth, collected a number of specimens of the common Starfish (Asterias rubens) that were brought up attached to the hooks. These starfishes were subsequently washed in a bottle containing methylated spirit, and the result was that nearly one hundred specimens of Dermatomyzon gibbernm were obtained, most of which, however, appeared to be immature, and only a few of them carried ovisacs. A short time after the capture of these specimens in the Firth of Forth, several examples of this starfish obtained in Liverpool Bay were examined, and these also, on being washed in methylated spirit, yielded a number of specimens of Dermatomyzon gibberum; but in this case, though the specimens were not so numerous as those taken in the Forth, a greater proportion of them were mature and carried ova. From these and other investigations made by us, we are inclined to think that this Copepod is probably parasitic on Asterias mubens, but whether it is confined to that starfish we are as yet unable to say.

The colour of the animal is brick-red, with a few whitish streaks, so that in the fresh state Dermatomyzon gibberum is not unlike the young of the mollusc Pectunculus glycimeris. The colour, however, soon disappears when the animal is put into methylated spirit.

\section{Lichomolgus hirsutipes, T. Scott.}

I 893. Lichomolgus hirsutipes, T. Scott, "Eleventh Annual Report of the Fishery Board for Scotland," part iii. p. 286, Plate IV. Figs. I-I 2.

This is a comparatively large Copepod, being in some cases at least $\frac{1}{20}$ of an inch in length. It was first obtained among some trawled material collected in the Firth of Forth at the "Rath Ground," a shallow bank situated a short distance north of the Bass Rock. Lichomolgus hirsutipes, like the Dermatomyzon just described, appears to be more or less parasitic in its habits, but at the time of its discovery we did not know of any animal with which it was likely to be associated. During the same line-fishing experiments that are referred to in the notes on Dematomyzon gibberum, various 
other things besides the starfishes mentioned were brought up on the hooks, and among others were a few large Annelids, probably belonging to a species of Sabella. These Annelids form tubes of fine mud, which is mixed with and held together by a glutinous substance secreted by the animal. These tubes were found to be invariably more or less covered by a growth of Alcyonium. In some instances these tubes contained the living Annelid, but several of them were empty. It was only when fishing in moderately deep water-i 5 to 20 fathoms or so- that these large worm-tubes were obtained. Though the Alcyonium had usually spread itself over a large portion of the tubes, the upper end-the end that corresponded with the head of the worm-was generally free from the enveloping Zoophyte. White specks were observed on nearly all the specimens, and were sparingly scattered over the upper part of the tube. These white specks all proved to be Copepods, which, when examined under the microscope, were without exception found to belong to the species mentioned above, viz. Lichomolozes hirsutipes.

Though we have not yet been able to ascertain if Lichomolgus hirsutipes is only to be obtained in the Firth of Forth associated with this Annelid, or whether it is associated with the same Annelid elsewhere in the British seas, the facts mentioned seem to indicate an association between the Copepod and Annelid not altogether accidental, and, if so, they may probably occur associated in the same manner in other localities where the conditions are suitable.

\section{Description of Plate IV.}

\section{Canthocamptus schmeilii, Mrazek.}

Fig. I. Female, lateral view

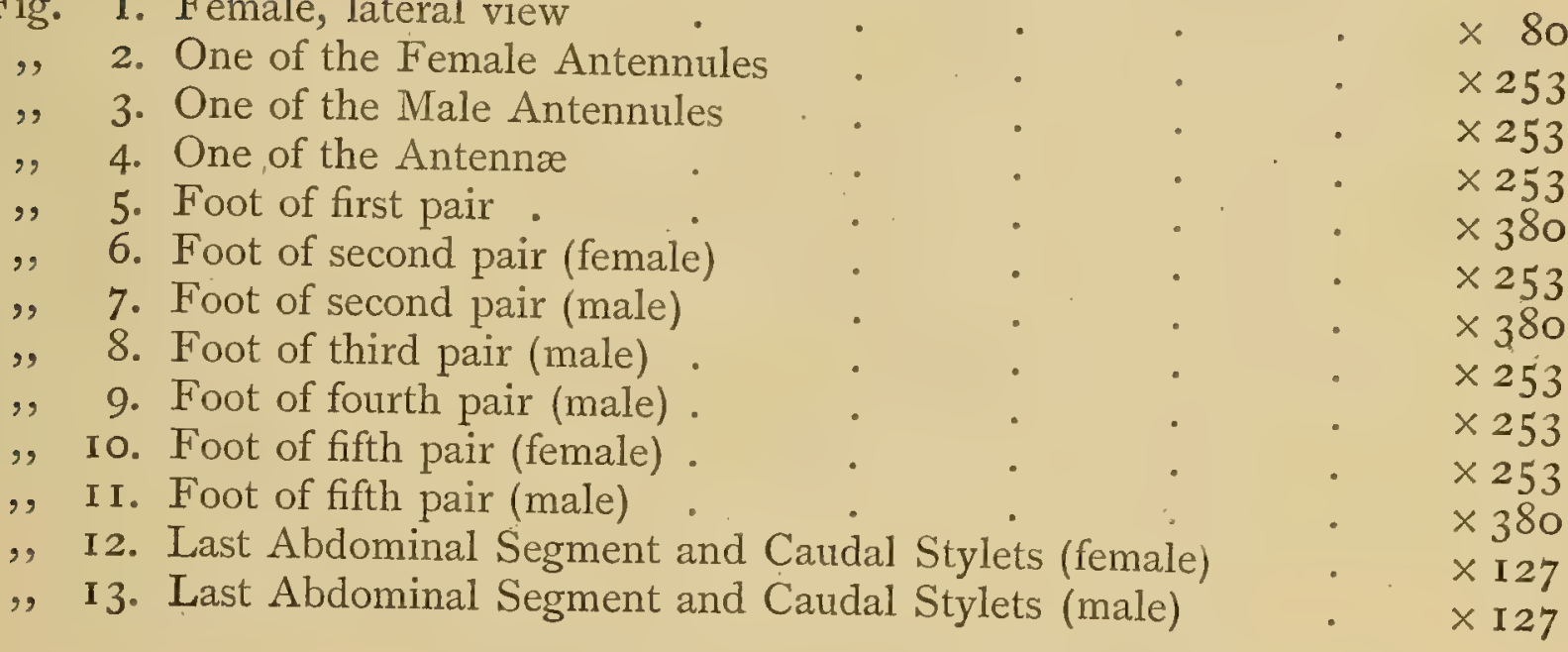

Canthocamptus minutus, Claus.

2. I4. Female, lateral view

, I 5. One of the Antennules

, I6. One of the Antennæ

I7. Foot of first pair .

I8. Foot of fourth pair

I9. Foot of fifth pair .

20. Last Abdominal Segment and Caudal Stylets 




XIII. Report on a Collection of Marine Dredgings and other Natural History Materials made on the West Coast of Scotland by the late George Brook, F.L.S. By Thonas Scott, F.L.S., Mem. Soc. Zool. de France, Naturalist to the Fishery Board for Scotland. [Plate V.]

(Read 15th January 1896.)

On the 4th of October last year (1894) my friend, Mr F. G. Binnie, formerly assistant to the late Mr George Brook, wrote to me concerning a collection of marine dredgings and other material that had been made by $\mathrm{Mr}$ Brook at various places on the West Coast of Scotland. Mr Binnie, with consent of Dr Woodhead, one of Mr Brook's executors, suggested that I might undertake the examination of the material, and, if found sufficiently interesting, prepare a report on the results of the examination of it. In the letter 
referred to, Mr Binnie says, "Amongst the material that belonged to the late $\mathrm{Mr}$ George Brook there is a set of dredgings from the West Coast of Scotland, collected by him while cruising in his father's steam yacht 'Dotterel.' In the collection there are a good many Crustacea, some other invertebrates, and a few fishes. We are most anxious that the material should be worked up and not wasted, so that Mr Brook may get some credit, even though it be posthumous."

The collection soon afterwards was handed over to me, and, as Mr Binnie anticipated, the examination of it has proved to be interesting. A record of the results of the examination is embodied in the following report, which I now desire to submit to the Royal Physical Society of Edinburgh.

\section{General Description of the Collection.}

Before proceeding to give a record of the various organisms contained in the collection, the following brief description of the collection itself may be of interest. The material was collected by means of the beam-trawl, the dredge, and the tow-net; tow-net gatherings, however, formed but a small part of the collection. The material forming the collection was contained in upwards of two hundred bottles and tubes of various kinds, but they were chiefly of small size. It was collected for the most part during the months of July, August, and September 1887, but it also included one or two small gatherings made in 1886 and in 1888. Moreover, it was collected at various localities,-as, for example, in Loch Fyne; in the vicinity of the Island of Mull, and in Loch Linnhe; off Ardnamurchan; in the Gairloch; in the vicinity of the Island of Skye; and at one or two places in the Outer Hebrides. The material was also collected at various depths, from close inshore down to 100 fathoms. The contents of a few of the bottles were somewhat decomposed, owing to the partial evaporation of the spirit, 
and in one or two instances the labels were scarcely legible, but otherwise the collection was in fairly good preservation. Greater attention appears to have been given to the collection and preservation of the larger invertebrates rather than to the more minute kinds; nevertheless, by carefully overhauling the larger forms,-washing off and collecting the mud and sand adhering to them-and by a careful examination of the finer matter in the bottom of some of the bottles, a considerable number of micro-Invertebrata have also been obtained, as will be seen by referring to the Table of Distribution:

The Vertebrata, which are represented by the fishes, are few in number. The Invertebrata consist chiefly of Mollusca, Crustacea, Echinodermata, and Foraminifera; a few other groups, as the Tunicata, Annelida, and Polyzoa, are also represented, but only by a small number of species. About 344 species in all have been more or less satisfactorily determined, but as a considerable number of them are moderately common and generally distributed, I have not considered it necessary to refer to these common forms in the body of the report, but have included thern in the Classified List and Table of Distribution at the end, so that only the rarer species will be specially noticed.

\section{Detalled Description of the Collection.}

In proceeding to describe more particularly the various groups of organisms represented in the collection, as well as the rarer and more interesting species, it will be better to do so according to some recognised method. I propose, therefore, in the general arrangement of the various groups, to adopt the classification used by Professor Nicholson in his "Manual of Zoology," but beginning with the higher forms first. Then as to the classification of each of the groups, and especially of those that are more numerously represented in the collection, I have endeavoured, 
as far as possible, to follow the arrangement and nomenclature of recent and authoritative works on each particular group.

The fishes are arranged here in the order in which they occur in the late Mr Day's work on British Fishes. The Mollusca are all arranged and named according to part iv. of Dr Norman's Catalogues ("Museum Normanianum"). In the arrangement of the Crustacea, I have followed part iii. of Dr Norman's Catalogues for the "higher" Crustacea, and Professor Henderson's “Decapod and Schizopod Crustacea of the Clyde" has also been consulted; the Amphipoda are arranged and named in accordance with vol. i. of Professor G. O. Sars" "Crustacea of Norway," recently published; Dr Brady's "Monograph of the British Copepoda" has been followed in the arrangement of that group; while in the arrangement of the Ostracoda the Monograph by Drs Brady and Norman has been consulted. Professor Jeffrey Bell's recently published "Catalogue of the British Echinodermata" is followed as to the Starfishes and Echini; while with regard to the Foraminifera the arrangement and nomenclature are those of part viii. of Dr Norman's Catalogues.

A considerable amount of time and care have been bestowed on the examination of the material, and the identification of the various organisms contained in it, and I desire in connection therewith to acknowledge my indebtedness to Mr William Eagle Clarke, F.L.S., of the Museum of Science and Art, Edinburgh, for identifying the fishes in the collection; to Dr G. W. Chaster, of Southport, Lancashire, for revising the list of Foraminifera, and identifying the more obscure and difficult species; and to Rev. T. R. R. Stebbing and Professor W. A. Herdman, F.R.S., for assistance with other groups; while my son has prepared drawings of what appears to be an undescribed Amphipod.

The following is a tabular view of the chief groups represented in the collection, their principal subdivisions, and the number of species belonging to each:- 


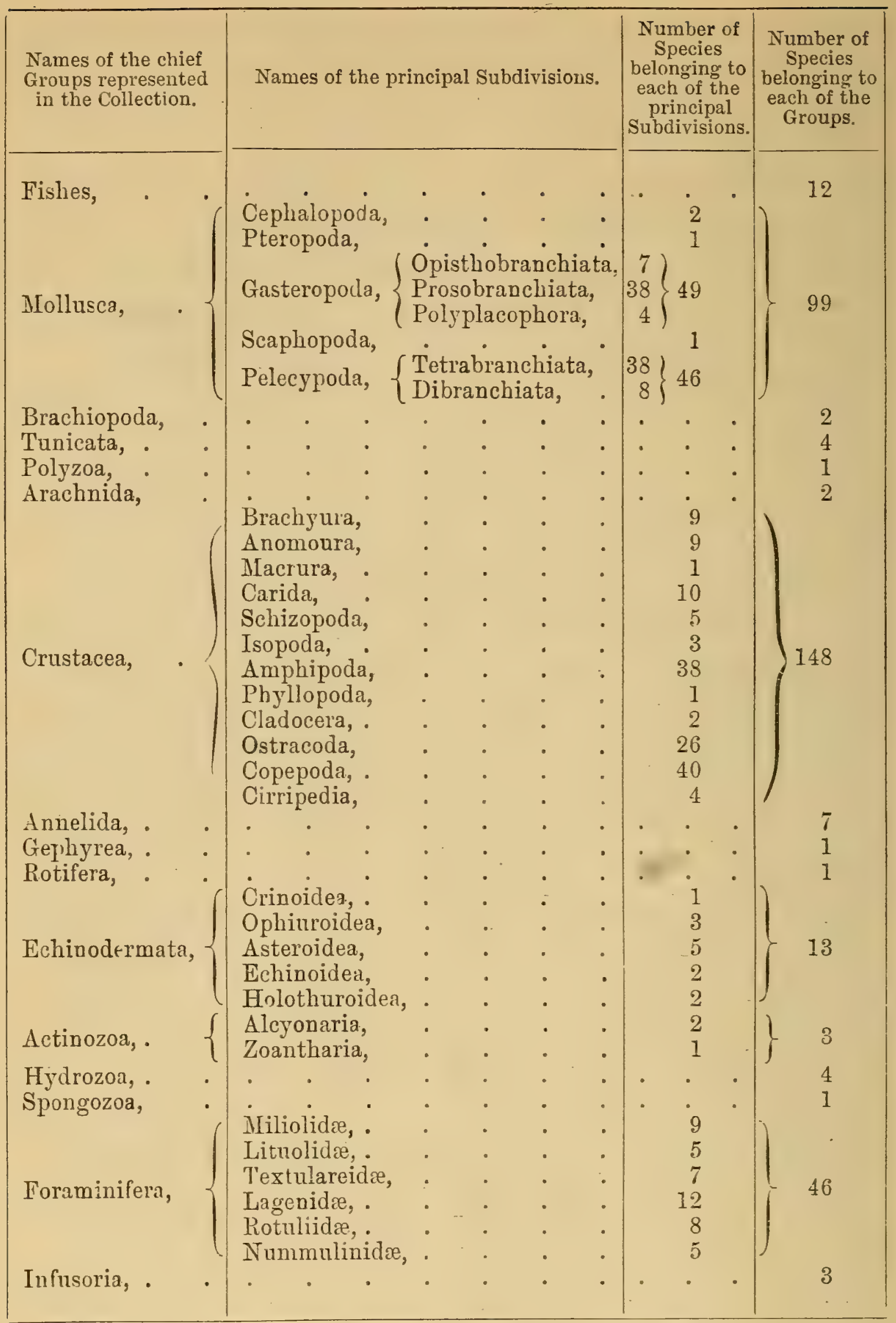

\section{FISHES.}

The fishes that fall to be noticerl in this report are mostly of small size, and with few exceptions are all of more or less frequent occurrence around our shores. They are-Trachinus vipera, Gobius Ruthensparri and Gobius minutus, Callionymus 
Marine Dredgings and other Natural History Materials. 171

lyra, Lepadogaster Decandolii and Lepadogaster bimaculatus, Motella cimbria, Hippoglossoides limandoides, Rhombus (Zeugopterus) norvegicus, Pleuronectes cynoglossus, Zengopterus punctatus, and Neroplius cequoreus.

Of these, perhaps the rarest and most interesting species is Rhombus (Zeugopterus) norvegicus, Günther. This is one of the more recent additions to the British fish-fauna. There were two specimens of this species in the collection, and both were of small size. One of the specimens was from Loch Bracadale, Skye, and measured 1.87 inch $(47.5 \mathrm{~mm}$.); the other was obtained in the Gairloch, West Ross-shire, and measured 2.3 inches $(58.0 \mathrm{~mm}$.). Rhombus norvegicus is described and figured by Dr Günther in vol. xv. of the Proceedings of the Royal Society of Edinburgh. There is also an interesting note on the same species, accompanied by a very good figure of an East Coast specimen, by Professor M'Intosh, St Andrews, in part iii. of the Twelfth Annual Report of the Fishery Board for Scotland.

\section{MOLLUSCA.}

Of the 96 species of Mollusca obtained in the collection, only a small number are of special interest; the others are all more or less common and generally distributed. A large proportion of the species are also represented by only one, or at most by a few specimens each; while, on the other hand, and in contrast to these, there are a few species that are represented by a considerable number of specimens. For example, Trochus zizyphinus (or Zizyphinus zizyphinus, as it is named in the Table of Distribution) was represented by at least five dozen specimens, most of them, however, young. Lima elliptica is another species that was numerously represented; so also were Pecten pes-lutrce (Pecten septemradiatus), Nucula nucleus, Leda minuta, Corbula gibba, and Astarte sulcata, but these were exceptional cases.

Among the Mollusca contained in the collection that appear to be of more or less interest, mention may be made of the following:-Among univalves, Phitine scabra, a small but pretty shell, that has the outside covered with microscopic sculpture resembling a succession of chain-links; Murex erinaceus, a somewhat rare Scottish shell, and seldom obtained living; Trophon barvicensis, a rare and pretty 
univalve. Modiolaria nigra (the corded mussel) is another comparatively rare shell, aduli specimens especially being uncommon. This species is represented in the collection by three or four young shells. Cuspidaria (Neæra) is an interesting and peculiar genus of shells much sought after by collectors, and is represented in the collection by one species, Cuspidaria cuspidata. Pandora incequivalvis, Lyonsia norvegica, and Poromya granulata are also represented in the collection, and may be described as rare shells; for though the distribution of Pandora extends from the Channel Islands to Shetland, it is not so common as its distribution is wide; the same may be said of Lyonsia and Poromya. Lyonsia appears, however, to be more generally distributed, and of more frequent occurrence than either of the other two.

\section{BRACHIOPODA.}

Of Brachiopoda only two species occur in the collection, namely, Terebratulina caput-serpentis and Crania anomala.

\section{CRUSTACEA.}

The Crustacea are largely represented in the collection, no fewer than 148 different kinds having been identified,including species belonging to nearly all the important subdivisions. Though the so-called higher Crustacea are fairly numerous, one only calls for special remark, namely, Xantho rivulosa, Risso. This species is represented in the collection by two small specimens obtained from the deep water (80-100 fathoms) off Loch Buy, Mull. The claws have the distal portion of both fingers very dark coloured, and, moreover, the movable finger is also distinctly grooved, and is one of the characters that distinguish this species from Xantho florida. It may be of interest to state that during last summer I obtained a specimen of Xantho rivulosa in the Moray Firth, from which it does not appear to have been previously recorded.

Among the Anomura in the collection there are, at least, five species of hermit crabs, and of these Spiropagurus Hyndmanni and Spiropagurus lcevis may be specially mentioned. The one has comparatively broad hands, in the other the hands are more elongate and polished, and in the living animal there is usually a red but not very well-defined band, extending the whole length of this hand, and sometimes branching off to 
the fingers. Munida rondeletii, another species of the Anomura in the collection, is of interest because of its remarkably long chelipeds. A considerable number of specimens of Munida occurred in a gathering from Loch Spelve.

Five species of Schizopods were obtained in the collection, viz.,-Mysidopsis didelphys, Mysis flexuosus, Mysis inermis, Mysis lamornoe, and Neomysis vulgaris. The latter occurred in great abundance in a gathering from Loch Dow. Mysis lamorne, when alive, is of a bright red colour, and its eyes are large and black.

The next group deserving of special notice is the Amphipoda. I find it difficult to select species for reference here, for almost all of them are of interest. Hyperia galba, with its large beautiful eyes, is not nearly so plentiful on the West Coast as it is on the East Coast of Scotland. I was therefore the more surprised to find a considerable number of specimens in $\mathrm{Mr}$ Brook's collection. Iysianassa costce, Phoxocephalus Holbölli, Ampelisca assimilis, Haploops tubicola, and Lencothoe Lilljeborgii are all of special interest. Eusirus longipes, a somewhat rare species with curious gnathopods, occurred in considerable numbers in a gathering from Loch Linnhe near Fort William. Dexamine spinosa appears to have a distribution the reverse of that of Hyperia galba; this Dexamine, though not uncommon on the West Coast, is, so far as my experience of it goes, much rarer on the East Coast-I do not have a single East Coast specimen in my collection. Cheirocrates Sundewalli, Gammaropsis erythrophthalmus (with its red eyes), Pleonexes gammaroides, and Podocerus Herdmanni, are also all more or less interesting. A species which has the posterior gnathopods armed with enormous claws was represented only by a fragment, consisting of the anterior half, extending from the head to the second gnathopod. I have not been able to identify this with any British species, and therefore submit the following description:-

\section{(?) Mcera Brooki, sp. n. [Pl. V., Figs. 1-6.]}

Description of the Species.-Cephalon nearly as in Mcera othonis (M.-Edw.), lateral corners produced and narrowly rounded. Eyes small. Superior antennæ elongated and VOL. XIII. 
slender, and closely resembling those of Mcera othonis, but the flagellum is proportionally somewhat longer; accessory appendage about twice the length of the last joint of the peduncle, and six-jointed, terminal joint very small. Inferior antennæ somewhat similar to those of Mora othonis, as are also the mandible palp, and other oral parts (Figs. 1-4). Anterior gnathopoda rather slender, densely setose; propodos nearly equal in length to the carpus, oblong oval in form; palm imperfectly defined (Fig. 5). Posterior gnathopoda strong and powerful; propodos subcylindrical, length equal to fully twice the breadth, lower margin slightly convex, and with a distinct and broadly rounded but shallow prominence anteriorly; dactylos very powerful, longer than the propodos, and reaching to about the middle of the carpus, not much curved except towards each end, the inner edge near the base but slightly posterior to the prominence on the lower margin of the propodos, is produced into a shallow triangular process (Fig. 6).

Remarks.-Only the anterior moiety of this Amphipod was obtained; it is only provisionally ascribed to the genus Mora. It is apparently a male specimen, and all the parts of it that could be utilised resemble more or less closely the parts similar to them in Morra othonis, with the exception of the second gnathopods, which are unlike those of any other known to me; and as the species is apparently undescribed, it gives me much pleasure to add to it the name of $\mathrm{Mr}$ Brook.

The abnormal Amphipoda are only represented by three species, viz., Phtisica marina, Protella phasma, and Caprella acanthifera.

Of the Phyllopoda there is but one species-Nebalia bipes; and of the Cladocera, two species-Podon and Evadne.

The Ostracoda.-Twenty-five species belonging to this group were obtained in the collection, but they are species that are all more or less commonly distributed around our shores.

The Copepoda.-There are forty species of this group, a considerable number of which are of special interest. Isias clavipes, for example, has very few Scotch records. Labidocera Wollastoni has not previously been recorded from the Scottish 
seas. Ectinosoma atlanticum, a slender species, with moderately long tail setæ, and of which there was no Scotch record till within recent years, was comparatively common in a gathering from Upper Loch Fyne. Ameira longicaudata and Laophonte depressa are two species added to the British list within recent years, and not before reported from the West Coast. Porcellidium viride, a representative of a curiously depressed group of Copepods, occurred in a gathering from Loch Bracadale, Skye. Cyclopicera nigripes, a handsome species, with the swimming-feet all more or less dark coloured, was obtained in a gathering from Loch Spelve, and in another collected off Duart, Island of Mull. Bomolochus Solece, a parasite Copepod on the black sole (Solea vulgaris), is from Lochnell Bay (Loch Linnhe), and is now first recorded for the West of Scotland. Another new West Coast record is the curious Monstrilla rigida (I. C. Thompson); it was obtained in a gathering from Mauchrie Bay, Arran. An interesting paper on the genus Monstrilla, by Gilbert Bourne, was published a few years ago.

The Cirripedia are represented by only four speciesScalpellum vulgare, Balanus crenatus, Balanus Hameri, and Peltogaster paguri.

\section{ECHINODERMATA.}

One or two interesting species belonging to this group have been obtained in the collection. The Rosy feather star, Antedon bifida (Pennant) $=$ (Comatula rosacea, Forbes and others), was obtained both in the adult form and in the young stalked (crinoid) stage; it occurred in gatherings from the deep water of Loch Buy, Mull; the Gairloch, West Rossshire; and Loch Boisdale, Outer Hebrides. The Bird's-foot starfish, Palmipes membranaceus, is from two localitiesviz., off Loch Buy and the Gairloch. The small and comparatively rare Echinus norvegicus was also obtained in the deep water of Loch Buy, Mull.

\section{FORAMINIFERA.}

The Foraminifera that have been identified in the collection number forty-six species, a few of which appear to be moderately rare. 


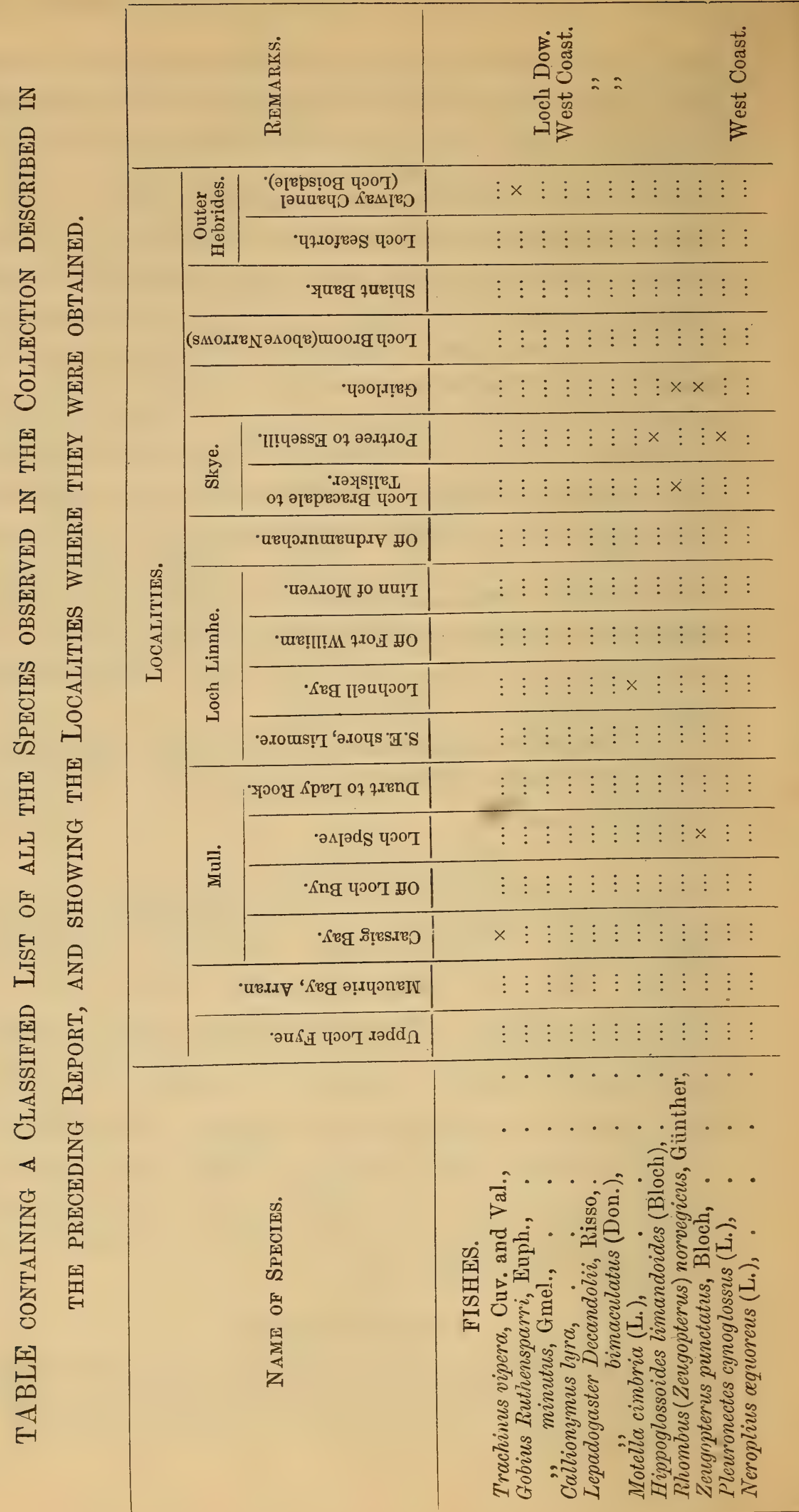


Marine Dredgings and other Natural History Materials. 177

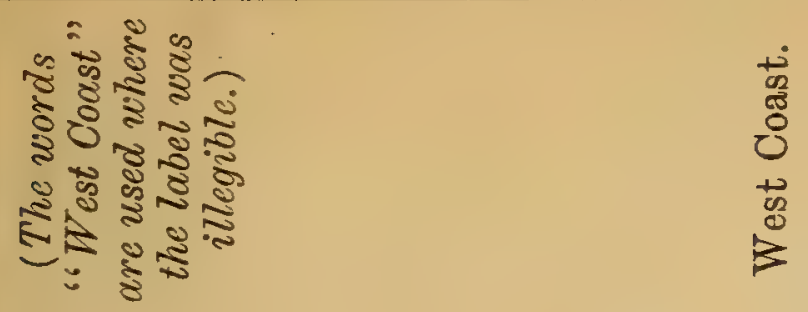

$\times \times \quad \vdots \quad \vdots \quad \vdots \quad \vdots \quad \vdots \quad \vdots \quad \vdots \quad \vdots \quad \vdots \quad \vdots \times \times \times \quad \vdots \quad \vdots \times \times \quad \vdots \quad \vdots \quad \vdots$ 


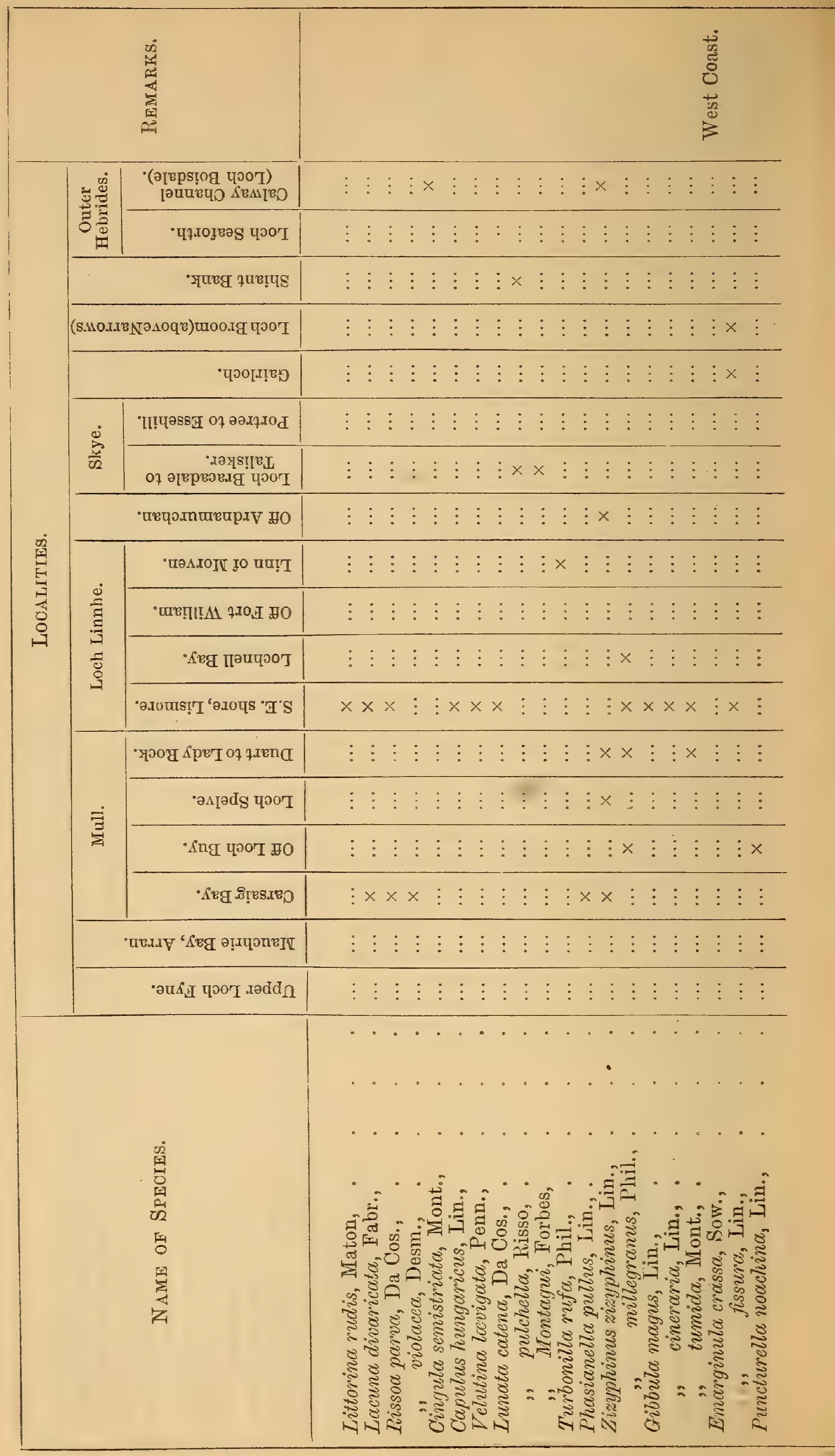


Marine Dredgings and other Natural History Materials. 179

苛

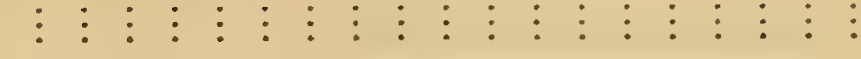

$\begin{array}{lllllllllllll}\vdots & \vdots & \vdots & \vdots & \vdots & \vdots & \vdots & \vdots & \vdots & \vdots & \vdots & \vdots\end{array}$

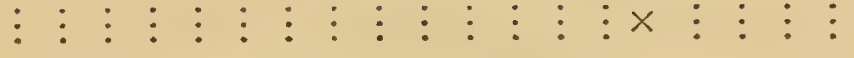

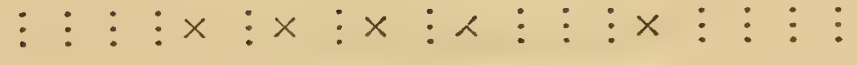
$\vdots \vdots \vdots \vdots$

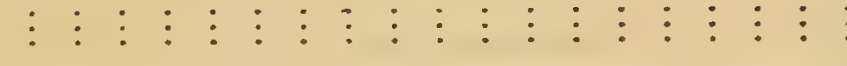
$\vdots \vdots \vdots \vdots$ $\begin{array}{llllllllllllll}\vdots & \vdots & \vdots & \vdots & \vdots & \vdots & \vdots & \vdots & \vdots & \vdots & \vdots & \vdots & \vdots & \vdots\end{array}$ $\vdots \vdots \vdots$ $\times$ $\vdots \vdots \vdots \vdots \times \quad \vdots \quad \vdots$ $\vdots \times \quad \times \quad \times \quad \vdots \times \vdots \vdots \vdots \vdots \times \times \vdots \vdots \vdots \vdots \times \times \times$

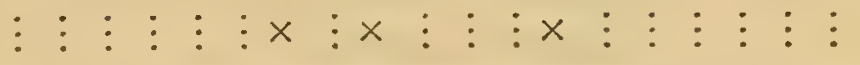
$\vdots \vdots \vdots \vdots$ $\begin{array}{llllllllllllll} & \vdots & \vdots & \vdots & \vdots & \vdots & \vdots & \vdots & \vdots & \vdots & \vdots & \vdots & \vdots & \vdots\end{array}$ $\times \quad \times \times \times \vdots \vdots \times \vdots \times \quad \vdots \vdots \vdots \vdots \times \vdots \vdots \vdots \times$ $\times \quad: \times \quad:$

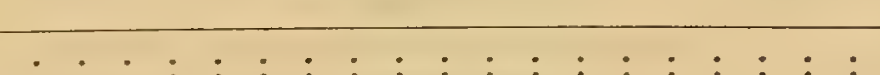

$\begin{array}{lllllllllllll} & \vdots & \vdots & \vdots & \vdots & \vdots & \vdots & \vdots & \vdots & \vdots & \vdots & \vdots & \vdots\end{array}$

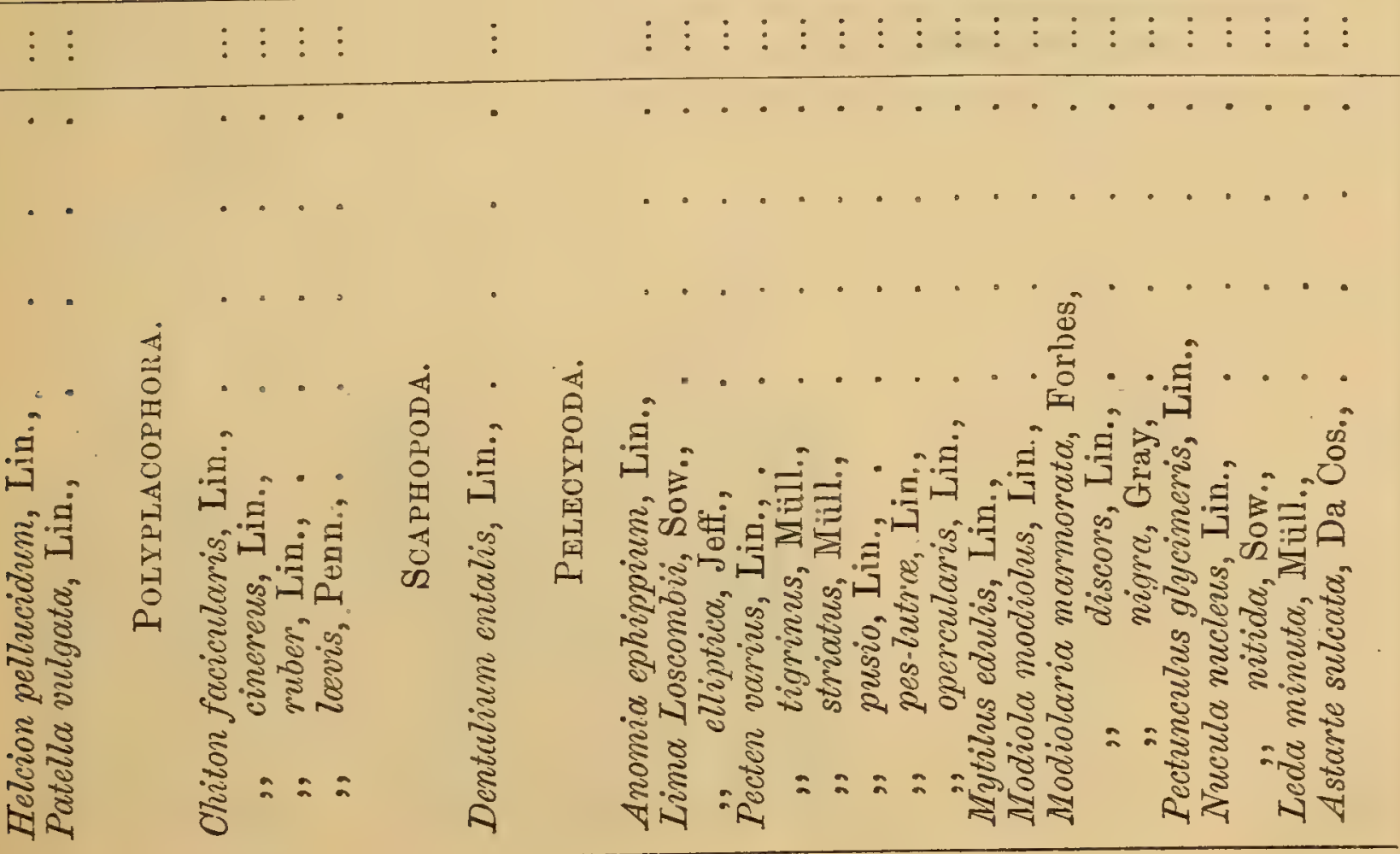




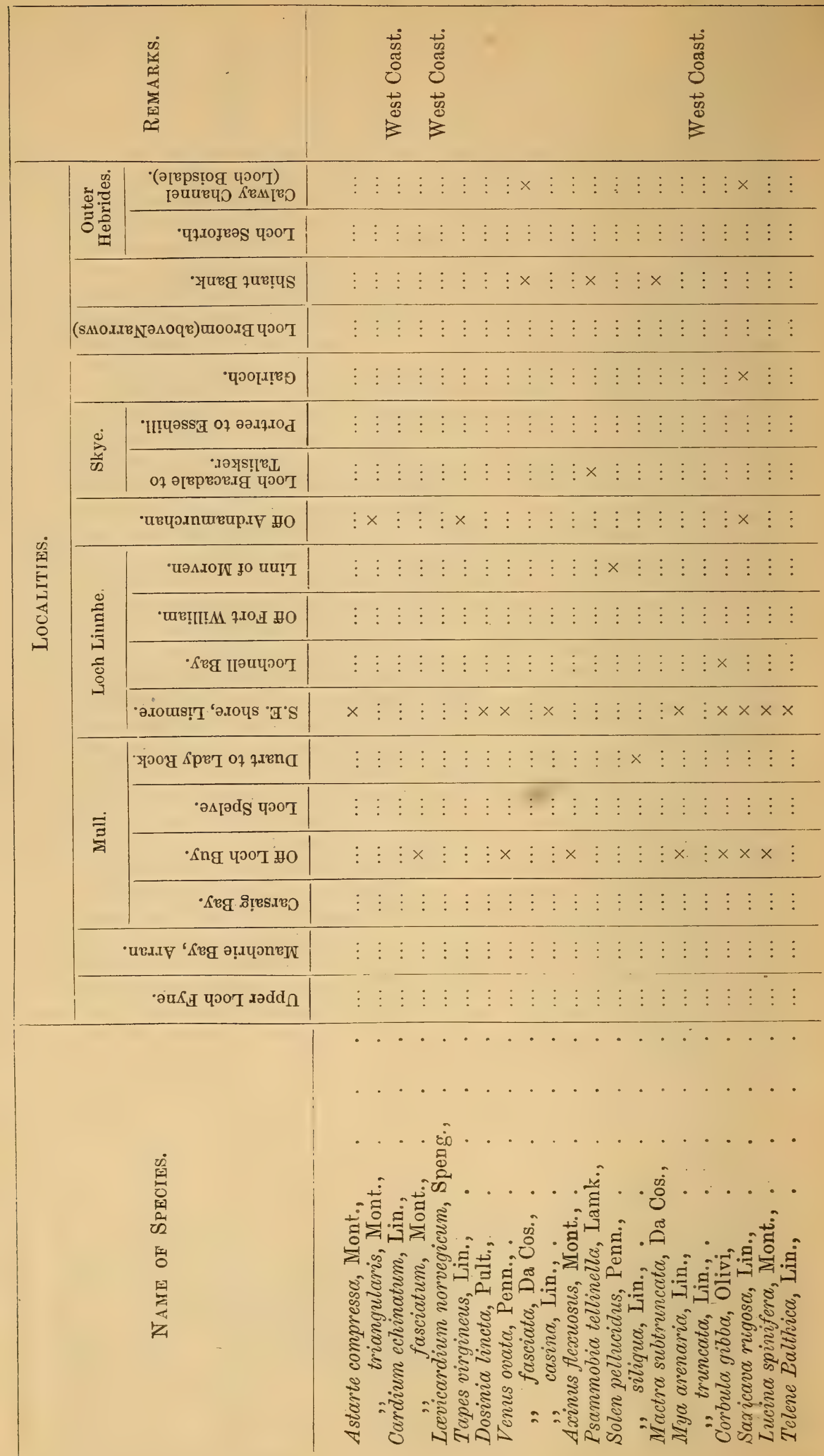


Marine Dredgings and other Natural History Materials. 181

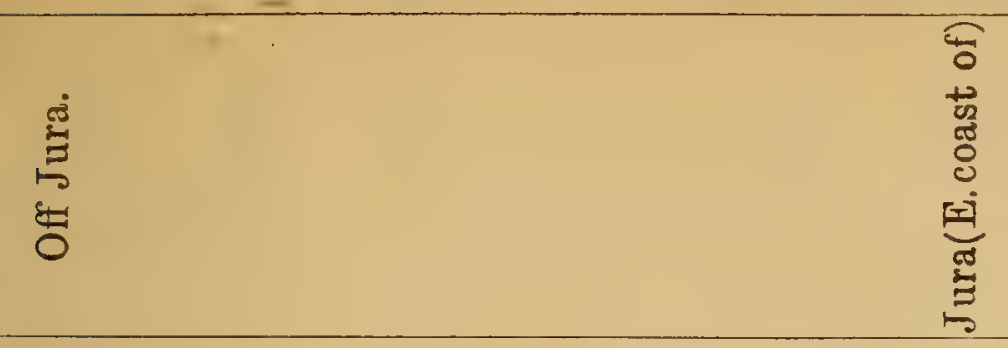

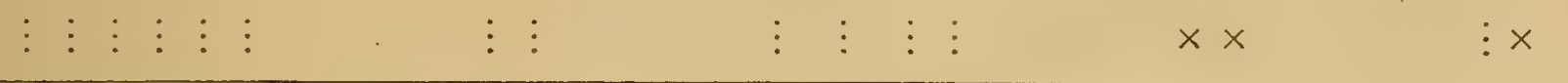

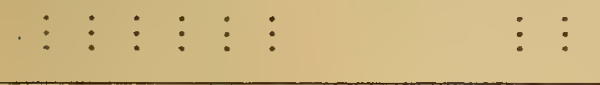

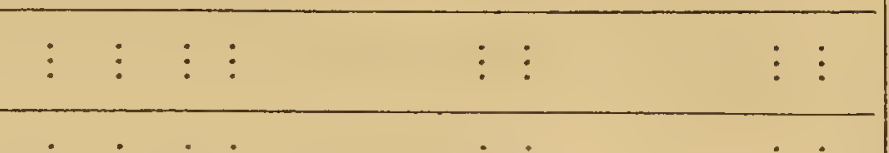

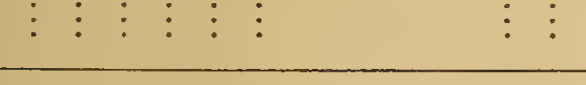

\begin{tabular}{|c|c|c|c|}
\hline$\vdots \vdots \vdots \vdots \vdots \quad \vdots$ & $x$ & $\vdots \times x$ & $x$ \\
\hline
\end{tabular}

$\vdots \vdots \vdots \vdots \vdots$

$\vdots$
$\vdots$
$\vdots$
$\vdots$

$\vdots \vdots \times \vdots \vdots \quad \vdots \quad \vdots$

\begin{tabular}{cccccc}
$\vdots$ & $\vdots$ & $\vdots$ & $\vdots$ & $\vdots$ & $\vdots$ \\
\hline$\vdots$ & $\vdots$ & $\vdots$ & $\vdots$ & $\vdots$ & $\vdots$ \\
\hline$\vdots$ & $\times$ & $\times$ & $\vdots$ & $\vdots$ & $\vdots$ \\
\hline
\end{tabular}

$\vdots \vdots$

\begin{tabular}{ccc}
$\vdots$ & $\vdots$ & $\vdots$ \\
$\vdots$ & $\vdots$ & $\vdots$ \\
\hline
\end{tabular}

$\begin{array}{cc}\vdots & \vdots \\ \vdots & \vdots\end{array}$

$\vdots \vdots \vdots \vdots \vdots \quad \vdots \vdots$

\begin{tabular}{l}
$\vdots \times \times \times \times \times$ \\
$\vdots \vdots \vdots \vdots \vdots$ \\
\hline$\vdots \vdots \vdots$
\end{tabular}

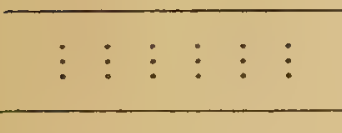

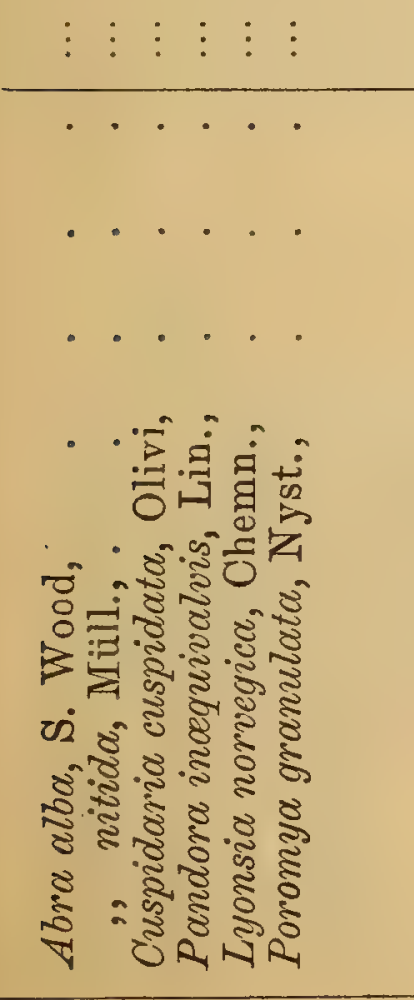

$\times$
$\times$
$\vdots$
$\vdots$




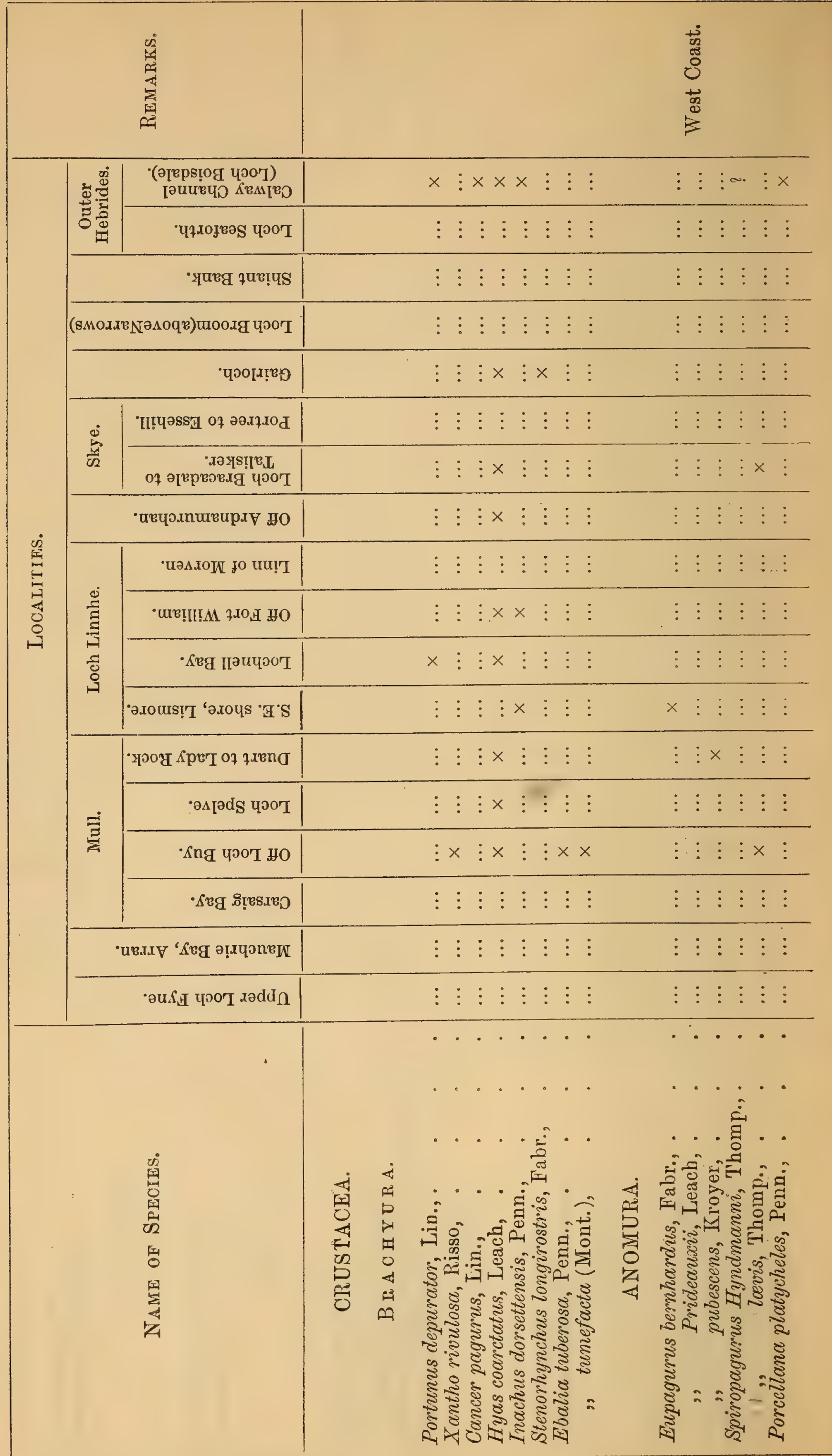


Marine Dredgings and other Natural History Materials. 183

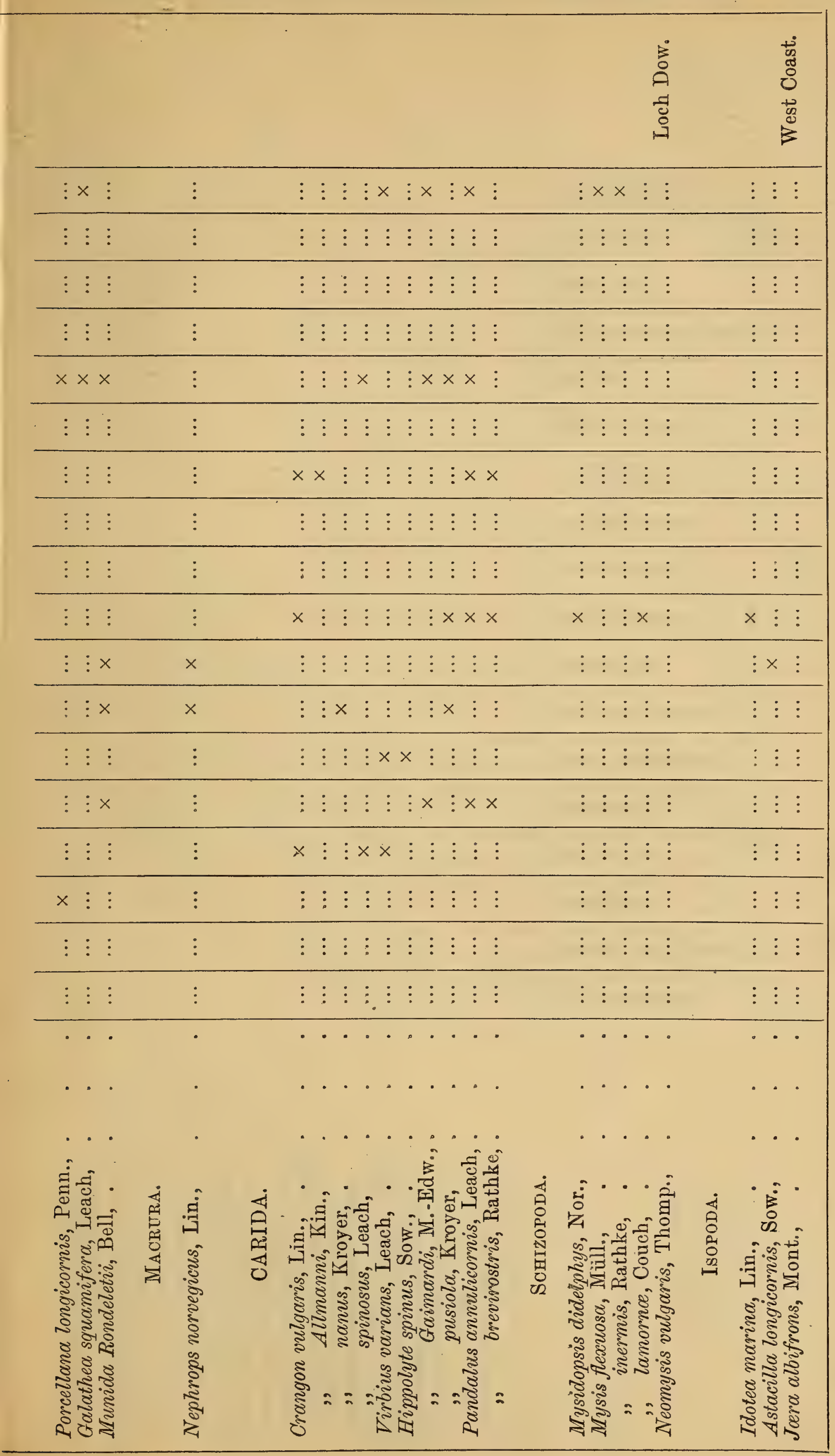




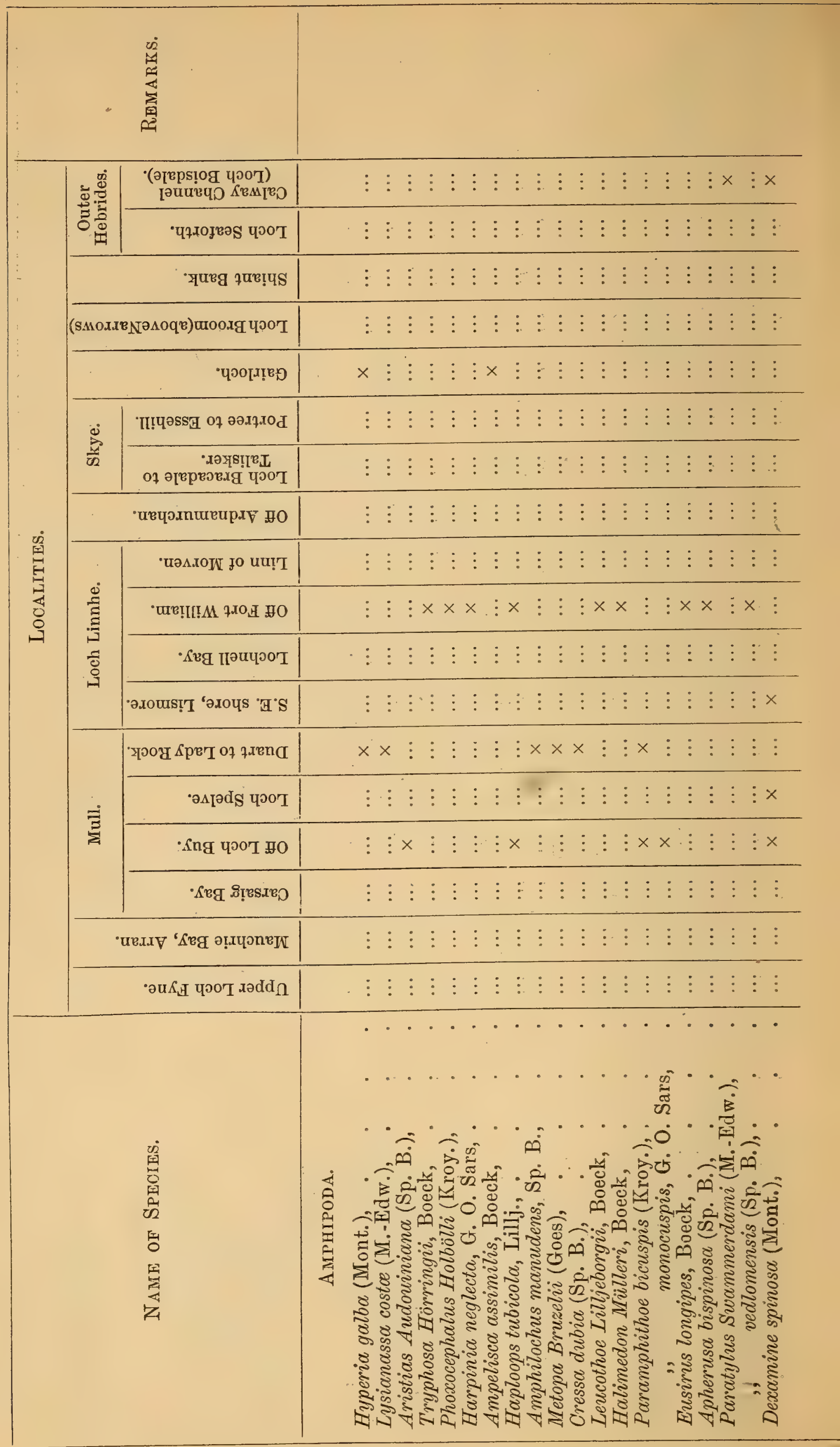


Marine Dredgings and other Natural History Materials. 185

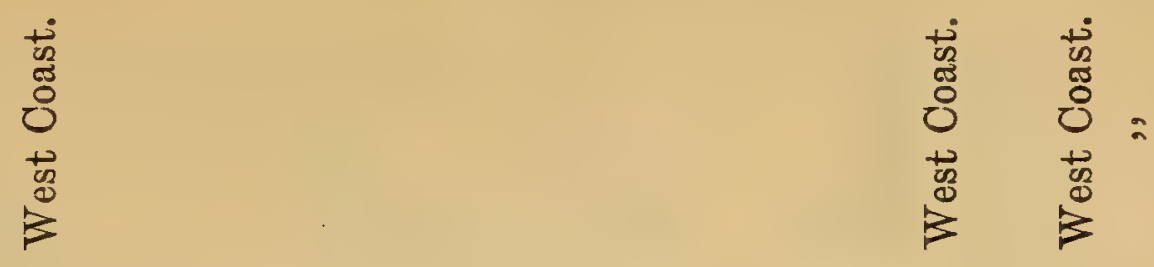

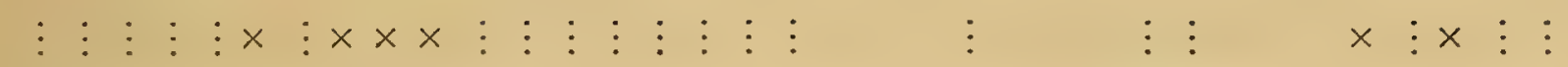

$\times$

$\vdots \vdots \vdots \vdots \vdots$

$\vdots \vdots$

$\vdots \vdots \vdots \vdots$

$\vdots \vdots \vdots \vdots \vdots$

$\vdots \times$

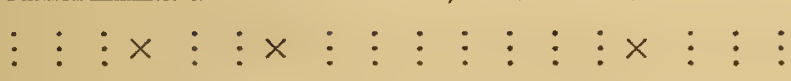

$\vdots \times \vdots \vdots$

$\vdots \vdots$

$\vdots \vdots \vdots \vdots \vdots$

$\vdots \times \quad \vdots \quad \vdots \times \quad \vdots \quad \vdots \vdots \vdots: \vdots \times \quad \vdots \times \quad \vdots \quad \vdots \vdots \quad \vdots \quad \times$

$\times \quad \vdots \quad \vdots \times \times \times \quad \vdots \times \vdots \vdots \vdots \times \vdots \vdots \times \vdots \times$

$\vdots \times \times \vdots \vdots$
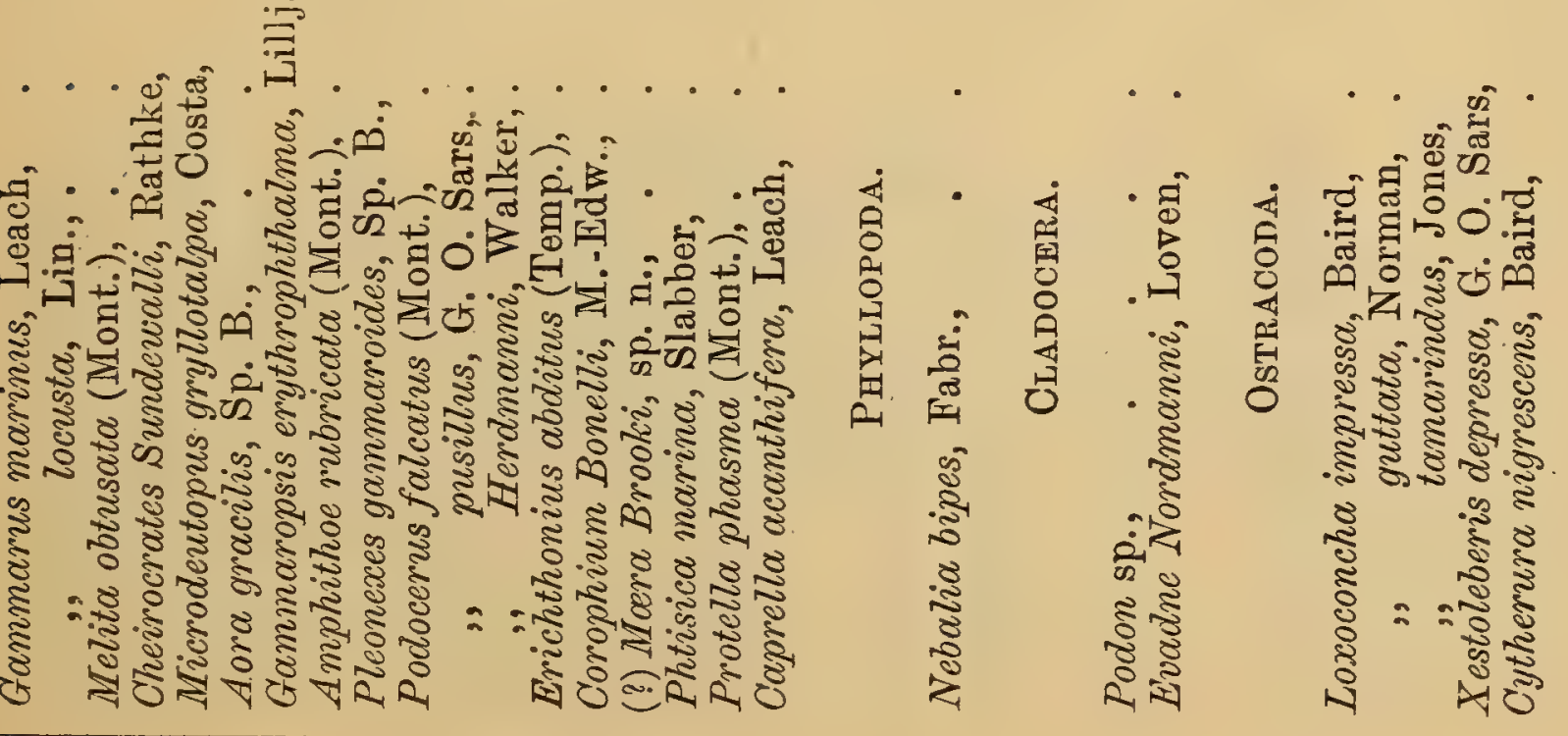


\begin{tabular}{|c|c|c|c|}
\hline \multicolumn{3}{|c|}{ 离 } & 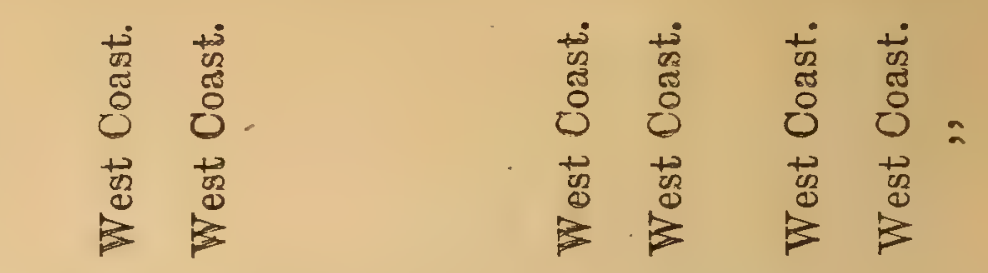 \\
\hline \multirow{18}{*}{ 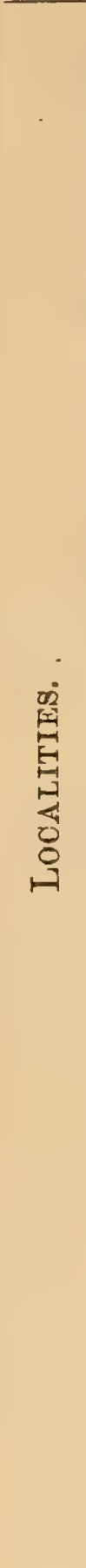 } & \multirow{2}{*}{$\mid$} & 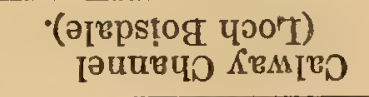 & $\vdots \vdots \vdots \vdots \vdots \times \vdots \vdots \vdots \vdots \vdots \vdots \vdots \vdots \vdots \times \times \times \quad \vdots$ \\
\hline & & 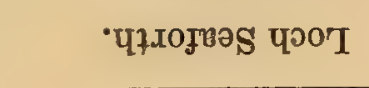 & 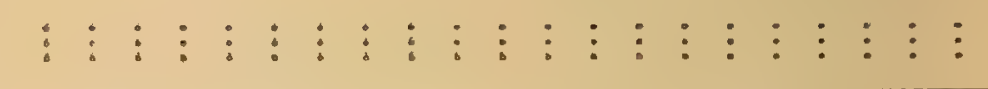 \\
\hline & \multirow{2}{*}{\multicolumn{2}{|c|}{ 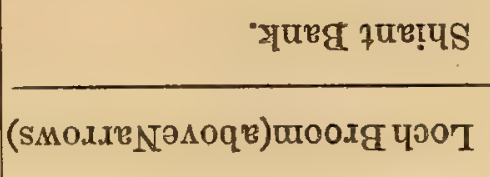 }} & 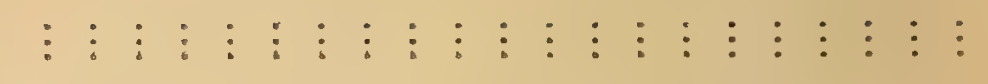 \\
\hline & & & 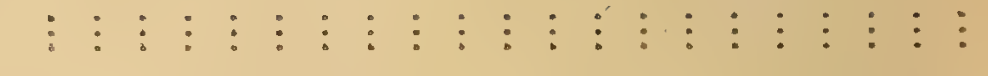 \\
\hline & \multicolumn{2}{|r|}{ • Чอоโมเฺฺ } & 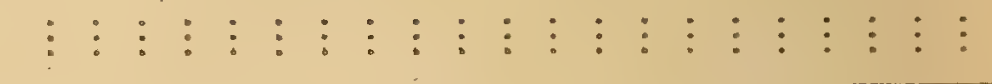 \\
\hline & \multirow{2}{*}{ 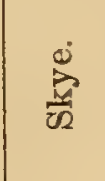 } & 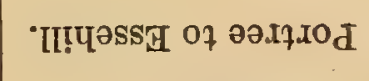 & 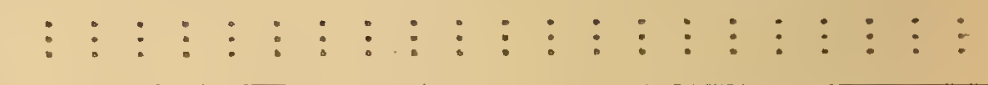 \\
\hline & & 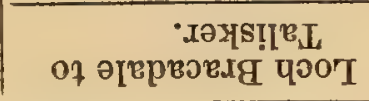 & $\vdots \vdots \vdots \vdots \vdots \vdots \vdots \vdots \vdots \vdots \vdots \vdots \vdots \vdots \vdots \vdots \vdots$ \\
\hline & & 'Uечрдпитеир.х ¥о & $\vdots \vdots \vdots \vdots \vdots \vdots \times \quad \vdots \times \quad \vdots \quad \vdots \quad \vdots \quad \vdots \quad \vdots \quad \vdots \quad \vdots \quad \vdots$ \\
\hline & & 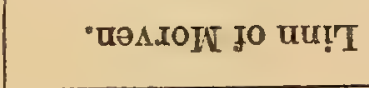 & 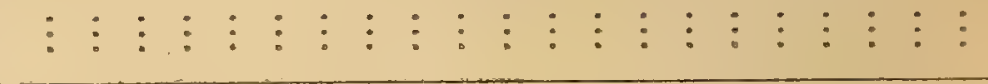 \\
\hline & & 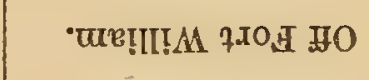 & 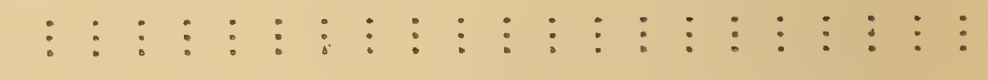 \\
\hline & & •Keg пाәицәот & $\vdots \vdots \vdots \vdots \vdots \vdots \vdots$ \\
\hline & & 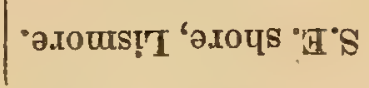 & $\vdots \vdots \vdots \vdots \vdots \vdots \vdots \vdots \vdots \vdots \vdots \vdots \vdots \vdots \vdots \vdots \vdots \vdots \vdots$ \\
\hline & \multirow{4}{*}{ 豆 } & 'яәоч Крвт о7 7.ґеп & $\vdots \vdots \vdots \vdots \quad \vdots \quad \vdots \quad \vdots \quad \vdots \quad \vdots \quad \vdots \quad \vdots \quad \vdots \quad \vdots \quad \vdots \quad \vdots \quad \vdots \quad \vdots \quad \vdots \quad \vdots$ \\
\hline & & •әлјәd, чрот & $\vdots \vdots \vdots \vdots \vdots \vdots \vdots \vdots \vdots \vdots \vdots \vdots$ \\
\hline & & •Кำ чрот \#о & $\times \times \quad \vdots \times \quad \vdots \times \quad \vdots \times \times \quad \vdots \times \times \times \times \quad \vdots \times$ \\
\hline & & 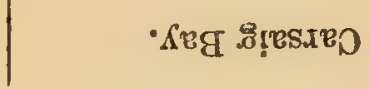 & 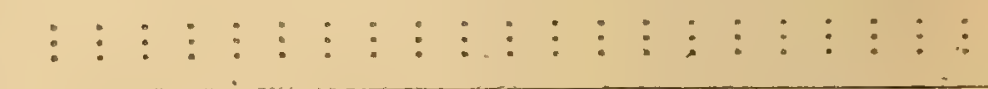 \\
\hline & \multicolumn{2}{|r|}{ 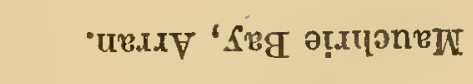 } & 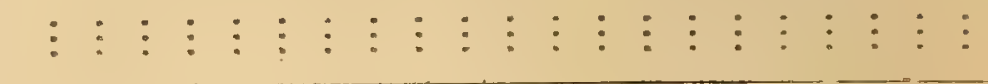 \\
\hline & \multicolumn{2}{|r|}{ 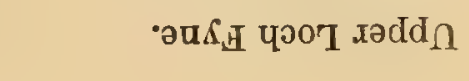 } & 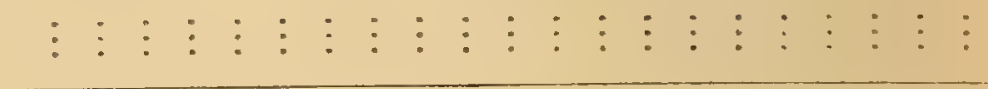 \\
\hline & & 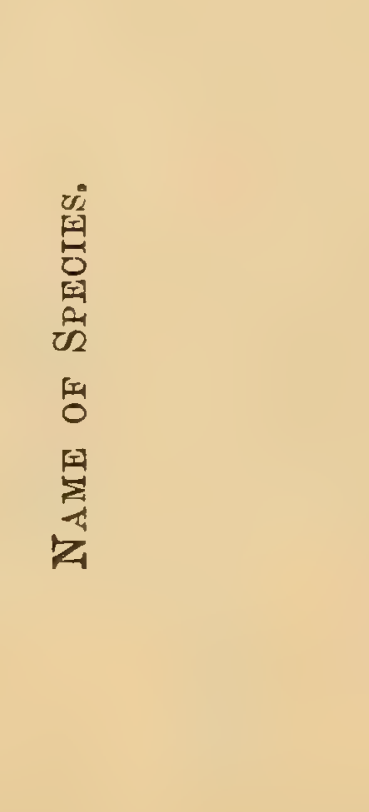 & 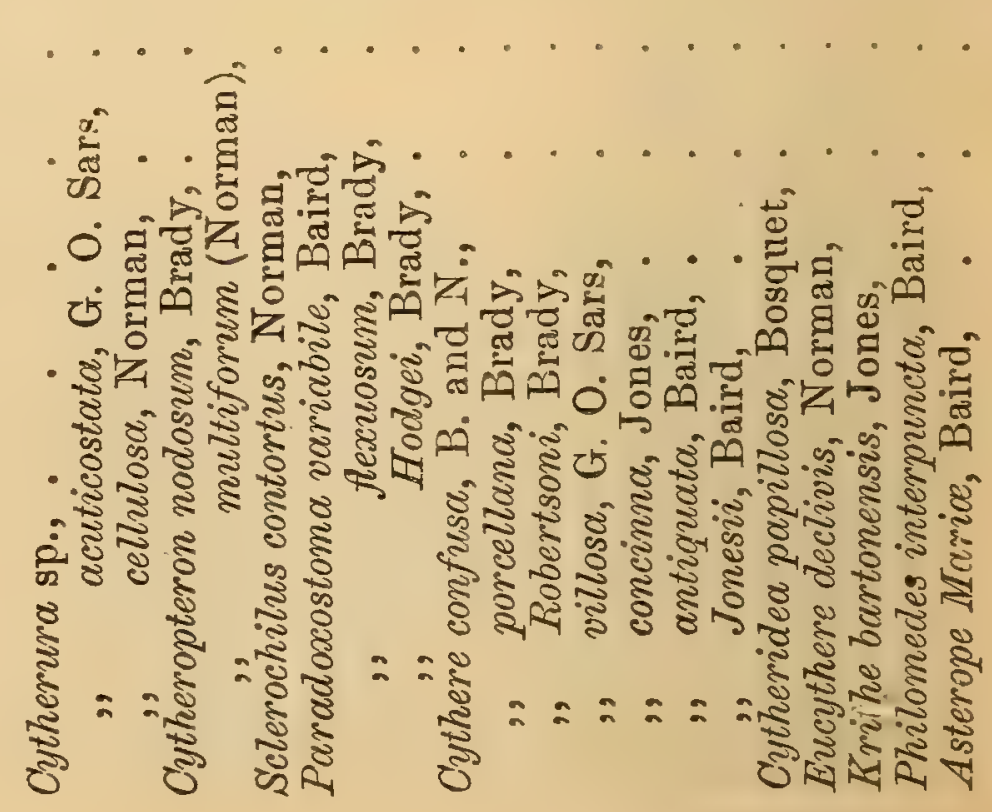 \\
\hline
\end{tabular}


Marine Dredgings and other Natural History Materials. 187

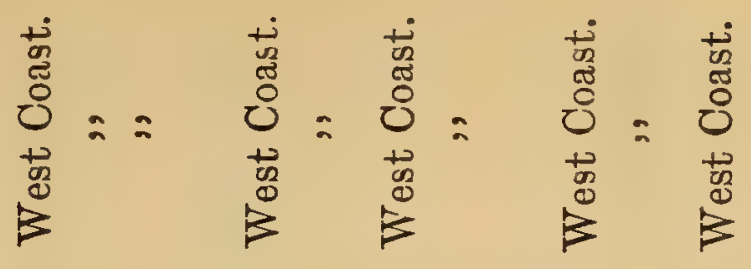

$\times \vdots \vdots \times \quad \vdots \times \quad \vdots \quad \vdots \quad \vdots \times \quad \vdots \quad \vdots \quad \vdots \quad \vdots \quad \vdots \quad \vdots \quad \vdots \quad \vdots \quad \vdots \quad \vdots \quad \vdots \quad \vdots \quad \vdots$

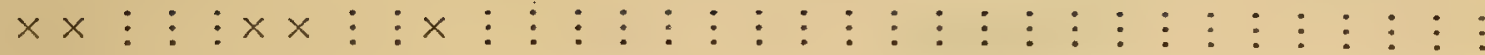

$\vdots \times \vdots \vdots \vdots \vdots \times \times \vdots \quad \vdots \times \quad \vdots \quad \vdots$

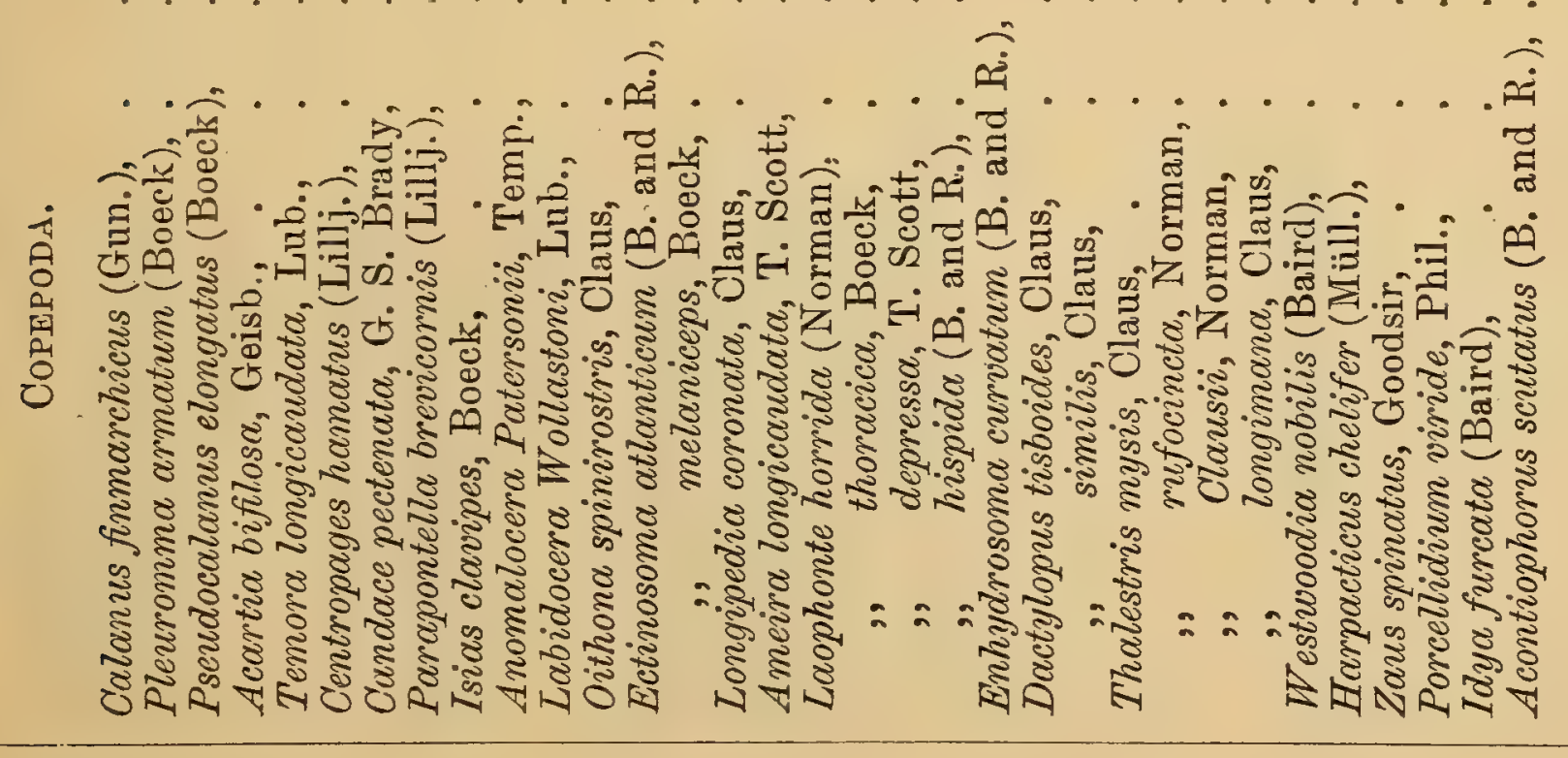




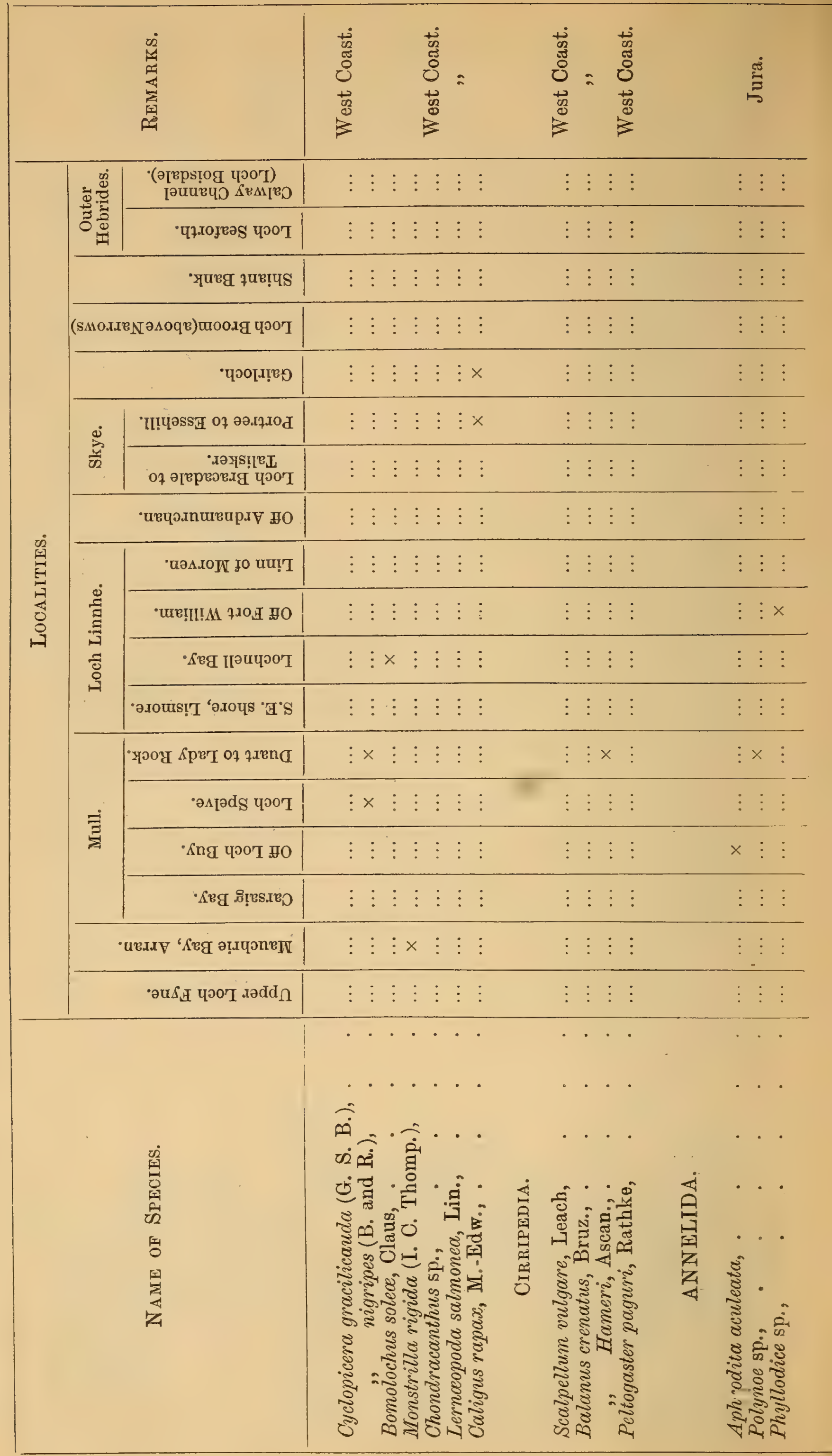




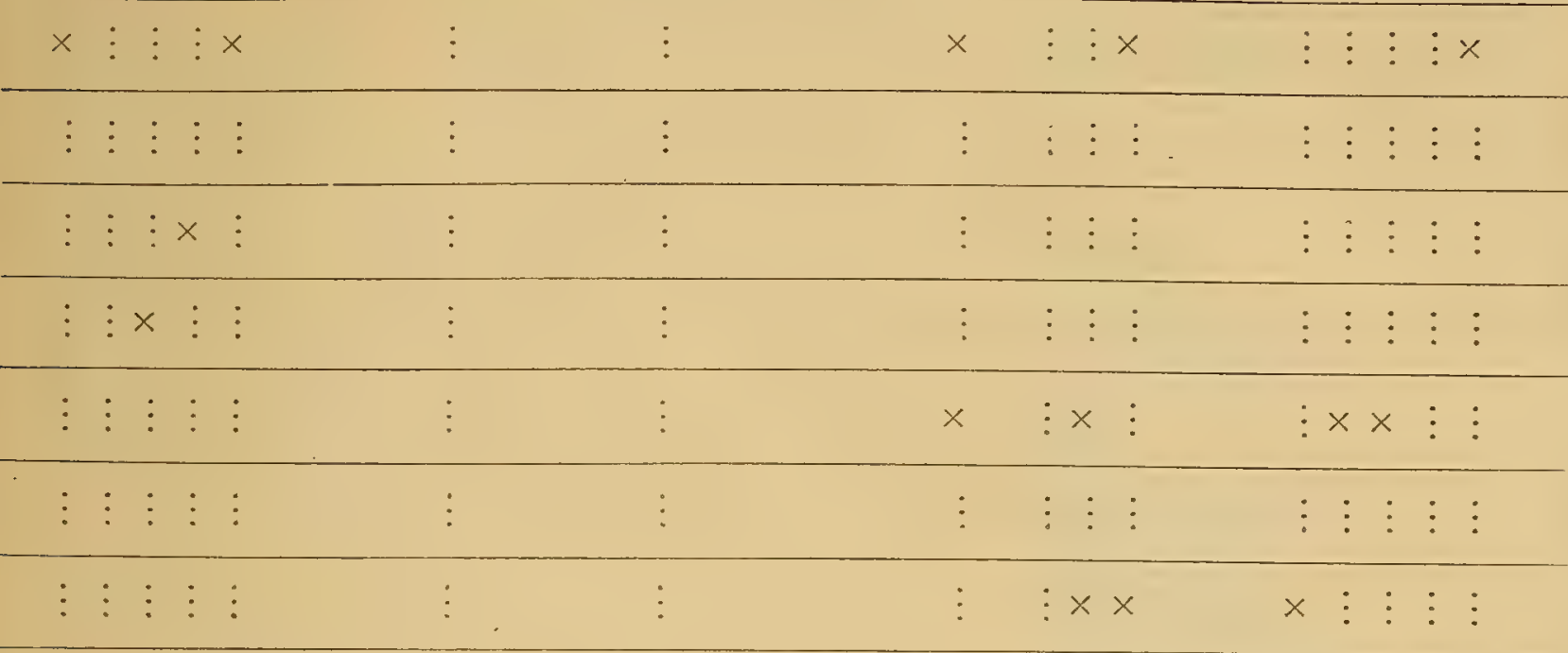

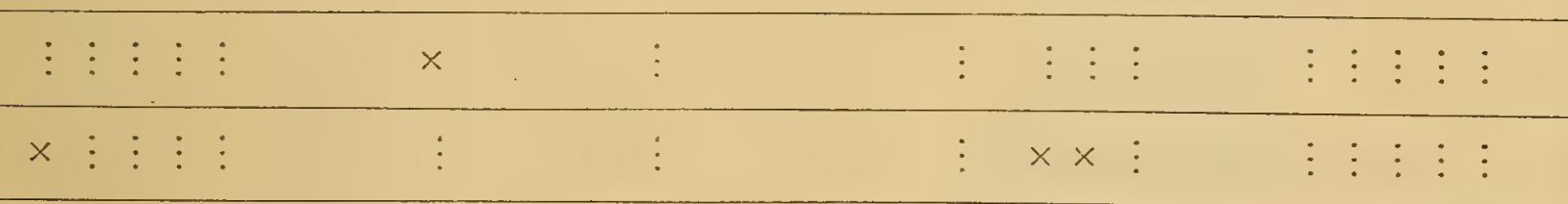

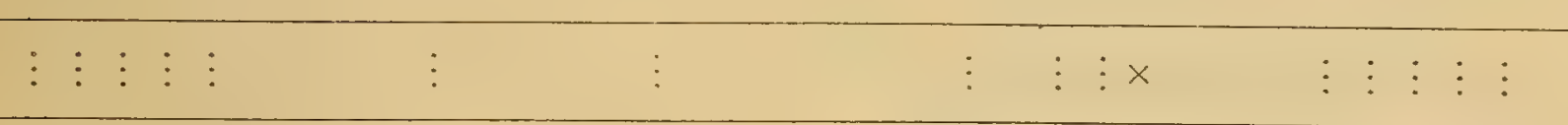
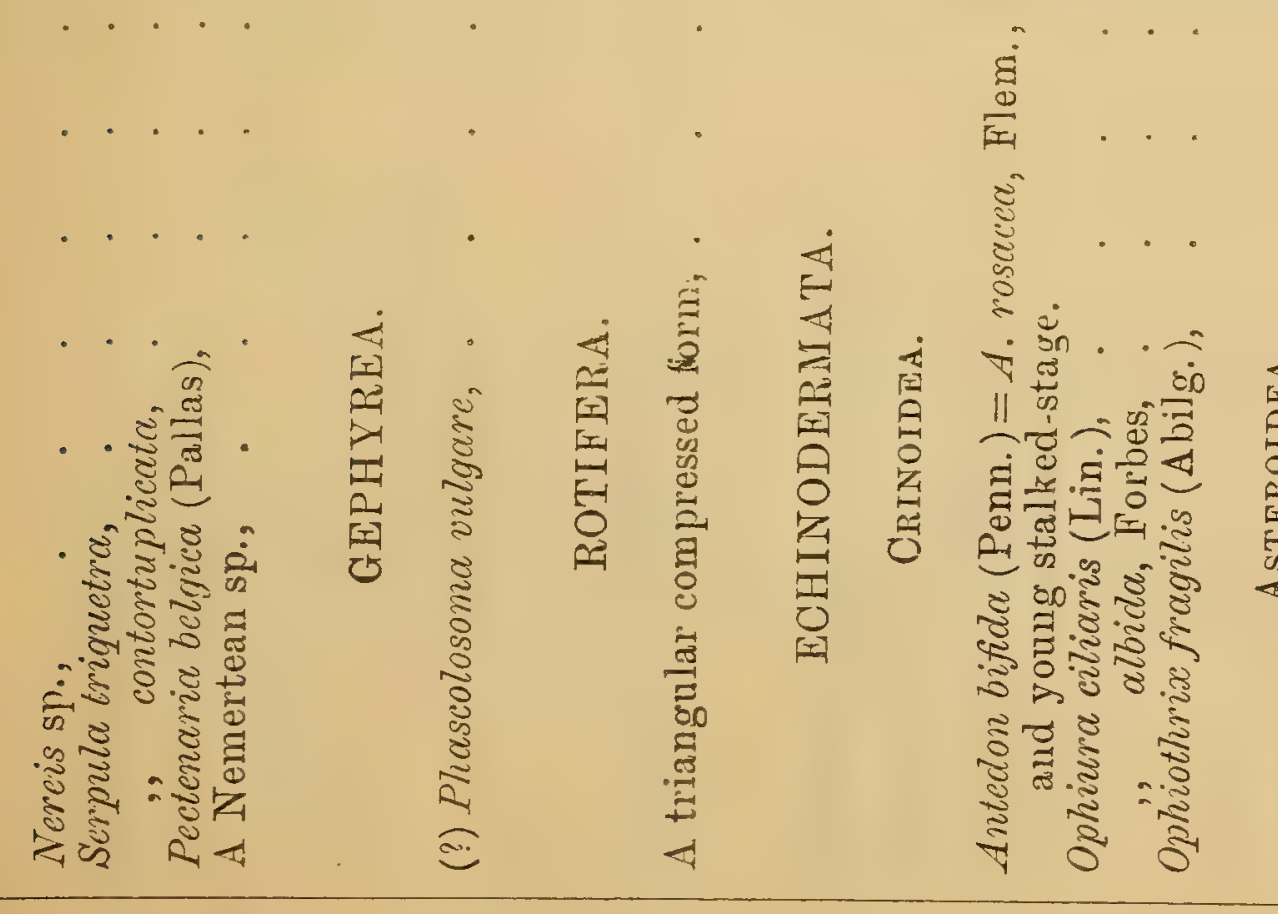

VOL. XIII.

$\begin{array}{ll}\vdots \vdots \times \vdots & \vdots \\ \times \times \times \vdots & \vdots \vdots \times \times \vdots\end{array}$




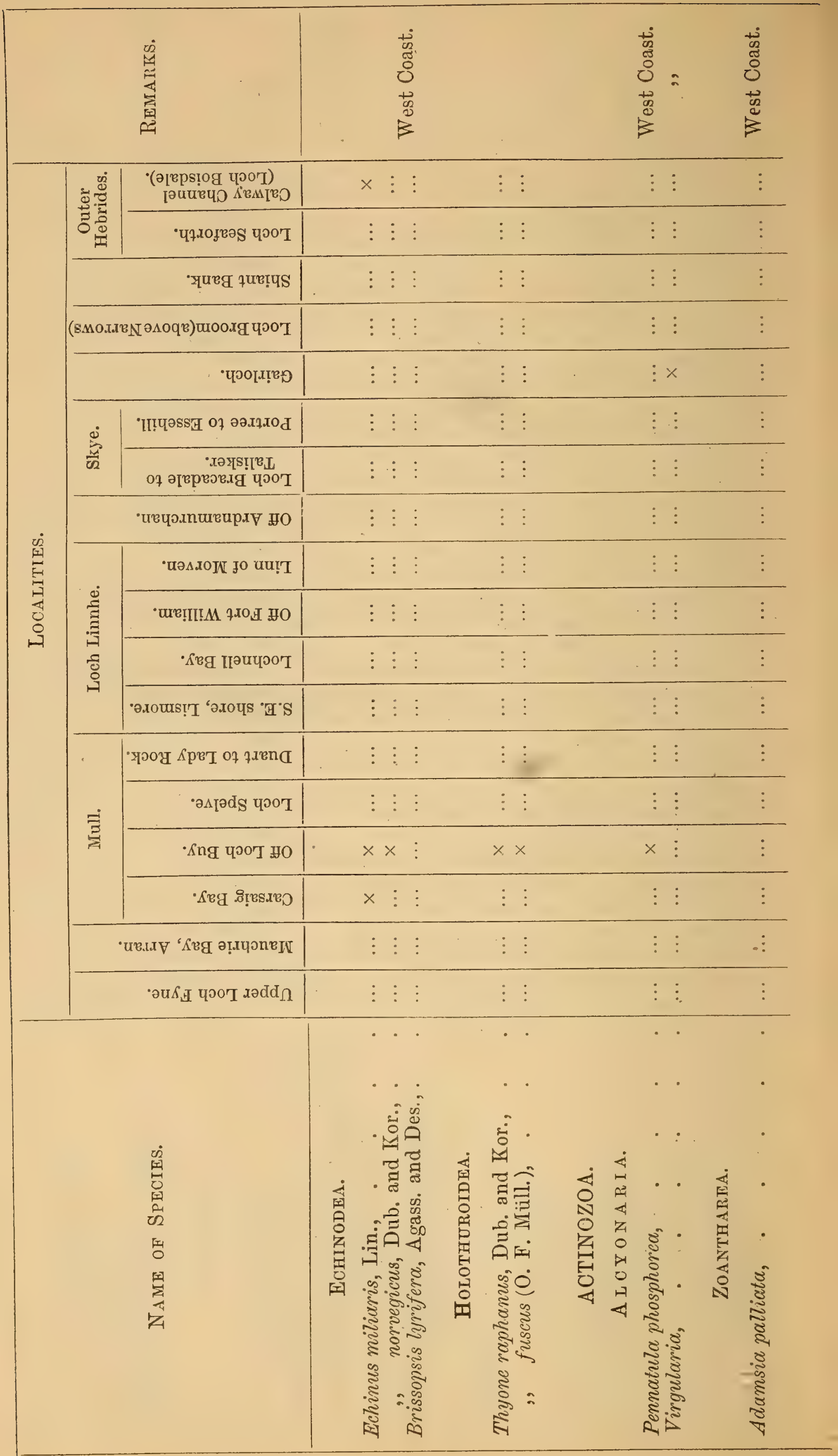


Marine Dredgings and other Natural History Materials. 191

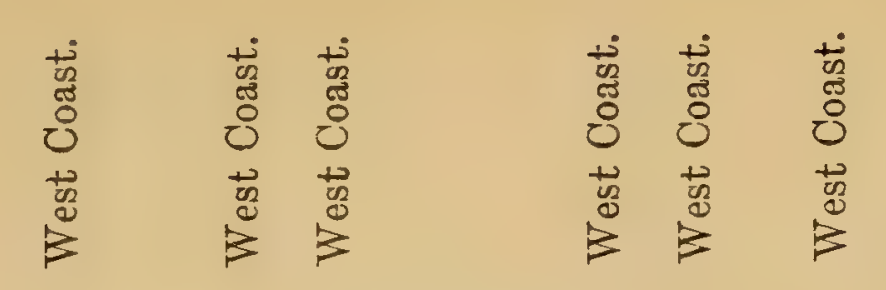

$\begin{array}{llllllllllll} & \vdots & \vdots & \vdots & \vdots & \vdots & \vdots & \vdots & \vdots & \vdots & \vdots & \vdots\end{array}$

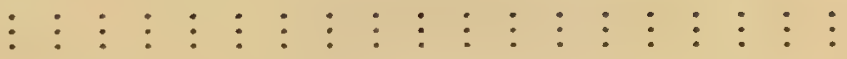

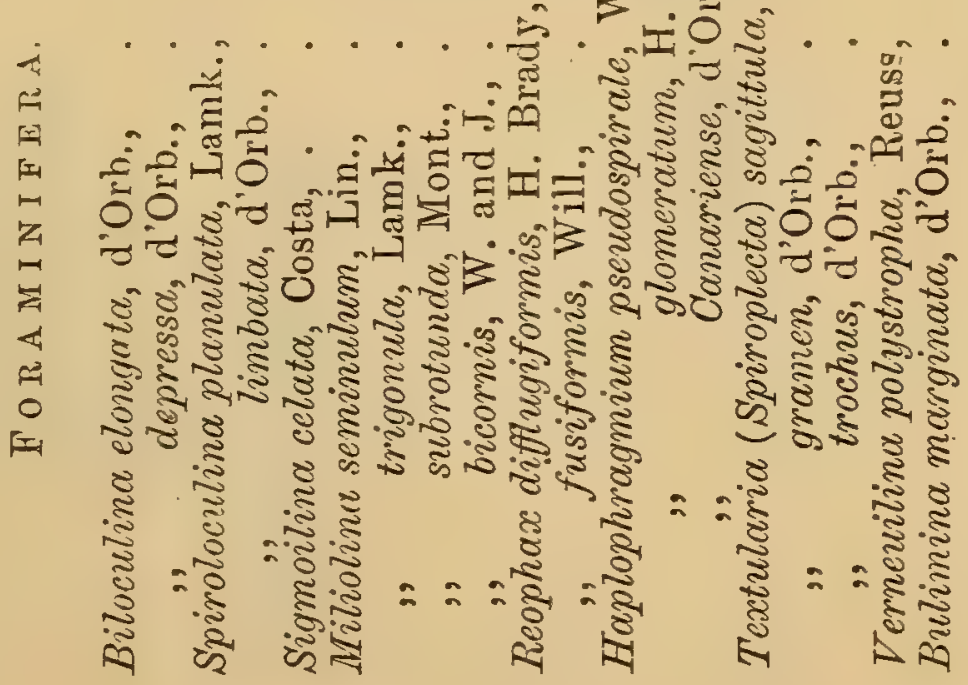




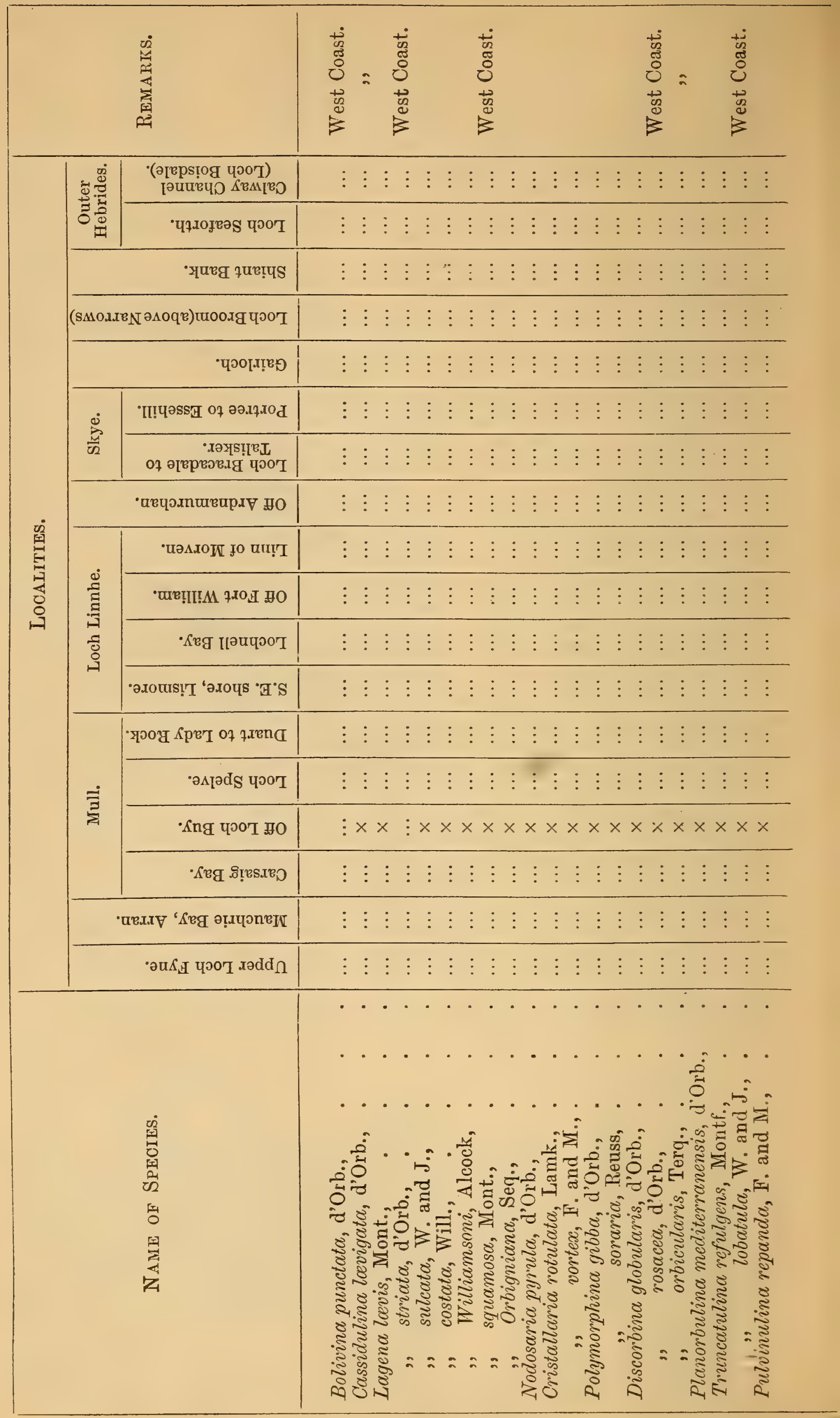


Marine Dredgings and other Natural History Materials. 193

$$
\text { II: }
$$

\begin{tabular}{|c|c|}
\hline$\vdots \vdots \quad \vdots \quad \vdots \quad \vdots$ & $\vdots \vdots \vdots$ \\
\hline$\vdots \vdots \vdots \vdots \vdots \vdots$ & $\vdots \vdots \vdots$ \\
\hline$\vdots:: \quad: \vdots \vdots \vdots$ & $\vdots \vdots \vdots$ \\
\hline$\vdots \vdots \vdots \vdots \vdots \vdots$ & $x \quad \vdots \vdots$ \\
\hline$\vdots \vdots \vdots \vdots \vdots \vdots$ & $x \times x$ \\
\hline$\vdots \vdots \vdots \vdots \vdots \vdots$ & $\vdots \vdots \vdots$ \\
\hline$\vdots \vdots \vdots \vdots \vdots \vdots$ & $\vdots \vdots \vdots$ \\
\hline
\end{tabular}

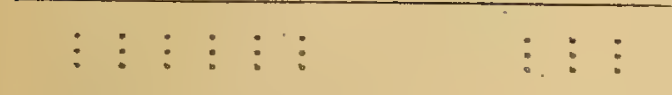

$\vdots \vdots \vdots \vdots \vdots \quad \vdots \vdots \vdots$

$\vdots \vdots \vdots \vdots \vdots \quad \vdots \vdots \vdots$

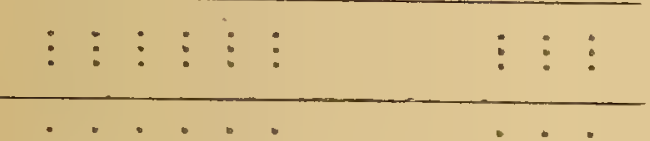

\begin{tabular}{|c|c|}
\hline$\vdots \vdots \vdots \vdots \vdots \vdots$ & $\vdots \vdots \vdots$ \\
\hline$x \times \vdots \times \quad \vdots \times$ & $\vdots \vdots \vdots$ \\
\hline$\vdots \vdots \vdots \vdots \vdots$ & $\vdots \vdots \vdots$ \\
\hline$\vdots \vdots \vdots \vdots \vdots \vdots$ & $\vdots \vdots \vdots$ \\
\hline$\vdots \vdots \vdots \vdots \vdots \vdots$ & $\vdots \vdots \vdots$ \\
\hline
\end{tabular}

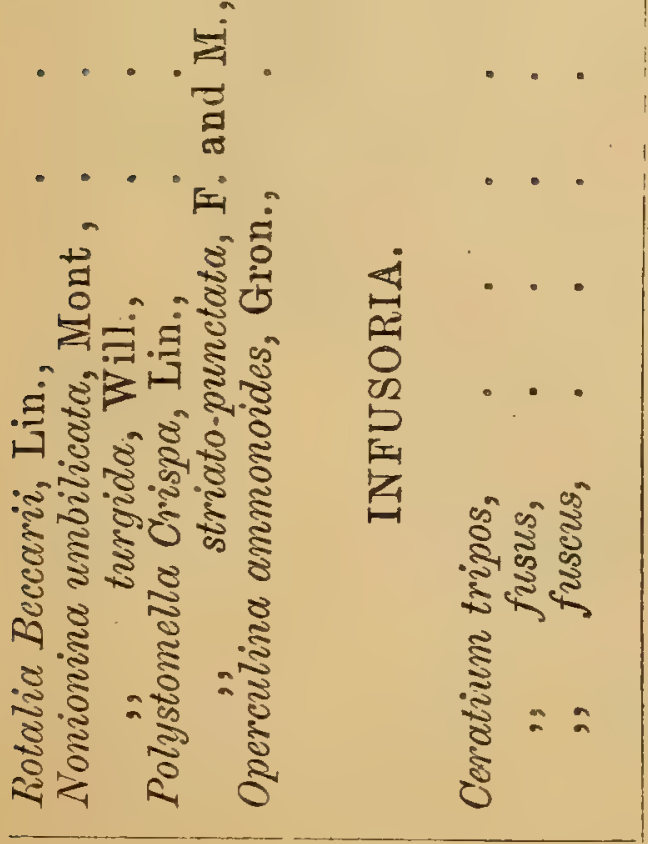





\section{Plate $V$.}

Royal Physical Sociely, Edinburgh

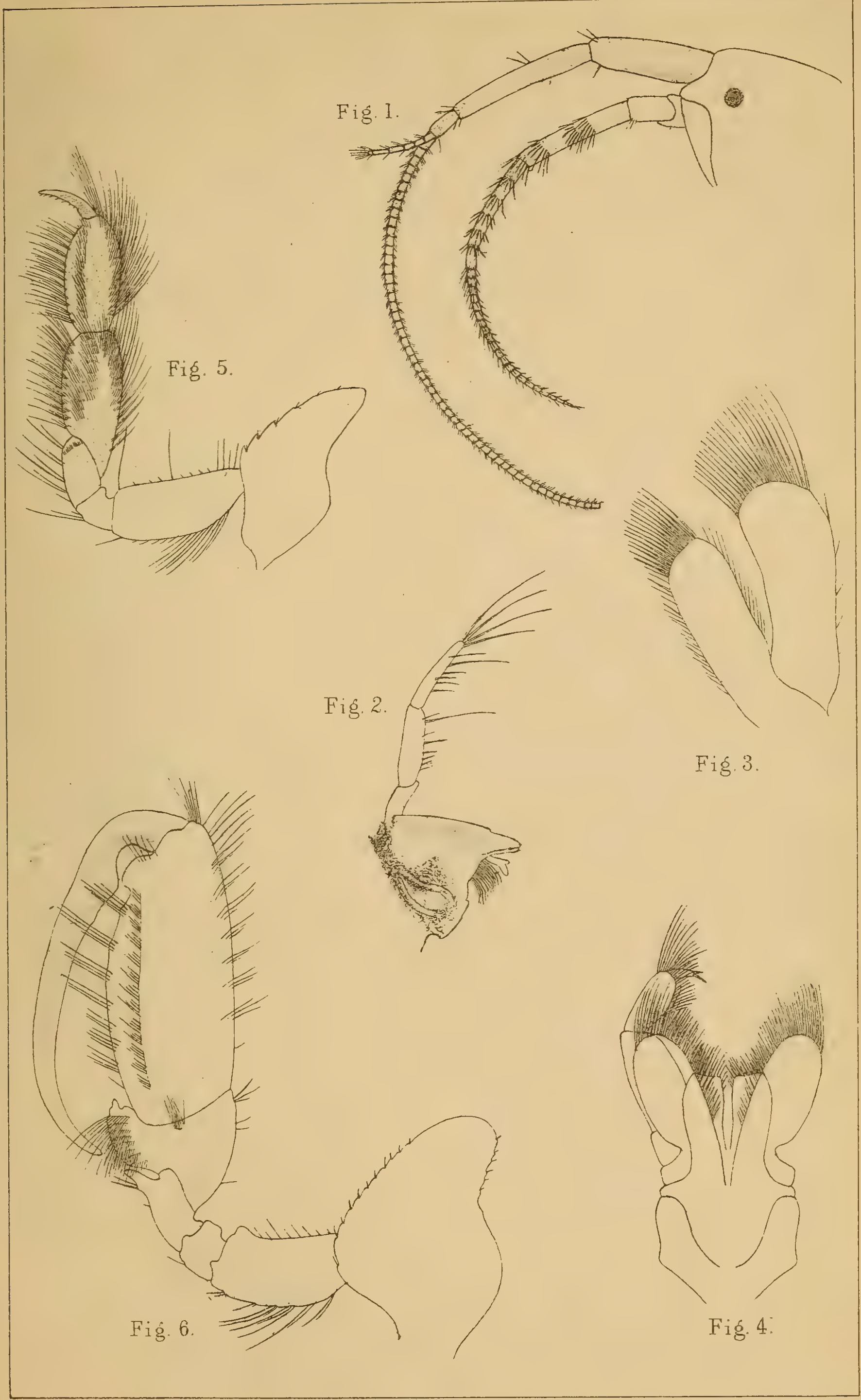

A. Scott, del. 



[Reprinted from "The Annals of Scottish Natural History," October I 896.]

\section{ON SOME NEW AND RARE COPEPODA} FROM THE CLYDE

By Thonas SCOTT, F.L.S., and ANDREN SCOTT, 


\section{The Annals}

OF

\section{Scottish Natural History}

A QUARTERLY MAGAZINE WITI WIICH IS INCORPORATED

" The Scottish Jaturalist"

EDITED BI

J. A. HARVIE-BROWN, F.R.S.E, F.Z.S.

Nember of the British Ornithologists' Union

JAMES W. H. TRAIL, M.A., M.D., F.R.S., F.L.S.

Professor of Botany in the University of Aberdeen

and

WILLIAM EAGLE CLARKE, F.L.S., MEM. BRIT. ORN. UNION

- Natural History Department, Museum of Science and Art, Edinburgh

EDINBURGH : DAVID DOUGLAS, CASTLE STREET 



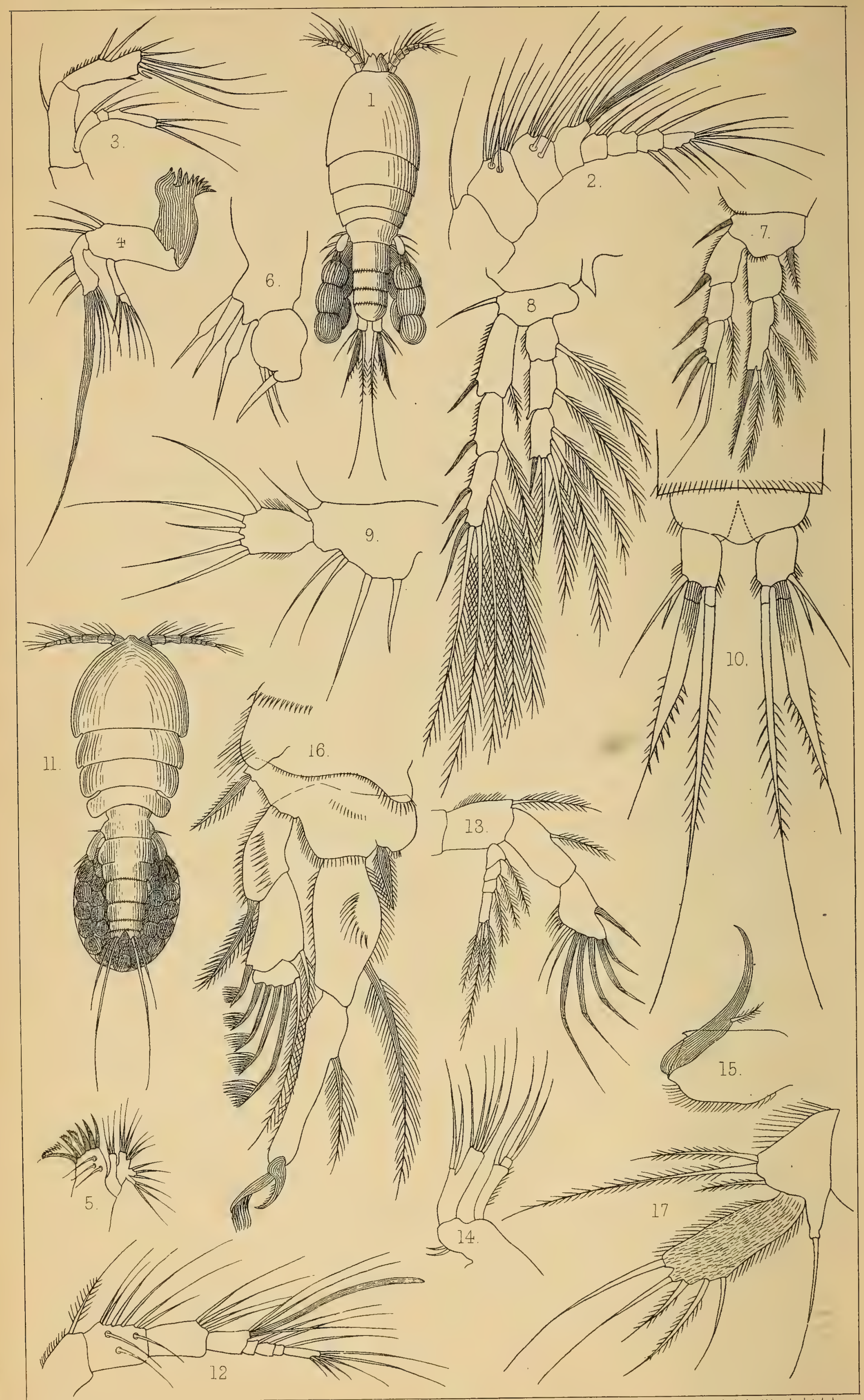

A. Scott, Delt.

R.\&K. Clark, Ltd. Imp

Figs. 1-10 DELAVALIA. GIESBRECHTI, Sp.n.

FIGS. 11-17 IDYA MINOR, Sp.n. 
[Reprinted from "The Annals of Scottish Natural History," October I 896.]

\section{ON SOME NEW AND RARE COPEPODA FROM THE CLYDE.}

By Thomas ScotT, F.L.S., Mem. Soc. Zool. France, Naturalist to the Fishery Board for Scotland,

and ANDREw SCOTT,

Fisheries Assistant, Liverpool.

\section{Plate IV.}

The Firths of Forth and Clyde, which are the two most important estuaries, have had both their fauna and flora investigated by quite a number of able and enthusiastic naturalists, and zoology and botany have been enriched by many interesting and important discoveries that, as a result of these investigations, have been made in both these branches of study. Yet notwithstanding all the research of previous years, prolonged and thorough though it has been, much still remains to be done ere it may reasonably be asserted that, even in regard to these restricted areas, our knowledge of the 
creatures to be found within their limits is approximately complete. No doubt the vertebrates and the larger of the invertebrates have been more or less exhaustively studied, so that additions to the number of species already known are now rarely met with; but in regard to the more minute invertebrates the case is different, and it is to these that our remarks chiefly apply. Of the various groups of these minute organisms, that of the Copepoda is perhaps one of the most interesting and most likely to reward the systematist with the discovery of new forms.

In the present contribution we give, as far as appears necessary, a brief account of the details of structure of two apparently undescribed Copepods from the Clyde, and new records for some rare species already described. The first we propose to describe is a species of Delavalia, viz:--

\section{Delavalia Giesbrechti, sp. nov, Plate IV. Figs. I-IO.}

\section{Description of the Female. - Length $\cdot 45 \mathrm{~mm}$. ( $\frac{1}{55}$ of an inch).} Antennules moderately stout, eight-jointed. The proportional lengths of the joints are approximately as follows :-

\begin{tabular}{lcccccccc} 
Proportional lengths of the joints & 9 & Io & 8 & 6 & 5 & 6 & 5 & 7 \\
\cline { 2 - 8 } Numbers of the joints & I & 2 & 3 & 4 & 5 & 6 & 7 & 8
\end{tabular}

Antennæ somewhat like those of Delavalia cemula, T. Scott, but the secondary joints, which are three-jointed, are rather more slender than in that species. The mandibles-the structure of which is characteristic of the genus-have the principal seta at the end of the apical branches of the palp spiniform and of considerable length, while the lateral branches appear to be two-jointed, the end joint being very small (Fig. 4). Posterior foot-jaws very small, and armed with a small terminal claw (Fig. 6). First pair of swimming feet somewhat similar to those of Delavalia palustris, Brady, but the first joint of the inner branches is proportionally shorter and the second joint longer and narrower than in that species; the second joint is also furnished with a moderately long spine and a plumose seta at the apex and two plumose setæ on the inner margin, while a similar seta springs from the inner distal angle of the first joint; the outer branches are armed somewhat similar to those of Delavalia palustris (Fig. 7). 
The second, third, and fourth pairs are somewhat similar to those of that species (Fig. 8). In the fifth pair the inner portion of the basal joints is only slightly produced; the posterior free margin, which is irregularly angular, bears four setæ- the two exterior setæ are close together, but the other two, which are moderately stout, are somewhat distant from each other as well as from the two exterior setæ; the secondary branches are subquadrangular, they are longer than broad, and are each furnished with five setæ ranged around the distal end-the middle seta is much shorter than the others (Fig. 9). Caudal stylets short, about equal in length to the last abdominal segment, and each furnished at the apex with a long slender seta interiorly and two small setæ at the outer angle, while intermediate between these is a broad spine-like appendage. This appendage, seen from the dorsal aspect, has its two margins apparently nearly parallel for rather more than half its length; they then taper towards the end, where the appendage terminates in a slender hair. This tapering portion is plumose on both sides, but the feathering shows most prominent on the inner edge. The middle portion of each long seta also appears to be plumose (Fig. Io). Ovisacs two, moderately large.

Habitat.-Ayr Bay, Firth of Clyde, not very rare.

Remarks.-Perhaps the most obvious character of this small but distinct and interesting species, and one which requires no dissection to render evident, is that of the curious broad spine-like appendages of the caudal stylets. The peculiar character of these appendages distinguish this species at a glance from any other member of the genus. The species is named in compliment to Herr Dr. W. Giesbrecht, of the Naples Zoological Station.

\section{Delavalia Æivula, T. Scott.}

This species was described in the "Eleventh Annual Report of the Fishery Board for Scotland" (part iii. p. 204, Plate IV., Figs. 36-47, I 893), from specimens obtained in Largo Bay, Firth of Forth, and till this year this was the only station for the species known to us; we are now, however, able to record its occurrence in the Clyde estuary, 
having found it not unfrequent in some dredged material from Ayr Bay. Delavalia cmula has both branches of the first pair of swimming feet three-jointed, the second and third joints of the inner branches being subequal and together rather longer than the first joint; and, though in this respect the species does not agree with the generic definition, it is nevertheless a typical Delavalia, and therefore we prefer to leave it in the genus to which it was first assigned.

\section{(?) Delavalia, $s p$.}

This is another interesting aberrant species of Delavalia, also from the Clyde, but we have not yet had time to prepare a description of it. It is apparently a typical Delavalia, except that, like Delavalia cmula, the inner branches of the first pair of swimming feet are threejointed; it differs, however, from that species in having the first joint of the inner branches long and slender, nearly equal to the entire length of the outer branches, while the second and third joints, though distinct, are very short. In this respect it resembles some of the species of Dactylopus.

\section{Delavalia (?) Robusta, Brady.}

A Delavalia, which appears to be identical with $D$. robusta, except in the form of the principal terminal seta of the inner branches of the first pair of swimming feet, was comparatively frequent in one or two of the Clyde dredgings recently collected, and especially in a dredging from Kilbrennan Sound. In these Clyde specimens the principal terminal seta of each of the inner branches of the first feet is stout at the base, but is otherwise long and slender, and is, so far as we have observed, invariably curved forward in a falcate manner: the concave margin of the seta is also furnished with a dense fringe of delicate cilia. The form of this seta appears to be the only point of difference betweer the Clyde specimens and Delavalia robusta as described and figured by Dr. Brady. Delavalia robusta has not previousiy been recorded for Scotland, Dr. Brady's specimens having been obtained off the coasts of Durham and Yorkshire. 
IDYA MINOR, $s p . n$., Plate IV. Figs. I I-I 7.

Description of the Female.-Length $.7 \mathrm{~mm}$. ( $\frac{1}{36}$ of an inch). Body closely resembling Idya furcata (Baird) in general appearance. Antennules eight-jointed, stout; second and third joints of about equal length, and longer than any of the others; the first, fourth, and last are also moderately elongate, and nearly equal in length. The formula shows approximately the proportional lengths of all the joints :-

\begin{tabular}{lccccccccc} 
Proportional lengths of the joints & I 2 & I 8 & I 8 & I 2 & 3 & 5 & 3 & I I \\
\cline { 2 - 8 } & I & 2 & 3 & 4 & 5 & 6 & 7 & 8
\end{tabular}.

The first three joints of the secondary branches of the antennæ are short; the fourth joint is as long as the second and third together (Fig. I 3). Mouth organs somewhat similar to those of Idya furcata. The first pair of swimming feet are robust; their outer branches do not reach much beyond the end of the first joint of the inner branches; the spine on the exterior distal angle of the first joint of the outer branches scarcely extends beyond the terminal joint (Fig. I 5). The second, third, and fourth pairs resemble those of Idya furcata. In the fifth pair the inner portion of the basal joint is subtriangular in outline and bears three setæ at the bluntly rounded apex, the middle seta being much longer than the other two; the secondary joint is somewhat spatulate, the width being greater towards the distal end, the length of the joint is equal to about three times its width, the end is truncate and furnished with five apical setæ, both surfaces of the secondary joint are covered with minute hairs. Caudal stylets short. Ovisac large.

Habitat.-In a few localities in Loch Fyne, especially where the water is shallow with a muddy bottom as in Loch Gair and in the vicinity of Carndow and Largabruach ; not uncommon.

Remarks.-Idya minor is the smallest member of the genus that we have yet observed. It may be distinguished by the structure of the antennules and antennæ, by the robust form of the first pair of feet and the comparatively broad and spatulate secondary branches of the fifth pair. In general appearance Idya minor resembles Idya furcata more closely than any of the other described forms; but in the latter species the third joint of the antennules is distinctly 
shorter than the second joint, and the secondary joints of the fifth pair of feet are narrow and of nearly equal width throughout; it is also a larger species.

Besides Idya minor and Idya furcata, two other species of Idya have been obtained in the Clyde district, viz. Idya gracilis, T. Scott, and Idya longicornis, T. and A. Scott.

Idya gracilis is about twice the length of Idya minor, and is easily distinguished by the remarkably long and slender inner branches of the first pair of swimming feet. This species was described in part iii. of the "Thirteenth Annual Report of the Fishery Board for Scotland (I 895)," from specimens obtained in the Firth of Forth. It has not hitherto been recorded from the Clyde district, but specimens have now been obtained by us in material (chiefly dredged) from one or two places in Loch Fyne and in Kilbrennan Sound.

Idya longicomis is the largest species of Idya known to us. It was described in the "Annals and Magazine of Natural History" for June 1 895, from specimens discovered in East Loch Tarbert (Loch Fyne). It has since been obtained in Caradale Bay and a few other Clyde stations, but we know of no record for the species beyond the Clyde area.

\section{Canuella Perplexa, $T$. and $A$. Scott.}

This interesting Copepod, so closely resembling Longipedia coronata in general appearance and in several of its structural details, and yet differing so much in other points as to make it generically distinct, has lately been obtained in some gatherings of Clyde Copepods; it was moderately frequent in dredged material from Ayr Bay, and is an addition to the Clyde Copepod fauna. Can the close resemblance between Canuella perplexa and Longipedia coronata be considered a case of "mimicry" ? : it looks like it. Canuella perplexa was described in the "Annals of Scottish Natural History" for April I 893, from specimens obtained in the Firth of Forth; it has also been observed in Liverpool Bay.

\section{Neobradya Pectinifer, $T$. Scott.}

This was one of a group of peculiarly slender species of Copepoda described in the "Tenth Annual Report of the Fishery Board for Scotland"; they had been discovered in 
the Firth of Forth off St. Monans, at a place locally known as "the Fluke Hole" and famous for the fine quality of its flat-fishes, especially plaice and lemon soles. In structure, Neobradya pectinifer is somewhat intermediate between Longipedia and Bradya (or Ectinosoma); it is, however, quite distinct from other British Harpactids, and is apparently local in its distribution. Till quite recently "the Fluke Hole" was the only habitat for Neobradya known to us. We are now, however, able to record its occurrence in the Clyde; a few specimens of it, along with specimens of other rare forms, having been obtained in a small gathering of Copepods from Ballantrae Bank.

\section{Pseudocletodes vararenses, $T$. and $A$. Scott.}

This genus and species were instituted to include a somewhat large Copepod from the Moray Firth, and descriptions were published in the "Annals and Magazine of Natural History" for October I 893. Only a very few specimens of this Copepod were obtained at that time, and no others have been observed by us till a short time ago, when, on re-examining a number of doubtful forms from the Clyde set aside for further study, several specimens of this apparently rare species were obtained. They had been collected from some material dredged near Sanda Lighthouse at the mouth of Clyde estuary, where the conditions as regards depth of water and the nature of the bottom are apparently somewhat similar to that part of the Moray Firth where the species was first discovered. The elongate cylindrical form of the species, with its somewhat long and peculiar caudal stylets, distinguish it from other allied Copepods.

\section{EXPLANATION OF PLATE IV.}

Delavalia giesbrechti, $s p$. $n$.

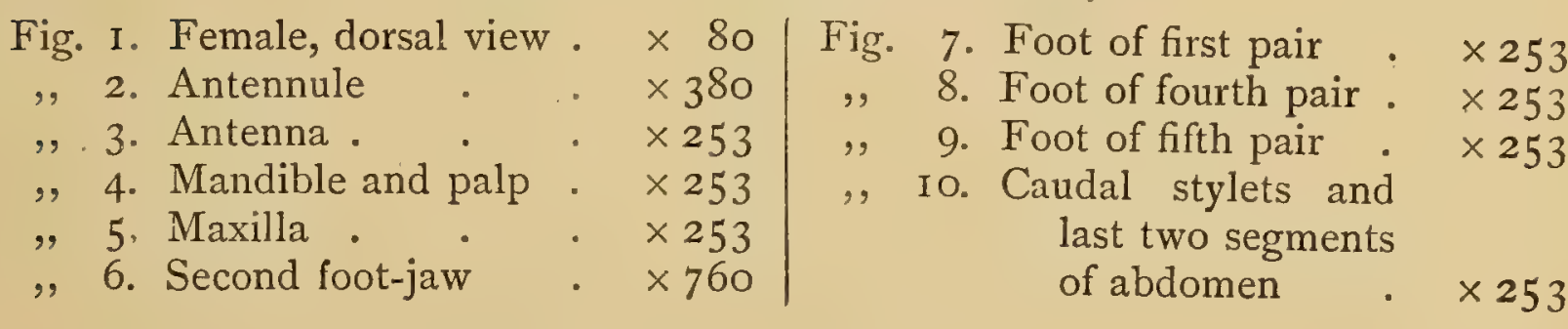

IDYA MINOR, sp. $n$.

Fig. I I. Female, dorsal view

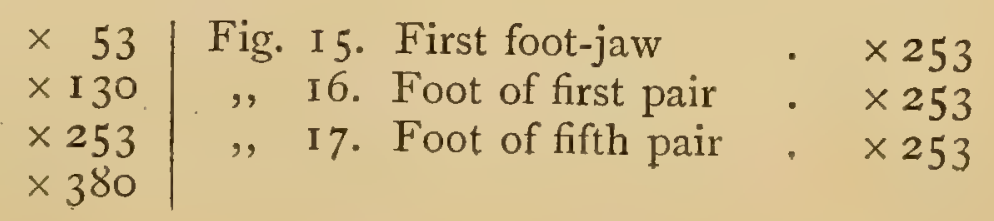





10

$$
\text { toit } 2 x+2 \ldots
$$



(Reprinted from the 'Transuctions of the Edinburgh Field Naturalists' and Microscopical Society,' Session 1897-98.)

THE UPPER ELF LOCH, BRAIDS. (Edimbara, h) [SegCond Paper.]

By Messrs THOMAS SCOTT, F.L.S., and JOHN LINDSAY.

IN continuation of our investigations with regard to the micro-flora and the micro-fauna of the Upper Elf Loch, we now beg to submit to the Society this second, and concluding, report, the result of gatherings taken at six different dates since the close of our first paper-viz., June 26, July 27, September 11, and November 20, 1897; February 5 and April 23, 1898. Appended to this paper will be found a list, arranged alphabetically, of the motile Algæ, Desmids, Diatoms, Rhizopods, Infusoria, Rotifera, and Entomostraca observed in the gatherings taken throughout the whole period of these investigations, from March 1896 to April 1898. These groups have been selected because they include many and varied forms interesting to microscopists; but it is not to be inferred that the list is an exhaustive one, though it is believed to be accurate, as far as it goes.

We shall now proceed to select from the groups abovementioned any forms collected since the close of our first paper which may seem to call for special notice. Before doing so, however, a few words may be given to a rather remarkable circumstance in the history of this little tarnviz., the large and rapid increase in the growth of rushes, grasses, and other vegetation, which has lately taken place at the north-west part, being the only portion of the loch to which the public have access. This growth began in the autumn of last year (1897), and continued throughout the winter and following spring, with the result that now the total water area is less by fully a third than it was in the spring of 1897. The loch is never cleaned out, and all that keeps rank vegetation in check is the rigour of winter, which usually cuts down much of the growth made during the previous season. The weather in this city, from the middle of 
October last to the beginning of February in the present year, was abnormally mild. According to $\mathrm{Mr}$ R. C. Mossman, on the 16 th of October 1897 one of the most noteworthy bursts of autumnal warmth ever recorded in Edinburgh set in. Mild weather continued to prevail throughout November; and although there was a cold "snap" in December, high temperatures again prevailed, continuing throughout Januarythe mean temperature of that month being $44^{\circ} \cdot 6$, or $7^{\circ} \cdot 8$ in excess of the average January temperature deduced from the records of the last 134 years. That the filling up of a considerable portion of the loch by aquatic vegetation was, to a large extent, due to these favourable weather conditions, there can be little doubt. Whether it may ever again assume its former dimensions is very doubtful; indeed, the silting-up process is more likely to go on apace. A very interesting view of the loch, from a photograph taken by Dr Davies in the spring of this year (1898), is here given, showing the growth of vegetation at the north-west part.

We looked forward with considerable interest to the effect of the past mild season on the inhabitants of the loch with the advent of spring; but by the beginning of February frost had set in, and at our visit on the 5 th of that month the tarn was covered with a thick coating of ice, which had to be broken in order to permit of a gathering being made. Life, however, even under these adverse conditions, was found to be abundant. Hundreds of caddis-worms were busy constructing their tiny dwellings; beetles and curious-looking larval forms were largely in evidence; entomostraca were particularly lively and numerous; while desmids and diatoms, with a few of the motile algæ, were observed. That all had been stirred into unwonted animation by the mildness of the winter was very evident.

Before leaving this February gathering, some interesting "finds" then made may be briefly referred to. The first was a Water Boatman (Notonecta glauca), which had attached to the hinder part of its body a large number of young ostracods (Cyclocypris serena). The problem remains whether these ostracods were parasitic at this stage, or whether they had become attached to the beetle accidentally. We are not aware of such a case having been recorded. Another curious 


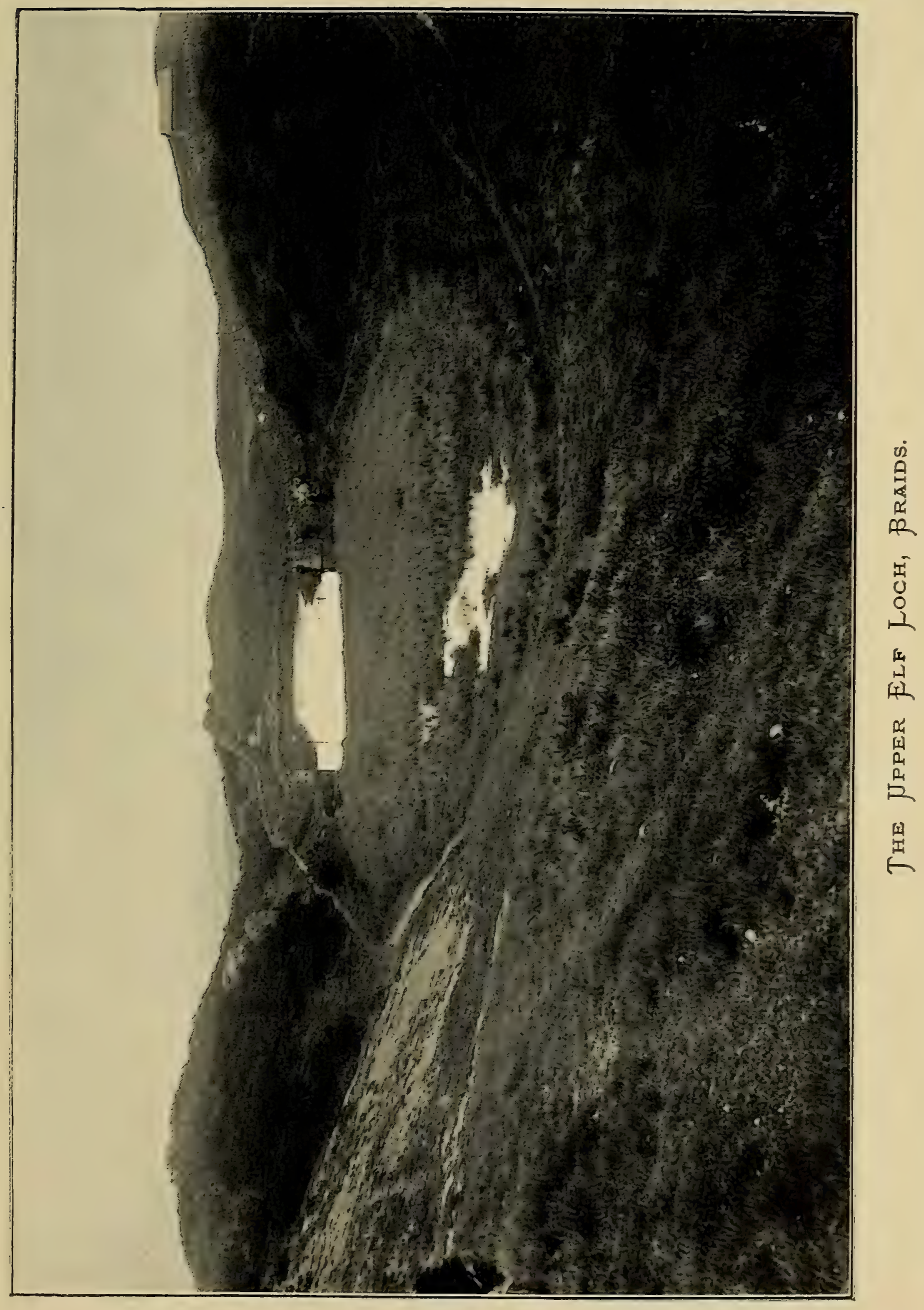



circumstance was the occurrence in the gathering of certain Entomostraca studded with an Epistylis - a ciliate infusorian allied to Vorticella. Of this remarkable combination there were numerous examples. The crustacean most particularly favoured in this respect was Cyclops strenuus, one of the species possessing long seventeen-jointed antennæ; and the infusorian clustered upon these antennæ from end to end, besides clinging to each side of the copepod's body, and even to the extremity of its long forked tail. Epistylis differs from Vorticella in being branched, with the calyces borne on short, non-contractile stalks; and it was a remarkable sight to witness a Cyclops with a hundred or more of these infusorians attached to it, while the young free-swimming "buds" of the Epistylis revolved round the crustacean. This case is not an uncommon one, the conditions requisite for its production being a shallow piece of water with a quantity of decayed or decaying vegetable matter covering the bottom. The infusorian thus readily joins itself to the crustacean, and neither seems to suffer from the strange "attachment." The Epistylis so attached was E. anastatica; but another species, E. leucoa, was found on a water-bug, as well as on the unprotected portion of the body of a caddis-worm.

The only addition to the flamentous algæ during the past year was Draparnaldia glomerata, which was rather scarce,indeed, with the exception of two or three of the commoner species of Spirogyra and Oscillaria, the members of this group are conspicuously absent in the Elf Loch. It is otherwise, however, with the motile or unicellular algæ, which are fairly abundant numerically, though not generically. Yet Volvox globator was not nearly so plentiful in 1897 as in the year previous; while in the present year, so far as yet observed, it is still scarce. This interesting alga is rather mysterious in its appearances and disappearances, and it almost seems as if some phases in its life-history were not yet perfectly understood. Our knowledge of the whole group of the motile algæ, indeed, is still in a very unsatisfactory condition. Saville Kent, in his 'Manual of the Infusoria,' regards Pandorina, for example, as synonymous with Eudorina; while Uroglena, Syncrypta, and some others, are said by him to be probably stages of development of Volvox or Pandorina. Some progress 
towards more exact knowledge has been made in recent years, though much yet remains to be done in this interesting field of study; and the worker in it will usually find abundant material in the Upper Elf Loch.

The Desmids have been increased during the past year by some additional forms, bringing up the list to eight genera and fifteen species. Three fresh species of Closterium were found, two of Cosmarium, and one each of Arthrodesmus, Pediastrum, and Ankistrodesmus, the last often now included amongst the Palmellaceæ. A few Diatoms have also been observed, including two species of Stauroneis and two of Navicula, with one species each of Pinnularia, Gomphonema, and Cymbella. The semi-stagnant condition of the water in this tarn no doubt accounts for such a paucity of Diatoms.

Coming to the unicellular Infusoria of the Animal Kingdom, we are met at the threshold by a similar state of matters to that which still prevails amongst the single-celled plants, seeing that "many of the reputed Infusoria may be but larval forms of higher organisms, instead of being themselves complete animals." 1 This group also furnishes a most interesting study for the microscopist, with its varied and beautiful forms, and its numerous problems still awaiting solution. No fewer than sixty-two species of Infusoria from this little hill-tarn have now been identified for us by $\mathrm{Mr}$ John Hood of Dundee, and forty-four of these have been added during the past year. Amongst the latter are three species belonging to a class not represented in our former paper-viz., the Tentaculifera or Suctoria. One of these, the "hairy-backed animalcule" (Chotonotus larus), is here included in this class, though some writers relegate it to the Turbellaria, and others to the Rotatoria, of which they regard it as an aberrant form. A very good description of Chætonotus, with figures, is given in the well-known 'Marvels of Pond-Life,' by Henry J. Slack, F.G.S.

While the Upper Elf Loch is thus abundantly supplied with representatives of the Infusoria, the members of the Rotifera present in it are yet more numerous. During the past year the following accessions have been made to their number. In the 1st order, the Rhizota, four additional species have been observed,--

'Carpenter's 'The Microscope and its Revelations,' 7th ed., p. 679. 
the Beautiful Floscule (Floscularia ornata); two of the Tubedwelling Rotifers (Melicerta ringens and M. tubicolaria); and what has been described as "perhaps the most beautiful of all the rotifers," Stephanoceros Eichhornii-a very rare rotiferon in Scotland. The 2nd order, the Bdelloida, has been increased by seven species; whilst the $3 \mathrm{rd}$ order, the Ploüma,- - the largest of all,-has had no fewer than sixty-six species added to it-making in all a record of ninety-seven species. Though none of these species are new to science, several of them are very rare. We are much indebted to $\mathrm{Mr}$ John Hood for his invaluable aid in the identification of the Rotifera,-a group with which he is so well acquainted. We have been favoured with the following notes by $\mathrm{Mr}$ Hood on three of the species enumerated in our list. The first refers to Euchlanis propatula (No. 48 of list), regarding which Mr Hood writes as follows :-

Mr Gosse was the first to describe this species (in 'The Rotifera, or Wheel-Animalcules,' vol. ii. p. 87), by the name of Diplois propatula, illustrated by two figures, a dorsal view and a lateral one. The dorsal view is a very good likeness of the creature, and a sufficient guide to its identity; but, on the other hand, the lateral view is very unsatisfactory, and not at all like it. It has been subsequently described by Dr Burn and Mr Bryce at its proper place in the genus Euchlanis. Its generic characters are undoubtedly those of a Euchlanis. Its ventral plate is a little larger than the dorsal one, which is quite the reverse of all the other species of the genus; but, notwithstanding this, the jaws, internal organs, and foot are those of a Euchlanis.

The next note refers to Salpina marina (No. 90 of list), which certainly calls for some explanation, as occurring here in a fresh-water loch. Mr Hood says :-

Mr Gosse has doubtless erred, at p. 39 of the Supplement to his monograph on the Rotifera, in placing this as a marine rotifer. The only example he described from was a dead one he found in a tube of water from the Firth of Tay which I sent him in 1886, and which contained Notholca spinifera and a few other marine forms. I have no doubt this Salpina had been introduced accidentally into the tube by me-possibly it had been in the dipper when I filled the tube with marine forms. I have never myself found a Salpina in a marine habitat.

The last note is on Triphylus lacustris, Huds. (Furcularia lacustris, Ehr.), (No. 97 of list), regarding which Mr Hood writes :-

This species has only recently been found in Britain. Dr Hudson placed 
it in a genus by itself, as it was not a Furcularia (in his Supplement to 'The Rotifera,' p. 19). It is a large and handsome species. Mr Western has found it in England, and I have found it in Scotland and in Ireland.

The mites are a group of the Arachnida, to which, unfortunately, very few workers devote themselves. Several genera and species are present in this sheet of water, but we have been unable to identify some of them. In two gatherings taken during the last year, a few specimens of a male or tailed swimming mite were found. The male mites are as rare as are the male Daphnias, to be afterwards referred to, amongst the Entomostraca; and they are, besides, so different in appearance from the round or female mites, that it is extremely difficult to pair them. The male mite found belonged to the Arrenuri (Arrenurus buccinator), and was a beautiful creature - the body blue, with tail yellow, shading off to deep orange, and the eyes bright vermilion. The spur on the last joint but two of the hind legs, characteristic of the male, was very large. The motions of the mites in the water are even and graceful,- - very unlike the jerky movements of the water-fleas, for example. It may be added that an insect found in the loch, or rather on its surface, which was very plentiful in some seasons, was the Common Water Spring-tail (Podura aquatica).

The study of the crustacean inhabitants of the Upper Elf Loch has proved very interesting. The following brief summary shows what has been done, and the results that have been obtained, in the course of our study of these organisms. Of the series of gatherings collected, twelve have been examined for crustacea. Four of these gatherings were made in 1896-in March, May, July, and October; six were collected in 1897-in March, May, June, July, September, and November; while in the present year (1898) one gathering was taken in February and another in April. The total number of crustacean species that have been obtained from these twelve gatherings is thirty-two. Sixteen species, or half of the total number, belong to the Copepoda, five to the Ostracoda, and eleven to the Cladocera. The Copepoda belong to two distinct groups-viz., the Cyclopidæ and the Harpacticidæ. The first is represented by nine and the second by 
seven species. No representatives of either the Amphipoda or Isopoda have been observed, though both Gammarus pulex and Asellus aquaticus are frequent enough in other parts of the Edinburgh district.

The greatest number of species observed in any single gathering was twenty-five; this gathering was collected in September 1897. The smallest number - twelve - was observed in a gathering collected in May 1896. Five species of the Entomostraca have been observed in every one of the twelve gatherings examined: the names of these species areCyclops viridis, C. bicuspidatus, Canthocamptus staphylinus, Cyclocypris serena, and Candona candida. Two speciesCyclops strenuus and Simocephalus veiulus-were observed in ten of the gatherings. Three species-Cyclops serrulatus, Alona quadrangularis, and Chydorus sphoricus-occurred in nine gatherings. Attheyella pygmoea, Cypria ophthalmica, Daphnia pulex, and Alonella nana-four species-were obtained in eight gatherings. Attheyella crassa and Alona guttata occurred in seven gatherings, Cyclops albidus and Cypris fuscata occurred in six, and Ilyocryptus sordidus in five. Cyclops vernalis, C. fimbriaius, Moraria Anderson-Smithi, and Graptoleberis testudinarius were observed in four gatherings; while Canthocamptus minutus was obtained in three. The following eight species were each observed twice-viz., Cyclops fuscus, C. affinis, Canthocamptus inornatus, Attheyella Zschokkei, Pionocypris vidua, Ceriodaphnia reticulata, Alona costata, and Chydorus barbatus.

With regard to the seasonal distribution of the Crustacea the following points may be noted. It has been already stated that five of the species obtained in the loch occurred in every one of the twelve gatherings examined. These gatherings were collected under very varying conditions of weather and temperature, as well as at different seasons of the year-for example, during the heat of midsummer, when the little loch was much contracted by drought and largely overgrown with vegetation; during the late autumn, when it was filled to overflowing with the autumnal rains and when the vegetation had to a considerable extent disappeared; and also during winter, when the only way in which a gathering could be taken was by breaking the ice that covered the 
surface of the water, to allow the hand-net to be introduced and worked underneath it, the ice at the time being fully half an inch in thickness. These five species may therefore safely be regarded as permanent inhabitants of the loch. Moreover, it will be observed that several other species have been obtained so frequently that they also may be expected to occur more or less constantly all the year round, and their absence from some of the gatherings may in some instances at least be accounted for by their being overlooked. But, on the other hand, though the non-occurrence of some species may be accounted for in this way, the intermittent appearance of others seems to require a different explanation. There are, for example, a few species, such as Cypris fuscata and Graptoleberis testudinarius, that appear to have a more or less regular seasonal increase and decrease. Cypris fuscata has been observed in spring and early summer, sometimes in considerable abundance: it was obtained in March and October 1896, in March and May 1897, and in February and April 1898 , but we failed to observe it on the 9 th of May and the 18th of July 1896 , as well as on our visits in June, July, September, and November 1897. Graptoleberis testudinarius differs somewhat from Cypris fuscata in its seasonal distribution. It was obtained in May and July 1896, and in July and September 1897, while no trace of it has been observed during the colder months. Another example of difference in seasonal distribution may be referred to, but in this case the difference is between species much more closely related to each other than Cypris fuscata and Graptoleberis testudinarius. Daphnia pulex ${ }^{1}$ and Simocephalus vetulus, which are both found in the Elf Loch, are so nearly related that they were formerly considered to belong to the same genus. In the gathering collected on the 9 th of May 1896, Daphnia pulex was common, but Simocephalus vetulus was rare. In the gathering collected on October 17 th of the same year, Daphnia is again predominant, and is recorded in our notes

I The Daphnia pulex found in the Upper Elf Loch is usually furnished with a moderately long and slightly curved posterior spine: this form has been described as a distinct species, under the name of Daphnia Schoedleri, but it is now regarded as merely a variety of Daphnia pulex. What is considered as the typical form of $D$. pultex has no elongate posterior spine, but the test terminates in an acute point. Like other Daphnias, it is extremely variable. 
as "frequent," while Simocephalus is described as "few." When, however, the records of the gathering collected on the 26 th of June 1897 are examined, it is found that Daphnia is now in the minority, and is described as "rare," while Simocephalus is "frequent." On the other hand, both species, in the gathering collected in February last (1898), are described as "rare." In addition to this apparently alternating increase and decrease in the numbers of certain species-an alternation which is probably due to seasonal variationanother interesting feature in the distribution of the Entomostraca has been observed, which it may be worth while to notice here. It was stated in our preliminary report, published last year, that a somewhat rare copepod known as Moraria Anderson-Smithi had been obtained in the Upper Elf Loch. The first time this copepod was observed here was on October 17, 1896 : it was again noticed in the gatherings collected on March 6, May 1, and June 26, 1897, but though it has been carefully searched for in subsequent gatherings, no trace of it, alive or dead, has been found. We cannot ascribe the disappearance of the copepod in these subsequent gatherings to any difference in the mode of collecting them, for the same method has been as far as possible adhered to throughout the whole series of visits we have made to the loch; and, on the other hand, we would hardly venture to assert that because we had not found this species in these gatherings it had therefore become extinct; but we think it is quite safe to say that, if it still exists in the loch, it must have become exceedingly rare. Moreover, if the appended tabular list of the Entomostraca obtained in the Upper Elf Loch be examined, it will be further observed that, shortly after the disappearance of Moraric Anderson-Smithi, another comparatively rare copepod-Canthocamptus inornatus - was obtained for the first time. This species, which occurred in the gathering collected on September 11, 1897, had only a few months previously been described by one of us as new to science, from specimens found in a loch in Forfarshire, and also in Linlithgow Loch. How this species happened to be introduced into the Upper Elf Loch, or, if usually present there, how it came to be so long overlooked, are questions more easily asked than answered. Canthocamptus inornatus 
is rather a distinct and readily recognised form, and was not at all rare in the September gathering referred to; yet, strange to say, the only time it has with certainty been noticed since was in the last gathering of the series, collected on the $23 \mathrm{rd}$ April last, when only one or two specimens were obtained. It may be stated in passing that Canthocamptus inornatus has also been recently, and for the first time, observed in Duddingston Loch.

These, then, are a few of the facts bearing on the distribution of the Entomostraca which our examination of this miniature loch has brought to light. They indicate how much interesting information a regular and systematic research, even of a very limited area, may yield. The curious, and apparently erratic, appearance and disappearance of the species we have specially referred to explains also to some extent why one collector may be more successful than another, or why the same collector may obtain a richer gathering at one time than at another.

As the study of the Entomostraca is now receiving greater attention, and many microscopists and pond-workers are doubtless desirous of becoming more familiar with them, the following notes on their reproduction may be of some little value to such amongst our own members. The reproduction and lifehistory of the Entomostraca have long engaged the attention of naturalists, and are still subjects of considerable interest to students of these crustaceans. The Cladocera, one of the more important orders of the Entomostraca, is of special interest, because of the peculiar reproductive processes observed. in several of the groups composing the order. Most part of the Cladocera are fresh-water organisms: a few of the genera, however, are marine, and species belonging to these marine genera are sometimes observed in immense numbers, so that the lack of variety in marine forms, as compared with those inhabiting the fresh waters, is somewhat compensated for by the greater number of individuals that are occasionally met with.

All, or nearly all, the fresh-water Cladocera produce two kinds of "eggs"- - viz., summer eggs, and winter- or restingeggs. The summer eggs are considered to be, not true eggs, but "buds," and they have received the name of "pseudova." 
In some of the Daphniadæ, and perhaps also in some of the other groups, broods of these pseudova are produced at more or less frequent intervals, and sometimes in considerable numbers during the life of the female; but in most of the Lynceidæ the production of summer eggs does not appear to be so frequent or so numerous. The winter- or resting-eggs - the latter name, as will be apparent from what follows, is the more appropriate one-are said to be true fertilised eggs, and they are produced usually towards the close of the life of the female, their production being her last efforts for the propagation of the species. In the Daphniadæ, and probably also in the Lynceidæ,-certainly in some of them,- - these resting-eggs are enclosed in a portion of the test of the mother that is somewhat modified for the purpose, and is technically called the ephippium (Gr. ephippion, a saddle, from its shape). Speaking generally, two resting-eggs are produced in the Daphniadæ, but only one in the Lynceidæ. These eggs appear as dark-coloured, or almost black, oval bodies, within the ephippium. The production of the ephippia is not limited to autumn or winter, as they may be produced at any season, just as the so-called summer eggs may be observed at all seasons-in winter as well as in summer. Resting-eggs, after being set free, and whether enclosed in a true ephippium or not, may, and frequently do, lie dormant for a considerable period, hence the name "resting-eggs." It is doubtful if the causes that in due time excite the active development of these resting-eggs are yet clearly understood: increase of temperature may have something to do with it. Ephippia enclosing one or two eggs are often met with by the pond-worker, and occasionally prove a source of perplexity: it is therefore hoped that what has just been stated as to their true character may prove useful to some.

Another interesting feature in the history of the Cladocera is the entire absence, or extreme rarity except at irregular and more or less distant intervals of time, of the males of many of the species. The Daphniadx may be referred to as furnishing examples of this phenomenon. The female Daphnia is frequently very prolific. She may develop brood after brood of young at short intervals for a considerable time, and these young, in their turn, may give birth to other 
young for several generations, while all the time not a single male may be observed. For this reason the female Daphnia has been regarded as parthenogenetic. The appearance of the males is not only irregular, but is also not limited to the autumn and winter months, as some have supposed. As a matter of fact, we have obtained them in July as well as in December, and they were even more numerous in the warm than in the cold months.

The young Entomostracan is usually very different in appearance from the adult, but in some groups the difference is less apparent than in others. One of the most interesting groups, in this respect, is that of the Daphniadæ, as some of them, and Daphnia especially, are subject to so much variation that there is still considerable doubt as to which are species and which mere varieties. Development and environment appear to have a modifying influence on the form of the Daphniæ, and even in some degree on their structure also, to a greater extent than on almost any of the other groups. It will thus be seen that the study of the Entomostraca, like so many of the other departments of nature, has its own diffculties and interesting problems, for the elucidation of which patient workers in larger numbers are needed.

In bringing these investigations to a close, we desire to emphasise the benefits to be derived from a continuous examination of a particular loch or pond. When such an examination is carried on throughout a whole year, or longer, not only seasonal variations may be noted, but the various phases in the life-history of a minute plant or animal come under one's observation, the cycle of growth and development is usually completed, and a more or less intelligent conception is gained of the various complex stages through which many, if not most, of these lowly organisms pass. That there must be a material gain in such a mode of procedure is evident. Patient observation of the processes of nature, as these go on silently around us, has its valuable uses, not to speak of its fascinations. In such a humble task as the repeated examination of even a hill-tarn, lessons can be learnt which may help to unlock some secret of nature never yet yielded up. 


\section{MICRO-FLORA AND MICRO-FAUNA OF THE UPPER ELF LOCH, BRAIDS.}

ALG正。

\section{COCCOPHYCE}

Volvocinece.

1. Chlamydococcus pluvialis, Cohn.

2. Gonium pectorale, Ehr.

5. Volvox globator, Ehr.

3. Pandorina morum, Bory.

4. Stephanosphæra pluvialis, Ehr.

\section{ZYGOPHYCE正.}

\section{Desmidiece.}

1. Ankistrodesmus falcatus, Ralfs.

2. Arthrodesmus octocornis, Ehr.

3. Closterium didymotocum, Corda.

4. " Ehrenbergii, Menegh.

5. " lineatum, Ehr.

6. " lunula, Ehr.

7. Cosmarium botrytis, Menegh.

8. Cosmarium cristatum, Ralfs.

9. " margaritiferum, Turp.

10. Euastrum didelta, Ralfs.

11. " oblongum, Grev.

12. Pediastrum De Barzanum.

13. " selenseum, Kutz.

14. Scenedesmus quadricauda, Breb. 15. Spondylosium pulchellum, Archer.

\section{SCHIZOPHYCER.}

\section{Diatomacece.}

1. Cymbella gastroides, Ag.

2. Diatoma elongatum, Ag.

3. " vulgare, Bory.

4. Gomphonema geminatum, Ag.

5. Navicula maxima, Ehr.

6. " Pinnularia major, Ehr.

7. Pinnularia viridis, W. Sm.

8. Stauroneis acuta, Ehr.

9. Stauroneis pulchella, Ehr.

\section{PROTOZOA.}

\section{RHIZOPODA.}

AMÆBEA.

1. Amœba princeps, Ehr.

2. " proteus, Leidy.

3. " radiosa, Ehr.

4. Amœba Schultzii, Ehr.

5. Difflugia globulosa, Duj.

6. " pyriformis, Perty.

\section{INFUSORIA.}

\section{Ciliata.}

1. Amphileptus gigas, C. \& L.

2. Aspidisca costata, Duj.

3. Carchesium polypinum, Linn.

4. Coleps hirtus, Ehr.

5. Colpidium cucullus, Schrank.

6. Epistylis anastatica, Linn.

7. " flavicans, Ehr.

8. " leucoa, Ehr.

9. Halteria grandinella, Müll.

10. Holophrya ovum, Ehr.

11. Kerona polyporum, Ehr.

12. Loxophyllum meleagris, Ehr.

13. Onychodromus grandis, Stein.

14. Oxytricha fallax, Stein.

15. Paramocium aurelia, Ehr.

16. Paramœeium bursaria, Ehr.

17. Prorodon niveus, Ehr.

18. Stentor igneus, Ehr.

19. " polymorphus, Müll.

20. Stichotricha remex, Huds.

21. Strombidium Claparedi, Kent.

22. Stylonychia mytilus, Ehr.

23. Trichodina pediculus, Ehr.

24. Uroleptus gibbus, C. \& L.

25. " piscis, Müll.

26. Vorticella alba, From.

27. " campanula, Ehr.

28. " communis, From.

29. " nebulifera, Ehr.

30. " nutans, Ehr, 


\section{Flagellata.}

32. Anisonema grande, Ehr.

33. " ludibundum, Kent. 34. " truncatum, Stein.

35. Anthophysa vegetans, Müll.

36. Chilomonas cylindrica, Ehr.

37. Cladonema laxa, Kent.

38. Codosiga botrytis, Ehr.

39. Dinobryon sertularia, Ehr.

40. " stipitatum, Stein.

41. Dinomonas vorax, Kent.

42. Diplomastix saltans, Ehr.
43. Euglena spirogyra, Ehr.

44. " viridis, Ehr.

45. Eutreptia viridis, Perty.

46. Lophomonas blattarum, Stein.

47. Phacus longicaudus, Ehr.

48. " pyrum, Stein.

49. " triqueter, Ehr.

50. Podostoma filigera, C. \& L.

51. Spongomonas discus, Stein.

52. Syncrypta volvox, Ehr.

53. Synura uvella, Ehr.

54. Uroglena volvox, Ehr.

\section{Cilio-Flagellata.}

55. Gymnodinium roseolum, Sichner.

56. Mallomonas Plosslii, Perty.

57. Mitophora dubia, Perty.

58. Peridinium apiculatum, Ehr.

59. " tabulatum, Ehr. 60. Stephanomonas locellus, From. 61. Trichonema hirsuta, From.

IV. SUCTORIA.

62. Chætonotus larus, Ehr.

| 63. Podophrya cyclopum, C. and L.

64. Podophrya fixa, Müll.

\section{METAZOA.}

\section{ANNULOSA.}

\section{ROTIFERA.}

Order 1. Rhizota.

1. Floscularia cornuta, Dobbie.

2. " cucullata, Hood.

3. " ornata, Ehr.

4. Melicerta ringens, Schrank.

5. " tubicolaria, Ehr.

6. Stephanoceros Eichhornii, Ehr.

ORDER 2. Bdelloida.

7: Actinurus neptunius, Ehr.

8. Callidina bidens, Gosse.

9. " elegans, Ehr.

10. Philodina citrina, Ehr.

11. " megalotrocha, Ehr.
12. Philodina roseola, Ehr.

13. $"$ tuberculata, Gosse.

14. Rotifer hapticus, Gosse.

15. " tardus, Ehr.

16. " trisecatus, Weber.

17. Rotifer vulgaris, Schrank.

Order 3. Piö́ma.

18. Anurra aculeata, Ehr.

19. " brevispina, Ehr.

20. " cochlearis, Ehr.

21. " serrulata, Ehr.

22. Brachionus angularis, Gosse.

23. " arceolaris, Ehr.

24. Cathypna luna, Ehr.

$25 . \quad$ " rusticula, Gosse.

26. Colopus brachyurus, Gosse.

27. " porcellus, Gosse.

28. Colurus caudatus, Ehr.

29. " deflexus, Ehr.

30. " obtusus, Gosse.
31. Copeus caudatus, Ehr.

32. " cerberus, Gosse.

33. " deflexus, Ehr.

34. " pachyurus, Gosse.

35. Diaschiza exigua, Huds.

36. " Hoodii, Gosse.

37. " semi-aperta, Gosse.

38. it tenuior, Gosse.

39. Diglena biraphis, Gosse.

40. " catellina, Ehr.

41. " giraffa, Gosse.

42. Dinocharis poecillum, Ehr.

43. " tetractis, Ehr. 
44. Distyla Gissensis, Eckstein.

45. Eosphora aurita, Gosse.

46. Euchlanis lyra, Huds.

47. " oropha, Gosse.

48. - " propatula, Bryce.

49. " triquetra, Ehr.

50. Furcularia ensifer, Gosse.

51. " giraffa, Gosse.

52. " gracilis, Gosse.

53. " longiseta, Ehr.

54. Hydatina senta, Ehr.

55. Mastigocerca bicristata, Hood.

56. " carinata, Ehr.

57. " lophoëssa, Gosse.

58. " macera, Gosse.

59. " " rattus, Ehr.

$60 . \quad$ Scipio, Gosse.

61. Metopidia acuminata, Ehr.

62. " emarginata, Gosse.

63. " lepadella, Ehr.

64. " oxysternum, Gosse.

65. " solidus, Gosse.

66. Microdon clavus, Ehr.

67. Monostylla bulla, Gosse.

68. " cornuta, Ehr.

69. " lunaris, Ehr.

70. Noteus quadricornis, Ehr.
71. Notholca Leptodon, Spencer.

72. " longispina, Kell.

73. Notommata aurita, Ehr.

74. " lacinulata, Ehr.

75. " ovulum, Gosse.

76. $\quad$ " tripus, Leidig.

77. Pleurotrocha gibba, Ehr.

78. Polyarthra aptera, Hood.

79. Proales gibba, Ehr.

80. " sordida, Gosse.

81. Pterodina patina, Ehr.

82. " valvata, Huds.

83. Rattulus calyptus, Ehr.

84. " cimolius, Gosse.

85. " tigris, Müll.

86. Sacculus cuirassis, Hood.

87. Salpina brevispina, Ehr.

88. " eustala, Gosse.

89. " macracantha, Gosse.

90. " marina, Gosse.

91. " mucronata, Ehr.

92. " spinigera, Ehr.

93. Scaridium eudactylotum, Gosse.

94. Stephanops armatus, Huds.

95. Synchæta tremula, Ehr.

96. Taphrocampa annulosa, Gosse.

97. Triphylus lacustris, Huds.

\section{ENTOMOSTRACA.}

\section{COPEPODA.}

1. Attheyella crassa (G. O. Sars).

2. " pygmæa (G. O. Sars).

3. " Zschokkei (Schmeil).

4. Canthocamptus inornatus, T. Scott.

5. " minutus, Claus.

6. " 1 staphylinus (Jurine).

7. Cyclops affinis, G. O. Sars.

8. " albidus (Jurine).

9. " bicuspidatus, Claus.

10. Cyclops fimbriatus, Fischer.

11. " fuscus (Jurine).

12. " serrulatus, Fischer.

13. " strenuus, Fischer.

14. " vernalis, Fischer.

15. " viridis (Jurine).

16. Moraria Anderson-Smithi, T. and A. Scott.

\section{Ostracoda.}

17. Candona candida, Müller.

18. Cyclocypris serena (Koch).

19. Cypria ophthalmica (Jurine).

20. Cypris fuscata, Jurine.

21. Pionocypris vidua (Müller).

\section{Cladocera.}

22. Alona costata, G. O. Sars.

23. " guttata, G. O. Sars.

24. " quadrangularis (Müller).

25. Alonella nana (Baird).

26. Ceriodaphnia reticulata (Jurine)

27. Chydorus barbatus (Brady).
28. Chydorus sphæricus (Müller).

29. Daphnia pulex, De Geer.

30. Graptoleberis testudinarius (Fischer).

31. Ilyocryptus sordidus (Liévin).

32. Simocephalus vetulus (Mïller). 
TABLE OF SEASONAL VARIATIONS IN THE ENTOMOSTRACA.

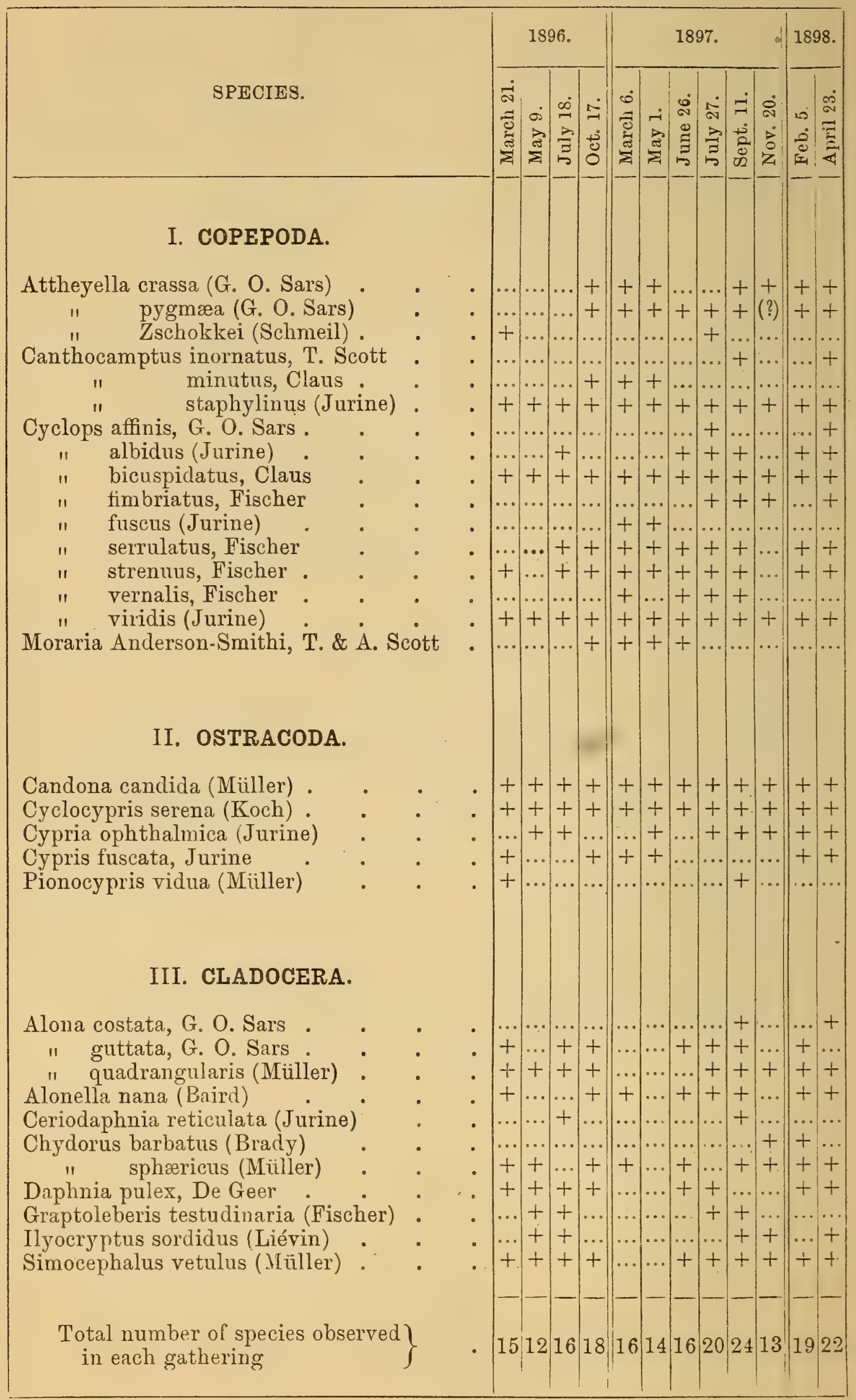


$\because$ 

From the Transactions of the Natural History Society of Glasgow, Vol. V. (New Series), Part II., I897-98.

\section{NOTES ON THE MICRO-FAUNA OF AILSA} CRAIG, FIRTH OF CLYDE.

THOMAS SCOTT, F.L.S., CORRESPONDING MEMBER. 



\section{Notes on the Micro-fauna of Ailsa Craig, Firth of Clyde.}

By Thомаs Sсотт, F.L.S., Corresponding Member.

[Read 30th Noviember, 1897.]

There was published in 1895, by the Rev. Robert Lawson, of Maybole, a new and enlarged edition of a rather interesting brochure on the History and Natural History of Ailsa Craig. This "lonely isle of the sea" is fully described by Mr. Lawson, and as the description is written in a plain and easy style, and illustrated by a series of fairly accurate and characteristic woodcuts, the wayfarer who happens to be stranded on the Craig, and who has a copy of this little book as companion and guide, will have his visit made both interesting and instructive. In that portion of the little work which deals with the natural history of Ailsa Craig, Mr. Lawson gives an account of its avi-fauna, and there is also an extensive list of plants, including both phænogams and cryptogams, that were collected on the island by the late Professor Balfour and a party of students in 1845; but there is very little information about any of the other natural history groups. Reference is made to the occurrence of the Slow-worm and a few other organisms, but that is all. It may be that the apparent barrenness of the rock has stood in the way of a very minute examination being made of it, or perhaps the interest in its bird-life may have usually monopolised the time of visitors with a taste for natural history pursuits; but, whatever be the reason, little appears to have been done in the investigation of its invertebrates. Like the Bass Rock, in the Firth of Forth, Ailsa Craig is, no doubt, pre-eminently the home of the sea birds, and truly, if during the breeding season one takes a cruise round the island, and views the great multitude of birds, watches their ceaseless activity, and listens to the strange sounds produced by the blending of their varied and incessant cries, the whole forms a combination indescribable, and as each moment brings into view some new and interesting scene, words fail to describe one's 


\section{TRANSACTIONS, NATURAL HISTORY SOCIETY OF GLASGOW.}

feelings, and silence becomes the truest exponent of our admiration and of the thoughts that elbow each other through the mind.

During the past two years I have had an opportunity of being at least twice ashore on the Craig, and my object in visiting it was partly to have a look at close quarters at the source from whence come the famous curling-stones, and partly to ascertain what kinds of Entomostraca and other crustacean species were to be found on its shores, or in the springs or pools of water that I had heard of as occurring on the island, but no special effort was made on these occasions to examine generally either the fauna or the flora. Moreover, the only part of the rock that has been visited by us hitherto is the south end, from Stranny Point on the west to the Lighthouse on the east. The last time I was ashore this vear was on the Queen's Birthday. A strong wind had been blowing all the previous night, and our little vessel, the s.s. "Garland," had been obliged to seek shelter under the lee of the Craig; but towards afternoon the wind abated considerably, and, as the sky was clear, the weather at the south end, where we were sheitered from the wind, was warm and pleasant. Taking advantage of such a favourable opportunity, and accompanied by the genial skipper of the "Garland," I paid a short visit to the island. On shore, insects of various kinds were taking advantage of the pleasant sunshine to fulfil their life work, and one of the more common among them was the beetle known as the Seven-spotted Lady-bird (Coccinella septempunctata, Linn.). Silpha thoracica, Linn., and a few other beetles were also observed, but were much scarcer than the lady-bird. The small white butterfly was flitting about among the rank vegetation, and under some of the stones that were turned over in searching for Slow-worms a few Centi pedes and Millepedes were noticed. Land mollusks, which art probably not very common on Ailsa Craig, were also occasionalls observed during our visit, and comprised such forms as Heli nemoralis, Linn., Hyalinia alliaria, Miller, Pupa cylindracea, Div Costa, and Clausilia rugosa, Draparnaud, but the weather conditions, though pleasant, were not very favourable for shell-hunting, and in my experience it is not unusual to find that a locality which at one time may appear to be unproductive will at another time, when more favourable conditions prevail, be thronged with living creatures. 
I have already stated, however, that my chief purpose for going ashore was to ascertain if there were any land or fresh-water Crustacea on the island, and, if so, what kinds they were. On my previous visit, I had examined some pools of water at the foot of the southern cliffs, but had only found the worm-like larvæ of insects in myriads - no Entomostraca were observed; indeed, had an Entomostracan happened to get into any of these pools, it would, no doubt, among such a ravenous crowd, have met with a short shrift. None of these pools was examined on our last visit, as it was considered that an attempt should rather be made to reach the so-called Garry Loch, which is situated fully midway up towards the top of the Craig, and therefore, acting on the instructions of the lighthouse keepers, whom we found most obliging, we selected the pathway that leads in a slanting direction up to the "Castle," as being, so far, the safest and most easy towaràs our goal. On reaching the sort of plateau on which the castle stands, a well in the vicinity of the castle was examined, but no Entomostraca were observed in it; the water was clear and cool, and almost devoid of animal life-at least such as could be seen with a hand lens. After a look at the old castle-near which, by the way, was a luxuriant bed of Wild Hyacinths in full bloom, a few of the flowers being pure white-we proceeded to the Garry Loch; and if the climb up to the castle was stiff, the path (if it could be called so) from thence to the loch was more so. We proceeded by what appeared to be the most direct route, but, whether it may have been so or not, we soon found that it was a rough road to travel. On reaching our destination, however, we considered ourselves repaid for all the trouble we had experienced in getting to it. The "Loch" occupies a nook which is surrounded on all sides, except the north, or north-east, by grassy and mossy banks, and only required a few bushy trees to be a typical "fairy dell." A large portion of the hollow is now filled up (forming a carpet soft and restful for the weary foot), and the loch is consequently reduced, especially in summer, to very small dimensions. The Marsh Marigolds referred to by Mr. Lawson were, at the time of our visit, in considerable abundance, and their golden flowers, which in the genial sunshine had expanded to their fullest extent, made the scene, though limited, very gay. It would appear that the loch was originally comparatively deep, for 
the moss, which to so large an extent, now zeplaces the water, has, according to Mr. Lawson, been probed to the depth of seventeen feet without touching the rock. With a hand-net I made a careful investigation of all that was left of the loch; and sometime afterwards, when the gathering I had collected was examined, some fairly interesting results were obtained. It was found that Entomostraca were moderately common in the gathering, though only four species were represented; it was also found that the species obtained were equally divided between the Copepoda and the Cladocera, and, moreover, that the two Copepods represented two very different groups, viz., the Cyclopidæ and the Harpacticidæ. One of the Copepods was Cyclops bisetosus, Rehberg, a species that was added to the British fauna a few years ago by Mr. D. J. Scourfield, of Ieytonstone, Essex, and has only recently been observed in Scotland. The other Copepod was Moraria AndersonSmithi, T. and A. Scott, which was first noticed in Scotland in 1892, in a gathering of shallow-water Entomostraca from Loch Morar, Inverness-shire. Our success in the examination of that loch was due, partly at least, to the active interest taken in our work by Mr. Anderson Smith, Ledaig, who was then a member of the Fishery Board for Scotland. Moraria Anderson-Smithi, T. and A. Scott, has, since its discovery in Loch Morar, been observed in several other places, and appears to be more or less generally distributed throughout Scotland-it was quite frequent in the gathering from the Garry Loch. The two species of Cladocera obtained in Garry Loch were Chydorus sphcericus, Müller, a common and widely-distributed species, and Alona rustica, T. Scott, which appears to be rare. Alona rustica was described in 1894 from specimens obtained in a collection of Entomostraca sent to me from Shetland, and has been observed in one or two other places since, but is always very scarce. Specimens of water mites, water beetles, and some other creatures were also noticed, and are included in the appended list, so far as they have been identified.

If the Garry Loch could have been examined towards the end of summer, it is quite possible that other Entomostracan species might have been obtained in it, as we find that different seasons frequently give different results; and also, if a thorough examination of the debris at the foot of the cliffs and of the more 
accessible parts of the hill could be made at suitable seasons of the year, the list I now give might be considerably extendeà.

I may say, before concluding these "Notes," that I was not aware of Mr. Lawson's interesting History till just after our last visit to Ailsa Craig, and was under the belief that its natural history was better known than a perusal of Mr. Lawson's work appears to indicate, otherwise a more careful search of that part of the Craig visited by us would have been made, and greater attention given to the numerous creatures we saw during the time we were ashore

In the following list, which includes all the invertebrates observed by us, I am responsible for the names of the Mollusca and Crustacea ; my friend Mr. Percy H. Grimshaw, F.E.S., of the Museum of Science and Art, Edinburgh, very kindly favoured me with the names of the Coleoptera and of the single species of Hymenoptera that was obtained; several other organisms that were met with have not yet been fully identified, and are referred to only by their family or generic names.

List of Invertebrata observed on Ailsa Craig, Firth of Clyde, as explained in the preceding "Notes":-

\section{MOLLUSCA.}

Hetix nemoralis, Linn., with dark bands.

Helix nemoralis, Linn., yeilow, and without bands.

Hyalinia alliaria (Miller) = Zonites alliarius of Jeffrey's "Conchology."

Pupa cylindracea, Da Costa, = Pupa umbilicata, of Jeffrey's

"Conchology."

Clausilia rugosa, Draparnaud.

\section{CRUSTACEA.}

ISOPODA.

Oniscus asellus, Linn.

Porcellio scaber, Latreille.
COPEPODA.

Cyclops bisetosus, Rehberg.

Moraria Anderson-Smithi, T. and

A. Scott.

Cladocera.

Alona rustica, T. Scott.

Chydorus sphcericus, Müller. 


\section{INSECTA.}

* Co L e OPT TR A.

Silpha thoracica, Linn.

Melanophthalma fuscala, Humm. Coccinella septempunctata, Linn. Agabus bipustulatus, Linn.

Philhydrus melanocephalus, Olivi.

HyMeNoptera.

Homalomyia canalicularis, Linn.

LEPIDOPTERA.

Small white butterfly (? Pieris rapa).

Hemiptera.

A species of "Boat-fly" (Corixa sp.).

Thysanura.

(?) Podura sp.
Arachnida.

A few "water mites."

MYRIAPODA.

Lithobius sp.

Iulus sp.

Adaitional notes.-(1) In Pennant's "Tour in Scotland," fourth edition, vol. ii., p. 190, that author, in referring to his visit to Ailsa Craig, says, inter alia_ "Three reptiles appeared here very unexpectedly, the naked black snail, the common and the striped shell snail: not volunteer inhabitants, but probably brought in the salads of some visitants from the neighbouring shores."

(2) My friend, Mr. James Steel, informs me that he observed the Wood Tiger Moth (?) Chelonia plantaginis, Linn., on one of his visits to Ailsa Craig, which adds still another to our list of invertebrates.

(3) I find, on looking through some literature relating to the West of Scotland, that two other and former members of this Society have taken a considerable interest in Ailsa Craig and its natural history, viz., Mr. Robert Gray, who studied its bird life, and Mr. Newton MacCartney, who examined its geological structure, and also in 1864 (according to Dr. Bryce) made a careful investigation of its plants, but apparently no systematic study of its invertebrates has hitherto been taken in hand, yet the study of these might prove to be as interesting as the others.

* At the meeting of the Society on 25th January, 1898, Mr. Anderson Fergusson exhibited the following additional species of Coleoptera from Ailsa Craig, viz., Byrrhus pilula, Linn., Otiorhynchus blandus, Gyll., and O. rugifrons, Gyll. 


[Reprinted from "The Annals of Scottish Natural History," October I 899.]

SOME NOTES ON THE FRESH-WATER ENTOMOSTRACA OF ABERDEENSHIRE

By THOMAS SCOTT, F.L.S. 


\section{The Annals}

\section{OF. \\ Scottish Natural History}

A QUARTERLY MAGAZINE WITH WIIICH IS INCORPORATEL

\section{"The Scottigh "Itaturalist"}

\section{EDITED BY}

J. A. HARVIE-BROWN, F.R.S.E., F.Z.S. Member of the British Ornithologists' Union

JAMES W. H. TRAIL, M.A., M.D., F.R.S., F.L.S. Professor of Botany in the University of Aberdeen and

WILLIAM EAGLE CLARKE, F.L.S., MEM. BRIT. ORN. UNION Natural History Department, Museum of Science and Art, Edinburgh

EDINBIJRGH : DAVID DOUGLAS, CASTLE STREET 
[Reprinted from "The Annals of Scottish Natural History," October 1899.]

SOME NOTES ON THE FRESH - WATER ENTOMOSTRACA OF ABERDEENSHIRE.

\author{
By Thomas SCotT, F.L.S., \\ Naturalist to the Fishery Board for Scotland.
}

THE fresh-water lochs of Aberdeenshire, though comparatively few in number, appear to contain as rich an entomostracan fauna as those of any other county in Scotland. In a gather- 
ing from one loch recently visited (Loch of Park), as many as forty-four species were obtained, while thirty-nine, thirty, and twenty-seven species respectively have been obtained in gatherings from other lochs.

I propose, in the following notes, to mention a few of the rarer or more interesting species that have been observed; and those that belong to the Cladocera will be referred to first, and afterwards those belonging to the Ostracoda and the Copepoda.

\section{THE CLADOCERA.}

The Cladocera obtained in gatherings recently collected, though perhaps not more numerous individually than the Ostracoda or the Copepoda, are represented by a greater number of species. All the families of the Cladocera, except the Holopedidae and Leptodoride, are represented, and both Holopedium and Leptodora may yet be found in some of the hill lochs, but as these are pelagic forms, a boat and tow-net may be required to capture them; the gatherings referred to in these notes are all shore gatherings.

The SIDADE are represented in recent gatherings by Sida crystallina (O. F. Müller) and Daphnella brachyura (Lievin), (or Diaphanosoma brachyurum as it is now called); the first is common in the Loch of Skene, and the other is equally common in Loch of Park. Latona setifera, another member of the same family, and much rarer than either of the two species just referred to, was also obtained in Loch of Park, as well as in a gathering from Corby Loch, but only one or two specimens of Latona were obtained in each of these gatherings.

The DAPHNID\& observed in recent gatherings include several interesting species, but I can only at present record three of them, viz. Ceriodaphnia laticaudata, P. E. Müller, Ceriodaphnia megalops, G. O. Sars, and Scapholeberis mucronata (O. F. Müller). The first, which has a comparatively broad and angulated post-abdomen, was obtained in Corby Loch. The second, which is the largest of the British species of Ceriodaphnia, and which occurred in a gathering from Loch of Park, has not previously been observed in Scotland; in this species the shell is distinctly but somewhat irregularly striate, after the manner of a Simocephalus - only females have been observed so far. The third (Scapholeberis) has been obtained in Loch of Skene, Loch of Park, and Corby Loch, and also in one of the ponds in Duthie Park. Amongst the specimens collected, some have the head rounded and without a tooth, others possess a vertex tooth which varies in length in different individuals, and the length of the posterior spines also varies more or less. 
The Bosminide. This family contains only one genus-Bosmina; specimens of the common $B$. longirostris (O. F. Müller) have been collected in ponds in the Duthie Park and in Loch Callater.

The LyNCODAPHNIDE are represented in the gatherings recently collected by, at least, three species, viz. Drepanothrix dentata (Euren), Acantholeberis curvirostris (O. F. Müller), and Ilyocryptus sordidus (Lievin). Drepanothrix was obtained in Bishop Loch and in Loch of Park: it is readily distinguished from its near allies by the hooklike process on the dorsal margin of the shell. The distribution of this species appears to be co-extensive with the British Islands. Acantholeberis was obtained for the first time in Aberdeenshire in a gathering of Entomostraca from Loch Callater, which Mrs. T. Wemyss Fulton kindly presented to me. Loch Callater, which is situated a few miles to the south of Braemar and near the road leading over the hills to Glen Dole and Glen Clova, has an elevation of considerably over a thousand feet above sea-level, and this adds very much to the interest of the gathering. The Acantholeberis was one of the most common of the species observed in the Loch Callater gathering, and many of the specimens were of large size and carried pseudova; the species has, more recently, been observed also in Bishop Loch near Parkhill. Ilyocryptus, the third Lyncodaphnid referred to,- - though not previously recorded from Aberdeenshire, probably occurs in most of the lochs of Scotland; its shell is usually more or less coated with mud, which prevents it from being readily noticed; it has been observed in Loch of Skene, in Corby Loch, and Bishop Loch.

The LXNCEIDE obtained in the Aberdeenshire lochs recently examined comprise several comparatively rare forms, and a few of these will now be referred to. Alona tenuicaudis, G. O. Sars, which is considered to be a rare species in Scotland, was obtained in a gathering from Loch of Park; in this species the post-abdomen is narrow and moderately elongate, the upper and lower margins are nearly parallel, and the marginal setæ are comparatively small except at the posterior angle at the base of the claw, where there are a few moderately long setæ. Alona rustica, T. Scott, was obtained in Bishop Loch. Alona intermedia, G. O. Sars, was also observed in this loch as well as in Corby Loch (this species is described in some of my previous papers as Alona neglecta, T. Scott). ${ }^{1}$ The very small, but pretty, Alonella nana (Baird) and Alonella exigua (Lilljeborg) ${ }^{2}$ were both obtained in Corby Loch and Bishop Loch, while the second was observed also in Loch of Skene. Pleuroxus uncinatus, Baird, Pleuroxus leèvis, G. O. Sars, and Pleuroxus trigonellus (Müller) were obtained in a gathering from Loch of

1 See remarks on this species in the "Seventeenth Annual Report of the Fishery Board for Scotland," part iii. p. 200 (I899).

2 See also remarks on this species, op. cit. p. $20 \mathrm{I}$. 
Park; P. uncinatus was also observed in Corby Loch. Chydorus barbatus (Brady) occurred in Loch of Skene, Bishop Loch, and Loch of Park.

The Polyphemide are represented by only one species-Polyphemus pediculus (Lin.), which occurred in all the lochs examined except Corby Loch. Bythotrephis longimanus, Leydig, another of the Polyphemidæ so common in some of the Lochs of Scotland, has not been observed in any of the Aberdeenshire lochs hitherto examined.

\section{THE OSTRACODA.}

Only eight species of Ostracoda have been observed in the gatherings of fresh-water Entomostraca recently collected, ail of which are moderately common. Cypris exculpta, Fischer, occurred in Loch of Skene, Loch of Park, and Corby Loch; Herpetocypris reptans (Baird) and Cypridopsis villosa (Jurine) were frequent in Loch of Park, while Limnicythere inopinata (Baird) was obtained in Corby Loch. In September I 890 I examined the north end of Loch Strathbeg, ${ }^{1}$ and obtained ten species of Ostracoda there; but, with the exception of Cypridopsis aculeata (Lillj.) and Ilyccypris biplicata (Koch), they are all similar to those recently observed. Only one species of Candona (Candona candida) has been observed in the lochs of Aberdeenshire hitherto examined.

\section{THE COPEPODA.}

The Copepoda obtained in the Aberdeenshire lochs recently examined comprise even a greater number of rare forms than those that have been found amongst the Cladocera, but these rare forms belong partly to the Cyclopidae and partly to the Harpacticida; the only Diaptomus observed hitherto is the common Diaptomus gracilis, G. O. Sars, which was moderately abundant in Loch of Skene, and was also obtained in Corby Loch and Bishop Loch. Amongst the Cyclopida, Cyclops dybowskiz, Lande, was moderately frequent in a gathering from Loch of Park; this species requires careful examination to distinguish it from Cyclops oithonoides, G. O. Sars. Loch Lomond is the only other loch in Scotland where I have obtained this species; it occurred there in a shore gathering collected to the south of Balmaha. Cyclops languidus, G. O. Sars, another rare species, was obtained in a gathering from Corby Loch; this Cyclops, which has the antennules sixteen-jointed, has only hitherto been observed in Scotland in Loch Doon in Ayrshire. Cyclops fuscus (Jurine) was obtained in a gathering from Loch of Park, so also were Cyclops macrurus, G. O. Sars, and Cyclops affinis, G. O. Sars;

1 See "Ninth Annual Report of the Fishery Board for Scotland," part iii. p. 282 (I 89 I). 
these three species of Cyclops, and especially the last two, are rare in the lochs of Scotland, and have not previously been recorded from Aberdeenshire. Cyclops varicans, G. O. Sars, which also appears to be a rare species in Scotland, has been observed in two of the gatherings collected recently, viz. in one from Loch of Skene and in another from Loch of Park. Cyclops phaleratus (Koch) was obtained in Loch of Skene and in Loch of Park; this species was also obtained many years ago, in a canal at Peterhead, by the late Dr. Robertson of Millport.

The following species belonging to the Harpacticida may now be mentioned. Canthocamptus minutus, Claus, occurred in gatherings from Loch of Skene, Corby Loch, and Bishop Loch. It is readily distinguished by the peculiar form of the caudal furca, and by the bifid spines that fringe the anal operculum; the species, though added to the British fauna only within recent years, ${ }^{1}$ seems to be widely distributed. Canthocamptus inornatus, T. Scott, was obtained in a gathering from Bishop Loch, in which it did not appear to be very rare; the species was described a few years ago from specimens gathered in Rescobie Loch, Forfarshire. Moraria anderson-smithi, T. and A. Scott, was also obtained in Bishop Loch; this species, though not previously recorded from Aberdeenshire, is widely distributed in Scotland and England. Marcenobiotus vejdovskii, Mrazek, which occurred in the gathering from Loch of Park, a locality that has also yielded not a few rare species of Cyclops, is, like most of the other Harpactids, a shore dweller. It was first observed in Scotland in a gathering collected on the north shore of Loch Vennachar, ${ }^{2}$ and afterwards in a shore gathering from Loch Doon, Ayrshire. This is now the third Scottish Loch in which the species has been observed. Mrazek obtained the species in Bohemia, and Mr. Bruce (of the Jackson-Harmsworth Expedition) collected it in fresh-water ponds in Franz Josef Land ; ${ }^{3}$ this seems to indicate that the species may have even a wider distribution than that now known to us.

The total number of entomostracan species obtained in the Aberdeenshire lochs recently examined reaches to over sixty; and, from the favourable appearance of the lochs already visited, there can be little doubt that this number will be largely increased. What at present appears somewhat noteworthy is the small number of the Ostracoda that have yet been observed. No species of Cypris (I use

1 "Ann. Scot. Nat. Hist.," July I895, p. I73, and Oct. I895, p. 236, Pl. IV. Figs. I4-20.

2 "Ann. and Mag. Nat. Hist." (6), vol. xviii. p. 3, Pl. I. Figs. I3-2I, P1. II. Fig. 23 (1896).

3 "Journ. Lin. Soc." (Zoology), vol. xxvii. p. 99, Pl. VI. Figs. I 2 - I 7 (I 899). 
this name in its recent restricted application) has been noticed, while Herpetocypris and Candona are represented by only one species each. As is well known, the distribution of the Ostracoda is even more erratic than that of the Copepoda or Cladocera ; and therefore, though apparently scarce at one time, at another they may be more or less common. This uncertainty in the distribution of these organisms, though at times somewhat disappointing, has one advantage: it tends to keep alive the interest in their study, as there is always the possibility that the results of the next gathering may be better than the last one. 



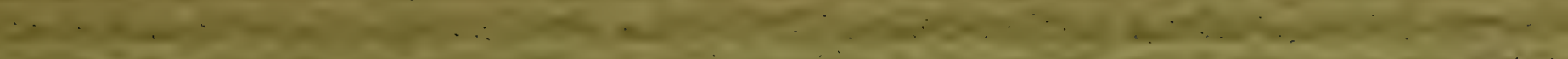

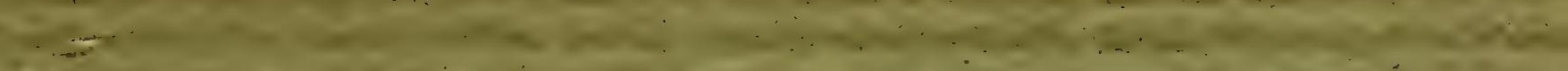

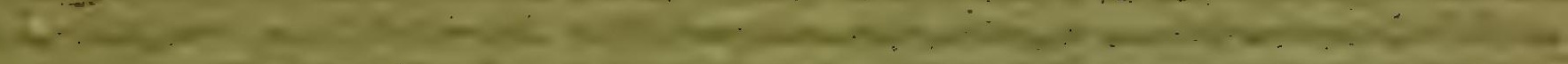

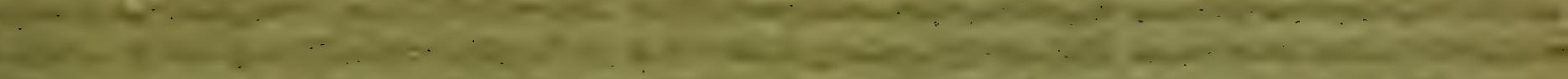

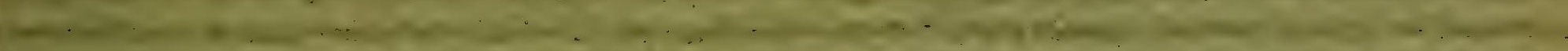
..

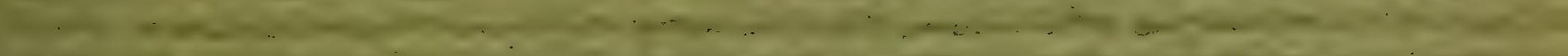

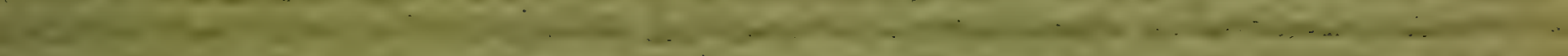

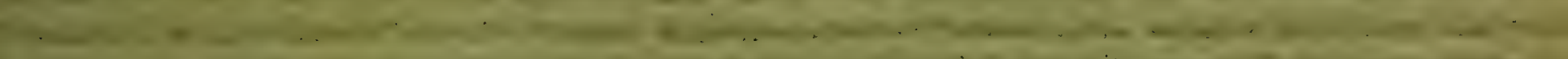

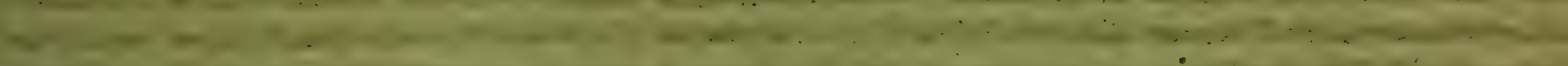

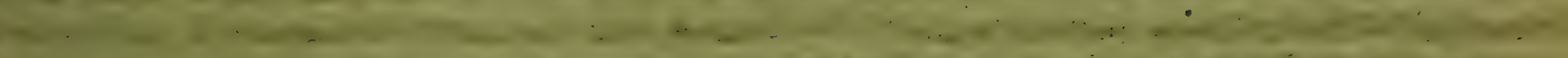

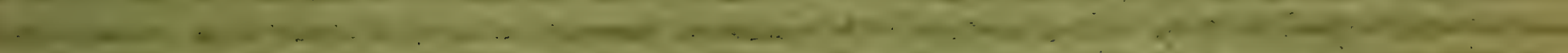

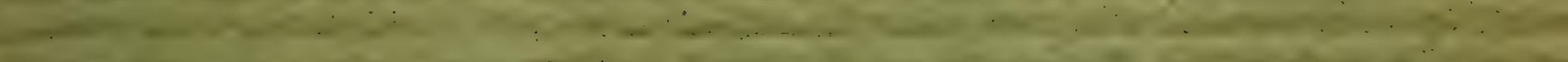

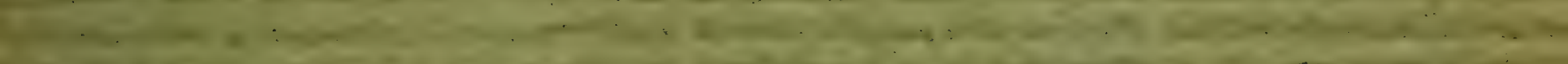

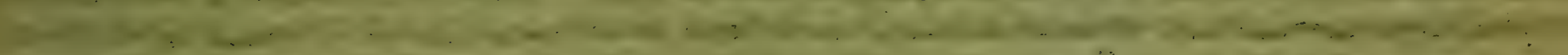

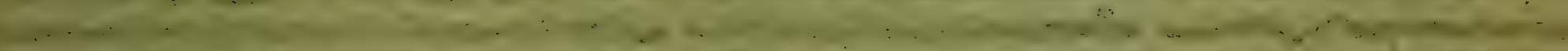

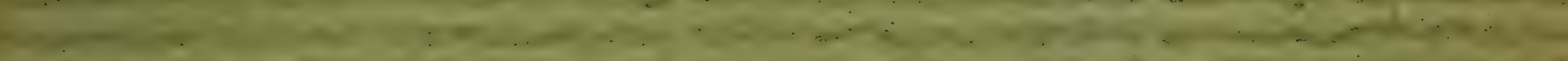

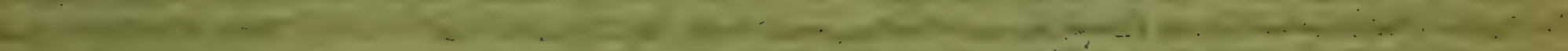

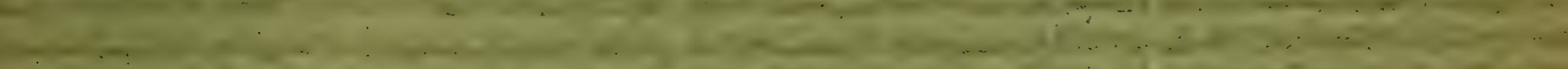

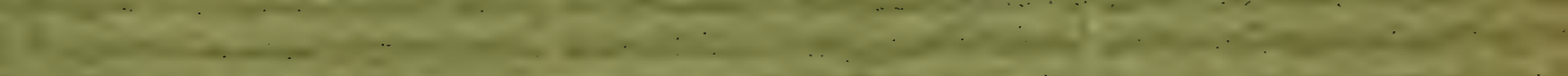

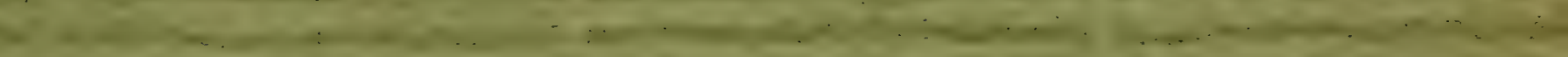

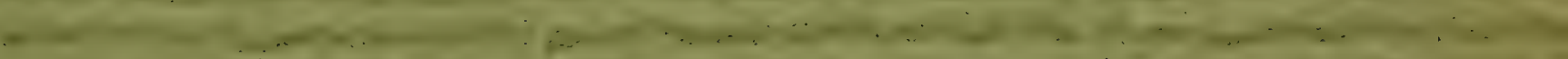

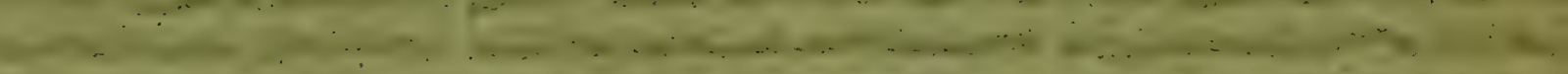
a

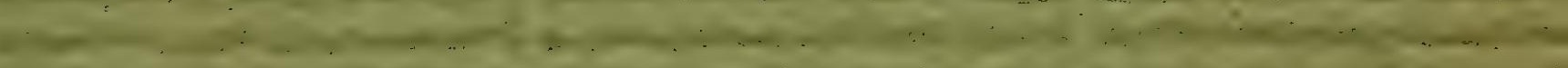

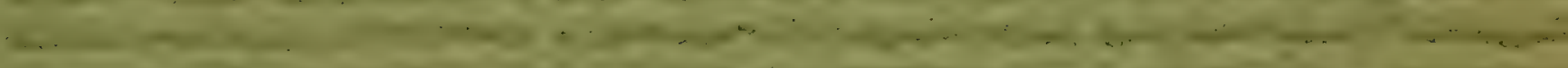

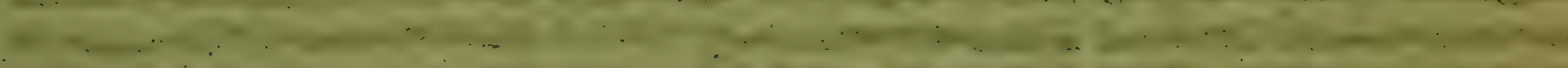

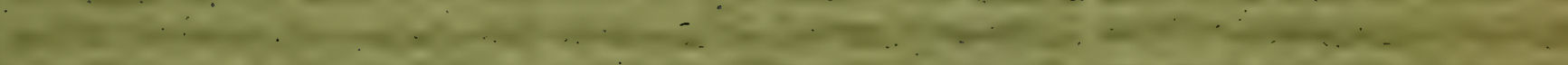

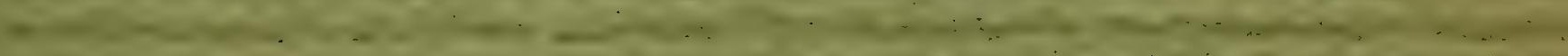

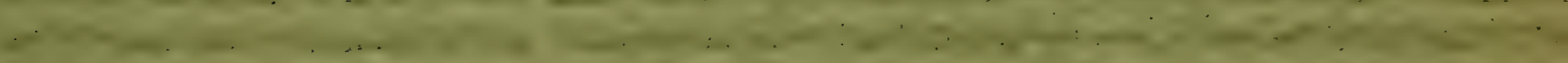

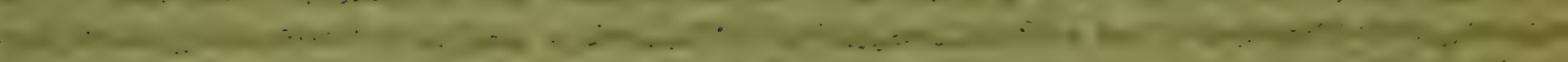

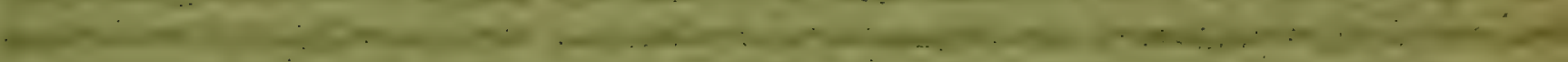

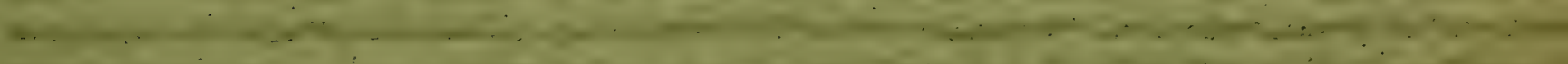

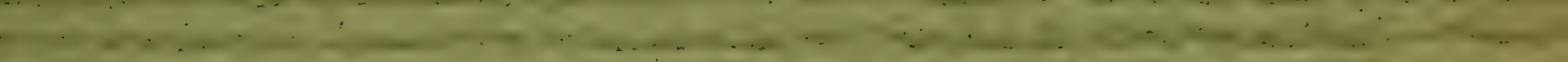

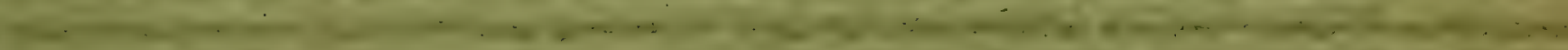

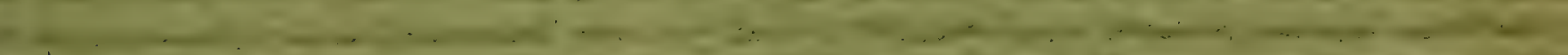

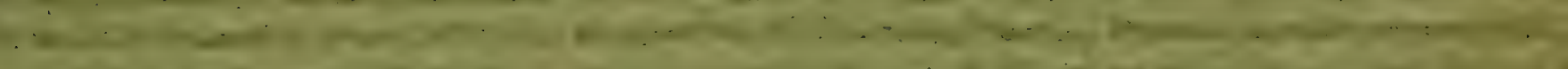

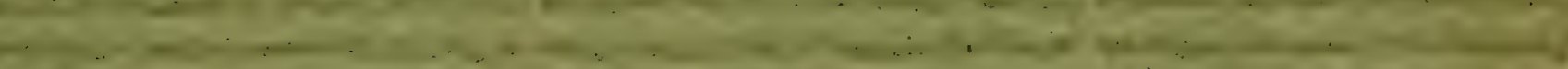

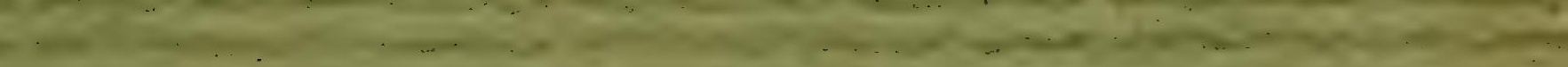

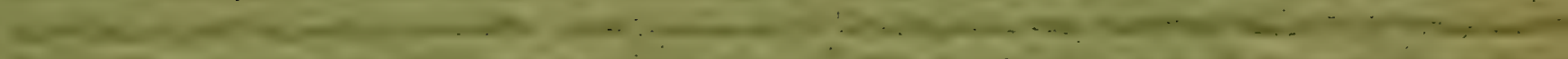

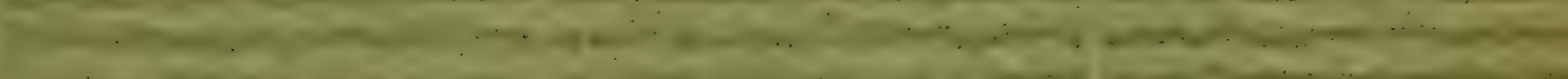

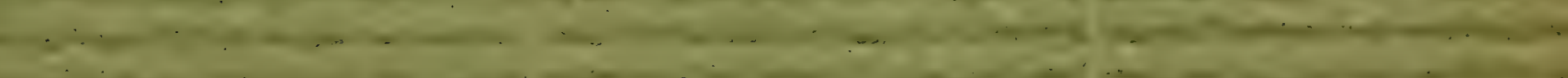

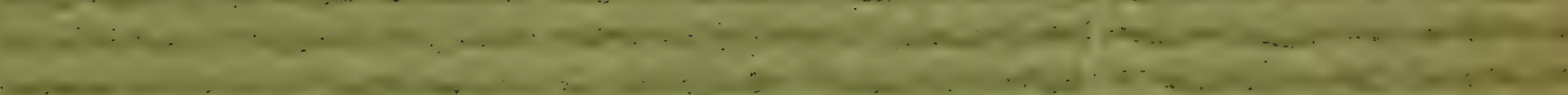

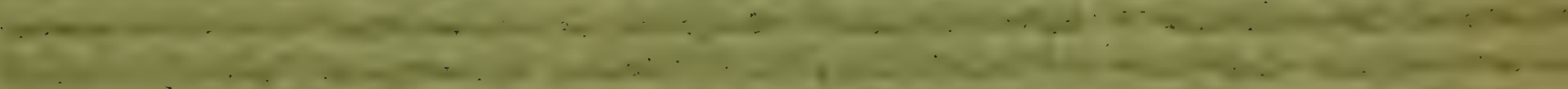

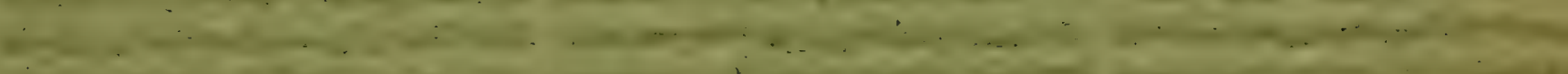

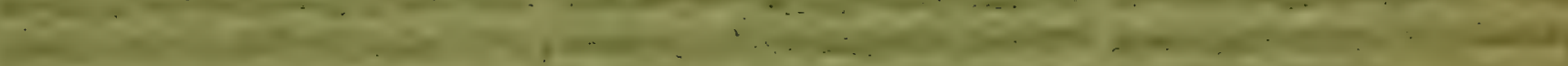

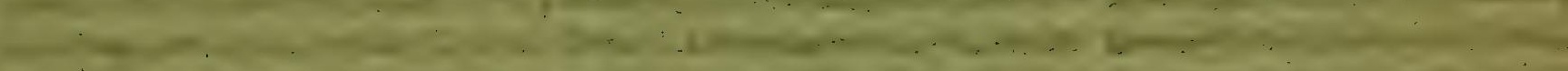

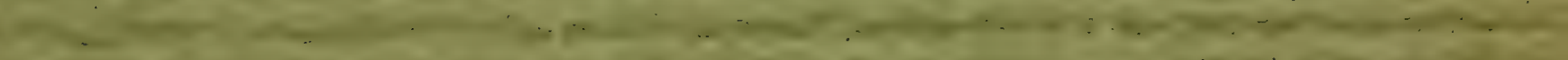

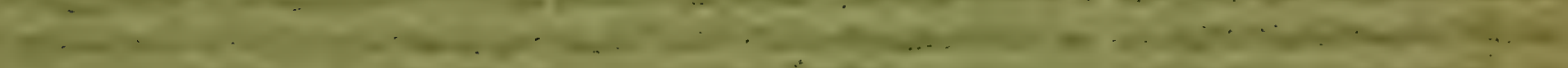

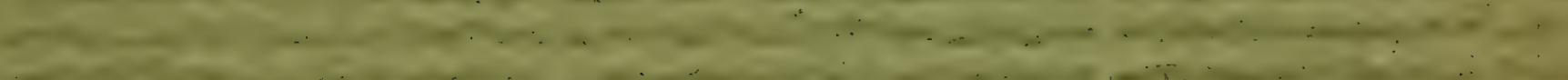

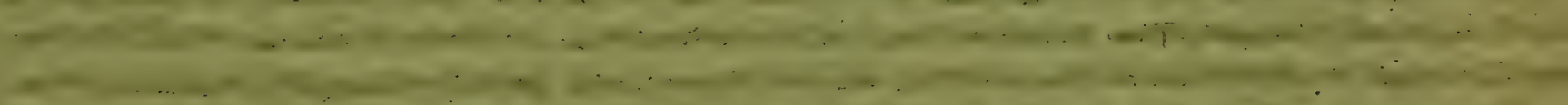

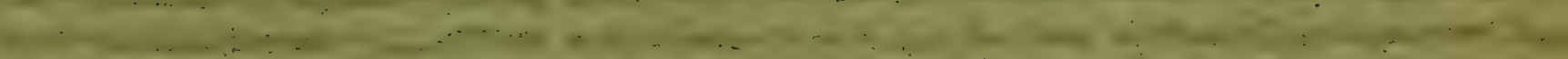

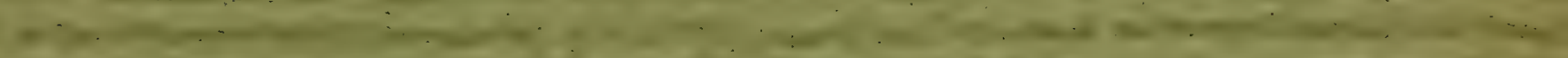

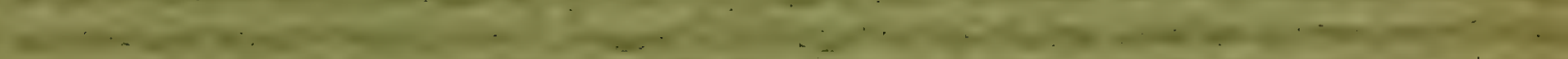

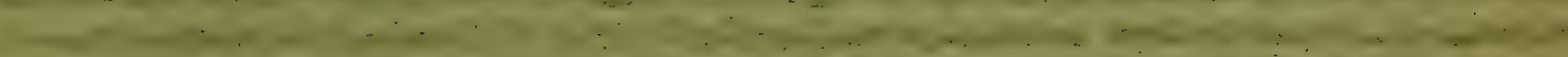

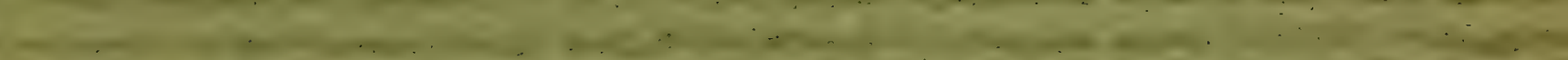

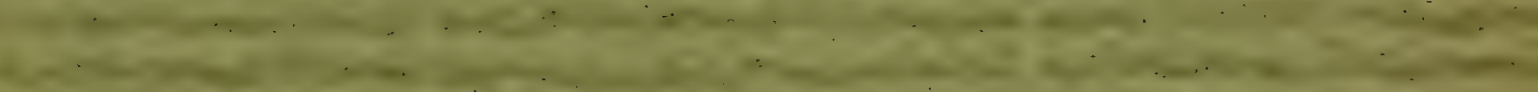

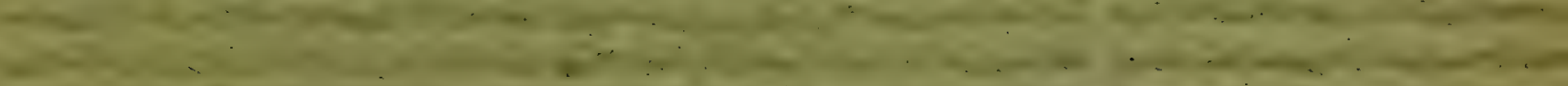

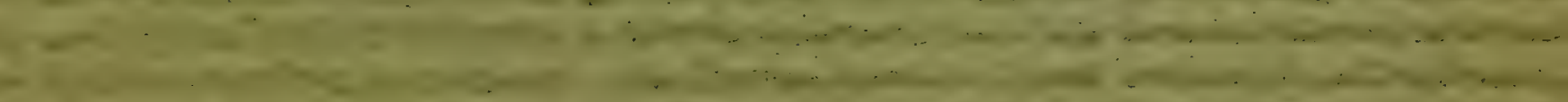

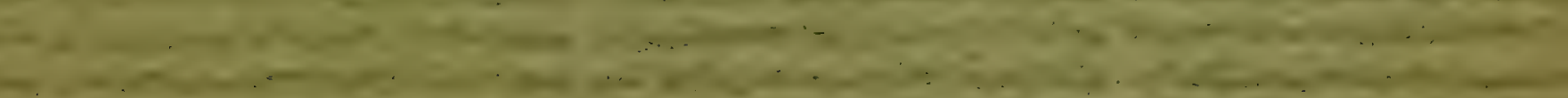

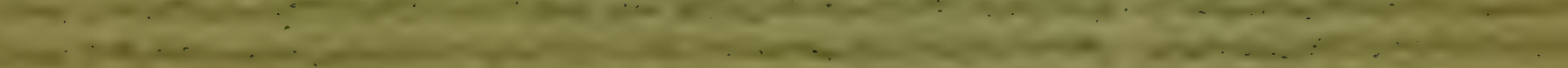

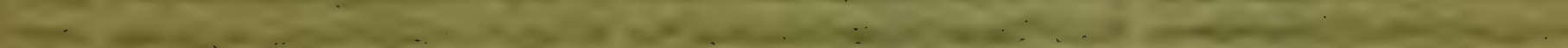




$$
\begin{aligned}
& \text { From the Transactions of the } \\
& \text { Natural History Society of Glasgow, } \\
& \text { Vol. V. (New Series), Part III., I898-99. }
\end{aligned}
$$

NOTES ON SOME CRUSTACEA FROM FAIRLIE AND HUNTERSTON, FIRTH OF CLYDE.

RY

\section{THOMAS SCOTT, F.L.S.,}

Men. Soc. Zool. De France, Naturalist to the Fishery BOARD FOR SCOTLAND.

Separate Copies-Issued April, rgoo. 



\title{
Notes on some Crustacea from Faiplie and Hunterston, Firth of Clyde.
}

\author{
By Tromas Scotт, F.L.S., Mem. Soc. Zool. de France, Naturalist
} to the Fishery Board for Scotland.

[Read 27th December, 1898.]

Fairlie, Hunterston, and Portincross are places on the Clyde, the names of which have been familiar to me for many years; yet the visit $I$ am about to refer to is the first $I$ have made to any of them. Among the various reasons that induced me to make this visit, the following may be given:- It is, for example, a notorious fact that not a few rarities, both botanical and zoological, have been recorded from one or other of the places named, and also that frequent reference to one or other of these places is to be found in natural history works of various kinds. Moreover, associated with the district are the names of some of our most eminent naturalists, who have occasionally made it their hunting ground, and have been rewarded by the interesting discoveries they have made. It might have been thought, however, that reasons like these should rather have tended to discourage the visits of subsequent investigators; such reasons were apt to suggest to the mind of the would-be discoverer, that the finding of all these rarities was a plain indication that the district must already have been more or less thoroughly examined, and was now scarcely likely to yield much that was 
new or rare. Nature's storehouse, however, is not so easily exhausted.

The conformation of the shore about Hunterston is somewhat peculiar; as the tide recedes, great stretches of sand and mud are exposed, and are only covered to a small extent even when the tide is full in. There are also numerous pools along the shore, so situated that the water they contain may be almost fresh at one time, and at another time decidedly brackish. Such a conformation presents conditions favourable to the existence of organisms that, in the great chain of life, constitute some of the links between those creatures whose habitat is the sea, and those that can only live in fresh water. Amongst the various groups of the animal kingdom, few of them contain such an interesting series of intermediate forms as that of the Crustacea. In Britain these intermediate forms are mostly of small size, and their study is considered to be correspondingly difficult. It therefore happens that the study of these Micro-crustaceans is not so popular as it deserves to be. Reflection on those matters led me to think that, notwithstanding all previous research, Hunterston might still retain some things that would more than repay the trouble incurred in the search for them.

My visit took place on a Saturday, early in September last, when various things conspired to make it successful. The weather could hardly have been better. I had also as a guide an old and esteemed friend, who was thoroughly familiar with the district, Mr. D. A. Boyd, of Seamill; and another old friend, Mr. James Steel, of Glasgow, also accompanied us. Our research commenced at Fairlie, and was continued till we were well round the Hunterston Sands. The shore pools were examined with a little hand-net, an instrument that has proved very serviceable for this kind of woriz. I confined my attention chiefly to these shore pools, as, after a little experimenting, it was found that they were likely to yield the best results, and in them a large number of the species I am now to record was secured. The Entomostraca obtained number fully sixty species, and there are also about eleven species of Amphipoda and Isopoda.

The Entomostraca include representatives of the Copepoda, the Ostracoda, and the Cladocera. The Copepoda are the most 
numerously represented, and there is also a considerable number of the Ostracoda; but the Cladocera are represented by only two species. This latter group, though frequently individually numerous in the sea, and sometimes also in brackish water, does not usually in such situations exhibit much variety of form; but when fresh-water pools or lochs are examined, very different results are obtained - the Cladocera are generally found to be not only numerous individually, but are also represented by a considerable number of species.

The names of all the Entomostraca, as well as of the Amphipoda and Isopoda, obtained during our visit to Fairlie and Hunterston, so far as they have been identified, will be found in the annexed list. A glance at the list will show that the Copepoda are represented by thirty-eight named species, several of which have not previously been recorded for the Clyde; and there are at least other two that appear to be undescribed. The Ostracoda are represented by twenty-two species, none of which is new to the Clyde, but a few of them are moderately rare. The Cladocera comprise two species, as already stated. The Amphipoda are also few in number, only three species being observed. The Isopoda observed number eight species. This makes a total of seventy-three species of Crustacea, exclusive of the two or three that appear to be new, and will be described later. A larger number of Amphipoda and Isopoda might have been obtained had a special effort been made to collect these forms, but, as the chief object of my visit was to investigate the Entomostracan fauna of the place, comparatively little attention was given to the other groups.

List of the Crustacea obtained during a visit to Fairlie and Hunterston, so far as they have been identified. A large proportion of the Copepods and Ostracods obtained is from the brackish water pools that have been referred to ; the others were collected between tide-marks.

\section{COPEPODA.}

Eurytemora velox (Lillj.). Cyclopina gracilis, Claus.

Cyclops bisetosus, Rehberg. Ectinosoma melaniceps, Boeck. serrulatus, Fischer. fimbriatus, Fischer. curticorne, Boeck. aquoreus, Fischer, herdmani, T. and A. Scott. Bradya minor, T, and A, Scott. 
*Tachidius brevicornis (Müller). littoralis, Poppe.

*Ameira exilis, T. and A. Scott. Delavalia palustris,

G. S. Brady. giesbrechti, T. and A.

Scott, var.

Canthocamptus palustris,

G. S. Brady.

minutus, Claus.

parvus, T. and A. Scott.

* Moraria poppei (Mrazek).

Mesochra lillieborgii, Boeck.

Diosaccus tenuicornis (Claus).

Laophonte curticauda, Boeck. similis (Claus).

* littorale, T. Scott.

* intermedia, T. Scott.
Cletodes propinqua, B. and $\mathrm{R}$. longicaudata, B. and R.

Itunella tenuiremis (T. Scott). * Nannopus palustris,

G. S. Brady.

Platychelipus littoralis,

G. S. Brady.

Dactylopus tisboides, Claus. stromii (Baird).

Thatestris forficulus, Claus.

harpactoides, Claus.

Harpacticus chelifer (Müller).

fulvus, Fischer.

Westwodia nobilis (Baird).

Idya gracilis, T. Scott.

Also two species apparently new to science, which will be described and figured later on. $\dagger$

\section{Ostracoda.}

Cypris incongruens, Ramdohr. Cythere gibbosa, B. and R.

Cyprinotus prasinus (Fischer).

Herpetocypris tumefacta

$$
\text { villosa (G. O. Sars). }
$$

Cytheridea torosa (Jones).

(B. and R.) Loxoconcha impressa (Baird).

Cypridopsis villosa (Jurine). aculeata (Lillj.)

Ilyocypris biplicata (Koch).

Candona candida (Müller). compressa (Koch).

Cythere lutea, Müller.

pellucida, Baird.

porcellanea, Brady. pusilla, B. and R.

Xestoleberis aurantia (Baird).

Cytherura sella, G. O. Sars.

nigrescens (Baird).

gibba (Müller).

Cytherois fischeri (G. O. Sars).

Paradoxostoma variabile

(Baird).

* Additions to Clyde Fauna.

+These two species are described in Part III. of the Seventeenth Annual Report of the Fishery Board for Scotland (1899), under the names Cylindropsyllus farliensis, sp. n. and Leptocaris minutus, gen. et. sp. n. 


\section{Cladocera.}

Alona guttata, G. O. Sars. Alona affinis, Leydig.

AMPHIPODA.

Orchestia mediterranea, Costa. Apherusa jurinii (M. Edw.) Gammarus duebeni, Lilljeborg.

ISOPODA.

Jara marina (O. Fabricius). Eurydice pulchra, Leach. Sphceroma rugicauda, Leach. Idothea baltica (Pallas). Ligia oceanica (Linné). Porcellio scaber, Latreille. Oniscus asellus, Linné. Philoscia muscorum (Scopoli).

\section{NOTES ON SOME OF THE SPECIES.}

As a detailed description of all the species mentioned in the list is beyond the scope of this Paper, I confine my remarks to a few of the rarer forms only, and chiefly to those among the Copepoda, as follows:-

\section{COPEPODA.}

(1) Eurytemora velox (Lilljeborg).-This species, so far as its British distribution is concerned, is most frequently found in brackish water, and more rarely in fresh water. Though it has not previously been noticed in the Hunterston district, it has on several occasions been recorded from places within the Clyde area, as at Rutherglen, where it was obtained by Mr. James Steel, and in Possil Marsh-these two are freshwater localities; at Langbank, where I observed it two years ago; and at Cumbrae, whence it is recorded by Prof. G. S. Brady. E. velox was quite common in some of the pools at Hunterston, and, being a moderately large species, the two younger members of our expedition could, with their keener eyesight and without artificial assistance, see the creatures quite distinctly swimming in the water.

Ectinosoma curticorne, Boeck.-This species is probably more common in the Clyde district than it at present appears to be; it is usually of a brownish colour, and as this harmonises with the sort of material in which it commonly occurs, it is readily passed over unobserved. In the examination of gatherings collected by 
hand-net, one has to be very much on the alert, as colour mimicry, as well as mimicry of form, is by no means rare among these low forms. E. curticorne has only lately been recognised as a Clyde species. My son records the interesting fact concerning it that young dabs from Morecambe Bay were found to have been feeding largely on this Entomostracan. He had obtained numbers of them in the stomachs of the young fish. ${ }^{1}$

Ectinosoma herdmani, T. and A. Scott.-This is quite a different species from the last, being more slender and elongate; its colour is white, or nearly so, and it is readily distinguished from any other British member of the genus. Though added to the British fauna only a few years ago, it does not seem to be very uncommon; probably its distribution is local.

Bradya minor, T. and A. Scott.-The species belonging to the two genera Ectinosoma and Bradya are so like each other in general appearance, that in some cases it is hardly possible to tell the genus to which they belong without dissection; one can usually, however, distinguish between Ectinosoma and Bradya by the difference in the structure of the posterior foot-jaws. Bradya minor has a superficial resemblance to Ectinosoma curticorne, but is not so dark coloured. These two resemble each other also in their habitat, which appears to be more or less estuarine.

Tachidius brevicornis (Müller) and T. littoralis, Poppe, were both found in the brackish pools at Hunterston. This is the first time $T$. brevicornis has been recorded from the Clyde area, but the other has been previously recorded. The genus is readily distinguished from other British Copepods by the structure of the fifth pair of thoracic feet, but $T$. brevicornis has fifth feet that are large and foliaceous, while those of $T$. littoralis are small, and their setæ are rather spinuliferous than plumose.

Ameira exilis, T. and A. Scott, is an addition to the Clyde fauna. It is a moderately large species, and was discovered a few years ago, near Dunbar, on the East Coast.

Canthocamptus parvus, T. and A. Scott.-This species was first discovered in Aberlady Bay, Firth of Forth, and is now for the first time added to the Clyde fauna. Though a small

ITrans. Lin. Soc., 2nd Ser, Zonl., Vol. VI, Part 5, p. 431. 
species, it appears to have an extensive distribution; it has been obtained as far north as Franz Josef Land. It was described as a Canthocamptus, but may ultimately have to be removed from that genus.

Laophonte littorale, T. Scott, and L. intermedia, T. Scott.These two species are also additions to the Fauna of the Clyde. They have only been described within recent years, but both appear to be widely distributed.

Nannopus palustris, G. A. Brady.-This curious Copepod appears to be a true brackish-water form, and this is, so far as I know, the first record of it for the Clyde. It seems to be a scarce species, though its rarity may be rather apparent than real, as the following incident would seem to indicate :-A short time ago I had an opportunity of examining some raised-beach material from Skye. The material was quite dry, having been collected a good while ago. In turning over the material I observed some objects that looked like Copepods, but they were so shrivelled up as to be indistinguishable. A careful treatment of them with caustic soda, however, relaxed the shrivelled-up skin and appendages, so as to render the discrimination of their structural details comparatively easy. I then found that a few of these mummified Copepods belonged to the species now under consideration, and was enabled in this curious way to extend somewhat our knowledge of the distribution of Nannopus palustris. There had likely been some marshy ground in the vicinity of the raised beach where the material had been collected, and, being near the sea, would form a suitable habitat for Nannopus, and probably other brackish-water species, and in the dry weather it would be a comparatively easy matter for the Copepods to become incorporated with the outer layers of the raised-beach deposit, and be mixed up in the sample collected.

Platychelipus littoralis, G. S. Brady.-This is another curious Copepod, with strong hooked terminal spines on the first thoracic feet which remind one very much of those iron hooks which are sometimes used by people who have the misfortune to lose a hand. Though found in brackish water, Platychelipus is not such a true brackish-water species as the last; its distribution should rather, perhaps, be described as "estuarine." 
Thalestris forficulus, Claus.-This is a very distinct species of Thalestris. The branches of the first thoracic feet are long and slender in comparison with those of most of the other members of the genus; it is also a small species. A few years ago we described, under the name of Thalestris forficuloides, a Copepod that seemed to be different from Claus's species, but both my son and $I$ are now inclined to regard this as merely a local form of $T$. forficulus.

The two apparently undescribed Copepods found in the Hunterston pools are both very slender and both appear to be rare. Only four specimens of the larger and rarer of the two have been observed, but specimens of the smaller form were somewhat more frequent. These smaller specimens were difficult to notice, because they so closely resembled the bits of fibre with which they were mixed up; it was on this account easy to miss them, and therefore they may have been less rare than they appeared to be.

Another Copepod, which I have recorded as Delavalia giesbrechti, var., resembles that species very closely. The typical D. giesbrechti was discovered in Ayr Bay about two years ago. It has a peculiarly broad terminal seta on each of the caudal furca, and it may be distinguished by this character alone. In the Hunterston variety the caudal setæ are of the usual form. The arrangement of the setæ on the fifth thoracic feet also differs slightly from the typical form, but it agrees in so many other points, that it seems better, for the present at least, to consider it as a local variety of $D$. giesbrechti than to make a new species of it.

Among other doubtful Copepods is an Harpactid that partakes somewhat of the characters of Canthocamptus cuspidatus and Moraria poppei, but it differs from them in various ways, but especially in the form and armature of the fifth thoracic feet, and I have not yet decided what to make of it.

These intermediate forms are very troublesome to the systematist. Their differences are such that they cannot very well take their place beside species already described, yet their affinities with them are so close that one hardly knows where to place them, or what characters to fix upon in order to discriminate them from others. This is where the chief difficulty in the study of the Copepoda comes in. 


\section{Ostracoda.}

Very few of the Ostracoda require special notice. The fine species Cypris incongruens was moderately common in some of the pools; being moderately large and of a light cream colour, they were quite conspicuous in the gathering when transferred from the hand-net to the bottle. Cyprinotus prasinus was also moderately common. This species is perhaps more familiar to Glasgow students under the name of Cypris salina. Cypridopsis aculeata is another Ostracod that was more or less frequent. As the name implies, the shell of this species is covered with stiff bristles. Candona candida is, though a common species, a very pretty one-the surface of the shell is a smooth, glossy white. It is also a somewhat interesting species from the fact that it seems to be equally at home in water that is more or less brackish and in perfectly fresh water; the form of the shell is also subject to a good deal of variation. It has never been found living in any truly marine locality. Cytheridea torosa is another brackish Ostracod, and it seems to be more restricted in its distribution than any of the species previously mentioned. Cythere gibbosa and Loxoconcha pusilla are also brackish-water species, but they differ from the others already referred to in this way-the distribution of those first-mentioned species may be described as extending from the brackish water towards fresh-water conditions, whereas the distribution of these two appears to extend more or less towards marine conditions. Xestoleberis aurantia and some others are also in the same category with Cythere gibbosa as regards general distribution.

\section{AMPHIPODA.}

The three Amphipods mentioned in the list appear to be all generally distributed within the Clyde area wherever suitable conditions prevail. Orchestia mediterranea appears, however, to to be somewhat rare. Dr. Robertson mentions that he saw only two Clyde specimens-one from the mouth of the Garnock (sent by Mr. J. Smith), and one taken at the west end of Cumbrae. ${ }^{1}$ The "hand" of the second Gnathopods is quite different in form

${ }^{1}$ Catalogue of the Amphipoda and Isopoda of the Firth of Clyde. By David Robertson, F.L.S., etc Part I. p. 13 (1888). 
NOTES ON CRUSTACEA FROM FAIRLIE AND HUNTERSTON. 355

from that of the more common Orchestia littorea, being somewhat pear-shaped, broad at the base, while a strong claw springs from the narrow apex; and the palm is furnished with a distinct tooth near the base of the claw.

\section{IsOPoDA.}

All the Isopods mentioned in the list have already been recorded for the Clyde area; they are all included in Dr. Robertson's Catalogue of the Amphipoda and Isopoda of the Firth of Clyde, published by this Society a few years ago. 



[Reprinted from "The Annals of Scottish Natural History," July I900.]

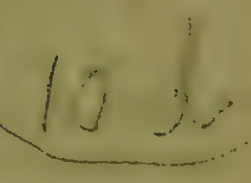

\section{ON COPEPODS LIVING IN THE N.OSTRILS OF FISHES}

By THOMAS ScotT, F.L.S. 


\section{The Annals.}

\section{OF \\ Scottish Natural History}

A QUARTERLY MAGAZINE WITH WHICH IS INCORPORATED

"The Scottist 四aturalist"

EDITED BY

J. Ai HARVIE-BROWN, :F.R.S.E., F.Z.S. Member of the British Ornithologists' Union

JAMES W. H. TRAIL, M.A., M.D., F.R.S., F.L.S.

Professor of Botany in the University of Aberdeen and

WILLIAM EAGLE CLARKE; F.L.S., MEM. BRIT. ORN. UNION Natural History Department, Museum of Science and Art, Edinburgh

EDINBURGH : DAVID DOUGLAS, CASTLE STREET 
[Reprinted from "The Annals of Scottish Natural History," July 1900.]

\title{
ON COPEPODS LIVING IN THE NOSTRILS OF FISHES.
}

\author{
By Thomas Scotr, F.L.S., etc.
}

In the course of some recent researches on fishes and their parasites, I have on various occasions made an examination of the nostrils of fishes, and have frequently obtained freemoving Copepods within these organs, apparently living on the mucus that is usually present. Where this mucus comes from-that is, whether it is secreted by a special gland within the nostrils themselves, or enters into them from the outside skin of the fish-is a question about which, in view of a paper lately published in the Journal of the Linnæan 
Society of London, ${ }^{1}$ there seems still to be some diversity of opinion. This question, however, does not need to be discussed here. The point of interest in the following remarks is rather the fact that Copepods are found in the nostrils of fishes, living apparently on the mucus they contain.

I have found free-moving (not fixed) Copepods in the nostrils of the following fishes:-The Lumpsucker (Cyclopterus lumpus); Cod (Gadus callarius); Whiting (Gadus merlangus); Pollack (Gadus pollachius); Plaice (Pleuronectes platessa); and Flounder (Pleuronectes flesus). All the Copepods that have hitherto been observed in the nostrils of these fishes belong to the genus Bomolochus, which was instituted by Professor Alex. von Nordmann in I 832 for a Copepod found on the gills of a fish from the Red Sea, and which is now known as Bomolochus parvulus, Nordmann. ${ }^{2}$ On the other hand, the specimens obtained in the nostrils of the fishes I have mentioned appear all to belong to a species described by Professor Claus under the name of Bomolochus solece, from specimens which had been found on the Sole (Solea vulgaris). I am not sure as to what part of the Sole the specimens described by Professor. Claus were taken from; but I may state that several years ago one or two specimens of a Copepod supposed to belong to Claus' species were found adhering to the coloured side of a Sole captured in the Humber near Grimsby. It may also be stated that there is in part iii. of the "Eleventh Annual Report of the Fishery Board for Scotland" a description, with drawings, of a specimen of the same Copepod species which was found amongst some dredged material collected in the Fluke Hole off St. Monans, Firth of Forth, in 1892.

The genus Bomolochus belongs to the Ergasilidæ, a family which contains two other genera besides the one mentioned, viz. Ergasilus, Nordmann; and Thersites, Pagenstecher. Dr. Basset Smith has published an excellent paper in the "Proceedings of the Zoological Society of London" for April I 899, in which he gives a "Systematic Description of Parasitic Copepoda found on Fishes." The number of

1 "On the Presence of Nasal Secretory Sacs and a Naso-pharyngeal Communication in Teleostei," by H. M. Kyle, M.A. ("Journ. Linn. Soc.," Zool,, vol. xxvii. p. 45 I et seq., April I 900).

2 "Mikrographische Beiträge," Zweites Heft, p. I 35 (I 832 ). 
species belonging to the Ergasilidæ noticed in this paper is twenty-two, and thirteen of them belong to the genus Bomolochus. On referring to the habitats of the various species, not only of Bomolochus but also of those belonging to the other two genera, we find that in no case are any of them described as occurring in fishes' nostrils. This is the more remarkable from the fact that Bomolochus does not seem to be at all rare, especially in the nostrils of the Cod. Moreover, the Copepods are not limited in their distribution to the Cod-fishes of the north-east of Scotland, for my son informs me that quite recently he has found them in the nostrils of Cod caught in the Irish Sea. As a matter of fact, they are found in the nostrils of most of the Cod-fishes I examine; frequently several, and occasionally a considerable number of, specimens are found in the nostrils of a single fish. In the nostrils of a moderately large Cod from the Moray Firth I found as many as twenty-nine specimens of Bomolochus. They included males, females (carrying ovisacs), and young. In the nostrils of another Cod caught in the salmon-nets in the Bay of Nigg, near Aberdeen, twenty-four specimens were obtained; several of these, when removed from the mucus with which they were surrounded and put into clean water, were very lively and very pretty. In seeking for them, the method I adopt is very simple. With the edge of my knife I press gently but steadily on the skin behind the nostrils till the mucus is forced out of the openings, when the Copeods, if they be present, usually appear as whitish specks amongst the mucus; but as some may be more transparent than others, it is better to transfer the mucus into some water in a shallow glass vessel placed on a sheet of black paper, or other dark-coloured substance. The mucus can then be spread out with a camel's-hair pencil, when the Copepods will come clearly into view, and especially if the eyes be assisted with a hand-lens.

The fact that the same species of Bomolochus should be found in the nostrils of such distinctly different fishes as the Lumpsucker, the Cod, and the Plaice, is of interest as showing a greater adaptability than would seem to be the case with some other of our parasitic Copepods affecting fishes. 



\section{$=$}

.

(n)

$\left(\frac{1}{2}\right.$

$=0 .+1$

$=0$

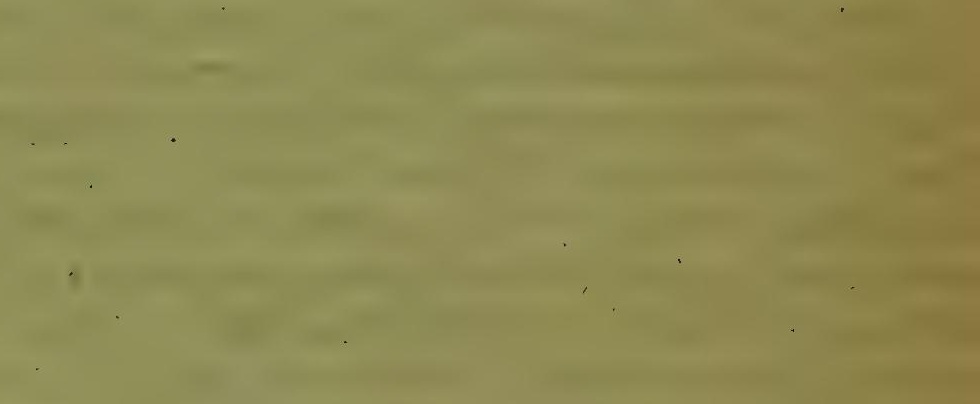

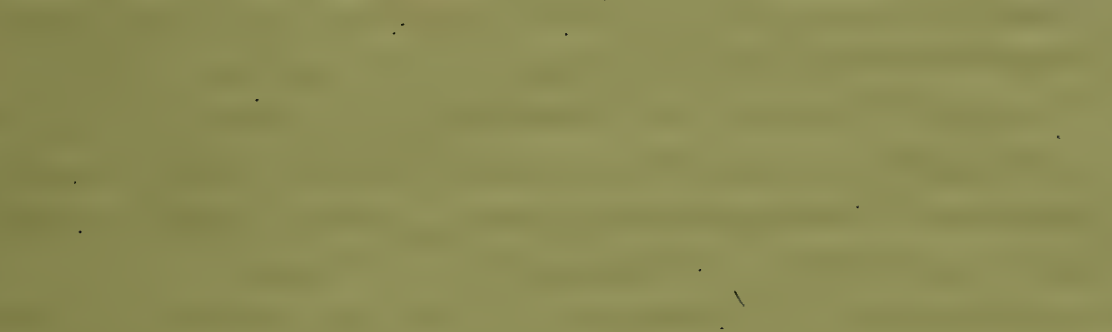
.
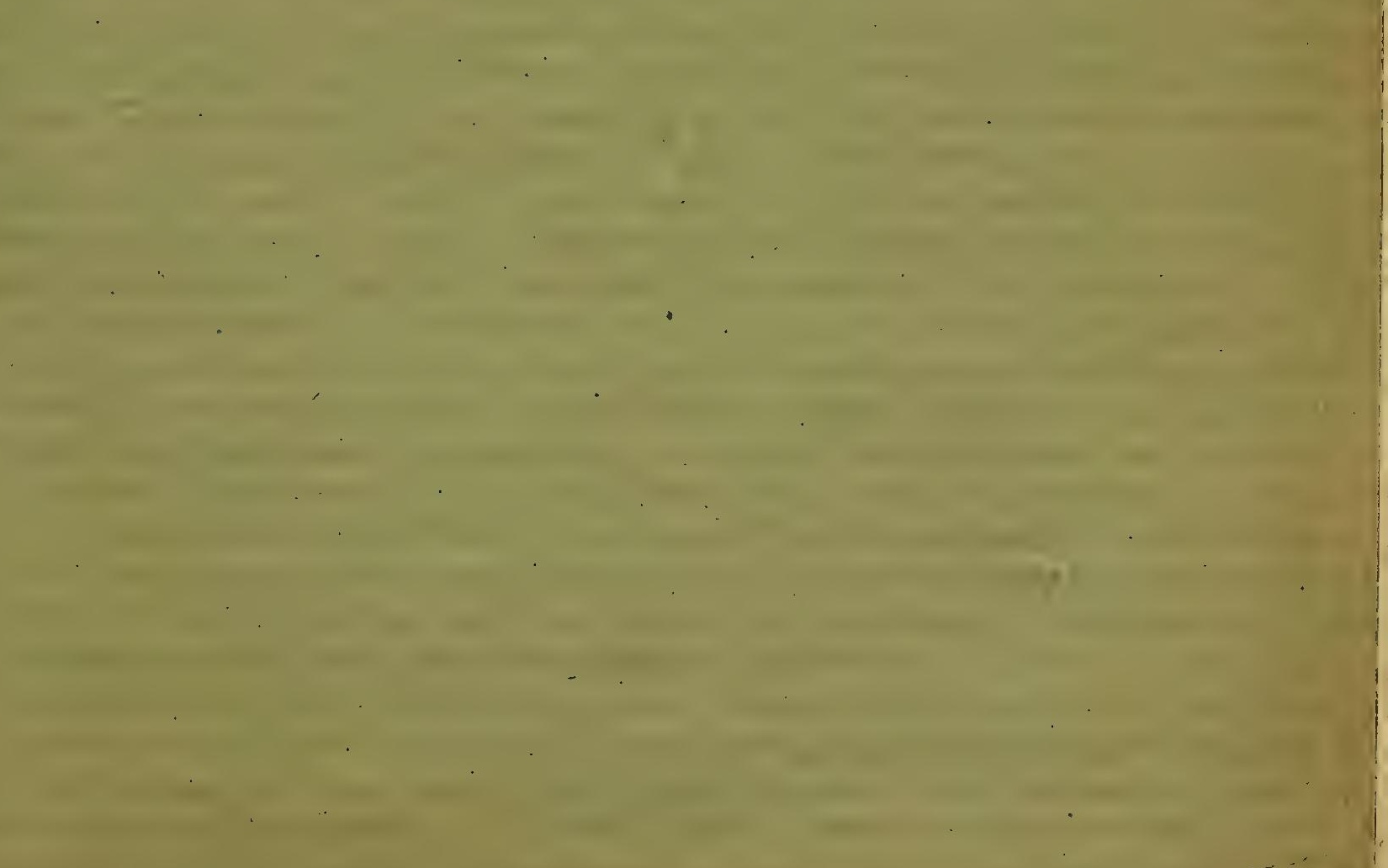

Reprinted from the British Association Handbook on the Natural History of Glasgow and the West of Scotland (1901).

\section{THE LAND AND FRESH-WATER MOLLUSCA.}

BY

THOMAS SCOTT. 



\section{THE LAND AND FRESH-WATER MOLLUSCA.}

\section{By Thomas Scott, F.L.S., Aberdeen.}

\section{Arrangement and Nomenclature.}

LisT of British Land and Fresh-water Mollusca, prepared by a Committee of the Conchological Society of Gt. Britain and Ireland (J. of Conch. vol. vii., p. 49-66, 1892.).

\section{Authorities and References.}

(B.)=Binnie, F. G., "List of the L. and F. W. Mollusca of Clydesdale." (Fauna and Flora of the West of Scotland, 1876).

(C.) "Census of Scottish L. and F. W. Mollusca," by W. Denison Roebuck, (Roy. Phys. Soc. Edin. Proc., vol. x., (1891), p. 437-503).

(D.) = Dougall, John, "The L. and F. W. Mollusca found within ten miles of Glasgow," (N. H. Soc. Glasg. Trans., vol. i., p. 188, 1867).

(E.) = Evans, Wm., F.R.S.E., MS. List of Clydesdale Mollusca.

(G.) = Scott, Thos., F.L.S., "On the L. and F.W. Mollusca of Greenock," (N. H. Soc. Glasg. Trans., 1886, vol. i., (N. S.), p. 279).

$(\mathrm{H})=$. Haddin, Wm., "On the distribution of the Helicidae in Bute, and in the vicinity. of Largs," ( $N$. H. Soc. Glasg. Trans., vol. i., p. 247, 1869).

(K.) = Knight, Rev. G. A. F., MS. List of Clydesdale Mollusca.

$(\mathrm{N})=$ "Supplementary Lists of L. and F. W. Mollusca," by W. D. Roebuck, (Ann. of Scot. Nat. Hist.).

(S.)=Scott, Thos., F.L.S., "The L. and F. W. Mollusea of Bute," (N. H. Soc. Glasg. Trans., 1881, vol. ii. (N. S.), p. 125, vol. iii., 1891, p. 170).

(T.) = Scott. Thos., F.L.S., "Preliminary notes on the L. and F. W. Mollusca about Tarbert, L. Fyne," (J. of Conch., vol. v., 1886, p. 72).

(W. $)=$ Watt, Hugh Boyd, MS. List of Clydesdale Mollusca.

M. =Marsh ; Cnl.=Canal ; Gl.=Glen; Wd.=Wood ; C.=Common ; $\mathrm{R}_{\text {. }}=$ rare, etc.

\section{Class Cephala.}

\section{Sub-order Pulmonata.}

\section{Fam. Arionidae.}

Arion ater (Lin.).-C. and gen. dist. var. succinea. Garscadden; nr. Skelmorlie; Maybole (C.). var. nigrescens. Garscadden; Bute ; E. Tarbert (C.). (Neither of these var. names occur in Conch. Soc. list).

A. subfuscus, Drap.-Dunoon; Bute; E. Tarbert (C.), bet. Elvanfoot and Leadhills (E.). 
A. hortensis, Fér.-Possil M. ; Sheilhill Gl.; nr. Greenock, Hunters' Quay ; Bute ; Girvan (C.).

A. minimus, Simroth.-Hunters' Quay; nr. Skelmorlie; Greenan L., Bute (C.); bet. Elvanfoot and Leadhills (E.).

A. circumscriptus, Johnst.-Possil M. ; Dumbarton Rock ; Sheilhill Gl. ; Dunoon ; Bute; W. Kilbride ; Girvan (C.) ; Arran (N., 1895); Faslane B., Gareloch (K.).

\section{Fam. Limacidae.}

Amalia gagates (Drap.).-C. nr. Aquarium at Rothesay (C.).

A. sowerbyi (Fér.).-Greenock ; Rothesay (C.), Eilean Aoidh, Minard (W.), (vide $J$. of Conchol., 1892, p. 68).

Limax maximus, Lin.-Nr. Forth and Clyde Cnl. by Maryhill; Greenock (C.). var. cellaria, D'Arg.-Greenock; Gl. Äpp., nr. Ballantrae (C.).

var. cinerea, Moq.-Greenock; Dunoon (C.).

var. fasciata,.Moq.-Greenock; Dunoon; Rothesay; Maybole (C.).

I. cinereo-niger, Wolf.--Nr. Brodick (N., 1895).

I. marginatus $(M$ iill.). (=L. arborum, B.-Ch.)-C. (B.); Cloch, etc. (G.): On beech trees nr. Rothesay, freq. (S.) ; Tarbert (T.); Arran (N., 1895); bet. Elvanfoot and Leadhills ( $\mathrm{E}_{0}$ ).

I. flavus, Lin.-R. Greenock, etc. (G.) ; c. Sugar Refinery, Baker St. (C.). var. griseasea. Greenock, in same locality with type (C.).

Agriolimax agrestis, Lin.-C. and gen. dist.

A. laevis, Miiller.-Locally freq.

\section{Fam. Vitrinidae.}

Vitrina pellucida (Miill.).-Widely dist., more or less freq., Lanark; Greenock ; Largs; Bute; Arran (C.).

\section{Fam. Zonitidae.}

[Hyalinia draparnaldi (Beck).-Rothesay, prob. this species (C.).]

H. cellaria (Miill.).-Mod. c. and gen. dist.

var. albina $\left(M \circ q_{0}\right)$.- Port-Bannatyne (C.) ; near Tarbert (T.).

H. alliaria (Mill.).-Mod. c. and gen. dist.

var. viridula (Jeff.).-Shore of L. Fad, Bute (C.); nr. Cloch L.-H. (G.); Glas Eilean (W.).

H. glabra (Studer).-Maryhill, Glasgow ; Port-Bannatyne ; Largs (C.).

H. nitidula (Drap.).-Gen. dist.

H. pura (Alder).-Skelmorlie; Tarbert; Bute; Arran (C.); Sheilhill Gl. (G.) ; c. (B.).

var. margaritacea (Jeff.).-Nr. Cloch L.-H.; Largs ; E. Tarbert; nr. Rothesay (C.).

H. radiatula (Alder).-C. (B.); Kenmuir Bank, nr. Greenock; Bute (C.); Arran (N., 1895); E. Tarbert (T.).

var. viridescenti-alba $\left(J_{e f f}\right.$ ). - - E. Tarbert, the only locality recorded.

H. crystallina (Müll.).-Gen. dist.

H. fulva (Müll.).-Gen. dist., more or less freq.

H. nitida (Miill.).-Bute (B.); shores of L. Fad (C.).

H. excavata (Bean.).-Cumbernauld Gl. ; Bute (B.); Sheilhill Gl. ; nr. Cloch L.-H. ; Cumbrae (C.).

\section{Fam. Helicidae.}

Helix rotundata, Miill.-C. and gen. dist.

var. alba, Moq.-Crosslet nr. Dumbarton; nr. Cloch L.-H. ; E. Tarbert (C.). vár. minor, Jeff.-Nr. Rothesay (C.).

var. pyramidalis, Jeff.-Sheilhill Gl. ; nr. Greenock (C.).

H. pygmea, Drap.-Nr. Baldernock ; Girvan (R.) ; L. Lomond (B.) ; Skelmorlie; nr. Port-Bannatyne; L. Ranza (C.). 
H. Iamellata, Jeff.-Calderwood and Auchentorlie Gls. (B.); nr. Cloch L.-H. (G.) ; Inveraray; skeoch Wds. Bute ; Skelmorlie (C.).

H. aculeata, Mrïller.-Calderwood and Auchentorlie Gils., Bute (B.); nr. Cloch L.-H. (G.) ; E. Tarbert ; Skelmorlie ; Largs ; Blantyre (C.).

H. pulchella, Müller.-Lime quarries, North Hill, Campsie; Bute (B.) ; nr. Port-Bannatyne; Ettrick B., Bute (C.) ; Hairmyres (S.).

H. aspersa, Mïller.-C. and gen. dist.

var. conoidea, Picard.-E. Tarbert (T.); Port-Bannatyne (S.).

var. depressa, T. S.-E. Tarbert (T.); Rothesay nr. the Aquarium (S.).

var. undulata, Moq.-Rothesay Castle (C.).

var. zonata, Moq.-E. Tarbert (C.).

monst. scalariforme, Taylor.-Crawford St., Greenock (C.).

H. nemoralis, Lin.C. and gen. dist.

var. castanea, Moq.-E. Tarbert (C.).

var. libellula (Risso).-E. Tarbert (T.); Lanark ; Greenock ; Skelmorlie ;

Bute (C.); Eilean Aoidh, Minard (W.).

var. rubella, Moq:-Lanark ; Greenock; Innellan; E. Tarbert; Maybole, etc. (C.); Glas Eilean (W.).

var. roseolabeata, Taylor.-Liath Eilean, Kilmory (W.).

var. albolabiata,'Von Martin.-Glas Eilean (W.).

H. hortensis, Müller:-Lanarkshire and Ayrshire.

var. incarnata, Moq.-Nr. Glasgow (C.).

var. lutea, Moq.-Greenock; Largs ; Ardrossan; Maybole (C.).

H. arbustorum, Lin.-Nr. Glasgow; Greenock; Rothesay ; Largs ; E. Tarbert;

Campbeltown, etc., (C.).

var. alpestris, Ziegl.-Nr. Summerston, Lanarkshire; Sheilhill Gl., nr.

Greenock (C.).

var. cincta, Taylor.-Nr. Summerston; nr. Greenock ; Tarbert (C.).

var. flavescens, Moq.-Kilkerran B., Kintyre (C.).

var. fuscescens, $D$. and $M$. (=var. Marmorata, Taylor.).-E. Tarbert (C.).

var. conoidea, Westerl.-Nr. Shandon; E. Tarbert (C.).

H. rufescens, Penn.-Greenock ; Inveraray ; Campbeltown (C.); Bowling ;

Largs ; Bute ; Arran, (Introduced ?) (B.).

var. alba, Moq.-Greenock, Hunters' Quay (C.).

var. minor, Jeff.-Greenock (C.).

var. rubens, Moq.-Hunters' Quay (C.).

H. hispida, Lin. (= H. concinna, Jeff.).-Rothesay nr. the Aquarium (S.);

Glasgow ; Dumbarton; Dumoon; Largs, etc. (C.).

var. albida, Jeff.-Dunoon (C.) ; Port Bannatyne (R.).

var. depilata, Alder.-Duntocher (C.).

var. subglobosa, Jeff.-Garscadden, Dumbartonshire (C.).

var. subrufa, Moq.-Greenock; Gl. Morag nr. Dunoon; E. Kilbride (C.).

"Var. fusca" is recorded from Campbeltown in the "Census," but the

name does not occur in the Conch. Soc. list.

H. granulata, Alder. (= H. sericea, Jeff.).-Gourock; Skelmorlie; Largs;

Port Bannatyne; Campbeltown (B. \& C.).

var. cornea, Jeff.-E. Tarbert, about the Old Castle (C.).

H. fusca, Mont.-Falls of Clyde; nr. Greenock; Skelmorlie ; Largs ; Inveraray ; Bute ; Arran (B. \& C.).

H. itala, Lin. (=H. ericetorum, Müll.).-St. Ninian's B., Bute (H. B. C.).

H. caperata, Mont.-E. Kilbride; Dumbarton; W. Kilbride; Maybole;

Bute; Campbeltown, etc. (C.).

var. fulva, Moq.-Ayr (C.).

var. ornata, Picard. - Campluetown (C.).

H. virgata, Da Costa.-Troon (C.).

var. alba, Taylor.-Troon (C.).

var. albicans, Girat.-Troon (C.). 
var. lineata, Olivi. (=var. maritima, Jeff.).-Troon (C.). The "var. subdeleta" (recorded in the "Census" from Troon) is not included in the Conch. Soc. list of names.

H. acuta, Müll.-Sand hills at Troon (B.).

var. strigata, Menke.-In same locality as the type (C.).

\section{Fam. Pupidae.}

Buliminus obscurus (Mïll.).-Bothwell Old Castle; Kenmuir Bank ; Auchentorlie Gl. (B.); Falls of Clyde nr. Lanark (C.).

Pupa anglica (F'́r.). (= P. ringens, Jeff.).-Largs (B.); Sheilhill Gl. nr. Greenock ; Skelmorlie (C.).

var. pallida, Jeff.-Sheilhill Gl. nr. Cloch L. H. (C.).

P. cylindracea (Da Cost $)$. (= P. umbilicata, Drap.)-C. and gen. dist. var. albina, Moq.--Sheilhill Gl. (C.).

var. edentula, Moq.-Houston nr. Paisley (C.) ; Shielhill Gl. (G.).

P. muscorum (Lin.). (=P. marginata, Drap.). var. albina, Menke-Millport (C.).

Vertigo antivertigo (Drap.).-Bute; Arran (B.); L. Fad; L. Ascog, on shore (C.).

V. pygmaea (Drap.).-Hairmyres ; E. Kilbride ; Largs ; Bute (B.) ; Shielhill Gl. ; Skelmorlie ; L. Fad, etc. (C.). var. pallida, Jeff.-Rottenburn Gl. by Greenock (G.).

V. substriata (Jeff.).-Shore of L. Fad (C.); Rottenburn Gl. (G.).

V. pusilla, Müll.-Nr. the Clyde about Lanark (J. Steel); Largs (C.).

V. edentula (Drap.).-Nr. Milngavie; Bute (B.); nr. Cloch L.-H. ; Largs ; Cumbrae; E. Tarbert (C.).

Balea perversa (Lin.).--Skelmorlie ; Largs; Kilmun; Inveraray ; Bute ; Campbeltown, etc. (B. C.).

Clausilia perversa (Pult.). (=C. rugosa, Drap.)-Freq. and gen. dist. var. parvula, Turt.-High Mains nr. Dumbarton (C.).

var. tumidula, Jeff.-Largs ; Ettrick B. Bute ; Campbeltown (C.).

\section{Fam. Stenogyridae.}

Cochlicopa lubrica (Miill.).-Freq. and gen. dist.

var. lubricoides, Fer.-W. Kilbride; nr. Rothesay ; L. Fad (C.). The "var. viridula" (recorded in the Census from Dunoon) is not in Conch. Soc. List.

\section{Fam. Succineidae.}

Succinea putris (Lin.).-Arran (B.); Possil M.; Cloch below Gourock; Largs; Bute (C.); nr. Arrochar ; Cumbrae (H.).

S. elegans, Risso. var. pfeifferi.-Arran (C.).

S. oblonga, Drap.-Quarry nr. Dalry (J. Steel) (C.); Auchinskeoch nr. Dalry (R.).

Order INoperculata.

Sub-Order Pulmonobranchiata.

Fam. Auriculidae.

Carychium minimum, Müll.-C. (B.); Greenock; Cloch ; Skelmorlie; Largs ; Blantyre; Bute, etc. (C.).

Fam. Limnaeidae.

Planorbis fontanus (Lightfoot). (=P. nitidus, Jeff.)-Forth and Clyde Cnl. at Firhill (B.); Paisley Cnl. (C.).

P. nautileus (Lin.).-Arran (B.); Hogganfield; L. Cumbrae; Shores of L. Ascog (C.) not unc. in district. var. crista (Lin.).-Nr. Elderslie, Renfrewshire (C.).

P. albus (Lin.).-C. (B.); Paisley Cnl. ; L. Fad (C.). 
P. parvus, Say. (= P. glaber, Jeff.)-L. Greenan nr. Rothesay (S.).

P. spirorbis, Müll.-Small M. on Rutherglen Rd. ; Bishop L. ; Pool nr. Inverkip; Arran (B.); nr. Paisley ; Port-Glasgow (C.); Pond above Kerrycroy, Bute (R.).

P. contortus (Lin.).-Pond nr. Robroyston ; Frankfield L. ; Arran (B.); L. Greenan and L. Fad (C.).

Physa fontinalis (Lin.).--C. (B.); Possil M., Paisley Cnl., Ditch at Greenock, L. Fad, etc. (C.).

Limnaea peregra (Müll.).-C. and gen. dist. var. lacustris (Leach).-R. Clyde above Rutherglen (C.).

var. ovata, Drap.-C. with the type (B.); Blantyre; Greenock; L. Greenan (C.).

L. auricularia (Lin.).--Paisley Cul. (C.); formerly c., now probably extinct as the canal bed has been utilized largely by a railway.

L. stagnalis (Lin.).-Possil M., introduced (B.) ; Old Quarry at Possil, introduced and now extinct (C.) ; dam at Greenock introduced, 1882 (S.).

L. palustris (Miill.).--Possil M.; Bardowie and Frankfield Ls.; Arran (B.); Pools nr. Port-Glasgow on side of Kilmalcolm Road (G.); L. Greenan (S.).

L. truncatula (Müll.).-C. (B.); R. Clyde above Rutherglen; Greenock; Largs ; E. Tarbert ; Bute (C.). var. minor, Moq.-Holy I. (C.).

I. glabra (Müll.). - Frankfield L., prob. introduced (B.).

Ancylus fluviatilis, Müll.-C. in running streams (B.); Coatbridge; Greenock; Dunoon ; Largs ; E. Tarbert ; Bute (C.).

Velletia lacustris (Lin.).--Possil M. ; Bishop L. ; Forth and Clyde Cnl. at Old Kilpatrick (B.).

Order Operculata.

Sub-Order Pulmonata.

Fam. Aciculidae.

Acicula lineata (Drap.).-Lanarkshire (Jeff.); nr. Cloch L. H.; Skelmorlie (C.).

Order Operculata.

Sub-Order Pectinibranchiata.

Fam. Paludinidae.

Bythinia tentaculata (Lin.).-Possil M. ; St. Germains' L. ; Forth and Clyde Col.; Paisley Cnl. (B.).

var. producta, Menke.-Glasgow and Paisley Cnl. (C.).

Fam. Valvatidae.

Valvata piscinalis (Müll.).-Possil M. ; Forth and Clyde Cnl. at Dalmuir ; Paisley Cnl. (B.).

V. cristata, Müll.-Possil M. ; Forth and Clyde Cnl. at Firhill (B.).

ACEPHALA.

Order Pelecypoda.

Sub-Order Isomya.

Fam. Unionidae.

Unio margaritifer (Lin.).-R. Clyde at Cambuslang (B.); R. Gryfe nr. Kilmalcolm (C.).

Anodonta cygnea (Lin.).-Paisley Cnl.; empty shells in Bardowie L.; R. Cart at Cardonald Mills ; R. Clyde above Cambuslang (B.).

var. incrassata (Shepp.).-Paisley Cnl. (C.).

var. radiata (Müll.).-Paisley Cnl. (C.) 


\section{Fam. Sphaeriidae:}

Sphaerium corneum (Lin.).-Possil M.; Forth and Clyde Cnl. (D.); Paisley Cnl. (C.). Locally though not geu. c.

S. lacustre (Müll.).-Possil M. ; Forth and Clyde Cnl. at Firhill, possibly introduced (B. D.).

Pisidium amnicum (Müll.).-Glasgow and Paisley Cnl. (C.); R. Clyde above Rutherglen Bridge (B.).

P. fontinale (Drap.).-Possil M.; ditch between Frankfield and Hogganfield (B.); E. Tarbert (T.).

var. henslowana (Shepp.).-Glasgow and Paisley Cnl. (Mihi.).

P. pusillum (Gmelin).-Cossil M. ; nr. Cloch L. H. (B.); Tarbert (C.); L. Fad and L. Ascog (R.).

P. nitidum, Jenyns.-Frankfield L. (B.); pools by side of road bet. PortGlasgow and Kilmalcolm (fide J. G. Jeffreys) (G.); L. Fad (R.).

Sub-Order Heteromya.

Fam. Mytilidae.

Dreissena polymorpha (Pallas)._Forth and Clyde Cnl. ; c., not native (B.); Paisley Cnl. (C.). 



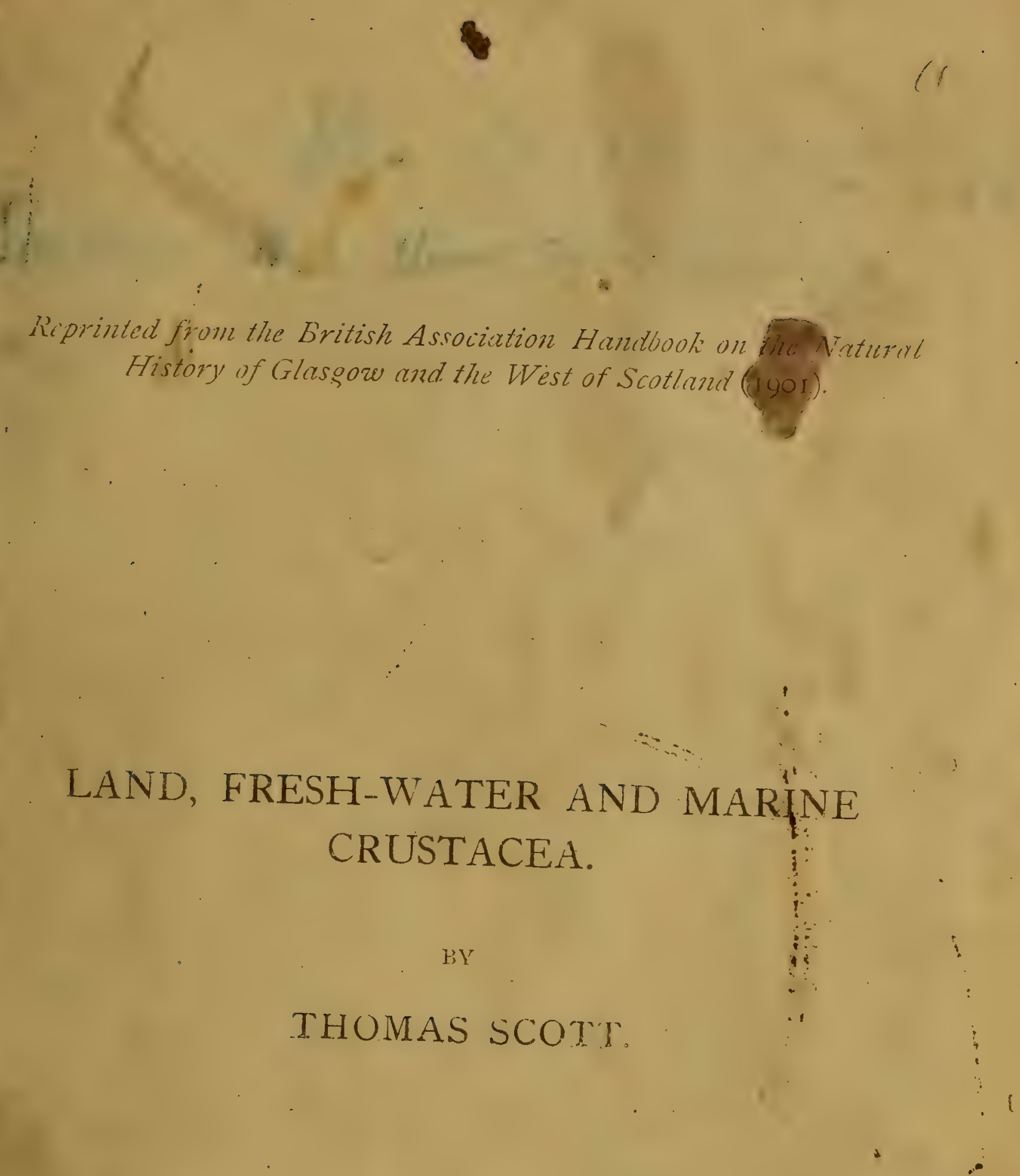






\section{LAND, FRESH-WATER, AND MARINE CRUSTACEA.}

By Thomas Scotr, F.L.S., Mem. Soc. Zool. de France, F.R.Ph.S.E., Corr. Mem. Geol. and Nat. Hist. Socs. of Glasgow, etc.

\section{Order Podophthalma.}

Adthorities and References.

(F. S. G.) = The Statistics of the work of the Fishery Board, S.S. "Garland."

(H.)= Prof. J. R. Henderson "The Higher Crustacea of the Clyde" (N. $H$. Soc: Glasg. Trans., vol. i. (N. S.) p. 315.

(M.) = MS. records of Sir John IMurray's S.Y. "Medusa."

(A. M. N.) = Rev. Canon A. M. Norman, F.R.S., "A Revision of the British species of Schizopoda" (Ann. and Mag. N.H., 1892).

$(\mathrm{R})=$. Records of the late Dr. Robertson, Millport.

(C.) = Dr. W. Y. Calman, Dundee, "On the genus Pandalus."

(S.) = Thomas Scott, F.L.S.

\section{Nomenclature and Classification Followed.}

Rev. T. R. R. Stebbing, "History of the Crustacea," 1893 (Intern. Scient. Ser.).

Shall. $\mathrm{w}_{.}=$shallow water $; 1 . \mathrm{m} . \mathrm{w}_{\mathrm{.}}=$ low water of ordinary or spring tides ;

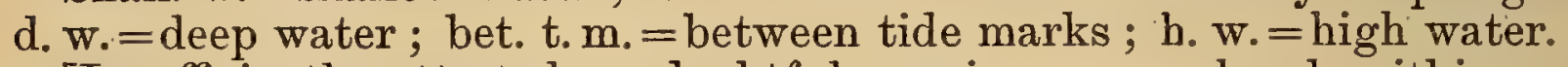

[Insufficiently attested or doubtful species are enclosed within square brackets.]

\section{Sub-Order Brachyura.}

\section{Fam. Cancridae.}

X Cancer pagurus, Lin.-C. on rocky shores (H.).

Xantho hydrophilus (Herbst.).-One captured at mouth of estuary 15/6/1899 (F.S. G.). Fishery Board's Coll., Aberdeen.

Pilumnus hirtellus, (Lin.).-Portloy, Cumbrae, under stones at l. w. (R.). Apparently $r$.

Fam. Portunidae.

x Carcinus maenas (Penn.).-C. bet. t. m., and in shall. w. inshore ; sometimes in 10-20 f. upwards.

Portunus puber (Lin.).-Cumbrae; Lamlash B.; L. Fyne (H.): Shallow Bays, Barmore (S.).

P. depurator (Lin.).-The most c. Portunus in the Clyde (H.).

P. corrugatus (Penn.).-One off Tan Buoy, 8 f. (H.).

P. arcuatus, Leach.-F. of Clyde, not $r$.

P. pusillus, Leach.-Mod. c.; hard ground, down to 30 f. (H.) : nr. Fort Matilda, Greenock (S.).

P. holestas zale. 
X P. marmoreus, Leach.--Several localities (H.).

x Portumnus latipes (Penn.).-Washed ashore, Irvine sands (R.).

\section{Fam. Corystidae.}

x Corystes cassivelaunus, (Penn.).-Kames B., Cumbrae, sand below l.w.m. $(\mathrm{R}$.$) : small male at mouth of estuary, 15/6/99 (F. S. G.).$

Atelecyclus septemdentatus (Mont.).--One from Alland Bank, Millport B. (R.).

Fam. Ocypodidae.

Gonoplax rhomboides (Lin.).-Ayrshire coast (G.\&M.) : nr. Ailsa Craig (trawled, F. S. G.): shore, Ardeer (J.Smith).

\section{Fam. Pinnotheridae.}

Pinnotheres pisum (Lin.).-Not unc. in $M$. modiolus, occasionally in C. edule.(H.).

\section{Fam. Inachidae.}

Macropodia rostratus (Lin.).-Not unc. in lower Clyde.

M. longirostris (Fabr.).-Mod. c., gen. dist. ; more c. than M. rostratus.

[Achaeus cranchii, Leach.-One, off Cumbrae by Mr. Kennedy (R.): U. L. Fyne, 10 f. (M.)].

Inachus dorsettensis (Penn.).-C. and gen. dist.

I. dorynchus, Leach.-Gen. dist., less c. than I. dorsettensis.

I. leptochirus, Leach.-F. of Clyde (A.M. N.): bet. Cumbrae and Bute, 20 f:, r. (R.).

\section{Fam. Maiidae.}

[Maia squinado (Herb.).-Off Dunoon, 1878 (Flemyng): off Ardrossan (Maj. Martin) : W. of Bute (Grieve) (See H.)].

Hyas araneus (Lin.).-C. and gen. dist., esp. inshore.

H. coarctatus, Leach.-C. and gen. dist., esp. in d. w.

Fam. Parthenopidae.

x Eurynome aspera (Penn.).-Not c. ; 10-60 f. ; usually hard ground (H.) : off Fort Matilda 10 f. (S.).

Fam. Leucosiidae.

X Ebalia tuberosa (Penn.).--Gen. dist.; usually hard ground, 5-50 f. (H.) : off Fort Matilda (S.).

E. tumifacta (Mont.).-LLamlash B. (G. ; H.) : Alland Bank, Millport B. (R.): Kilbrennan Sd., 15 f. (Brook.).

E. cranchii, Leach.-Lamlash B. (L. : M.) : off Lion Rock Cumbrae (Alex. Patience)!

\section{Sub-Order Macrura.}

\section{Fam. Lithodidae.}

Lithodes maia (Lin.).-D. w. L. Fyne, and Clyde ; gen. dist. ; somewhat r. (H. ; F. S. G.).

\section{Fam. Paguridae.}

$\times$ Eupagurus bernhardus ( $\operatorname{Lin}$ ).-Abund., more inshore than in d. w.

E. prideauxi (Leach).-Mod. c., more in d. w. than inshore.

E. cuanensis (Thomp.).-Skelmorlie Bank ; off Portincross ; Cumbrae ; Lamlash B. ; not very c. (H.).

E. pubescens $(K r$.$) .-Mod. c. ; hard ground; usually enveloped by Hymeni-$ acidon tuberea (H.).

Anapagurus hyndmanni (Thomp.).-F. of Clyde, 10-15 f. (A. M. N.) : off Cumbrae (R.): E. L. Tarbert (S.).

x Eu. Reulftimanes, Narm. 
A A. laevis (Thomp.).-Gen. dist., 10-105 f. (H.): mod. freq. in Clyde and L. Fyne.

A. chiroacanthus (Lillj.).-Skelmorlie Bank; off Portincross ; Tan Buoy; Lamlash B. (H.): E. L. Tarbert (S.).

\section{Fam. Porcellanidae.}

$\times$ Porcellana platycheles (Penn.).-Under stones, nr. Cumbrae ; Lamlash B. (H.): Lunderston B. (S.).

$X \quad$ P. longicornis $($ Lin.).-C. and gen. dist., more freq. inshore ; usually hard ground.

\section{Fam. Galatheidae.}

x Galathea squamifera, Leach.-Under stones 1. w., Cumbrae ; Lamlash B. ; off Fairlie (H.): U. L. Fyne (M.) : E. L. Tarbert ; Lunderston B.

* G. nexa, Embleton.-L. Fyne, 20-40 f.; Tan Buoy, $7-8$ f.; Lamlash B. ; Skelmorlie Bank ; etc. (H.); U. L. Fyne (M.).

G. dispersa, Bate. - Mod. c. and gen. dist.; usually hard ground.

G. intermedia, Lillj.-C. hard ground, 10-20 f. (H.) : L. Fyne 10-20, f. (M.).

G. strigosa, Fabr.-Under stones at l.w. spring tides, Cumbrae; young dredged off Roseneath Pt., 15 f., hard ground (H.): Strachur B. (S.).

$\times \quad$ Munida rugosa $(F a b r$. .).-Gen. dist. and mod. c., usually d. w.

\section{Fam. Thalassinidae.}

Jaxea nocturna, Nardo.-Adult fragments twice (1899) in fish stomachs nr. Ailsa Craig (F. G. Pearcey): Young at times freq. in bottom tow-net (F.S. G.).

\section{Fam. Thaumastochelidae.}

(qu) Calocaris macandreae, Bell.-L. Fyne, 40-105 f.; off Tarbert; off Wemyss B., 40 f.; off Brodick B., 93 f. (H.).

\section{Fam. Palinuridae.}

Palinurus vulgaris, Latr.-Off Campbeltown ; L. Fyne (H.) : r.

\section{Fam. Nephropsidae.}

* Nephrops norvegicus (Lin.).-C., usually d.w.

Astacus gammarus (Lin.).- Rocky shores nr. mouth of Firth, c., (H.): E. L. Tarbert, etc.

\section{Fam. Crangonidae.}

× Crangon vulgaris (Lin.).-Mod. c.; shall. w. inshore, on sandy, weedy bottom.

× C. allmanni, Kinahan -C. and gen. dist., mostly in d. w.

Egeon sculptus (Bell.).-Lamlash B., 5 f., two (A. M. N.); off Muggie Pt., L. Cumbrae, 20 f., one (H.).

$\times$ Pontophilus spinosus, Leach.-Not c.; many localities as far up as Cloch L.H., usually soft ground 20-60 f. (H.).

20) $X^{(16)}$ Cheraphilus nanus $\left(K r_{0}\right)$. - Off Cumbrae (R.): Ballantrae Bank (F. S. G.).

C. echinulentus, M. Sars. - Off Skate I., L. Fyne, 105 f., one (H.): not very r. at mouth of estuary (F.S. G.).

9) C. neglectus, $G$. O. Sars.-Occasionally in E. L. Tarbert and vicinity, 5-20 f. (S.).

Fam. Nikidae.

Nika edulis, Risso.-One off Skate I., 105 f. ; one off Brodick 93 f. (H.) : occasionally in shrimp-trawl in seaward part of estuary (F. S. G.).

\section{Fam. Hippolytidae.}

Caridion gordoni (Bate).-Lamlash B. (A. M. N.) : not c. throughout Firth ; d. w. (H.). 
X Hippolyte varians, Leach.-C. ; rock pools 1. w., and lam. zone (H.): c. E. L. Tarbert.

H. prideauxiana, Leach.--Shrimp trawl nr. mouth of estuary, 11/96 (F.S.G.). $X($ ) $[H$. fascigera, Gosse.-E. L. Tarbert, amongst zoster $\alpha$, not $r$. Now considered to be a form of $H$. varians.]

$\times$ Spirontocaris spinus (Sowerby), var.XHippolyte securifrons, Norm.-Is mod. c. Typical S. spinus at mouth of estuary, but r. (vide Stebbing).

$X$. S. cranchii (Leach).-L. Fyne ; off Cumbrae ; off Craigmore ; Hawk's Neb, Bute $\left(\mathrm{H}_{\mathrm{.}}\right)$ : E. L. Tarbert (S.).

(20) X(16)S. pusiola $\left(K r_{0}\right)$.-Off Cumbrae (R.): L. Goil ; L. Long (H.).

( ) S. gaimardii (M. Edw.).-Gen. dist., prob. not very r. (H.).

\section{Fam. Pandalidae.}

X(6) Pandalus montagui, Leach.-C. and gen. dist. ; largest and most highly coloured from $d$. w.

P. bonnieri, Caullery.-L. Fyne ; L. Long (Calman).

P. propinquus, G. O. Sars.-I. L. Fyne ; L. Long, 40 f. (Calman).

x (16) Pandalina brevirostris, (Rathke).-C. and gen. dist. (H.)

\section{Fam. Palaemonidae.}

X Leander squilla (Lin.).-C. ; rock pools (H.).

Palaemonetes varians (Leach)._Cumbrae at l. w. (R.) : Inverkip (S.)

Fam. Pasiphaeidae.

Pasiphaea sivado (Risso)._-Off Skate I. 105 f. (H.) : off Strachur 70 f. (M.) : mid-water tow-net, L. L. Fyne; not r. at mouth of estuary (F. S. G.).

\section{Sub-Order Schizopoda.}

Arrangement and Nomenclature Followed.

Rer. Canon A. M. Norman, F.R.S., D.C.L., "Revision of the Brit. Species of Schizopoda" (Ann. and Mag. N.H., Ser. 6, vol. ix., pp. 454-464, and Ser. 6, vol. x., pp. 143-166 : and pp. 241-263, 1892).

\section{Fam. Euphausiidae.}

X(16) Rhoda raschii ( $M$. Sars) (=Boreophausia raschii).-Gen. dist., sometimes c. esp. in L. Fyne.

R. inermis $(K r$.$) .-Clyde (Brook ; Hoyle). Off Sanda I. 20-27 f. (F.S.G.,$ 15/12/98).

X. Nyctiphanes norvegica (M. Sars).-Gen. dist., usually more c. in L. Fyne than elsewhere.

10) Thysanoessa neglecta $\left(K r_{0}\right)$. - In bottom tow-net bet. Ailsa Craig and Sanda I. 20 f. (F. S. G., 16/1/99).

\section{Fam. Mysidae.}

Siriella clausii, G. O. Sars.-E. L. Tarbert ; L. Gilp ; r. (F. S. G.).

S. brooki, Norman.-E. L. Tarbert, 1886 (S.).

(Y,16) S. armata $\left(M_{.} E d w_{0}\right)$.-Cumbrae, in surface tow-net, r. (R.) : E. L. Tarbert; I. Gilp (S.).

Gastrosaccus spinifer (Goës).-F. of Clyde (R.) ; nr. Sanda I. ; nr. Ailsa Craig 20-30 f.; S. of Davaar T. 7-10 f. (F. S. G.).

Anchialus agilis, G. O. Sars.-Nr. Sanda I. 20-27 f. (F. S. G., 15/12/98).

(Y) Heteromysis formosa, S. I. Smith.-Dredged, Tarbert Bank, L. L. Fyne (F.S.G., 1899) : r.

(20) Erythrops elegans, G. O. Sars.-Gen. dist. from U. L. Fyne to seaward limits of estuary; rarely captured except in bottom tow-net.

8 E. serratus, $G$. O. Sars.-Dist. somewhat similar to $E$. elegans.

$\times$ Serriclla cracac/w, 9.0.8. (7) (6) Srytterofes soeaii (erythrophthalma)

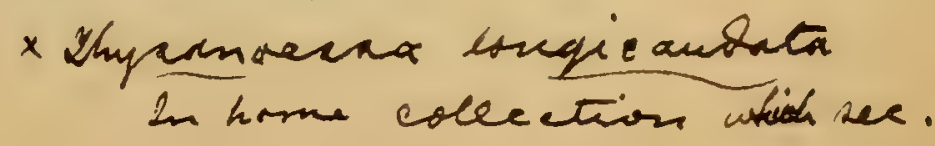


Mysidopsis didelphys (Norman).-Off Cloch L.H. 43 f. (H.) : dist. from U. L. Fyne to mouth of estuary.

x (16) M. gibbosa, G. O. Sars. - Gen. dist. but not very c.

M. angusta, G. O. Sars.-L. Fyne and nr. Ailsa Craig; not c. (F. S. G.)

Leptomysis gracilis, G. O. Sars.-U. L. Fyne; nr. Ailsa Craig, etc.

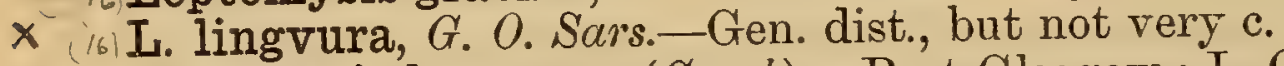

$X$ (16) Hemimysis lamornae (Couch).-Port Glasgow ; L. Goil (R.) : E. L. Tarbert ; nr. Ailsa Craig ; Davaar I. (F. S. G.).

x (16) Praunus flexuosus (Müller).-More or less c. ; usually more so inshore than in $\mathrm{d}$. $\mathrm{w}$.

P. inermis (Rathke).-Cumbrae in Lam. zone (H.): E. L. Tarbert, etc. (F. S. G.).

[P neglectus (G.O. Sars).-Mouth of L. Fyne $60 \mathrm{f}$. (H.): never met with by $(\mathrm{S})$.$] .$

$\times$ (16) Schistomysis spiritus, Norman.-E. of Sanda I., surface tow-net 24/1/99 (F.S. G.).

S. ornata, (G. O. Sars).--Head of L. Fyne; bet. Ailsa Craig and Sanda I.; scarce.

S. arenosa (G. O. Sars).-E. L. Tarbert ; shallow water, not r.; Ettrick B., Bute (1887) (S., A. M. N.).

$X$ (6) Neomysis vulgaris (J. V. Thompson).-Dhu Loch, nr. Inveraray, not r.; in stomach of 15 spined stickleback nr. head of L. Fyne (S.). (Bell suggests this $=$ Mysis integer recorded by Leach from L. Ranza.)

$X$ (16) Macrofuin alobbcri v. Ben

ORDER EDRIOPHTHaLMa.

Sub-Order Sympoda. ${ }^{1}$

Arrangement and Nomenclature.

Prof. G. O. Sars, Crustacea of Norway; vol. iii.

\section{AUTHORITIES.}

$(\mathrm{R})=$. Dr. Robertson, F.G.S., "Thirteen Cumacea from the Firth of Clyde" (Nat. Hist. Soc. Glas. Trans., vol. iii. (N. S.), p. 47, 1889).

(S.) = Thomas Scott, F.L.S., "Scottish Cumaceans" (Ann. Scot. N. H., Oct. 1900). Rev. T. R. R. Stebbing, A History of the Crustacea.

(A. M.N.) = Rev. Canon A. M. Norman, D.C.L., F.R.S, "On a Crangon, some Schizopoda and Cumacea, new or rare in the British Seas" (4th Ann. Rep. Fish. Bd. for Scot., 1886).

Hsee Stebbing on change of "Cuma" and "Cumacea" to "Bodotria," and "Sympoda," in Memoir On Crustacea brought by Dr. Willey from the South Seas (Camb. Univ. Press) Dec. 1900].

\section{Fam. Bodotriidae.}

Bodotria arenosa, Goodsir.-Blackwaterfoot, Arran, 4-5 f. (R.).

B. scorpioides (Mont.).-Dredged, Ballantrae Bank, 6/9/98 (S.).

B. pulchella, G. O. Sars.-Dredged nr. Sanda I. (S.).

Iphinoë trispinosa (Goodsir).-Plentiful Kames B., Millport; L. Ranza (R.): U. L. Fyne ; Kilbrennan Sd. (S.).

I. serrata, Norman.-Kames B., Bute, 1887 ; off Ballantrae, 1899 (S.).

I. tenella, G. O. Sars.-Clyde (Stebbing).

(16) Cumopsis edwardsii (Spence Bate) (=C. goodsiri), V. Ben.).-Whore pools Millport (S.).

C. longipes (Dohrn).-Whore pools Millport (R.; S.)

Fam. Vaunthompsoniidae.

(14) Vaunthompsonia cristata, Sp. Bate.-E. L. Tarbert 1886 ; Ballantrae Bank, 15-20 f. 1899 (S.). 


\section{Fam. Lampropidae.}

x Lamprops fasciata, G. O. Sars.-W. of Helensburgh Pier (R.) : E. L. Tarbert; Hunterston Sands (S.), freq.

Hemilamprops rosea (Norman).-U. L. Fyne; Kilbrennan Sd. 1899, r. (S.)

H. cristata, G. O. Sars.-F. of Clyde 1860 by Robertson (A. M. N.).

\section{Fam. Leuconidae.}

x(16)Leucon nasica, Kröyer.-U. L. Fyne ; off Arran, E. side 43 f. (S.).

Eudorella emarginata (Kröyer).-Rothesay B., 12 f. (R.): d. w. bet. Arran and Ayrshire (S.).

E. truncatula (Sp. Bate).--L. Fyne ; nr. Ailsa Craig (S.).

(8) Eudorellopsis deformis (Kröyer).-Nr. Ailsa Craig; off Sanda I. (S.).

\section{Fam. Diastylidae.}

$\times$ Diastylis rathkii (Kröyer).-E. L. Tarbert, 1886-87 (S.), r.

6) (8) D. rugosa, G. O. Sars.-L. Ranza, 5 f.; Blackwaterfoot, Arran, 20 f. (R.): E. L. Tarbert, 1886 (S.).

$x$ D. lucifera (Kröyer).-Clyde district, mod. r. (S.).

$x$ D. rostrata (Goodsir).-Blackwaterfoot, 20 f. (R.): Kames B., Bute, 15 f. (S.).

D. tumida Lillj.-R., Blackwaterfoot, 20 f. (R.).

D. spinosa, Norman.-Dredged Blackwaterfoot; W. side of Helensburgh Pier l. w. ( $R_{0}$ ).

Diastyloides biplicata, G. O. Sars.-Blackwaterfoot, 20 f. (R.): L. Fyne; off E. of Arran 40 f. ; nr. mouth of estuary $64 \mathrm{f}$. (S.).

Leptostylis villosa, G. O. Sars.-Bet. Arran and Ayrshire coast, $40 \mathrm{f}$. 1896 (S.).

\section{Fam. Pseudocumidae.}

X (j6)Pseudocuma cercaria $\left(\nabla \cdot B e n_{0}\right)$.-Kames B., Millport $\left(\mathrm{R}_{.}\right)$: freq. and gen. dist.

(20) P. similis, G. O. Sars.-D. w. nr. seaward limit of estuary, 12/1899 (S.).

\section{Fam. Nannastacidae.}

Nannastacus unguiculatus, Sp. Bate--Kames B., Millport, m. c. (R.): L. Fyne; Kilbrennan Sd., \&c. (S.).

(20) Cumella pygmaea, G. O. Sars._Cumbrae (R.) : L. Fyne ; Whiting B. ; Kilbrennan Sd., \&c. (S.).

\section{Fam. Campylaspidae.}

16) 8) Campylaspis rubicunda (Lillj.).-U.L. Fyne, 30-40 f. ; E. of Arran, 40 f. ; E. of Sanda I., 30 f. (S.).

C. sulcata, G. O. Sars. - Single specimen off Cumbrae 20 f., 15/8/88 (A.M. N.).

C. costata, G. O. Sars.-U. L. Fyne 30-40 f.; Kames B., Bute, 15-20 f. (S.) : off Cumbrae, 20 f. (A. M. N.).

\section{Sub-Order Isopoda.}

\section{Arrangement and Nomenclature.}

Sars, Prof. G. O., Crustacea of Norway, vol. ii.

\section{AUTHORITIES.}

$($ R. $)=$ Robertson, Dr. D., F.G.S., F.L.S., "Catalogue of the Amphipoda and Isopoda of the Clyde," Parts i. and ii. (N. H. Soc. Glas. Trans., vol. ii. iii. (N. S.).

Stebbing, Rev. T. R. R., History of the Crustacea.

(A. M. N.) = Norman, Rev. Canon, A.M., D.C.L., F.R.S., "British Isopoda Chelifera" (Ann. and Mag. N. H., Ser. 7, vol. iii., 1899). 
(S.) = Scott, Thos., F.L.S., "Notes on some Scottish marine Isopods" (Ann. Scot. N. H., 1898).

Explanation of Abbreviations.

(R. I, 70) =reference to page 70, Part I. of Robertson's Catalogue.

(R. I, 24. 73, II, 15.) = recorded three times under different or corrected names. This formula used both in Isopoda and Amphipoda.

\section{Fam. Apseudidae.}

Apseudes talpa (Mont.)-Roots of Laminaria Tan, Cumbrae, 7 f. (R. II, 28).

\section{Fam. Tanaidae.}

× Tanais cavolinii, M.-Edw. (T. vittatus, Bate and Westw.).-Farland Pt., Cumbrae (A. M. N.) : amongst barnacles at 1. w. E. L. Tarbert (S.) : Cumbrae (R. I, 70).

Paratanais batei, G. O. Sars.-Cumbrae (R. I, 70): L. L. Fyne ; Whiting B. (S.).

Leptognathia longiremis, (Lillj.).-L. Fyne (S.).

L. rigida, (Bate \& Westw.).-Nr. Tan Buoy 7-8 f. (R. I, 70).

L. breviremis (Lillj.).-Bet. Arran and Ayrshire, 40 f.; Tarbert Bank; L. L. Fyne, 25 f. (S.).

I. brevimana (Lillj.).-Off Sanda I. 20-30 f. ; Ballantrae Bank, 14 f. (S.).

Tanaopsis laticaudata, G. O. Sars.-Nr. Cumbrae (A. M. N. : R. II, 29) : L. Gair (L. Fyne), 2-3 f. ; Campbeltown L. 5 f. (S.).

$\times \quad$ Pseudotanais forcipatus (Lillj.).-Tarbert Bank; L. L. Fyne 25 f. (S.).

\section{Fam. Gnathiidae.}

Gnathia maxillaris (Mont.).-Gen. dist.; female more c. than male.

G. halidaii (Sp. Bate).-Kames B., Cumbrae (R. I, 71).

\section{Fam. Aegidae.}

Aega tridens, Leach.-Off S. end of Cumbrae; nr. Arran (R. I, 72): Rothesay B. (S.) : parasitic on fishes.

[Ae. rosacea (Risso), (Ae. bicarinata, Leach).-L. Fyne 15 f. (R. I, 72).].

\section{Fam. Cirolanidae.}

Cirolana borealis (Lillj.), (C. spinipes, Bate and Westw.).-Cumbrae; L. Cumbrae, N. side, 27 f.; mouth of L. Fyne 37 f. (R. I, 73): not r. from $d$. $w$.

C. cranchii, Leach.-Farland Pt., Cumbrae, 14 f. r. (R. I, 72).

Conilera cylindracea (Mont.).-Bet. Bute and Cumbrae, 50 f. (R. I, 73) : F. of Clyde (A. M. N.).

X(16) Eurydice achata (Slabber), (E. pulchra, Leach.).-Fairly freq. shall. sandy bays (R. I, 74).

\section{Fam. Sphaeromidae.}

Sphaeroma serratum (Fabr.).-Taken on Ayr sands (R. I, 81).

S. curtum, Leach.-Off Portincross, Ayrshire, 6 f. (R. I, 82).

(5) S. rugicauda, Leach.-Brackish pools; Hunterston (R. I, 82): Inverkip; Langbank, c. (S.).

S. hookeri, Leach.-Brackish pool, S. side of L. Cumbrae (R. II, 29).

Dynamene rubra, Mont.-Cumbrae (A. M. N. vide R. I, 82).

D. viridis, Leach.-Bet. t. m., Portloy, Cumbrae (R. II, 29).

Naesa bidentata (Adams).-With the last at Portloy (R. I, 84). [Note.For last three species and D. montague, Leach., vide Stebbing, p. 361.]

F́am. Limnoriidae.

x Limnoria lignorum (Rathke).-C. on woodwork of piers and jetties (R. I, 77). 


\section{Fam. Idotheidae.}

(x)Idothea baltica (Pallas), (I. tricuspidata, R.).-C. and gen. dist. (R. I, 79).

I. pelagica, Leach.-Amongst weeds at l. w. Cumbrae (R. I, 79) : rocks nr. l. w., E. L. Tarbert (S.).

I. emarginata (Fabr.).-Amongst weeds at l. w., Cumbrae (R. I, 80).

I. linearis (Pennant). - In a sandy pool at l. w., Cumbrae (R. I, 80).

Zenobiana prismatica, Risso, (Idotea parallela, $R$.).-Dredged bet. Tan Buoy and Hawk's Neb, Bute, 50 f. (R. I, 80).

Stenosoma acuminata (Leach), (Idotea acuminata, $R$.).-Nr. 1. w., Cumbrae; sandy pools, Kilchattan B. (R. I, 81).

Fam. Astacillidae.

Astacilla longicornis (Sowerby), (Arcturus longicornis, $R_{\text {. }}$.- -gen. dist. (R. I, 78).

[A. gracilis (Goodsir).-(R. I, 78), is the male of A. longicornis (Sars.)].

Arcturella dilatata, G. O. Sars. (Leacia dilatata, $R$.).-Off Blackwaterfoot, Arran, 20 f. (R. II, 28).

Fam. Asellidae.

Asellus aquaticus (Lin.).-C., in fresh-water ponds, canals, \&c. (R. I, 77)

Fam. Janiridae.

Janira maculosa, Leach.-L. w., Portloy, Cumbrae; mouth of L. Fyne 40-60 f. ; off Dunoon 13 f. (R. I, 76) : E. L. Tarbert; Campbeltown L., \&c. (S.).

Jaera marina (Fabr.).-C. in shall. w., and under stones bet. t. m. (R. I, 74).

[J. nordmanni (Rathke).-(R. I, 75). Sars suggests that the form described by Spence Bate under this name may not be the true Rathkian species but the male of $I$. marina].

\section{Fam. Munnidae.}

Munna boeckii, $K r$. - Whiting B. (S.).

M. kroyeri, Goodsir.-Cumbrae, from nests of Lima hians (R. I, 76).

[M. Whiteana, Sp. Bate.-(R. I, 75), is the female of M. kroyeri (Sars).].

Paramunna bilobata, G. O. Sars.-F. of Clyde (A. M. N.) : E. L. Tarbert; Kilbrennan Sd., \&c. (S.).

[Leptaspidia brevipes (Sp. Bate).-Off Cumbrae (R. I, 76). Norman suggests this is a Pleurogonium].

Pleurogonium rubicundum, G. O. Sars. -F. of Clyde (A. M. N.). At mouth of estuary 64 f. Dec. 7th, 1899 (F. S. G.).

P. inerme, $G$. O. Sars.-Off Farland Pt., Cumbrae, 23 f. (R. II, 29) : Kilbrennan Sd. ; Campbeltown L. (S.).

P. spinosissimum, G. O. Sars.-Off Farland Pt., Cumbrae (R. II, 29).

\section{Fam. Munnopsidae.}

Eurycope phallangium, G. O. Sars.-L. Fyne, r., 30-40 f. (S.).

\section{Fam. Oniscidae.}

Ligia oceanica ( Lin.).-Under stones, \&c. ; more or less c. in various places. (Note:-This and the following eight species are land Isopods, and may be found under stones, old wood, \&c.)

\section{Fam. Trichoniscidae.}

Trichoniscus pusillus, Brandt.-Cumbrae (R. I, 86): Rothesay, nr. Aquarium (S.). Prob. not unc. if carefully sought for.

T. roseus, Koch.-E. Tarbert (S.) 


\section{Fam. Oniscidae.}

Oniscus asellus (Lin.).-Gen. dist. and mod. c.

Philoscia muscorum (Scopoli).-Widely dist. and not very unc. (R. I, 85).

Porcellio scaber, Latr.-C. and gen. dist.

P. pictus, Brandt.-Cumbrae (R.): Ayrshire (Smith): nr. Campbeltown, 1896 (S.).

Cylisticus convexus (De $\left.G^{\gamma} e r^{r}\right)$, (Porcellio armadilloides, R.).-Kilwinning (Smith, vide R. I, 88) : Lanarkshire; Rothesay (S.).

Armadillidium vulgare (Latr.).-Mouth of Garnock (Smith, see R. I, 88).

\section{Fam. Bopyridae.}

Cryptothir balani (Sp. Bate).-One taken from a Balanus, on shore, E. L. Tarbert, 1886 (S.).

Pseudione affinis, G. O. Sars.-On a Pandalus montagui in shrimp trawl nr. Sanda I., $5 / 97$ (F. S. G.).

P. hyndmanni (Bute \& Westw.).-L. Fyne, 1886 ; and Clyde (S.).

P. crenulata, G. O. Sars.-From a small Mrnida rugosa in shrimp trawl, nr. Sanda I., 5/97 (F. S. G.).

Pleurocrypta hendersonii, Giard \& Bonnier.-On Galathea dispersa. Clyde (Henderson, vide Stebbing).

* Atheleges paguri (Rathke).-On Eupagurus bernhardus, L. Fyne; E. L. Tarbert.

x (20) Phryxus abdominalis $(K r$.$) .-On Spirontocaris spinus in shrimp trawl, nr.$ Sanda I. (F. S. G.).

Fam. Dajidae.

Aspidophryxus peltatus, G. O. Sars.-On backs of Erythrops nr. Davaar I., \&c.

Note.-A recent monograph on the Bopyridae by M. Jules Bonvier gives the following Clyde records. Bonnier often differs from Sars as to what are distinct species.

Bopyroides sarsi, Bonnier.-Branchial cavity of a typical Spirontocaris spinus (Sowerby), dredged nr. mouth of Clyde estuary (F. S. G., Ang. 30th, 1899). Distinct from B. hippolytes $(K r$.$) .$

Pseudione affinis, G. O. Sar's.-Branchial cavity of Pandalus leptorhynchus, Kinahan. Firth of Clyde (Hoyle).

P. hoylei (Giard \& Bonnier). - Branchial cavity of Pandalus montagui, Leach. Firth of Clyde (Henderson; Hoyle; F. S. G. ; Patience). According to Sars $P$.hoylei is identical with $P$. affinis.

P. hyndmanni (Bate \& Westwood).-Branchial cavity of Eupagurus bernhardus (Lin.). Clyde (Henderson and myself). See remarks by Yrof. Sars and M. Bonnier.

P. insignis (Giard \& Bonnier) (=P. crenulata, G. O. Sars, of my list).According to M. Bonnier the Pseudione of Munida rugosa is a different sp. from P. crenulata, G. O. Sars, found on Munida tenuimana; Sars considers them the same species.

P. sp.-From the branchial cavity of Pandalina brevirostris (Rathke). Clyde (Henderson, as Bopyrus sp.).

(?) P. sp.-From the branchial cavity of Eupagumus prideauxi (Leach). Clyde (Henderson, as Bopyrus sp.).

Pleurocrypta. hendersoni, Giard \& Bonnier (=P. marginata, G. O. Sars. Scott, in 18th Ann. Rept. Fishery Board for Scotland, Pt. III., p. 403). From branchial cavity of Galathea dispersa, Bate. F. of Clyde (Henderson; F.S.G. ; Patience). According to M. Bonnier the P. marqinatis, G. O. Sars, from Norwegian specimens is different from that on Englisls specimens of the same decapod. 
P. intermedia, Giard \& Bonnier (=P. microbranchiata, G. O. Sars).Branchial cavity of Galathea intermedia, Lillj., F. of Clyde (Henderson, as Bopyrus sp.).

Atheleges paguri (Rathke).-On abdomen of Eupagurus bernhardus (Iin.). F. of Clyde (Henderson (as Phryxus paguri); F. S. G.).

Phryxus abdominalis ( $K r_{\text {. }}$ ).-.On abdomen of Spirontocaris spinus (Sowerby), S. securifrons, Norm., and Pandalus montagui, Leach. F. of Clyde (Henderson; F.S.G.; Patience). M. Bonnier doubts whether the Phryxus found on these species are identical with abdominalis, Kroyer, found on Spirontocaris gaimardi (M.-Edw.). Prof. G. O. Sars, on the other hand, regards them as belonging to that species.

P. cranchii, Giard \& Bonnier.-On abdomen of Hippolyte cranchii, Leach. F. of Clyde (Henderson as Phryxus sp.).

\section{Sub-Order Amphipoda.}

Arrangement Followed.

Prof. G. O. Sars, Crustacea of Norway, vol. i.

Authorities.

Robertson, Dr. D., F.G.S., F.L.S._- "Catalogue of the Amphipoda and Isopoda of the Clyde," (N.H. Soc. Glas. Trans., N.S.), vol. ii. p. 1, vol. iii. p. 199.

Norman, Rev. Canon A. M., D.C.L., F.R.S., "A Revision of the British Amphipoda," Ann. and Mag. N. H.

Stebbing, Rev. T. R. R., Papers on British Amphipoda.

Walker, A. O., Papers on British Amphipoda.

\section{Fam. Hyperiidae.}

X Hyperia galba (Mont.).-In folds of Rhizostoma pulmo, Cumbrae (R. I, 64): E. L. Tarbert (S.). F. of Clyde (A. M. N.).

(16) Hyperoche tauriformis $(\dot{B} . \& W$. $)$.-Off Sanda; nr. Ailsa Craig; Kilbrennan Sd. ; U. L. Fyne (S.).

Parathemisto oblivia $(K r$. $)$.-Nr. Sanda, in surface net $(\mathrm{R} . \mathrm{I}, 65)$ : off Ailsa Craig (F. S. G.).

\section{Fam. Orchestiidae.}

Talitrus locusta (Pallas).--Sandy shores, abund. (R. I, 10). U. L. Fyne (S.).

Orchestia littorea (Mont.).- Under stones nr. and above h.w. m., freq. (R. I, 11).

0. mediterranea, Costa.-Cumbrae ; mouth of R. Garnock (R. I, 13): bet. Fairlie and Hunterston (S.). Inveraray (A. M. N.).

Hyale nilssoni (Rathke).-Kames B., Millport (R. I, 13).

H. Iubbockiana (Bate).-Largs Pier; tide pools Cumbrae (R. I, 13-14): E. L. Tarbert ; Fintry B., Bute (S.).

\section{Fam. Lysianassidae.}

Normanion quadrimanus $(B . \& W$.).-Off Farland Pt., Cumbrae (R. II, 12): Nr. Davaar Is., 1898 ; Tarbert Bank, L. L. Fyne, 1901 (F. S. G.).

Acidostoma obesum (Bate).-Off Farland Pt., Cumbrae (R. I, 17).

Lysianax septentrionalis, Della Valle.-Cumbrae; off Skelmorlie Buoy; W. end of L. Cumbrae (R. I, 15-16): E. L. Tarbert; U. L. Fyne (F.S. G.).

I. ceratinus A. O. W.-F. of Clyde (A. M. N.).

I. atlanticus (M. Edw.).-Nr. Tan Buoy, Cumbrae (R. I, 17).

Socarnes vahli $(K r$.$) . - N. side of Clach Rock, Cumbrae, 6$ or $7 \mathrm{f}$. (R. II, 5).

S. erythrophthalmus, Robertson.-Tan, Cumbrae ; Castle-B., L. Cumbrae ; Rothesay; Millport B. (R. II, 6). 
Sophrosyne robertsoni, Stebbing and Robertson-(Clyde R. II, 9): U. L. Fyne (M:).

Perrierella audouiniana (Bate).-In a sponge, mouth of L. Fyne, 40-60 f. (R. I, 16; II, 7): U. L. Fyne (M.) : Tarbert Bank; E. of Sanda', $30 \mathrm{f}$. (F. S. G.).

(y) Callisoma hopei, $A$. Costa [=Callisoma crenata (Bate)].-L. Fyne, 80 f. ; Kilchattan B., 30 f. (R. I, 19). Gen. dist.

(8) (6) Hippomedon denticulatus (Bate).-Nr. Tan Buoy; Castle-B., L. Cumbrae, \&c. (R. I, 18 ; II, 9). Gen. dist.

Orchomene humilis (A. Costa) (=Anonyx edwardsii, Bate and Westwood).-Tan Buoy; L. Striven; L. Goil ; L. Fyne (R. I, 17; II, 11); Whiting B. (S.).

Tryphosa pinguis (Boeck).-Dredged w. of Tan Buoy, 18 f. (R. II, 9).

T. nana $(K r$.).-W. of Tan Buoy, 14 f. (R. II, 10): off Ballantrae, rather r. (F. S. G.).

T. minuta (Kr.).-Minard, U. L. Fyne (M.).

Tryphosella sarsi, Bonnier.-Off Farland Pt., Cumbrae, 23 f. (R. II, 11): off Largabruach ; off Inveraray, U. L. Fyne (F. S. G.).

(4) T. höringii, (Boeck). - Cumbrae, on back of a codfish (R. I, 92).

T. nanoides (Lillj.).--Cumbrae, on back of a codfish (R. I, 92).

[T. pusilla, G. O. Sars.--Tan buoy 12 f. (R. II, 12).].

Tryphosites longipes (Bate).-Off N.E. corner of L. Cumbrae $14 \mathrm{f}$; ; bet. Kilchattan and Cumbrae 66 f. $($ R. I, 18) : Kilbremnan Sd.; E. L. Tarbert, \&c. (F.S. G.).

Hoplonyx cicada (Fabr:).-Bet. the Allans, Cumbrae, 2-4 f. (R. I, 18): Tarbert Bank, L. L. Fyne, 20-25 f. ; rather r. (F. S. G.).

H. similis, G. O. Sars.-Off Farland Pt., Cumbrae (R. Il, 12).

Lepidepecreum carinatum (Bate). - L. Ranza B. 5 f.; S. E. of Bute 10-12 f. (R. I, 91).

Euonyx chelatus, Norman.-Off Mull of Kintyre 49 f. (R. I, 90) : several dredged nr. mouth of estuary, 11/95 (F. S. G.).

\section{Fam. Pontoporeiidae.}

Bathyporeia pelagica, Bate.-Sandy shores bet. t. m., various places (R. I, 42) : Cumbrae (A. M. N.).

(II) B. norvegica, G. O. Sars. -Cumbrae (A. M. N.).

B. robertsoni, Bate.-Cumbrae (A. M. N.).

(10) Haustorius arenarius (Slabber).-Sandy shores nr. l. w. m., mod c. (R. I, 23) : Cumbrae (A. M. N.).

(8) Urothöe elegans, Bate.-Cumbrae (A. M. N.).

(14) U. marinus, Bate.-Bet. t. m. Irvine and Fairlie; Lamlash B. ; Kames B. ; Fintry B.; Balloch B., Cumbrae (R. I, 29-30): Barmore, L. L. Fyne (S.).

U. brevicornis, Bate. - F. of Clyde (R., vide A. M. N.).

Argissa hamatipes (Norman).-Kilchattan B., Bute, 8-9 f. (R. II, 12) : not unc. in seaward part of estuary.

\section{Fam. Phoxocephalidae.}

Phoxocephalus holbölli $(K r$.).-Dredged bet. the Allans, taken nr. l. w. m. Balloch B., Cumbrae (R. I, 24): Millport B. bet. t. m. (A. M. N.).

(8) P. fultoni, T. Scott.-Cumbrae, l. w. m. (R.): L. Ryan (Fullerton): F. of Clyde (A. M. N.).

(2.) P. simplex (Bate).-Tan Buoy 6 f. (R. I, 23).

P. oculatus, G. O. Sars. - (I think R. obtained this sp. in the Clyde).

× Harpinia neglecta, G. O. Sars.-L. Ranza, 6-8 f. ; L. Fyne 80 f. (R. I, 24): Clyde, gen. dist. (A. M. N.).

(4) H. crenulata, G. O. Sars.-Campbeltown L. (S.): off Farland Pt.; Cumbrae (A. M. N.) : r. 
Amplizea aequecormi 13ru. Fam. Ampeliscidae.

Ampelisca typica (Bate). $-\mathrm{R}$. records this as A. gaimardii (Spence Bate) from various places (R. I, 20): Cumbrae (A. M. N.).

A. tenuicornis, Lillj.-L. Fyne 80 f.; bet. Tan Buoy and Bute; L. Goil 12 f. (R. I, 21-22) : Campbeltown L. (A. M. N.).

A. assimilis, Boeck.-Row B., Gareloch, 10-12 f. (R. I, 22) : off Sanda (F.S. G. . $_{0}$.

A. brevicornis (A. Costa).-Off S. shore, Cumbrae; opposite Largs, 15 f.; off Fairlie 20 f. ; l. w. Crarae, L. Fyne, \&c. (R. I, 21): nr. Ailsa Craig ; off Sanda I. (F. S. G.).

A. macrocephala, Lillj.—Off Brodick 80 f. (R. I, 22): Cumbrae (A.M.N.).

(II) A. spinipes, Boeck.-Off Cumbrae L.H. 60 f. ; off Holy I. 36 f. ; nr. Skate I. 80-100 f. (R. I, 91): Cumbrae (A. M. N.).

(12) Haploops tubicola, Lillj.-Off L. Cumbrae $60 \mathrm{f}$.; L. Striven $35 \mathrm{f}$.; off Dunoon 15-25 f. ; off Fairlie 6-8 f. (R. I, 22, 92) : off Sanda I. (A. M. N.).

H. setosa, Boeck.-Off Skate I., L. Fyne, 100 f., two specimens (R. I, 23).

Bytlis gaimardi vrozer

Fam. Stegocephalidae.

Stegocephaloides christianiensis (Boeck).-L. Fyne 40-70 f. (R. II, 20) : nr. head of L. Fyne (F. S. G.).

\section{Fam. Amphilochidae.}

Amphilochus manudens, Bate.-Off Tan Buoy 7-8 f. ; off Cumbrae L.H., 60 f. (R. I, 28).

A. tenuimanus, Boeck.-Off Farland Pt., Cumbrae, 17 f. (R. I, 28): Ballantrae Bank (F. S. G.).

Amphilochoides serratipes (Norman).-Off Blackwaterfoot 20 f.; off Clach Rock, Cumbrae (R. II, 20-22) : off Sanda ; at Ballantrae Rk. ; off Ailsa Craig (F. S. G.).

Gitanopsis bispinosa (Boeck).-Off Blackwaterfoot 20 f. (R. II, 20).

(5) Gitana sarsii, Boeck.-Kilchattan B. 5 f. (R. II, 2): Whiting B., Arran ; off Sanda I. 20 f. (F. S. G.).

Cyproidia damnoniensis, Stebbing.-Off Blackwaterfoot; off Farland Pt., Cumbrae (R. II, 21).

Stegoplax brevirostris (T. and A. Scott).-Tarbert Bank, L. Fyne, r. (S.).

Fam. Stenothoidae.

Stenothoe marina, Bate.-Cumbrae at 1. w.; off Dunoon (R. I, 15): Whiting B. ; off Ailsa Craig (F. S. G.).

S. monoculoides (Montagu). - Various places about Cumbrae (R. I, 14) : F. of Clyde (A.M. N.).

\section{Fam. Metopidae.}

Metopa alderi (Bate).-Bet. Cumbrae L. H. and Arran (R. I, 90).

M. borealis, G. O. Sars.-Off Fariand Pt., Cumbrae, 20 f. (R. II, 21) : E. of Arran 30-40 f. (F. S. G.).

M. rubrovittata, G. O. Sars.-Off the N. side of L. Cumbrae, 10-15 f. (R. II, 21).

[M. affinis, Boeck.--W. of Tan Buoy; Mull of Kintyre (R. I, 90).]

(20) M. pusilla, G. O. Sars.-Off Farland Pt., Cumbrae, 20-24 f. (A. M. N.).

Metopella nasuta, (Boeck). - Off Farland Pt., Cumbrae, 19 f. (R. II, 22).

\section{Fam. Cressidae.}

10) Cressa dubia, Bate.-W. of Tan Buoy, 7-8 f. (R. I, 15): Whiting B.; off Sanda I. (F. S. G.) : Cumbrae (A. M. N.).

Metopua nollexmas, 12 ate 
Fam. Leucothoidae.

(8) Leucothoë spinicarpa (Abilgaard).--Nr. Tan Buoy, 5 f.; L. Fyne, 92 f. (R. I, 39): Whiting B. (F. S. G.).

[L. incisa, Robertson.-L. w. Balloch B.; Farland Pt., Cumbrae, 20 f. (R. II, 23) (?): L. Gair (L. Fyne) (F. S. G.). Norman considers this only a form of the next species.]

(12) L. lilljeborgii, Boeck.-L. Gair; head of U. L. Fyne ; r. (F. S. G.).

\section{Fam. Oediceridae.}

(8) Monoculodes carinatus, Bate.-Several places about Cumbrae (R. I, 25.).

M. borealis, Boeck.-Off Blackwaterfoot, (R. II, 15).

M. tuberculatus, Boeck.-In d. w. E. of Arran, r. (F. S. G.).

M. packardi, Boeck.-L. Striven, 40 f. (R. II, 14) : L. Fyne, 30-60 f. ; E. of Arran, 40 f. ; not very r. (F. S. G).

$\times$ ('́) Perioculodes longimanus (Bate).--Gen. dist., not unc. in d. w. (vide R. I, 26).

Pontocrates altamarinus (Bate).-Callum's Bay, Bute, 16 f. (R. I, 27): U. L. Fyne (S.).

P. norvegicus, Boeck.-Shall. w. in sandy bays freq. (R. I, 26).

(io) Synchelidium brevicarpum (Bate).-Nr. Cumbrae; L. Fyne; Blackwaterfoot (R. I, $25 ; \mathrm{II}, 16)$.

10) Halimedon parvimanus (Bate)._-Various places (R. I, 24, 93 ; II, 15) : gen. dist. ; not r. in d. w.

\section{Fam. Pleustidae.}

Paramphithoë bicuspis $\left(K r_{0}\right)$.- - In surface tow-net after sunset, Cumbrae (R. I, 36).

P. monocuspis, G. O. Sars.-Off Sanda I., r. (F. S. G.).

P. assimilis, G. O. Sars. - Off Cumbrae, 15-20 f. (R. I, 94).

Stenopleustes nodifer, G.O. Sars.-Off N. side of L. Cumbrae, $20 \mathrm{f}$.; off Fairlie Perch, 20 f. (R. II, 18).

\section{Fam. Epimeridae.}

(5) Epimeria cornigera ( $F a b$.).--Not unc. in d.w. (R. I, 32). Mouth of estuary, and in d. w. bet. Arran and Ayrshire coast (F. S. G.).

\section{Fam. Iphimedidae.}

(16) Iphimedia obesa (Rathke).-Gen. dist. ; not very r.

(v2) I. minuta, G. O. Sars.-Off Farland Pt., Cumbrae, 20 f. (R. II, 23).

I. elbanae, Bate.-Dredged nr. mouth of estuary (F. S. G.).

Odius carinatus (Bate).-Off Garnock Beacon, $5 \frac{1}{2}$ f. (R. II, 31):

\section{Fam. Laphystiidae.}

(y) Laphystius sturionis $(K r$.).-Kilbrennan Sd. (R. I, 93) : Rothesay B. (S.). Parasitic on Cod, Anglerfish, etc.

\section{Fam. Syrrhoidae.}

Syrrhoë fimbriatus, Stebbing and Robertson.-Clyde (R. II, 22).

Bruzelia typica, Boeck.-W. of Tan Buoy, 12-20 f. (R. II, 22).

\section{Fam. Eusiridae.}

Eusirus longipes, Boeck.-W. of Tan Buoy, 10 f. ; L. Goil, 12 f. (R. I, 38) : nr. Sanda I. ; head of L. Fyne, etc. (F. S. G.).

\section{Fam. Calliopiidae.}

(16) Apherusa bispinosa (Bate).-C. in Clyde (R. II, 17): Kilbrennan Sd. ; off Ailsa Craig, etc. (F. S. G.).

A. jurinii (M. Edw.).-Bet. t. m., Farland Pt., Cumbrae (R. II, 17). 
X Calliopius laevicusculus ( $K r$.).-Mod. c., Kames B., Balloch B., Cumbrae (R. I, 37, 39, 94).

C. rathkei (Zaddoch).-Amongst weedy stones at I. w. Cumbrae (R. I, 38).

Fam. Atylidae.

Paratylus swammerdami $(M .-E d w$.$) . C. and gen. dist.$

P. vedlomensis (Bate).-Not unc. in Clyde (R. I, 36).

P. uncinatus, G. O. Sars.-Kilbrennan Sd., 4/96 (F. S. G.)

Fam. Dexaminidae.

Dexamine spinosa (Mont.).-Mod. c. all round our shores (R. I, 32).

(14) D. thea, Boeck.-Portloy, Cumbrae; Clach Rock, and off Hunterstone, opposite Millport (R. I, 33, 34) : head of L. Fyne (F. S. G.).

(4) Tritaeta gibbosa (Bate).-Freq., by dip-net among seaweed, \&c. (R. I, 34): nr. Davaar I. (F.S. G.).

(४) (8) Guernea coalita (Norm.).--Taken twice off Millport (R. II, 24): gen. dist. esp. in d. w., scarce (F. S. G.).

Fam. Melphidippidae, Stebbing (1899).

Melphidippa goesi, Stebbing.-On N. side of L. Cumbrae 20 f. (R. II, 19).

Melphidippella macera (Norm.).-N. side of L. Cumbrae (R. II, 19) : Kilbrennan Sd. ; off Ailsa Craig (F. S. G.).

\section{Fam. Gammaridae.}

(6) Amathilla homari (Fabr.). - In surface-net after sunset, Cumbrae, and Sanda B. (R. I, 41, 92) : Bet. t. ms., E. L. Tarbert (S.).

-(10) Gammarus marinus, Leach.-C. under stones bet. t. ms., and in tidal pools (R. I, 50).

G. locusta (Lin.).--Bet. t. ms., and dredged nr. Cumbrae, 6-35 f. (R. I, 50, 94). Gen. dist.

(14G. duebeni (Lillj.).-Fresh water lochs nr. Campbeltown (S.).

(9) G. pulex (de Geer).-C. in slow streams and ditches (R. I, 52).

Melita palmata (Mont.).-Clyde (A. M. N.) 1889.

$\times \quad$ M. obtusata (Mont.). - C. and gen. dist. (R. I, 47, 48).

M. gladiosa, Bate. -Taken bet. the Allans, Cumbrae, 4-5 f. (R. II, 18).

Eriopisa elongata (Bruzel).-Taken in Clyde by Norman (R. II, 25).

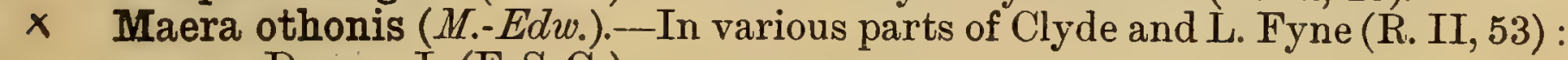
nr. Davaar I. (F. S. G.).

M. semiserrata (Bate).-Dredged twice at Tan Buoy (R. I, 52).

x(20) M. loveni (Bruzel).-Off L.H., L. Cumbrae, 55-60 f. ; off Arran, 80 f. (R. I, 52).

Gammarella brevicaudata, $\left(M .-E d w_{0}\right)$.-Off Hunterstone (R. I, 47 ; II, 24). Megaluropus agilis, Norm.-Garrison B., and Kames B., nr. Millport (R. II, 25) : nr. Sanda I, 5/9/99 (F. S. G.).

(14) Cheirocratus sundewalli (Rathke).-Various places (R. I, 45, 46) : nr. Largabruach, U. L. Fyne ; Tarbert Bank (F. S. G.).

(14) C. intermedius, G. O. Sars.-E. L. Tarbert (S., 1886): L. Gair, (L. Fyne); Tarbert Bank, 17-20 f. (F. S. G.).

(14) C. assimilis, (Lillj.).-L. L. Fyne, $104 \mathrm{f}$. ; off Farland Pt., Cumbrae, $20 \mathrm{f}$. (R. II, 18): Tarbert Bank, 20-25 f. (F.S. G.).

\section{Fam. Iilljeborgiidae.}

Lilljeborgia pallida, Bate.-Off Farland Pt., Cumbrae, 20 f. (R. II, 23).

(20) L. kinahani (Bate). -Nr. Tan Buoy, 7 f. (R. I, 46): Tarbert Bank, $20 \mathrm{f}$. (F.S. G.).

Fam. Aoridae.

[Phaedra antiqua (Bate).--In surface-net off the Allans, Millport B., after sunset (R. I, 94).] 
Microdeutopus anomalus (Rathke).--Off Tan Buoy, \&c., Cumbrae (R. I, 41). Whiting B. (S.).

M. versiculatus (Bate).-Dredged a little beyond 1. w., Cumbrae (R. I, 42).

M. danmoniensis (Bate).-One S. of Tan Buoy (R. I, 40): on E. side and in centre of U. L. Fyne 10-17 f. (M.).

Aora gracilis (Bate). - Gen dist., but mod. $\mathrm{r}$.

Autonoe websteri (Bate).--Under stones nr. 1. w., Portloy, Cumbrae, (R. I, 40).

\section{Fam. Photidae.}

Leptocheirus hirsutimanus (Bate). - Clach Rock, nr. Tan Buoy; bet. Fairlie and Millport (R. I, 42): off Sanda I. (F. S. G.).

(20) L. pilosus, Zaddach.-Castle B., L. Cumbrae, 2-3 f. (R. II, 27): Tarbert Bank, L. L. Fyne, 20-25 f. (F.S. G.).

Gammaropsis maculata, Johnstone.-Otter Spit, L. Fyne; nr. Cumbrae (R. I, 48). Gen dist.

G. palmata (Stebbing and Robertson).-Cumbrae; Clyde one (Steb. and Rob.): off Ballantrae, 24/9/98; Kilbrennan Sd. (F. S. G.).

(20) (14) Megamphopus cornutus, Norm.-Off Earland Pt.; Castle B., Cumbrae ; off Blackwaterfoot (R. II, 24, 26).

Microprotopus maculatus, Norm.-Garrison B.; Kames B., Cumbrae (R. II, 26).

Photis longicaudata (Bate).-Millport B. ; Clach Rock, Cumbrae; off S. end of Bute, 16 f. (R. I, 95): Kilbrennan Sd. (F. S. G.).

Podoceropsis sophiae, Boeck.-Skelmorlie Bank, $10 \mathrm{f}$; ; off Skelmorlie Pt., 39 f.; S. of L. Cumbrae (R. I, 60,61).

$\times \quad$ P. excavata (Bate).-Gen. dist. and mod. c. (R. I, 60).

\section{Fam. Amphithoidae.}

Amphithoë rubricata (Mont.).-Mod. c. : gen. dist. (R. I, 53, 54).

Pleonexes gammaroides, Bate.-Portloy and Kames B., Cumbrae; off L. Cumbrae 8 f. (R. I, 56 ; II, 27).

\section{Fam. Ischyroceridae.}

Ischyrocerus minutus, Lillj.-W. of Clach Rock; off Farland Pt. ; on the

Allans, Cumbrae (R. II, 28).
Jassa pusilla (G.O. Sars).-Amongst algae on Millport pier (R. II, 27). Off Sanda I. (F. S. G.).

J. falcata (Mont.). - Millport pier, amongst algae ; on Tan Buoy ; Portloy and bet. the Allans, Cumbrae; off Dunoon 4 f. (R. I, 57).

14) J. dentex (Czerniavski) (= Podocerus herdmanni, A.O. Walker).-Off Sanda I. [A. O. Walker now thinks this is only a form of $J$. falcata.] J. ocia (Bate).-N. of Tan Buoy 8 f.; off Clach Rock 6 f. (R. I, 58).

Microjassa cumbrensis (Stebbing and Robertson).-Off Farland Pt. 20 f. (R. II, 27).

Parajassa pelagica (Leach) [=Janassa capillata (Rathke)].-On Millport pier; Kames B. ; Tan Buoy, Cumbrae ; off Dunoon (R. I, 57).

Erichthonius abditus (Templeton).-N. of Cloch L.H. 6 f. (R. I, 58) : Campbeltown L.; nr. Ailsa Craig (F.S. G.).

E. difformis, M.-Edw.-L. w., Portloy; off Farland Pt. Cumbrae 17 f., (R. I, 59).

\section{Fam. Corophiidae.}

(8) Siphonoecetes colletti, Boeck.-W. of Cumbrae 10 f. (R. I, 59).

$\times \quad$ Corophium grossipes (Lin.).-Brackish water; Langbank; Roseneath ; Balloch B., Cumbrae ; mouth of Garnock (R. I, 61): Inverkip, c. (S.).

$\times$ 14) C. crassicornis, Bruzel.-Balloch B., Cumbrae; shore pool, L. Cumbrae, c. (R. I, 62): Campbeltown L. (F.S. G.).

(20) Protomedia jarceata, kroyer (II) Cerrizus crasscarnes 


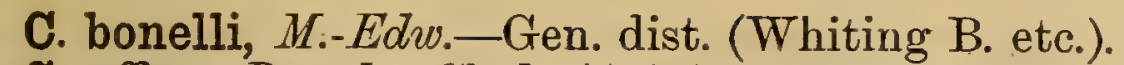

C. affine, Bruzel.-Clyde (A. M. N.) : E. L. Tarbert (S.).

Unciola planipes, Norm.-Off Sanda I. (E. S. G., 1/9/98).

\section{Fam. Cheluridae.}

Chelura terebrans, Philippi-All round coasts in submerged timbers of piers and jetties (R. I, 63).

\section{Fam. Dulichiidae.}

(9) Dulichia porrecta, Bate.-Off Farland Pt., Cumbrae (R. II, 28).

(zu)D. monacantha, Metzger.-One found in stomach of haddock caught in Clyde (1897) (S.).

D. tuberculata, Boeck.-Dredged nr. Mull of Kintyre 49 f. (R. I, 95).

D. valeata kate

Fam. Caprellidae.

x Phtisica marina, Slabber.-Gen. dist. (R. I, 65, 66) : freq. Tarbert Bank (F. S. G.).

× Protella phasma (Mont.).-Gen. dist., and not very r. (R. I, 66) : Tarbert Bank freq. (F. S. G.).

X(16) Pariambus typicus (Kr.).-Gen. dist., not unc. on Asterias rubens (R. I, 69).

$x$ Caprella linearis (Lin.).-Cumbrae among weedy stones l. w. ; off Garrochhead, Bute 15 f. (R. I, 67).

C. septentrionalis $(K r$.$) . - Cumbrae (R.).$

$X$ C. acanthifera, Leach.-Cumbrae bet. the Allans amongst zostera, plentiful R. I, 68).

[C. tuberculata, Guerin.-Cumbrae, rare (R. I, 69).]

\section{ORDER Branchiopoda.}

Sub-Order Phyllocarida.

Fam. Nebaliadae.

Nebalia bipes (Fabr.).CClyde; L. Fyne, various places (S.).

Sub-order Cladocera.

Arrangement Followed.

Prof. C. L. Herrick, Crustacea of Minnesota, 1884.

AUTHORITIES.

Baird, W., Monog. of the Brit. Entomostraca, 1849.

(A. M. N.) Norman, Rev. Canon A. M., and Prof. G. S. Brady, A Monograph of Brit. Entomostraca belonging to the Bosminidae, Macrothricidae, and Lynceidae, 1867.

Brady, Prof. G. S., on The Brit. species of Entomostraca belonging to the Daphnia and other allied species, 1898.

Scott, Thomas, F.L.S., "The Fauna of the inland waters of Scotland" (Ann. Reps. Fish. Bd. for Scotland).

\section{Fam. Sididae.}

(14) Sida crystallina (Miiller).-Bardowie L., nr. Glasgow ; L. Lomond ; Greenan L., Bute ; Park L., Campbeltown ; L. Doon, Ayrshire.

(14) Diaphanosoma brachyurum (Lievin).--Bardowie L.; Park L.

Fam. Holopedidae.

(1y) Holopedium gibberum, Zaddach.-L. Arklet; L. Doon, c. during summer. 


\section{Fam. Daphnidae.}

(q) Ceriodaphnia reticulata (Jurine).-Possil Marsh.

(17) C. quadrangula, Müller.-Bardowie L. ; St. Germains' L., Glasgow ; Dhu Lochan, nr. L. Lomond ; Park L., nr. Campbeltown.

(15) C. laticaudata, Müller.-Possil Marsh, rather r.
C. sp.-L. Lomond; L. Doon; appears to be $\mathrm{r}$.

(9) Scapholeberis mucronata, Miiller.-Bardowie L.; Dhu Lochan, not c.

(9) Simocephalus vetulus, Müller.-Possil Marsh; L. Lomond ; Greenan L. ; Park L. '; L. Doon.

i) Daphnia lacustris, G. O. Sars.--L. Lomond, with and without a vertex tooth.

var. aquilina, G. O. Sars.-L. Arklet, freq.

(q) D. (?) longispina, Leydig.-L. Fad, Bute.

var. nasuta, G. O. Sars.-L. Doon, Ayrshire.

(14) D. (?) jardinii, Baird.-St. Germains' L., Glasgow. A crested form which may belong either to this or to D. galeata, G. O. Sars.

Fam. Bosminidae.

(14) Bosmina longirostris (Müller).-Gen. dist. esp. in smaller lochs and ponds.

(4) B. Iongispina, Leydig. - Not unc. in larger lochs, as L. Lomond and L. Doon.

\section{Fam. Macrothricidae.}

(7) Lathonura rectirostris (Müller).-L. Doon-the shore on W. side. Streblocercus minutus, G. O. Sars.-Dhu Lochan, nr. L. Lomond, r.

(13) Drepanothrix dentata (Euren).-Cumbrae (R.) : L. Arklet; L. nr. L'ranza; L. Doon, \&c., not unc.

Acantholeberis curvirostris (Müller).-Cumbrae (R.) : L. Arklet; L. nr. L'ranza, not $r$.

(15) (9) Ilyocryptus sordidus (Lieven).-_Cumbrae (R.) : Possil Marsh; L. Arklet; L. Doon ; Park L., Campbeltown, not r.

\section{Fam. Lynceidae.}

(14) (13) Eurycercus lamellatus (Müller).-C. and gen. dist.

Acroperus harpae, Baird.-Gen. dist. and mod. c.

(1) Camptocercus macrurus (Müll.).-L. Lomond; L. Doon, freq. The Camptocercus found in Scotland is usually ascribed to $C$. macrurus, Müll., but seems to agree better with Schoedlers' $C$. rectirostris.

(13) Alonopsis elongatus, G. O. Sars.-C. and gen. dist. (9) Ledigia quadrangularis (Leydig).-Pond nr. Rutherglen (J. Steel)! St.
Germains' L., not c.

Graptoleberis testudinaria (Fischer).-L. Arklet; L. Doon ; freq.

Alona guttata, G. O. Sars.-Gen. dist., freq.

(14) A. costata, G. O. Sars.-St. Germains' Loch; L. Lomond (shore nr. Balmaha); not c.

A. quadrangularis (Müller).-Gen. dist., mod. c. A. quadrangularis (17) (14, A. affinis (Leydig).-L. Lomond; L. Doon; L. behind L'ranza; Park L.,
Campbeltown \&c., freq. (1) A. intermedia, G. O. Sars (=A. neglecta, T. S.)-L. Arklet; L. Doon,
not c.

(1) A. rustica, T. Scott.-L. Arklet; L. Lomond; L. Doon ; Park L.

A. rectangula, G. O. Sars.-Nr. E. Tarbert, L. Fyne; Park L., Campbeltown.

Alonella exigua (Lilljeborg).-C. and gen. dist.

A. nana, Baird.-L. Arklet ; L. Lomond; L. Doon, \&c., not r., but being so small is easily overlooked.

Pleuroxus trigonellus (Müller).-L. Lomond; I. Doon, not r.

(4) P. laevis, G. O. Sars.-Possil Marsh is the only station I know of. 
(9) P. uncinatus, Baird.-Pond nr. Rutherglen (J. Steel): Possil Marsh; L. Lomond.

Harporhynchus falcatus, G. O. Sars.--L. Arklet; L. Lomond; L. Doon, not $r$.

Peracantha truncata (Miiller).-L. Arklet; Dhu Lochan; Greenan L., Bute; L. Doon.

(14) Chydorus sphaericus, Muiller.-C. and gen. dist.

(17) C. globosus, Baird.--Possil Marsh ; Bardowie L., nr: Glasgow ; L. Lomond ; Park L., nr. Campbeltown.

(14) C, (?) latus, G. O. Sars.-Only observed in L. Arklet.

C. barbatus (G.S. Brady).-In most Lochs within Clyde area.

(17)D. coelatus, Schoedler.-L. Arklet; L. Doon; Park L., not c.

Anchistropus emarginatus, G. O. Sars.-Paisley Canal in 1863 (R.). Not observed since.

Monospilis tenuirostris (Fischer).-L. Lomond (shore bet. Balmaha and mouth of R. Endrick), rather $\mathrm{r}$.

Fam. Polyphemidae.

Polyphemus pediculus (Lin.).-Possil Marsh; L. Arklet; L. Lomond; Park Li:

(9) (4) Bythotrephes longimanus, Leydig.-L. Arklet; L. Lomond; L. Doon, not unc.

Podon polyphemoides, Leuckart.-F. of Clyde; L. Fyne, sometimes pretty abund.

P. intermedius, Lilljeborg.--Dist. similar to preceding but much less c.

(16) Evadne nordmanni, Loren.-Dist. similar to Podon; c., sometimes very abund.

Fam. Leptodoridae.

(9) Leptodora hyalina, Lilljeborg.-L. Arklet; L. Lomond; L. Doon, not unc., esp. during summer.

\section{Sub-Order Branchiura.}

win Argulus foliaceus, Lin.-Plentiful a few years ago on the Greyling, cincesphin Thymallus vulgaris in the upper waters of R. Clyde (Jas. Steel)!

\section{Order Ostracoda.}

Arrangement and Nomenclature followed.

(B. \& N.) = Prof. G. S. Brady and Rev. Canon A. M. Norman, "The marine and fresh water Ostracoda of the N. Atlantic and North-Western Europe (Roy. Soc. Dub. Sci. Truns., vol. iv. (S. ii.) Pt. iı. and vol. v. (S. ii.) Pt. xii.).

R. = Robertson, Dr. D., F.G.S., F.L.S. Ostracoda in "Notes on the fauna and flora of the W. of Scotland," 1876.

"Fresh and Brackish water Ostracoda" (N. H. Soc. Glas., vol. iv., 1879).

B. \& R.=Brady and Robertson.

B. C. \& R. = Brady, Crosskey, and Robertson.

\section{Fam. Cyprididae.}

(3) Cypria exculpta (S. Fischer).-Somewhat local but not very r.; Possil Marsh (R.) : Cumbrae (B. \& N.) : Dalry (J. Smith) : L. Doon, \&c. (S.). C. ophthalmica (Juvine).-C. and gen. dist.

(9) Cyclocypris laevis (O.F. Miiller).-Mod. c.; liable to be confounded with next species.

(13) C. serena (Koch).--One of the most c. and gen. dist. 
(1) (14) C. globosa (G. O. Sars).-Nr. L. Ascog and L. Greenan, Bute (B. \& N.) : L. Lomond ; L. Arklet; L. Doon (S.).

Scottia browniana.(Jones).-Marshy ground at side of L. Fad, Bute (B. \& N.) : Binend L. 1877 (J. Smith).

(1\%) Cypris fuscata, Jumine.-Frankfield L., nr. Glasgow ; brackish ponds, Cumbrae (R.): Dalry (J. Smith): L. Doon (S.).

artobele C. incongruens, Ramdohr.--Pond nr. Paisley; brackish pool, Hunterston \&c. (R.) : sometimes very abund.

17) (14) - C. virens (Jurine).--Pond nr. Crosshill; Frankfield L. ; Callum's Tarn, Bute (R.): Dalry (J. Smith): Pools nr. Fort Matilda, Greenock ; L. Ascog, Bute, \&c.

(8). C. reticulata, Zaddoch.-Possil Marsh ; side of Paisley Canal (R.).

(9) (14) C. obliqua, Brady.-Callum's Tarn, Bute ; Cragengower Tarn, Cumbrae (R.): Binend L. (J. Smith): L. Lomond (S.).

C. prasina, Fischer.-Pond on shore at Hunterston ; Pond nr. Ferry Ho., Cumbrae (R.): Brackish pools at Langbank (S.).

(9) (13). Herpetocypris reptans (Baird).-Mod. c. and gen. dist.

(9) H. strigata (Müller).-Burnside L. nr. Glasgow; ponds at Port Glasgow ; Cumbrae, \&c. (B. \& N.).

(9) (14) H. tumefacta (B. \& R.).-Cumbrae; L. Greenan; L. Fad ; L. Ascog, Bute ; Tarbert, \&c. (B. \& N.).

(15) Ilyodromus robertsoni (B.\& $N$.).-Side of L. Fad (B. \& N.) : L. Doon (S.).

(9) Cypridopsis villosa (Jurine).-L. Lomond ; Frankfield L. ; ponds, Cumbrae (R.): Dalry, \&c. (J. Smith): L. Fad; L. Ascog, Bute (B. \& N.) : L. Doon.

C. newtoni (B.\& R.).-Little L. and Pilmuir Dam, Renfrewshire; Cumbrae; Bute (B. \& N.).

C. aculeata(Lilljeborg).-Brackish pools, S.W. end of Cumbrae (R.) : Tarbert; Langbank (S.).

(9) Pionocypris vidua (Müller).-Pond at Paisley; L. Fad (R.): Kilwinning (J. Smith) : L. Lomond.

P. obesa $\left(B . \& R_{\text {. }}\right.$.-L. Lomond ; old dam at Govan Colliery, Glasgow (R.): Kilwinning (J.Smith).

(9) Potamocypris fulva, Brady.-Paisley Canal; Cumbrae; Kilwinning (R.): Dalry; Pilmuir Dam; L. Goin (J.Smith): L. Fad, and Ascog, Bute; Tarbert.

Paracypris polita, G. O. Sars.--Off Tarbert, 25 f. (B.\&N) : Tarbert Bank, 20 f. (S.).

(q) Notodiomus monacha (Miiller).-Cumbrae; L. Cumbrae (R.): Kilwinning (J. Smith): Pools nr. L. Fad, Bute (S.).

(13) Candona candida (Miiller).-C. and gen. dist.

(G) C. lactea, Baird.-Paisley Canal (R.): Pilmuir Dam (J.Smith): Park L. and Achy-Lochy, Campbeltown.

(9) C. compressa (Koch).-Mod. c. ; more or less gen. dist.

(8) (9) C. rostrata $(B . \& N$.).-Hairmyres, nr. E. Kilbride (B.\& N.) : Possil Marsh ; L. Doon (S.).

(8) (9) C. fabaeformis (Fischer).-Hairmyres; Crosslea, nr. Paisley; Cumbrae, etc. (B. \& N.): Dalry, Eaglesham Dams, etc. (J.Smith): L. Lomond.

C. acuminata (Fischer).--Kilmuir Dam, Renfrewshire; Tarbert (B.\& N.) : Eaglesham Dam, Craigton Dam, Harelaw Dam (J.'Smith): L. Lomond (S.).

pph.s.์. C. euplectella, Robertson.-Tarn, L. Cumbrae; Callum's Tarn, Bute (R.): Nockewart, Dalry (J.Smith): Pools nr. Pt. Glasgow ; Mossclave Pond, nr. Greenock (S.).

(17) (9) C. hyalina (B.\& R.).-Frankfield L. ; Possil Marsh, etc. (R.): Long Loch (J.Smith): Loch Lomond; L. Arklet; L. Doon (S.).

(8) (14) Candonopsis Kingsleii $(B . \& R$.).-Mod. c. and gen. dist. 
(9) Ilyocypris biplicata (Koch).-Mod. c., but somewhat local.

Pontocypris mytiloides (Norman).-Gen. dist. throughout Estuary.

(8) P. acupunctata, Brady.-Nr. Pt. Glasgow 1892, Campbeltown L. 1897 (S.).

(8) P. trigonella, G. O. Sars.-Gen. dist., not r.

Argilloecia cylindrica, G. O. Sars.-Inveraray ; Largs ; Campbeltown (R.) : off Greenock ; L. Long (B. \& N.) : off Tarbert (S.).

Fam. Bairdiidae.

(8) Bairdia inflata, Norman.-Cumbrae ; Lamlash (R.): L. Fyne, off Tarbert ; Campbeltown L. (S.).

B. complanata, Brady.-L. Fyne (A. M. N.).

Fam. Darwinulidae.

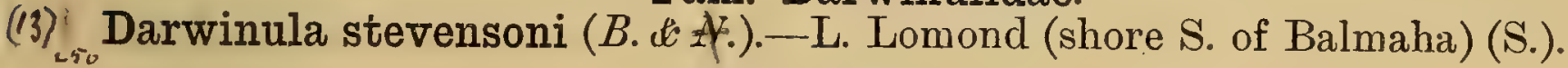

\section{Fam. Cytheridae.}

Cythere lutea, Müller,-C. and gen. dist.

C. pellucida, Baird.-Brackish water, freq. (Langbank; Inverkip ; Hunterston shore, etc.).

C. confusa $(B . \&$ \&.).-Mod. c. and gen. dist.

C. porcellanea, Brody.-More or less gen. dist.

C. macallana $(B . \&$ R.).-Off Fairlie, 5 f. (A. M. N.) : off Cumbrae; Roseneath (R.).

$\times \quad$ C. tenera, Brady.-C. (R.). Not very c. (S.).

(y) C. (?) semipunctata, Brady.-L. Fyne, off Tarbert; bet. the Cumbraes, $25 \mathrm{f}$. (A. M. N.) : off Sanda I., mod. r.

C. badia, Norman.-Kames B. ; Cumbrae ; off Bute (R.).

C. crispata, Brady.-Freq. (R.) : L. Tarbert ; Campbeltown L., etc.

C. gibbosa (B. \& R.).-Kames B., Cumbrae ; L. Gilp; L. Tarbert (B. \& N.) : Brackish pools nr. Langbank (S.).

C. rubida, Brady.-Kames B., Cumbrae; Clachland Pt., Arran (B. \& N.).

C. albomaculata, Baird.-Freq. (R.) : mod. c. and gen. dist.

* C. robertsoni, Brady.-Freq. (R.): Tarbert Bank; Campbeltown L., etc.

C. convexa, Baird.-Freq. and gen. dist.

C. marginata, Norman.-Off Tarbert, L. Fyne, 25 f. (A. M. N.) : Tarbert Bank; rather r. (S.). C. limicola, Norman.-Girvan (R.): Cumbrae ; L. Cumbrae (A.M.N.):

(\%) C. cunieformis, Brady.-Freq. (R.).

(Y) C. navicula, Norman.-Off Port Glasgow 1892 ; off Sanda I. 1897.

C. cluthae, B.C.\&R.-L. Fyne, 20 f. (B. \& N.).

C. villosa (G.O.Sars).-C. and gen. dist.

10. C. pulchella, Brady.-Kames B., Cumbrae; Kilchattan B. (B.\& N.).

C. quadridentata, Baird.-Off Cumbrae (R.) : Tarbert Bank, 25 f. ; not r.

C. emaciata, Jones.-Freq. (R.): Tarbert Bank, 25 f.

C. tuberculata (G. O. Sars).-Gen. dist., c.

C. emarginata (G.O.Sars).-Off Inveraray (R.) : Tarbert Bank (prob. subfossil), not c. (S.).

rem.s. C. finmarchica (G.O.Sars).-Off Inveraray (R.) : Campbeltown L., 1897 (S.).

C. angulata $(G$. O. Sars). - Various places in F. of Clyde and L. Fyne (B. \& N.).

C. dunelmensis (Norman).-Mod. freq. and gen. dist.

C. antiquata Baird.-Various places in F. of Clyde (B. \& N.): Tarbert Bank; Campbeltown L.

8 C. whitei (Baird).-Kilchattan B. ; Campbeltown L. (R) : Tarbert Bank.

C. jonesii (Baird).-Gen. dist. ; not r.

(9) Limnicythere inopinata (Baird).-Not unc. in Fresh-water Lochs and ponds.

Cottere Concinma "Brdely.

Cythere semuoveta, seots.

8) 3 A glaia complanata B $\times 12$. 
I. sancti-patricii (B. \& R.).-L. Libo ; side of Bishop L. (R.).

Cytheridea elongata, Brady.-Freq. (R.): nr. Fort Matilda; Campbeltown L., \&c.

C. papillosa, Bosquet.-C. (R.): off Greenock ; Roseneath ; Rothesay (B. \& N.): L. Fyne.

y C. punctillata, Brady.-C. (R.) : off Roseneath; Rothesay; Inveraray; Skipness ; Tarbert (B. \& N.).

(8) C. torosa (Jones).-Langbank; Pt. Glasgow; Greenock (R.). A brackish water species.

(9) C. lacustris (G. O. Sars).-Glasgow and Paisley Canal (W. of Pollokshields); Clyde, nr. Langbank (R.): Pilmuir Dan (J. Smith): L. Lomond (B. \& N.).

C. (?) subflavescens, Brady-L. Fyne; nr. Rothesay; bet. the Cumbraes (B. \& N.).

Eucythere declivis (Norman).-Freq. and gen. dist.

(8) Krithe bartonensis (T. R. Jones).--C. (R.). Clyde nr. Greenock; L. Fyne; off Rothesay, \&c. (B. \& N.).

(y) Loxoconcha impressa, Baird.-C. and gen. dist.

L. guttata (Norman).-Freq. and gen. dist. (B. \& N.).

(8) I. viridis (Müller).--Brackish pools at Inverkip (1880); Campbeltown L. (1897) (S.). Irvine sands (J. Smith).

(\&) . L. multifora (Norman).-C. (R.). L. Fyne (A. M. N.) : Cumbrae and Rothsay B. (B. \& N.) : Campbeltown L. (S.).

B. Nob 86 L. pusilla, B. \& R.-Greenock ; Cumbrae (R.) : Campbeltown L. (S.).

L. tamarindus, (Jones).-C. and gen. dist.

L. fragilis, G. O. Sars.-Clyde nr. Greenock and Pt. Glasgow (R.) : [probably fossil, not unc. in Artic shell beds bet. these two places].

Xestoleberis aurantia (Baird).-Kames B., Cumbrae (R.): Tarbert Bank ; E. L. Tarbert ; Campbeltown L. ; not r.

X. depressa, G. O. Sars.-Gen. dist. throughout estuary.

(8) Cytherura gibba (Müller).-Freq. (R.), but mostly in brackish water.

(8) C. cornuta, Brady.-Gen. dist. and mod. c.

C. sella, G. O. Sars.-Gen. dist. and mod. c.

C. acuticostata, G. O. Sars.-Gen. dist. but scarcely so c. as the last.

C. striata, G. O. Sars.-Gen. dist. Freq. (R.).

C. angulata, Brady.-Rock-pools, Arran (A.M. N.): L. Fyne; Campbeltown L. ; not so c. as some otber Cytherurae (B. \& N.).

C. undata, G. O. Sars.-Gen. dist. freq. throughout estuary.

(7) C. producta, Brady.-F. of Clyde (B. \& N.): L. Fyne, not c.

C. nigrescens (Baird).-Gen. dist. throughout estuary.

(8) C. simplex, $B . \&$ \& $N$.-St. Ninian's B., Bute; off Fairlie (B. \& N.) : Campbeltown L. (S.).

C. concentrica, B., C., \& R.-Off Fairlie (A. M. N.). Appears to be r.

C. similis, G. O. Sars.-L. Fyne ; Rothesay B. ; off Fairlie (B. \& N.) : Campbeltown L. (F. S. G.).

(8) C. fulva, B. \& K.-Off Greenock; L. Fyne; F. of Clyde (B. \& N.): Campbeltown L. (F. S. G.).

C. clathrata, G. O. Sars.-Callum's B., Bute (R): Tarbert Bank, not c. (F.S. G.).

C. cellulosa, Norman.-Gen. dist.; freq. (very small).

C. bodotria, T. Scott.-Greenock Bank, off Pt. Glasgow, 1892 (S.).

Cytheropteron latissimum (Norman). - Gen. dist. throughout estuary.

C. nodosum, Brady.-F. of Clyde, freq. (R.): off Tarbert (A. M. N.): Campbeltown L. (F.S. G.).

C. inflatum, $B ., C ., \& R$. - L. Fyne (A.M. N.).

(8) C. punctatum, Brady.-Inverkip; Cumbrae; L. Riddon; off Girvan, r. (R.): off Tarbert, 25 f. (A.M. N.). 
C. alatum, G. O. Sars.-Off Tarbert, (A. M. N.) : Fintry B. ; Kilchattan B. ; Rothesay B. (B. \& N.) : off Sanda I. (F. S. G.).

(7) C. angulatum, B. \& R.-Off Tarbert (A. M. N.) : Roseneath ; Cumbrae ; Bute (R.) : off Sanda I. (F. S. G.).

(y) C. depressum, $B . \& N$.-Campbeltown L. (1897) : r. in estuary (S.).

C. humile, $B . \& N$. - Off Fort Matilda, Greenock (B. \& N.): U. L. Fyne ; Kilbrennan Sd. (S.).

(7) Bythocythere constricta, G. O. Sars.-Off Roseneath, etc.; L. Long; L. Fyne (B. \& N.).

(8) B. turgida, G. O. Sars.-Off Roseneath; Rothesay B.; Kilchattan B. (B.\&N.): off Tarbert (S.).

B. simplex (Norman).-Gen. dist., but not very c.

Pseudocythere caudata, G. O. Sars.-Mod. freq. throughout estuary, and L. Fyne.

Selcrochilus contortus (Norman).-Gen. dist. throughout estuary.

Cytherideis subulata, Brady.-Cumbrae; Bute; Ardrossan, r. (R.): Campbeltown L. (F. S. G.).

(8) Cytherois fischeri ( $G$. O. Sars).-Gen. dist., but more freq. inshore amongst algae, Inverkip ; Campbeltown L. (F.S.G.).

\section{Fam. Paradoxostomatidae.}

(8) Paradoxostoma variabile (Baird).--C. and gen. dist.

P. ensiforme Brady.-Mod. c. ; but more so off shore than in shall. w.

P. abbreviatum, G. O. Sars.-Gen. dist., but not very plentiful.

(8) P. obliquum, G. O. Sars.-Cumbrae; Bute; Arran, r. (R.). Off Tarbert (F.S.G.).

P. normani, Brady.-Campbeltown L., 1897 (S.). Somewhat r. in Clyde.

P. pulchellum, G. O. Sars.-L. Goil ; Cumbrae ; Arran ; Ardrossan, r. (R.): L. Fyne, 1885 (S.).

(8) P. hibernicum, Brady.-Cumbrae; Bute ; Arran ; Campbeltown, r. (R.).

(8) P. arcuatum, Brady.-Off Pt. Glasgow, r. (S.).

P. orcadense, $B$. \& R.-White B., Cumbrae ; off Glensannox, r. (R.).

(5) P. hodgei, Brady.-Off Callum's Bay, Bute (R.): off Tarbert, 25 f. (A.M.N.).

P. flexuosum, Brady.-Freq. in Clyde (R.): L. Fyne; Campbeltown L. (F.S. G.).

(8) P. affine, T. Scott.-Off Inveraray, 25-40 f. (A. M. N.).

Machaerina tenuissima (Norman)._-Off Skelmorlie; Fairlie ; nr. Cumbrae; Kilchattan B. (B. \& N.) : off Tarbert (F.S. G.).

Fam. Asteropidae.

Asterope mariae (Baird).-OOff Tarbert (A. M. N.) : Cumbrae (R.): U. L. Fyne ; East L. Tarbert.

A. teres (Norman).-Lamlash B. (A. M. N.) : Cumbrae (R.) : E. L. Tarbert.

Fam. Cypridinidae.

Philomedes brenda (Baird).-Nr. Arran (E. side) 40 f. 1896 (S.).

P. interpuncta (Baird).-Gen. dist., in surface and bottom tow-nets, as well as dredge.

P. macandrei (Baird). -Nr. Cumbrae (R.).

\section{Fam. Polycopidae.}

(8) Polycope orbicularis, G. O. Sars.-Gen. dist. throughout estuary.

P. punctata G. O. Sars.-"Some specimens dredged in L. Fyne are doubtfully referable to this species" (B. \& N.).

\section{Fam. Cytherellidae.}

Cytherella serrulata, Brady and Norman.-Nr. Sanda I., 1896 (S.).

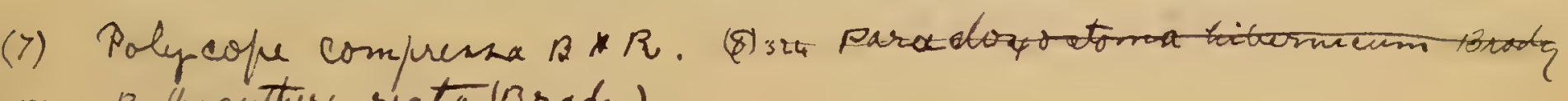




\section{ORder COPEPODA.}

Arrangement and Nomenclature Followed.

Brady, Prof. G. S. (1) Monog. of the free and semi-parasitic Copepoda of the Brit. Islands (Ray Society, 1878-80).

(2) Revision of the Brit. species of the fresh-uater Cyclopidae and Calanidae. Nat. Hist. Trans., N.D. and N.C., vol. xi., Pt. 1 (1891).

Giesbrecht, Dr. W. (1) Die Pelagischen Copepoden des Golfes von Neapel.

(2) Die Asterocheriden des Golfes von Neapel.

Canu, Dr. Eugene, Les Copépodes du Boulonnais.

Schmeil, Dr. Otto, Deutschlands freilebende sïsswasser Copepoden.

List of species from Irish Sea (Brit. Assoc. Rep., Sect. D, Liverpool, 1896.

Drs. W. Giesbrecht and O. Schmeil, Copepoda Gymnoplea, Das Tierreich (6 Lieferung).

Dr. Basset Smith, A systematic description of the parasitic copepoda found on fishes (Proc. Zool. Soc. Lond., 1899).

Scott, T. \& A., Revis. of Brit. Copep. belonging to the Gen. Bradya and Ectinosoma (Tr. Lin. Soc., 2nd ser.; Zool., vol. vi., Pt. 5 (1896)): papers in Ann. and Mag. Nat. Hist., and Ann. Scot. Nat. Hist. (1892-98).

Scott, T., papers in H.B. Reports, 1886-1900.

\section{helgolandiern, blaus. Fam. Calanidae.}

Calanus fmarehicus (Gunn). - Throughout estuary, surface and bottom.

(12) Paracalanus parvus, Claus.-Off Minard, U. L. Fyne; Kilbrennan Sd.; Ayr B. ; off Sanda I. etc., not c.

Pseudocalanus elongatus, Boeck.-Gen. dist. and mod. c. (surface and bottom townets).

g.a.s. (20) Stephus -L. Gair (U. L. Fyne), r., dredged.

(v) S. minor, T. Scott.-Otter Spit (U. L. Fyne) ; off Sanda I., r., dredged.

S. fultoni, T. Scott.--Otter Spit (U. L. Fyne) ; Kilbrennan Sd., r., dredged.

(10) Pseudocyclopia crassicornis, T. Scott.-Otter Spit (U. L. Fyne), r., dredged.

(12) P. caudata, T. Scott.-Otter Spit; Ayr B.; Ballantrae Bank, r., dredged.

Bradyidius armatus (Vanhöffen).-Gen. dist. throughout estuary.

Euchaeta norvegica, Boeck.-U. L. Fyne, very c. ; much less so in seaward part of estuary; chiefly in bottom townet.

Scolecithrix hibernica, A. Scott.-U. L. Fyne; d. w. E. of Arran; off Davaar I. ; nr. Ailsa Craig (in bottom townet).

S. pygmaea, T. Scott.--U. L. Fyne; Kilbrennan Sd. ; Whiting B. ; nr. Ailsa Craig (in bottom townet), not c.

\section{Fam. Centropagidae.}

(16) Centropages typicus, $K r$.-Gen. dist. and mod. freq.

(10)C. hamatus (Lillj.).-Gen. dist., c.

Isias clavipes, Boeck.-Off Cumbrae; off Portincross (Brady): Machrie B. (Brook) : off Ailsa Craig.

(14) (13)Diaptomus gracilis, G. O. Sars.-C. in fresh-water lochs, as L. Doon, Ayr. shire; L. Lomond, etc.

(1) D. hircus, Brady.-Tangy L., nr. Campbeltown.

D. laciniatus, Lillj.-L. Doon, Ayrshire ; freq. during summer.

Temora longicornis (Miiller).-Gen. dist. throughout estuary.

Eurytemora velox (Lillj.).-Cumbrae (Brady): pond at Rutherglen ( $\mathrm{J}$. Steel): Possil Marsh; marshy ground at Langbank; brackish pools at Hunterstone.

Metridia lucens, Boeck.-E. L. Tarbert (Calderwood) : Largabruach, U. L. Fyne; nr. Ailsa Craig.

Paramisophria cluthae, T. Scott.-Largabruach, U. L. Fyne ; Tarbert Bank,

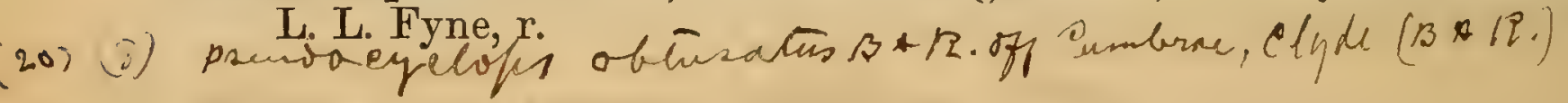




\section{Fam. Candaciidae.}

(E) Candacia pectinata, Brady.-Whiting B.; mid-channel E. of Pladda I.; off Sanda I., not very c.

\section{Fam. Pontellidae.}

Labidocera wollastoni (Lubbock).-Machrie B. (Brook): nr. Ailsa Craig; off E. of Arran ; not c. ; 12-26 f.

Anomalocera patersoni (Temple).-Gen. dist. sometimes mod. c.

Parapontella brevicornis (Lubbock). - E. L. Tarbert (Calderwood) : Ayr B. ; Machrie B. ; off Davaar I. ; nr. Ailsa Craig.

(1) Acartia clausii, Giesbrecht.-Gen. dist. and mod. c. throughout estuary. " tongiremes Lilli. Mamentaly prequent.

Misophria pallida, Boeck.-Portincross (Brady): Largabruach, U. L. Fyne ; Otter Spit, r.

\section{Fam. Cyclopidae.}

Oithona helgolandiat, Claus.-Gen. dist., mod. c.

Cyclopina littoralis, Brady.--Largabruach, and Head of U. L. Fyne ; not c. C. Gracilis, Claus. - Loch Gair ; off Inveraray, Hunterstone ; not c.

Cyclops strenuus, Fischer.-C. in most fresh-water lochs.

(17) C. leuckarti, Claus.-L. Lomond, not c.

C. dybowskii, Lande--L. Lomond-shore S. of Balmaha.

4) C. bicuspidatus, Claus.-L. Lomond; L. Doon; Achy L. (nr. Campbeltown); Possil Marsh.

var. lubbockii, Brady.-Brackish pools at Langbank.

C. languidus, G. O. Sars.-L. Doon, Ayrshire; not c.

C. vernalis, Fischer.-L. Lomond; L. Doon.

(7) C. bisetosus, Rehberg.-L. Lomond (shore); pools at Langbank; Garry L., Ailsa Craig.

C. viridis (Jurine).-L. Lomond ; L. Fad ; L. Doon ; Park L., nr. Campbeltown; mod. c.

(I) C. fuscus (Jurine).-L. Arklet; Park L.

(14) C. albidus (Jurine).-L. Lomond; L. Doon; pond at Castlemilk; Possil Marsh.

3)C. serrulatus, Fischer.-C. and gen. dist. in lochs and ponds throughout the district.

('3) C. macrurus, G. O. Sars.-L. Arklet.

(9) C. affinis, G. O. Sars.-Achy L., nr. Campbeltown.

C. nanus, G. O. Sars.-Dhu Lochan, nr. L. Lomond; L. Doon.

(4) C. fimbriatus, Fischer.-Gen. dist. and mod. c.

(4) C. phaleratus, Koch.-Bardowie L. ; not c.

C. aequoreus, Fischer.-Brackish pools at Langbank and Hunterstone.

Thorellia brunnea, Boeck.-Gen. dist. throughout estuary, freq.

\section{Fam. Ascidicolidae.}

Notodelphys allmani, Thorell.-E. L. Tarbert; Tarbert Bank (inside large Ascidians, as are most of the species in this family).

N. agilis, Thorell. -E. L. Tarbert; Tarbert Bank 20-25 f. (F. S. G.).

N. prasina, Thorell.-E. L. Tarbert; Tarbert Bank ; Kilbrennan Sd.

Doropygus porcicauda, Brady.-E. L. Tarbert; off Largabruach, U. L. Fyne ; Tarbert Bank (F. S. G.).

D. pulex, Thorell.-In ascidians, Tarbert Bank; nr. Millport in Corella parallelogramma (Gray).

D. (?) gibbosa, Thorell.-In ascidians Tarbert Bank (F. S. G.).

Botachus cylindratus, Thorell.-Same localities as the last; Whiting B.

Notopterophorus papilio, Hesse.-In large Ascidians in E. L. Tarbert; not une.; Kilbrennan Sd. 29/10/96 (F. S.G.). 
Ascidicola rosea, Thorell.-In large Ascidians dredged nr. head of L. Fyne ; Tarbert Bank (F. S. G.).

Enterocola fulgens, van Beneden.-In the intestines of small Ascidians dredged at Tarbert Bank (F. S. G.).

Gunenotophorus globularis, Cost $\alpha$.-In material dredged nr. Sanda I. 12/98 (F.S. G.).

Botryllophilus (?) ruber, Hesse-Associated with Botryllus sp., dredged Tarbert Bank, 1899 ; not very c. (F. S. G.).

14) Lamippi proteus, Claparède.-Parasitic in Alcyonium digitatum in various parts of Clyde area.

Fam. Harpacticidae.

(NoтE.-The Copepods belonging to this family-both marine and freshwater-are for the most part found on or near the bottom.)

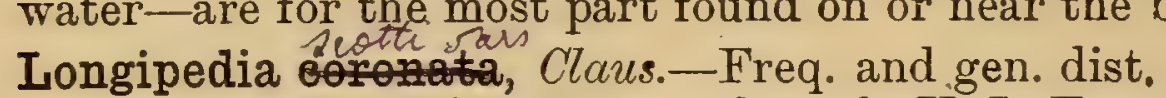

(ii) I. minor, T. \& A. Scott.-Largabruach, U. L. Fyne; off Sanda I. (with ova).

ii) Canuella perplexa, T. \& A. Scott.-Ayr B. ; Cumbrae, bet. tide marks; Inverkip, in shore pools.

(q) Ectinosoma atlanticum (B. \& $R$.).-Gen. dist., sometimes abund. in tow-net.

E. sarsi, Boeck.-Gen. dist., and not unc.

(8) E. melaniceps, Boeck.-Gen. dist., not r.

(I) E. herdmani, T. \& A. Scott.-L. Gair and Largabruach, U. L. Fyne ; shore at Hunterston.

13) E. curticorne, Boeck.-Dubh 'L., nr. Inveraray ; Largabruach ; shore pools at Hunterston; Ayr B.

(3) E. normani, T. \& A. Scoit.-Ayr B., r.

(8) E. erythrops, G. S. Brady.-Otter spit, U. L. Fyne, not c.

(13) E. gracile, T. \& A. Scott.--Shore pools at Inverkip ; dredged nr. Sanda I., r.

F. pygmaeum, T. \& A. Scott.-Tarbert Bank 20 f., Kilbrennan Sd., r.

Bradya typica, Boeck.-Gen. dist., not very c.

B. minor, T. \& A. Scott.-Shore at Hunterston; Ayr B.

B. elegans, T. \& A. Scott.-L. Gair and Largabruach, U. L. Fyne.

B. hirsuta, T. \& A. Scott.-Ayr B., r.

B. similis, T. \& A. Scott.-Largabruach ; Kilbrennan Sd. ; Ayr B.

Zosima typica, Boeck.-Lowburn, and Largabruach, U. L. Fyne; Kilbrennan Sd., not $\mathrm{r}$.

q) Tachidius brevicornis (G. F. Miill.).-Cumbrae, nr. Millport (Shore); Hunterston in brackish water pools.

T. littoralis, Poppe.-Shore pools, Dumbarton and Hunterston.

Robertsonia tenuis $(B . \& R$. ).-Rothesay B.

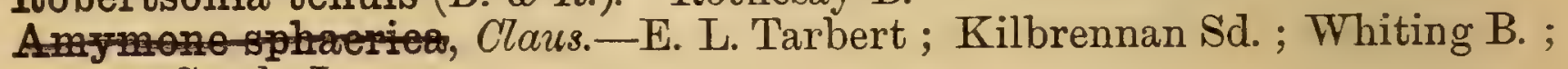

farme) nr. Sanda I.

A. nigrans, T. \& A. Scott.-Otter Spit, L. Fyne 12/1/99.

(12) Stenhelia hispida, Brady.-Off Portincross, Ayrshire 15 f. (Brady).

$\times \quad$ 20) S. ima, Brady.-Off Callum's Hole, Bute; off Glen Sannox (Brady); E. I. Tarbert; off Inveraray.

S. intermedia, T. Scott.- Kilbrennan Sd.

(12) S. hirsuta, I. C. Thompson.-Tarbert Bank; Campbeltown L.

(8) Ameira longipes, Boeck.--Off Portincross, Ayrshire (Brady).

10) A. longicaudata, T. Scott.-U. L. Fyne; Kilbrennan Sd., off Sanda I.

(i2) A. exilis, T. \& A. Scott.-Shore pools at Hunterston.

(12) A. exigua, T. Scott.-Kilbrennan Sd.

(12) A. longiremis, T'. Scott.-L. Gair ; Kilbrennan Sd.

(9) Jonesiella spinulosa (B. \& R.).-Largabruach; Kilbrennan Sd. ; Campbeltown L.

J. fusiformis $\left(B . \& R_{\text {. }}\right.$ ).--Tarbert Bank 20 f. ; off Sanda I.

(9) 301 Aploztoma

(ii). romesible hquainais, Thormp 
(II) Delavalia palustris, Brady-Brackish pools, Dumbarton; Hunterston.

(I) D. reflexa, $B$. \& $R$. - Nr. Sanda I., rather r.

D. robusta, $B$. \& $R$.-Largabruach ; Kilbrennan Sd., nr. Sanda I.

D. mimica, T. Scott.-L. Gair; Kilbrennan Sd., Ayr B.

(II) D. aemula, T. Scott.-Ayr B. ; Campbeltown L., not c.

D. giesbrechti, T. \& A. Scott.-Ayr B. ; Campbeltown L. var... ?-Brackish-water pools, Hunterston.

Pseudotachidius coronatus, T. Scott.-Off Lowburn, Hd. of I. Fyne ; off Skate I., 105 f.; bet. Arran and Heads of Ayr, $40 \mathrm{f}$.

Cervinia bradyi, Norman.-D. w. E. of Arran, very r. (14) Canthocamptus staphylinus (Jurine). - C. in fresh water lochs, ponds,
ditches, \&c.

(g) C. palustris, G. S. Brady-Brackish pools, Dumbarton; Langbank; Hunterston; Dubh L., nr. Inveraray.

(4) C. parvus, T. \& A. Scott.-Brackish pools, Hunterston, not c. (15) C. minutus, Claus.-L. Lomond; L. Doon; Park L. and Achy-L., nr.

(15) C. inornatus, T. Scott.-L. Arklet; Park L., not c.

(i) C. schmeilii, Mrazek.-L. Lomond; L. Doon ; Park L.

(14) C. hirticornis, T. Scott.-Brackish pools at Langbank.

('sz C. cuspidatus, Schmeil:-L. Fad, Bute, r.

(13) C. crassus, G. O. Sars.-Freq. in most fresh-water lochs and ponds.

(14) C. pygmaeus, $G$. O. Sars.-More or less freq. in lochs, ponds, ditches.

(13)C. zschokkei, Schmeil.-Dhu Lochan, nr. L. Lomond; L. Fad, Bute; Black L. and Park L., nr. Campbeltown.

(4) Moraria anderson-smithi, T.\& A. Scott.-L. Arklet; L. Lomond; L. Doon ; Garry L. (Ailsa Craig); Black L., nr. Campbeltown.

II. brevipes (G. O. Sars).-L. Doon, not c.

M. poppei (Mrazek).-L. Fad, Bute; Shore pools at Hunterston, r.

(14) Maraenobiotus vejdovskei, Mrazek.-L. Doon, amongst shore vegetation.
Psyllocamptus fairliensis, T. Scott.-Shore pools bet. Fairlie and Hun-
terston.

Mesochra lilljeborgii, Boeck.-Brackish-water pools at Hunterston.

M. spinicauda, T. \& A. Scott.-Shore pools, nr. Millport.

Neobradya pectinifer, T. Scott.-Ballantrae Bank, r.

(12) Tetragoniceps consimilis, T. Scott.-Ballantrae Bank ; Otter Spit, L. Fyne.

(10) T. macronyx, T. Scott.-Dredged, Ballantrae Bank, $18 \mathrm{f}$.

Diosaccus tenuicornis (Claus).-Cumbrae, surface net; Portincross, dredged (Brady): E. L. Tarbert; Kilbrennan Sd.

Laophonte serrata (Claus). E. L. Tarbert; Kilbrennan Sd. r. (10) L. horrida (Norman).-OOff Cumbrae and Portincross (Brady): U. L. Fyne ;
Kilbrennan Sd., not unc.

L. thoracica, Boeck.-Off Inveraray and Largabruach, U. L. Fyne.

I. similis (Claus).-E. L. Tarbert; L. Fyne (Calderwood). Shore pools,

L. curticauda, $B$

Hunterston.
Humongst weeds at L. Cumbrae (Brady) : shore pools

L. longicaudata, Boeck.-Otter Spit ; Kilbrennan Sd.

L. lamellifera (Claus).-Portincross, Ayrshire; off Cumbrae and Bute (Brady) ; Otter Spit; Ayr B.

(13) L. intermedia, T. Scott.-Shore pools Hunterston. 8) L. hispida ( $B . \& R$. ). Off Glen Sannox ; off Cumbrae and Bute (Brady):

12) L. littorale, T.\& A. Scott.-Shore pools Hunterston.

L. mahommed, Richard.-Brackish pools Langbank.

12) I. depressa, T. Scott.-Tarbert Bank $25 \mathrm{f}$. not c. 
(12) I. simulans, T. Scott.-Off Inveraray; Kilbrennan Sd. ; freq. in crevices of decaying wood.

(8) (12) I. denticornis, T. Scott.--Machrie B. ; Kilbrennan Sd.

Pseudolaophonte spinosa (I. C. Thompson).-Dredged nr. Otter Spit 15-18f., Jany. 99.

(21) (12) Laophontodes typicus, T. Scott.-Nr. Otter Spit; Carradale B.

L. bicornis, A. Scott.-Machrie B., not c.

(14) Pontopolites typicus, T. Scott.-L. Gair ; Largabruach, U. L. Fyne ; Kilbrennan Sd.

12. Normanella dubia $(B . \&$ R.).-L. Gair ; Largabruach ; Machrie B. ; Carradale B. ; Ayr B.

$\times \quad$ Cletodes limicola, Brady.-Kilbrennan Sd.

( 8 (20)C. longicaudata, B.\& R.-Off Portiucross, Ayrshire (Brady) : E. L. Tarbert; L. Gair ; Largabruach ; Kilbrennan Sd. ; Campbeltown L.

$\star \quad$ C. propinqua, $B$. \& $K$.- - Shore pools Hunterston.

C. linearis (Claus).-r. ; E. L. Tarbert; bet. Sanda and Bennan Hd.

(13) C. similis, T. Scott.-Otter Spit.

(12). C. curvirostris, T. Scott.-Carradale B. ; Campbeltown L.

(21) (10)C. lata, T. Scott.-Kilbrennan Sd. ; Campbeltown L. ; nr. Davaar I.

(12) C. irrasa, 'T. Scott.-Kilbrennan Sd.

C. tenuipes, T. Scott.-r. ; Carradale B., off Sanda I.

C. hirsutipes, T. Scott.-Carrarlale B.

1) Itunella tenuiremis $(T$. Scott).-Nr. Lowburn and Largabruach, U. L. Fyne; shore pools Hunterston.

Leptopsyllus minor, T. Scott.-Shore pools, nr. Millport, not c.

L. herdmanni, I. C. Thompson \& A. Scott. -Shore pools, "r. Millport, wot c.

(8) Enhydrosoma curvatum, B. \& R.-Off Portincross; Cumbrae; Bute (Brady): L. Gair ; Ayr B.

Pseudocletodes vararensis, T. \& A. Scott.-Nr. Sanda I. twice.

(12) Nannopus palustris, Brady.-Brackish pools Inverkip and Hunterston.

il) Platychelipus littoralis, Brady.-Dumbarton; Ayr B.; Carradale B.; Hunterston, shore pools.

Huntemannia jadensis, S. A. Poppe-Whore pools nr. Millport; Inverkip.

(i $)$ Heteropsyllus curticaudatus, T. Scott. - Carradale B., r.

Dactylopus pectinatus, T. Scott.-Nr. head of L. Fyne (18 f.).

D. tisboides, Claus.-Off L. Cumbrae, and Portincross (Brady) ; E. L. Tarbert; Kilbrennan Sd., etc.

D. similis, Claus.-Off Portincross (Brady); L. Fyne; Whiting B. ; Campbeltown L.

(12) D. stromii (Baird).-Nr. Cumbrae (Brady); Ayr B.; Whiting B., etc.

(q) D. flavus, Claus.-Off Callum's Hole, Bute (Brady); head of L. Fyne: Otter Spit; Ayr B.

(21) (9) D. brevicornis, Claus. - Whiting B. ; off Sanda I.

(9) D. minutus, Claus.-E. L. Tarbert (16 f.); off Sanda I.

/13) Thalestris mysis, Claus.-E. L. Tarbert; Machrie B.

(9) T. helgolandica, Claus.-Clyde (A. M. N.); Whiting B. ; Kilbrennan Sd.

T. rufocincta, Norman.-Off Cumbrae, and Portincross (Brady); Otter Spit; Whiting. B., freq.

T. harpactoides, Claus.-Shore pools Hunterston.

(4) (9) T. clausii, Norman.-L. Fyne (Calderwood); off Cumbrae (Brady): Machrie B.; Ayr B.

T. (violascens, Claus.-Nr. the 'Allans' Cumbrae (Brady), r.

T. hibernica, B.\&R.-Off Cumbrae (Brady), r.

T. longimana, Claus.-Off Portincross (Brady); Machrie B.

(21) T. peltata (Boeck).-Otter Spit, rather $\mathrm{r}$.

(12) T. forficulus, Claus.-Off Inveraray, and Largabruach, U. L. Fyne; Machrie B. ; Shore pools Hunterston, not very $r$.

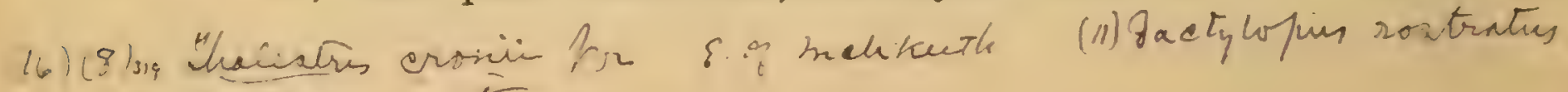

(9) Lactelofuzen te nucrema 
Psecudothatestria mapor $T$. A. Sura shoreporoh at lunterstor 1898, . !

13) Pseudothalestris pygmaea, T.\&A. Scott.-Machrie B. ; Ballantrae Bank, r. ( (1) Westwoodia nobilis (Baird).-Off Portincross, 10-30 f. (Brady); E. L. Tarbert (Calderwood) ; shore at Hunterston.

Harpacticus chelifer (Müller).-Gen. dist., freq.

H. fulvus, $F$ ischer.-Brackish pools, Hunterston.

H. flexus, B. \& R.-Kames B., Cumbrae, 1-2 f. (Brady); E. L. Tarbert; shore at Hunterston.

Zaus spinatus, Goodsir.-E. L. Tarbert; L. Fyne (Calderwood): Otter Spit; Machrie B., freq.

(\&) Z. goodsiri, Brady.-Off Portincross, 15 f. (Brady): Otter Spit; off Sanda I.

Alteutha bopyroides, Claus.-E. L. Tarbert ; L. Fyne (Calderwood).

A. crentata (Bad)-Off Sanda I. ; Ballantrae Bank. (-defrearn Baire

Eupelta purpurocinctum (Norman).-E. L. Tarbert (Calderwood) : Ayr B. ; N.-E. of Sanda I. Mod. freq. in Clyde.

Peltidium purpureum, Philippi.-E. L. Tarbert; off Largabruach; nr. Lowburn, L. Fyne, rather r.

9) Porcellidium fimbriatum, Claus.-Cumbrae; Portincross (Brady): E. L. Tarbert (Calderwood): Machrie B. Freq. on fronds of Laminaria.

P. viride (Phitippi) - Cumbrae; Portincross (Brady).

P. subrotundum, Norman.-L. Fyne (M.); Portincross (Brady).

Idya furcata (Baird).-E. L. Tarbert (Calderwood) : Cumbrae; Portincross (Brady); Machrie B.

(13) I. gracilis, T. Scott.-L. Gair ; off Inveraray ; off Lowburn (U. L. Fyne) ; shore pools Hunterston.

I. longicornis, T.\&A.Scott.-E. L. Tarbert; Machrie B. ; Campbeltown L.

I. minor, T. \& A. Scott.-Largabruach, U. L. Fyne; Machrie B.

I. cluthae, T. Scott.-Nr. head of L. Fyne; off Ailsa Craig.

Scutelidium fasciatum, Boeck.-E. L. Tarbert (Calderwood).

( ) (8) Cylindropsyllus laevis, Brady.-E. L. Tarbert; Ballantrae Bank.

8) (10) C. minor, T'. Scott.-Ballantrae Bank $18 \mathrm{f}$., not c.

C. fairliensis, T. Scott.-Brackish pools at Hunterston, rather r.

Ieptocaris minutus, T.Scott.-Brackish pools at Hunterston, $r$.

Fam. Monstrillidae.

Monstrilla danae, Claparède.--U. L. Fyne, sometimes freq.; Kilbrennan Sd.

Fam. Corycaeidae.

(4) Corycaeus anglicus, Lrubbock.-In surface net nr. Ailsa Craig, 29/5/99.

Fam. Lichomolgidae.

Modiolicola insignis, Aurivitius.-Commensal in shell of $M$. modiolus.

Lichomolgus albens, 7 horell.-Dredged nr. Otter Spit.

I. agilis, Leydig.-Kilbrennan Sd., on branchial plumes of Doris sp.

(4) L. maximus, I.C. Thompson.-Freq. in Clyde ; commensal with Pecten maximus and $P$. operculare.

I. fucicolus, Brady.-Nr. Largabruach, U. L. Fyne.

I. furcillatus, Thorell.-Off Inveraray, r.

L. forficulus, Thorell.-E. L. Tarbert; Tarbert Bank, in branchial chamber of large Ascidians.

Sabelliphilus sarsi, Claparède.-Kilbrennan Sd. ; off Sanda I. ; on branchial plumes of Sabella sp.

10 Hermanella arenicola (Brady). - Off Battery Pt., Cumbrae (Brady): Nr. Otter Spit, 8-15 f. ; L. Gilp, 2-3 f. ; not c.

Pseudanthessius liber $(B . \& R$.).-S. of Bute, $16 \mathrm{f}$. (Brady): nr. Lowburn and Inveraray.

(12) P. thorellii $(B . \& R$.). - From various parts of estuary.

Clausia cluthae, T. \& A. Scott.-Tarbert Bank, 20-25 f. ; Ayr B.

(II) Lichomilyas twinatifus 


\section{Anterocheres brectii Fam. Asterocheridae.}

$\checkmark$ Asterocheres lilljeborgi, Boeck.-Tarbert Bank, 20-25 f., r.

i1) A. echinicola (Norman). - Gen. dist., freq. in water passages of Suberites.

A. simulans (T. Scott).--L. Fyne and Clyde, r.

A. violaceus (Claus).--Nr. Otter Spit; off Pladda; r.

(u) . Dermatomyzon nigripes $(B . \& R$.).- - E. L. Tarbert (Calderwood) : off Callum's Hole, Bute ; Portincroșs (Brady).

II) Rhynchomyzon purpurocinctum (T.Scott).-Otter Spit, 8-15 f., Jany./99.

(12) Scottomyzon gibberum (T.\&A. Scott).-Nr. head of L. Fyne on E.chinus esculentus.

- Acontiophorus scutatus (B. \& R.).-Off Portincross (Brady): Otter Spit; Machrie B. ; off Sanda I.

(12) Scottocheres elongatus (T.\&A. Scott).-.Off Sanda I., r.

Neopontius angularis, T. Scott.--Otter Spit; Kilbrennan Sd., r.

(20) Cribropontius normani ( $B$. \& R.).-L. Gair, r.

$\times$ (20) Bradypontius magniceps (Brady).-Off Portincross (Brady): E. L. Tarbert (Calderwood): nr. Head of L. Fyne.

Dyspontius striatus, Thorell. - Whiting B., $r$.

Artotrogus orbicularis, Boeck.-Tarbert Bank, 20 f., very r.

(II) Parartotrogus richardi, T. \& A. Scott.-Nr. Otter Spit, 15-18 f. (Jany. 99).

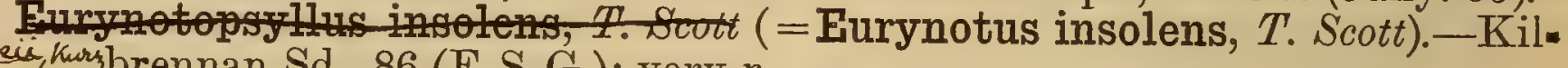
la clusie, hurbsbrennan Sd., 86 (F. S. G.); very r.

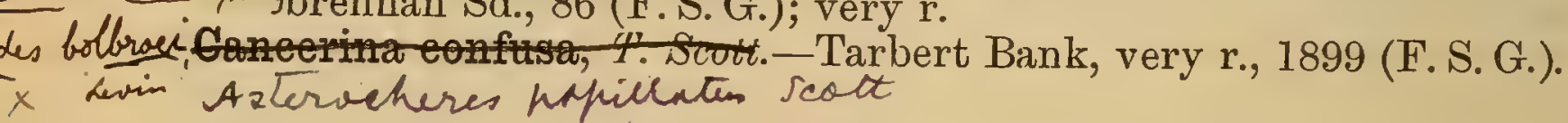

\section{C!OPEPODA PARASITA.}

Classification Adopted: Dr. Basset Smith, "Systematic description of parastic Copepoda found on fishes," (Proc. Zool Soc. London, April 1899).

\section{Fam. Ergasilidae.}

(II) Bomolochus soleae, Claus.-Back of Solea vulgaris, captured in Clyde (F. S. G.). Freq. in nostrils of Cod.

Fam. Caligidae.

(9) Caligus curtus, O. F. Miill.-On various fishes, Cod, Saithe, etc., mod. c.

(9) C. rapax, M.-Edw.-On various fishes, also in townet; c. and gen. dist.

C. diaphanus, Nordmann.-Chiefly in gill cavity of Gurnards, Trigla gurnardus; T. lineata, etc.

Lepeophtheirus pectoralis $(O . F . M$ uill.). - Not unc, under pectoral fins of flat fishes, as the Plaice, Pleuronectes platessa, and Flounder, P. flesus.

L. thompsoni, Baird.-Freq. on the gills of Turbot, Bothus maximus, (F. S. G.).

L. stromi, Baird.-On Salmon nr. Girvan (Duthie, Fishery Officer).

L. (?) obscurus, Baird.-On gills of Brill, Bothus rhombus, Clyde (F. S. G.).

(9) Trebius caudatus, $K r$.-On Raia batis and $R$. clavata, F. of Clyde; freq.

\section{Fam. Dichelestiidae.}

Clavella labracis, van Ben.-On gills of stripped wrasse Labrus mixtus, nr. Ayr, Jan. 1900.

gericolh Cycuns pallidus (van Ben.).-On gills of Conger, Conger niger, F. of Clyde; not r. (F.S. G.)

\section{Fam. Lernaeidae.}

9) Lernaea branchialis, Lin.-Not Wunc. on gills of Haddocks, Whitings and other Gadoids (F. S. G.). 


\section{Fam. Chondracanthidae.}

(9) Oralien asellinus (Lin.).-Not unc. on gills of Gurnards, flat fishes, etc.

9 Chondracanthus cornutus, (O.F. Miill.).-On gills of Plaice, Pleuronectes platessa; Clyde (F.S. G.).

C. clavatus, Basset Smith.-Mod. freq. on gills of Lemon Soles, Plereronectes microcephalus, F. of Clyde (F.S. G.).

C. soleae, $K r$. - On gills of Black Sole, Solea vulgaris, F. of Clyde (F. S. G.). C. flurae, $K r$.-On gills of Long Rough Dabs Drepanopsetta platessoides, F. of

C. merluccii, Holten.-Clinging to roof and sides of mouth of Hake Merlucius merluccius, Clyde.

C. lophii, Johnston.-Inside gill pouches of Angler-fish, Lophius piscatorius, Clyde (F. S. G.). (10) C. zeus, De la Roche.-Occasionally on gills of John dory, Zeus faber, Clyde
(F.S. G.). C. limandae, $K r .-$ On gills of common Dab, Pleuronectes limanda, Clyde
(F.S.G.).

C. ornatus, T. Scoti.-On gills of a Spotted dragonet, Callionymus maculatus, Clyde 1899 (F.S. G.).

\section{Fam. Lernaeopodidae.}

Charopinus dubius, T. Scott.-On gills and gill-arches of Raia circularis, Clyde, Dec., 99 (F. S. G.).

Lerneopoda galei, $K r$.-Attached bet. ventral fins of Galeorhinus galeus (Duthie): also on Scylliorhinus caniculus (F. S. G.).

L. bidiscalis, $W . F$. de V. Kane.-Attached to end of claspers of Galeorhinus galeus, Clyde Jany. 1900 (Duthie).

I. cluthae, T. Scott.-On gills of Raia fullonica, Clyde, April 1897 (F. S. G.).

Brachiella insidiosa, Heller.-On gills of Hake, Merlucius merluccius, Clyde (F. S. G.).

B. triglae, Claus.-From gills of Trigla lineata, nr. Ailsa Craig 1897.

B. merluccii, Basset-Smith.-On gill-rakers of Merlucius merluccius, Clyde (F.S. G.).

(9) Anchorella rugosa, $K r$.-On gills of Anarrhichus lupus, not unc. in Clyde (9) A. uncinata, O. F. Müll.-Not unc. on Whiting and other gadoids in Clyde

A. stellata, $K r$-On skin of Hake Merlucius merluccius, Clyde, 18/12/99 (F.S. G.).

\section{Fam. Choniostomatidae.}

(20) Aspidoecia normani, Giard and Bonnier.-Living upon Erythrops serrata, G. O. Sars, Clyde, rather r. (S.). (See Dr. H. J. Hansen's Monog. on the Choniostomatidae).

\section{Order Thoracica.}

\section{Fam. Balanidae.}

Balanus porcatus, Costa.-U. L. Fyne, on shells of Mytilus (M.). Gen. dist.,
freq. B. crenatus, Brug.--U. L. Fyne (M.). Bet. Corswall and Mull of Kintyre
(F.S. G.), freq.

B. balanoides (Lin.).-U. L. Fyne (M.). Gen. dist., freq.

B. hameri (Ascan.).-U. L. Fyne in 12-20 f, and also on the shore (M.). Occasionally by dredging. 
Fam. Verrucidae.

Verruca stromia (O. F. Müll.).-Freq. on stones and dead shells.

Fam. Lepadidae.

Scalpellum vulgare, Leach.-Attached to Zoophytes; not very r. in Clyde.

\section{Order Rhizocephala.}

\section{Fam. Sacculinae.}

(NoтE.-Several Sacculines have been obtained in the Clyde ; but without. a knowledge of their development it would be unsafe to say whether they are distinct or not, and with one or two exceptions I am therefore unable to ascribe them to particular species).

Sacculina carcini (Thomp.).-On abdomen of shore crab, Carcinus maenas, not unc. in some parts of the Clyde.

S. sp.-On abdomen of Galathea dispersa, Clyde 1895-1896, r. (F. S. G.).

S. sp.-On abdomen of Munida rugosa (Fabr.). Clyde 1896-1897 (F. S. G.) : 1899 (Alex. Patience). Not very r. in seaward part of estuary.

S. sp.-On the abdomen of Inachus dorsettensis, dredged bet. Arran and Ayrshire, 20-43 f., 1897 (F. S. G.), apparently r.

S. sp.-On the abdomen of Stenorhynchus rostratus, in the trawl net E. of Arran in 20-43 f., 9/97 (F. S. G.).

Peltogaster paguri (Rathke).-On abdomen of Eupagurus bernhardus, E. L. Tarbert (1886), etc. (S.).

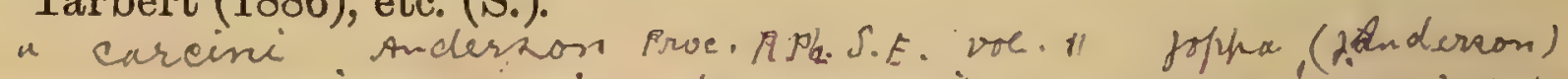

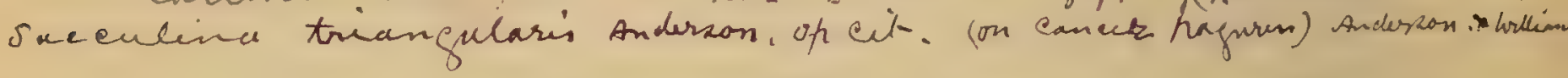

PYCNOGONIDAE.

BY M. LAURIE.

Pycnogonum littorale, Fabr:-Mod. c.

Phoxichilidium sp.-Cumbrae, among sea weed, l. w. (R.).

Pallene brevirostris, Johnst.-L. w. Allans, Cumbrae (R.): Lamlash B. (H.).

Nymphon gracile, Fabr.-L. Cumbrae, Lam Zone and l. w. (R.) : Lamlash B. (H.). 
Reprinted from the British Association Handbook on the Natural History of Glasgow and the West of Scotland (I90I).

\section{THE MARINE AND FRESH-WATER}

FISHES.

BY

THOMAS SCOTT AND ALFRED BROWN. 



\section{THE MARINE AND FRESH-WATER FISHES.}

By Thomas Scotт, F.L.S., Fishery Board Laboratory, Aberdeen, and Alfred Brown, Luss.

\section{Nomenclature FolLowed.}

A History of Scandinavian Fishes by B. Fries, C. U. Ekström, and C. Sundevall, 2nd edit., revised by Prof. F. A. Smitt (1893-95).

Arrangement Followed.

Dr. Francis Day, The Fishes of Gt. Britain and Ireland, 2 vols. 1880-84.

Authorities with their Abbreviated References.

B. \& S.="A list of L. Fyne fishes," by Geo. Brook, F.L.S., and Thos. Scott, F.L.S. (Fourth Ann. Rep. Fishery Bd. for Scot., 1886).

H. B. =J. A. Harvie-Brown, F.R.S.E., F.Z.S., and T. E. Buckley, B.A., F.Z.S., Vertebrate fauna of Argyll and the Inner Hebrides, 1892 (separate reprint).

G. =Dr. A. C. L. G. Günther, F.R.S., "Rep. on fishes obtained by Sir John Murray on N. W. coast of Scotland" (Proc. Roy. Soc. Edin., vol. xv., 1888).

F. S. G. = Fishery Statistics of the Scottish Fishery. Bd. S. S. 'Garland.'

M. = Records of the S. Y. 'Medusa,' obtained by Sir John Murray.

R. = Fishery records of the late David Robertson, LL.D., F. G. S., Millport.

S. = Thos. Scott, F.L.S., (a) "Fishes of L. Fyne" (Fifteenth Ann. Rep. Fishery Bd. for Scot., Pt. iii., 1897).

(b) "Fishes of the F. of Clyde" (Eighteenth Ann. Rep. Fishery Bd. for Scot., 1900).

\section{SUB-CLASS TELEOSTEI.}

ORDER ACANTHOPTERYGII.

\section{Fam. Percidae.}

Perca fluviatilis, Lin.-Perch; c. low-lying lakes, ponds, and sluggish streams; usually absent from high-lying waters.

Polyprion americanum (Bloch.). - Stone Basse. One taken years ago at mouth of Clyde (Aflalo), off L. Cumbrae 1870 (H.B., p. 184).

Fam. Mulliāae.

Mullus barbatus, Lin.-Surmullet, Red Mullet. One L. Fyne (Capt. Campbell of Inverneil, H. B., p. 185). 


\section{Fam. Sparidae.}

Sparus centrodontus, De la Roche.-Common Sea-bream. Cumbrae, one (M. P. Bell R. in Proc. N. H. S. Glasg., vol. i., p. 119), E. L. Tarbert, 1886 one (S.).

\section{Fam. Cottidae.}

Cottus gobio, Lin.-Miller's Thumb. Upper Kelvin and tributaries ; Carmel Water, Ayrshire (H. A. Woodburn); Dobbs Burn, nr. Paisley (J.M. B. Taylor).

C. scorpius, Lin.-Sea Scorpion. Gen. dist., esp. inshore. var. groenlandica. Occasionally obtained.

C. bubalis, Euphr.-Father Lasher. Mull of Kintyre, 60 f.; Sd. of Sanda, 20 f. (G.) ; Little Harbour ; off Inveraray, L. Fyne (F. S. G.).

C. lilljeborgii, Coll.-Norway Bullhead. Off Ardrossan, 15-30 f.; Sd. of Sanda, 20 f. (G.).

Trigla lineata, Gmel.-Streaked Gurnard. E. L. Tarbert, not c. (B. \& S.); r. (F.S. G.).

T. pini, Bloch.-Red Gurnard. Occasionally, trawl (F. S. G.) lower estuary.

T. Iucerna, Lin.-Sapphirine Gurnard. Ballantrae, in Salmon nets (Thompson) (Day, vol. i., p. 62).

T. gurnardus, Lin.-Grey Gurnard ; c., and gen. dist., esp. during summer.

Triglops murrayi, Gïnther-Murray's Triglops. Mull of Kintyre, 64 f. ; off Sanda I., 35 f. (G.); nr. Sanda, one in Shrimp-trawl (F.S.G., 11/96).

\section{Fam. Cataphracti.}

Agonus cataphractus (Lin.).-Pogge. Ardrishaig (Dr. Scouler); L. Fyne and Clyde estuary occasionally (F.S. G.).

\section{Fam. Pediculati.}

Lophius piscatorius, Lin.-Angler-fish. Freq. (F.S. G.), esp. in deep water; sometimes 45 in. long.

\section{Fam. Trachinidae.}

[Trachinus vipera, Cuv.-Lesser Weaver. Arran, Landsborough's Nat. Hist. Arran (1875), p. 318.]

\section{Fam. Scombridae.}

Scomber scombrus, Lin.-Mackerel. L. Fyne; Clyde estuary ; sometimes in L. Long and L. Goil.

Orcynus thynnus (Lin.).-Tunny. One, $9 \mathrm{ft}$. long, in Gareloch nearly opposite Greenock, 7/31, (Day). One weighing 460 lbs., at Inveraray in 1769, (Pennant, Zool., vol. iii., p. 268).

[Euthynnus pelamis, Lin.--Bonito. One in Clyde, July, 1832, (Scouler).]

Sarda pelamis (Briin.).-Belted Bonito. One, 1859, now in Hunterian Museum.

\section{Fam. Coryphaenidae.}

Brama raii (Bloch.).-Ray's Sea-bream. Specimen in Hunterian Museum, said to have been taken nr. Ayr, (H. B., p. 188).

Lampris pelagicus (Gunn.).-Opah or King-fish. One taken in Clyde in 1833, (Scouler). One in 1864, in Hunterian Museum. One in L. Fyne early in 1899, (Late Duke of Argyll, in letter to Rev. G. A. Frank Knight).

\section{Fam. Cyttidae.}

Zeus faber, Lin.-John Dory. Off Rothesay, (H. B., p. 187); L. Fyne, (B. \& S.) ; Kilbrannan Sd., in Shrimp-trawl, (F. S. G.).

\section{Fam. Gobiidae.}

Gobius flavescens, Fabr.-Two-spotted Goby. L, Fyne (Scouler); amongst zostera, E. L. Tarbert, (B.\& S.); Clyde ; L. Fyne various parts (F.S.G.). 
G. niger, Lin.-Black Goby. Freq. (F. S. G.).

G. minutus, Gmel.-Speckled Goby ; c. and gen. dist.

G. jeffreysii, Gïnther.-Jeffrey's Goby. Kilbrannan Sd., 6-18 f.; off Whiting B., 20 f. ; off Cumbrae, 56 f. (G.).

\section{Fam. Callionymidae.}

Callionymus lyra, Lin.-Dragonet. Not unc. (F. S. G.).

C. maculatus, Bonap.- Spotted Dragonet. Kilbrannan Sd., rather abund., $26 \mathrm{f}$; Sd. of Sanda, 24-28 f., (H. B., p. 194); occasionally in shrimptrawl (F. S. G.).

\section{Fam. Discoboli.}

Cyclopterus lumpus, Lin.-Lumpsucker. Occasionally in trawl (F. S. G.); young sometimes in tow-net.

Cyclogaster liparis (Lin.).--Sea-snail. Not unc., Clyde ; L. Fyne ; usually in shall. inshore w.

C. montagui (Donov).--Montagu's Sucker. Not so c. as last; habitat somer what similar.

\section{Fam. Gobiesocidae.}

Lepadogaster gouanii (Lacep.).-Cornish-sucker. "Millport, Clyde," (H.B.).

I. bimaculatus, (Donov).-Doubly spotted sucker; c. everywhere except in mud.

Anarrhichus lupus, Lin.-Cat or Wolf-fish. Not unc., Clyde; L. Fyne, (F. S. G.).

\section{Fam. Blenniidae.}

Blennius pholis, Lin.-Shanny. Clyde area (H. B., p. 185); nr. Millport (Gray.).

Chirolophis galerita (Lin.).-Yarrell's Blenny. E. L. Tarbert, one (B.\& S.) ; Ballantrae Bank, one, 1/99 (F. S. G.).

Pholis gunnellus ( $\operatorname{Lin}$.).-Butter-fish ; c. and gen. dist. esp. inshore amongst weed and stones.

Enchelyopus viviparus (Lin.).-Viviparous Blenny. One near Row (R.).

Lumpenus lampretiformis ( Walb.).-Sharp-tailed Lumpenus. Bet. Cumbrae and Skelmorlie, 20 f. ; off Cumbrae L. H., 60 f. (G.). Occasionally offshore in shrimp trawl (F. S. G.); a dozen have been taken in one haul.

\section{Fam. Cepolidae.}

[Cepola rubescens, Lin.-Red Band-fish. 7 mls. S. of Ayr (Harvie) ; beach at Ballantrae after a storm (Thomp.). See $H$. B., p. 195.]

\section{Fam. Atherinidae.}

Atherina presbyter, Cuv.-Sand Smelt or Atherine. Freq. amongst zostera, E. L. Tarbert, in spring 1885, but not later (B. \& S.); Campbeltown L. twice (Gray).

Fam. Mugilidae.

[Mugil capito, Cuv.-Grey Mullet. The "earstones" of one captured off Fairlie are in the Robertson Museum, Millport.]

IM. chelo, Cuv.-Thick-lipped Grey Mullet. Gregarious in estuaries of Clyde, Leven, and some Ayrshire rivers; advancing with tide to top of flood.

\section{Fam. Gasterosteidae.}

Gasterosteus aculeatus, Lin.-Three-spined Stickleback. Fairly freq. round shores of Clyde estuary, also in F. W.lakes, ponds, etc., throughout district. var. spinulosa. L. Lomond with the other, $r$.

G. pungitius, Lin.-Ten-spined Stickleback. Mod. c. L. Lomond, Possil Marsh, etc.

Gastraea spinachia (Lin.).-Fifteen-spined Stickleback. Mod.c.round shores, but more purely marine. 


\section{Fam. Labridae.}

Labrus bergylta, Ascan.-Ballan Wrasse. Ayrshire (Thomp.); Clyde area (H. B., p. 199) ; L. Fyne, freq. in autumn (B.\& S.).

I. mixtus, Lin.-Striped Wrasse. E. L. Tarbert (B. \& S.) ; Clyde area (H. B., p. 199) ; Two, $\delta$ and , in Ayr Bay, 30/1/1900 (R. Duthie, Fishery Officer)!

L. (Crenilabrus) melops, Lin.-Goldsinny. Nr. Cairndow, 8/99 (F. S. G.) ; Lamlash B., 6-18 f. (G.).

L. (Ctenolabrus) rupestris, Lin.-Jago's Goldsinny. c., esp. nr. Skate I., L. Fyne (B. \& S.) ; Lamlash B., 6-18 f. ; bet. Cumbrae and Skelmorlie Buoy, 20 f. (G.).

L. (Centrolabrus) exoletus, Lin.-Small-mouthed Wrasse. L. Fyne, occasionally (B. \& S.).

Coris julis (Lin.).-Rainbow Wrasse. Clyde area (H. B., p. 200).

\section{Order Anacanthini.}

Fam. Gadidae.

Gadus callarius, Lin.-Cod-fish; c. and gen. dist., esp. in seaward portion. G. aeglefinus, Lin.-Haddock. More or less freq. and gen. dist.

G. luscus, Lin.-Bib, or Brassie. Fairly c. and gen. dist., esp. in seaward part.

G. minutus, Lin.-Poor, or Power-cod. Not unc. in seaward part of estuary (F. S. G.) ; Kyles of Bute, Arran, etc.

G. esmarkii, Nils.-Norway Pout. Kilbrannan Sd. to Lo. L. Fyne, not unfreq. (G.) ; sometimes in shrimp-trawl (F. S. G.).

G. merlangus, Lin.-Whiting. Mod. c. and gen. dist., esp. in seaward portion of estuary.

G. poutassou (Risso.).-Couch's Whiting. Three in shrimp-trawl at mouth of estuary, 54 f., 22/9/97! (F. S. G.).

G. virens, Lin.-Saithe, or Coal-fish. Mod. c. and gen. dist.

G. pollachius, Lin.-Lythe, or Pollack. Fairly freq. and gen. dist.

Merlucius merluccius (Lin.).-Hake. Freq. at all the "stations" in the Clyde (F.S. G.).

Phycis blennoides (Brïn.).-Greater Fork-beard. Nr. Cumbrae, 4/90 (R.).

Molua molva (Lin.).- - Ling. Not unc., sometimes in trawl-net (F. S. G.).

Onos mustela (Lin.).-Five-bearded Rockling. E. L. Tarbert, bet. tide-marks; not c. (B. \& S.).

o. cimbrius (Lin.).-Four-bearded Rockling. Very c. and gen. dist. (G.).

O. tricirratus (Brïn.).-Three-bearded Rockling. Rothesay B.; Up. L. Fyne (F.S. G.), etc. ; r.

[0. maculatus, Risso.- Spotted Rockling. L. Fyne, $40 \mathrm{f} . ;$ Mull of Kintyre, 65 f. (G.). "If this and O. tricirratus be really distinct, the Clyde specimens should perhaps be all included under the latter name" (S. b.)].

Raniceps raninus (Lin.).--Lesser Fork-beard. L. Fyne (Scouler).

\section{Fam. Ophidiidae.}

Ammodytes lanceolatus, Le Sauvage.-Greater Sand-launce. Occasionally nr. E. L. Tarbert (B.\& S.), nr. Sanda I. (G.), abund. at Lamlash.

\section{Fam. Pleuronectidae.}

Hippoglossus vulgaris, Flem.-Halibut. L. Fyne (B.\&S.), occasionally; mod. freq. in sea-ward part of the estuary.

Drepanopsetta platessoides (Fabr.).-L Long Rough Dab; c. and gen. dist. esp. in deep water.

Bothus maximus ( Lin.).-Turbot. A regular fishery is carried on off Girvan. Sometimes in Clyde and L. Fyne (F.S. G.). 
B. rhombus (Lin.).-Brill. Dist. and freq. somewhat similar to turbot. Zeugopterus punctatus $(B l$.).-Müller's Topknot. Clyde area, 60 f. (G.); U. L. Fyne 10-25, f. (M.); Kilbrannan Sd., Ailsa Craig (E. S. G.).

Scophthalmus unimaculatus (Risso.).-One-spotted Topknot. One off Ardrossan, 10 f., 4/88 (G.). Several in a shallow sandy B. at Barmore, L. Fyne, 1885 (B. \& S.).

S. norvegicus (Günther).--Ekström's Topnot. Off Cloch L. H., 43 f. ; Lamlash B., 6-18 f. ; Kilbrannan Sd. (G.) ; trawl-net (F. S. G.), r.

Lepidorhombus whiff (Walb.).-Sail-fluke or Whiff. Clyde area (G.) ; fairly freq., esp. in seaward portion of estuary (F. S. G.).

Platophrys laterna (Walb.).-Scald-tish. Clyde area (G.) ; sometimes Kilbrannan Sd., etc. (F. S. G.).

Pleuronectes platessa, Lin.-Plaice. Mod. c. and gen. dist., esp. on sandy bottom ; ascends most tidal rivers, and is occasionally obtained in $\mathrm{L}$. Lomond.

P. microcephalus, Donovan.-Lemon or Smooth Dab. Fairly freq. and gen. dist.

P. cynoglossus, Lin.-Witch-sole, or Pole Dab. Very c. in deeper parts of estuary.

P. limanda, Lin.-Common Dab. c. and gen. dist.

P. flesus, Lin.-Flounder or Fluke; c. and gen. dist. ; ascends most tidal rivers, and frequents some lakes as L. Lomond, where it is not unc.

Solea vulgaris, Guensel.-Black-*ole. Occasionally; esp. in sea-ward portion (F. S. G.).

S. variegata, Donov.-Variegated-sole, or Thickback. Mull of Kintyre, 65 f., (G.) ; nr. Sanda I., 15/6/99 (F. S. G.) ; r.

S. lutea, Risso.-Solenette. Nr. mouth of estuary, r. (F. S. G.).

\section{Order Physostomi, Miiller.}

\section{Fam. Salmonidae.}

Salmo salar, Lin.-Salmon ; c. in estuary, and all larger rivers; also Lochs Eck, Lomond, Doon, Dhub, and Iorsa.

S. trutta, Lin.-Sea Trout. Very c. Distribution same as S. Salar, but penetrating into higher and smaller waters.

S. eriox, Gmel.-Grey Salmon or Bull Trout. Scarce. Occasionally in L. Lomond and the Ayrshire rivers.

S. levenensis, Walker.-Loch Leven Trout. Introduced in many smaller lakes, e.g. Cochno, Craigallian, Castle Semple, etc. ; in most of which it thrives.

S. fario, Lin.-Brown Trout. Very abuud. in almost every stream and lake.

[S. ferox, Jardine.-The Ferox, or Great Lake Trout (doubtless a var. of fario) said to inhabit L. Lomond. No satisfactory authority for this.]

S. lemanus, Moreau.-Geneva Lake Trout. Introduced many years ago in L. Lomond; now very. r.

S. estuarius, Knox.-Estuary Trout. Not unc. in tidal waters at mouths of streans. Merely a var. of fario.

S. umbla, Lin.-Char. Scarce. Only record, L. Doon, Ayrshire, where it is now.

S. fontinalis, Mitchell.-American Brook Trout. Introduced in many small lakes throughout district, also in L. Lomond where it still maintains its identity, but has not thriven. Has been distributed throughout Renfrewshire and Ayrshire, and is thriving in Rivers Ayr and Irvine, and the Waters of Borland, Kilmarnock, Cessnock, Carmel, and Alnwick (H. A. Woodburn).

Osmerus eperlanus (Lin.).-Smelt. One taken with mussel-bait, Brodick, 10/88 ; not unc. (H. B., p. 218). 
Coregonus levaretes (Lin.).-Powan or Fresh-water Herring. Very c. L. Eck; exceedingly c. L. Lomond, attaining over 3 lbs. weight.

Thymallus vulgaris, Nits.-Greyling; c. in upper reaches of Clyde, introduced many years ago ; frequents also Rivers Ayr, Lugar (H. A. Woodburn); Gryffe, and Greenburn (J.M. B. Taylor).

Argentina sphyraena, Lin.-Hebridean Smelt. Not unc., esp. in deep water (G., F. S. G.).

\section{Fam. Esocidae.}

Esox lucius, Lin.-Pike ; c. most lakes, ponds, canals, and sluggish streams.

\section{Fam. Scombresocidae.}

Rhamphistoma belone (Lin.).-Garpike. One 28 in. long, off Dunoon, 25/5/77 (Dr. R. P. Fleming); occasionally in shoals (H.B., p. 212).

* Scombresox saurus (Walb.).--Saury Pike. Clyde (H.B., p. 212).

\section{Fam. Cyprinidae.}

Cyprinus carpio, Lin.-Carp. Various ponds doubtless introduced.

C. auratus, Lin.-Goldfish. Semi-domesticated; waste ponds nr. Paisley and elsewhere in that district, where it breeds freely.

Leuciscus rutilus (Lin.).--Roach or Braise; c. gregarious ; low-lying lakes and ponds; some streams, e.g. Clyde (above Glasgow), Kelvin, Endrick, Leven, and their tributaries; and in all canals.

Phoxinus aphya (Lin.).-Minnow.-Very c. and gregarious in most clear streams and lakes in Lanark, Renfrew, Ayr, and Dumbarton; gen. absent from Argylishire and Arran, except where introduced.

Tinca vulgaris, Flem.-Tench. Scarce and local. L. Lomond and R. Endrick; probably nowhere else.

Cobitis barbatula, Lin.-Loach or Beardie. Shallows of streams and lakes throughout district; fairly c.

\section{Fam. Clupeidae.}

Clupea harengus, L.-Herring. Abund., F. of Clyde; L. Fyne.

C. sprattus, Lin.-Sprat. Not unc. in Clyde; frequently mistaken for young herrings, so their numbers and distribution are somewhat uncertain.

C. alosa, Lin.-Allis Shad. Large specimens in L. Fyne 1888, (H. B., p. 221). A fine specimen in seine-net off Ross, winter 1894 (Gray).

\section{Fam. Muraenidae.}

Anguilla vulgaris, Leach.-Eel. Very c., all lakes, ponds, canals and streams ; occasionally in "Shrimp-trawl," inshore L. Fyne, (F. S. G.).

A. latirostris, Risso.- Yellow broad-nosed Eel. Is now generally considered a form of the Common Eel. Both are about equally abund.

Conger niger (Risso).-Conger. Occasionally in trawl-net in various parts of the Clyde (F. S. G.) ; Lunderston B. bet. tide-mark.

\section{Order Lophobranchit.}

\section{Fam. Syngnathidae.}

Syngnathus typhle, Lin.-Broad-nosed Pipe-fish. E. L. Tarbert (B. \& S.); r. S. acus, Lin.-Great Pipe-fish. Not unc. in Clyde and L. Fyne.

Nerophis aequoreus (Lin.).-Straight-nosed Pipe-fish. E. L. Tarbert, (B. \& S.); Cumbrae (R.) ; r.

N. lumbriciformis, (Will.).-Worm Pipe-fish. E. L. Tarbert (B. \& S.); Lunderston B. (S.); Campbeltown L. (F. S. G.).

Hippocampus antiquorum, Leach.-Sea-horse. Kilbrannan Sd.; Fairlie Sands, (Gray, v. S. b., p. 289). 


\section{Order Plectognathi.}

\section{Fam. Gymnodontes.}

Orthagoriscus mola, (Lin.).- Short Sun-fish. One off Greenock Esplanade, 10/9/81, $7 \mathrm{ft} .9 \mathrm{in}$. long, and $3 \mathrm{ft} .9 \mathrm{in}$. high, and weighed about a ton (J. M. Campbell.).

\section{SUB-CLASS CHONDROPTERYGII.}

Order Ganoldei.

\section{Fam. Acipenseridae.}

Acipenser sturio, Lin.-Sturgeon. Often noticed in L. Fyne during herring fishery, seldom captured (B. \& S.) ; Carradale ; Penimore B. (Gray, v. S. b., p. 289).

\section{Order Elasmobranchit.}

Fam. Carchariidae.

Carcharias glaucus (Lin.).-Blue Shark. stranded Ayr Bay, 9/99 (H. B. Watt).

L. Fyne (H. B., p. 177). One

Galeorhinus galeus (Lin.).-Tope. Several landed at Girvan, 12/99 (S.b., p. 290).

\section{Fam. Lamnidae.}

[Alopias vulpes (Gmel.). - Thraser or Fox-Shark. L. Fyne, bet. Crarae and Cas. Lachlan (Capt. Campbell, F. S. G., S. b., p. 290.) ]

Cetorhinus maximus (Gunn.).-Basking-Shark. Young specimen, $8 \mathrm{ft}$. long. Captured in Maidens B., nr. Turnberry (Scotsman, Sept. 26th, 1898 ; confirmed by Fishery Officer, Girvan). Vide also Landsborough, Nat. Hist. of Arran, pp. 95, 96.

\section{Fam. Scylliidae.}

Scylliorhinus canicula (Lin.).-Lesser-spotted Dog-fish, or Rough-Hound. Sd. of Sanda (G.). Occasionally, esp. in seaward part of estuary (F. S. G.).

Pristiurus catulus (Gunn.).-Black-mouthed Dog-fish. U. L. Fyne, 37 f. (G.). Occasionally in deep water, bet. Arran and Turnberry (F. S. G.).

\section{Fam. Spinacidae.}

Squalus acanthias, Lin.-Picked Dog-fish. Sometimes in Clyde and L. Fyne, esp. during herring fishing.

Fam. Rhinidae.

Rhina squatina (Lin.).-Angel-fish. F. of Clyde. Not unc., freq. after gales (Norman, Zool., v. xv., p. 5366. Occasionally trawled on Ballantrae Bank (Wright of Barrow in Furness).

Raia batis, Lin.-Grey Skate. Mod. c., and gen. dist., esp. off shore.

R. intermedia, Parnell.-Flapper Skate. Bet. Sanda and Ailsa Craig (G.). deep water E. of Arran ; nr. Ailsa Craig (F. S. G.).

R. oxyrhynchus, Lin.-Long or Sharp-nosed Skate. Two small specimens in deep water E. of Arran (F. S. G.). One, 51 in. long, captured in Clyde, was brought to Girvan, 1/2/1900 (Duthie, Fishery Officer).

R. fullonica, Lin.-Shagreen or Fuller's-ray. L. Fyne, off Skate I., 100 f. ; Kilbrannan Sd., 20 f. (G.). Occasionally (F. S. G.).

R. clavata, Lin.-Thornback-ray. Fairly c. and gen. dis.

R. maculata, Mont.-Spotted, or Homelyn-ray. Bet. Cumbrae and Weniyss Pt., 30-40 f.; Sd. of Sanda, 20 f. ; off Ardrossan; Whiting B. (G.), occasionally (F. S. G.).

R. circularis, Couch.-Cuckoo or Sandy-ray. Sd. of Sanda, 20 f. (G.) ; not very r. in seaward portion (F. S. G.). 


\section{SUB-CLASS CYCLOSTOMATA.}

Fam. Petromyzontidae.

Petromyzon marinus, Lin.-Sea Lamprey. Very r. Occasionally frequents $R$. Leven, and tributaries of L. Lomond; ascending from sea in pairs to spawn.

P. fluviatilis, Lin.-River Lamprey; c. in most streams and lakes. Not migratory, and does not spawn in pairs, but promiscuously in groups of from 10 to 30 individuals.

Fam. Myxinidae.

Myxine glutinosa, Lin.-Hag-fish, Rothesay; said to be numerous off Girvan, and destructive to line-fishes (H.B., p. 225).

\section{SUB-CLASS LEPTOCARDII.}

\section{Fam. Cirrhostomi.}

Branchiostoma lanceolatum (Pallas).-Lancelet, or Amphioxus; nr. L. Cumbrae (R.); bet. L. Cumbrae and Hunterston (Gray). ( p. 225, Landsborough, etc.) 
$=$ 

[Reprinted from "The Annals of Scottish Natural History," January 1902.]

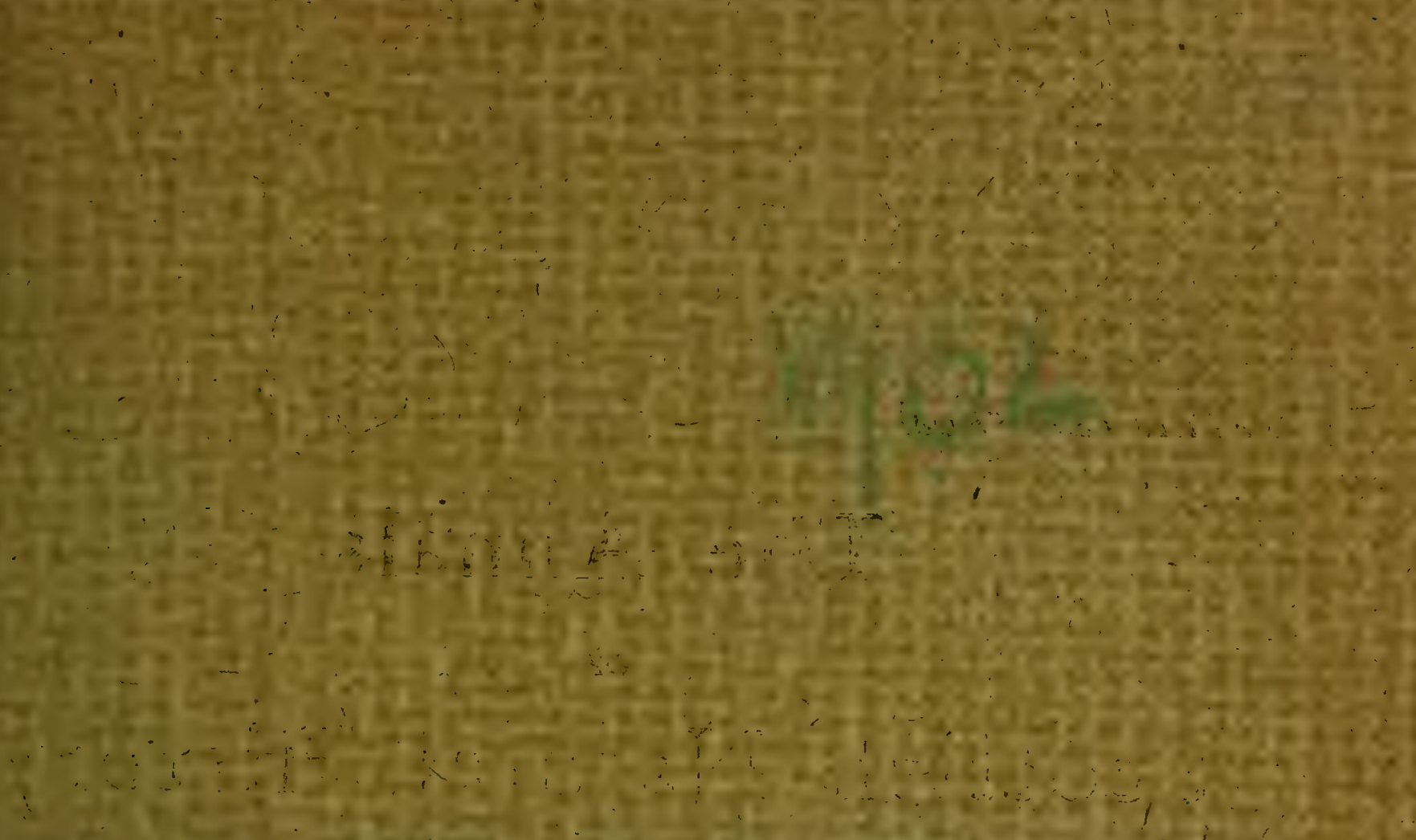

NOTES ON FRESH AND BRACKISH-WATER ENTOMOSTRACA FOUND IN ABERDEENSHIRE

BY THOMAS SCOTT, F.L.S.

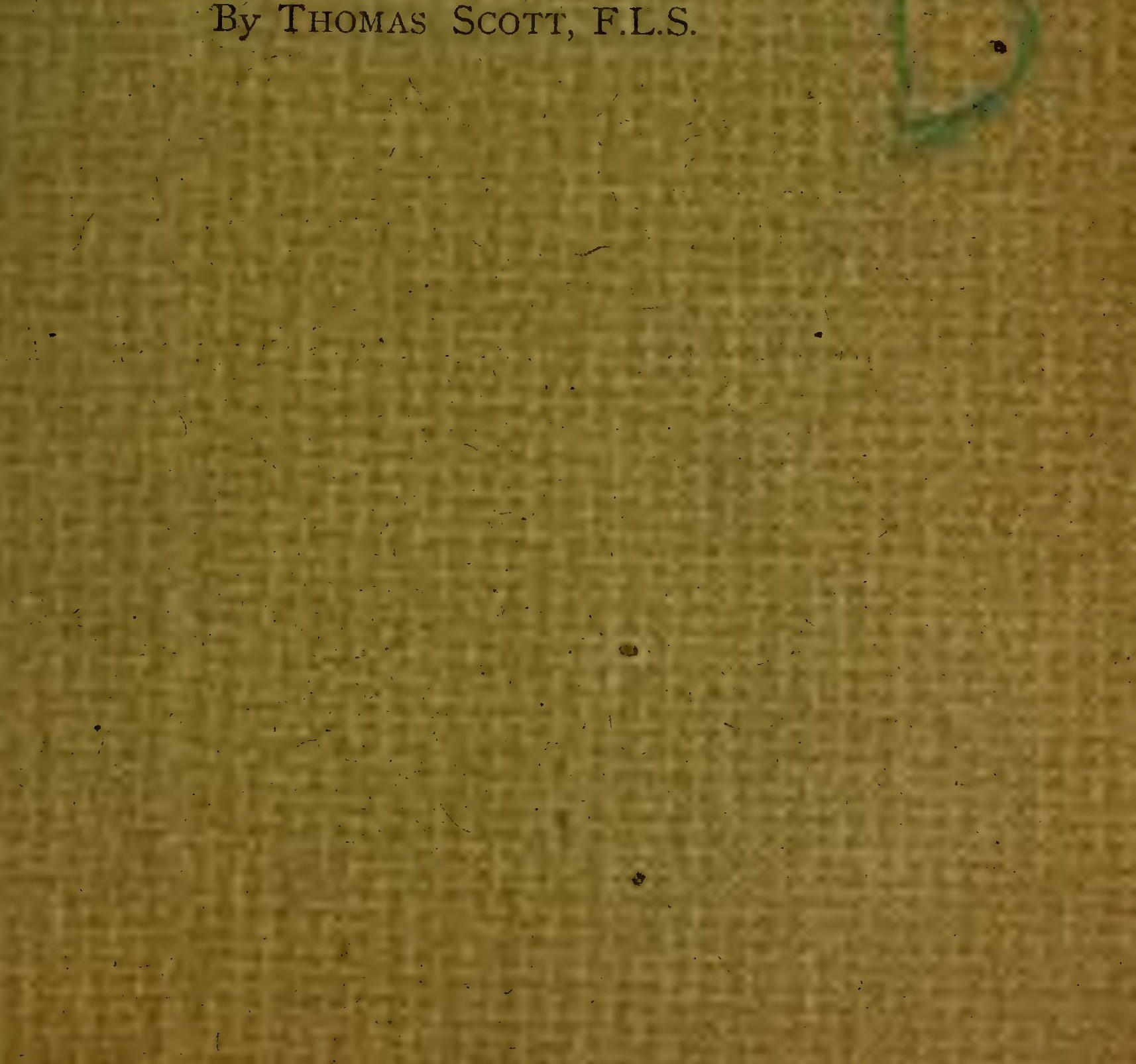




\title{
The Annals
}

of

\section{Scottish Natural History}

A QUARTERLY MAGAZINE WITH WIICH IS INCORPORATED

\section{" Cbe Scottigh 牯aturalist"}

\author{
EDITED BY
}

J. A. HARVIE-BROWN, F.R.S.E., F.Z.S.

Member of the British Ornithologists' Union

JAMES W. H. TRAIL, M.A., M.D., F.R.S., F.L.S.

Professor of Botany in the University of Aberdeen

and

WILLIAM EAGLE CLARKE, F.L.S., MEM. BRIT. ORN, UNION

Natural History Department, Museum of Science and Art, Edinburgh

EDINBURGH : DAVID DOUGLAS, CASTLE STREET 
[Reprinted from "The Annals of Scottish Natural History," January I902.]

\section{NOTES ON FRESH AND BRACKISH-WATER ENTOMOSTRACA FOUND IN ABERDEEN- SHIRE.}

By Thomas Scott, F.L.S.

THE Entomostraca recorded in the following notes were collected chiefly in the vicinity of the river Ythan, from a short distance above the railway viaduct at Ellon to a little beyond the point where the river is joined by the Burn of Forvie. But in addition to the species obtained here, I am enabled, through the kindness of Mr. R. M. Clark, B.Sc., F.L.S., to record three species from another district, two of which are new to the Entomostracan fauna of Aberdeenshire; these are separately described at the end of this paper.

I had two reasons for selecting for examination the part of the Ythan referred to above. First, because of its being within easy reach of Aberdeen, and, second, because the lower portion of the river, being a tidal estuary, was likely to yield a number of brackish-water Entomostraca, which are always interesting since they form a kind of borderland where the true fresh-water species are found merging into those that are truly marine. 
Three visits were made to this part of the Ythan during the past summer, twice in July and once in August, and the results, briefly set forth in the sequel, were fairly satisfactory.

The bridge which spans the river at the village of Ellon is said to be the limit to which the influence of the tide extends, but it is not till one gets below Waterton that any difference in the Entomostracan fauna of the river begins to be observed. It may be stated further that the river for some distance both to the east and the west of the bridge does not present conditions very favourable to Entomostracan life; it is only when we get beyond the railway viaduct on the one hand and below Waterton on the other that good hunting ground is met with. A little above the viaduct the land bordering the Ythan on the south side assumes the form of a flat, low-lying meadow, and here, there is what looks like part of an old bed of the river, and through which the water may still find a channel when in flood. I visited this place on I 3 th July, and at that time this old channel had practically no connection with the river except at its lower end, and the water it contained, being undisturbed, seemed to be a very suitable habitat, and, along with a few other places in the neighbourhood, yielded no fewer than forty-two species of these minute crustaceans. It was noticeable, however, that though there was great variety, the individuals of each kind were comparatively few; it was in marked contrast to what is sometimes observed in lochs and ponds, where myriads of individuals will sometimes be met with, but with very little variety as regards species. Several of the species obtained have not before been recorded for the county. The part of the river examined in August was the north shore, from about half-way down the Waterside Road to a little beyond the confluence of the Burn of Forvie. Near the ferry, between Denhead and the Kirkton of Logie-Buchan, is a considerable amount of marshy ground, intersected by a burn and a few ditches. Here some moderately rare freshwater species were found, while near and beyond the mouth of the Forvie several interesting brackish-water Copepoda and Ostracoda were collected. The number of species obtained on this occasion was thirty-nine, only two of which belonged 
to the Cladocera, while the remainder was about equally divided between the two groups mentioned above.

A small portion of the north shore bordering the Waterside Road had been examined during an earlier visit, viz. on 6th July, when about twenty species of Entomostraca were obtained, five of which were not observed in August. On 6 th July the tide was flowing, and while watching the gradual and steady advance of the water upon the land, I noticed myriads of Schizopods crowding up with the advancing water, all of which appeared to be eagerly seeking for and catching the minute organisms that were being stirred into activity by the incoming tide. A single dip of the hand net was sufficient to capture a considerable number of these busy crustaceans, and when examined at close quarters they were found to consist entirely of Neomysis vulgaris (J. V. Thompson). Lower down the river, where the conditions become more estuarine, there are forests of tall reeds growing along the river side; here in pools in the mud the curious amphipod Corophium grossipes was obtained.

The total number of Entomostracan species captured during my three visits to the Ythan is sixty-five, seventeen of them belonging to the Cladocera, twenty-six to the Ostracoda, and twenty-two to the Copepoda. Included amongst these were seven species of the Ostracoda and six of Copepoda which are more or less decidedly brackish-water forms.

The following are the names of the species captured on these three occasions, their abundance or rarity being indicated by the following abbreviations $-\mathrm{c}=$ common, n.c. $=$ not very common, $r .=$ rare, and v.r. $=$ very rare; a blank, that it was not obtained at that particular visit, and an * is placed opposite the names of the brackish-water species.

\section{Cladocera.}

Ceriodaphnia quadrangula, Müller Scapholeberis mucronatus, Müller. Simocephalus vetulus, Müller Daphnia longispina, Leydig Bosmina longirostris (Müller) Ilyocryptus sordidus (Lieven)
Ist Visit, 2nd Visit, 3rd Visit, July 6. July 13. Aug. 24.

n.c.

n.c.

c.

n.c.

c.

c. c. 


\section{Cladocera-continued.}

Eurycercus lamellatus (Müller) rst Visit, and Visit, 3rd Visit, July 6. July 13. Aug. 24. Acroperus harpe, Baird Lynceus (Alona) guttatus (G. O. Sars). c. n.c. "quadranoularis (Miiller)

$\begin{array}{ccc} & \text { c. } & \\ & \text { n.c. } & \\ & \text { n.c. } & \\ & \text { n.c. } & \\ \text { n.c. } & \text { n.c. } & \text { n.c. } \\ & \text { v.r. } & \\ \text { r. } & \text { r. } & \\ & \text { n.c. } & \\ & \text { n.c. } & \\ & \text { n.c. }\end{array}$

Peratacantha (Peracantha) truncata, Müller . Chydorus spharicus, Müller

c. c.

With the exception of Ceriodaphnia quadrangula and Lynceus (Alona) rectangularis, the species enumerated have already been recorded for Aberdeenshire, but not from the district under consideration. Ceriodaphnia quadrangula appears to be somewhat of a local species and not very common; Lynceus (or Alona) rectangularis is sometimes not uncommon in pools near the sea where the water is slightly brackish, and has been obtained not only in the vicinity of the river Ythan, but also on the Links at Aberdeen.

I may mention that in the large recently published work on the Cladocera of Sweden by Prof. W. Lilljeborg, ${ }^{1}$ the name Alona of Baird is set aside in favour of Lynceus of Müller. The genus Lynceus, instituted by Müller in I776, came in course of time to include forms that differed so considerably from one another that a revision and rearrangement of the species it contained became more and more urgent. Dr. Baird took the work in hand, and one has only to read his "Natural History of the British Entomostraca" to see how thoroughly it was done. He broke up the old genus into a number of genera, but the name which Müller had instituted was not given to any of them, yet, curiously enough, he reserved the name Lynceidæ for the family. In Lilljeborg's work Müller's name Lynceus is restored for that group of species to which Baird gave the name of Alona.

I may also state that Lilljeborg has altered Baird's name Peracantha to Peratacantha.

\section{OSTRACODA.}

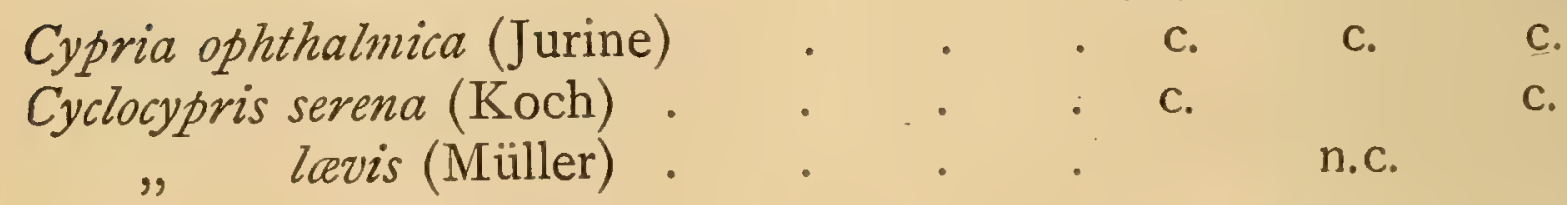

1 "Cladocera Suecicæ," von Prof. W. Lilljeborg [Nova Acta Regiæ Societatis Scientiarum Upsalensis, Ser. Tertiæ, vol. xix. (I90I)]. 


\section{OSTRACODA-continued.}

Cyclocypris globosa (G. O. Sars)

Ist Visit, 2nd Visit, 3 rd Visit,
July 6. July r3. Aug. 24.

Cypris obliqua, Brady

n.c. n.c.

Herpetocypris reptans (Baird)

r.

n.c. V.r.

tumefacta (Brady and Robertson) n.c. n.c.

$\mathrm{v}, \mathrm{r}$.

Cypridopsis villosa (Jurine).

Pionocypris vidua (Müller).

n.c. n.c. n.c.

Potamocypris fulva, Brady.

n.c. r.

Candona candida (Müller) .

c. c. ${ }^{1}$ n.c.

" lactea, Baird

", rostrata, Brady and Norman

" fabaformis (Fischer)

" hyalina, Brady and Robertson

$" \quad$ acuminata, Fischer

Candonopsis kingsleii (Brady and Robertson)

* Cythere pellucida, Baird

*

" macallana, Brady and Robertson

* ", gibbosa, Brady and Robertson

Limnicythere inopinata (Baird)

* Cytheridea torosa (Jones) .

* Cytherura gibba (Müller).

* Sclerochilus contortus (Norman).

* Cytherois fischeri (G. O. Sars)

c. c.

c.

n.c. n.c.

r.

n.c. n.c.

V.r. ${ }^{2}$

n.c.

r.

c.

n.c.

c.

c.

C.

C.

c.

n.c.

n.c.

Several of the species in this list have not previously been recorded for Aberdeenshire, and nowhere else in the county have I found the genus Candona so well represented. The species marked with an * are inhabitants of brackish water, a few of them being also found in the sea within the littoral zone.

Copepoda.

Cyclops vernatis, Fischer

Ist Visit, 2 nd Visit, 3 rd Visit,
July 6. July 13. Aug. 24.

\section{" bisetosus, Rehberg}

" viridis (Jurine)

$" \quad$ albidus (Jurine)

" serrulatus, Fischer.

" affinis, G. O. Sars

n.c.

n.c.

n. C.

*Iachidius littoralis, Poppe

$\begin{array}{ccc} & \text { n.c. } \\ & \text { n.c. } \\ \text { c. } & \text { c. } \\ & \text { n.c. } \\ \text { n.c. } & \text { n.c. }\end{array}$

c.

1 Males and females were obtained. I counted twenty-one or twenty-two ova in one of these females.

2 The male only of this species was observed. 


\section{COPEPODA-continued.}

*Delavalia palustris, Brady

Canthocamptus staphylinus (Jurine)

Ist Visit, 2nd Visit, 3 rd Visit,

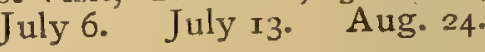

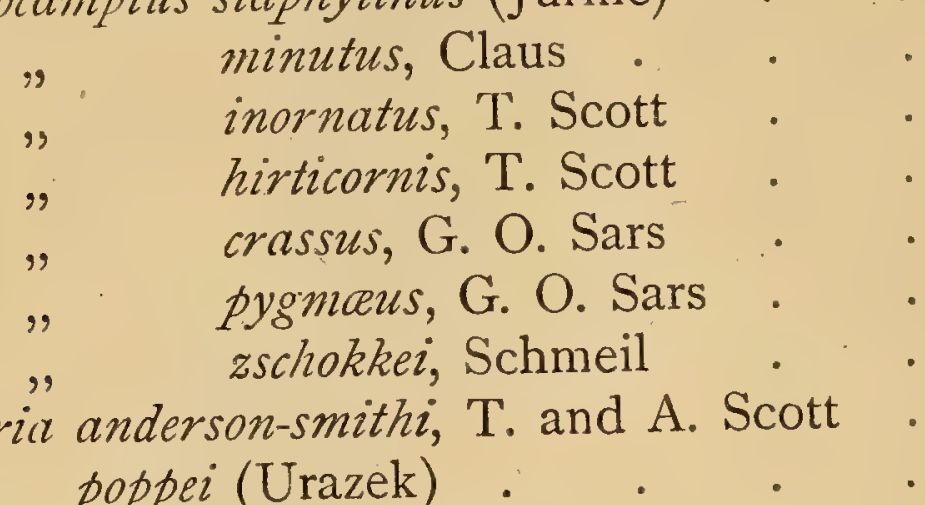

$\begin{array}{ccc}\text { n.c. } & \text { c. } & \text { c. } \\ \text { n.c. } & \text { n.c. } & \text { n.c. } \\ \text { r. } & \text { n.c. } & \text { n.c. } \\ & & \text { c. } \\ \text { n.c. } & \text { c. } & \text { n.c. } \\ \text { n.c. } & \text { c. } & \text { n.c. } \\ & \text { r. } & \text { n.c. } \\ & & \text { n.c. }\end{array}$

n.c.

n.c.

n.c.

n.c.

n.c.

* Platychelipus littoralis, Brady

The species marked thus (*), though occasionally found in the open sea, are usually more frequent in pools and estuaries where there is a large admixture of fresh water. The following remarks on some of the species may be of interest:-

Tachidius littoralis was described and figured in part iii. of the "Tenth Annual Report of the Fishery Board for Scotland," I 892, as a new species under the name of Tachidius crassicornis, but I subsequently learned that it had been described by Dr. S. A. Poppe in I 88 I under the name which it now bears. It is readily distinguished from Tachidius brevicornis (Müll.) by the short stout antennules, which terminate so abruptly that they look as if their ends had been snipped off ; the fifth thoracic feet are also narrow and quite unlike the two big, almost semicircular plates that form the fifth feet of $T$. brevicornis.

Canthocamptus minutus is a sinall species, and apparently widely distributed. When viewed laterally, the principal tail setæ seem to spring from beneath the overlapping short furcal joints; from above, the minute bristles that fringe the anal operculum are bifid, and by these two characters alone the species may be distinguished.

Canthocamptus inornatus was first observed in Rescobie Loch, Forfarshire, and has since been found in various other parts of Scotland and also in England. This species may be distinguished by the moderately long and tapering furcal stylets.

Canthocamptus hirticornis is found most frequently in pools and lochans near the sea coast, but not necessarily in brackish water. 
Canthocamptus zschokkei. ${ }^{1}$-This so closely resembles $C$. pygmaus, that it may easily be mistaken for that species. There are two characters, however, by which the females of both may usually be distinguished; in the former the long setæ of the first four pairs of thoracic feet are straight ; in the latter the long setæ of the fourth pair are distinctly curved at the ends; in the first the anal operculum projects upwards at an acute angle; in the latter the operculum is depressed. These peculiarities are best seen when the specimens are viewed laterally. $C$. zschokkei was described and figured in part iii. of the "Eleventh Annual Report of the Fishery Board for Scotland," I 893, under the name of Attheyella propinqua.

Moraria poppei.-This is one of the rarer fresh-water Harpactids of Scotland. Hitherto I have observed it in only two localities, namely, in pools by the side of Loch Fad in Bute, and near the shore at Hunterston, Ayrshire; this is therefore the first time it has been recorded for the east of Scotland. It is a very small species and requires careful examination. A third species of Moraria-M. brevipes, G. O. Sars-has been recorded from several places in Scotland, and among others in Rescobie Loch, Forfarshire.

Laophonte curticauda. - This Laophonte is not so frequently met with in brackish water as one or two others of the same genus, such as Laophonte mohammed, Richard, which was discovered in brackishwater pools near Langbank, Renfrewshire, in $1897,{ }^{2}$ but which had previously been observed by Mr. Scourfield in a marsh at Barmouth Junction, North Wales, in November 1895. Laophonte littorale, T. and A. Scott, another brackish-water species, has been found near Aberlady, Firth of Forth, and at the mouth of the river Alness, Cromarty Firth. ${ }^{3}$

Nannopus palustris and Platychelipus littoralis are two curious brackish and estuarine species described by Dr. G. S. Brady in his "Monograph of British Copepoda." Formerly they were considered to be moderately rare, but the extended research of recent years has shown their distribution to be fairly extensive.

Dactylopus tisboides. - As pointed out by Dr. Brady, there appear to be two forms (or races) of this species-a brackish-water and a marine; that found in the Ythan belongs to the first, and is not

1 The two species mentioned here (C. zschokkei and C. pygmaa) should perhaps be more correctly referred to the genus Attheyella of Dr. G. S. Brady, as they differ from the typical Canthocamptus in the structure of the first pair of thoracic feet.

2 Part iii. of the "Fifteenth Annual Report of the Fishery Board for Scotland," p. 3 I 7 .

3 "Ann. and Mag. Nat. Hist." (6), vol, xii. p. 238, pl. xi. figs. 7-I4 (October 1893). 
uncommon between tide-marks, and I have found it in rock pools above high water.

In the study of these, as of many other organisms, it is found that when one tries to limit his observations to the so-called "freshwater" or to the "marine" species, the barrier set up between the two has to be more or less an arbitrary one, it being practically impossible to draw a line that will enable him to say "all on this side belong to the freshwater group and all on that to the marine." We have in these brackish waters a kind of "no man's land," where the organisms of the sea and of the fresh water appear as if engaged in a perpetual struggle for the invasion of each other's domain. Take, for example, the Neomysis already referred to. This Schizopod is found in the Firth of Forth, in the Moray Firth, and elsewhere in water that differs little from typical sea-water, and it belongs to a group of crustacea whose habitat is decidedly marine, yet this species has been found in lochs such as Loch Wester in Caithnessshire, and Sinclair Loch in the Island of Barra in water which was quite fresh. On the other hand, we have Cyclops bicuspidatus-a typical fresh-water Copepod with I 7 -jointed antennules-represented in brackish-water pools by a form whose only apparent difference is that its antennules are I4-jointed, the difference being brought about by three joints having become coalescent with those next to them. This variety (var. lubbockii, Brady) is found associated with Cyclops bisetosus (another fresh-water Cyclops), Delavalia palustris, Canthocamptus palustris, Eurytemora velox, and others. Then again we have Cyclocypris serena, and Candona candida, so common in our fresh-water lochs and ponds, sharing the same pools with Cythere pellucida, Cythere gibbosa, and Cytheridea torosa, which are all more or less typical brackish-water species. It will thus be seen that this "borderland" presents a most interesting field for investigation.

For the following species I am indebted to Mr. R. M. Clark, B.Sc., F.L.S., who obtained them in a shallow pool near Millden, about six or seven miles north of Aberdeen, and not far from the sea. The names of the species are as follows:-

Diaptomus castor (Jurine).-Mr. Clark found this large and well-marked species moderately common in the pool referred to, and its occurrence there is all the more interesting from the fact that, so far as known to me, this is only the third time the species has with certainty been recorded from Scotland. In the "Annals of Scottish Natural History" for July I 892, p. 202, I have a note on its occurrence in the Braid Ponds near Edinburgh, but the place where these ponds existed has in recent years been greatly altered, and this Diaptomid is now probably extinct. The second was observed in a gathering of fresh-water Entomostraca collected in Helliers Water, Unst, Shetland, on 22 nd June 1897 , and sent to me by Mr. Robert 
Duthie, Fishery Officer. ${ }^{1}$ Diaptomus castor has been recorded from several parts of England. ${ }^{2}$

Cypris Reticulata (Zaddach).--This species, which was also moderately common, has not before been recorded for Aberdeenshire. Considerable numbers of the same species have also been obtained by Mr. Clark in Corbie Loch.

Cypris virens (Jurine).-A few fine specimens of this species were observed in the same pool with the other two.

It may be noted in conclusion that in the present paper over a dozen species of Entomostraca, exclusive of brackishwater forms, are apparently new records for the county.

1 "Sixteenth Annual Report of the Fishery Board for Scotland," part iii. p. 259 (I898).

2 Revision of the British species of Cyclopidæ and Calanidæ, by Dr. G. S. Brady, "Nat. Hist. Trans. Northumb. and Durham," vol. xi. p. 94 (I89I). 



-

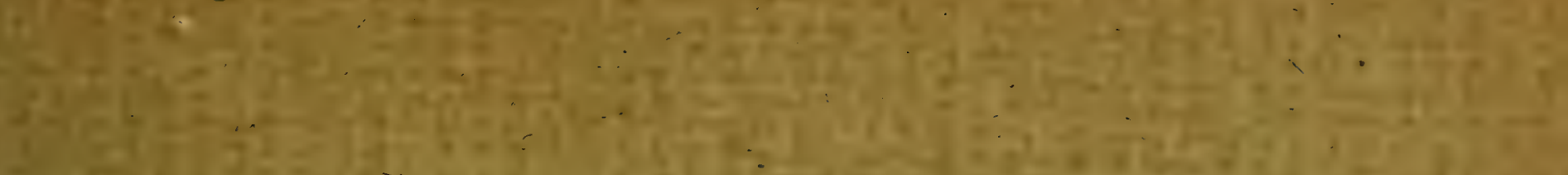

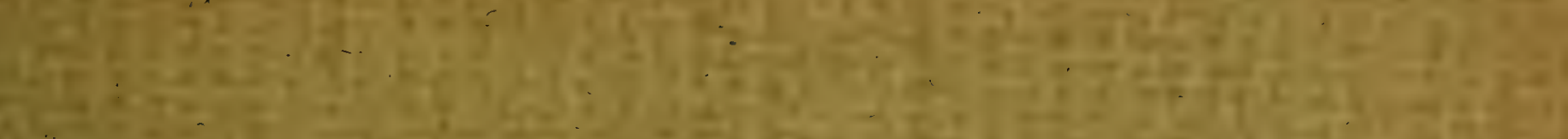

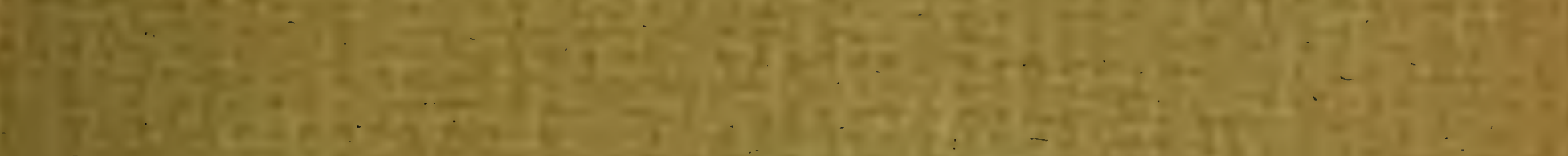

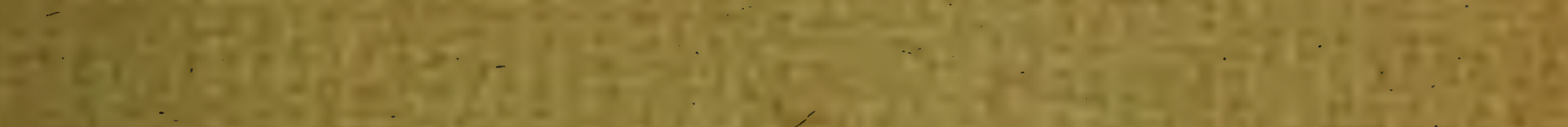

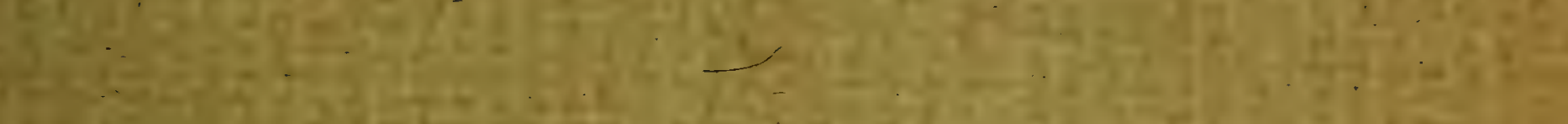

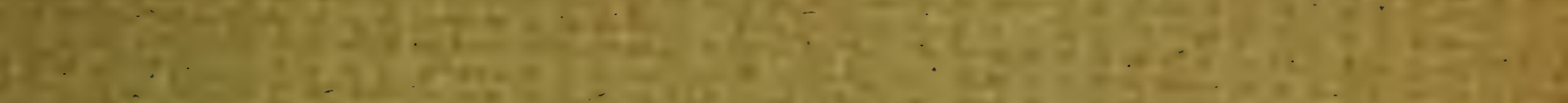

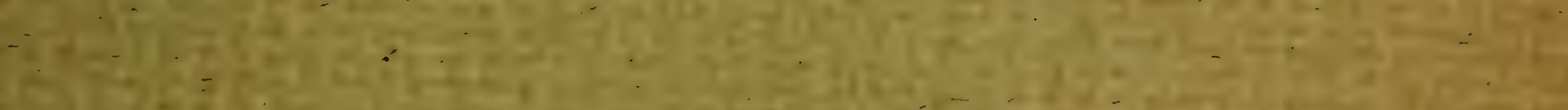

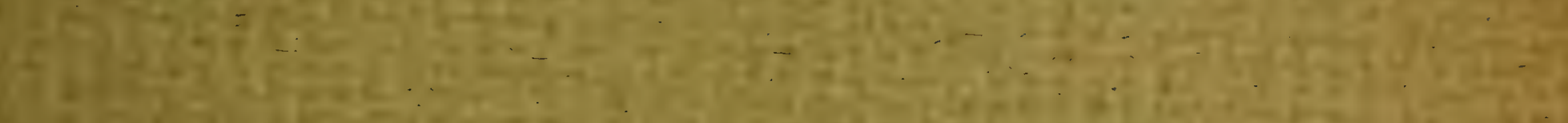

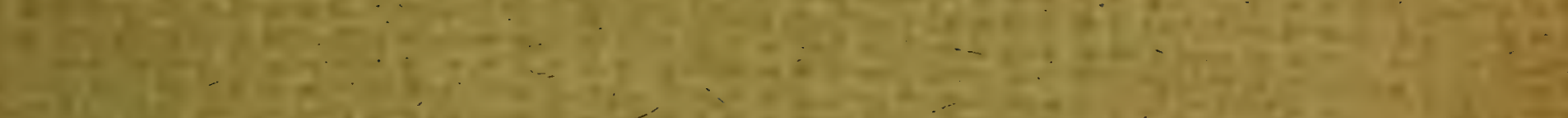

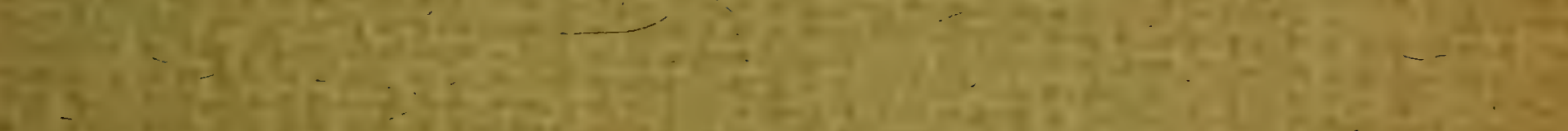

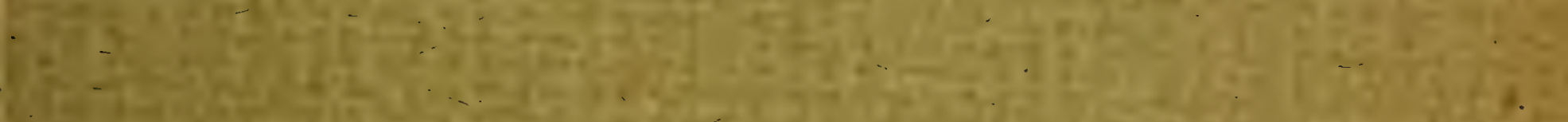

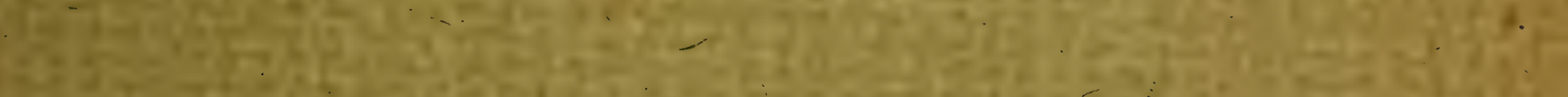

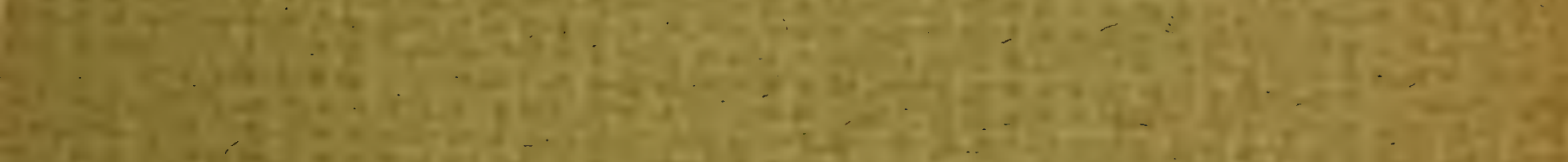
.

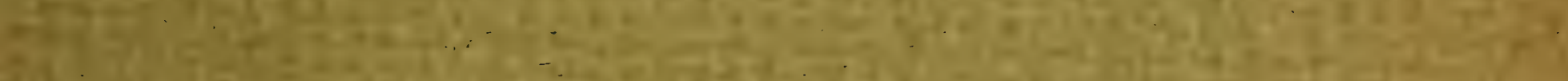

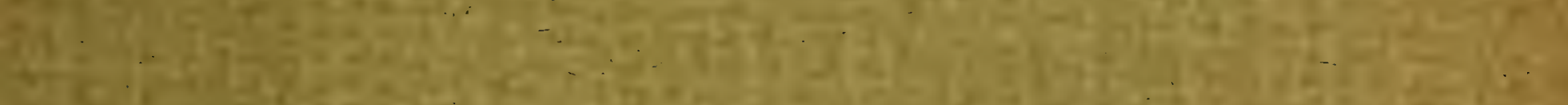

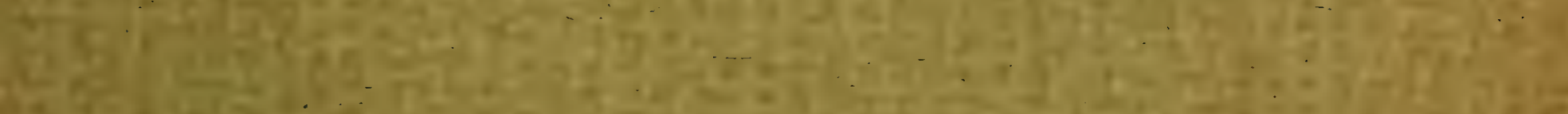

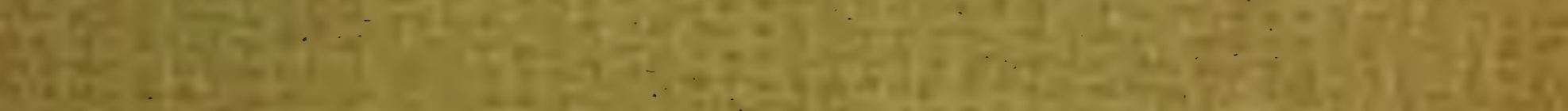

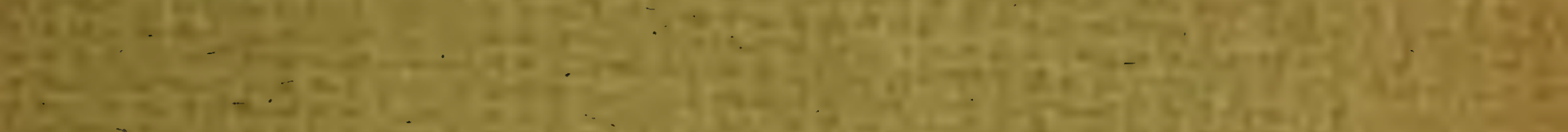

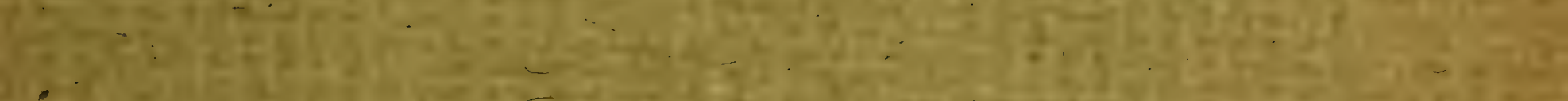

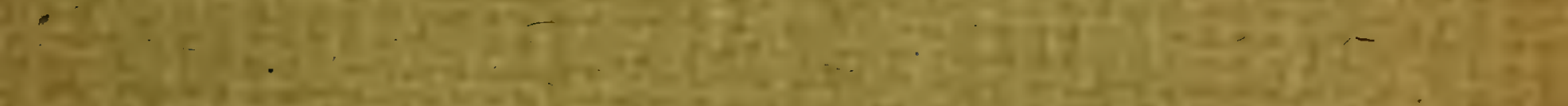

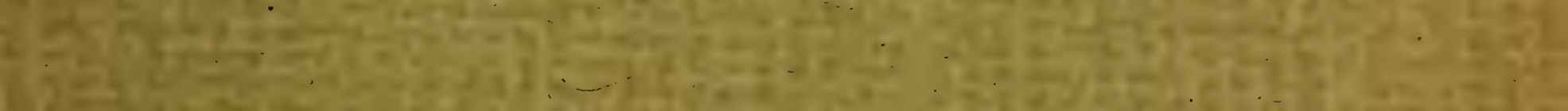
.

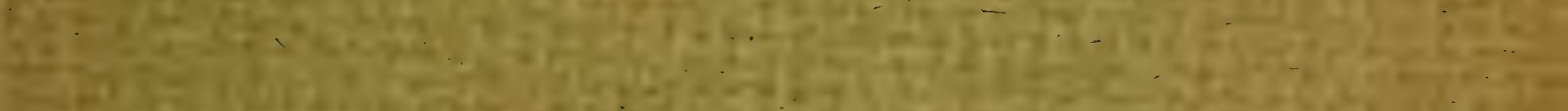

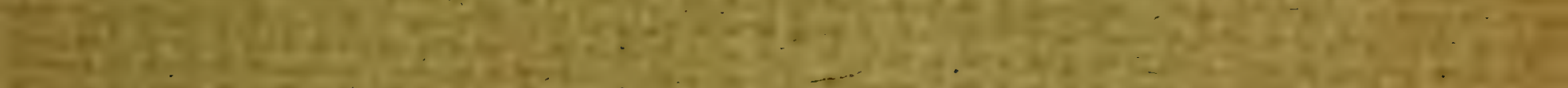

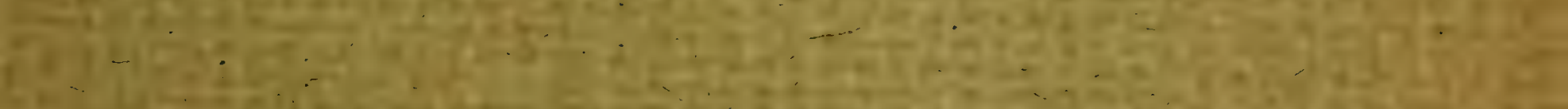

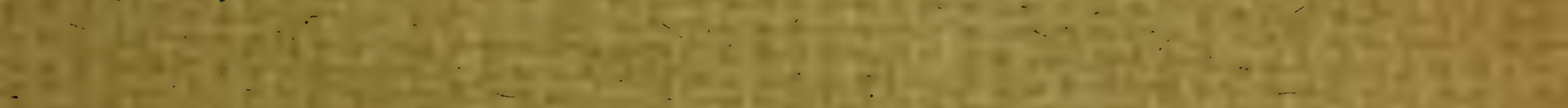

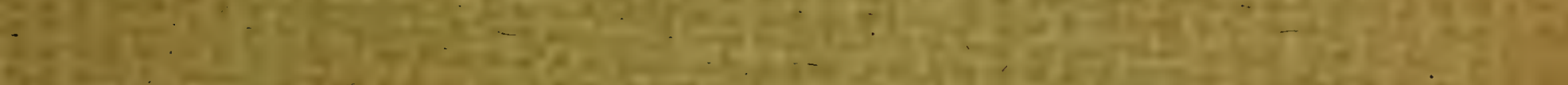
.

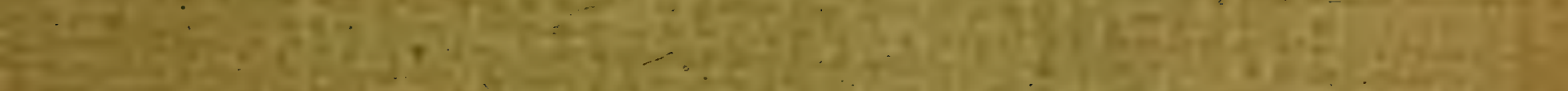

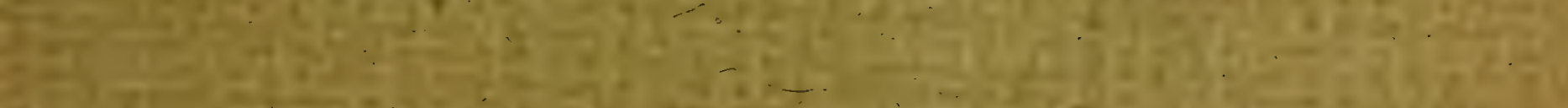

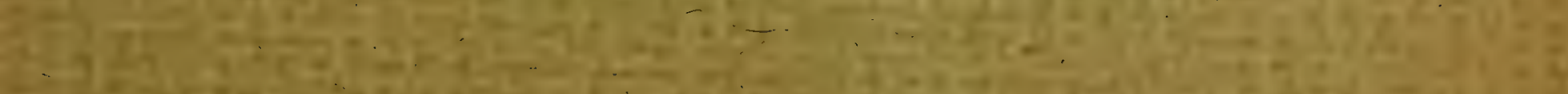

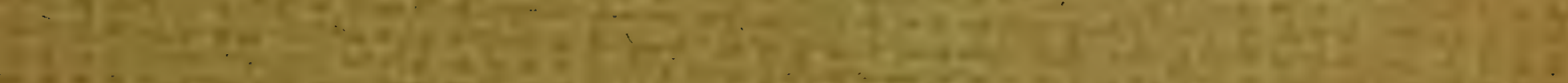

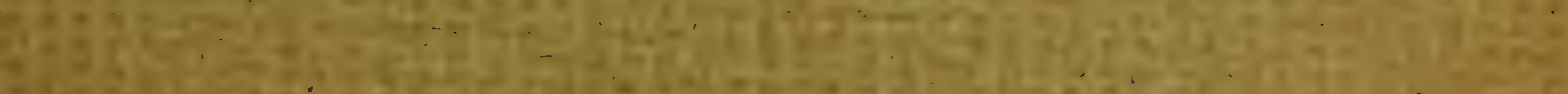

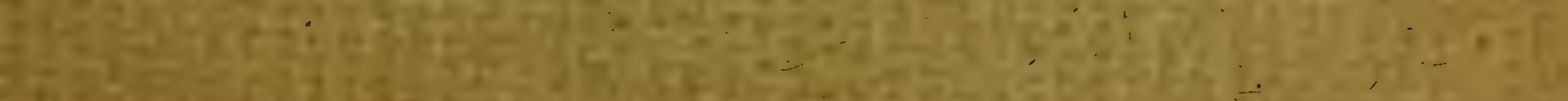

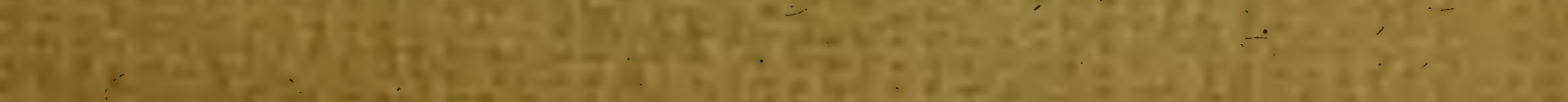




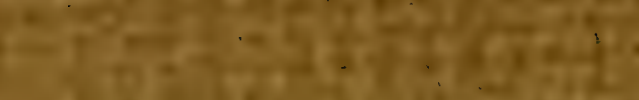

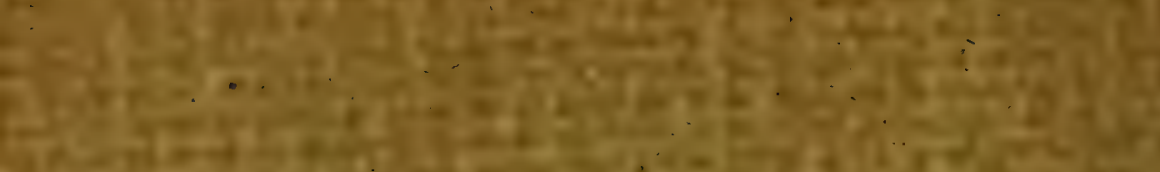

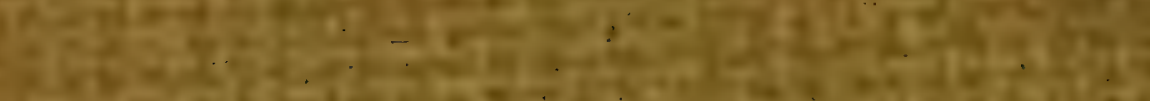

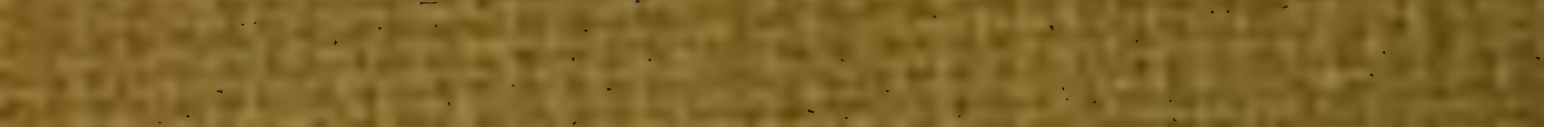

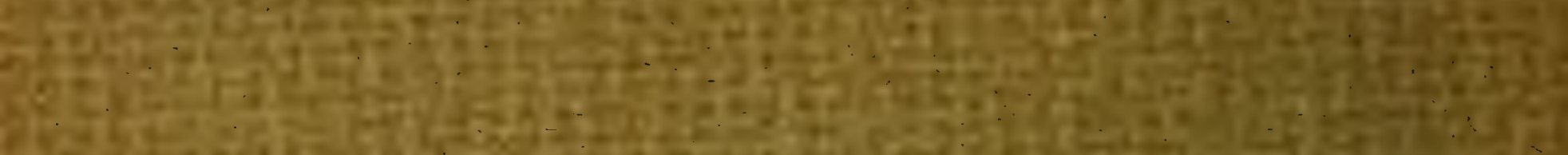

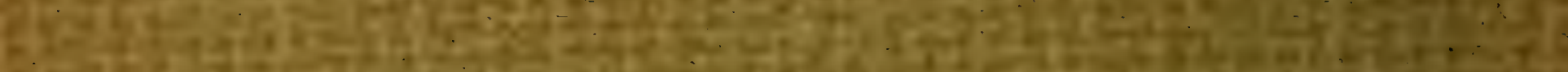

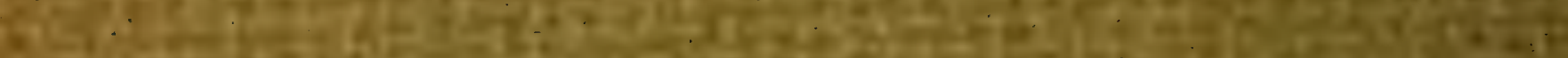

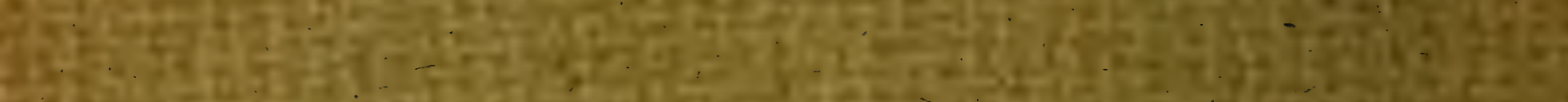
a

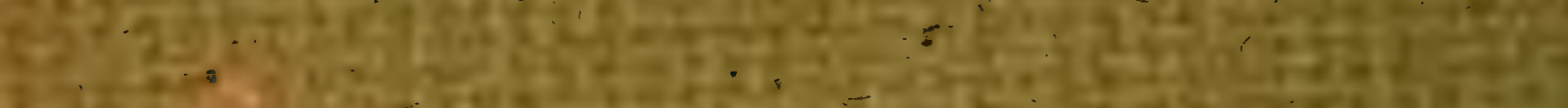

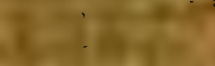

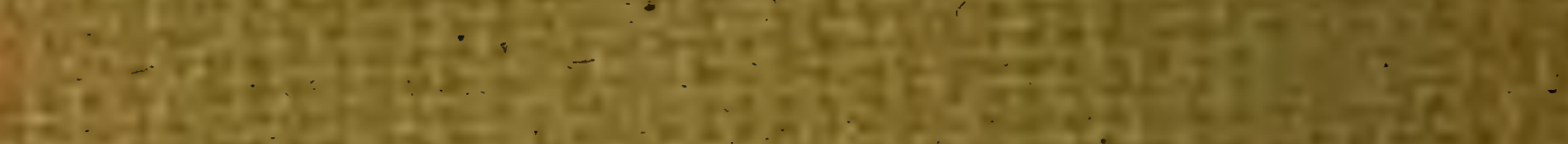
.

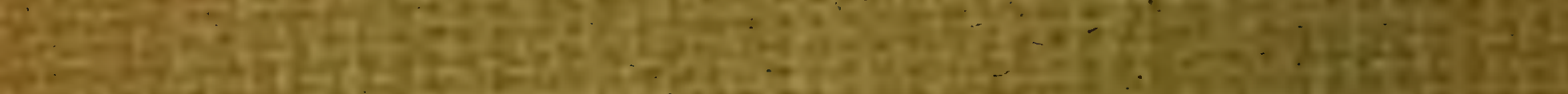

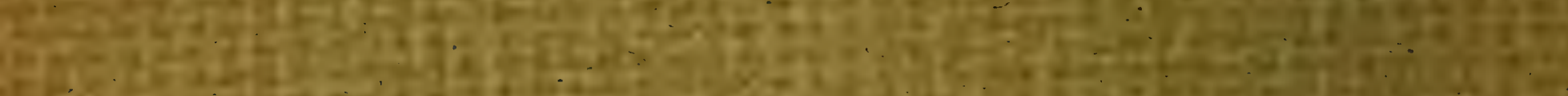

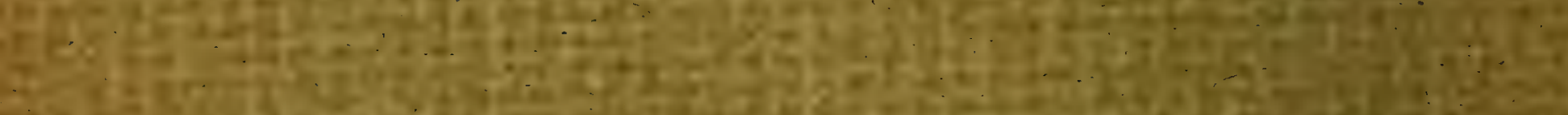

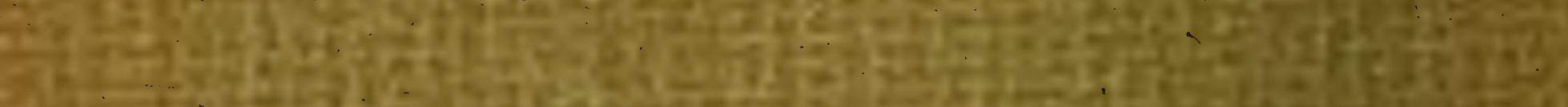

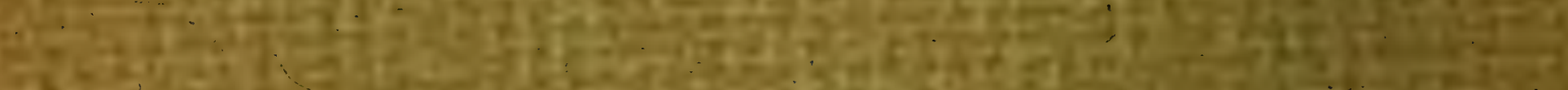

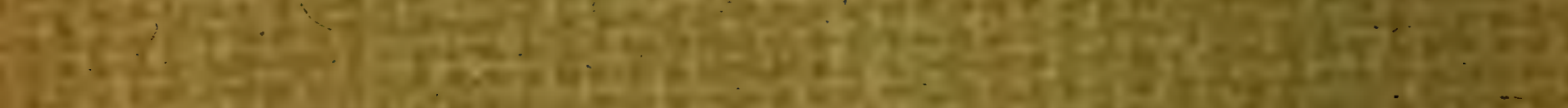

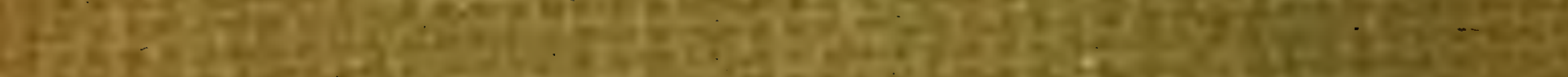

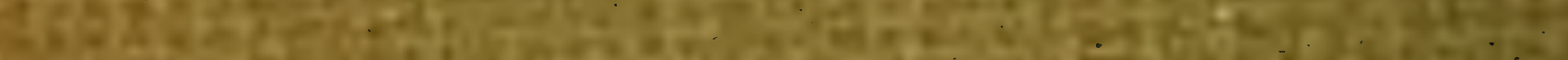

-

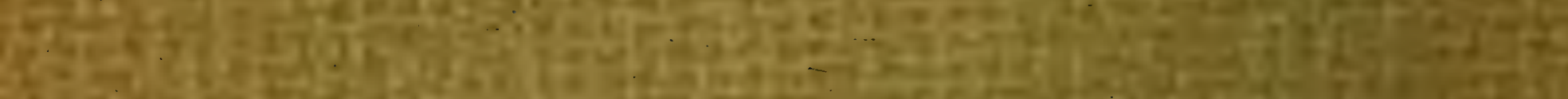
.

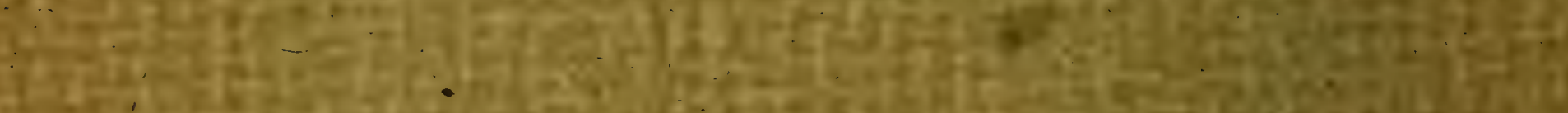

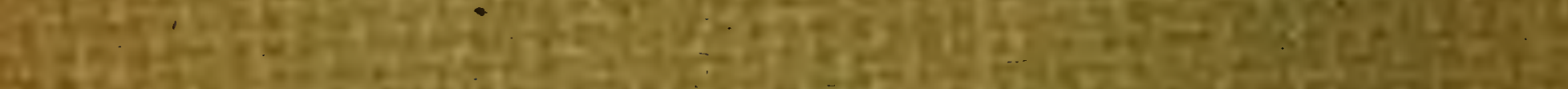

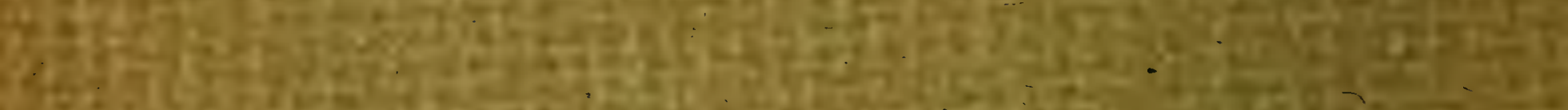

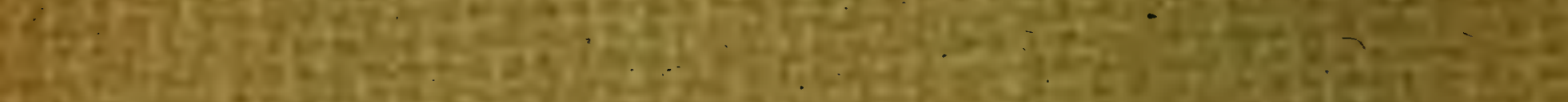

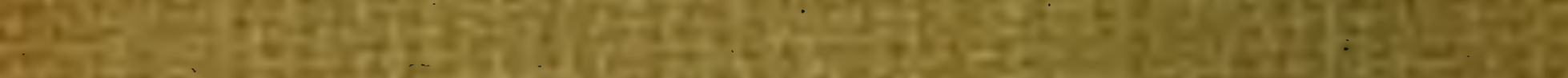

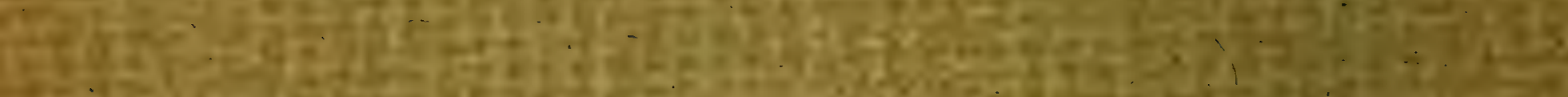
.

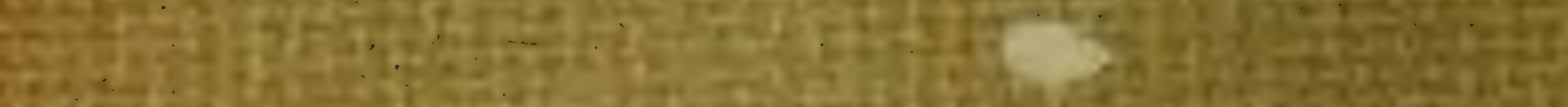

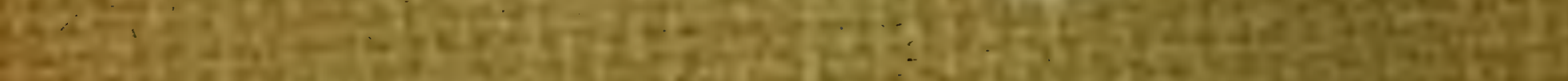

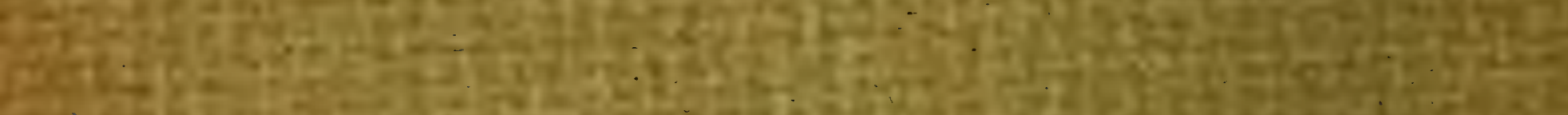

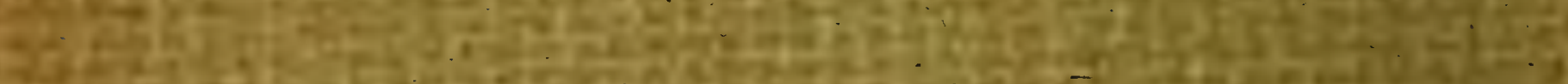

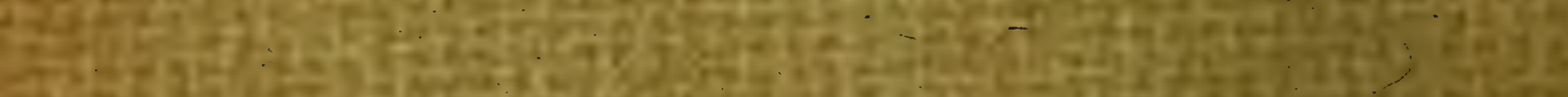

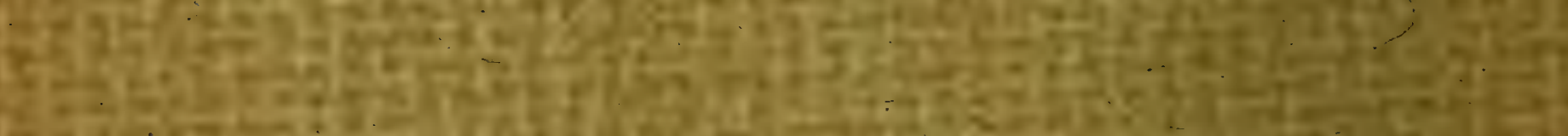
(2) 6.

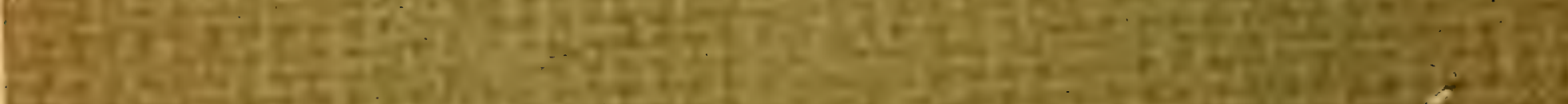

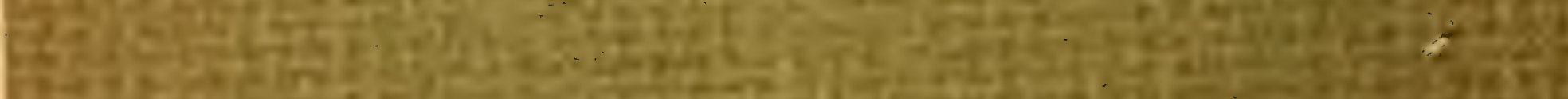
a

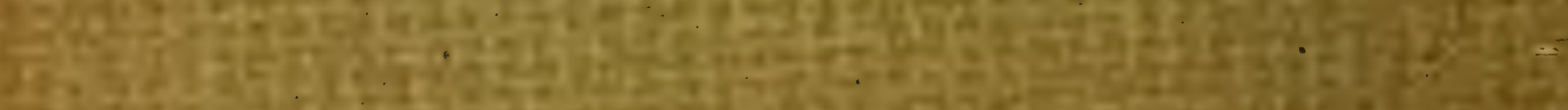


(Reprinted from the 'Transactions of the Edinburgh Field Naturalists' and Microscopical Society,' Session 1902-1903.)

\title{
SOME OBSERVATIONS
}

\author{
ON THE \\ DISTRIBUTION OF THE SMALLER CRUSTACEA
}

BY

THOMAS SCOTT, LL.D., F.L.S. 

(Reprinted from the 'Transactions of the Edinburgh Field Naturalists' and Microscopical Society,' Session 1902-1903.)

\section{SOME OBSERVATIONS ON THE DISTRIBUTION OF THE SMALLER CRUSTACEA.}

By Thomas SCOTT, LL.D., F.L.S., Honorary Member.

THE distribution of the Crustacea, and especially of the smaller species, has in recent years been attracting more attention than formerly. That it should do so is not only not surprising, but one is rather inclined to wonder why these minute crustaceans have been so long and so much neglected. For whether we regard their extremely varied and often beautiful forms, or their interesting, and in many cases strange, life-histories, they are found to constitute one of the most fascinating studies that can engage the attention of the zoologist.

In the following observations on the distribution of the smaller species of crustacea, I shall for the most part confine my remarks to those that have been observed in connection with the investigations which have for a considerable number of years been carried on under the direction of the Scottish Fishery Board. And, first, I propose to notice, briefly, the influence of the seasons on the distribution of the smaller crustacean species: this is sometimes more easily observed in regard to fresh-water forms than amongst those that live in the open sea. Second, reference will be made to the occur- 
rence of certain species off the Scottish coasts which seem to owe their presence there to the influence of oceanic currents. And, third, a number of species-chiefly parasitic-will be referred to, the distribution of which appears, so far, to be inexplicable.

First, The influence of the seasons on the distribution of the smaller crustacea. Though the changes of the seasons have, no doubt, a certain influence on the distribution of the smaller crustacean species, it is not always easy to ascertain, even approximately, how far this influence may be exerted, or to what extent the ordinary seasonal influences may be neutralised by changes that are accidental and temporary. Only by continuous observations extending over a number of years can any satisfactory knowledge concerning the influence of the seasons on distribution be acquired. But though such a study may be difficult, and the results sometimes disappointing, it is nevertheless full of interest; and one of the reasons which make it unusually interesting is due to the unlooked-for incidents which are to be met with occasionally. I have stated that the ordinary seasonal influences may be interfered with by accidental and temporary changes: the following example will show how this may occur. The various species of Daphnic are, under ordinary circumstances, not greatly affected by seasonal changes. I have found them in Duddingston Loch, Loch Leven (Kinross), Forfar Loch, and other lochs which I have visited at various seasons, to be nearly, though not quite, as numerous in winter as in summer. (See Part III. of the 16th Annual Report of the Fishery Board for Scotland, p. 132 et seq.) But though the distribution of Daphnia in these lochs did not appear to be greatly affected by seasonal changes, it was otherwise with those observed in an artificial pond near Comely Bank, Edinburgh. I visited this pond, with a friend, on July 3, 1898, and found Daphnia pulex abundant; on the 25th of the following month, or a little more than seven weeks after the first visit, I examined the pond a second time: the weather in the interval had been dry and warm, so that there was less water in the pond than at the first visit. Under 
these circumstances I had expected that the entomostraca would have become more crowded together, and that a larger gathering would thus be obtained. The actual result, however, was very different. Entomostraca of any kind were few, and as for Daphnia, not a single specimen was got, even though the pond was carefully searched. Probably in this case the warm dry weather, acting on a decreasing body of water, had killed them. In this connection I would refer to the joint observations of $\mathrm{Mr}$ Lindsay and myself at the Upper Elf Loch, Braids, in the years 1896, '97, and '98, the results of which were communicated to the Society in two papers now embodied in the Society's 'Transactions.' In the second of these papers will be found a description and tabular view of the seasonal variations in the entomostraca of this little sheet of water-some of these variations being rather remarkable. ${ }^{1}$

Amongst the many species met with in the lochs of Scotland, the following may be mentioned as being more markedly susceptible to ordinary seasonal influences. Holopedium gibberum was common in Loch Arklet in September and November 1897, and abundant in June 1898, but not a trace of it was observed on the 15th of March of the latter year. It was common in Loch Achray in September 1897 and June 1898, but was entirely absent on November 27 and March 17. It was common in Loch Doon (Ayrshire) on July 6, 1898, but was not observed in September, December, and March preceding. The same species was taken in Loch Oich in August 1897 and in August and October 1898, but was absent from the gatherings collected in December and January. Two other species of cladocera also exhibit a somewhat marked susceptibility to seasonal changes, but the first more distinctly so than the other. In the lochs in which they occur they are usually common in the summer months, but are scarce or absent in winter.

Amongst the pelagic copepoda which I have found in the lochs of Scotland, the only species which exhibited any marked susceptibility to seasonal influence is Diaptomus laciniatus, Lilljeborg. This species was found in Loch Doon, in Ayr-

1 See 'Transactions,' vol. iii. pp. 375-378. 
shire, but only in September 1897 and July 1898, while in the intervening months of December and March no trace of it could be detected. The distribution of Diaptomus gracilis, G. O. Sars, is very different. I have found this species not only in most of the lochs examined, but have gathered it all the year through. There are other fresh-water species which exhibit a tendency to seasonal change in their distribution, but the change does not appear to be so marked as in those already alluded to.

The effects of the seasons on the distribution of the marine crustacea are no doubt also considerable, but other changes, accidental and temporary, may occur which may so obscure and neutralise those more regular changes which the seasons usually produce as to cause them partly or wholly to escape our observation. Continuous stormy weather, for example, gives rise to currents, which may be comparatively cold or warm according to the direction from which the wind has been blowing, and these currents, pushing their way along our coasts, alter for a time the normal temperature of the surrounding water, and so react on both animal and vegetable life. But such currents will not only have a certain influence on the local fauna,-they may also be the means of bringing occasionally within our faunal limits, and even into our estuaries, rare and interesting organisms whose usual habitat is beyond the British area.

Many examples might be given which seem to indicate the effect of seasonal change on the smaller marine crustacea, but the following may suffice. In some gatherings of small crustacea sent from the Clyde in 1901, Podon Leuckartii (G. O. Sars), one of the cladoceran species, was found moderately frequent in those collected in the spring months, but not in those collected later in the year. On the other hand, Podon intermedius (Lilljeborg) and Podon polyphemoides (Leuckart) were observed only in the later gatherings. In a paper on some of the results of the investigations carried on in the Firth of Forth by the Fishery Board for Scotland I have shown, for the seven years from 1889 to 1895 , both inclusive, that the maximum abundance of Calani in their young free-swimming stage, in the Firth of Forth, occurred during April and May, and 
occasionally in June. The increase is rapid till the maximum is reached, and the subsequent decrease appears to be as rapid. This was due to the fact that these three months form the principal spawning period of this group of the crustacea. It is also shown in the same paper that though Calanus heligolandicus, one of the more common of the marine copepoda, exhibited for the seven years scarcely any perceptible difference in its distribution as the result of seasonal changes, the distribution of Temora longicornis showed, on the contrary, considerable diversity in the frequency of its records for the different months; and as this diversity occurred year after year with a certain amount of regularity, it was probably caused by the succession of the seasons, and the changes consequent thereupon. The maximum number of records for each of the seven years occurred in April and May; the records for the succeeding months, from June to October, were fairly regular, and were on an average scarcely half the number recorded for April and May; but the average monthly records from November to March were only about two-fifths of the average for the previous five months. In other words, the average number of records for April and May was 51; for the five months from June to October, 23; but for the five months from November to March it was only 9.

Second, The influence of currents on the distribution of the smaller crustacea. The species whose distribution is chiefly affected by currents are those usually described as pelagic or free-swimming; and several interesting examples, exclusively marine, have been observed. One of the more prominent of these is the occurrence on the north and east of Scotland of Eucalanus crassus and Eucalanus elongatus. Eucalanus crassus, Giesbrecht, was described by Dr Giesbrecht in 1888, and it has been recorded by him off the east coast of South America, in the South Pacific, and in the North Atlantic up to latitude $41^{\circ}$, as well as from the Mediterranean; and I have also obtained it in gatherings collected in the Gulf of Guinea. This species has on several occasions been taken in the Moray Firth, and on November 19, 1897, a considerable number of specimens were captured there; but though they included 
several adult males and females, the majority were immature. I do not know of a single record of this species from the east or south-east coast of England, but Dr Wolfenden has taken it, along with other southern forms, in the Faroe Channel. Its occasional occurrence in the Moray Firth may therefore be owing to the action of currents passing round the north of Scotland into the North Sea. I have lately met with what looks like a southward extension of the distribution of the species on the east of Scotland, several specimens having been obtained in a tow-net gathering of crustacea collected off Aberdeen on November 11, 1901. This is the first time I have met with Eucalanus crassus so far south on the East Coast. Eucclanus elongatus (Dana) has also occasionally made its appearance in the Moray Firth, as well as another nearly allied form-Rhincalanus nasutus, Giesbrecht,-a form which I am inclined to regard as identical with Prof. G. H. Brady's Rhincalanus gigas. These probably, like the others, owe their presence in the Moray Firth to the action of oceanic currents.

In a paper in Part III. of the Eighteenth Annual Report of the Fishery Board for Scotland, I record Corycoeus anglicus for apparently the first time in the Firth of Clyde. The specimens had been obtained in a surface tow-net gathering collected on May 29, 1899, in the vicinity of Ailsa Craig. At about the time these specimens were obtained near Ailsa Craig, Mr I. C. Thompson had been getting the same species in abundance off Port Erin, Isle of Man. It is therefore probable that these Clyde specimens were stragglers from the same swarm that Mr Thompson had met in with, and that this swarm had entered the Irish Sea by the North Channel. I had once before observed Corycoeus anglicus in Scottish waters - viz., in the Firth of Forth in 1896; and it has more recently been captured, but very sparingly, between Lerwick and Sumburgh Head, Shetland, in the Moray Firth, and off Aberdeen.

But besides the occasional introduction of southern species within our faunal limits by oceanic currents, other forms whose natural habitat is arctic or sub-arctic make their appearance at intervals, and sometimes in abundance. These are usually found early in the year, and are probably brought 
to our shores by a more than usual southward trend of cold water from the North Atlantic. The following examples will illustrate this migration of sub-arctic and arctic forms. Thalestris krohnii (Kröyer) (=Thalestris serrulatus of Brady's Monograph) is a free-swimming arctic copepod, of a brick-red colour when living. This copepod has been recorded from various parts of the Arctic Sea, off the coasts of Finmark, and between Novaya Zemlia and Spitzbergen and elsewhere. But though a decidedly northern species, it sometimes makes its way far to the southward. Dr Brady, in his 'Monograph of the British Copepoda,' records its occurrence at the Scilly Isles (1880); I. C. Thompson obtained it near Puffin Island (Irish Sea) in 1889 ; and in 1890 I reported its occurrence in the Firth of Forth and in Dornoch Firth. My son has also obtained it in a surface gathering from the Gulf of St Lawrence. In all these instances, however, so far as known to me, it occurred very sparingly.

The next species I would refer to is the amphipod Euthemisto compressa (Göes). In 1892 an immense shoal of Euthemisto compressa was observed off the Yorkshire coast. The sea was described as literally alive with them, and great numbers were afterwards washed ashore by sea-winds, and afforded a feast for starlings and other frequenters of the tidal line (see T. H. Nelson in the 'Naturalist' for May 1892). Some of the specimens made their way into the Firth of Forth, and were captured in the tow-nets of the fishery steamer which was at that time in the Forth estuary, being mentioned among the "records" for that year. This species is not uncommon in the Arctic seas. It is interesting to notice that in 1891 and 1892 there was also a considerable increase in the numbers of Parathemisto oblivia (Kröyer) taken by our tow-nets. The greatest increase inside the estuary occurred in 1891, while at the mouth of the estuary the greatest increase observed was in 1892. The cause of this remarkable southward migration of Euthemisto compressa along our east coast might be due to an unusual southerly movement of cold water from the North Atlantic. No similar migration has been observed in recent years.

In 1893 I reported the occurrence of the sub-arctic amphipod Anonyx nugax (Phipps) in the vicinity of May 
Island. The specimens, however, were captured in February 1889 , but at that time, as the species was unknown to me, I hesitated to record it. The same species was taken for the second time in Scottish waters by Mr F. G. Pearcey on Jan. 10, 1901. Specimens were captured by tow-net in the Cromarty Firth at a depth of about $7 \frac{1}{2}$ fathoms; and it is of interest to note that on both occasions the species was obtained so early in the year. The Rev. A. M. Norman, in his revision of the British Amphipoda ("Annals and Magazine of Natural History,' ser. 7, vol. v., February 1900), has some interesting remarks on this species. My largest Scottish specimen measures about four-fifths of an inch in length, but Arctic specimens attain to over one and a half inch in length (40-43 millimetres).

Having thus given several examples of crustacean species whose distribution appears to be directly or indirectly influenced by seasonal changes and by oceanic currents, I now proceed, thirdly, to mention a number of species whose distribution is somewhat peculiar, and for which there is, so far, no satisfactory explanation. Some of the best examples of this kind of distribution are to be met with amongst parasitic species, but I shall first refer to one or two free-living forms which, in this respect, are not without interest. The first I shall mention is the marine ostracod Conchocia elegans. We owe the addition of this species to the British fauna to the researches of Sir John Murray, who, a number of years ago: found it abundantly in Loch Etive, near Oban, at a depth of 50 fathoms, and it is still common in the deeper parts of that loch. But though Conchcecia elegans is so common in this particular loch, it has been rarely met with anywhere else in the British seas, - indeed, I know of only two other records: one specimen was dredged in deep water 180 miles north-east of Buchan Ness on May 22, 1901; and another was obtained from the stomach of a whiting captured at a depth of 65 fathoms about ten miles off Aberdeen a few days previous to the one last mentioned. Professor G. O. Sars of Christiania describes the species as very abundant among the Lofoten Islands down to 300 fathoms.

The next species I shall notice is the fine large copepod, 
Euchceta norvegica, Boeck, - another of Sir John Murray's additions to the British fauna. This copepod is found, sometimes in great abundance, in the deep water of Upper Loch Fyne, so much so that a large drop-jar may be filled by a single short haul with the tow-net. It is also got, but more sparingly, in other parts of the Clyde area. Yet it is so scarce in other parts of the British seas that there is no mention of it in the excellent 'Monograph of the British Copepoda,' by Professor G. S. Brady, published in 1878-80; and $I$ have never once met with it on the east coast of Scotland, and only occasionally off the Shetland Islands. There are similar interesting examples among fresh-water species, such as the occurrence in Duddingston Loch of Cyprois flava, an ostracod discovered in this loch many years ago by the Rev. A. M. Norman, and which I have occasionally found there. On one of these occasions the species was moderately common, yet it is doubtful if this ostracod is found living anywhere else in Britain. Other examples might be given, but I shall rather proceed to notice the curious habitats of some of the parasitic species.

Although a number of the parasitic crustaceans found on fishes are not confined to one particular kind of fish, such, for example, as Caligus rapax, - a species which seems to have a kind of "roving commission," - the habitat of many of them is limited to a particular kind of fish, and sometimes even to a particular part of the fish. This is well shown in the case of Lerneopoda bidiscalis, de Vismis Kane. This parasitic copepod has hitherto only been found adhering to the ends of the claspers of male specimens of the tope (or toper), - a large kind of dog-fish. The ends of the claspers, where these parasites adhere, are frequently lacerated and bleeding. Whether the laceration is caused directly by the parasite, or by the efforts of the fish to shake off its tormentors, is not known. The Lernocenicus sprattoe (Sowerby), found on the eye of the sprat, is another interesting example of limited distribution, for not only is the species confined to the sprat, but it is also confined to the eye of the fish. Another species of the same genus is found on the eye of the herring, and a Lerneopoda on the eye of the Greenland shark. The head of the Lernoenicus, which is buried deep in the substance of the eye, 
is furnished with two divergent barbs, one on each side of the head, so that the head cannot be removed without dissecting the eye. The presence of the parasite probably causes the eye to become blind. In illustration of this, on one occasion my son tried to catch a sprat-one of a number which had made their way into one of the Leith Docks. This particular sprat had a parasite on one of its eyes, and its would-be captor managed to get his hand almost within touch of the fish on that side on which the parasite was attached, apparently without being noticed, and was about to grasp it, when it turned round, and, seeing him, made off like a flash of lightning.

Nicothoë astaci furnishes a most interesting example of limited distribution. This copepod, so frequent on the gills of the common lobster, is apparently found nowhere else, at least in its adult stage; and it is somewhat strange that, though the parasite is so frequent, there are so few published records of its occurrence. Indeed, I know of no Scottish records of Nicothö̈ except those I have myself published. I seldom fail to find the parasite on lobsters that have not cast their shells for some time previously. Though comparatively a small species, this parasite is of interest from the two great wing-like lateral expansions of the posterior part of the thorax. These expansions appear to be the result of an extraordinary development of the fourth thoracic segment. The ovisacs are also large, and, with the lateral expansions, give to the species, which otherwise is not unlike some of our common Harpactids, an appearance unusual among copepods. Adult specimens of the parasite are extremely inactive, and if removed from the lobster's gills and placed in sea-water, they make no apparent effort to change their position. The only evidences that they are alive are the peristaltic movement of the intestine and the persistence of their semi-transparent pinkish colour. Speaking of their sluggishness, Milne-Edwards - quoted by Dr Baird-states that they allowed themselves to be torn to pieces without making the least movement or quitting their hold. But they also seem to be tenacious of life, for my son removed several specimens from a lobster's gills and placed them in sea-water, where they continued to live for at least five weeks. 
A copepod is found on the hake (Merlucius merluccius) which differs from many others in the mode of its attachment. This species, instead of fixing itself to some vital part of the fish, such as the gills, sends out a process which penetrates one of the scales, and expands between the outer and inner surfaces of the scale into a thin round disc, which is ornamented with several clear narrow slits arranged like the radii of a circle: it is from this latter peculiarity that the species derives its name of Anchorella stellata. It is scarcely possible to remove the copepod without also removing the scale along with it. All the specimens I have hitherto noticed have been attached to scales in the neighbourhood of the pectoral and ventral fins, especially the former. The first specimens observed looked like globules of semi-transparent mucus, but finding that the globules were somehow fixed, I was led to examine them more closely, and so was enabled to add another species to the copepod fauna of our seas. I have so far only found this parasite on hake sent from the Clyde, but it is likely to occur on the same fish from other parts of our coast. It is interesting to note that Kröyer, who first described the species, obtained his specimens also from the hake.

Another parasitic crustacean, remarkable because of its size and from the position in which it is found, is the large Charopinus dalmanni of Retzius. This species is usually found in the spiracles of the grey skate (Raia batis), and adult female specimens attain a length of fully two inches. I have sometimes found the parasite in both the spiracles of the same skate, and frequently two, and occasionally three, specimens in the one spiracle. The species is not uncommon on large grey skate brought to the Aberdeen fish-market, and it has also been obtained on a grey skate captured at the mouth of the Forth estuary. Two other species of Charopinus have been recorded-viz., C. ramosus, Kröyer, found on Raia clavata and Raia maculata, and C. dubius, found on Raia circularis; but these two species are usually found on the gills of the different skates, instead of in the spiracles.

Two parasitic copepods belonging not only to two different genera but also to two different families have been found on the gills of the spotted dragonet (Callionymus maculatus). The one is called Homobaphes ambigurs, and belongs to the 
family Lernæidæ; while the other is Chondracanthus ornatus, and is a member of the family Chondracanthidæ. Usually only one specimen belonging to one or other of the two species is found on the one fish, but sometimes two, and even three, specimens are obtained on the same fish, and in that case they may both belong to the same species, or both species may be represented. For example, one of the fishes examined had a Chondracanthus on one side of the head and a Homobaphes on the other; another specimen had a Chondracanthus and a Homobaphes on the same side; while a third had two Chondracanthi, both being on the same side. A sample of fiftyfive fishes yielded twenty-three parasites, and comprised fifteen Homobaphes and eight Chondracanthi. Both species were undescribed. Though the parasites are moderately large, it is difficult to make out, without dissection, whether they are present or not; and probably it is on account of this, and because the spotted dragonet is a fish that is not very common, that these parasites were not sooner observed.

The fish parasites referred to in the preceding notes differ greatly in their sexual forms, for while the females are comparatively large the males are usually very small, and, moreover, the females in their adult stage are fixed to their host for life, though the males are to some extent free, and may therefore be found adhering to different parts of the body or appendages of the female. Notwithstanding this difference in the adult stage of the female and male, the female in its earliest stage is also usually a free-living organism. During this early stage in the life of these parasites, the difference between the species, or at least between some of them, is scarcely, if at all, recognisable; and because of this close identity it has been suggested that the changes observed in their adult forms, and which have led to their separation into distinct species and genera, are simply the result of the difference in their host, or the particular part of the host to which they have fixed themselves. Take, for example, the Lernoea branchialis, so frequently found on the gills of whiting, cod, and other Gadoids, and which has the appearance of a red worm twisted round upon itself. The Lernoca when young is a free-swimmer, and should therefore be able to attach itself to any fish that happens to come in its way, 
and for that matter, to any part of the fish; but the adult is never found anywhere except on the gills of the fish, and usually on the gills of a Gadoid. It may be that only those young Lernæa that happen to attach themselves to the gills are able to survive and reach the adult stage, while those which become fixed to other parts, finding an environment unsuited to the kind of life they have to live, and food differing from that which they require, necessarily perish. But only a knowledge of the life-histories of these parasites will throw light on some of the difficulties that have been alluded to.

Though the examples of restricted distribution I have referred to are no doubt interesting, the next example I would mention seems to me to be still more remarkable, and a reference to it will, for the present, conclude these observations. It is the occurrence of what appear to be free-living copepods in the nostrils of the cod and of some other teleostean fishes. My attention was first directed to this peculiar habitat by observing a whitish coloured object close to the outer edge of one of the nostrils of a lumpsucker (Cyclopterus lumpus). This whitish object, on being carefully examined, proved to be a Bomolochus, apparently identical with Bomolochus solece, Claus, so named from its having been taken by Claus on the back of the common sole (Solea vulgaris). But though the Bomolochus happened to be first noticed in the nostrils of the lumpsucker, it did not appear, from subsequent examination, to be very common on that fish. I was, however, not a little surprised to find that the lumpsucker was not the only fish that harboured copepods in its nostrils, but that they were also present in the nostrils of other kinds, and especially in those of the cod-fish. I have examined a considerable number of cod-fish since the copepods were first observed, and find that they are moderately common in the nostrils of that fish. My son has obtained them in the nostrils of cod captured in the Irish Sea; and $\mathrm{Mr}$ Lindsay has also found them in the nostrils of cod he examined, and which were caught near the Isle of May. Bomolochus solece has now been found in the nostrils of at least six other kinds of fishes besides the lumpsucker and the cod-viz., the haddock, whiting, saithe (or coal-fish), ling, plaice, and flounder, 
and probably also in the nostrils of the lythe (or pollack). In view of the frequent occurrence of these copepods in the nostrils of the cod, it is somewhat curious that they should have been so long overlooked. As many as twenty-nine specimens have been obtained in the nostrils of a single codfish, and these comprised males, females (with ovisacs), and young in various stages of development. These copepods do not seem to be true parasites, but should perhaps rather be called commensals, as they appear to live on the mucus which the nasal fossæ usually contain. Should the copepods, while they are alive, be removed from the nostrils of the fish and placed in sea-water, they will be seen to swim quite freely, which seems to indicate that their habitat in the nostrils of fishes is not compulsory, but that they live there from choice, and find in the nasal fossæ both food and shelter. Two other, and apparently undescribed, species of Bomolochus have been recently obtained, and are described in Part III. of the latest Report of the Fishery Board. One of them, $B$. onosi, was obtained on the inside of the gill-covers of a five-bearded rockling from the Firth of Forth; while the other, B. zeugopteri, was found adhering to the back of a specimen of Müller's topknot (Zeugopterus punctatus) from the Firth of Clyde.

In mentioning these parasitic copepods I have merely touched the fringe of a most interesting part of the subject of distribution-a part the study of which may yet yield important results to those who have time to take it up. 

$=$ 



[Extracted from the Linnean Sociery's JounnaL-Zoologx, vol. xxix.]

Notes on some Copepoda from the Faroe Channel. By Thomas Scotт, LL.D., F.L.S.

(Plates 1-3.)

IT sometimes happens, during marine investigations, that pieces of water-logged and partly-decayed wood are brought up in the dredge or trawl-net. These pieces of wood, if carefully examined, will not infrequently be found to harbour rare, and sometimes undescribed, species of Entomostraca. In such pieces of wood dredged in the Clyde, the Firth of Forth, and elsewhere I have obtained the somewhat rare ostracod Cytheropteron humile, Brady \& Norman, in considerable numbers; and my son, Mr. Andrew Scott, has found the same ostracod in similar pieces of wood from Barrow Chaunel, Lancashire*. This ostracod was described in 1889 \%, and at that time the Clyde near Greenock, and Vigo Bay, Spain, were the only two places where it was known to have been obtained. Moreover, it is in such pieces of wood, and often associated with the ostracod named, that I usually find the curious copepod Laophonte simulans, T. Scott $\ddagger$. The Copepoda recorded in the following notes were, like the two species just referred to, obtained from

* Trans. Liverpool Biol. Soc. vol. xv. (1901) p. 348.

† "Mon. Marine and F.-W. Ostrac.," by Prof. G. S. Brady and Rev. A. M. Norman (Trans. Roy. Dublin Soc. yol. iy. s. II. p. 219, pl. 20. figs. 4-7). $\ddagger 15$ th Ann. Rep. Fishery Board for Scotland, part iii. (1897) p. 151. 
a piece of wood dredged from about 87 fathoms in the Faroe Channel; the wood was perforated to a considerable extent by the boring mollusk, Xylophaga dorsalis, Turton. Seven species of Copepoda, each representing a separate genus, and all belonging to the Harpacticidæ, were obtained in this piece of wood; three of the species appear to be undescribed, but the others are all more or less widely distributed.

The drawings which illustrate these notes were made a few years ago by my son, Mr. Andrew Scott, but shortly afterwards were mislaid and have only recently been recovered.

\section{COPEPODA.}

\section{HARPACTICIDE.}

Zosrme, Boeck, 1872 *.

Zosime trpica, Boeck.

This species, which is somewhat widely distributed, was represented by very few specimens.

\section{Pseudotachidius, T. Scott, 1898 †.}

The genus Pseudotachidius was instituted in 1898 for an interesting copepod discovered in the deep water at the mouth of Loch Fyne, and as there was but one species known at the time, the generic description was included in that of the species; but as another copepod has been found belonging apparently to the same generic type, it will be better now to give a separate definition of the genus.

\section{Definition of the Genus Pseudotachidius, T. Scott.}

Cephalothorax moderately broad, somewhat depressed; abdomen moderately narrow, more or less distinct from the cephalothorax. Antennules short, five- or six-jointed. Antennæ with secondary branches well developed and composed of three joints. Mandibles nearly as in Tachidius, Lilljeborg, and with a moderately developed two-branched palp. Other mouth-organs also similar to those of Tachidius. Both branches of the first four pairs of thoracic feet three-jointed, inner branches of first pair

* Mon. British Copepoda, Brady, vol. ii. p. 14 (1880).

$\dagger 16$ th Ann. Rep. Fishery Board for Scotland, part iii. p. 267 (1898). 
non-prehensile. Fifth pair small, composed of two joints ; basal joints usually not greatly developed; secondary joints usually small, but quite distinct.

Remarks.-This genus appears to be more nearly related to Tachidius than to any of the other allied genera, but it differs distinctly in the structure of the secondary branches of the antennæ and of the fifth pair of thoracic feet. Moreover, though it might be included in the subfamily Tachidiince, Boeck, with as much propriety as the genus Robertsonia, G. S. Brady, which has the fifth pair also composed of two joints, I prefer meanwhile, till we know more about the structure of the male, to regard Pseudotachidius simply as a member of the Harpacticidæ.

Pseddotachidids similis, sp. n. (Pl. 1. figs. 1-8.)

Description of the female.-Length about $\cdot 8 \mathrm{~mm}$. ( $\frac{1}{30}$ of an inch). The body is moderately robust and, when seen from above, is subcylindrical, but tapering slightly towards the posterior end; the rostrum is moderately broad and rounded (fig. 1).

The antennules are short and stout, and composed of five joints, but the fourth joint is very small (fig. 2); they are each provided with numerous plumose setæ, and a short and stout sensory filament springs from the distal end of the third joint, as shown in the figure.

The antennæ (fig. 3) are somewhat similar in structure to those of Pseudotachidius coronatus, T. Scott; but there is some difference of the armature, especially of the primary branches, the terminal spines of which are stouter than in that species.

The mandibles (fig. 4) are moderately stout, the biting-edge in each is subtruncate and armed with several small teeth: The basal joint of the palp is somewhat dilated and provided with two small setiferous branches; the upper branch is composed of one and the lower of two joints, as shown in the drawing. The mandibles and other mouth-organs resemble the organs corresponding to them in Pseudotachidius coronatus.

The first four pairs of thoracic feet have both branches threejointed. In the first pair the second basal joints are each provided with a stout setiferous spine on both its outer and inner aspects; both branches of this pair, as well as the marginal spines of the outer branches, are also setiferous (fig. 6). The inuer branches are scarcely so long as the outer ones, whereas 
in the first pair in Pseudotachidius coronatus the inner are longer than the outer branches.

The second, third, and fourth pairs are somewhat similar to the same appendages in Pseudotachidius coronatus; figure 7 represents the fourth pair, and the second and third do not appear to differ very greatly from this.

The fifth pair also resembles the fifth pair of the species referred to, but the armature is somewhat different, and there appears to be no distinct secondary joint (fig. 8).

The furcal joints are very short.

No males were observed.

Remarks. - The species just described may be distinguished from Pseudotachidius coronatus, T. Scott, the only other member of the genus, by the difference in the structure of the antennules, by the inner branches of the first pair of thoracic feet being not longer than the outer branches, and by the difference in the armature of the fifth pair.

This was one of the rarest of the copepods obtained from the piece of wood already referred to, and only a single specimen *as observed.

\section{Cervinia (Norman, MSS.), Brady, 1878 *.}

Cervinia Bradyi (Norman, MSS.), Brady, loc. cit.; Giesbrecht, Mitth. a. d. Zool. Stat. zu Neapel, vol. xiv. pt. 1, p. 58 (1900).

We owe the discovery of this interesting species to the Rev. A. M. Norman, who captured three specimens at Oban in July 1877, while dredging there $\uparrow$. Cervinia Bradyi appears to be a scarce species, for although, subsequent to its discovery at Oban, it has been found in a few other places in Britain, it has never occurred but in single, or at most few, specimens at one time. This, like the last, was rare in the material washed from the perforated wood.

\section{LaOpHonte, Philippi, 1840 †.}

LAOPHONTE FARöENsis, sp.n. (Pl.1. figs. 9-14; Pl.2.figs.1-8.)

Description of the female. - The length of the specimen represented by the drawing is $.77 \mathrm{~mm}$. (about $\frac{1}{32}$ of an inch); it

* Mon. British Copepoda, G. S. Brady, vol. i. p. 85 (1878).

† Ibid. p. 86, pl. xxiv A. figs. 3-13.

$\ddagger$ Ibid. vol, ii, p. 78 (1880). 
somewhat resembles Laophonte curticauda, Boeck, in general appearance, except that the second segment of the abdomen is rather wider than the segment which precedes it, and also than those which follow (Pl. 1. fig. 9).

The rostrum, which is moderately broad, is bluntly rounded at the apex, and scarcely reaches to the end of the first joint of the antennules.

The antennules are about as long as the cephalothoracic segment, seven-jointed, and moderately setiferous; the first three joints are subequal, and together are equal to fully one and a half times the entire length of the remaining four joints; the fourth and fifth joints are rather shorter than the sixth and seventh, and the fourth is furnished with a sensory filament (Pl. 2. fig. 1).

The penultimate joints of the antennæ are each provided with a small uniarticulate secondary appendage which bears a few plumose setæ (Pl. 2. fig. 2).

The mandibles (Pl. 2. fig. 3) are of moderate size, but the palp is very small and uniarticulate.

The other mouth-organs resemble those of Laophonte curticauda, but the second maxillipeds (Pl. 1. fig. 11) are proportionally rather stouter.

The first pair of thoracic feet are somewhat similar to those of the same species, but the joints of the outer branches are subequal in length (Pl. 1. fig. 12). The second, third, and fourth pairs have the inner branches short and two-jointed, the first joints being small ; the outer branches are moderately elongatc $d$. The drawing (Pl. 2. fig. 4) represents the fourth pair.

In the fifth pair, which are foliaceous, the basal joints have a somewbat triangular outline, but the inner portion is produced so as to reach to near the middle of the secondary joints; the inner margin of the produced part is provided with apparently three moderately stout setæ in addition to a small seta at the apex. The secondary joints are subcylindrical; they are fully twice as long as broad, and are each furnished with about five small setæ on the distal half of the outer margin and apex, as shown in the drawing (Pl.2. fig. 5).

The furcal joints are about as long as the last abdominal segment.

The male appears to differ very little from the female, except in the following particulars:- Whe antennules, as shown in the 
drawing (Pl. 2. fig. 6), are modified for grasping; the first two joints are moderately stout, the third is very small, while the fourth is considerably dilated; the remaining joints, which are small and hinged to the fourth, form together a kind of movable claw. The inner branches of the third pair of thoracic feet appear to be three-jointed (Pl. 2. fig. 7); the end joint, which is small and somewhat indistinct, is furnished with four terminal plumose setæ of variable lengths, while the distal end of the second joint is produced into a moderately stout hook-like process; the outer branches are not only proportionally more robust, but are also provided with rather stouter spines than the same pair in the female.

The outer branches of the fourth pair are also more robust than the outer branches of the same pair in the female; the inner branches scarcely reach to the end of the first joint of the outer branches; they are composed of two joints, but the end joint is about twice the length of the other, and bears a long spine-like seta on its outer distal angle, and four moderately long plumose setæ-two at the apex and two on the inner margin, as shown in the drawing (Pl. 1. fig. 13).

The fifth pair (Pl. 1. fig. 14) are very small; the basal joint is not produced interiorly, and is provided with a single plumose seta; the secondary joint is subcylindrical, but somewhat wider at the distal end, and provided with about four apical setæ.

This species, like most of the others, was a moderately rare one in the material washed from the perforated wood; it seems to differ from any Laophonte known to me.

\section{Cletodes, Brady, $1872 *$}

\section{Clettodes armata, sp. n. (Pl. 3. figs. 4-14.)}

Description of the female represented by the drawing (fig. 4) :Length about 1.5 (fully $\frac{1}{16}$ of an inch); seen from above the body is elongated and subcylindrical; the cephalic segment is somewhat longer than the next two taken together, the second to the fifth segments are subequal in length. The first two segments of the abdomen appear to be coalescent, but the others are distinct. The thoracic and abdominal segments are all fringed with a few short and moderately stout spines, as shown in the drawing. The furcal joints are elongated and slender, being

* Mon. British Copepoda, vol. ii. p. 89 (1880). 
nearly as long as the abdomen. The forehead is somewhat angular and armed with a minute spine.

The antennules (Pl. 3. fig. 5) are moderately long and slender and composed of five joints ; the first three joints are short, but the other two are elongated and narrow, and a moderately long sensory filament springs from the end of the penultimate joint; the formula shows approximately the proportional lengths of the various joints :-

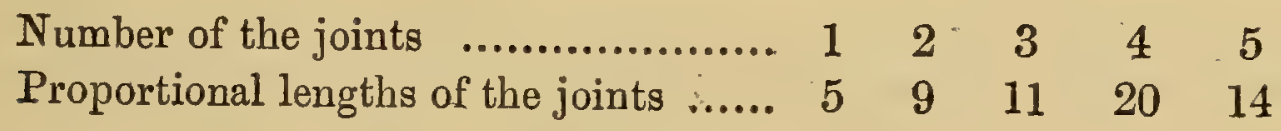

The antennæ, which are slender and of moderate length, are sparingly setiferous; the secondary branches appear to be entirely obsolete (Pl. 3. fig. 6).

The mandibles (Pl. 3. fig. 7) are stout, and have the biting-edge obliquely truncate and armed with several teeth; the mandiblepalp is small, and composed of a single uniarticulate branch.

The first pair of maxillipeds are each moderately stout and armed with a stout terminal claw, bearing a few small setæ, and also with two bisetose marginal papillæ (Pl. 3. fig. 8).

The second maxillipeds are also moderately stout, and the terminal claw is curved and somewhat slender and elongated (Pl. 3. fig. 9).

The thoracic feet are all moderately slender. In the first four pairs the outer branches are all composed of three and the inner of two joints. The first pair has the inner branches very short, they scarcely reach to the end of the second joint of the outer branches, and their first joint is almost obsolete, the second joint bears two small spiniform apical setæ; the outer branches are moderately elongate, and armed with long slender marginal and terminal spines, as shown in the drawing (Pl. 3. fig. 10). Both branches of the next three pairs are slender, the outer branches being more slender than those of the first pair; the first joints of the inner branches are very short, but the second is elongate, and the terminal setæ of both the inner and outer branches are considerably longer than the branches from which they spring ; figure 11 represents the fourth pair.

The fifth pair (Pl. 3. fig. 12) are small; the inner portion of the basal joint is produced into a moderately long and narrow appendage, which is furnished with four spiniform setæ on the apex and distal part of the inner margin; the outer portion of 
the basal joint extends into an elongate and slender process bearing a single seta at its extremity. The secondary joints are very narrow and reach to about the end of the inner produced part of the basal joints; they are each provided with two apical setæ-one long and one very short-and a small seta near the distal end of the outer margin (Pl. 3. fig. 12).

The male differs little from the female, except in the following particulars:-The antennules are modified as shown in the drawing (Pl. 3. fig. 13). The third pair of thoracic feet are furnished with a sigmoid appendage, which is moderately stout at the base, but tapers towards the extremity (fig. 14). The fifth pair of feet also differ slightly from those of the female.

The Cletodes just defined is distinctly different from any described species with which I am familiar; its slender form, elongated caudal furca, and the peculiar structure of the antennules distinguish it almost at a glance from allied species. Only a few specimens were obtained.

\section{DaCtrLopus, Claus, $1863 *$.}

Dactrlopus Strönit (Baird), var. fanöensis, var. n. (Pl. 2. figs. 9-14; Pl. 3. figs. 1-3.)

1837. Cyclops Strömii, Baird, Mag. Zool. \& Bot. vol. i. p. 330, t. 9. figs. 23-25.

1863. Dactylopus Strömii, Claus, Die frei-lebenden Copepoden, p. 126, t. 16. figs. 1-13.

Description of the female-Body moderately stout; rostrum short (Pl. 2. fig. 9). Length from the extremity of the rostrum to the end of the caudal furca about $1 \mathrm{~mm}$.

Antennules eight-jointed, somewhat similar in structure to those of Dactylopus Strömii; hut when compared with the description and figures given by Claus there appears to be a slight difference in the proportional lengths of the last four joints. Claus states that the fifth and seventh joints are sbort, and his figure shows them as being subequal; whereas in our specimen the fifth joint is short, the sixth and seventh subequal and longer than the fifth, while the last, which is longer than either of the three preceding joints, is about equal in length to

* Mon. British Copepoda, Brady, vol. ii. p. 105 (1880). 
the fourth (Pl. 2. fig. 10). The proportional lengths of the various joints are shown by the formula:-

$\begin{array}{lcccccccc}\text { Number of the joints .............. } & \mathbf{1} & \mathbf{2} & 3 & 4 & \mathbf{5} & \mathbf{6} & \mathbf{7} & 8 \\ \text { Proportional lengths of the joints. } & 16 & 14 & 10 & 13 & \mathbf{5} & \mathbf{7} & 8 & 13\end{array}$

The antennæ (second antennæ) are somewhat similar to those of Dactylopus Strömii.

The mandibles (Pl. 2. fig. 11) are also similar to those of the same species.

The second maxillipeds (second foot-jaws) are moderately stout; the first and second joints are each provided with two small setx, as shown in the drawing (Pl. 2. fig. 12). The terminal claw, which is nearly as long as the second joint, is only slightly curved, and furnished with a small lateral seta.

The first four pairs of thoracic feet are almost similar to those of Dactylopus Strömii (Pl. 2. fig. 13).

The fifth pair (Pl. 2. fig. 14) have a general resemblance to the same pair of feet in Dactylopus Strömii, but the armature of the basal joint and the form as well as the armature of secondary joint are different; the basal joint is furnished with about five terminal setæ, the two innermost of which are short and of nearly equal length, the next two are also subequal, but they are about twice the length of the others-all these four setæ are moderately stout; the fifth, which is close to the fourth, is comprratively small and slender. The secondary joint is broadly ovate and is provided with six setæ round the distal end; the innermost and the three outermost of these setæ are moderately stout and plumose, while the remaining two are slender and elongate.

The furcal joints are very short.

The male differs from the female in several particulars, the following of which appear to be the more obvious:-The antennules (anterior antennæ) are modified for grasping. The first joint of the inner branches of the first thoracic feet (Pl. 3. fig. 1) is shorter and proportionally much stouter than that of the inner branches of the first pair in the female. The end joint of the inner branches of the second pair of feet is prolonged into a stout and spiniform process, which extends beyond the end of the outer branches, and which bears one or two setæ, as well as an elongated slender filament (Pl. 3. fig. 2). The fifth pair 
are nearly similar in form and armature to those of the male of Dactylopus Strömii (Pl. 3. fig. 3).

Perhaps the Dactylopus just described ought to be regarded as a distinct species, because of the differences which characterize both sexes when compared with its nearest of kin, Dactylopus Strömii (Baird), but meanwhile I prefer to consider it merely as a variety of that species. A number of males and females were found.

$$
\text { IDYA, Philippi, } 1843 * \text {. }
$$

IDYA FURCATA (Baird).

This species was also washed from the piece of perforated wood dredged at Faroe, and is the last $\mathrm{I}$ have at present to record. Idya furcata appears to have an extensive distribution; it is a moderately common form around the British Islands, and it sometimes occurs in large numbers in the material washed from the filters at the Sea-fish Hatchery of the Fishery Board for Scotland; it has been obtained in gatherings of Copepoda from Franz-Josef Land and other places within the Arctic seas, and also in material collected by the aid of a ship's pump in the viciuity of Suez. Its occurrence near Faroe at a depth of over 80 fathoms is an indication that the species is not limited to iittoral or shallow-water conditions.

\section{EXPLANATION OF THE PLATES.}

\section{Prate 1.}

Pseudotachidius similis, sp. $\mathrm{n}$.

Fig. 1. Female, dorsal view. $\times 64$.

2. One of the antennules. $\times 190$.

3. One of the antennæ. $\times 190$.

4. One of the mandibles. $\times 300$.

5. One of the maxillæ. $\times 253$.

6. One of first pair of thoracic feet. $\times 253$.

7. One of fourth pair. $\times 253$.

8. Foot of fifth pair. $\times 253$.

Laophonte faröensis, sp. $\mathrm{n}$.

Fig. 9. Female, dorsal view. $\times 52$.

10. First maxilliped. $\times 500$.

11. Second maxilliped. $\times 300$.

* Mon. British Copepoda, Brady, vol. ii. p. 171 (1880). 
Fig. 12. Foot of first pair of thoracic feet. $\times 253$.

13. Foot of fourth pair (male). $\times 200$.

14. Foot of fifth pair (male). $\times 300$.

\section{Plate 2.}

Laophonte faröensis, ip. $\mathbf{n}$.

Fig. 1. One of the female antennules. $\times 300$.

2. One of the antennæ. $\times 253$.

3. One of the mandibles. $\times 253$.

4. Foot of fourth pair of thoracic feet. $\times 168$.

5. Foot of fifth pair. $\times 300$.

6. One of the male antennules. $\times 300$.

7. Foot of third pair of thoracic feet (male). $\times 200$

8. Appendage to first abdominal segment. $\times 380$.

\section{Dactylopus Strömii, var. faröensis, var. $\mathrm{n}$.}

Fig. 9. Female, lateral view. $\times 53$.

10. One of the antennules. $\times 168$.

11. One of the mandibles. $\times 252$.

12. Second maxilliped. $\times 300$.

13. Foot of first pair of thoracic feet. $\times 200$.

14. Foot of fifth pair. $\times 168$.

\section{Plate 3.}

Dactylopus Strömsii, var. faröensis, var. $\mathbf{n}$.

Fig. 1. Foot of first pair of thoracic feet (male). $\times 25 \%$.

2. Foot of second pair (male). $\times 252$.

3. Foot of fifth pair (male). $\times 252$.

\section{Cletodes àrmata, sp. $\mathrm{n}$.}

Fig. 4. Female, dorsal view. $\times 40$.

5. Antennule and portion of cephalothoracic segment. $\times 152$

6. One of the antennæ. $\times 190$.

7. One of the mandibles. $\times 252$.

8. One of the first maxillipeds. $\times 300$.

9. One of the second maxillipeds. $\times 380$.

10. Foot of first pair of thoracic feet. $\times 253$.

11. Foot of fourth pair. $\times 126$.

12. Foot of fifth pair. $\times 190$.

13. One of the male antennules. $\times 152$.

14. Foot of third pair of thoracic feet. $\times 190$. 



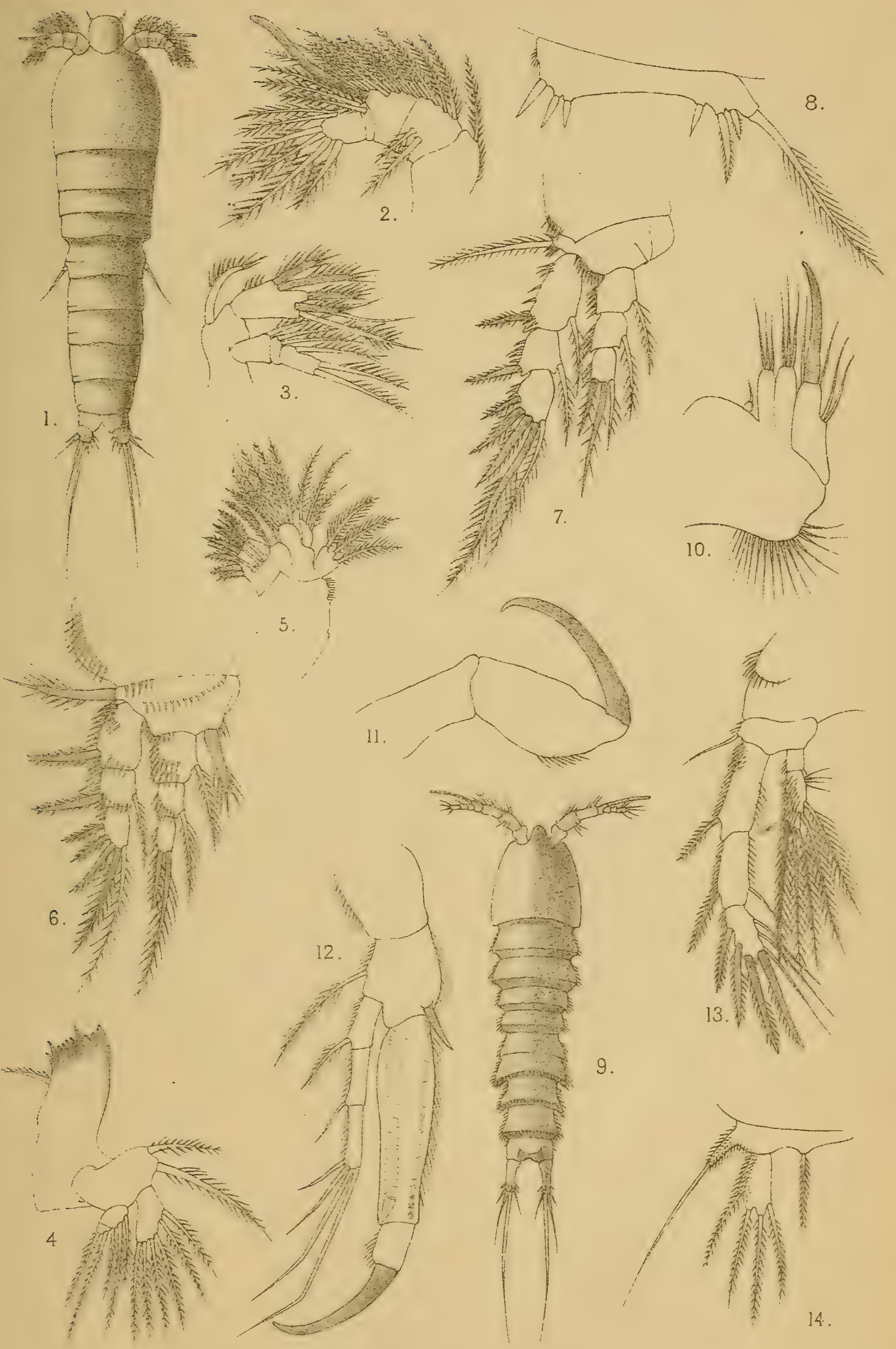




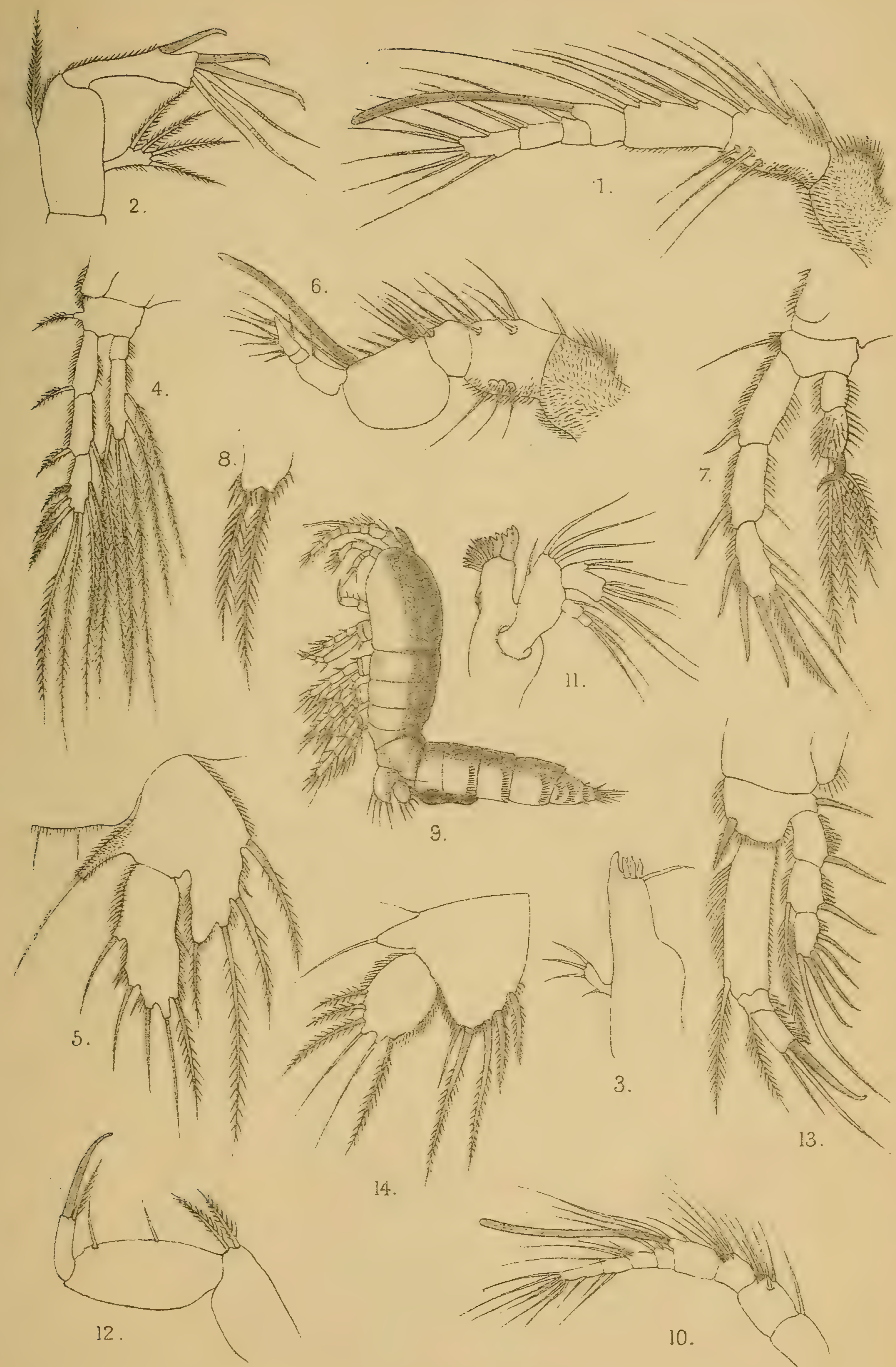

9.

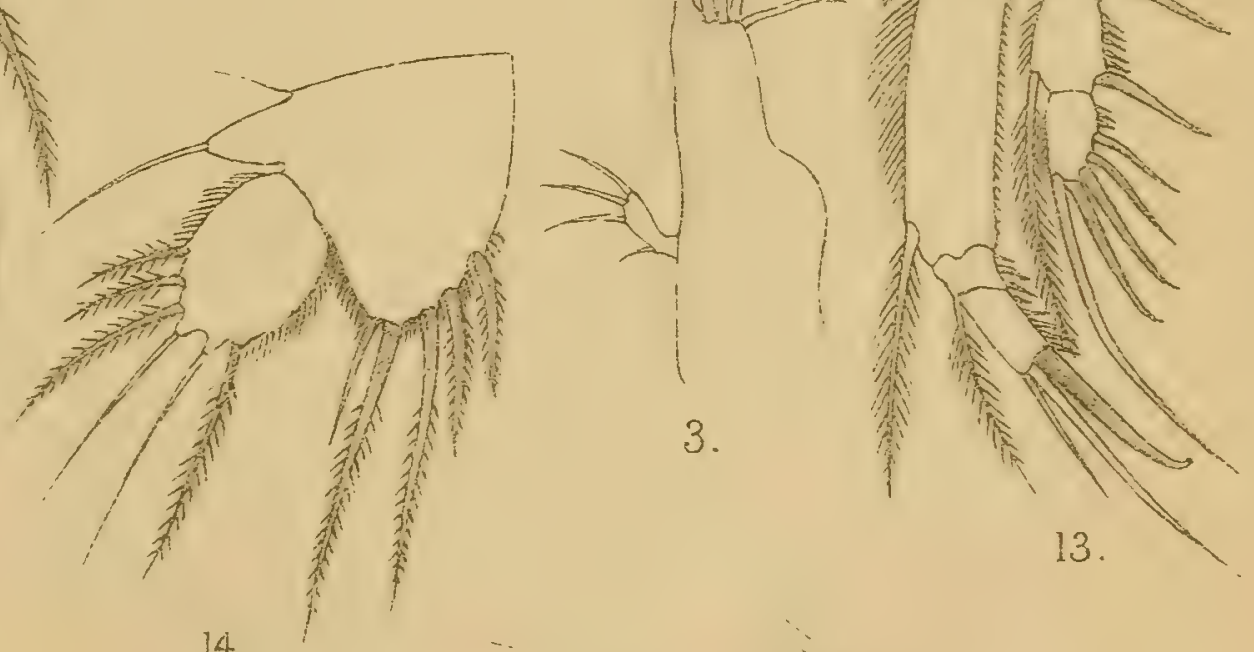

14.

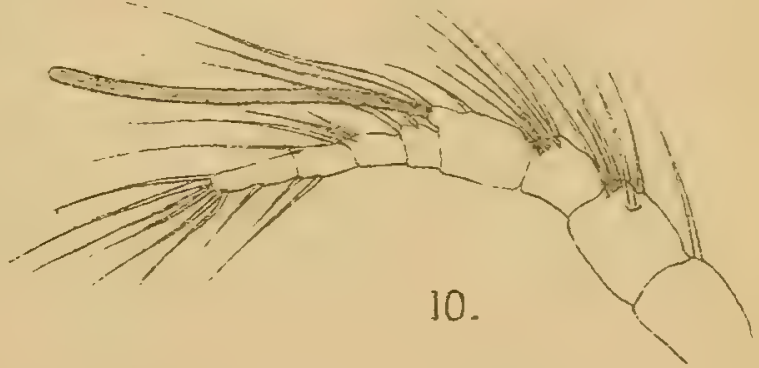

A. Scott, de1 



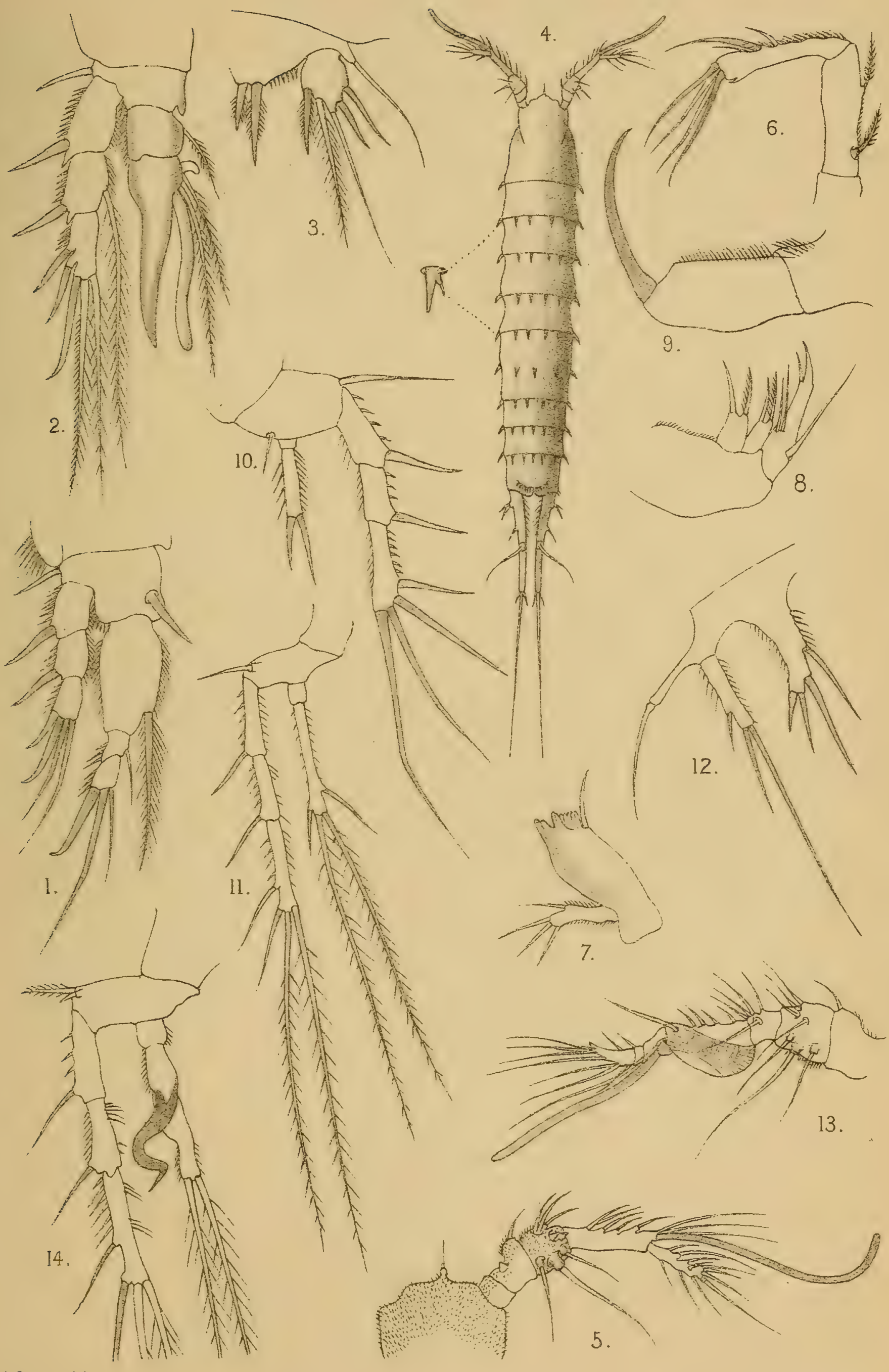







\section{PROCEEDINGS}

OF THE

\section{ROYAL SOCIETY OF EDINBURGH. SESSION 1904-1905.}

\section{VOL. XXV.-PART IX.}

A Report on the Free-Swimming Crustacea found in the Firth of Clyde, 1901 to 1902.

By Thomas Scott, LL.D., F.L.S., etc.

EII N U URG :

Published by ROBERT GRaNT \& SON, 107 Princes Street, ANd Williams \& NORGate, 14 Henrietta Street, Covent Garden, London. MDCCCCV. 

- 
A Report on the Free-Swimming Crustacea found in the Firth of Clyde, 1901 to 1902. By Thomas Scott, LL.D., F.L.S., etc. Communicated by Sir JoHn Murray; K.C.B., F.R.S.

(MS. received April 26, 1905. Read June 5, 1905.)

\section{INTRODUCTION.}

The material upon which this report is based was collected by Mr Alexander Gray, curator of the Biological Station at Millport. The tow-nettings were specially taken for Mr E. T. Browne, to aid his investigation of the Medusæ of the Firth of Clyde. After the material was examined by Mr Browne, all the Crustacea were forwarded to me for identification.

In 1902 most of the tow-nettings were taken off the Cumbrae Islands, within a limited area between the northern and southern extremities of the two islands.

The temperature of the sea, the mesh of net, etc., are given in Mr Browne's "Notes on the Pelagic Fauna" (pp. 781-782).

Notes on the Crustacea mentioned in the Table for 1901. TABLe I.

The collection examined in 1901 consisted of twenty-nine plankton samples. Seven of these samples were collected in April, ten in May, three in June, seven in July, one in August, and one in September. Moreover, seven were from the neighbourhood of Little Cumbrae; one was collected off Largs and off Loch Ranza; one in Lamlash Bay and in Inch Marnoch Sound, and also in Loch Striven and Loch Long; all the others were from the vicinity of Greater Cumbrae.

Seventeen species of the Crustacea observed in these samples belonged to the Copepoda, four to the Cladocera, and one each to the Isopoda and Amphipoda. Several groups of Crustacea were also represented in their larval or post-larval stages. 


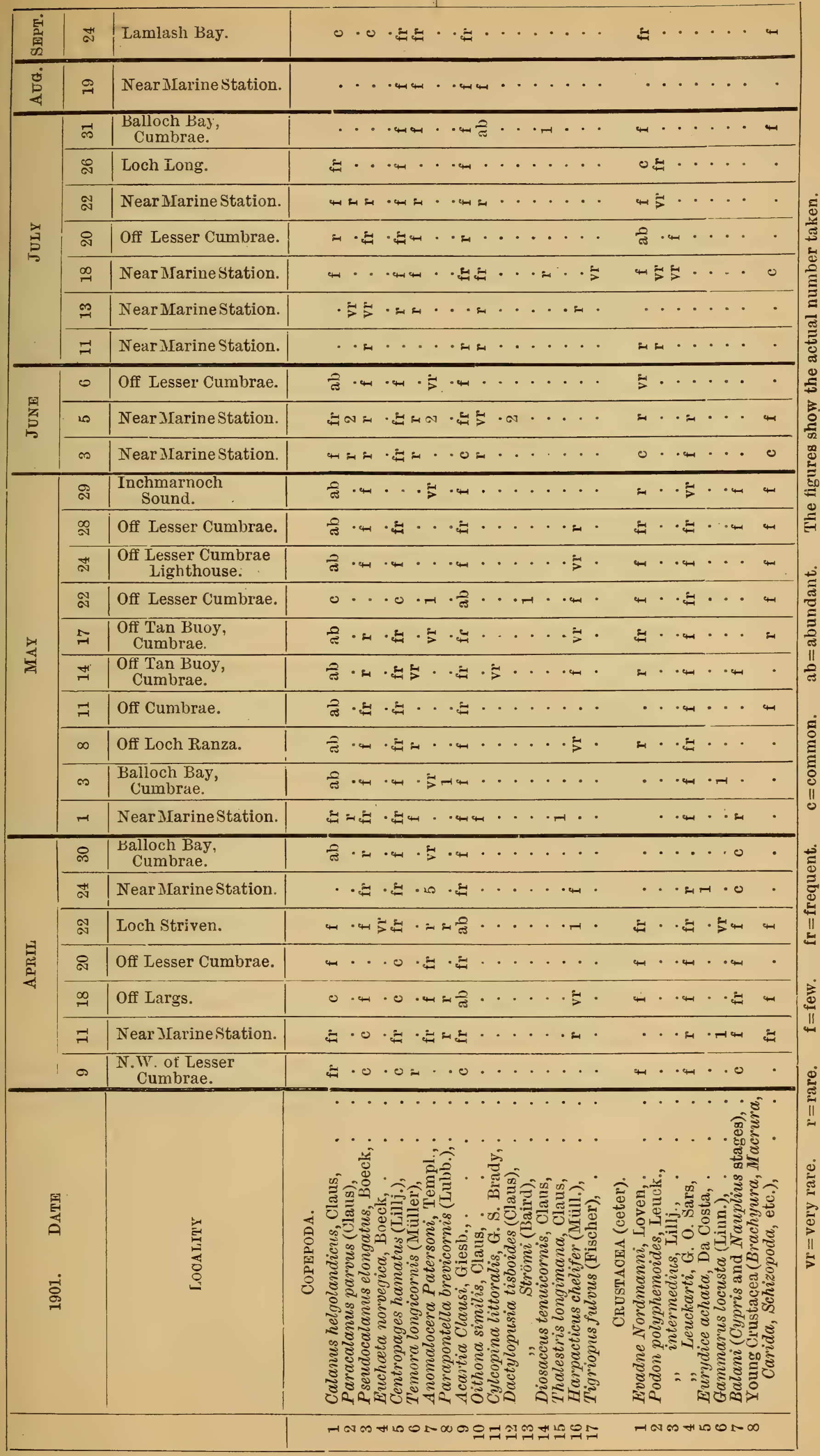




\section{Remarks on the Species. (1) The Copepoda.}

* Calanus helgolandicus, Claus.-The Calanus mentioned here is not the typical C. finmarchicus (Gunner), but the form described by Claus, which G. O. Sars considers to be specifically distinct. This form occurred in considerable numbers from the end of April to the first week in June, and also in September, but was only sparingly represented in the samples collected in July and August; indeed, in four of these samples this species appeared to be entirely absent.

Paracalanus parvus (Claus) was observed in five of the samples, but only a few specimens were obtained; these samples were all from the vicinity of the Marine Station.

Pseudocalanus elongatus, Boeck.-This Calanoid, though not so plentiful as the Calanus, was observed in nearly the same number of samples, and appeared to have a somewhat similar seasonal distribution.

Euchceta norvegica, Boeck, was only noticed in the sample from Loch Striven ; it is abundant in Loch Fyne, but usually near the bottom and in the deeper parts of the loch.

Centropages hamatus, Lilljeborg.-This species occurred in all the samples examined, save two; its seasonal distribution was somewhat similar to that of Calanus, being generally common or frequent from April till June, after which time it appeared to become scarcer.

Temora longicornis (Muiller), though sometimes occurring in considerable abundance, was only sparingly observed in the plankton samples under consideration, and its seasonal distribution appeared to be somewhat the reverse of that of the species already referred to. It was only noticed in four of the seventeen samples collected in April and May, and was only absent in three of the remaining twelve samples.

Anomalocera Patersoni, Templeton.-This species occurred more or less sparingly in twelve of the samples collected during April, May, and June, but was absent in all the others.

Parapontella brevicornis (Lubbock) was only noticed on four

* The names and classification of Prof. G. O. Sars' great work on "The Crustacea of Norway" are followed here. 
occasions-three times during April and once in May. Para. pontella brevicornis, though occasionally found in the open sea, is more truly a littoral species.

Acartia Clausi, Giesbrecht, was absent from only one of the samples examined in 1901 ; its seasonal distribution resembled that of Centropages hamatus, being more plentiful during April, and becoming subsequently rather scarcer.

Oithona similis, Claus, was observed only once during April and May, but occurred more frequently during the following months, and is recorded as abundant in the sample collected on 31st July, in Balloch Bay.

The following species were noticed only once or at most twice in the twenty-nine samples examined, and very few specimens at most were obtained. Cyclopina littoralis was only observed in the sample collected on 14th May. Dactylopusia tisboides in that collected on 5th June. Dactylopusia Strömi on 22nd May. Diosaccus tenuicornis was obtained in the two samples collected on 18th and 31st July. While Tigriopus fulvus, of which only one or two specimens were observed, occurred in the same sample with the Diosaccus. Another species, Harpucticus chelifer, closely allied to the one last mentioned, was observed in several of the samples collected during April and May, but only in one of those collected subsequently.

These Copepods are all more or less demersal in their habits, and therefore, though sometimes common in gatherings from the bottom, they are not often present in plankton collections.

\section{(2) The Cladocera.}

This suborder of the Crustacea was represented in the collection for 1901 by Evadne Nordmanni, and by three species of Podon, viz., $P$. polyphemoides, $P$. intermedius, and $P$. Leuckarti. The Evadne occurred in most of the samples examined, but appeared to be rather more frequent in those collected after the end of May. Podon polyphemoides and $P$. intermedius were only noticed in the samples collected in July; while P. Leuckarti, on the other hand, was present in all of those, save two that were collected during April, May, and June, but was absent in all the others; this seems 
to indicate a difference in the seasonal distribution of the species of Podon.

(3) The Isopoda.

Eurydice achata, Da Costa.-A single specimen of this Isopod was obtained in a plankton sample collected near the Marine Station on 24th April. This species, which is not uncommon in some parts of the Clyde estuary, is an active swimmer, and this may account to some extent for its absence in these gatherings.

\section{(4) The Amphipoda.}

Gammarus locusta (Lin.) was the only Amphipod observed, and it occurred in three of the earlier gatherings; it is a demersal species, and therefore its presence even in these three may have been accidental.

\section{(5) Larval and other Young Forms.}

Young Balani, especially in the Cypris stage, were moderately common in the samples collected in April, and they occurred, though only at intervals, up till the end of May, but after that time no more were observed.

Other young Crustacea, representing various groups, as the Brachyura, Macrura, Carida, Schizopoda, etc., were observed at more or less regular intervals throughout the summer, sometimes sparingly and at other times moderately common. They were present in all the samples collected from about the middle of May till the first week in June, but both before and after that time they were only occasionally observed.

It will be observed, from the remarks on the various species and also from the table (Table I.), that four of the Copepods have a distribution more or less continuous throughout the six months during which the collection was made; there is an apparent increase and decrease in the numbers of individuals captured belonging to each species, which may possibly be due to seasonal variation; this variation is, however, rather more marked in one or two of the species whose distribution is not so continuous as those specially referred to, as, for example, in Temora longicornis. 
Most, if not all, of the species mentioned in Table I. appear to be "residenters" within the Clyde estuary, for, though they may disappear for a time, their appearance or disappearance may only be the result of periodic reproduction. Species are occasionally observed, sometimes in considerable numbers, the presence of which can only be explained by their having been transported thither by tidal or other currents.

\section{Notes on the Crustacha observed in the Plankton Samples Collected during 1902. Table II.}

The Crustaceans observed in the plankton samples collected during 1902 comprised forty-nine species of Copepoda, four species of Cladocera, and two species of Ostracoda; while the Amphipoda were represented by six species, the Isopoda by two, and the Sympoda by three; and also young forms belonging to the Decapoda, the Cirripedia, and various other groups. A few of the species were of frequent or common occurrence, but a large proportion of them occurred very sparingly; while several were observed only once, or at most only a few times, during the year. The number of samples examined for 1902 amounted to sixty-eight.

In the following observations on the distribution of the various species, those belonging to the Copepoda, which are most numerously represented, will be noticed first, and the others in the order indicated above.

\section{Copepoda.}

An examination of the subjoined table (Table II.) shows, even more distinctly than the previous one (Table I.), that only certain species have a distribution more or less continuous throughout the year; and of those, Calanus helgolandicus, Pseudocalanus elongatus, and Acartia Clausi (Nos. 1, 3, and 17 on the table) are the most common.

The Calanus was observed in each of these sixty-eight samples; and on several occasions, from February till the end of June, it occurred in considerable abundance, but in the majority of the samples its numbers were more limited. Moreover, though it appeared to be scarcer in the samples collected in August 
than during the rest of the year, the difference was not very marked.

The distribution of Pseudocalanus, on the other hand, showed a fairly distinct variation in the larger numbers obtained during the earlier and later months of the year than during those of summer. It occurred in considerable numbers from January till the end of March; but after that the numbers became fewer, till about the beginning of September, when there was again a perceptible increase that continued till December.

The distribution of Acartia Clausi exhibited changes somewhat similar to those of the Pseudocalanus, but the changes were scarcely so well marked; it also appeared to become proportionally more plentiful from the end of August till the beginning of October than at any other time during the year.

Paracalanus parvus (No. 2 in the table).-This species was present in every sample from January till about the middle of April, but from that time till the beginning of July it was only observed once, and for the remainder of the year its appearance was more or less irregular.

Centropages hamatus (No. 9).- - This species, in curious contrast to the Paracalanus, was observed in none of the samples till about the middle of March; but after that time it occurred, though at first very sparingly, in nearly every sample collected, till about the middle of November, when no more specimens were noticed.

The distribution of Temora longicornis (No. 11) was somewhat similar to that of the Centropages. Like that species, it appeared to be entirely absent during the early part of the year: It was noticed for the first time in the sample collected on the 19th of March; but thereafter it occurred at intervals, and for the most part very sparingly, till near the end of June it then occurred more regularly, though still in limited numbers, till the beginning of October, when it became more scarce and intermittent in its appearance.

The only other species present more or less throughout the year was Oithona similis (No. 18), and its distribution was somewhat similar to that of Acartia, except that it was absent in nearly all the samples collected in April, and in half of those collected in May and June. 
Among the various Crustacean species observed in 1902, the seven just referred to were by far the most numerous, and constituted almost the whole of the contents of several of the gatherings in that year.

The majority of the other species mentioned in the table are, for the most part, demersal in their habits, and this may explain to some extent their rare occurrence in the collections.

Stephos Scotti, G. O. Sars (No. 4), was only observed in a sample collected in January. It was at first ascribed to Stephos gyrans (Giesbrecht), but was afterwards shown to be a new species. S. Scotti, though not very common, appears to have a fairly wide distribution, and is one of the species found in Norway by Professor G. O. Sars.*

Undinopsis bradyi, G. O. Sars (No. 5).-This species, which occurred on several occasions, may be found in the Clyde at nearly all seasons, though usually not very plentiful. It is a species that has had various names, i.e., Pseudocalanus armatus, Bradyidius armatus, and now Undinopsis bradyi. $\dagger$

Euchoeta norvegica (No. 6).- - This species was observed in only one of the samples under consideration. It is abundant in the deep water of Upper Loch Fyne.

Diaixus hibernicus (A. Scott), (No.7), was noticed several times during the year. It is a deep-water species, and is moderately frequent in Upper Loch Fyne. It has been found in other parts of the British seas, and is also represented in the marine fauna of Norway. $\ddagger$

Diaixus pygmoeus (No. 8) is a smaller species than the last, and is also a moderately rare form. It has not yet been recorded outside of the British islands.

Isias clavipes (No. 10) is also a comparatively rare species in the Clyde. It was only observed in one or two samples collected late in the autumn.

Metridia lucens, Boeck (No. 12), though observed very sparingly in the present collections, is widely and generally distributed throughout the British seas.

\footnotetext{
* Crustacea of Norway, by G. O. Sars, vol. iv. p. 63, pl. xliii. (1903).

† Op. cit., p. 32, pls. xix. and xx.

$\ddagger$ op.cit。, p. 59, pls. $x \times x i x$ 。 and $x l$.
} 
Candacia armata, Boeck (No. 13).-This species was observed for the first time early in February, when a single specimen was obtained, and it did not occur again till September, but after that it was noticed at odd times till near the end of the year. As stated by the late I. C. Thompson, in his remarks on the Copepoda of Valencia Harbour, ${ }^{*}$ this species, though widely distributed, is "generally rare in our seas," and appears to some extent to be affected by seasonal influences.

Labidocera Wollastoni (No. 14) is a moderately rare species in the Clyde. It was represented in the collection by only two specimens, which occurred in a gathering collected at the end of October.

Anomalocera Patersoni (No. 15).- - This species is widely, but at times not very regularly, distributed. Sometimes it occurs sparingly, and at other times it may be the most common form in the gathering. In the present collection there was no trace of it till September, and from that time onwards no more specimens were noticed.

Parapontella brevicornis (No. 16).-This species occurred very sparingly towards the end of April, and again in September, October, and November.

Cyclopina littoralis and C. gracilis (19 and 20). - These two species are demersal in their habits, and therefore, though frequent in gatherings made with the dredge, they are only occasionally taken with the tow-net.

Longipedia Scotti and L. minor (21 and 22) are also demersal forms of frequent occurrence, especially the former (21). Till recently, this species has been recorded under the name of Longipedia coronata, Claus; but Prof. G. O. Sars has shown that this common British form is not the species described by Dr Claus, and he has therefore renamed it as above. $\uparrow$

Microsetella norvegica (No. 23) [Microsetella (or Ectinosoma) atlantica, Brady and Robertson]. This minute species was obtained in a sample collected about the end of January, and this was the

* "The Fauna and Flora of Valencia Harbour," Proc. Roy. Irish Acad., 3rd ser., vol. .. No. 5 (1899).

+ Crustacea of Norway, vol. v., Copepoda Harpacticoida, parts 1 and 2, pp. 10, 11 (Jan. 1904). 
only time it was observed. It differs from its nearest allies in being truly pelagic in its habits, and is at times moderately common in the open sea.

Tegastes falcuta, Norman (No. 24), is the species that has frequently been described as Amymone sphcerica, Claus; but Rev. Canon Norman has shown, ${ }^{*}$ however, that the generic name Amymone is preoccupied, and that the species is his Amymone falcata, described in 1868. $\dagger$ A single specimen of this curious form was observed in a plankton sample collected on 9 th December.

Ameira longicaudata

Laophonte horrida

Diosaccus tenuicornis

$\ddagger$ Dactylopusia tisboides

$\begin{array}{ll},, & \text { Strömi } \\ ,, & \text { similis } \\ ,, & \text { breviconnis }\end{array}$

These are all demersal in their habits, and are therefore more frequently obtained by the dredge than the tow-net. They only occurred at a few odd times throughout the year.

The three species of Thalestris, as well as the Harpacticus and Westwooria mentioned in Table II. (Nos. 32-38), are all of them bottom forms, and are more or less frequent amongst the roots of Algæ and Zoophytes within the laminarian and littoral zones. They are all very sparingly represented in the present collection.

Tigriopus (Harpacticus) fulvus (Fischer) and Porcellidium fimbriatum, Claus, are each represented in the collection by a single specimen. The Tigriopus was observed in one of the December gatherings, and the Porcellidium in one of those collected in October. The first is sometimes not uncommon in shore pools even above high-water mark, and the other is frequent on the fronds of Laminaria and other sea-weeds, on the surface of which it can run quickly and adhere firmly when alarmed.

Tisbe (or Idya) furcata, longicornis, cluthoe and minor, though not so free swimmers as some of the Calanoids, they all appear to have, to a certain extent, adopted pelagic habits, as they are frequently found in tow-net gatherings collected near the bottom. Tisbe cluthce, which has only hitherto been observed in such

* Ann. and Mag. Nat. Hist. (7), vol. xi. p. 368 (April 1903).

+ Brit. Assoc. Report for 1868 (pub. 1869), p. 296.

¥ Canon Norman points out (Ann. and Mag., April 1893) that, as Dactylopus is preoccupied, he has substituted Dactylopusia for it.

PROC. ROY. SOC. EDIN.-VOL. XXV. 
gatherings, was first noticed in a deep-water sample from Upper Loch Fyne.

Thaumaleus rigidus and Monstrilla longicornis (45 and 46) belong to a somewhat remarkable group of Copepoda, and were first made known to science by the late Mr I. C. Thompson of Liverpool. The life history of the species belonging to this group does not yet appear to be very well known, but it is generally considered that they are parasitic-at least, at some stage of their life. The first of the two species mentioned here was observed only twice, and the other once during the whole year.

'The next two species, 47 and 48 , belong to a family on which an interesting and elaborate monograph has been published by Dr Giesbrecht of Naples. Nearly all the members of this family appear to live as commensals with other organisms, several being found living in the water passages of various sponges. The two mentioned in the table were only noticed in samples collected in December. They appear to live about the roots of sea-weeds.

Caligus rapax (49) was noticed on two occasions, once in October and once in November. It is the only species of a group of fish parasites which adopts, to a large extent, the free-swimming habits of the pelagic Copepoda; and though numerous examples may be found running over the skin of large Gadoids, the species is also of frequent occurrence in tow-net gatherings collected in the open sea.

\section{Remarks on the Species enumerated in Table III.}

In the preceding notes, the Copepoda only are referred to, but, as previously stated, species belonging to various other groups of Crustacea were also observed; these are recorded in Table III. They were, however, with a few exceptions, very seldom noticed, and chiefly towards the end of the year. Four species of Cladocera, viz., Evadne Nordmanni and Podon polyphemoides, intermedius, and Leuckarti were moderately frequent, so also were some larval and young forms. The first two species occurred more commonly in July, August, and September, while the third was more frequent in the latter month than at any other time during the year. Podon Leuctiarti, on the other hand, occurred sparingly from March till near the end of July. Larval Balani were, with one or two 
exceptions, observed only in April and May; but young Decapoda appeared to be more generally distributed. One other point of interest in connection with the distribution of the larval forms is that minute organisms, generally known by the name of Microniscus, which at times are found adhering to Calanus, Pseudocalanus, and other free-swimming Copepods, were sparingly observed during the first three and the last three months of the year.

These Micronisci are now considered to be the larvæ of parasitic Isopoda which live in their adult stages in the higher Crustacea, as, for example, on various hermit crabs, shrimps, etc. The occurrence of these larvæ during the early and later months, and their apparent absence during summer, seems to indicate that the propagation of these parasites takes place chiefly during the months from October till March.

\section{Notes on Plankton Samples collected odtside the "Cumbrae} IsLANDS" Area in 1902.

In 1902 a few plankton samples were submitted for examination, which had been collected outside the Cumbrae Islands area.

These samples-seven in number-were collected in April, May, and September, but chiefly during the latter month. Three were collected in Ettrick Bay, on the west side of the Island of Bute; and the others at different places off the Island of Arran, two being from Loch Ranza, one from Mauchrie Bay, and one from Brodick Bay.

Twelve species of Crustacea were observed in these samples; nine of the species belonged to the Copepoda and three to the Cladocera; a few young Decapoda, Isopoda, Balani, and perhaps one or two larval forms, were also noticed.

The following are the species that were of most frequent occurrence, viz.:-Calanus helgolandicus, Claus; Pseudocalanus elongatus, Boeck ; Centropages hamatus (Lilljeborg); Temora longicornis (O. F. Müller); and Acartia Clausi, Giesbrecht. These five species were present in all the samples. The Calanus was abundant in the sample collected in May, but only sparingly represented in the others; Pseudocalanus, on the other hand, was common in four of the samples collected in September; Centro- 
pages hamatus was common in April, but less so in May and September; Temora, though present in the seven samples, appeared to be scarce in all of them. The Acartia was the most common of the five species referred to, especially in the September gatherings, as shown in the following tabulated list of all the species :-

\begin{tabular}{|c|c|c|c|c|c|c|c|}
\hline М्NTH & APRIL & MaY & \multicolumn{5}{|c|}{ SEPTEMBER - } \\
\hline DATE & 25 & 15 & 5 & 9 & 11 & 24 & 26 \\
\hline LOCALITY & 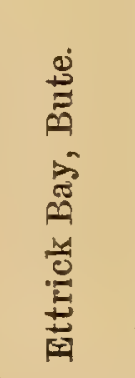 & 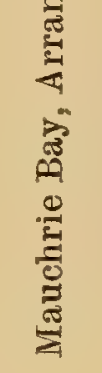 & 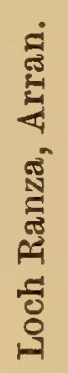 & 焉 & 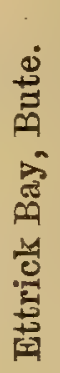 & 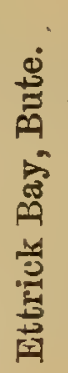 & 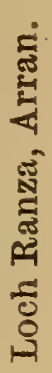 \\
\hline 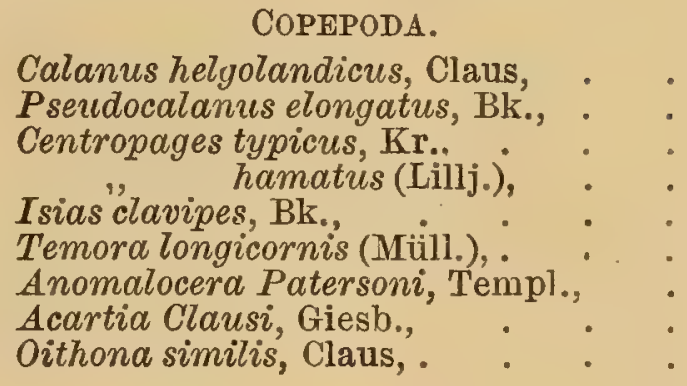 & $\begin{array}{c}\mathrm{c} \\
\dot{\mathbf{f}} \\
\mathbf{f} \\
\mathrm{fr} \\
.\end{array}$ & $\begin{array}{l}a b \\
f \\
\dot{f r} \\
\dot{f} \\
\mathrm{f} \\
\mathrm{ir}\end{array}$ & $\begin{array}{l}f \\
\mathrm{c} \\
\dot{\mathrm{fr}} \\
\dot{\mathrm{f}} \\
\dot{\mathrm{c}} \\
\mathrm{fr}\end{array}$ & $\begin{array}{l}\mathrm{fr} \\
\mathrm{c} \\
\dot{\mathrm{f}} \\
\dot{\mathrm{f}} \\
\mathrm{r} \\
\mathrm{ab} \\
\mathrm{f}\end{array}$ & $\begin{array}{l}\mathrm{fr} \\
\mathrm{c} \\
\ddot{\mathrm{f}} \\
\dot{\mathrm{f}} \\
\dot{\mathrm{c}} \\
\mathrm{fr}\end{array}$ & $\begin{array}{l}\mathrm{f} \\
\mathrm{fr} \\
\dot{\mathrm{f}} \\
\dot{\mathrm{r}} \\
\dot{\mathrm{c}} \\
\mathrm{fr}\end{array}$ & $\begin{array}{l}\mathrm{r} \\
\mathrm{c} \\
2 \\
\mathrm{fr} \\
\mathrm{r} \\
\mathrm{r} \\
\mathrm{r} \\
\mathrm{c} \\
\mathrm{fr}\end{array}$ \\
\hline $\begin{array}{l}\text { CRUSTACEA (ceter). } \\
\text { Evadne Nordmanni, Loven, } \\
\text { Podon intermedius, Lillj., } \\
\text { Leuckarti, G. O. Sars, } \\
\text { Microniscus (larvæ of Isopod species), } \\
\text { Young Crustacea - Decapoda, Bal- } \\
\text { ani, etc., . . . . . }\end{array}$ & $\begin{array}{l}\text { fr } \\
\dot{f} \\
\cdot \\
f\end{array}$ & $\begin{array}{l}\text { fr } \\
\text { fr } \\
\cdot \\
f\end{array}$ & f & $\mathbf{f}$ & $\begin{array}{l}\mathbf{f} \\
\mathbf{f} \\
\dot{r}\end{array}$ & $\begin{array}{c}f \\
: \\
\text { fr }\end{array}$ & $\begin{array}{c}\mathrm{fr} \\
\mathbf{f} \\
\dot{\mathrm{r}} \\
\mathbf{r}\end{array}$ \\
\hline
\end{tabular}

Centropages typicus, Kröyer, so frequent round the north-east and north of Scotland, was only observed in one of the September samples; so also was Isias clavipes, Boeck, a species though not unfrequent round the south and west of the British Islands is very sparingly distributed along the whole east side of Scotland and on the west side north of the Firth of Clyde. Anomalocera Patersoni, Templeton, one of the most finely coloured of the pelagic Copepoda found in the British seas, and which sometimes occurs in considerable swarms, was only noticed very sparingly in four gatherings. Oithona simitis, Claus, which was more or less frequent in the September gatherings, was absent in those collected in April and May. 


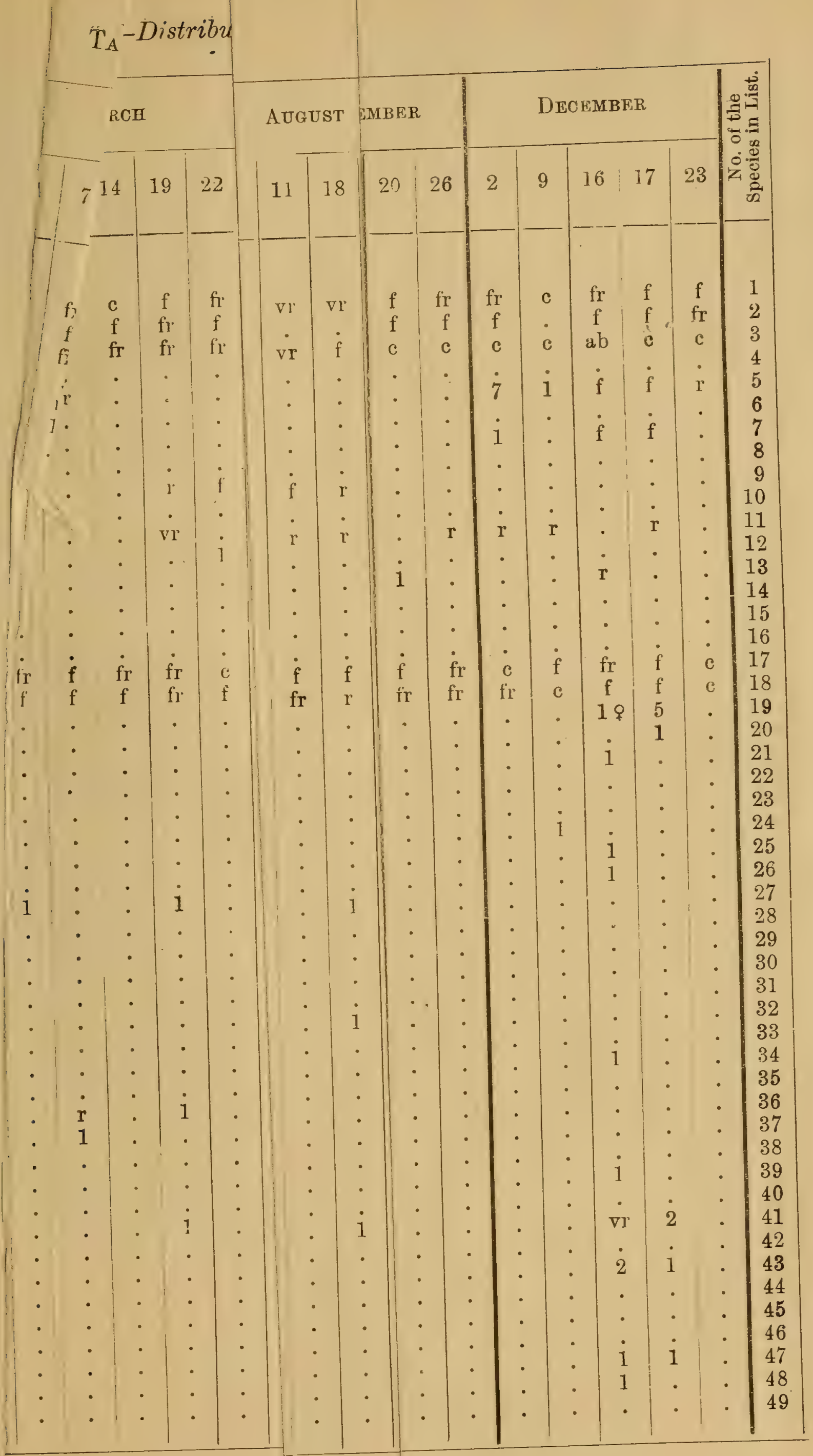






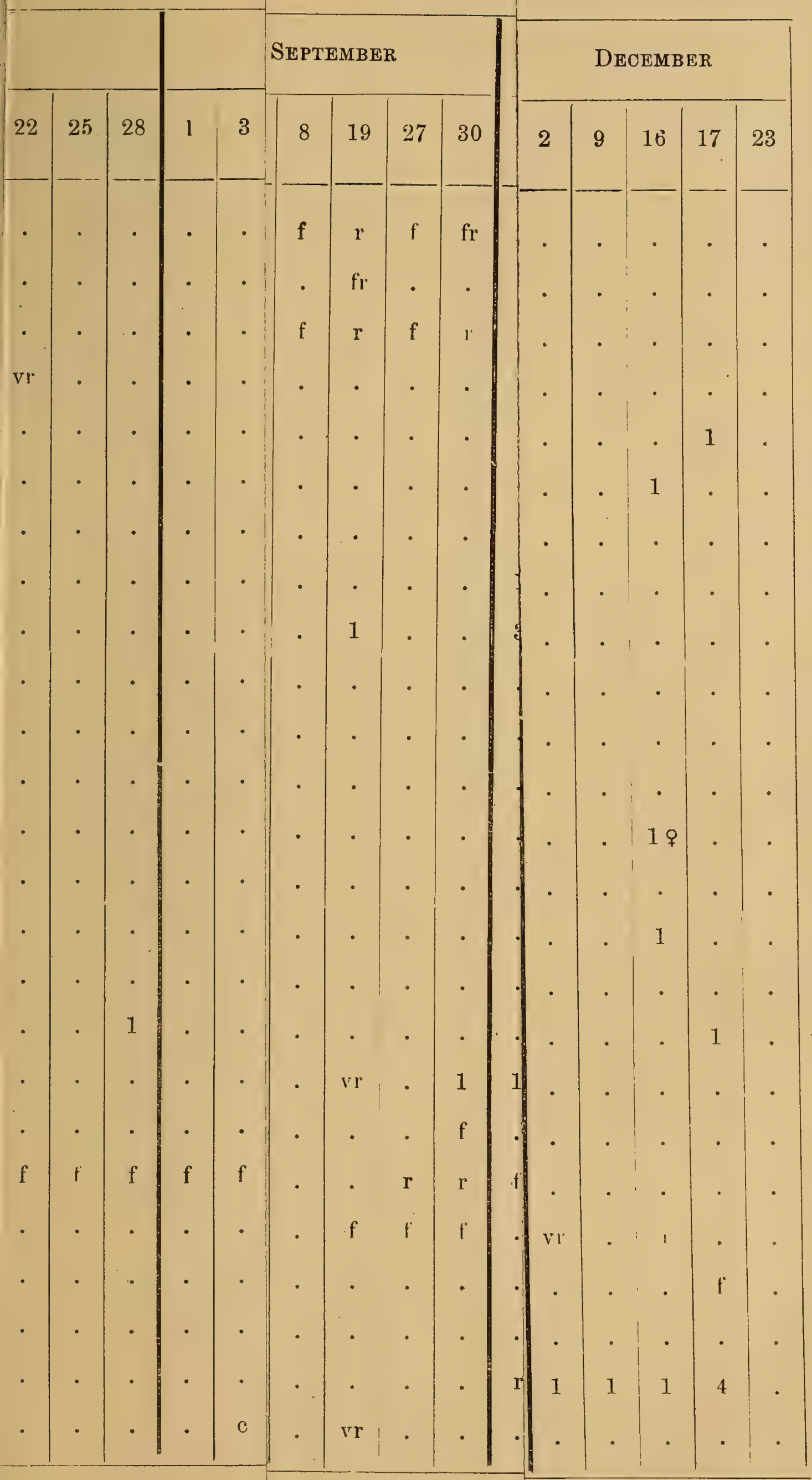





Cladocera were not very numerous in the gatherings under consideration. Evadne Nordmanni was observed in those collected in April and May and in three of the September samples. The two species of Podon differed in their distribution in rather a marked way, Podon intermedius being present in three of the September gatherings, but absent in those collected in April and May; while P. Leuckarti was present in the two earlier gatherings, but was absent in all those collected in September.

It will be observed from these remarks on the various species, and also from the tables referred to, that there is a tendency for the distribution of several of the more common of the free-swimming Copepoda to be influenced by the seasonal changes that take place throughout the vear. But without a study over a lengthened period of these seasonal changes, and of their effect on the distribution of marine organisms, the results obtained will be incomplete. 

$\operatorname{Pin} x$ 


$=$ 
$33=35\} 3 \mid 32\}$

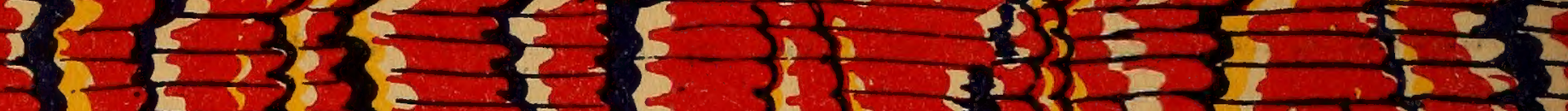

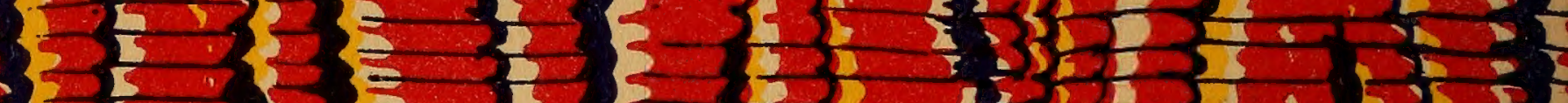

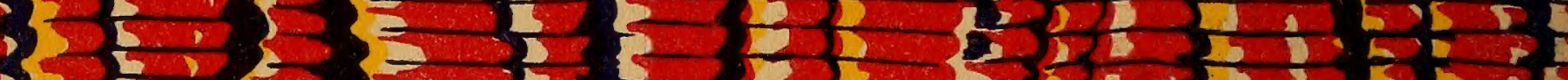

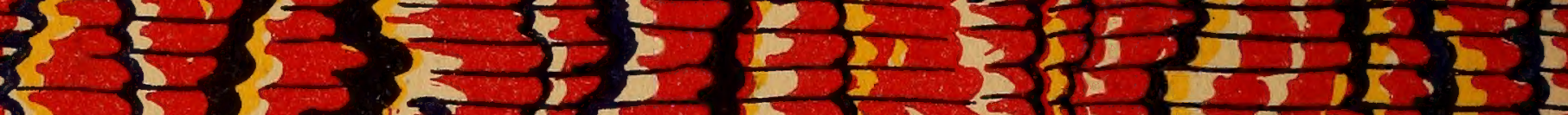

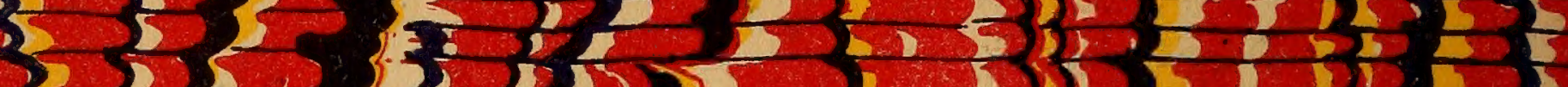
$225,\{3,25525$

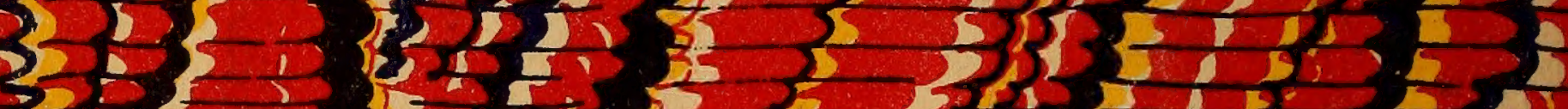

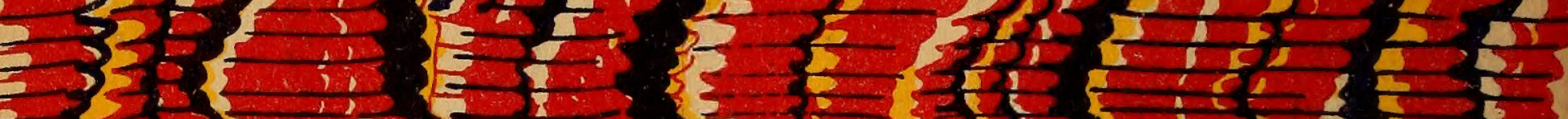

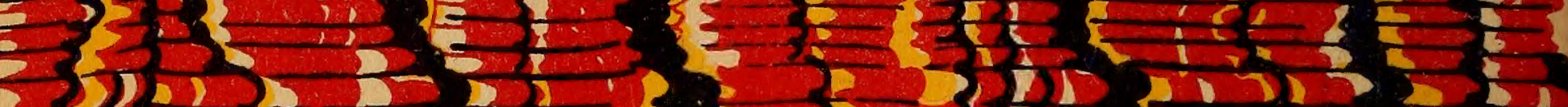

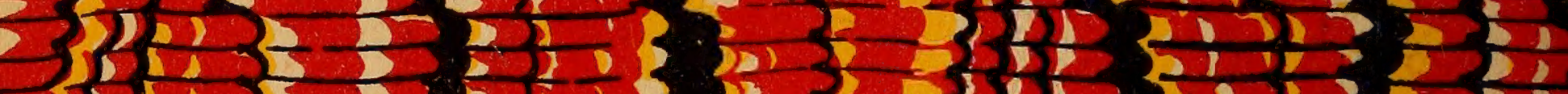

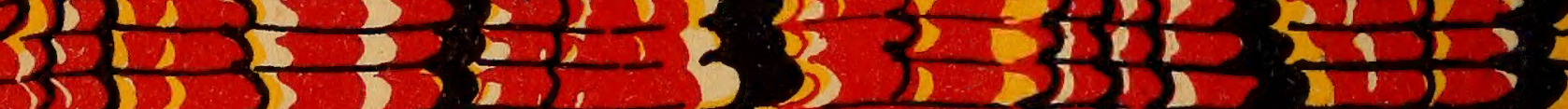

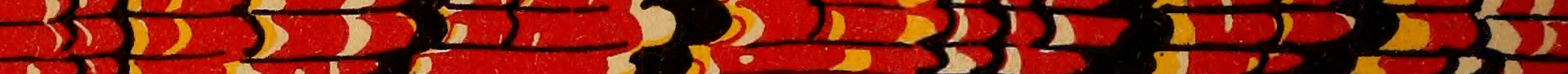

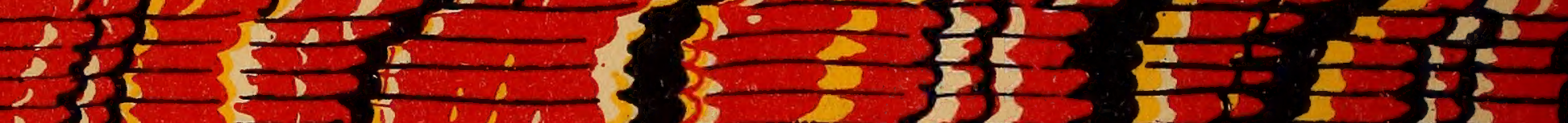

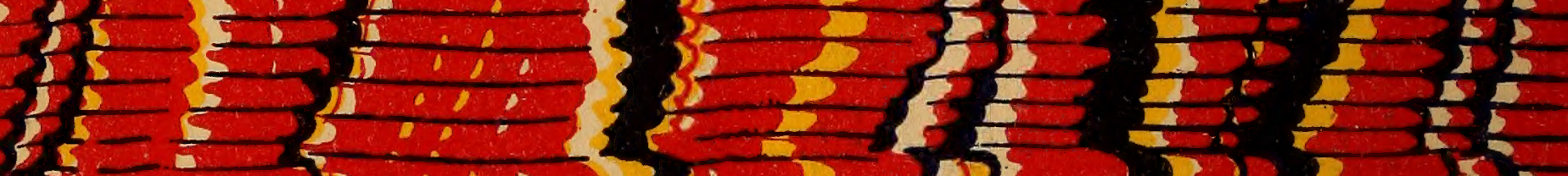

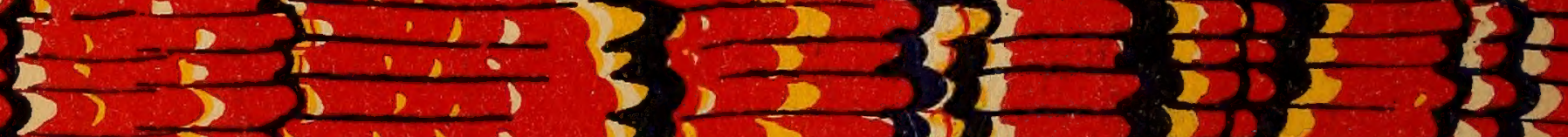

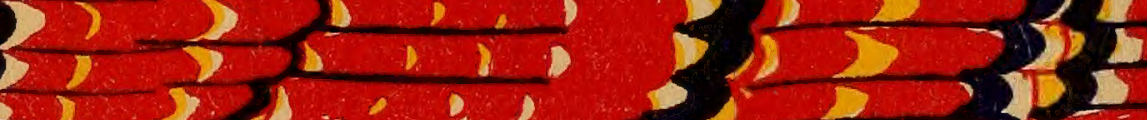

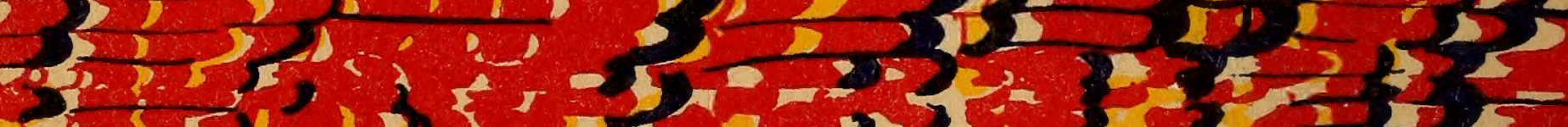

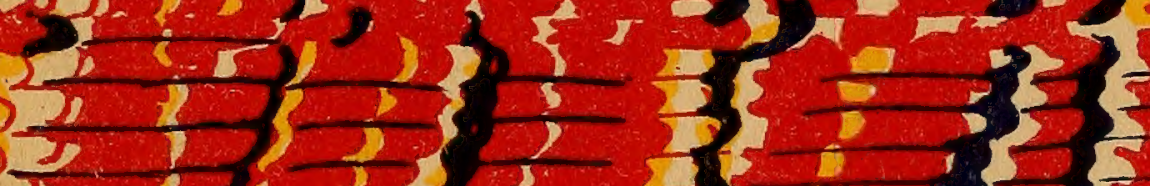

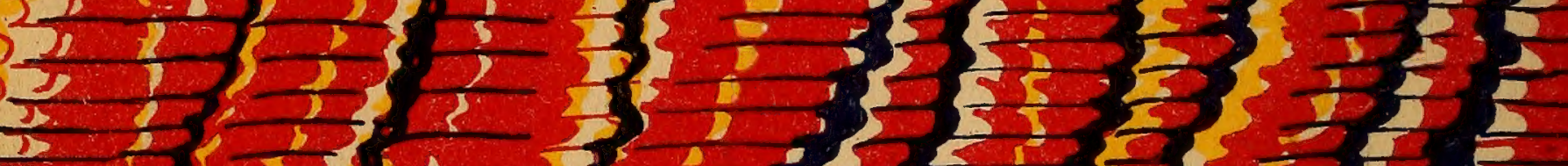

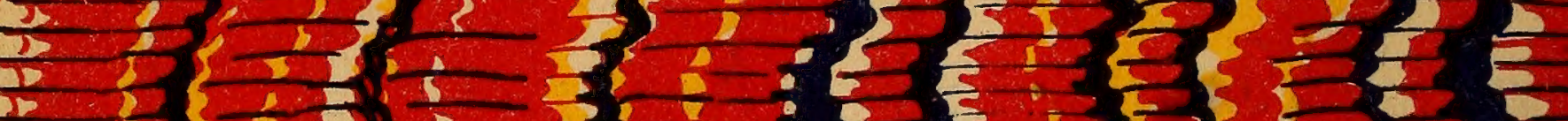

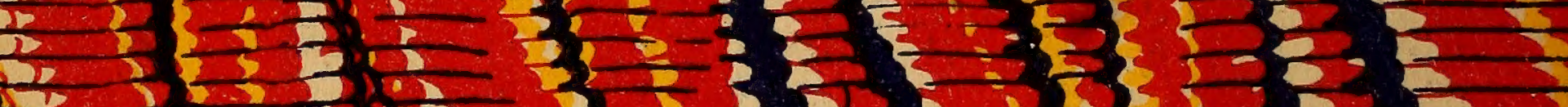
$5,-3, \frac{15}{2,5}$

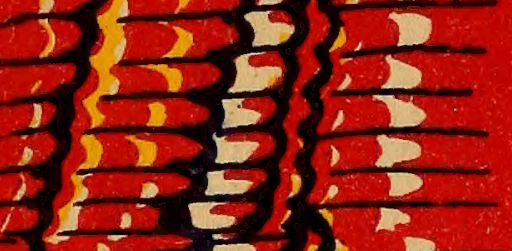

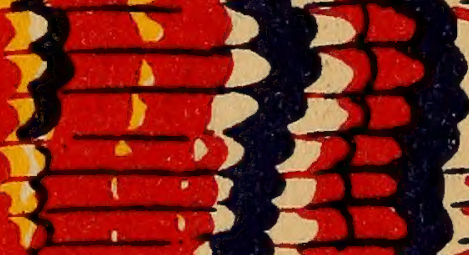
$3 \frac{3}{2}+3 \frac{25}{2}$

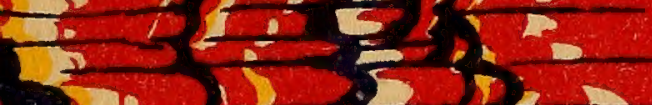

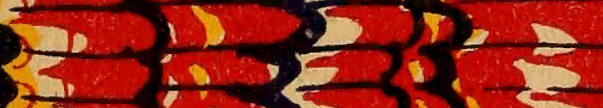
$30,23,5$ $1-5,53=25$

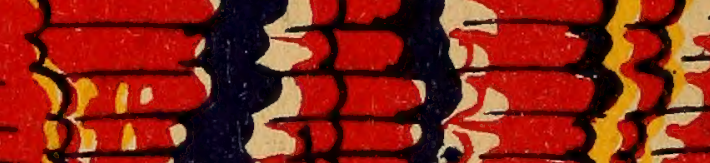

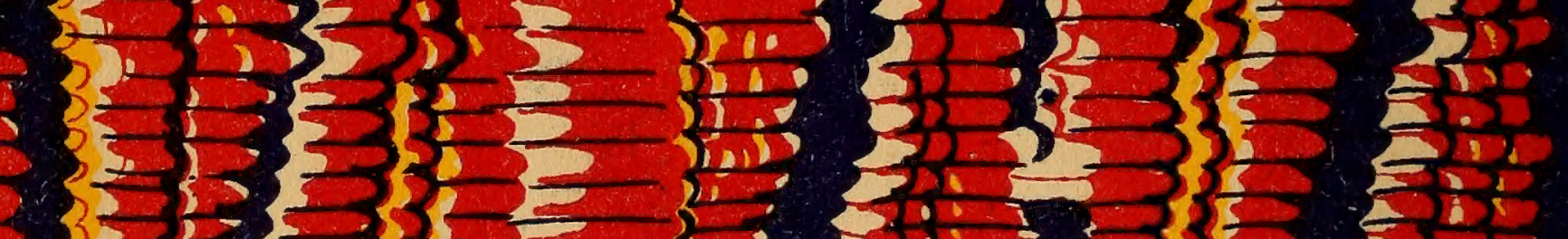
$3-25$ $\sum_{1}^{2} \frac{1}{1}$

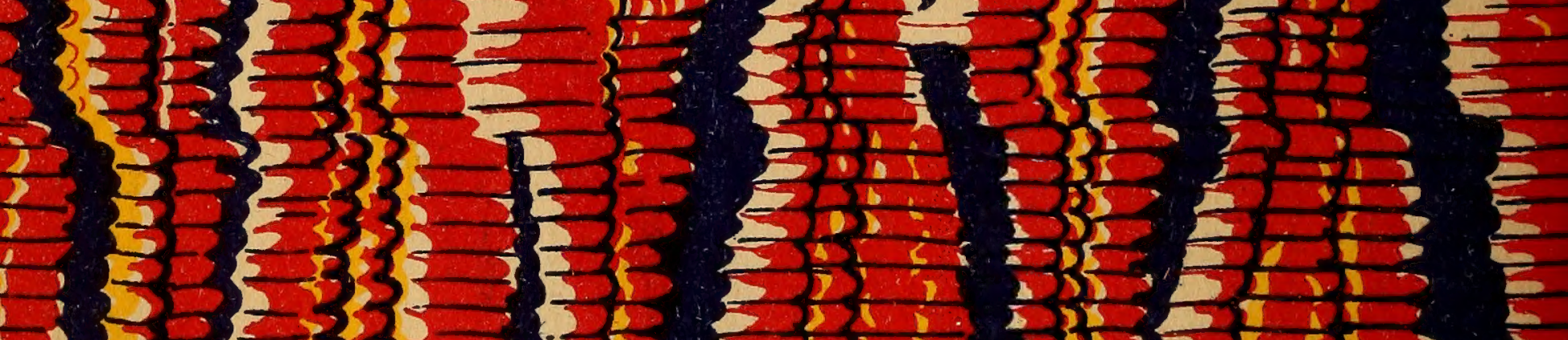

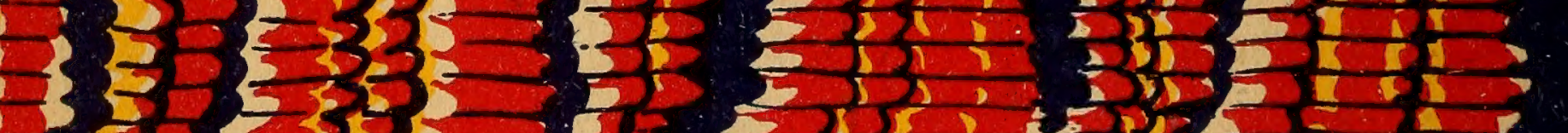

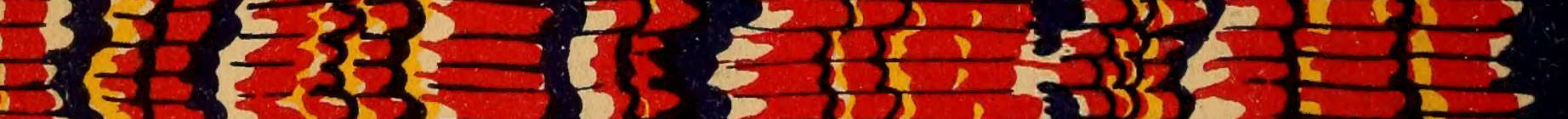

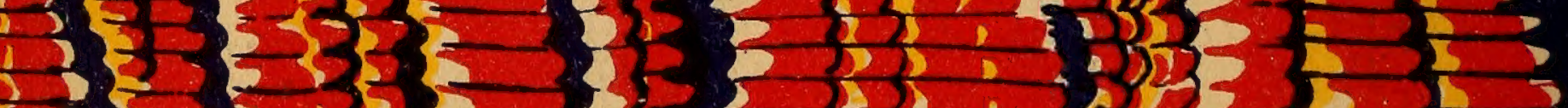

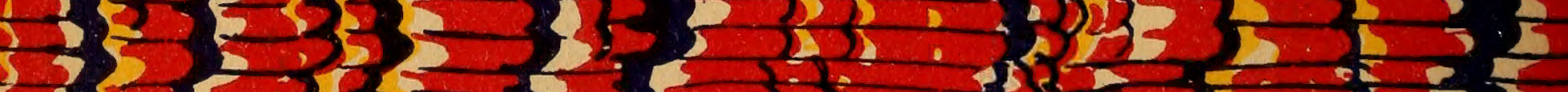

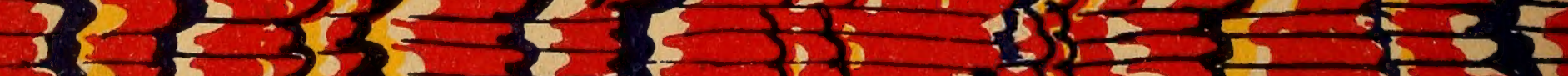

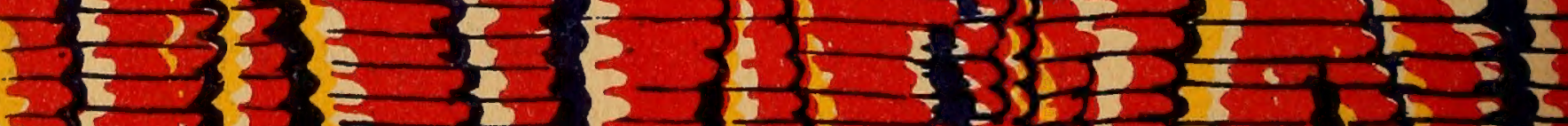

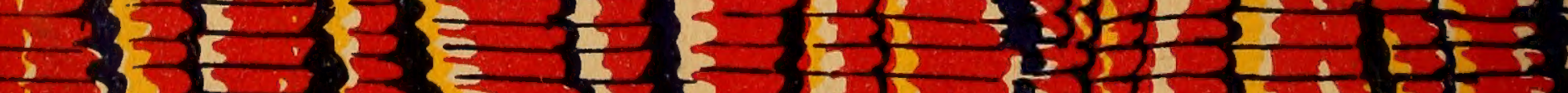


$352535335335,33: 33$

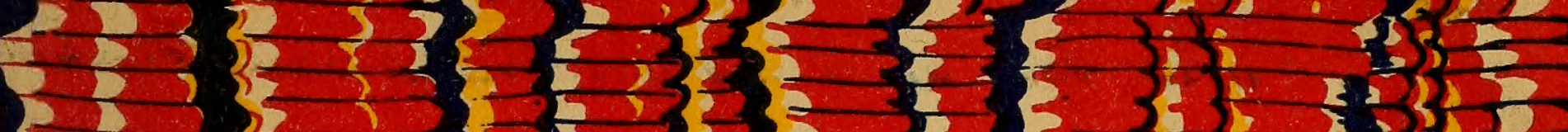
$353,3\} 353\}$

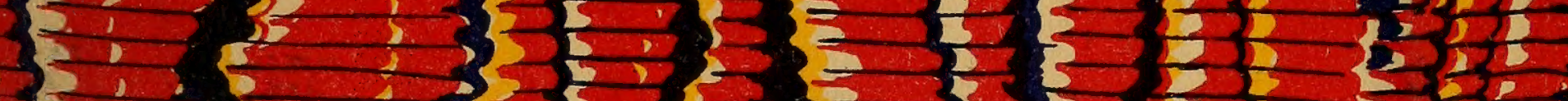

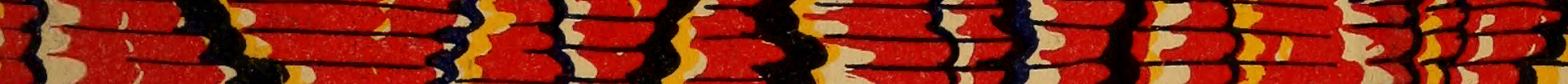

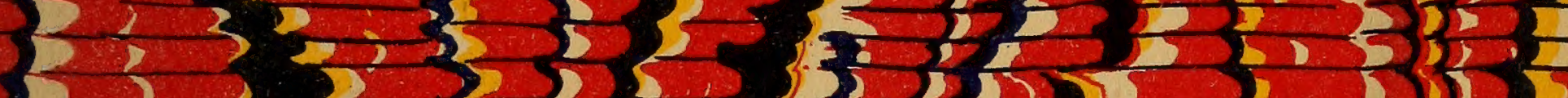
3235,3253

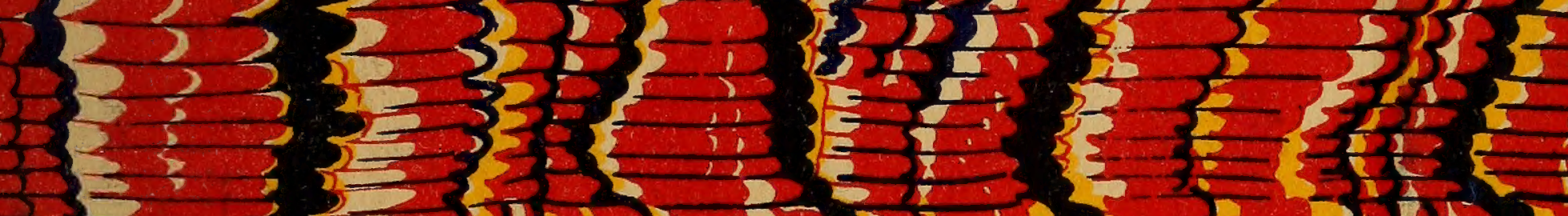

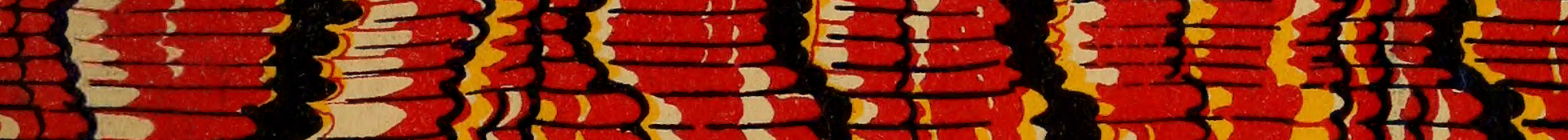

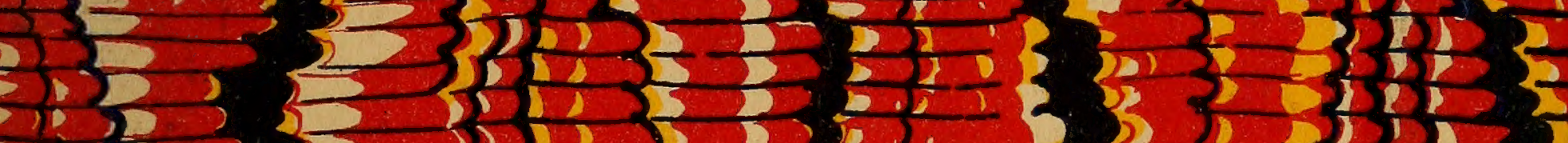

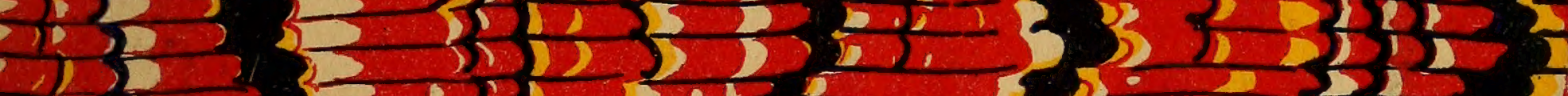

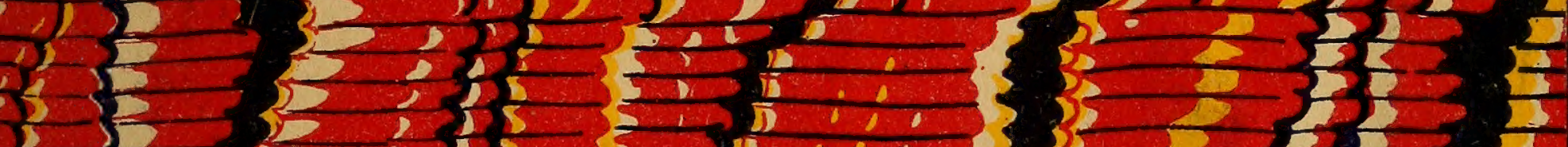

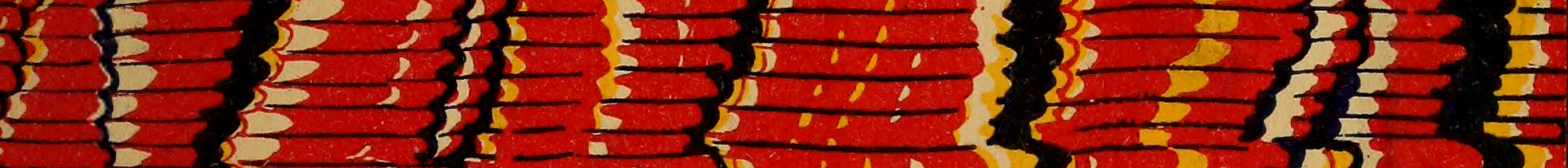

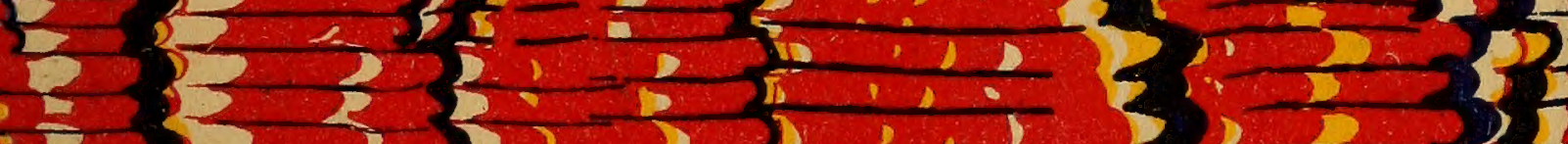
$3,3353,33,1,13,5$

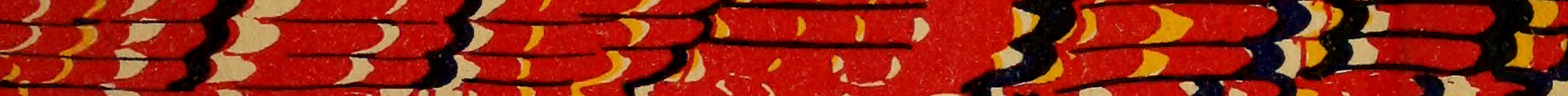

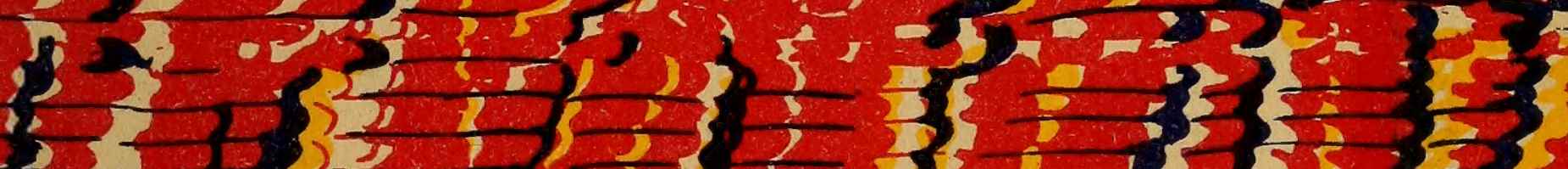

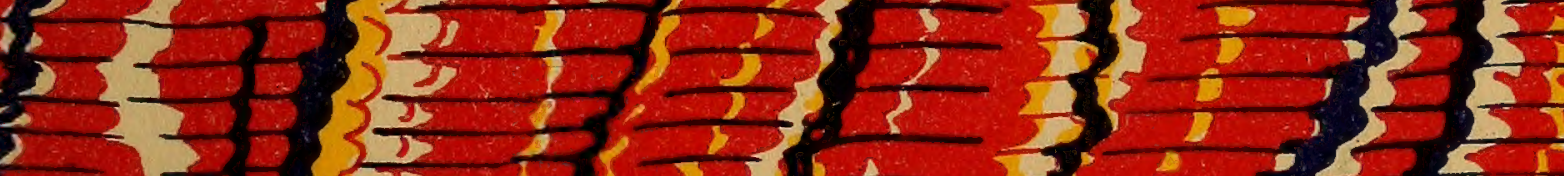

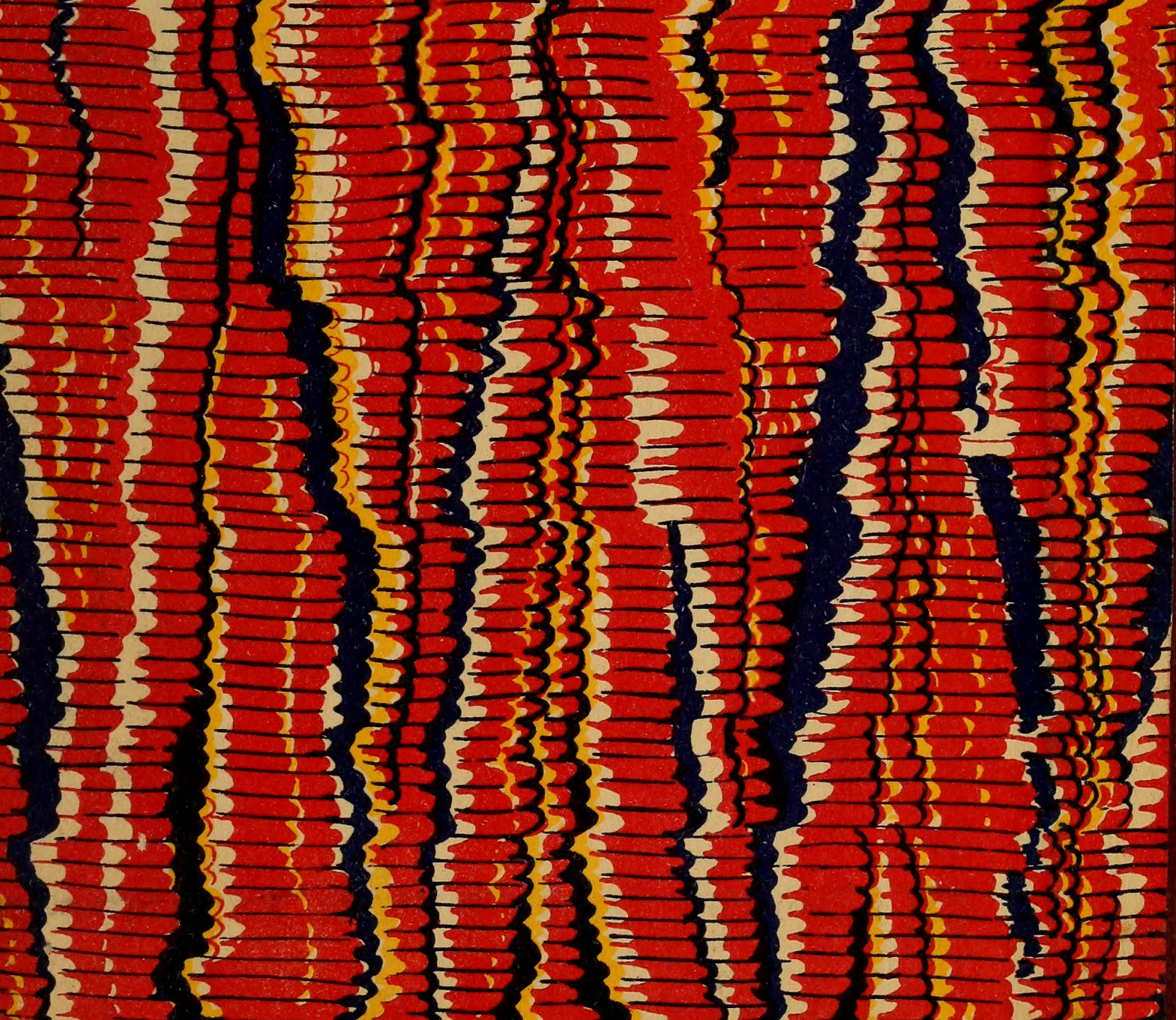


